Tomasz Ochinowski

Tradycje przedsiębiorczości w Polsce jako źródło kapitału kulturowego organizacji
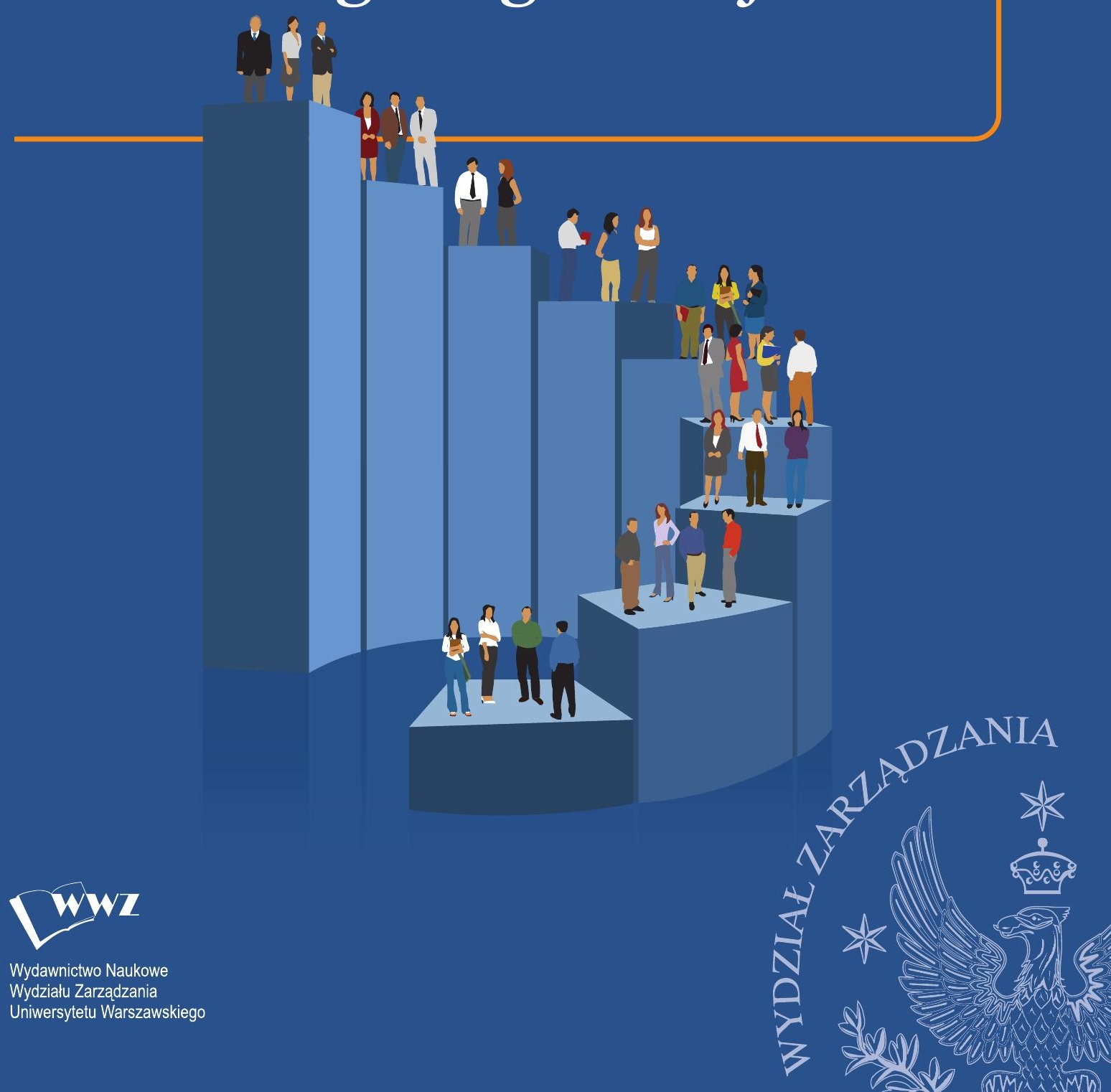


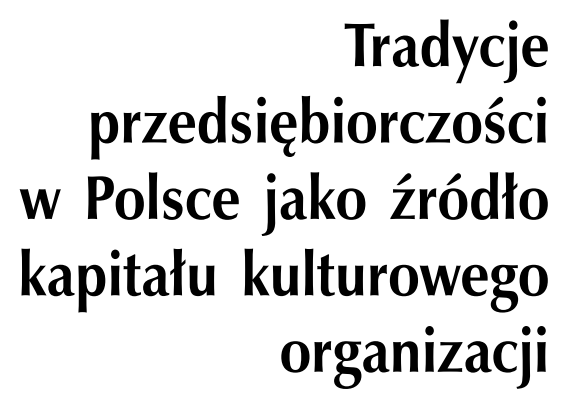





\section{Tradycje przedsiębiorczości w Polsce jako źródło kapitału kulturowego organizacji}

\section{Tomasz Ochinowski}

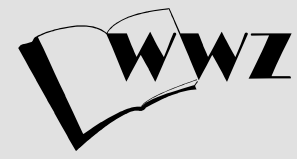

Wydawnictwo Naukowe Wydziału Zarzadzania Uniwersytetu Warszawskiego
WARSZAWA 2013

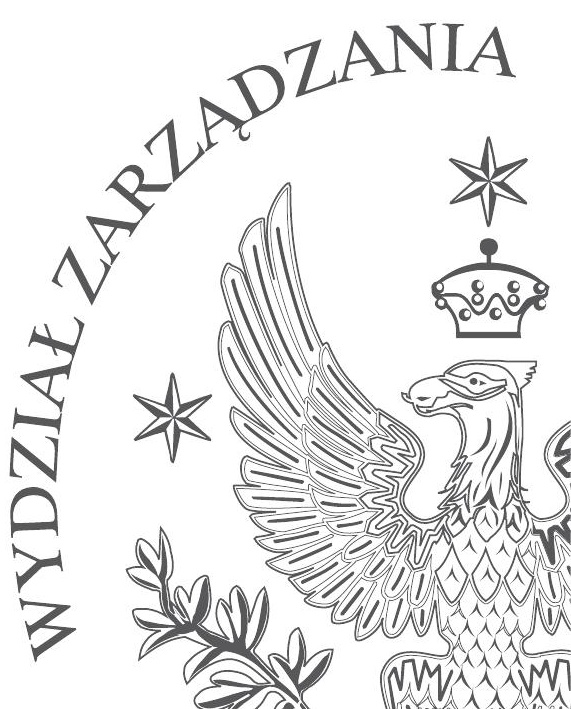


Recenzenci naukowi:

prof. dr hab. Tadeusz Oleksyn, SGH

dr hab. Marian Dobrzyński, prof. UW

Redakcja

Danuta Wojcieszak

Monika Pujdak-Brzezinka

Projekt okładki

Agnieszka Miłaszewicz

(C) Copyright by Wydawnictwo Naukowe Wydziału Zarządzania

Uniwersytetu Warszawskiego

Warszawa 2013

ISBN 978-83-63962-31-9

ISBN 978-83-63962-32-6 (online)

DOI: $10.7172 / 2013 . w w z .10$

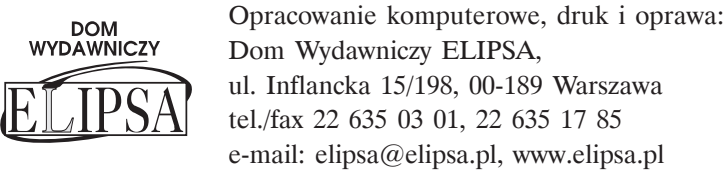




\section{Spis treści}

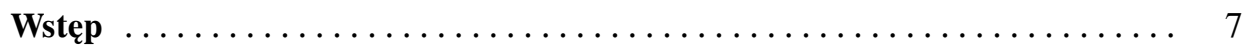

\section{Rozdział I}

ROLA KAPITALU KULTUROWEGO W ZARZĄDZANIU

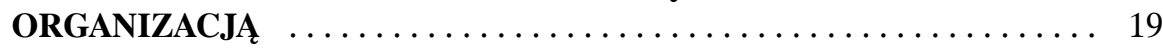

1.1. Kapitał kulturowy miejsca pracy a kapitał kulturowy organizacji ..... 19

1.2. Kapitał kulturowy a funkcje zarządzania współczesną organizacją .... 32

1.3. Kapitał kulturowy w kontekście kultury organizacyjnej $\ldots \ldots \ldots \ldots 47$

\section{Rozdzial II}

KAPITAŁ KULTUROWY ORGANIZACJI W KONTEKŚCIE KRYZYSU

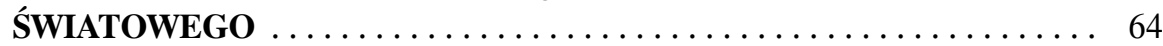

2.1. Psychologiczne i kulturowe aspekty kryzysu $\ldots \ldots \ldots \ldots \ldots \ldots \ldots . \ldots 64$

2.2. Zachowania organizacyjne menedżerów $w$ czasach kryzysu $\ldots \ldots \ldots \ldots 72$

2.3. Moralny nurt dyskusji wokół kryzysu światowego $\ldots \ldots \ldots \ldots \ldots \ldots .78$

\section{Rozdzial III}

HISTORIA ORGANIZACYJNA W NAUKACH O ZARZĄDZANIU ....... 86

3.1. Znaczenie kultury organizacyjnej i pamięci organizacyjnej dla rozwoju nurtu historycznego w zarządzaniu . . . . . . . . . . . . . . . . 86

3.2. Geneza historii organizacyjnej i jej ewolucja $\ldots \ldots \ldots \ldots \ldots \ldots \ldots . . \ldots 9$

3.3. Specyfika i funkcje poznawcze historii organizacyjnej w naukach o zarządzaniu ................................ 106

3.4. Relacje człowiek-organizacja jako problem badawczy historii

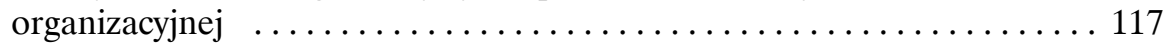

\section{Rozdziat IV}

HISTORIA ORGANIZACYJNA I PRAKTYKA ZARZĄDZANIA W PRZEDSIĘWZIĘCIACH BADAWCZYCH

4.1. Koncepcja historii organizacyjnej w ujęciu Theodore'a Zeldina i jej implikacje dla zarządzania organizacją $\ldots \ldots \ldots \ldots \ldots \ldots \ldots \ldots \ldots \ldots \ldots$

4.2. Heroiczne przywództwo w ujęciu Chrisa Lowneya ............. 134

4.3. Tradycje przedsiębiorczości jako dziedzina badań historii organizacyjnej na przykładzie prac Kordiana Tarasiewicza 


\section{Rozdział V}

WPEYW IDEOWEGO DZIEDZICTWA PRZEDSIĘBIORCZOŚCI

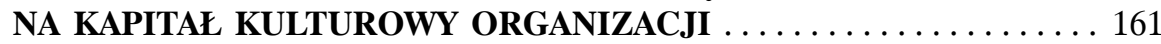

5.1. Kulturowe wzorce przedsiębiorcy powstałe na ziemiach polskich ..... 161

5.2. Lokalne mity proprzedsiębiorcze jako źródło inspiracji dla współczesnego biznesu . ......................... 182

5.3. Idee środowiska Nowej Kultury Pracy (1945-1948) i ich współczesne aplikacje ........................................ 189

\section{Rozdzial VI}

KAPITAE KULTUROWY W WYBRANYCH PRAKTYKACH Z TRADYCJI POLSKIEJ PRZEDSIĘBIORCZOŚCI _.................. 223

6.1. Historia mówiona odbudowy Warszawy w ujęciu Jana Górskiego a metodologiczne problemy badania zarządzania ludźmi

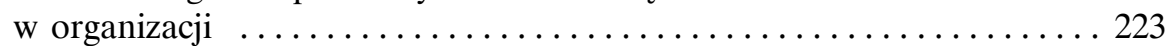

6.2. Dobre praktyki zarządzania w branży zdominowanej przez małe i średnie przedsiębiorstwa na przykładzie doświadczeń Palarni Kawy „Pluton” (1882-1950) ............................... 234

6.3. Rekonstrukcja biografii Władysława Jachniaka (1915-1994) i jej znaczenie dla dyskusji o optymalnym modelu biznesowym w kontekście kryzysu ............................... 265

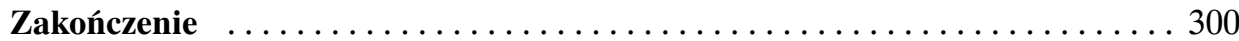

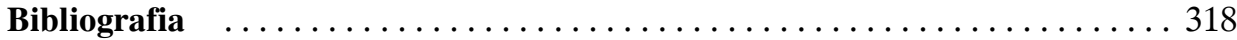




\section{Wstęp}

Wśród wielu toczących się dyskusji na temat współczesnych problemów zarządzania, wyraźnie wyodrębnia się nurt historyczny. Różni autorzy sięgają do koncepcji z dziejów myśli ekonomicznej lub menedżerskiej także dotyczących kryzysów jako punktu odniesienia dla współczesności. Przy czym w dyskusjach tych nie chodzi o odtwarzanie historii, ale o jej rozumienie, aby można ją było wykorzystać jako narzędzie intelektualne do analizy obecnej sytuacji i zainspirowania dobrych praktyk ułatwiających przezwyciężenie kryzysu (np. deNeeve 2009 i brak roku wydania, Keen 2010, Barnes 2011, Hansen 2012, Vanderbroeck 2012, Sutowski 2013).

Nieco inny niż już wspomniany sposób odwoływania się do przeszłości w kontekście zarządzania nawiązuje do tradycji zapoczątkowanej przez Throsteina Veblena (2008, oryg. opublikowany w 1899 r.). Twórca teorii klasy próżniaczej uważał, że istotę rozumienia życia gospodarczego i społecznego stanowi badanie historii takich „miękkich” czynników jak: postawy, upodobania, tradycje i motywacje ludzi ${ }^{1}$. Przydatne przy tym także dla nauk o organizacji okazują się kategorie retoryczne historiografii, które opisał Maciej Bugajewski (2010) proponując rozróżnienie „dziedzictwa” i „brzemienia” historii. Odnośnie do problematyki zarządzania oraz drugiej z wymienionych metafor, warto wskazać publikacje polskich badaczy, takich jak Roman Głowacki (Głowacki i Karasiewicz 2009), profesor z Uniwersytetu Warszawskiego czy Sławomir Magala (2002), profesor z Uniwersytetu Erazma w Rotterdamie, którzy również zachodniemu czytelnikowi przypominają o brzemieniu czasów gospodarki planowej obecnym do dziś w mentalności i praktykach menedżerskich społeczeństw dotkniętych niegdyś tym doświadczeniem.

Zarysowane wcześniej rozumienie problemów współczesnego zarządzania z perspektywy przeszłości systematycznie rozwija od kilkunastu lat historia organizacyjna, rozumiana jako włączenie refleksji historiograficznej do teorii organizacji. Za Andrzejem F. Grabskim (1990) przyjmuję, iż historia historiografii stanowi analizę sposobów rozumienia zmienności ludzkiej rzeczywistości, a mówiąc bardziej szczegółowo - analizę obecnych w świadomości społecznej

1 Na ten pogląd Veblena zwrócił mi uwagę Marian Dobrzyński, profesor w Katedrze Psychologii i Socjologii Zarządzania WZ UW. 
(łącznie z pracami naukowymi) wyobrażeń o historyczności ludzkiej rzeczywistości (Stobiecki 2002).

Historia organizacyjna, podejmująca wątki historiograficzne dla potrzeb współczesnych organizacji, wyraźnie stanowi odmianę nurtu kulturowego w naukach o zarządzaniu. Można więc treści historyczne zawarte w teorii i praktyce menedżerskiej traktować jako formę kapitału kulturowego organizacji. Tak też robię w niniejszej pracy.

W polskiej literaturze naukowej bardzo niewiele jest opracowań dotyczących perspektywy historycznej w zarządzaniu. Z kolei prace autorów zachodnich koncertują się na doświadczeniach „centrów globalizacji”2 i prezentują historię organizacyjną głównie tam powstałą. W niewielkim stopniu wykorzystywane są doświadczenia „prowincji”, co zubaża zarówno nauki o zarządzaniu w niej uprawiane, jak i historię organizacyjną „głównego nurtu”.

Do opracowania propozycji sukcesywnego wypełniania tych luk, czemu, jak mam nadzieję, może służyć niniejsza praca, ośmielił mnie dług intelektualny, który zaciągnąłem wobec środowiska badaczy skupionych wokół prof. Andrzeja Wierzbickiego.

Przywołany historyk był uczniem Andrzeja Feliksa Grabskiego. Twórczo rozwija myśl historiograficzną swego mistrza, skupiając się przede wszystkim na dziejopisarstwie polskim. W wersji Wierzbickiego (1993, 1999, 2001, 2006, 2009, $2010 \mathrm{i}$ in.) historia historiografii wyraźnie stała się namysłem nad sposobami rozumienia zmienności (nad wyobrażeniami o historyczności) kategorii istotnych dla relacji „prowincja-centrum”.

Środowisko, które skupia Wierzbicki, to interdyscyplinarny zespół dawnej pracowni Dziejów Myśli Społecznej i Politycznej Instytutu Historii PAN, głównego ośrodka w naszym kraju zajmującego się historiografią polską. Od 2001 roku należę do tego zespołu. Obecnie środowisko to utworzyło warszawski oddział międzynarodowego Towarzystwa Historiograficznego. Spotyka się też na historiograficznym seminarium w ramach Pracowni Badania Dziejów Inteligencji IH PAN. Moje rozumienie istoty refleksji historiograficznej i jej użyteczności

2 Termin „globalizacja” jest pewnym skrótem myślowym, związanym z działaniem w skali światowej, całego globu. W tym sensie nie ma „centrów globalizacji”. W tej pracy używa się terminu „centra globalizacji”, ujętego w cudzysłowie, w odniesieniu do krajów, które najaktywniej tworzyły przesłanki ideowe, prawne i organizacyjne dla ułatwiania, promowania i rozszerzania działalności gospodarczej (i nie tylko gospodarczej) w skali całego globu. W tym rozumieniu do „centrów globalizacji” można zaliczyć w szczególności takie kraje, jak: USA, Japonia, Niemcy, Wielka Brytania, Holandia, które w tym procesie były i są najbardziej zaangażowane oraz wykształciły szereg firm o charakterze globalnym i których gospodarki są przeorientowane $\mathrm{z}$ wymiaru narodowego na światowy. Z punktu widzenia tak rozumianej globalizacji można mówić o centrach i o peryferiach globalizacji. Te ostatnie jedynie dostosowują się, z opóźnieniem i nie zawsze chętnie, do zasad kształtowanych i narzucanych przez te centra. Do peryferiów globalizacji można zaliczyć także i Polskę. 
dla zarządzania ukształtowało się przede wszystkim podczas seminariów obydwu z wymienionych pracowni.

Historię historiografii traktuję jako intelektualne laboratorium ewolucji (z uwzględnieniem perspektywy dziejowej) kategorii teoretycznych i pojęć mogących służyć opisowi oraz interpretacji rzeczywistości społecznej, gospodarczej, politycznej czy kulturowej. Natomiast historia historiografii polskiej jest w tym ujęciu intelektualnym laboratorium przyswajania wspomnianych kategorii na poziomie „prowincjonalnym”, prowadzenia za ich pomoca „,dialogu z centrum” oraz tworzenia przez „,prowincję" swoich kategorii i pojęć na użytek wspomnianego dialogu i dyskutowania własnej tożsamości.

Wierzbicki pokazuje, że w przypadku Polski do podstawowych kategorii i pojęć służącym nam na przestrzeni dziejów do dyskusji z sąsiadami czy/oraz „reprezentantami centrum”, a także do określania własnej tożsamości należą opozycje: Wschód - Zachód, orientacja wschodnia - orientacja zachodnia, chrześcijaństwo - pogaństwo, barbarzyństwo - cywilizacja, niewola - wolność, a także takie elementy świadomości zbiorowej jak ,przedmurze” (Wierzbicki 2001, 2009, 2010).

Koncepcja historiograficzna Wierzbickiego może uchronić polskiego badacza, również badacza zarządzania, zarówno przed prowincjonalizmem (przekonaniem, że coś jest warte zainteresowania naukowego, tylko dlatego, że jest polskie i samo dla siebie stanowi jedyny punkt odniesienia), jak i kompleksem prowincji ${ }^{3}$ (nie warto zajmować się doświadczeniami polskimi, liczą się tylko przykłady „Z centrum”). Jako intelektualne antidotum na obydwie skrajności cytowany historyk proponuje świadomość faktu, iż zjawiska intelektualne, które opisuje „odwołując się do przykładów z dziejów historiografii polskiej, to, rzecz prosta, zjawiska o znacznie szerszym, ponadpolskim zasięgu. Historiografia polska stanowi w tym wypadku jedynie niewielką cząstkę, posiadającą wprawdzie swą własną specyfikę, ale też w znacznej mierze recypującą to, co zachodziło i zachodzi „na zewnątrz. I jedno i drugie nie powinno martwić” (Wierzbicki 2006: 195). W niniejszej pracy wybieram z tradycji przedsiębiorczości w naszym kraju wątki, które spełniają te kryteria, czyli są niewielką cząstką, posiadającą swą specyfikę zjawisk o znacznie szerszym, ponadpolskim zasięgu. I interpretuję je zgodnie z przytoczoną sugestią Wierzbickiego. Przy realizacji badań skutkuje ona następującym porządkiem czynności poznawczych:

1) przegląd zagadnień i wątków w uogólniającym ujęciu,

2) próby nowych interpretacji,

3) poszukiwanie w ramach wspomnianych nowych interpretacji polskich osiagnięć lub propozycji o charakterze prekursorskim (por. Wierzbicki 2009;

3 Określenie to zawdzięczam Marianowi Dobrzyńskiemu, profesorowi w Katedrze Psychologii i Socjologii Zarządzania WZ UW. 
autor omawiając na kartach tej publikacji wizje Europy w polskiej myśli historycznej i politycznej XIX i XX wieku, jako przykłady polskich pomysłów prekursorskich wobec idei integracyjnych analizuje Konstytucję dla Europy Wojciecha Bogumiła Jastrzębowskiego z 1834 roku, koncepcje europejskie Adama Mickiewicza oraz Kodeks zjednoczeniowy Stefana Burczyńskiego z 1857 roku).

Staram się przenieść ten sposób myślenia z historiografii do zarządzania, próbując - w oparciu o wspomniane środowisko warszawskich historiografów i Wydział Zarządzania UW - rozwijać od kilku lat historię organizacyjną, ze szczególnym uwzględnieniem dziejów przedsiębiorczości w Polsce jako źródła dobrych praktyk na dziś. Wspomniane tradycje traktuję jako przedmiot analiz zarówno historycznych, jak i historiograficznych (czyli krytycznych przeglądów prac poświęconych tym tradycjom). Prezentowana publikacja stanowi relację z obecnego stanu tych wysiłków.

Komentarza wymagają, zasygnalizowane dwa akapity wcześniej, możliwości uogólniające analizy historiograficznej. Omawiana dyscyplina badań jest z gruntu jakościowa. Jak zwraca uwagę Wierzbicki (2009: 8), szczególnie historyk polskiej historiografii dysponuje źródłami, które „dotyczą przeważnie (...) myśli naszych elit”. „Ale przecież nic innego, tylko właśnie ta myśl wyznaczała intelektualne ramy procesów o dalszym zasięgu”. Chodzi więc nie o nakreślenie uśrednionego obrazu występowania danych zjawisk intelektualnych, ale o wyodrębnienie wzorów ideowych, które można by uznać za propozycje dla szerszych kręgów potencjalnych ich odbiorców, łącznie z ludźmi nam wspó1czesnymi. I tylko w takim znaczeniu należy rozumieć uogólnienia dokonywane w toku analiz historiograficznych i historycznych prezentowanej pracy. Przy czym wciąż słabo zaawansowany stan badań nad dziejami przedsiębiorczości w Polsce sprawił, iż wybór przedstawicieli elit działań gospodarczych do podjętych przeze mnie analiz był z konieczności subiektywny, a także w znacznym stopniu intuicyjny.

Warto na marginesie wspomnieć, iż czasami historia historiografii polskiej dostarcza informacji wprost dotyczących współczesnego zarządzania.

Sporo tego typu danych przynosi na przykład książka Wierzbickiego Europa w polskiej myśli historycznej i politycznej XIX i XX wieku (2009). Oprócz sygnalizowanych już projektów Jastrzębowskiego, Mickiewicza i Burczyńskiego, warto wskazać choćby na poglądy międzywojennego historyka i historiozofa Feliksa Konecznego, który negował istnienie kultury europejskiej. Koneczny uważał, iż społeczeństwa naszego kontynentu muszą wybierać między różnymi, konkurencyjnymi wobec siebie wzajemnie zbiorami kultur. Zbiory te nazywał cywilizacjami (Wierzbicki 2009). Nietrudno zauważyć związków zasygnalizowanego tu podejścia $\mathrm{z}$ wyzwaniami współczesnego zarządzania międzykulturowego. 
Wieloletnie badania, które Wierzbicki prowadzi praktycznie przez cały okres swej aktywności naukowej, nad koncepcjami „polskiego charakteru narodowego" pokazały, iż jest to kategoria nie naukowa a mityczna. Stanowi to istotną przestrogę dla twórców różnorodnych konstruktów teoretycznych także na potrzeby zarządzania. Warta uwagi w kontekście badań organizacyjnych jest także metodologiczna konkluzja Wierzbickiego: „Żywotność i intensywność nurtu charakterologicznego $\mathrm{w}$ historiografii nie jest jednak tożsama $\mathrm{z}$ jego naukową płodnością. Stało się tak przede wszystkim dlatego, że nie sprawdziła się żadna ze stosowanych przez historyków procedur rozpoznawania charakteru narodowego, czyli - innymi słowy - procedur dochodzenia do sądów charakterologicznych. Sądy oparte na 'intuicji', 'głębokim przeświadczeniu' nie poddawały się naukowej kontroli, natomiast pozostałe metody, którymi posługiwano się mniej lub bardziej świadomie, również dalekie były od naukowej poprawności" (Wierzbicki 2010: 307). Cytowany historyk jako przykład wspomnianych błędów metodologicznych podaje przeświadczenie sporej liczby badaczy, iż „charakter narodowy" lub jego poszczególne cechy można zoperacjonalizować za pomocą wydarzeń dziejowych. „I tak na przykład (...) - pisze Wierzbicki - niedorozwój miast kojarzył się z 'brakiem przedsiębiorczości”' (Wierzbicki 2010: 308).

"Charakter narodowy" okazał się więc konstruktem teoretycznym, którego „naturę” dobrze oddaje popularna wśród polskich romantyków (mająca także swe odpowiedniki w innych krajach) kategoria „ducha narodu”, wywołująca skojarzenia mitologizacyjne i ,archetypiczne”, by jeszcze raz zacytować Wierzbickiego (2006: 185), będąca „na poły metafizyczną siłą sprowadzającą do wspólnego mianownika narodową przeszłość i przyszłość". W ten sposób badania z dziedziny historii historiografii wskazały na polską tradycję zainteresowania archetypami jako narzędziami analizy rzeczywistości kulturowej. Metodę badawczą tego rodzaju, wykorzystującą koncepcję Carla Gustawa Junga, rozwija obecnie w naukach o zarządzaniu, także poprzez publikacje anglojęzyczne, Monika Kostera (2012, Kociatkiewicz i Kostera 2012b), profesor zwyczajna Uniwersytetu Warszawskiego i profesor Uniwersyetu Linneusza w Szwecji. „Przecież już w dobie zafascynowanego mitami romantyzmu właśnie w obrębie historiografii sformułowany został u nas pogląd, że w polskich 'dziejach bajecznych' niejako archetypicznie zarysowany został charakter przyszłych rzeczywistych dziejów narodu. Oczywiście trudno tu mówić o antycypowaniu teorii archetypów, niemniej skojarzenia są dość bliskie" (Wierzbicki 2006: 185; szerzej zob. Wierzbicki 1999).

Stale powracający w mojej pracy motyw stanowi historia organizacyjna, ze szczególnym uwzględnieniem dziejów przedsiębiorczości w Polsce, jak też refleksja, że historia organizacyjna stanowi ważny, choć jeszcze nie w pełni doceniany element współczesnych nauk o zarządzaniu. 
Cel główny pracy to analiza użyteczności podejścia historycznego dla współczesnego zarządzania oraz rekonstrukcja polskiego wkładu do historii organizacyjnej. Najczęściej opisywane są i powielane, a przez to szerzej znane, historie organizacyjne światowych korporacji. Celem pracy jest wskazanie na potrzebę rozszerzenia takiego podejścia na kraje i organizacje, nie będące w centrum powszechnej uwagi, celem szerszego optymalizowania współczesnych działań biznesowych za pośrednictwem historii organizacyjnej. Celem blisko z tym związanym jest „ocalenie od zapomnienia” historii organizacji i związanych z nimi przedsiębiorców, do czego zachętą mają być historie przypomniane w tej publikacji.

Główna teza pracy jest następująca: Rekonstrukcja dobrych praktyk biznesowych i wartości organizacyjnych zawartych $w$ wybranych tradycjach polskiej przedsiębiorczości dostarcza narzędzi intelektualnych do optymalizowania dzialań wspótczesnych organizacji.

Przez „narzędzia intelektualne” rozumiem kategorie pojęciowe i pomysły dotyczące wartości oraz dobrych praktyk biznesowych. Stanowią one zawartość treściową kapitału kulturowego organizacji.

Termin „kulturowy kapitał organizacji” wprowadzam dla potrzeb niniejszej monografii wzorując się na „kapitale kulturowym miejsca pracy” w ujęciu Michelle Lamont i Williama Lockharta. Doprecyzowaniu i wyjaśnieniu tych pojęć poświęcam podrozdział 1.1. pierwszego rozdziału prezentowanej publikacji.

Praca na Wydziale Zarządzania UW zwalnia mnie z rozważań terminologicznych, dotyczących drugiego z tytułowych pojęć prezentowanej pracy, to jest „przedsiębiorczości”. W Zakładzie Innowacji Organizacyjnych i Przedsiębiorczości mojego wydziału sukcesywnie powstają prace badawcze oraz opracowania monograficzne i podręcznikowe dotyczące zjawiska przedsiębiorczości pióra prof. Beaty Glinki i jej współpracowników (np. Glinka 2008, 2013, Glinka i Gudkova 2011, Gudkova 2011). Z kolei pracownicy Szkoły Wyższej Psychologii Społecznej opublikowali niedawno obszerne analizy psychologicznych uwarunkowań działań przedsiębiorczych (Strzałecki 2011). Kontakt z Małopolską Szkołą Administracji Publicznej Uniwersytetu Ekonomicznego w Krakowie oraz z warszawską Fundacją „Nadzieja”, centrami rozwoju przedsiębiorczości społecznej w Polsce, ułatwił mi poznanie także tej formy aktywności gospodarczej (zob. półrocznik „Ekonomia społeczna” i Ochinowski 2010). Nie wchodząc $\mathrm{w}$ istotne dyskusje terminologiczne, rozwijane przez badaczy $\mathrm{z}$ wymienionych i innych ośrodków, dla potrzeb niniejszej pracy stosuję minimalistyczne określenie przedsiębiorczości jako działalności gospodarczej lub, szerzej, zawodowej, związanej ze „sposobem myślenia, rozumowania oraz działania, nakierowanego na wyszukiwanie szans" (w znacznej części wykorzystuję tu określenie przedsiębiorczości według Jeffry'a Timmonsa, cyt. za Glinką 2013: 63). Ważne doprecyzowanie opisu rzeczywistości, określanej terminem „przedsiębiorczość, 
zawdzięczam pracy Ekonomia biednego (2012, ang. Poor Economics) opublikowanej niedawno przez Abhijita V. Banerjee i Esther Duflo, profesorów Massachusetts Institue of Technology na podstawie globalnych badań dotyczących gospodarczego funkcjonowania ludzi biednych. Cytowani badacze częściowo polemizują ze słynną tezą Muhammada Yunusa (np. 2010), że człowiek biedny jest „naturalnym przedsiębiorcom” (Banerjee i Duflo 2012: 207). Przyznają, iż „prawdziwa przedsiębiorczość” ujawnia się w sytuacji opisywanej zadaniem: „jeśli masz bardzo mało, użyj swej pomysłowości, by stworzyć coś więcej niż nic" (Banerjee i Duflo 2012: 206). Jednak, zauważają Banerjee i Duflo (2012), jest to przedsiębiorczość ,z przymusu”, sposób na przetrwanie (bo nie ma innego wyjścia), a nie realizacja działań, które zgodnie z intencją cytowanych badaczy (którzy nie używają takiego sformułowania) można by określić jako motywowane „duchem przedsiębiorczości”. Żeby przedsiębiorca chciał angażować w swój biznes nie tylko pieniądze, ale także emocje i zasoby intelektualne, to jego przedsięwzięcie musi być na tyle finansowo znaczące, by dawało realną, odczuwaną przez niego szansę na zmianę życiową (oczywiście w kierunku podwyższenia standardów, Banerjee i Duflo 2012). Właśnie takich przykładów przedsiębiorczości poszukiwałem w polskich tradycjach biznesowych. Spełniając przytoczony warunek „istotności życiowej”, mogą one stać się źródłem wartości i dobrych praktyk dla współczesnego zarządzania (na temat relacji przedsiębiorczość-zarządzanie zob. Kostera i Śliwa 2012). Monografia Łukasza Sułkowskiego (2012) poświęcona kulturowym procesom zarządzania, pokazała, iż w profesjonalnej literaturze im poświęconej, trzeci z kluczowych dla mojej pracy terminów - „tradycje” - ma raczej wartościujące, negatywne konotacje. Kojarzony jest z konserwatyzmem członków organizacji i oporem wobec zmian. W prezentowanej publikacji używam wyłącznie potocznego rozumienia pojęcia „tradycja”, na co pozwala perspektywa historii historiografii. Tradycje przedsiębiorczości $w$ Polsce to dla mnie wszelkie idee i praktyki związane z przedsiębiorczością, które powstawały, urzeczywistniały się lub/i rozwijały w przeszłości na ziemiach polskich. Nie postrzegam ich negatywnie.

Stosunkowo często przewija się przez strony niniejszej pracy termin „mit”. Używając go przeciwstawiam się sugestiom Andrzeja Wierzbickiego, który na określenie tzw. mitów historiograficznych woli pojęcie „metafory” zaproponowane w Polsce przez Wojciecha Wrzoska (1995, 2011, por. Wierzbicki 2006), a w kontekście mojej pracy sugerował pisanie o „etosie”. Jednak zarówno „metafora”, jaki i „etos” mają w zarządzaniu ugruntowane znaczenie. Jeśli chodzi o metaforę, to jest ono podobne do tego, które jest używane przez historiografów. Odnośnie do idei naukowych także w mojej pracy używam czasami pojęcia „metafora”. Natomiast z perspektywy praktyki zarządzania „etos” budzi raczej skojarzenia związane $\mathrm{z}$ misją firmy czy zawodu, jak też z pracą, co bardzo zawęża jego rozumienie. Stosuję więc pojęcie „mit” w różnych kon- 
tekstach znaczeniowych, za każdym razem je wyjaśniając na stronach poszczególnych podrozdziałów. Łączy je najszersze z podawanych przez Wierzbickiego znaczeń terminu „mit”, których używali polscy historycy ostatniego półwiecza. Chodzi o zbiór idei, zyskujących „mityczny status (...) poprzez aksjologiczne nacechowanie i przesłanie skierowane ku przyszłości” (Wierzbicki 2006: 186).

Metodyka badawcza mojej pracy związana jest z podejściem jakościowym. Wykorzystane tu zostały w szczególności:

1. metoda historiograficzna, czyli jakościowa analiza idei dotyczących rozumienia historyczności zjawisk istotnych dla zarządzania oraz rekonstrukcja tych idei zawartych w mało znanych pracach autorów polskich i działaniach polskich przedsiębiorców z przeszłości;

2. metoda historyczna - jakościowe badanie kapitału kulturowego zawartego w wybranych tradycjach polskiej przedsiębiorczości za pomocą:

- analizy treści historycznych tekstów publicystycznych dotyczących przedsiębiorczości,

- analizy treści literatury pięknej,

- krytycznej analizy dokumentów archiwalnych oraz relacji spisanych i mówionych (częściowo wywołanych na potrzeby niniejszej pracy);

3. wykorzystanie metodyki „uczenie się przez działanie” (ang. learning by doing) - obserwacja uczestnicząca aplikacji historycznego modelu przedsiębiorczości we współczesnej firmie;

4. analiza porównawcza kapitału kulturowego zawartego w tradycjach polskiej przedsiębiorczości z wybranymi ideami i koncepcjami współczesnego zarządzania.

W niektórych wypadkach do analizy treści wykorzystuję technikę analizy pól semantycznych ${ }^{4}$ oraz porządkuję dane za pomocą statystycznej techniki

$4 \quad$ Nieco zmodyfikowana klasyczna wersja analizy pól semantycznych, skonstruowanej przez Reginę Robin (1980), polega na wyodrębnieniu z analizowanego tekstu słów-kluczy i zbadaniu relacji tych wyrazów z innymi elementami treści. Należy wziąć pod uwagę następujące składniki:

- określenia - „wszystko to, co określa istotę lub sposób bycia podmiotu bądź wykonawcy czynności” oznaczanego przez słowo-klucz (Robin 1980: 255) i ekwiwalenty, czyli takie elementy treściowe które posiadają takie same określenia, asocjacje i opozycje jak słowo-klucz,

- asocjacje, czyli wszystkie występujące w tekście pozytywne skojarzenia ze słowemkluczem,

- opozycje - wszystkie elementy treściowe przeciwstawiane w tekście słowu-kluczowi,

- „działania czyjeś” - wszystkie elementy treściowe opisujące działania podmiotu określanego przez słowo-klucz,

- „działania na” - wszystkie elementy treściowe opisujące działania „skierowane na podmiot przez inne siły, przez kogoś trzeciego. W tym (...) wypadku podmiot podlega raczej jakiemuś działaniu, a nie kieruje nim, jest bierny i to nim się manipuluje" (Robin 1980, 255). 
taksonomii wrocławskiej. W celu pozyskania niektórych pomocniczych danych używam też dodatkowych badań jakościowych i kwestionariuszowych, których wyniki również opracowuję za pomocą taksonomii wrocławskiej.

Taksonomia wrocławska służy mi jako narzędzie pomocnicze w docieraniu do kategorii treściowych badanych przeze mnie różnych rodzajów kapitału kulturowego. Identyfikacja kategorii treściowych jest oczywiście możliwa jedynie na drodze analizy jakościowej. Warto jednak, przy realizacji takiego zadania poznawczego, posłużyć się także narzędziami statystycznymi, które nie będą weryfikować jakichkolwiek hipotez, ale pomogą uporządkować intuicje badacza.

Walory takiej właśnie techniki statystycznej posiada moim zdaniem taksonomia wrocławska, dzięki której możliwe jest uporządkowanie zbioru danych z badań ankietowych lub narracyjnych w postaci specjalnie utworzonych quasi-czynników, które traktować można jako „wewnętrzne kategorie” (relacjonowane przez badanych lub zawarte $\mathrm{w}$ materiałach archiwalnych) analizowanej organizacji (Nowak 1990). Określenie „czynnik”5 rezerwuję dla wyników procedury statystycznej noszącej nazwę „analiza czynnikowa”. Dla rezultatów „słabszych” technik grupowania zmiennych proponuje używanie pojęcia „quasi-czynnik”. Taksonomia wrocławska należy do technik nie wymagających testów parametrycznych, ani też normalnego rozkładu zmiennych. Przy zastosowaniu nieparametrycznych współczynników korelacji możliwa jest do zastosowania także na porządkowym poziomie pomiaru, tak jak to ma miejsce w wypadku badań jakościowych ${ }^{6}$.

Jednostką analityczną jest zdanie. Należy wypisać wszystkie elementy występujące w każdym zdaniu. Gdy któryś z elementów powtarza się należy go wypisać tyle razy, ile razy się powtarza. Analizy wykonuje niezależnie przynajmniej od niezależnych sędziów kompetentnych. Mają oni za zadanie kierować się zasadą: „liczy się jakość nie ilość” (zidentyfikowanych kategorii). Do dalszej interpretacji brane są pod uwagę kategorie zidentyfikowane przez co najmniej dwóch sędziów.

5 Chodzi tu o statystyczne znaczenie słowa „czynnik”.

6 Polega ona na konstrukcji dendrytu, czyli podzbioru lub podzbiorów zmiennych uporządkowanych według linii łamanej rozgałęziającej się. Łamana ta nie zawiera łamanych zamkniętych. Łączy ona wszystkie obiekty należące do analizowanego zbioru zmiennych. Długości „wiązadeł” dendrytu zależą od odległości (mierzonych siłą współczynnika korelacji) pomiędzy odpowiednimi parami zmiennych. Dendryt umożliwia nieliniowe uporządkowanie zmiennych. Za najlepsze takie uporządkowanie nieliniowe danego zbioru zmiennych autorzy metody (Florek, Steinhaus i in.) uznali sytuację dla którego dendryt ma najmniejszą długość. Nieco bardziej szczegółowy opis procedur tej techniki zawarłem w podrozdziale 2.3. rozdziału II niniejszej pracy. Zarówno analizę pól semantycznych, jak i taksonomię wrocławską używam w mojej pracy jedynie jako techniki pomocnicze. Nie zamieszczam schematów pól semantycznych uzyskanych podczas poszczególnych analiz, ani dendrytów powstałych przy pomocy taksonomii wrocławskiej. Każdemu zainteresowanemu prześlę je drogą e-mailową (mój adres: ochinto@wz.uw.edu.pl). 
Praca składa się z 7 rozdziałów: dwa pierwsze dotyczą kapitału kulturowego organizacji, kolejne dwa historii organizacyjnej, rozdz. V i VI - wybranych tradycji polskiej przedsiębiorczości.

Autor niniejszej pracy czuje się jak muzyk, który pojedynczym uderzeniem w talerze kończy długi i emocjonujący koncert całej orkiestry. Prezentowana publikacja, zawierające analizy i badania, które powstawały na przestrzeni kilkunastu ostatnich lat, nie byłaby możliwa bez współpracy bardzo wielu życzliwych mi osób. Imiennie jestem teraz w stanie podziękować tylko niektórym z nich.

Bardzo wiele wspierających sugestii dotyczących różnych wersji poszczególnych rozdziałów tej książki (także fragmentów wersji pierwotnych publikowanych przeze mnie w artykułach) zawdzięczam profesorowi Andrzejowi Wierzbickiemu z Instytutu Historii PAN, profesorowi Tadeuszowi Oleksynowi z SGH, Piotrowi Gołaszewskiemu, refleksyjnemu praktykowi przedsiębiorczości i jego żonie Urszuli Gołaszewskiej oraz dr Waldemarowi Grzywaczowi i Jerzemu Jagodzińskiemu z Wydziału Zarządzania UW. W przypisach odnotowuję tylko przypadki, gdy wprost wykorzystałem ich myśli. Tak naprawdę jednak to wiele kwestii niniejszej pracy nosi ślad dyskusji lub współpracy badawczej z nimi. Wymienione osoby obdarzają mnie od wielu lat wsparciem, które znacznie przekracza formalne relacje zawodowe. Jak teraz widzę, oni także bardziej ode mnie wierzyli, że prezentowana praca będzie kiedyś zakończona.

Wiele zawdzięcza dyskusjom z prof. Haliną Grzymałą-Moszczyńską (Uniwersytet Jagielloński), prof. Davidem Hayem (Aberdin University w Szkocji i UJ) oraz korespondencji z prof. Michaelem Billigiem (Loughborough University, Wielka Brytania) na pierwszym etapie powstawania projektu tej publikacji.

Profesor Grażyna Wieczorkowska-Wierzbińska, Kierownik Katedry Psychologii i Socjologii Zarządzania UW WZ, w której pracuję, stworzyła mi możliwości rozwijania perspektywy historycznej dla potrzeb zarządzania, mimo iż to podejście jest bardzo dalekie od paradygmatu nauki uprawianej przez profesor Wieczorkowską-Wierzbińską na poziomie międzynarodowym. Podobnej tolerancji doświadczyłem wcześniej ze strony mojego poprzedniego przełożonego na Wydziale Zarządzania, profesora Jerzego Bogdanienki, Kierownika Katedry Teorii Zarząazania. Profesor Marian Dobrzyński, pod którego kierunkiem pracowałem jak dotąd najdłużej w Katedrze Psychologii Organizacji WZ UW, mimo iż wiele moich pomysłów uważał za dyskusyjne, to na różne sposoby wspierał zainteresowania historią w zarządzaniu. Jego wnikliwa recenzja wydawnicza uchroniła niniejszą pracę od licznych niedoskonałości. Podobnie jak uwagi autora drugiej recenzji, wspomnianego już profesora Tadeusza Oleksyna.

Dr Martyna Śliwa z Uniwersytetu w Essex (Wielka Brytania), jedyna przedstawicielka polskich nauk o zarządzaniu w głównym nurcie historii organizacyjnej krytyczniej przeczytała fragmenty mojej monografii poświęcone prezentacji tej dziedziny wiedzy i podzieliła się ze mną cennymi uwagami. 
Osadzenie prezentowanej pracy w aktualnej problematyce zarządzania byłoby niemożliwe bez merytorycznej pomocy i życzliwości profesora Romana Głowackiego, nestora marketingu w Polsce i wieloletniego Kierownika Katedry Marketingu na Wydziale Zarządzania UW, profesora Grzegorza Karasiewicza, obecnego Kierownika tejże Katedry oraz również w niej pracującego doc. dr Krzysztofa Cybulskiego, z którym odbyłem trudną do oszacowania ilość zawsze płodnych poznawczo dyskusji.

Bardzo cennym doświadczeniem intelektualnym jest dla mnie współpraca z prof. Jerzym Kisielnickim (Katedra Systemów Zarządzania WZ UW), który regularnie od wielu lat zaprasza mnie do uczestniczenia w ogólnopolskich i zagranicznych projektach badawczych oraz do pracy nad publikacjami.

Dzięki dyskusjom na seminarium historiograficznym w Instytucie Historii PAN mogłem kompetentnie zając się historią organizacyjną. Oprócz prof. Wierzbickiego szczególnie wiele intelektualnych inspiracji zawdzięczam innnym uczestnikom tych dyskusji: prof. Katarzynie Błachowskiej z Instytutu Historycznego UW, z którą współpracuję również dydaktycznie, prof. Zbigniewowi Romkowi, który po prof. Wierzbickim przejął funkcję koordynowania prac seminaryjnych, dr. Marcinowi Wolniewiczowi oraz dr Annie Zalewskiej z Instytutu Archeologii UMSC w Lublinie. Prof. Błachowska krytycznie przeczytała finalne wersje rozdziałów tej pracy dotyczące problematyki historiograficznej. Poza „seminarium Wierzbickiego” wiele kwestii dotyczących współpracy historii i innych dziedzin wiedzy mogłem i nadal mogę przedyskutować z historykami historiografii: dr Anną Zapalec (Uniwersytet Pedagogiczny w Krakowie) i prof. Tomaszem Pawelcem (Uniwersytet Śląski). Anna Jagodzińska z IPN umożliwiła mi korzystanie z zasobów archiwalnych tego Instytutu oraz uczyła mnie warsztatu pracy badawczej w archiwum. Profesor Andrzej Rzepliński z Instytutu Profilaktyki Społecznej i Resocjalizacji, obecnie Przewodniczący Trybunału Konstytucyjnego, zechciał dwukrotnie objąć kierownictwo merytoryczne projektów zajęć z pogranicza zarządzania, nauk społecznych i historii, które zyskały wsparcie Funduszu Innowacji Dydaktycznych UW (byłem inicjatorem i kierownikiem wykonawczym tych projektów).

$\mathrm{Na}$ Wydziale Zarządzania płaszczyznę dla dyskusji nad historią organizacyjną stworzył doc. dr Mariusz Szałański, regularnie zapraszając mnie, bym przedstawiał referaty prezentujące tę perspektywę podczas konferencji poświęconych rozwojowi Mazowsza, które organizuje corocznie. Wcześniej możliwość wspomnianych dyskusji dawało mi współprowadzenie z dr. Waldemarem Koziołem i Jerzym Jagodzińskim zajęć dotyczących historii gospodarczej dla studentów zarządzania. Wykłady promujące problematykę historyczną na Wydziale Zarządzania UW zawsze wspierali kierujący poszczególnymi typami studiów: doc. dr Zofia Skrzypczak, doc. dr Ewa Krakowińska, obecnie prodziekan do spraw studenckich oraz Jacek Kiryło. 
Wiele trudu w pomoc w zakresie przygotowania materiałów do tej pracy, a także udziału w ich analizie i w różnych badaniach włożyli doktoranci: Beata Sapiejewska-Dąbrowska (dawniej UKSW, obecnie badaczka niezależna) wraz z mężem Jackiem Dąbrowskim i Piotr Katus (Wydział Zarządzania UW) oraz moi byli studenci, a później partnerzy przedsięwzięć badawczych: Monika Strocka, Agnieszka Kseba, Karolina Rasińska, Krzysztof Zadrożny i Szymon Terlecki. Udział moich studentów, dyplomantów i magistrantów w badaniach składających się na niniejszą publikację staram się odnotować w przypisach. Niestety zidentyfikowanie wszystkich nie jest dziś możliwe, za co pominiętych serdecznie przepraszam.

Moi najbliżsi, żona Danusia Ochinowska oraz nasze dzieci: Januszek, Pawełek i Karolinka, nie tylko przetrwali wieloletnie zmagania autora z problematyką prezentowaną w niniejszej pracy, ale także sprawili, że przetrwał on również.

Wszystkim wymienionym i niewymienionym serdecznie dziękuję. Odpowiedzialność za to, iż mimo dużej pomocy ze strony znacznej liczby osób, prezentowana publikacja jest tylko taka jak jest, a nie dużo lepsza, spada wyłącznie na mnie. 


\section{Rozdział I}

\section{Rola kapitału kulturowego w zarządzaniu organizacją}

\subsection{Kapitał kulturowy miejsca pracy a kapitał kulturowy organizacji}

\subsubsection{Koncepcja kapitału kulturowego miejsca pracy według Michelle Lamont i Williama Lockharta}

Ćwierć wieku temu George T. Milkovich i John W. Boudreau (1988) zauważyli, iż współczesny im czytelnik miał do dyspozycji wiele tomów napisanych na temat istotnej roli, jaką kultura organizacyjna odgrywa w efektywności działań organizacji. Podczas następnych dekad przekonanie o znaczeniu tej problematyki dla świata biznesu wydawało się ugruntować jeszcze bardziej. Wystarczało przejrzeć choćby publikacje podręcznikowe używane na studiach menedżerskich, także w Polsce (np. Makin, Cooper i Cox 2000 oraz Robbins 2000 i nast., por. Grzywacz, Ochinowski i Nawrocki 2001).

Dziś ranga wspomnianej problematyki w zarządzaniu nie jest już tak bezdyskusyjnie wysoka. Potoczne doświadczenie nauczyciela akademickiego pozwala (bez przesadnego niebezpieczeństwa nieuzasadnionego uogólnienia) wyobrazić sobie obecnie studenta, który zmuszony do przeczytania podręcznika z dziedziny biznesu, napotkawszy część poświęconą problematyce kulturowej odetchnie z ulgą: „No, ten rozdział mogę spokojnie pominąć. O kulturze nie muszę się uczyć, bo to już niemodne".

Rzeczywiście, szczyt zainteresowania problematyką kultury organizacyjnej, zwany „boomem lat osiemdziesiątych”, minął dość dawno. Opublikowana przed pięciu laty praca Sylwii Stańczyk (2008) i ostatnio wydana obszerna monografia pióra Łukasza Sułkowskiego (2012) mówiące wręcz o „kulturowym nurcie w zarządzaniu" pozornie wydają się być łabędzim śpiewem (bądź przejawem głębokiej intuicji poznawczej) także na polskim rynku wydawniczym. Dziś większym powodzeniem niż problemy kulturowe cieszą się wśród autorów fachowych 
publikacji takie kwestie, jak zarządzanie wiedzą, inne zagadnienia związane z procesami poznawczymi, precyzyjnym modelowaniem zjawisk organizacyjnych, finansami, innowacją i tak dalej, i temu podobne. Jednak powracające jak bumerang kłopoty firm międzynarodowych, a szczególnie nagłe i kosztowne powroty „expatów” przerywających swe misje, niedające się rozwiązać „twardymi” metodami wyzwania w zarządzaniu ludźmi, także te niezależne od kontekstu międzynarodowego czy różne nietypowe przejawy ostatniego kryzysu, „oporne” wobec precyzji ekonomistów, by sięgnąć po przykłady leżące na wyciągnięcie ręki, usprawiedliwiają refleksję, iż głoszenie „śmierci” perspektywy kulturowej w zarządzaniu byłoby cokolwiek przedwczesne. Jeśli prawdziwe jest stwierdzenie, popularne wśród antropologów, iż katar jest przejawem natury, ale już zrobienie z nim czegokolwiek należy do kultury, to problematyka kulturowa wyraźnie zasługuje na miano „stałej antropicznej” ${ }^{1}$ zarządzania i nigdy nie wiadomo, kiedy stare z pozoru kwestie, a także próby odpowiedzi nie staną się znowu zaskakująco aktualne.

W każdym razie liczba 4600 artykułów dotyczących samej tylko kultury organizacyjnej od początku wspomnianych lat 80 . ubiegłego stulecia do dziś 2 musi robić wrażenie nawet na największych sceptykach. A, co warto raz jeszcze podkreślić, kultura organizacyjna to tylko jeden z kulturowych tematów istotnych dla współczesnego biznesu. Szczególną dynamikę, jeśli chodzi o zainteresowania teoretyków i praktyków zarządzania, ujawniają na przykład dwa zbiory problemów: kulturowe uwarunkowania działań gospodarczych oraz kontakty międzykulturowe w biznesie. Obecnie obszary te są tak rozbudowane, iż rozwijają się jako odrębne dziedziny nauk o gospodarce: jako antropologia ekonomiczna oraz zarządzanie międzykulturowe. W ciągu ostatnich lat również polski czytelnik otrzymał nowe podręczniki dotyczące tych dziedzin. Pierwszą z wymienionych przybliża studentom publikacja Ekonomie i kultury. Podstawy antropologii kulturowej Richarda R. Wilka i Lisy Cligett (2011) przełożony przez Joannę Gilewicz, drugą choćby Zarzadzanie międzykulturowe pod redakcją Beaty Glinki i Adama W. Jelonka (2010) czy Kompetencje międzykulturowe Sławomira Magali (2011), przekraczając zresztą znacznie charakter podręcznika.

Monografii, które zawierają bogaty materiał empiryczny, doczekały się ostatnio na polskim rynku wydawniczym (co stanowi wyraz przybliżania polskiemu odbiorcy trendów światowych w naukach o zarządzaniu) kulturowe uwarun-

1 Zapożyczam tu termin sformułowany przed laty przez Józefa Kozieleckiego, pomijając kwestię istnienia bądź nieistnienia natury ludzkiej. Chodzi tylko o to, że problematyka kulturowa wyraźnie stanowi stały element relacji człowiek-organizacje, niezależny np. od mód w zarządzaniu.

2 Przy czym chodzi o teksty dostępne autorom amerykańskim (Hartnell, Ou i Kunicki 2011). Sporą liczbę zarówno międzynarodowych jak i polskich badań poświęconych kulturowej problematyce zarządzania od lat 90. do pierwszej dekady po roku 2000 analizuje cytowana wcześniej Stańczyk (2008). 
kowania przedsiębiorczości (Glinka 2008) i zarządzania kapitałem społecznym (Juchnowicz 2009), a także szeroko rozumiane kulturowe procesy zarządzania (Sułkowski 2012). Podręcznik teorii organizacji pióra Moniki Kostery i Martyny Sliwy (2012), będący prezentacją najbardziej aktualnych ujęć tej problematyki, Zarzadzanie w XXI wieku zawiera w podtytule trzy kategorie: ,jakość”, „twórczość” - i właśnie - „kultura”.

Do przykładów szerszego (niż tylko ograniczenie się do zagadnień kultury organizacyjnej) ujęcia tej problematyki należy problematyka kapitału kulturowego przynajmniej od początku lat 90 . ubiegłego wieku przekraczająca dynamicznie granice socjologii, w obszarze której się narodził i „goszcząca” na terenie różnych nauk (Ochinowski 2012a, 2013).

Przykład bezpośredniego połączenia kategorii kapitału kulturowego z praktyką zarządzania stanowi koncepcja kulturowego kapitału miejsca pracy, która pojawiła się przy okazji klasycznych już dziś badań Michelle Lamont (1992) nad kulturowym kapitałem miejsca pracy. Przywołana autorka wykorzystała dobrze już zadomowioną na terenie nauk społecznych bourdierowską konceptualizację pojęcia „kapitał kulturowy” przy analizie między innymi zjawisk biznesowych.

Przywołany tu pomysł Pierre'a Bourdieu, należący do zasobu podręcznikowej wiedzy nawet przeciętnego studenta socjologii, ma też - jak to bywa $z$ teoriami humanistycznymi - swe ideowe poprzedniki literackie. Polski czytelnik literatury pięknej bez trudu znajdzie intuicje dotyczące koncepcji bourdierowskich kapitałów choćby w słynnym dialogu z Ziemi Obiecanej sugestywnie sfilmowanym przez Andrzeja Wajdę: „Tak, ja nie mam nic, ty nie masz nic, on nie ma nic (...). To razem właśnie mamy tyle, w sam raz tyle, żeby założyć wielką fabrykę. Cóż stracimy? Zarobić zawsze można” (Reymont 1990: 10).

Używając nieco pretensjonalnej metaforyki można uznać, że pozornie odmiennego zdania był wspominany już Bourdieu, zmarły przez kilkunastu laty francuski socjolog (np. Bourdieu 2006, 2008 zob. także Wielicki 2012). Żeby zarobić - jak uświadamiał on czytelnikom swoich prac - a dokładnie rzecz biorąc, żeby osiągnąć sukces w działalności gospodarczej potrzeba trzech różnych kapitałów: (1) ekonomicznego (co zrozumiałe samo przez się, przecież głównie o pieniądzach zaczynają rozmawiać Karol, Maks i Moryc z Ziemi Obiecanej zaledwie chwilę po przytoczonym wyżej buńczucznym stwierdzeniu);

3 Perspektywa poznawcza mojej monografii osadzona w kontekście myśli historiograficznej upoważnia do spostrzeżenia, iż pierwszy człon tytułu publikacji Kostery i Śliwy (2013), przez odwołanie się do słynnej książki Petera F. Druckera Management Challenges for the 21st Century (wyd. pol. 2000, wyd. oryg. 1999), która w polskiej wersji wyszła pod właśnie pod tytułem Zarzadzanie w XXI wieku (w przekładzie Anny Śliwy i Leszka Śliwy), stanowi rzadki w naukach o zarządzaniu przykład kontynuacji tradycji, a nawet interseksualności. 
(2) społecznego („to my potrzebujemy mieć kredyt i zaufanie u tych, co go nam dadzą", jak u Reymonta konkluduje Moryc; oraz (3) kulturowego ${ }^{4}$.

Właśnie ostatni z wymienionych kapitałów pozwala uchwycić, zazwyczaj niedostrzegalne z perspektywy innych ujęć teoretycznych, relacje między kulturą i zarządzaniem.

Użyteczność pojęcia „kapitału kulturowego” dla praktyki menedżerskiej staje się oczywiste, gdy przyjrzeć się najpierw innemu pomysłowi cytowanego socjologa to jest „habitusowi”, „będącego - zdaniem Michela de Certeau (1990/ 2008: 53) znakiem, jaki Bourdieu odcisnął w teorii" (socjologicznej - dopisek T.O.). Tenże de Certeau (proponuje syntetycznie uważać „habitus” za coś, co jest nabyte. Pod omawianym pojęciem kryje się więc opis kompetencji, które człowiek nabywa mimochodem, poprzez samo bycie członkiem danej grupy społecznej ${ }^{5}$ czy innego środowiska. Badacze anglojęzyczni mówią przy tej okazji o tak zwanym street smart - jednostce, która posiada dużo zdrowego rozsądku podzielanego przez jej środowisko (Lockhart 2001, 2002). Dzięki temu jest intuicyjnie, „na nos” rozpoznawana oraz - co najważniejsze - wspierana „przez swoich”, na przykład wtedy, gdy zdaje egzaminy lub stara się o pracę. Jeśli komisję egzaminacyjna/rekrutacyjną tworzą osoby reprezentujące inną klasę społeczna/środowisko kulturowe niż kandydat, to od razu, bez niczyjej złej woli radykalnie zmniejszają się jego szanse na sukces. Kontynuując ten tok myślenia, Bourdieu wskazuje, iż ktoś posiada kapitał kulturowy, jeśli nabył kompetencje w zakresie kultury wysokiej ${ }^{6}$ swojego społeczeństwa.

Francuski socjolog wyróżnia klika form istnienia wspomnianego kapitału. Szczególną wagę, ze względu na znaczenie dla funkcjonowania jednostek i różnorodnych podmiotów społecznych, Bourdieu przywiązuje do ucieleśnionego kapitału kulturowego, który tworzą „długotrwałe dyspozycje ciała i umysłu jednostki" (Thorsby 2010: 54). Ucieleśniony kapitał kulturowy potwierdzony formalnie, na przykład dyplomem wyższej uczelni, staje się zinstytucjonalizowanym. Zaś kapitał kulturowy zamieniony w dobra kultury Bourdieu nazywa uprzedmiotowionym.

4 Bourdieu mówi także o czwartym rodzaju kapitału - symbolicznym (chodzi o symbole używane przez danego człowieka, które uprawomocniają posiadanie przez niego wspomnianych wcześniej kapitałów). Kapitał symboliczny jest szczególnie popularny wśród przedstawicieli krytycznego nurtu w zarządzaniu (ang. „CMS - Critical Management Studies”), którzy tropią za pomocą tej kategorii różnorodne przejawy przemocy symbolicznej w praktykach menedżerskich, a więc przede wszystkim ideologie usprawiedliwiające niesprawiedliwe stosunki pracy, dyskryminację itp. (Kostera i Śliwa 2012, Sułkowski 2012).

5 Oryginalnie Bourdieu sformułował koncepcję habitus w odniesieniu do klas społecznych.

6 Warto zauważyć, iż w ten sposób kultura wysoka, a więc dziedzictwo i twórczość kulturowa danego społeczeństwa zagościła także w kontekście problematyki zarządzania. I to na znacznie głębszym poziomie znaczeń niż tylko zarządzanie kulturą (to jest działalność menedżerska związana $\mathrm{z}$ funkcjonowaniem muzeów, teatrów itp.). 
Bourdierowskie rozumienie pojęcia „kapitał kulturowy” wykorzystała wprost do analizy zjawisk biznesowych, jak już pisałem, Michelle Lamont (1992). Pokazała ona w swoich badaniach, iż zarówno francuscy, jak i amerykańcy menedżerowie milcząco oczekują, że ich pracownik będzie ujawniał określony zespół zachowań oraz wyznawał szczególne wartości dotyczące głęboko rozumianej oraz autentycznie wyznawanej moralności pracy. Właśnie te dwa „filary” behawioralny i związany z wartościami - tworzą kulturowy kapitał miejsca pracy. Dla jednostek, które nie posiadają takiego „wyposażenia” (choć nie ma o nim oficjalnie mowy na żadnym etapie żadnego procesu rekrutacji czy selekcji), bardzo trudne, jeśli wręcz niemożliwe, jest awansowanie, a nawet przetrwanie w miejscu zatrudnienia realizującego standardy zachodniej gospodarki kapitalistycznej.

Aspekt „kulturowego kapitału miejsca pracy” związany z postępowaniem pracownika reprezentują takie zasady zachowania się, jak: bycie punktualnym w pracy, ładne ubieranie się na rozmowy kwalifikacyjne (interviews) oraz bycie uprzejmym wobec klientów i wobec przełożonych.

Z kolei moralność pracy („filar” dotyczący wartości), w ramach prezentowanej tu pokrótce koncepcji, sprowadzona jest do rzeczywiście wyznawanych przez danego pracownika przekonań pozwalających mu odpowiedzieć na, rozumiane głęboko, egzystencjalnie pytanie „dlaczego pracuję?”. Według Williama Lockharta (2002), którego publikacja stała się dla mnie główną inspiracją intelektualną prezentowanego paragrafu, amerykańska wersja aksjologicznego „filaru” „kulturowego kapitału miejsca pracy” ma dwa alternatywne oblicza. Sukcesowi pracownika pomaga zarówno moralizm ascetyczny, jak i ekspresyjny.

Ten pierwszy stanowi współczesną, zsekularyzowaną postać tradycyjnie rozumianego protestanckiego etosu pracy i wynika z przekonania rozwijanego od czasów reformacji, iż praca stanowi czynność tak samo przybliżającą człowieka do Boga jak modlitwa. Dziś dla wielu ludzi miejsce Boga zajmuje własny potencjał rozwojowy. Moralizm ascetyczny można więc sprowadzić do tezy „pracuję, bo to mnie rozwija". Pochodną takiego podejścia stanowi dyrektywa, mówiąca że „należy unikać lenistwa i nastawienia na materialną przyjemność, a zamiast tego lepiej jest oszczędzać i inwestować w przyszłe zyski”.

Moralizm ekspresyjny również ma korzenie religijne. Cytowany Lockhart (2002) za innymi autorami sytuuje jego genezę w nauczaniu pewnego kręgu amerykańskich kaznodziejów protestanckich z przełomu XIX i XX wieku, czerpiących inspiracje także $z$ europejskiego romantyzmu. Wychwalali oni - ich zdaniem naturalną dla ludzkiej duszy (daną przez Boga) - potrzebę zabawy i przyjemności. W takiej perspektywie działalność ekonomiczna zmierzająca do zaspokojenia podstawowych potrzeb życiowych jest pożądana i ostatecznie nieunikniona, ale nie jest pożądana działalność ekonomiczna poświęcona pościgowi za bogactwem lub wynikająca $\mathrm{z}$ żądzy prześcignięcia innych. Cel 
zarabiania pieniędzy nie stanowi więc proste pomnażanie zysków, ale dobrobyt. We współczesnej wersji, także dla ludzi niepodzielających przekonań religijnych, moralizm ekspresyjny przybrał postać przekonania: „pracuję, żeby mieć więcej zabawy i przyjemności”.

Poza zakresem zainteresowań niniejszej pracy pozostawiam dyskusję na temat tego, czy genezę obydwu typów moralizmu wiązać należy tylko z protestanckim kręgiem kulturowym.

Trudno się jedynie oprzeć wskazaniu podobieństwa koncepcji moralizmu ekspresyjnego do idei „otium”, zapożyczonej ze starożytności przez europejskich twórców i myślicieli epoki renesansu. W XVI wieku była ona dyskutowana szeroko niezależnie od przekonań religijnych rozmówców. Chodziło o uprawianie pożytecznego zajęcia wynikającego z postawy niezależności, z osobistej, nie nakazanej przez nikogo inicjatywy. Polszczyźnie pojęcie „otium” przyswoił Wespazjan Kochowski, posługując się poetyckim przekładem omawianego terminu „niepróżnujące próżnowanie”. Ludzie renesansu szeroko dyskutowali problem, czy taka aktywność jest pracą (Otwinowska 1980).

Dziś kategoria „otium” wraca na przykład poprzez ideologię ruchów Slow-Down (np. Laskowska-Otwinowska 2010). Zaś w obszarze zarządzania jej ewidentną, a zarazem bardzo praktyczną formę obecności stanowi opisane przeze mnie zjawisko flow (,przepływ”, ,uskrzydlenie”) wraz ze swym wkładem do problematyki motywowania, coachingu, innowacyjności i temu podobnych (Csikszentmihályi 2005 i in.).

Zresztą obydwa rodzaje moralizmów niedawno znalazły się blisko psychologicznych badań nad postawami wobec pracy. Amy Wrześniewski (Seligman 2005) wykazała, iż wśród przedstawicieli praktycznie każdego zawodu można wyróżnić osoby traktujące swą aktywność zarobkową przede wszystkim jako zajęcie, takich, którzy widzą w niej przede wszystkim sposób realizacji kariery i wreszcie takich, którzy kierują się przede wszystkim „zewem” (ang calling, Seligman $2005^{8}$ ). Treściowo „kariera” odpowiada mniej więcej moralizmowi ascetycznemu, „zew” - ekspresyjnemu9 . Zaś postawa „zajęcie” to wyraźnie psychologiczny wskaźnik, innego niż wcześniej omówione, typów „moralności pracy”, który sprowadza się do przekonania „pracuję, bo muszę”. Jak widać,

7 Prowadzone sukcesywnie w Polsce, pod moim kierunkiem, badania funkcjonariuszy Służby Więziennej (wykorzystujące eksperymentalne tłumaczenie kwestionariusza Wrześniewski) pokazują, że również w tej grupie zawodowej istnieje wspomniane zróżnicowanie postaw wobec pracy.

8 Używam spolszczenia terminu calling zaproponowanego przez Monikę Strocką (,zew”, a nie „powołanie” jak przekłada wspomniany termin tłumacz cytowanej pracy; moim zdaniem „zew” znacznie lepiej niż „powołanie” pasuje do kontekstu koncepcji A. Wrześniewski).

9 Słabością techniki proponowanej przez Wrześniewski jest fakt, iż najwyraźniej nie odróżnia ona osób pracujących „,z powołaniem” od pracoholików. 
bywa ono podzielane przez zatrudnionych, ale nie wchodzi w skład kulturowego kapitału miejsca pracy. $\mathrm{Z}$ takim nastawieniem jednostce bardzo trudno więc awansować, a nawet utrzymać pracę $\mathrm{w}$ warunkach zachodniego rynku. Jeszcze badania z połowy lat dziewięćdziesiątych ubiegłego stulecia sugerowały, iż ta ostatnia $\mathrm{z}$ wymienionych postaw dominowała wśród Polaków. Dziś sprawa jest bardziej skomplikowana (por. np. Juchnowicz 2009 oraz Kochanowicz i Marody 2010). Wymaga szczegółowych analiz.

Warto przy tym podkreślić, iż przestrzega przed zbytnim idealizmem wskazując, że nawet w USA wielu ludzi z klasy średniej (i klas wyższych) może zakładać, iż wszyscy dorośli posiadają kapitał kulturowy miejsca pracy. Jest to złudzenie. Cytowany autor postuluje więc uczenie umiejętności związanych z kulturowym kapitałem miejsca pracy poprzez treningi zorientowane praktycznie, „życiowo”. W każdym razie, konkluduje Lockhart (2002), moralność pracy stanowi formę opisywanego tu kapitału.

Pamiętając o zastrzeżeniach Lockharta (2002), nietrudno zauważyć istotne znaczenie zarówno moralizmu ascetycznego, jak i ekspresyjnego jako kulturowych podstaw rozwoju kapitalizmu. Z pominięciem subtelności, które pozostawiam dyskusjom historyków gospodarki, można bez dużego ryzyka pomyłki zasugerować, iż pierwszy typ moralności pracy wspomógł szczególnie europejską, XVIII i XIX-wieczną wersję systemu kapitalistycznego, zaś drugi - jego nowoczesną amerykańską postać zapoczątkowaną na przełomie stuleci XIX i XX.

Obydwa zaś moralizmy proponuję uznać za aksjologiczną (dotyczącą wartości) podstawę znanego powszechnie mitu american dream, czyli idei „od pucybuta do milionera”, którą - również powszechnie - uważa się za „kulturowe paliwo" globalnego rozwoju amerykańskiej wersji kapitalizmu (Ochinowski 2012a, 2013).

\subsubsection{Kulturowy kapitał organizacji}

Zasugerowane w poprzednim paragrafie konteksty znaczeniowe terminu „kapitał kulturowy miejsca pracy” ośmielają do poszerzenia wspomnianej koncepcji o kategorię „kulturowy kapitał organizacji”. Tę niewielką ekstrapolację znaczenia bourdieurowskiego pojęcia proponuję oprzeć na koncepcji treści kultury organizacyjnej sformułowanej przed laty przez Edgara H. Scheina (1999), z wykorzystaniem również konstruktywistycznego oraz retorycznego podejścia w naukach o zarządzaniu.

Warto zwrócić na marginesie uwagę, iż przywołany amerykański badacz funkcjonuje na polskim rynku idei trochę niczym wiatr z zagadki dla dzieci: „Co to jest - słychać go, ale nie widać?”. O pracach Scheina słyszał zapewne każdy student zarządzania, ale niewiele z nich zostało dotąd przetłumaczonych na język polski. Stąd wynika wybiórczość i częsta niejednoznaczność recepcji 
myśli Scheina w naszym kraju. Następnie wydobywam te wątki z koncepcji kultury organizacyjnej według Scheina, które wydają się mniej „zadomowione” wśród polskich studentów i menedżerów niż znana powszechnie, przynajmniej w szkołach biznesu, metafora „góry lodowej”, a które wyraźnie są bliskie problematyce kapitału kulturowego.

Zgodnie z popularną w myśli menedżerskiej klasyfikacją rozumienia „natury kultury organizacyjnej” zaproponowaną przez Lindę Smircich (Kostera 2005 i Glinka 2011), koncepcja Edgara Scheina (1999, 2004, zob. także Marcinkowski 2000, Grzywacz, Ochinowski i Nawrocki 2001, Kostera, Kownacki i Szumski 2002 i in.) ujmuje kulturę organizacyjną jako „zmienną wewnętrzną”, jako podsystem organizacji, którym można zarządzać, by uzyskać efekty korzystne finansowo.

Warto podkreślić konsekwentne podejście kliniczne reprezentowane przez Scheina. Wyraźnie wręcz denerwują go jakiekolwiek próby badania kultury organizacyjnej za pomocą testów. Podobnie sądzi o typologiach. Amerykański badacz uważa, iż jest tyle kultur organizacyjnych, ile organizacji, i to tylko w danym momencie. W świetle ustaleń Scheina, kultura organizacji ma wyraźnie „naturę” temporalną, zmienia się na przestrzeni czasu. Jego zdaniem, na kulturę organizacyjną składa się suma wszystkich założeń:

- których grupa nauczyła się w ciągu swojej historii,

- które podzielają członkowie grupy,

- które grupa uważa za oczywiste.

Kultura reprezentuje sposób myślenia, odczuwania i postrzegania świata, który przyniósł grupie sukces. Według omawianego badacza stanowi ona łączny wynik uczenia się danej zbiorowości. Dlatego też jest bardzo trudna do intencjonalnej zmiany. Warto przypomnieć, iż zdaniem Scheina, na głębszym poziomie kulturę tworzą wspólne sposoby myślenia i „umysłowe modele rzeczywistości”, które członkowie organizacji uznają oraz uważają za oczywiste. Założenia kulturowe dotyczą nie tylko wewnętrznych działań organizacji, ale także określają to, jak dany zespół widzi sam siebie w relacji z różnymi aspektami środowiska, w którym funkcjonuje. Autor Organizational Culture and Leadership jest przekonany, że nie można mówić o kulturach lepszych lub gorszych (tak jak nie można mówić o lepszej lub gorszej osobowości). Jedynym kryterium pozwalającym na elementy oceny jest odniesienie się do tego, na co pozwala środowisko.

Wszelkie zmiany muszą uwzględnić odpowiedź na zasadnicze pytanie o to, jak założenia leżące u podstaw postulowanych nowych wartości są możliwe do zastosowania w otoczeniu, w którym organizacje muszą funkcjonować. Oprócz opisywanych przez liczne podręczniki i monografie, także w języku polskim, trzech poziomów kultury organizacyjnej ujętej za pomocą znanej metafory góry lodowej. Te trzy poziomy to: (1) widoczne i uświadomione artefakty; (2) częściowo widoczne i częściowo uświadomione normy, czyli niepisane zasa- 
dy postępowania i reguły gry wskazujące uczestnikom organizacji, jak mają postępować oraz wartości określające, co jest dobre dla organizacji; (3) poziom najgłębszy - całkowicie niewidoczne i nieuświadomione tak zwane założenia wyznaczające najważniejsze wartości firmy. Schein opisał także obszary treści kultury różnicujące organizacje. Dotyczą one następujących kwestii:

1) co i jak organizacja ma robić, by przetrwać w środowisku oraz wzrastać - chodzi w tym przypadku o tak zwane kwestie dotyczące przetrwana w środowisku zewnętrznym, które cytowany autor porządkuje w trzy grupy: (a) przekonania na temat misji, strategii i celów organizacji, (b) przekonania na temat struktur, systemów i procesów, (c) przekonania na temat sposobów pomiarów błędów oraz systemu ich korekty;

2) co ma na celu zrobienie $z$ danej organizacji bardziej produktywnego, a zarazem przyjemnego miejsca pracy - chodzi o tak zwane kwestie dotyczące integracji wewnętrznej, które tworzą cztery zespoły zagadnień: (a) wspólny język i sposób myślenia charakterystyczny dla danej organizacji, (b) granice określające grupę i czynniki wyznaczające tożsamość jej członków, (c) natura autorytetów i relacji ludzkich, (d) przyznawanie nagród i stanowisk;

3) pogląqów założycieli, liderów i członków danej organizacji odzwierciedlających podstawowe idee kultury narodowej - chodzi o tak zwane głębsze założenia dotyczące relacji ludzi ze środowiskiem, natury człowieka, stosunków międzyludzkich, oraz natury prawdy i rzeczywistości.

Powierzchownego czytelnika uderzyć może brak precyzji w przytoczonych określeniach autora Podręcznika przetrwania kultury organizacyjnej. Antropomorfizacja grupy, która „uczy się założen” oraz „uważa je za oczywiste”, a także teza o tym, że założenia tworzące kulturę organizacyjną są „podzielane przez członków grupy" nie rozstrzygają choćby tak oczywistej kwestii, jak sprawa kryteriów ilościowych i jakościowych pozwalających określić minimalny zbiór członków organizacji podzielających te same założenia oraz umiejscowić tych członków w strukturze tak, by można ich było uznać za reprezentatywnych przedstawicieli danej kultury organizacyjnej. I niejasności te dotyczą oczywiście zarówno tak zwanych założeń umiejscawianych przez Scheina na trzecim, najgłębszym poziomie „góry lodowej”, jak i założeń w sensie elementów treściowych kultury danej firmy.

Nie do końca jasno rysują się relacje między obszarami treści kultury organizacyjnej a jej poziomami w ujęciu cytowanego klasyka omawianej problematyki.

Wydaje się, że zasadniczą treść kultury danej organizacji (czyli odpowiedzi na pytania, co pozwala organizacji przetrwać, co sprawia, że jest efektywnym, a zarazem przyjemnym miejscem do pracy oraz jakie poglądy wnoszą do firmy jej członkowie) wyznaczają przekonania członków firmy z drugiego i trzeciego poziomu „góry lodowej”. Oczywiście trzeci poziom (założenia podstawowe), jako niewidoczny oraz nieuświadomiony jest bardzo trudny do zbadania. 
Z kolei zwartość treściowa drugiego poziomu (normy i wartości) przekształcić się może w procedury i politykę organizacji.

Jednak powyższe uwagi można formułować jako zastrzeżenia tylko wtedy, gdy koncepcję Scheina uzna się za jedną z propozycji teoretycznych dla badań kultury organizacji, rozumianych neopozywistycznie (ilościowe analizy obserwowalnych wskaźników, oparte na doborze losowym). Tymczasem, jak przypomniały o tym ostatnio Monika Kostera i Martyna Sliwa (2012: 246), nie taki był cel cytowanego autora. Stworzył on model „diagnostyczny, służący celom doradczym". Chodziło o narzędzie pogłębionego wglądu w organizację. Schein wykorzystał do jego konstrukcji swoje wieloletnie doświadczenie konsultingowe i badania nad tą sferą praktyki menedżerskiej. Jeśli zaś chodzi o kontekst teoretyczny, to - co jest powszechnie znane - inspirował się podejściem psychoanalitycznym. Jest to perspektywa bardzo mi bliska w tej pracy, choć świadomy jestem związanych z nią niebezpieczeństw. Będę do niej wracał (por. aktualną dyskusję w zarządzaniu wokół racjonalnego i „wyobrażeniowego” podejścia do poblemów organizacyjnych, Kociatkiewicz i Kostera 2012).

Schein, jako konsekwentny klinicysta, sformułował propozycje sposobu diagnozy kultury organizacyjnej typowe właśnie dla podejścia klinicznego. Sugeruje on, aby uczestnik danej zbiorowości zadał sobie i wspólpracownikom szereg szczegółowych pytań, dzięki którym będzie mógł dobrze zrozumieć, na czym polegają praktyczne implikacje poszczególnych grup treści kulturowych. Nic nie stoi na przeszkodzie, aby pytania te uznać za swoistą operacjonalizację koncepcji Scheina dokonaną przez samego autora.

Omawiana wersja koncepcji Scheina stanowi wyraźny przejaw ewolucji myśli jej autora od funkcjonalizmu do narrtatywizmu, którą to ewolucję sygnalizuje na przykład Sułkowski (2012). Doprecyzowanie zasygnalizowanego tu zagadnienia wymaga oczywiście oddzielnej analizy myśli Scheina, przekraczającej znacznie możliwości niniejszej pracy.

W każdym razie omawiana koncepcja, mimo, a może właśnie ze względu na swe nastawienie praktyczne, inspiruje również do dyskusji teoretycznych. Trudno na przykład zgodzić się z widocznym w niej założeniem, iż kulturę organizacyjną da się sprowadzić do prostej sumy przyjętych założeń i doświadczeń danej zbiorowości. Holistyczny punkt widzenia, zapoczątkowany niegdyś także na terenie psychologii organizacji przez psychologię humanistyczną, każe uznać kulturę (również kulturę organizacyjną) za nową jakość wykraczająca poza prostą sumę składających się na nią elementów ${ }^{10}$.

Najbardziej konsekwentnie takie ujęcie rozwinęli teoretycy organizacji związani z konstruktywizmem. Korzystając z ich ustaleń, na potrzeby niniejszej

$\overline{10}$ To spostrzeżenie zawdzięczam Waldemarowi Grzywaczowi, mojemu współpracownikowi w Katedrze Psychologii i Socjologii Zarządzania WZ UW (zob. Grzywacz, Ochinowski i Nawrocki 2001). 
pracy wykorzystuję definicję kultury sformułowaną przez polską badaczkę zarządzania, obecnie profesor Uniwersytetu w Göteborgu, Barbarę Czarniawską. Wspomnianą definicję propaguje wśród studentów i menadżerów-praktyków na terenie naszego kraju Monika Kostera (np. 2007 i 2010), uznając ją za pomocną przy badaniu znaczeń oraz praktyk kulturowych w organizacjach. Opinię tę podzielam.

Według Czarniawskiej kultura „to 'medium życia społecznego' (medium of life) lub otoczka znaczeń/sensu (bubble of meaning), [jest] otoczką przez nas stworzoną, w której żyjemy - i choć postrzegamy wiele spośród tego, co widzimy, jako nie przez nas stworzone, widzimy to zawsze pokryte przezroczystą powłoką naszej otoczki” (Czarniawska-Joerges 1992: 60, cyt. za Kosterą 2007: 174). Określenie kultury zaproponowane przez Czarniawską używam jako ujmujące precyzyjnie (choć metaforycznie) istotę zarówno kultury organizacyjnej według Scheina, jak i kapitału kulturowego w ujęciu Lamont. To właśnie, moim zdaniem, „medium społeczne” organizacji bądź miejsca pracy badają obydwoje cytowani autorzy, nie używając tego terminu. Przytoczona propozycja teoretyczna Czarniawskiej pozwala też, bez zbyt dużej dawki eklektyzmu, przejść od idei kapitału kulturowego miejsca pracy do kategorii kapitału kulturowego organizacji przy pośredniczącej roli scheinowskiej koncepcji kultury organizacyjnej.

Trzecią inspirację teoretyczną dla proponowanego w tym podrozdziale ujęcia kapitału kulturowego organizacji dostarczył mi nurt retoryczny w naukach społecznych oraz ekonomicznych.

Zainteresowanie retoryką jako metodologią krytycznego nurtu nauk społecznych rozpoczęło się w latach 80 . XX wieku. Ku retoryce zwrócili się wówczas naukowcy, którzy nie byli usatysfakcjonowani scjentystyczną ideologią uprawianych przez nich dyscyplin. Szczególną rolę odegrał wówczas amerykański Uniwersytet Iowa. W 1984 roku ekonomista Donald McCloskey wraz ze współpracownikami zorganizował tam sympozjum gromadzące przedstawicieli różnych dyscyplin humanistycznych i społecznych. Ujawniło ono istnienie sporej grupy „metodologicznych dysydentów”, którzy nie wiedząc o sobie nawzajem, odnaleźli drogę do retoryki, poprzez krytykę retorycznej struktury uprawianych przez siebie dziedzin nauki.

Do najważniejszych publikacji wpływających na rozwój omawianego nurtu metodologicznego zalicza się zazwyczaj Retoryke ekonomii ${ }^{11}$ wspomnianego Donalda McCloskey. Na kartach tej pracy amerykański badacz pokazał, w jaki sposób klasyczne teksty ekonomiczne, mimo pretendowania do „naukowej neutralności” w rzeczywistości służą przede wszystkim perswazji, czyli są kon-

11 Tytuł oryginału The Rethoric of Economics; I wyd. 1986; II wyd. 1998, w międzyczasie autor zmienił płeć, w drugim wydaniu książki występuje jako Deirdre McCloskey, zob. także 2001. 
strukcjami retorycznymi. Zaproponował również praktyczne analizy retorycznej zawartości publikacji opisujących rzeczywistość gospodarczą. McCloskey (1999) wykazał na przykład, iż retoryka książek i artykułów na temat finansów pełna jest metafor walki oraz rywalizacji sportowej. Propagowane przez cytowanego autora analizy retoryczne znalazły również zastosowanie w badaniach organizacji, czego dobrym przykładem na polskim gruncie są podręczniki pióra Moniki Kostery (np. 2005). Ich szczególne nasilenie wydawało się przypadać na lata 90. ubiegłego stulecia (Barley i Kinda 1992, Dobrzyński i Klincewicz 2006).

Niezależnie od wspomnianych badaczy amerykańskich, choć mniej więcej w tym samym czasie, podejście retoryczne na obszarze nauk społecznych rozpoczęło rozwijać środowisko skupione wokół Michaela Billiga (1996, 2008), dziś znane jako nieformalna, interdyscyplinarna „Grupa Dyskursu i Retoryki” na Uniwersytecie w Loughborough (Wielka Brytania). Obok wspomnianego psychologa społecznego do jej liderów należą Derek Edwards, David Middleton (również psycholodzy) oraz socjolodzy John Shotter i Jonathan Potter. Wychodzą oni z założenia, iż argumentowanie jest istotną cechą natury człowieka, odróżniającą go od zwierząt. Psychika, a także zjawiska społeczne mają - z omawianej perspektywy - naturę perswazyjną i procesualną. Są nie tyle zjawiskami, ile procesami konstruowanymi w toku szeroko rozumianych dyskusji społecznych, interpersonalnych lub prowadzonych przez jednostki ludzkie same ze sobą. Takie podejście stanowi propozycję jakościowego uprawiania nauk społecznych, wśród których omawiane środowisko rozwija przede wszystkim, choć nie wyłącznie, psychologię retoryczną, czy - szerzej - dyskursywną. Billig (2008) traktuje ją jako odmianę „krytycznej psychologii społecznej”. Jej korzenie poznawcze upatruje w filozofii oświeceniowych myślicieli Johna Locke’a, Anthony'ego Shaftesbury'ego i Thomasa Reida.

Nieco wcześniej niż przedstawiciele nauk społecznych podejściem retorycznym zainteresowali się teoretycy i historycy historii zainspirowani słynną publikacją Haydena Whita Metahistory. The Historical Imagination In Nineteenth-Century Europe z 1973 roku, otwierającą nurt narracyjny w historiografii (wyd. pol. ukazało się w 2000 roku pod redakcją Ewy Domańskiej i Marka Wilczyńskiego i pod tytułem Poetyka pisarstwa historycznego). Typowym zwolennikiem perspektywy retorycznej przy badaniu dziejów jest na przykład Patric H. Hutton, autor pracy pod znamiennym w tym kontekście tytułem Historia jako sztuka pamięci (ang. History as an Art of Memory 1993). Cytowany badacz postuluje zastosowanie starożytnych, retorycznych technik doskonalenia zapamiętywania do analizy współczesnego nam dziejopisarstwa. Warto podkreślić, iż w środowiskach naukowych naszego kraju prawdopodobnie po raz pierwszy zaproponowała wykorzystanie retoryki jako metodologii (w tym wypadku do analizy tekstów literackich) Barbara Otwinowska w niepublikowanym referacie w Instytucie Badań Literackich PAN jeszcze w latach 60. XX wieku (referat 
spotkał się z krytyką środowiska) ${ }^{12}$. Później znaczącym popularyzatorem stosowania retoryki także jako narzędzia analitycznego, dla potrzeb zarządzania był Mirosław Korolko (np. 1998, 200113).

W światowej nauce już w 1990 roku Herbert Simons znalazł tyle przykładów podejścia retorycznego, iż sformułował sugestię, że można mówić o „zwrocie retorycznym”, który postulował uznać za jeden z najbardziej znaczących intelektualnych trendów naszych czasów (Billig 1996). Trudno jednak powiedzieć na ile, po następnych dwudziestu trzech latach, można przyznać mu rację.

Jednym z nowszych przykładów zastosowania podejścia retorycznego jest wykorzystanie tej perspektywy do badania i rozumienia różnic międzykulturowych. Na przykład Zhu i Hildebrandt (2002) pokazali, iż odmienności zachodniej i chińskiej tradycji retorycznej mogą wyjaśniać różnice w komunikacji międzykulturowej we współczesnym biznesie (por. Kisielnicki, Ochinowski i Yu 2010 oraz Ochinowski, Kisielnicki, Kodwani, Tsai i Strocka 2013).

W niniejszej pracy nie wykorzystuję metodologii nurtu retorycznego, polegająca na stosowaniu technik analiz wypracowanych przez starożytnych retorów, odwołując się jedynie to perspektywy ujmowania zjawisk kulturowych zaproponowanej przez to podejście (kultura jako wynik wielorakich dyskusji).

Sięgając do wspominanych inspiracji teoretycznych traktuję kulturowy kapitał organizacji jako zbiór oczekiwań wobec organizacji (bądź organizacji w liczbie mnogiej) formulowanych przez jej/ich otoczenie społeczne.

W ujęciu bardziej szczegółowym chodzi o oczekiwania wobec organizacji:

1) stanowiące wynik szeroko rozumianych dyskusji;

2) zawarte w koncepcjach oraz propozycjach teoretycznych z zakresu zarządzania;

3) a także w treściach dyskusji sensu stricto nad aktualną sytuacją biznesu.

Oczekiwania te wynikają z kulturowych uwarunkowań biznesu na danym obszarze geograficznym lub z kulturowych podstaw biznesu branego pod uwage globalnie w danym okresie. Wspomniane oczekiwania dotyczą postulowanych dobrych praktyk (odpowiednik behawioralnego aspektu kapitału kulturowego miejsca pracy) oraz wartości nadających sens funkcjonowaniu organizacji (odpowiednik aksjologicznego aspektu kulturowego kapitału miejsca pracy).

Obydwa wspomniane filary kulturowego kapitału organizacji mają sprawiać, iż firma ma możliwość przetrwania na rynku i rozwijania się, jest miejscem pracy pozwalającym na efektywne wykonywanie zadań pracowniczych, a jednocześnie takim, w którym zatrudnieni chcą żyć, jak również przystaje do panujących w danym czasie i środowisku zwyczajów, filozofii życiowych, a także

12 Choćby zasygnalizowanie nurtu retorycznego w literaturoznawstwie oczywiście przekracza zakres niniejszej pracy.

13 Druga z przywołanych praca Korolki, Retoryka i erystyka dla prawników, Warszawa 2001, powstała pierwotnie jako podręcznik dla studentów zarządzania. 
mód dotyczących zarządzania (na temat ostatniego z wymienionych elementów zob. np. Klincewicz 2004).

Przy czym na obecnym etapie rozważań i analiz zawieszam sąd odnośnie do tego, czy kapitał kulturowy organizacji istnieje realnie ${ }^{14}$ czy stanowi na przykład metaforę. Pozostaję na poziomie idei menedżerskich.

Uważam, iż wspomniane oczekiwania formułowane wobec organizacji przez jej/ich otoczenie mają właśnie charakter „otoczki sensów i znaczeń”.

Kapitał kulturowy tak ujęty posiada strukturę retoryczną. Jest zmieniającym się $\mathrm{w}$ czasie wynikiem szeroko rozumianych dyskusji, między koncepcjami (i w ramach poszczególnych koncepcji), autorami (i wewnętrznych dyskusji poszczególnych autorów) czy praktykami bądź szeroko rozumianymi interesariuszami biznesu (i wewnętrznych dyskusji poszczególnych praktyków czy interesariuszy).

Niniejsza praca stanowi propozycję rozszerzenia wspomnianych dyskusji także o wymiar historyczny (a zarazem „prowincjonalny”). Celowi temu służy poszukiwanie nośników kulturowego kapitału organizacji w tradycji przedsiębiorczości na ziemiach polskich.

\subsection{Kapitał kulturowy a funkcje zarządzania współczesną organizacją}

Historia historiografii oraz nauki o zarządzaniu, dwie perspektywy poznawcze, wyznaczające ramy niniejszej pracy, zazwyczaj traktowanie są jako odległe od siebie. Mają one jednak wspólny obszar zainteresowań. Stanowi go problematyka zmiany.

Jak pisałem we wstępie do niniejszej pracy, środowisko polskich historiografów dość powszechnie przyjmuje za Andrzejem F. Grabskim (1990: 8, tenże 2003), iż główny przedmiot ich badań określa analiza sposobów „rozumienia zmienności ludzkiej rzeczywistości” (zob. także Sobiecki 2003).

Z kolei wszechobecna zmiana (którą uznać trzeba za jedyną chyba "stałą" w świecie współczesnych firm), jest podstawowym wyzwaniem dla zarządzających organizacjami, o czym wie nawet najsłabszy student szkoły biznesu. Pojawia się perspektywa znacznie szersza niż tradycyjnie rozumiane zarządzanie zmianą w organizacji. Chodzi o konieczność praktycznie nieustannej konfrontacji zadań menedżera z rzeczywistością totalnej zmienności - czy, za Zygmuntem

14 Pomijam kwestię wieloznaczności tego terminu, obciążonego wielowiekową tradycją dyskusji filozoficznych. Ten poznawczy „unik” usprawiedliwiam przyjęciem konstruktywistycznego rozumienia organizacji (Czarniawska 2010). 
Baumanem (np. 2007, zob. także Kostera i Śliwa 2012) - płynności współczesnego życia.

To właśnie skuteczne (w sensie realizacji celów danej organizacji) odpowiadanie na zmianę wyznacza przecież współczesny kontekst realizacji klasycznych funkcji zarządzania: planowania, organizowania, przewodzenia, ale i kontroli. Zaś kapitał kulturowy organizacji byłby w takim razie zmienną pośredniczącą, kontekstem kulturowym potencjalnie ${ }^{15}$ pomagającym optymalizować działania menedżerskie konfrontowane $\mathrm{z}$ ciaggła zmianą.

Konfrontacja wspomnianych podstawowych funkcji zarządczych z płynnością organizacji i ich otoczenia pozwala, już przynajmniej od kilkunastu lat, określić główne zadania menedżera trójczłonowo.

Po pierwsze - chodzi o rozpoznawanie, opis oraz praktyczne wykorzystanie zbioru takich instytucji i szeroko rozumianych sit, które wchodzą lub w przyszłości mogą wchodzić $\mathrm{z}$ daną organizacją $\mathrm{w}$ interakcje $\mathrm{w}$ jej złożonym i gwałtownie zmieniającym się środowisku, a jednocześnie oddziałują na możliwości organizacji w zakresie obsługi klientów.

Konsekwentnie następna grupa zadań kadry kierowniczej to nieustanne monitorowanie środowiska i takie przystosowanie się do niego, aby organizacja przetrwała oraz dobrze prosperowała. Istotnym warunkiem skuteczności zarządzania jest w tym kontekście zdolność menedżera do wartościowania zmian, wynikająca ze świadomości, iż mogą one oznaczać zarówno poważne zagrożenia, jak i nowe perspektywy dla przedsiębiorstwa.

Trzeci podzbiór zadań kierownictwa firmy można więc sprowadzić do precyzyjnego identyfikowania i oceniania wspomnianych szans i zagrożeń oraz odpowiadania na nie.

W zarysowanym tu kontekście zarządzania wyraźnie wyłania się możliwość określenia roli współczesnego menedżera przez pryzmat przydatnych, bądź nawet koniecznych kompetencji społecznych, ujętych funkcjonalnie. Wspomniane kompetencje powinny być wystarczające do tego, by kierujący wiedział jak analizować i zwiększać (doskonalić) możliwości organizacji, które pozwalają jej na przetrwanie, jak również na rozwój w skomplikowanym i zmiennym świecie (Allen 1998, Kostera i Śliwa 2012, Kisielnicki 2013).

Już Peter Drucker (1999, 2002 i in.) był jak najbardziej świadomy wspomnianego kontekstu zmiany. Główne zadania „lidera XXI wieku w społeczeństwie wiedzy"16 klasyk współczesnych nauk o organizacji i zarządzaniu określał następująco:

15 Pozwolę sobie przypomnieć, iż z perspektywy niniejszej pracy kapitał kulturowy organizacji stanowi zespół oczekiwań formułowanych w toku różnorodnych dyskusji o organizacji. Ma więc charakter retoryczny i postulatywny.

16 Odnoszę się tu do tytułu jednego z późnych wykładów Druckera. Była to videoprezentacja przygotowana dla polskiego odbiorcy, 2001. 
- wyznaczanie priorytetowych zadań; pracowanie i dawanie przykładu,

- podsumowania,

- wprowadzanie zmian w organizacji,

- budowanie zespołu,

- konkretyzowanie zadań; wyznaczanie wykonawców; branie odpowiedzialności za nominacje do zadań.

W ramach szczegółowych wskazań Drucker (2001) postulował, aby dobry menedżer wzbudzał zaufanie oraz potrafił odmawiać innym, by mógł realizować swoje cele zgodnie z zasadą: „każde 'tak' to zobowiązanie”. Funkcjonalnie istotna jest również świadomość, iż wpływa się na pracowników przede wszystkim przez modelowanie. Warto więc pamiętać, że kadra kierownicza jest pod obserwacją podwładnych. Należy nagradzać ludzi z dobrą inicjatywą. Firmom, w których to nie występuje, cytowany autor odmawiał konsultingu. Ważny czynnik efektywnego liderowania stanowi też poszukiwanie nowych okazji. Drucker sformułował również tak zwane zadanie zadań menedżerskich. Według niego jest to ciągła zmiana misji, którą trzeba nieustannie dostosowywać do potrzeb klienta. Pozbawiać ją tego, co zbędne. Myśliciel, uważany często za intelektualnego fundatora współczesnego zarządzania, pod koniec swej działalności zanegował więc stałość, wydawałoby się najbardziej stałego „miękkiego” elementu organizacji, to jest jej misji. I następnie konkludował: „Można więc kontrolować zmiany, ale trzeba uważać, żeby one nie kontrolowały nas" (Drucker 2001: brak nr. strony).

Postulaty Druckera nigdy nie miały, przynajmniej według niego, wyłącznie pragmatycznego znaczenia. Autor słynnej Praktyki zarządzania traktował uprawianą przez siebie dziedzinę wiedzy także jako projekt kulturowy, czy nawet metakulturowy. „Management jest przecież czymś znacznie więcej niż czystą ekonomią, mianowicie pomostem pomiędzy cywilizacją i kulturą" twierdził (cyt. za Lüchingerem 2007: 125). Interesowała go nie tylko treść, ale również sposób promocji tego projektu. Przy czym wspomniany sposób przekazu kapitału kulturowego organizacji jest sam także merytorycznym (treściowym) problemem zarządzania organizacjami. Drucker był wielkim zwolennikiem zagospodarowania rzeczywistości wirtualnej. Jon Baldoni (2003: 73) tak o nim pisał na początku obecnego stulecia: „Znany jako mędrzec z Claremont, co odnosi się do uczelni w południowej Kalifornii, gdzie mieszka, uczy i pisze. Na początku dziewięćdziesiątki wciąż jest energiczny, a ludzie przybywają z całego świata by go słuchać. I on także 'przybywa do świata' poprzez wykłady przekazywane drogą satelitarną. 'Lubię duże rozmiary' - deklaruje".

Drucker został też uznany za jeden z „osobowych nośników” tak zwanej komunikacji przywódczej. Chodzi o technikę menedżerską wspierającą podstawowe funkcje zarządzania organizacją, gdy chodzi o realizację takich celów jak: 
- afirmacja wizji i misji organizacyjnej,

- wzbudzanie inicjatyw transformacyjnych, na przykład zmian,

- wzywanie do działania,

- wzmocnienie potencjału organizacji,

- tworzenie środowiska sprzyjającego motywacji,

- promowanie produktu lub usługi (oraz potwierdzenie ich związku z misją, wizją i wartościami danej organizacji).

Wobec wspomnianych celów cytowany już Baldoni (2003) proponuje menedżerom perswazyjny model komunikacji przywódczej, jak wskazuje nazwa łącząca perspektywę nauk o komunikacji i badań dotyczących przywództwa. Model ten składa się z czterech czynników: „doniosłość - wartości - konsekwencja - rytm”. Komunikacja przywódcza ma zastosowanie wtedy, gdy treści perswadowane członkom organizacji dotyczą bardzo znaczących zagadnień, określających teraźniejszość i przyszłość firmy. Chodzi o tematy związane z ludźmi, osiągnięciami, produktami lub usługami (te elementy przykładowo tworzą czynnik „doniosłość”). Komunikat przekazywany przez lidera odzwierciedla wizję, misję i kulturę organizacji (czynnik „wartości”). Przesłanie zawiera przykłady wartości i zachowań ustalonych w danej firmie (czynnik „konsekwencja”) oraz występuje z odpowiednią częstością i regularnością (czynnik „rytm”).

Drucker realizował zarysowany tu model komunikacji przywódczej poprzez stosowanie w swoich wypowiedziach analogii, ilustrowania tez za pomocą odniesień historycznych, dzielenia się wiedzą z innymi (chodzi o nauczanie z pasją), przyznawania się do błędów ${ }^{17}$ oraz utrwalania przesłania (konsekwencja i stałość głównego przekazu); Drucker nieustannie „bronił 'sprawy' danego menedżera, który był krytykowany, zawsze próbując wskazać mu lub jej najlepsze rozwiązanie" (Baldoni 2003: 76).

Jeśli uznać myśl i formę jej propagowania przez Druckera za projekt kapitału kulturowego organizacji, kreowany przez myśliciela uznawanego od lat 70. ubiegłego stulecia za twórcę nowoczesnego zarządzania jako nauki, a w każdym razie jednego z głównych nośników jej mitu (zob. np. Twórcy teorii ekonomicznych... 2007), to interesujące jest sprawdzenie funkcjonowania jego dziedzictwa wśród współczesnych praktyków (aktualnych lub potencjalnych) tej dziedziny wiedzy.

Kilka miesięcy po śmierci Druckera ${ }^{18}$ uczestnicy studenckiego ruchu naukowego na Wydziale Zarządzania UW przeprowadzili pod moim kierunkiem

17 Drucker (zob. np. 1999) przyznał, iż przed lekturą prac Maslowa nie doceniał znaczenia czynnika behawioralnego w zarządzaniu. Po zapoznaniu się z ustaleniami wspomnianego autora zmienił swój punkt widzenia.

18 Peter Ferdinand Drucker zmarł w 2005 r. w Claremont, k. Los Angeles. 
pilotażowe badanie pamięci zbiorowej uczestników zajęć na tym wydziale, dotyczące wspomnianego klasyka myśli menedżerskiej19.

Spośród 511 pytanych osób, 12\% nie wiedziało kim jest Drucker (ponadto bardzo niewielki odsetek respondentów „uciekał” w kierunku kuriozalnych odpowiedzi typu „niemiecki sędzia piłkarski”, „wynalazł drukarnię” i in.).

Ponad $71 \%$ rozpoznało analizowaną postać prawidłowo, $66 \%$ studentów deklarowało, iż czytało prace Druckera, ale mniej niż połowa tej grupy (48\% spośród „czytających”) potrafiła podać przykłady przeczytanych treści, co uznaliśmy za warunek wiarygodności odpowiedzi twierdzącej. Przy czym najczęściej czytano nie tyle publikacje badanego autora, ile czytano o nim w podręcznikach (27\% odpowiedzi w grupie „podających przykłady”) oraz na łamach prasy (także 27\% odpowiedzi, z tym że tu respondenci najprawdopodobniej mówili także o tekstach prasowych pióra Druckera).

Swoiste zagubienie przy identyfikacji twórcy współczesnej wersji nauki, którą studiują, ukazały analizy skupień dotyczących swobodnych charakterystyk omawianej osoby wykonane przez respondentów. Prezentowany pilotaż ujawnił trzy wyraźne sposoby postrzegania postaci Druckera:

- skupienie 1: „Sedno sprawy” - tworzyły je następujące określenia: „twórca 7 zasad zarządzania; specjalista ds. zarządzania; ojciec zarządzania; wykładowca/profesor; autor wielu definicji z dziedziny zarządzania; niedawno zmarly",

- skupienie 2: „Trafiony - zatopiony?” - wyraźnie grupowało odpowiedzi udzielane na „,chybi1-trafi1”: „guru zarządzania; psycholog; praktyk”,

- skupienie 3: „Z odrobiną nieśmiałości” - powstało w wyniku zgrupowania następujących kategorii: przedstawiciel nurtu w zarządzaniu; twórca zarządzania; psycholog; ojciec zarządzania; nie wiem/nie pamiętam".

Jak widać, pamięć o twórcy zarządzania jako współczesnej nauki wśród studentów tej dziedziny, aczkolwiek podczas wspomnianego pilotażu całkiem świeża, charakteryzowała daleko idąca ambiwalencja.

Niejednoznaczność pamięci zbiorowej na temat Druckera ujawniona przez studencki pilotaż ma - oczywiście z zachowaniem wszelkich proporcji - swój odpowiednik w środowisku badaczy świata biznesu. Jeszcze za życia omawianego naukowca James Hoopes (2003) zaliczył go do grona „fałszywych proroków” współczesnego zarządzania. Zarzucił mu złe rozpoznanie natury władzy biz-

19 Badanie zostało zrealizowane w marcu 2006 przez członków Koła Psychologii Biznesu i Organizacji. Respondentów pytano o skojarzenia związane z Petrem Druckerem („Peter Drucker to...") o opinię na temat znaczenia Druckera dla zarządzania oraz o lekturę jego prac. Odpowiedzi na drugie pytanie zostały opracowane za pomocą analizy skupień techniką taksonomii wrocławskiej. Badani byli studenci Wydziału Zarządzania UW lat I-IV studiów dziennych i wieczorowych, liczebność próby: $\mathrm{N}=511$. Dobór był przypadkowy. 
nesowej, staranie się na siłę o nadanie jej moralnej legitymizacji, a co za tym idzie - formułowanie rad zupełnie nieprzydatnych dla menedżerów. Zdaniem Hoopesa, trzy główne propozycje Druckera, to jest: (1) skierowanie korporacji $\mathrm{ku}$ formom prawnych struktur samorządowych, (2) uprawomocnienie władzy menedżerskiej przez odniesienia jej do dobra pracowników oraz (3) nadzieja, iż organizacje non-profit staną się wzorem moralnego zarządzania dla firm, kolejno okazywały się chybione jako zbyt idealistyczne ${ }^{20}$. Zresztą zdaniem cytowanego historyka biznesu, „fałszywymi prorokami”21 byli z różnych względów praktycznie wszyscy klasycy współczesnej myśli menedżerskiej, o których uczą się studenci szkół biznesu. Teza ta wymaga oczywiście oddzielnej dyskusji, znacznie przekraczającej ramy niniejszej pracy.

W odniesieniu do przeprowadzonej przez Hoopesa krytyki myśli Druckera trudno zaprzeczyć faktom przytaczanym przez pierwszego $\mathrm{z}$ wymienionych, iż przynajmniej niektórzy menedżerowie znaczących korporacji ignorowali postulaty „mędrca z Claremont, a organizacje non-profit raczej zaczęły przejmować reguły zarządzania od „twardego biznesu” a nie odwrotnie.

Niemiej jednak Hoopes wyraźnie nie wziął pod uwagę, że myśli i działania Druckera miały charakter dyskusji z biznesową rzeczywistością. Autor Zarzadzania $w$ XXI wieku nie tyle więc, jak chce Hoopes, pomylił się co do „natury” świata pracy i nie rozpoznał jego „szorstkości” (termin Hoopesa), ile raczej świadomie proponował mu swój model kapitału kulturowego organizacji, będący autorską wersją odpowiedzi na wyzwania zmiennej rzeczywistości. Konsekwentnie „perswadował”, „trącał łokciem” i za pomocą pochlebstw nakłaniał organizacje do tego, by „traktowały pracowników jako zasoby, a zarządzanie jako możliwość uzyskania efektywności organizacyjnej” (Baldoni 2003: 73, zmieniony czas gramatyczny cytatu).

Nowe problemy, także natury kulturowej, na styku druckerowskich „zasobów” i funkcji zarządzania przynoszą organizacje wirtualne. Cytowany już Hoopes (2004) początkowo uwypuklał przede wszystkim związane $\mathrm{z}$ nimi zagrożenia. Rozwijając swe obszerne badania historyczne, dotyczące relacji praktyki biznesowej i teorii zarządzania (zob. Hoopes 2003), ostrzegał przed dehumanizacją relacji pracowniczych, która stanowi, jego zdaniem, realne kulturowe niebezpieczeństwo wirtualizacji zatrudnienia. Amerykański historyk biznesu przywoływał w tym kontekście metaforę chaplinowskiego filmu „Dzisiejsze czasy” i podkreślał, iż „ciemna strona IT leży w ośmielaniu szefów do tego, by patrzyli na pracowników jako na bity i bajty" (Hoopes 2004: 40). Ostatnio

20 Hoopes (2003) przedstawił Druckerowi swoją analizę jego poglądów. Drucker, już wówczas w podeszłym wieku, spotkał się z Hoopesem, ale nie skomentował wspomnianej krytyki.

21 Taki termin jest kluczowym w tytule książki Hoopesa uznanej przez Amerykańskie Stowarzyszenie Menedżerów za najlepszą książkę roku (2003) z dziedziny historia biznesu. 
jednak Hoopes (2011) przyznał także rację tym badaczom, dla których wirtualizacja biznesu daje nadzieję na demokratyzację rynku poprzez stwarzanie szans rozwoju małym i średnim przedsiębiorcom. Przekonanie takie na kartach swych publikacji konsekwentnie propaguje w Polsce Jerzy Kisielnicki (2003 i nast.).

W czasie gdy rozpoczynało się zainteresowanie e-biznesem w naszym kraju, przeprowadziłem pilotaż (rok akademicki 2004/2005) na temat obaw dotyczących organizacji wirtualnych ${ }^{22}$ (zob. Kisielnicki i Ochinowski 2005). Respondenci byli proszeni o udzielenie swobodnych, nieustrukturyzowanych, pisemnych odpowiedzi na pytanie wynikające $\mathrm{z}$ historyjki mającej charakter projekcyjny ${ }^{23}$. Zebrane odpowiedzi zostały skategoryzowane (sprowadzone do 22 rozłącznych kategorii). Po odrzuceniu kategorii obaw pojawiających się sporadycznie, do

22 Osobami badanymi byli studenci drugiego roku zaocznych studiów magisterskich Wydziału Zarządzania UW w Warszawie i Płocku (4 grupy, razem 161 osób) oraz pierwszego roku studiów licencjackich na Wydziale Pedagogicznym Wyższej Szkoły Humanistycznej im. A. Gieysztora w Pułtusku (50 osób). Ogółem badana próba liczyła 211 osób. Powstał tu problem jednorodności badanej próby. Początkowo planowałem wyłączyć z analiz studentów WSH w Pułtusku. Jednak wstępny, jakościowy przegląd wyników pokazał, iż odpowiedzi tej podgrupy wydają się nie różnić wiele od odpowiedzi studentów zarządzania. Nie sprawdzałem również tego, czy osoby badane posiadały jakieś doświadczenia z organizacjami wirtualnymi. Studenci zarządzania mieli wcześniej wykład kursoryczny na temat zarządzania informacją, prowadzony przez Jerzego Kisielnickiego. Generalnie uznałem, iż niedostatki w doborze próby usprawiedliwia pilotażowy charakter badań. Znacząca rekompensatą był niewątpliwie fakt mojego dobrego kontaktu z osobami badanymi. Opisywane badanie odbywało się podczas zajęć z etyki w biznesie (studenci zarządzania) i psychologii ogólnej (studenci pedagogiki), na których nie było wymogu obowiązkowej obecności. Słuchacze przyszli więc względnie dobrowolnie. Podkreślany też był dobrowolny i anonimowy charakter udziału w badaniach.

23 Realia do tej sytuacji zaczerpnąłem z przetargu, który opisał Jerzy Kisielnicki (2003). Instrukcja brzmiała następująco: Proszę sobie wyobrazić, iż każdy z Państwa jest wtaścicielem małego, ale dobrze prosperującego biura rachunkowo-finansowego. Otrzymujesz przez internet propozycję od firmy budowlanej średniej wielkości (zatrudniajacej 100 osób) $z$ zagranicy. Propozycja jest sformułowana $w$ języku, który dobrze znasz. Masz też na etacie ttumacza, który $w$ razie potrzeby będzie ttumaczyt co potrzeba, bez dodatkowych kosztów. Wspomniana firma budowlana proponuje Ci, abyś pod jej szyldem wzią udziat w przetargu na budowe kompleksu hotelowego nad Morzem Śródziemnym. Wartość przetargu wynosi 160 milionów euro. Oprócz Twojego biura, pod szyldem wspomnianej firmy budowlanej do przetargu maja wspólnie przystapić takie organizacje jak:

- firma konsultingowa,

- przedsiębiorstwo pośrednictwa pracy i doradztwa personalnego,

- przedsiębiorstwa specjalistyczne, które będa podwykonawcami.

Jakie wątpliwości musiatbyś rozwiać, żeby pozytywnie odpowiedzieć na tę propozycję? (jakie watpliwości zrodzitaby $w$ tobie taka propozycja $i$ jakie musiatbyś rozwiać, by pozytywnie na niq odpowiedzieć?). 
dalszej analizy wybrano $12^{24}$. Kategorie te zostały pogrupowane za pomoca taksonomii wrocławskiej25.

Powstało 5 skupień zmiennych określających obszary obaw respondentów wobec przedsięwzięć biznesowych, związanych z organizacjami wirtualnymi.

Skupienie 1: „Wiarygodność firmy inicjującej organizację wirtualną” (utworzyły je kategorie: legalność przedsięwzięcia/wiarygodność zleceniodawcy/jak będzie wyglądała zapłata, jak realizowane będą płatności).

Skupienie to pokazało, iż dla osób badanych wiarygodność zleceniodawcy była ściśle związana z prawnym wymiarem przedsięwzięcia oraz z problematyką wynagrodzenia. Powstał w ten sposób swoisty trójczłonowy model warunków efektywnej współpracy z organizacją wirtualną: etyka - prawo - wynagrodzenie. Jest on oczywiście uniwersalny i odnosi się także do organizacji tradycyjnych.

Skupienie 2: „Partnerzy w organizacji wirtualnej”.

Opisywany czynnik dotyczył obaw co do klarowności sytuacji i intencji partnerów, którzy mają współpracować w ramach organizacji wirtualnej. W referowanym pilotażu badani deklarowali wyraźne kierowanie obaw raczej pod adresem zleceniodawcy niż własnej firmy. Warto dodać, iż w wypowiedziach badanych ujawniła się alternatywa: deklarowali oni albo obawy wobec zleceniodawcy, albo wobec siebie, a nie i wobec zleceniodawcy i wobec siebie. Alternatywa ta sama w sobie jest interesującą kwestią, którą warto podjąć w oddzielnych badaniach.

Pozostałe skupienia, odzwierciedlające kolejne obszary obaw, nie wymagają dodatkowego komentarza.

Skupienie 3: „Ryzyko finansowe związane z podjęciem współpracy w ramach organizacji wirtualnych" (opłacalność: zyski, straty itp./konsekwencje nieterminowego wybudowania, wycofania się).

Skupienie 4: „Rozmiar koniecznej, szeroko rozumianej inwestycji” (wstępny wkład w inwestycję, koszty, ile muszę zainwestować/jakie są wobec mnie oczekiwania, jaką funkcję miałaby pełnić moja firma w tej inwestycji, czy podołamy zadaniu).

24 (1) wiarygodność zleceniodawcy (w tym wiarygodność kontaktu oraz podejmowania decyzji przez internet); (2) opłacalność: zyski, straty, itp.; (3) informacje o zleceniodawcy: zadłużenie, wypłacalność, sytuacja na rynku, przeszłość, opinie, obecne działania, kontakt z byłym klientem; (4) legalność przedsięwzięcia, czy przetarg jest prawdziwy; (5) dlaczego pod szyldem innej firmy? czy pojawi się nazwa mojej firmy, czy praca pod innym szyldem nie zepsuje mojej renomy? (6) dlaczego wybrano moją firmę, jaki jest tego cel? (7) wstępny wkład w inwestycję, koszty, ile muszę zainwestować? (8) realność inwestycji, zapotrzebowanie na taki obiekt; (9) konsekwencje nieterminowego wybudowania, wycofania się; (10) jakie są wobec mnie oczekiwania, jaką funkcję miałaby pełnić moja firma w tej inwestycji, czy podołamy zadaniu?; (11) jak będzie wyglądać zapłata, jak realizowane będą płatności?; (12) okres zwrotu z inwestycji.

25 Kategoryzacji dokonał Piotr Letachowicz. Procedury taksonomii wrocławskiej wykonały Justyna Cieplak-Pączkowska i Monika Dąbrowska. 
Skupienie 5: „Realność przedsięwzięcia w kategoriach opłacalności finansowej" (realność inwestycji, zapotrzebowanie na taki obiekt/okres zwrotu z inwestycji).

W celu oszacowania ważności poszczególnych „wyjściowych” kategorii obaw potencjalnych uczestników e-biznesu w badanej grupie zostały one porangowane ${ }^{26}$. Okazało się, iż główne zagadnienia budzące niepokój respondentów to informacja o zleceniodawcy, opłacalność przedsięwzięcia oraz wiarygodność zleceniodawcy.

Spośród różnych kulturowych problemów związanych z organizacjami wirtualnymi na centralne miejsce zdaje się wysuwać kwestia wiarygodności - przede wszystkim, choć nie tylko - inicjatorów tworzenia przedsięwzięć tego typu (Kisielnicki i Ochinowski 2008).

Jeśli uświadomić sobie oczywisty fakt, że psychologicznym ekwiwalentem wiarygodności jest zaufanie, to omawiane zagadnienie staje się w znacznym stopniu uniwersalne. Bo przecież turbulentny (a więc szybki, trudno przewidywalny, chaotyczny, przynoszący jednocześnie zagrożenia i szanse) charakter zmian otoczenia współczesnych organizacji uczynił zaufanie jednym z głównych zagadnień zarządzania (np. Micklethawit i Wooldridge 2000).

Organizacje wirtualne po prostu wyostrzają generalny problem ważny także dla organizacji tradycyjnych. Hans Ramo (2004) wysunął wręcz tezę, iż to właśnie organizacje wirtualne lepiej niż tradycyjne chronią zaufanie, które ma naturę kruchą i ulotną. Jest to możliwe dzięki komunikacji opartej na „odpowiednich działaniach w odpowiednich momentach”. Tymczasem systemy porozumiewania się i szerzej - zarządzania - typowe dla organizacji tradycyjnych często instrumentalizują lub/oraz osłabiają zaufanie.

Nietrudno zauważyć, iż sprzeczność między spostrzeżeniami Ramo a świadomością elektoratu organizacji wirtualnych, reprezentowanego przez uczestników relacjonowanego badania, stwarza, przynajmniej w Polsce palące zadanie

26 Zestawienie to przedstawiało się następująco (przy każdej kategorii podaję bezwzględną ilość osób, a w nawiasie procent $\mathrm{w}$ stosunku do liczebności badanej próby $\mathrm{N}=211$ ):

1. informacje o zleceniodawcy

2. opłacalność

3. wiarygodność zleceniodawcy

4. legalność przedsięwzięcia

5. oczekiwania wobec mnie

6. wstępny wkład w inwestycję

7. dlaczego wybrano moją firmę

8. realność inwestycji

9. dlaczego pod szyldem innej firmy

10. okres zwrotu inwestycji

11. jak będzie wyglądać zapłata $91(43 \%)$

$89(42 \%)$

$78(37 \%)$

$60(28 \%)$

$42(20 \%)$

$32(15 \%)$

$24(11 \%)$

12. konsekwencje nieterminowego wybudowania 
edukacyjne. Sygnalizują one również rolę wartości w kształtowaniu relacji człowiek-organizacja (Kisielnicki i Ochinowski 2005).

Po 8 latach od wspomnianych badań warto na ich wyniki spojrzeć także z perspektywy kulturowych wyzwań niesionych ogólnie przez elastyczne formy zatrudnienia, których pojedynczy przykład - e-pracy - wspomniałem wcześniej.

Aktualnie (w roku 2013) elastyczne formy pracy, szczególnie te związane $\mathrm{z}$ pracą tymczasową, wydają się sytuować $\mathrm{w}$ centrum dyskusji związanych z zarządzaniem, dyskusji, z których wyłaniają się kolejne modele kapitału kulturowego organizacji (zob. np. Dobrzyński i in. 2012). Zagadnienie to interesuje zarówno specjalistów, jak i szerokie kręgi społeczne. I tak na przykład latem 2012 wspomnianą dyskusję zdynamizowała wiadomość podana przez „References”, beligijski dodatek do francuskiego „Le Soir”, iż nasz kraj jest europejskim liderem, jeśli chodzi o ilość tak zwanych umów śmieciowych, którym to mianem potocznie określa się również formy zatrudnienia typowe dla pracy tymczasowej. Informację tę podjęły polskie media, niezależnie od orientacji. „Tygodnik Solidarność” zrobił z niej temat na okładkę. Choćby pobieżny przegląd internetu pokazuje, iż wspomniana wiadomość szybko dotarła także do użytkowników blogów „Newsweeka” i „Gazety Wyborczej”. Drugie spośród wymienionych tu przeze mnie przykładowo mediów już od dłuższego czasu dyskutuje różne aspekty pracy tymczasowej, ujmując je znacznie szerzej niż tylko przy okazji problemów „umów śmieciowych”. W każdym razie trudno nie zadumać się choć przez chwilę nad sugestią belgijskiego dziennikarza, iż ,jeden na trzech zatrudnionych w Polsce ma niestabilną pracę, która niczego nie gwarantuje" (Guźla 2012: brak nr strony). Cytowany publicysta podkreśla, że niestabilność zatrudnienia bardzo utrudnia, jeśli wręcz nieuniemożliwia, zakładanie młodym ludziom rodzin. Odmienne stanowisko reprezentuje choćby Wojciech Cellary. Wywiad z nim nosi tytuł mówiący sam za siebie: Żegnaj nam etacie. Na zawsze. Zdaniem Cellary'ego właśnie praca tymczasowa jest dla młodych uczestników rynku pracy najlepszą szkołą przedsiębiorczości (Staszewski i Cellary 2012). Jeszcze radykalniej sprawę tę stawia Marek Goliszewski, prezes Business Center Club. Według niego umowy na czas określony są w zbyt małym stopniu stosowane dziś na polskim rynku pracy. Pomagają one firmom przetrwać okresy spadku ilości kontraktów oraz zwiększać liczbę osób, które mogą otrzymać pracę. „Te umowy nazywane są przez związkowców śmieciowymi. Ale ci, którzy tak mówią, chyba zawsze mieli pracę, nigdy nie byli głodni i nigdy nie szukali zatrudnienia. (...). Ale ci, którzy chcą pracować, którzy są głodni, którzy potrzebują pieniędzy na rodzinę, wezmą każdą pracę, tak jak ja brałem, bo byłem bezrobotny i byłem głodny" (Goliszewski i Wilkowicz 2013: A14). Badania z lipca 2013 roku przeprowadzone przez Instytut „Homo Homini” na zlecenie „Work Service” pokazały, iż niemal 40\% Polaków zmieniło pracę w ciągu ostatnich pięciu lat. Tomasz Hanczarek, prezes firmy zlecającej to 
badanie, następująco skomentował wyniki: „Niecałe 40 proc. ankietowanych - to stosunkowo mało, ale wskaźnik rośnie i będzie rósł. Daleko nam jeszcze do Zachodu, ale będziemy go gonić. Przyczyną trendu jest przede wszystkim rosnąca mobilność Polaków oraz zmiana podejścia do pracy, która nie jest już postrzegana jako jedna na całe życie'. Kryzys wzmacnia ten trend, jednak nie jest jego główną przyczyną" (cyt. za Inglotem 2013: 1)27.

W kontekście tematyki niniejszego rozdziału warto zwrócić uwagę na oczywisty fakt, iż efektywne stawianie czoła zmianie, często bardzo intensywnej stanowi - w psychologicznej perspektywie - istotę elastycznych form pracy (Ochinowski 2012d).

Nie chodzi tylko, choć zapewne przede wszystkim, o zmianę ilościową, spowodowaną zaburzeniem poczucia bezpieczeństwa zatrudnienia. Różne odmiany elastycznych form pracy wymagają od realizujących je ludzi także głębokich przemian o charakterze jakościowym w zakresie pełnionych ról zawodowych, a także pozazawodowych, podejmowania na nowo problemu równowagi pracażycie i temu podobnych. Niektóre z tych wyzwań dotykają wręcz poziomu podstawowych wartości regulujących funkcjonowanie zarówno jednostek, jak i szerszych zbiorowości. Przykładem niech będą tu choćby badania Katy Marsh i Gilla Mussona (2008) ukazujące telepracę jako formę zatrudnienia powodującą zamazanie fizycznych oraz emocjonalnych granic między życiem zawodowym i rodzinnym. Sytuacja ta stanowi poważne wyzwanie dla poczucia tożsamości pracowników ${ }^{28}$. Zdaniem cytowanych autorów, mężczyźni zatrudniani we wspomniany sposób, zarządzając emocjonalnymi aspektem telepracy, będą konstruowali swą tożsamość w sposób zmieniający się w czasie. Czasami skupią się na zawodowej, czasami na rodzicielskiej stronie życia, czasami zaś podejmą wysiłek „posiadania wszystkiego w całości”. Ponadto, zdaniem cytowanych autorów, wspomniana forma zatrudnienia ma szansę stworzyć „przestrzeń, w której mężczyźni będą mogli zaadoptować dla siebie dyskurs emocjonalny oraz praktyki tradycyjnie wiązane z kobietami, a szczególnie z pracującymi matkami” (Marsh i Musson 2008: 32, zob. Ochinowski 2012d).

Marian Dobrzyński (2012: 27 i 35) uważa, iż „zasada elastyczności jest obecnie główną metodą zarządzania potencjałem społecznym wielkich organizacji” i podkreśla odmienność perspektyw psychologicznych między pracodawcą i pracownikiem, należącą do istoty elastycznych form zatrudnienia. Wskazuje też na społeczne konsekwencje takiego stanu rzeczy. „To, co dla przedsiębiorcy jest elastycznością - dla pracownika stanowi źródło niepewności, a w wymiarze

27 Obszerne, publicystyczne omówienie wyników wspomnianych badań przedstawił Jarosław Kałucki na łamach tygodnika „Do rzeczy” w artykule Pożegnanie z etatem (nr 29/2013, 80-81).

28 Marsh i Musson (2008) badali amerykańskich mężczyzn wykonujących telepracę w domu. 
społecznym powoduje powstanie i rozszerzanie się współczesnego prekariatu, czyli kategorii ludzi żyjących pod presją permanentnej walki o przetrwanie".

Rozwijając kategorię wprowadzoną do literatury fachowej przez Guya Standinga, autora The Precariat. The New Dangerous Class (2011), Dobrzyński (2012: 34-35) charakteryzuje prekariusza jako osobę, która ,żyje w warunkach generalnie niestabilnych”, „nie posiada trwałych materialnych podstaw utrzymania” oraz „podejmuje zatrudnienie poniżej swoich kwalifikacji”. Rzeczywistości współczesnego rynku „produkującego” prekariuszy cytowany autor przeciwstawia, za Stèphane Hesselem, wizję obywatelstwa pracowniczego. Istotę tej wizji stanowi zasada odpowiedzialności państwa za warunki życia obywateli, włącznie z zapewnieniem godziwej pracy (por. Judt 2011). Podobnie problematykę relacji państwo-obywatel ujmuje przywoływany już wielokrotnie Hoopes (2011: 2002) zauważając, iż „przedsiębiorczość nie jest demokratyczna, jeśli to po prostu oznacza 'tworzenie miejsc pracy' (ang. job creation), co zwykle kończy się listą płac u kogoś innego. Przedsiębiorczość jest demokratyczna tylko wtedy, gdy oznacza szansę na samozatrudnienie dla ludzi, którzy w innym przypadku mogliby wykonywać mniej płatną pracę". Zdaniem cytowanego autora podstawowy warunek demokratyczności przedsiębiorczości na terenie danego państwa stanowi odpowiedni system opieki socjalnej przysługujący jego mieszkańcom, ze szczególnym uwzględnieniem opieki zdrowotnej29.

Jak widać, zarówno kategoria „prekariatu”, jak i idea obywatelstwa pracowniczego bezpośrednio wiąże się z kapitałem kulturowym w kontekście funkcji zarządzania organizacją. Przy czym zagadnienie wspomnianych funkcji zarządzania zostaje rozszerzone także na funkcje organizacji biznesowych w szeroko rozumianym otoczeniu społecznym, przede wszystkim państwowym, ale także międzynarodowym i globalnym. Ponadto, co warto zauważyć, obydwie kategorie przywołują perspektywę historyczną.

Zasady obywatelstwa pracowniczego były wprowadzone po II wojnie światowej przez rządy wielu krajów Europy Zachodniej (Dobrzyński 2012, Judt 2011 $\mathrm{i}$ in.). Fakt ten wiąże się $\mathrm{z}$ dość nieoczekiwanym dla dzisiejszego uczestnika czy obserwatora świata biznesu „kalejdoskopem” ideowym, czy raczej kulturowym (w znaczeniu kapitału kulturowego organizacji). Chodzi o przenikanie do praktyki menedżerskiej w krajach zachodnich naszego kontynentu postulatów katolickiej nauki społecznej, paradoksalnie współwystępujące z radykalną sekularyzacją Europy. Przy czym wstrząs wojenny i wojenne oraz powojenne dyskusje oczyściły te propozycje z niepraktycznych wątków bądź naleciałości. Dobrze to pokazuje przykład idei korporacjonizmu. Nie jest oczywiście prawdą, choć ten stereotyp pojawia się jeszcze dziś nawet na łamach prac historycznych, że kor-

29 Bezpośredni społeczny kontekst tez Hoopesa (2011) określała dyskusja nad systemem ochrony zdrowia w USA. 
poracjonizm został skompromitowany przez praktykę gospodarczą takich państw jak Hiszpania Franco czy bardziej jeszcze Portugalia Salazara. Poza bowiem wspólną nazwą to korporacjonizm głoszony przez faszystów zasadniczo różnił się znacząco od tego, który propagowali papieże Leon XIII, Pius XI (autor kluczowej dla tej kwestii encykliki Qudragesimo Anno) i Pius XII. W międzywojennych Włoszech Kościół i reżim faszystowski, ówcześnie rządzący Italią, odwoływały się do terminu „korporacjonizm”, lecz „wypełniały go zupełnie inną treścią" (Burleigh 2006: 171). Dla faszystów ten system miał być narzędziem wzmocnienia kontroli państwa nad gospodarką. Katoliccy zwolennicy korporacjonizmu liczyli na rozkwit, dzięki niemu, organizacji zrzeszających różnych aktorów życia gospodarczego (by użyć języka współczesnej socjologii) na zasadach ochotniczych. Struktury korporacyjne miały wychodzić poza granice konfliktów klasowych. Konkludując, katolicki „korporacjonizm miał pomóc w utrzymaniu stabilnego kursu między Scyllą liberalizmu gospodarczego realizowanego w myśl zasady lasisez-faire a Charybdą socjalistycznego kolektywizmu i umasowienia" (Burleigh 2006: 171). Na łamach przedwojennej publicystyki omawiany system jawi się jednak jako propozycja totalnej reorganizacji życia społecznego wokół gospodarki, nie wolny od wątków idealistycznych i pewnej przynajmniej dozy (a nie raz dużo więcej) niechęci wobec rynkowego kapitalizmu, co jeszcze dziś ostro wytykają mu niektórzy historycy idei, szczególnie ci związani z myślą liberalną (zob. np. Król 2001). Nie powinno to oznaczać zupełnego zapomnienia pomysłów niesionych, choćby implicite przez korporacjonizm, które odegrały swą rolę dla rozwoju myśli i praktyki menedżerskiej, a być może i dziś są warte reinterpretacji, szczególnie w czasach okołokryzysowych. Wymaga to oczywiście oddzielnej analizy przekraczającej znacznie zakres niniejszej książki ${ }^{30}$. Tym bardziej, że choć sam korporacjonizm odgrywał raczej niszową rolę pośród dyskusji menedżerskich międzywojnia (odnośnie Polski zob. Górski 2005), to jednak od początku stanowił interesujący przykład „spotkania ponad podziałami” idei religijnych i socjalistycznych dotyczących rynku, choć formalnie podziały te wzmacniał. Że było to jednak właśnie tego typu spotkanie ideowe pokazała praktyka gospodarcza i polityczna rządów niektórych krajów europejskich po 1945 roku.

W warunkach powojennej odbudowy Europy podstawowe idee korporacjonizmu (jeśli chodzi o wersję pochodzącą z katolickiej nauki społecznej), „oszlifowane" nowymi doświadczeniami świata, takie jak reguły regulowania relacji centrum-peryferie zgodnie z zasadą pomocniczości, łączenie świadczeń socjalnych $\mathrm{z}$ warunkami rozwoju przedsiębiorczości i inne, legły u podstaw - obok amerykańskiej pomocy finansowej - rozwoju społecznego oraz gospodarczego, nie tylko rządzonych przez chadecję Niemiec i Austrii, ale także protestanckiej,

$\overline{30}$ Zbieram materiały do podjęcia takiej analizy w przyszłości. 
silnie zorientowanej ku socjaldemokracji Skandynawii. I podkreślę raz jeszcze, nie chodziło o konfesyjne konotacje tez korporacyjnych, ale wyłącznie o ich praktyczne znaczenie. Brytyjski historyk Tony Judt (2008) bardzo daleki od afirmowania jakiejkolwiek roli wartości religijnych w rozwoju gospodarczym, wyraźnie pokazał karierę „ducha” korporacjonizmu nie w powojennej Portugali, której dyktator realizował swoją wersję omawianego systemu, ale właśnie na terenie wymienionych wcześniej państw.

Krytykę współczesnego świata biznesu, z ducha podobną do tej, którą przed laty zawierały dyskusje wokół korporacjonizmu, rozwija aktualnie Richard Sennett. Jego koncepcja „kultury nowego kapitalizmu” stanowi wyraz troski (2006/2010) o stan kulturowego kapitału współczesnych organizacji biznesowych $^{31}$ i szerzej, kulturowych wymiarów gospodarki kapitalistycznej od której, jak zauważyli na kartach swego podręcznika antropologii ekonomicznej Richard R. Wilk i Lisa Cliggett (2011: 68), nie da się odłączyć „zagadnień moralności i motywacji człowieka”. Richard Sennett (już od dłuższego czasu) zajmuje się analizowaniem wpływu, który wywiera na kulturę funkcjonowanie innowacyjnych instytucji gospodarczych. Wspomniany badacz sprawdza, jak ,wirtualny kapitalizm" wpływa na ludzi zanurzonych w tym systemie. Zdaniem cytowanego socjologa dominujące wcześniej organizacje o strukturze hierarchicznej coraz bardziej ustępują miejsca tak zwanym organizacjom typu MP3, charakterystycznym głównie dla branży High Tech, choć nie tylko, które cechuje przede wszystkim (przejawiającym się w różny sposób) zwiększaniem dystansu pomiędzy zatrudnionymi oraz zarządzającymi. Mimo iż MP3 wypierają aktualnie nowsze technologie, to mam nadzieję, że studenci pamiętają jeszcze, iż centralnym elementem odtwarzacza jest zarządzający całością procesor. Podobnie sytuacja wygląda w elastycznej organizacji, w której ośrodek zarządzający decyduje o bardzo wielu sprawach, na przykład o rozmiarze firmy. Wiąże się to między innymi ze zmianą sposobu nadzorowania poszczególnych elementów organizacji. Michael Foucault nazywa te nowe sposoby kontrolowania zasobów i operacji jako „nadzór panoptyczny” możliwy dzięki nowym technologiom. Inne cechy organizacji typu MP3 to:

- praca często oparta na tworzeniu zespołów roboczych, posiadających określony stopień samodzielności, które konkurują ze sobą na zasadach ustalonych przez „centrum”. Taki system ma dać możliwość szybkiego i elastycznego osiagania wyników. W konsekwencji jego stosowania pracownicy zaczynają postrzegać siebie nawzajem zarówno jako kolegów, jak i rywali. Rosną również dysproporcje między pracownikami. Obowiązuje bowiem zasada: „zwycięzca bierze wszystko”,

31 Przy czym sam Sennett nie używa tego terminu. 
- likwidacja różnych pośrednich szczebli w firmie ostatecznie prowadzi do pozostawienia tylko „centrum” i „peryferii”. Proces ten skutkuje też zmianami komunikowania się. Nieraz relacje zmieniają się wręcz w transakcje (termin Sorosa). Taki na przykład charakter mają stosunki łączące azjatyckich pracowników produkujących obuwie z jego europejskimi projektantami,

- pogłębianie dystansu społecznego przez fakt, iż trudne decyzje w firmie cedowane są na zewnętrznych konsultantów,

- trudności z utrzymaniem autorytetu instytucjonalnego przez kadrę kierowniczą (częste zmiany kierowników, dystans, zarządzanie przez e-maila, także przy przekazywaniu trudnych decyzji, z decyzją o zwolnieniu włącznie).

Sennett (2006/2010) alarmuje, iż zasygnalizowane zmiany strukturalne prowadzą do następujących trzech deficytów społecznych w firmach:

- małej lojalności pracowników wobec instytucji,

- spadku zaufania pomiędzy pracownikami,

- uszczuplenia wiedzy instytucjonalnej (normalnie nabywanej przez pracowników poprzez długotrwałe funkcjonowanie w jednej firmie).

Problemy kulturowego kapitału współczesnej organizacji biznesowej silnie więc wpływają na możliwości realizacji przez jej menedżerów podstawowych funkcji zarządzania.

Jako remedium na zasygnalizowane problemy amerykański socjolog zaleca przywrócenie pewnych elementów zarządzania biurokratycznego, co niewątpliwie wymaga oddzielnej dyskusji.

Oczywiście wspomniane deficyty nie muszą być wcale związane z tymczasowością miejsca pracy. Warunkiem podstawowym pozostaje opisany przez Foucaulta „nadzór panoptyczny” (niezależnie od jego formy technologicznej) połączony z „wolnością” od wartości, poza zorientowaniem na zysk. Prowadzi to do reakcji pracowników w postaci „drugiego życia”, wymykającego się najsilniejszej nawet kontroli. A w dłuższej perspektywie skutkuje „korozją charakteru” zatrudnionych, procesem destrukcji szczególnie tych „właściwości charakteru, dzięki którym człowiek odczuwa więź z innymi i nie wątpi w trwałość własnego 'ja'” (Sennett 2008: 29, zob. także Kostera 2012 i Dobrzyński 2012).

Znacznie głębiej niż koncepcja obywatelstwa pracowniczego sięga do historii idea „prekariatu”. Nazwa pochodzi ze starożytnego Rzymu. „Była to kategoria mieszkańców, którzy nie byli ani niewolnikami, ani obywatelami. Pracowali dla miasta, a także utrzymywali się z rzemiosła” (Dobrzyński 2012: 34).

Warto zaznaczyć, iż doświadczenie starożytnego Rzymu, choć zgodnie ze stylistyką swoich esejów, wyłącznie aluzyjnie proponował wykorzystać do rozumienia współczesności także polski znawca świata klasycznego Zygmunt Kubiak (2003). Jego częste przywoływanie działań i roli ekwitów (equites) wskazywało na kulturowe korzenie i funkcje ludzi biznesu. „Była to klasa (chodzi o ekwitów - uwaga T.O.) złożona pierwotnie z tych obywateli, którzy byli w stanie 
służyć na własnym koniu w kawalerii. Teraz (II w. n.e. - uwaga T.O.) to już była warstwa prawdziwie zamożna i właśnie pieniądze uprawniały ludzi do uczestnictwa w niej. Jedynie ta klasa wypełniała państwowe umowy pieniężne; senatorom nie wolno było zajmować się nimi” (Kubiak 2003: 323-324). Autor Dziejów Greków i Rzymian pokazuje przy różnych okazjach sukcesywnie wzrastające znaczenie ekwitów dla funkcjonowania państwa.

W takiej perspektywie rzymskich metafor warto umieścić na przykład klasyczną pracę Charlesa Wrighta Millsa Biate kotnierzyki. Amerykańskie klasy średnie (Warszawa 1964, oryg. 1951), uważaną za najlepszy opis „rewolucji menedżerskiej" 32 w USA lat 40. i 50., a zarazem trafną krytykę nieograniczonej władzy menedżerów. Można ją dzisiaj czytać jako charakterystykę procesów prowadzących do tego, iż kapitał kulturowy organizacji biznesowych wykreowany przez „ekwitów” przyczynia się do powstania i rozwoju współczesnego „prekariatu”.

Perspektywa historyczna pogłębiająca rozumienie aktualnych relacji między kapitałem kulturowym a funkcjami zarządzania współczesną organizacją, pozwala też uwypuklić praktyczne znaczenie krytycznego nurtu refleksji nad tą problematyką. Zdolność do autokrytycyzmu stanowi bowiem, zdaniem cytowanego Kubiaka (2003: 528), centralny element europejskiego dziedzictwa epoki klasycznej, które umożliwia również pragmatyczne osiągnięcia Zachodu. „Wiele ułomności Europy są ułomnościami człowieczeństwa, ludzkiej historii. Wspaniała osobliwość tradycji zachodniej polega na tym, że widzi swoje skazy ostrzej niż swoje widzi jakakolwiek cywilizacja. I, jak ufamy, ona się nigdy z tymi skazami nie pogodzi”.

\subsection{Kapitał kulturowy w kontekście kultury organizacyjnej}

\subsubsection{Kapitał kulturowy na tle rozwoju problematyki kultury organizacyjnej}

Wobec wielkiej ilości „materiału intelektualnego” dotyczącego koncepcji kultury organizacyjnej, zgodnie z logiką niniejszej pracy, warto sięgnąc do kulturowych warunków narodzin i rozwoju zainteresowania wspomnianą tematyką, jako swoistego prototypu, a przez długie lata „podstawowego typu” problematyki kulturowej w zarządzaniu ${ }^{33}$.

32 Hoopes (2011) argumentuje, iż Mills lepiej zrozumiał istotę rewolucji menedżerskiej, niż autor tego terminu James Burnham.

33 Niniejszy rozdział skupia się przede wszystkim na funkcjonalistycznym paradygmacie badań kultury w zarządzaniu, według podziału Sułkowskiego (2012), jako najbardziej jak dotąd rozpowszechnionym w teorii i praktyce menedżerskiej. Przy czym do oddzielnego opracowania pozostawiam problematykę kapitału kulturowego organizacji związaną $\mathrm{z}$ neoewolucyjnym nurtem rozwijanym $\mathrm{w}$ ramach wspomnianego paradygmatu. 
Mam przy tym nadzieję, iż warunki te wyraźnie już się rysują na tle wcześniejszych rozważań. I wyraźny jest ich związek z obszarem zagadnień, który określam jako kapitał kulturowy organizacji.

Wbrew entuzjastom ideologii human relations, nie polegały one (warunki powstania i rozwoju problematyki kultury organizacyjnej w zarządzaniu) na „niebiańskim” dążeniu do humanizacji doli pracownika. Wiązały się raczej z „czyśćcową" świadomością napięcia między potrzebami jednostki ludzkiej a wymogami efektywności firmy. Napięcie to musiało stać się szczególnie widoczne wówczas, gdy niektórzy badacze funkcjonowania ludzi w pracy przesunęli swe zainteresowania ze szczegółowych zagadnień HR na płaszczyznę makro, traktując organizacje jako system społeczny, a także jako część szerszych społeczności.

Tak postępowali na przykład naukowcy, których skupiał londyński Tavistok Institute of Human Relation. Wśród założycieli wspomnianej instytucji naukowej był Elliot Jacques. Poszukiwał on możliwości stworzenia „postulowanej organizacji" (ang. requiste organization), to jest takiej, która stwarzałaby ludziom możliwość pracowania razem, a także bycia razem w sposób dający wszystkim poczucie, iż relacje między nimi opierają się na sprawiedliowści (ang. feel to be fair). By zdobyć materiał empiryczny do realizacji tego celu ${ }^{34}$, Jacques przeprowadzil ponad dwuletnie badania (1948-1950) w fabryce Glacier Metal Company, stosując metodologię studium przypadku i wykorzystując teorię pola Kurta Lewina ${ }^{35}$. Treścią przytoczonych działań badawczych były codzienne problemy doświadczane przez firmę w jej wysiłkach, aby stworzyć warunki dające satysfakcję zatrudnionym (osoby zaangażowane w przedsiębiorstwo Jacques nazywał uczestnikami ,życia pracy”, ang. working life), przy zachowaniu wymogów konkurencyjności (Jacques 1951). Jacques wyraźnie personifikował, wręcz psychologizował, organizację. Na kartach książki podsumowującej wspomniane

Paradygmaty intepretatywno-symboliczny i krytyczny tu jedynie wzmiankuję. Te dwa paradygmaty w znacznym stopniu określają moje rozumienie kapitału kulturowego organizacji. Są też „ideową ojczyzną” historii organizacyjnej. Pisałem więc już o nich w podrozdziale 1.1. i 1.3. oraz poświęcę im nieco miejsca w rozdziałach III i IV. Zawartość treściowa niniejszego podrozdziału wynika $\mathrm{z}$ jego skrótowego oraz częściowo historiograficznego (w znaczeniu spojrzenia na problematykę kultury organizacyjnej z perspektywy historycznej) charakteru.

34 Przytoczone badania były pierwszym etapem wieloletnich poszukiwań przez Jacquesa „postulowanej organizacji”. Książkę pod takim właśnie tytułem (Requisite Organisation) cytowany badacz wydał w 1997 roku.

35 Dla zagadnień kultury organizacyjnej istotne jest przypomnienie, iż Lewin w swej teorii pola podkreślał interakcję wpływów środowiska i cech osobowości. Postulował, by zachowanie człowieka wyjaśniać nie za pomocą pojedynczych czynników, ale poprzez analizę różnorodnych związków wszystkich sił działających „w obrębie przestrzeni życiowej jednostki” (Benjamin 2008: 225). Jak więc widać, psychologowie byli u narodzin problematyki kultury organizacyjnej. Później także nieraz przyczyniali się do jej rozwoju (Baker 2004). 
badania The Changing Culture of a Factory (1951), jako jeden z pierwszych badaczy odniósł on pojęcie „kultury” do firmy produkcyjnej. Wprowadzony przez siebie termin „kultura fabryki” definiował następująco: „zwyczajowy i tradycyjny sposób myślenia oraz działania, podzielany, w mniejszym lub większym stopniu, przez wszystkich członków, a którego nowi członkowie muszą się nauczyć i przynajmniej częściowo go zaakceptować, tak aby sami mogli być zaakceptowani jako personel firmy" (Jaques 1951: 251, cyt. za Aniszewską 2007: 14 z pewnymi modyfikacjami). Najprawdopodobniej tak zaczęła się intelektualna kariera pojęcia, które w końcu zadomowiło się wśród teoretyków i praktyków zarządzania jako „kultura organizacyjna”.

Rozpoczęcie niniejszego paragrafu od skrótowego opisu wysiłków poznawczych Jacquesa (1951) nie oznacza, że kulturę organizacyjną odkrył dopiero cytowany kanadyjski psycholog. Sprawa ma się bardzo podobnie do „kwestii powietrza” z popularnego dowcipu. „Wiesz, że powietrze zostało odkryte dopiero w XVIII wieku? ${ }^{36}$ - pyta kolega kolegę. - A to ciekawe, czym ludzie oddychali wcześniej? - odpowiada zagadnięty".

Zarządzający spotykali się z praktycznymi problemami, które dziś określa się mianem „kultury organizacyjnej”, przynajmniej od czasu budowy egipskich piramid czy chińskiego muru, jak ostatnio przypomniał Kazimierz Doktór (2011) ${ }^{37}$.

Do dziś badacze tego zagadnienia (a przynajmniej niektórzy $\mathrm{z}$ nich zaliczani do znaczących) podkreślają przecież, że kultura stanowi ważny społecznie fenomen mający duży wpływ na organizację, grupy oraz na indywidualne zachowania. Jest czymś, co podzielają członkowie danej organizacji. Istnieje na wielu poziomach (m.in. grupowym, organizacyjnym, narodowym). Składa się ze wspólnych wartości, przekonań czy założen. Wpływa na zachowania, a także na postawy członków danej organizacji. Przy czym, co warto raz jeszcze podkreślić, w obszarze myśli menedżerskiej panuje duża różnorodność znaczeń i kontekstów dotyczących kultury organizacyjnej (Hartnell, Ou i Kinicki 2011 oraz Kostera 2007, 2010, 2011 i in.).

Wiążą się z tym spory, na dłużej lub krócej, wprost lub domyślnie ożywiające środowiska zainteresowane omawianą problematyką. Przepraszając tych wszystkich teoretyków i badaczy, którzy szczegółowo tropią nawet subtelne kontrowersje w obszarze kultury organizacyjnej (zob. np. Alveson 2002, Chan 2001, Glinka 2011, Kostera 2007, 2010, 2011 i Sułkowski 2012) - kontrowersje

36 Anegdota nawiązuje do pierwszej analizy powietrza dokonanej przez Antoine'a L. Lavoisiera (1774) lub nieco późniejszego pełnego określenia składu powietrza przez Henry'ego Cavendisha.

37 Monika Strocka, komentując niniejszy fragment mojego rozdziału, zasugerowała, iż można w kontekście kultury organizacyjnej wskazać także starsze fenomeny, jak na przykład budowę kanałów Mezopotamii. Tego typu uwagi wyznaczają interesujące pole poszukiwań dla historyków organizacji. 
bardzo często istotne dla codziennej pracy menadżerów - z punktu widzenia tych ostatnich najistotniejsze wydają się dwa pytania. One też w znacznym stopniu określają ramy ideologiczne dla różnych projektów kapitału kulturowego w kontekście problematyki kultury organizacyjnej. Chodzi o następujące pytania: 1. Jak należy badać kulturę organizacyjną, by otrzymać wiedzę operacyjną przydatną dla praktyki zarządzania?

2. Czy kulturę organizacyjną można zmieniać bądź wykorzystać do zmiany organizacyjnej?

Jeśli na któreś z tych dwóch pytań można odpowiedzieć pozytywnie, to rodzi się oczywiście następne: jak to robić?

Nawet niezbyt zainteresowany omawianą problematyką praktyk zauważy, że wymienione, z pozoru czysto funkcjonalne pytania, niosą ze sobą cały kompleks szczegółowych kwestii dotyczących „,natury kultury organizacyjnej”. Na różnych etapach intelektualnych dziejów charakteryzowanej tu tematyki, często także w tym samym czasie, teoretycy, a nieraz także praktycy formułowali różnorodne propozycje odpowiedzi, które proponuję uważać za przejawy kapitału kulturowego organizacji, traktowanego, pozwolę sobie przypomnieć, jako zjawisko postulatywne o naturze retorycznej.

I tak lata 60. ubiegłego stulecia to przede wszystkim okres kontynuacji zainteresowań rozbudzonych pracą Jacquesa. Badacze kultury organizacyjnej koncentrowali się na kwestiach dynamiki grupowej oraz procesach tworzenia się wspólnych mitów i wyobrażeń (Kostera 2007; 168). Ósma dekada XX wieku przyniosła podstawowe prace unowocześniające omawiany obszar dążeń poznawczych nadające mu kształt mniej więcej aktualny do dziś. Za szczególnie ważny uznaje się w tym kontekście artykuł Andrew Pettigrewa On Studying Organizational Cultures (1979). Zintegrował on różne spojrzenia na kulturę organizacyjną, rozwijane obecnie przez socjologów i antropologów, oraz spowodował wzrost zainteresowania kulturą jako główną cechą zachowań organizacyjnych (Hartnell, Yi Ou i Kinicki 2011 oraz Kostera 2007). Nieco wcześniej (1976 i 1978) typologię kultur organizacyjnych opublikował Charles Handy, nazywany „badaczem o cechach angielskiego gentelmana”. Richard Koch pisał (1997: 88), iż czyta książki tego autora „z największą przyjemnością, gdyż zarówno treść, jak i styl (...) są oryginalne, zachęcające do myślenia i zajmujące”. Zdaniem tegoż Kocha (1997: 36) przypisanie przez Handy'ego typom organizacji pomysłu Rogera Harrisona symboli greckich bogów stanowiło „uderzająco oryginalne sformułowanie prawd natychmiast rozpoznawalnych przez każdego, kto pracował w jakichś organizacjach”. Wiązało to problematykę kultury organizacyjnej z kulturą wysoką, co samo w sobie stanowiło dość rzadką w myśli menedżerskiej perspektywę modelowania kapitału kulturowego organizacji.

Także w latach 70. XX wieku, zadaniem Ewy Trojnar (2011), spopularyzowany został termin „kultura korporacyjna”. Choć pokrywa się on znaczeniowo 
z pojęciem „kultura organizacyjna”, to niektórzy badacze wolą pisać właśnie o „kulturze korporacyjnej”.

W latach osiemdziesiątych ubiegłego stulecia, a zdaniem Hoopesa (2011) dekadę wcześniej, kultura organizacyjna urosła do rangi „problemu biznesowego”.

Barley i Kunda (1992) precyzują wspomniane procesy. Wskazują na dwie ścieżki zainteresowania kulturą organizacyjną.

Pierwsza, powstała w latach 70. XX w., związana była z interakcjonizmem symbolicznym. Koncentrowała się na poszukiwaniu alternatywnego dla tak zwanego racjonalnego ujęcia organizacji. Zaowocowała paradygmatem interpretatywno-symbolicznym (Sułkowski 2012). Mieści się w jego ramach cały szereg podejść poznawczych, zapożyczonych przez badaczy zarządzania z innych nauk społecznych i humanistycznych. Obok interakcjonizmu symbolicznego można jako przykłady wymienić tu fenomenologię, etnometodologię, antropologię kulturową (por. antropologię organizacji w ujęciu Kostery 2010), perspektywę retoryczną czy narratywizm. Ostatni z wymienionych nurtów przeniesiony do zarządzania przez Barbarę Czarniawską osadza metodologię badań organizacyjnych (w tym także badań kultury organizacyjnej) na fundamencie przekonania, iż piśmiennictwo naukowe dotyczące problematyki menedżerskiej stanowi pewną odmianę stylu literackiego. Badacze organizacji mogą wiele nauczyć się od wybitnych powieściopisarzy, poetów i dramaturgów. Zaś ujmowanie procesów organizowania jako narracji przedstawiciele paradygmatu interpretatywno-symbolicznego uzasadniają tezą, że „doświadczenie stale przyjmuje formę narracyjną, jeśli narrację uważa się za przebiegające w czasie uobecnianie (ang. embedding, chodzi o osadzanie w konkretnej opowieści danych wydarzeń, przeżyć itp. - uwaga T.O.)" w myśl poglądów Kennetha Gergena (Kociatkiewicz i Kostera 2012b: 165, Czarniawska 2012). Według zwolenników prezentowanego tu skrótowo paradygmatu, będących zazwyczaj radykalnymi konstruktywistami społecznymi, kulturę tworzą sieci znaczeń. Mają one zawsze charakter lokalny, są specyficzne dla danej organizacji czy danego środowiska. Tworzą je ludzie poprzez różnorodne gry społeczne i językowe. Taką samą „naturę” ujawnia też kultura organizacyjna. Jest siecią znaczeń negocjowaną przez uczestników danej organizacji, a dokładniej rzecz ujmując, procesem wspomnianego negocjowania. Może ją poznawać jedynie badacz zaangażowany, który rezygnuje z dążenia do pozytywistycznego obiektywizmu i nastawiony jest na osiagnięcie intersubiektywnego rozumienia kultury organizacyjnej. Ma ponadto świadomość tego, iż jego działania badawcze są równocześnie interwencją zmieniającą analizowany proces (Sułkowski 2012). Kapitał kulturowy organizacji byłby więc z tej perspektywy specyficznym dla danej organizacji w danym momencie wynikiem interpretacji wymagań stawianych jej przez szeroko rozumiane otoczenie. Chodzi o interpretacje negocjowane przez członków organizacji między sobą oraz $\mathrm{z}$ podmiotami zewnętrznymi łącznie $\mathrm{z}$ badaczem. 
Druga spośród ścieżek rozwoju problematyki kultury organizacyjnej wyróżnionych przez Barleya i Kundę (1992) - praktyczna - wynikła z konkurencyjności firm japońskich. Obydwie ścieżki rozwijały się powoli aż do boomu 1982 roku, gdy sprawę nagłośniły fachowe czasopisma: „Fortune” i „Business Week” (por. artykuł Kostery i Koźmińskiego z 2010 roku o współczesnym nam znaczeniu „Harvard Business Review”).

Cytowani Barley i Kunda (1992) uogólniają, iż zainteresowanie kulturą organizacyjną wrasta, gdy turbulentne warunki ekonomiczne wymagają szczególnego zaangażowania pracowników, którzy nie będą odróżniać dobrobytu/bogactwa firmy od własnego. W tekstach dotyczących zarządzania dominuje wówczas retoryka jedności i lojalności, stanowiąca charakterystyczną cechę problematyki kultury organizacyjnej.

Wracając do „boomu lat osiemdziesiątych”, dobrze oddaje atmosferę tamtego czasu, nieco późniejsze, a najwyraźniej wówczas mające swe ideowe źródło, stwierdzenie wielokrotnie przywoływanego przeze mnie Kocha (1997: 85): „czytelnik zainteresowany zagadnieniami kultury - a zakładam, że dotyczy to wszystkich $(\ldots)^{38}$ ". Trudno nie zauważyć czynnika inspirującego wspomniany boom, jakim była zazdrość. Chodziło przecież o dynamiczny rozwój firm japońskich zagrażających coraz bardziej amerykańskim interesom na świecie. Książki Williama G. Ouschiego Theory Z: How American Business Can Meet the Japanese Challenge (1981) oraz Richarda T. Pascale'a i Anthony'ego G. Athosa The Art of Japanese Management: Applications for American Executives (1982) sugerowały, że sukces biznesowy, który odniosła Japonia, w dużej mierze może wiązać się z kulturą korporacyjną wspomnianego kraju. Z kolei „amerykański odpór” dali na kartach swych prac Terrence E. Deal i Allan A. Kennedy jako autorzy Corporate Cultures: The Rites and Rituals of Corporate Life (1982) oraz Robert $\mathrm{H}$. Waterman Jr i Tom Peters jako autorzy In Search of Excellence: Lessons from America's Best Run Companies (1982, wydanie polskie pt. Poszukiwanie doskonatości w biznesie, 2000).

Wszystkie cztery wspomniane w poprzednim akapicie książki przedstawiały kulturę organizacyjną jako klucz do osiągnięć firmy oraz narzędzie pozwalające instytucji zwiększyć przewagę konkurencyjną. Jednocześnie ich autorzy, a szczególnie Waterman i Peters wskazywali na kartach swych publikacji amerykańskim menedżerom, którzy chcą nadal odnosić sukcesy - pomimo wzrastającej konkurencji ze strony Japonii - pewne realne recepty. Wymienione w poprzednim akapicie książki cieszyły się tak dużą popularnością, iż stały się absolutnymi bestsellerami.

38 W dalszej części zdania Koch poleca lekturę The Gods of Management Handy'ego zawierającą omówioną przeze mnie jego i Harrisa typologię kultur organizacyjnych. 
Wzrastające zainteresowanie kulturą organizacyjną sprawiło, że badacze organizacji zamiast poświęcać większość swej uwagi funkcjonalnym i technicznym aspektom zarządzania (związanym z podejściem ilościowym), jak to było do tej pory, zaczęli bardziej skupiać się na interpersonalnych oraz symbolicznych wymiarach organizacji (mających związek z pogłębionymi badaniami jakościowymi). W wyniku tej zmiany zainteresowania badawczego wzrosła liczba książek dotyczących przywództwa oraz poszczególnych wariantów kultury organizacyjnej, by wymienić przykładowo publikacje dotyczące kultury zorientowanej na zmiany, na zespoły czy innowacje.

Wreszcie kolejny etap rozwoju problematyki kultury organizacyjnej sprawit, że obiektem zainteresowań badaczy stało się identyfikowanie oraz kreowanie kultury organizacyjnej jako medium ułatwiającego między innymi alianse, partnerstwo, tworzenie sieci, a także umożliwiającego zarządzanie wiedzą oraz różnorodnością. Cały czas od wspomnianych „złotych lat osiemdziesiątych” powstawały i powstają również prace poszerzające wiedzę o tym, jak kultura jest tworzona, utrzymywana i rozprzestrzeniana (Baker 2004, Hartnell, Yi Ou i Kinicki 2011 oraz Kostera 2007, Kostera i Śliwa 2012).

Prace w tym kierunku znacznie przekraczają wspominany „boom”, bowiem rozwijane były i przed nim i po nim (a także rozwijają się nadal). Zyskały na popularności podczas jego trwania trzy koncepcje kultury organizacyjnej: wspomnianego już przeze mnie Edgara Scheina, Geerta Hofstede (ostatnio publikuje razem ze swym synem Gertem Janem Hofstede) oraz Kima S. Camerona i Roberta E. Quina. Na przykładzie aplikacji jednej z tych koncepcji (Hofstedów) nieco szerzej rozwinę w następnych paragrafach problematykę obecności zagadnienia kapitału kulturowego w kulturowym kontekście współczesnego zarządzania.

Nową perspektywę dla obszaru zagadnień, które w niniejszej pracy określam terminem „kulturowy kapitał organizacji”, stworzył postmodernizm obecny w naukach o zarządzaniu mniej więcej od lat 90. ubiegłego stulecia (Kostera 1995 i Sułowski 2012).

Z punktu widzenia problematyki kapitału kulturowego organizacji najcenniejsze w postmodernistycznych nurcie było uznanie kategorii „kultura” za „metaforę rdzenną”, by sięgnąc do znanej nawet studentom szkół biznesu terminologii zaproponowanej przez Lindę Smircich (Kostera 2005 i Glinka 2011). W takim świetle organizacja po prostu jest widziana jako kultura. „Wszystkie aspekty organizacji na przykład ekonomiczne, finansowe, polityczne mają znaczenie kulturowe i mogą być odczytane z kulturowego punktu widzenia. Można starać się widzieć i rozumieć symbole zarówno plastyczne (na przykład kolory), jak i księgowe (bilanse i sprawozdania finansowe) i starać się odtworzyć głębszy kulturowy sens, odpowiedzieć na pytania dotyczące tego, w jaki sposób zjawiska powstają i jak są tworzone i odtwarzane. Tworzenie kultury organizacyjnej 
jest aktywne (dynamiczne) aczkolwiek niekoniecznie intencjonalne. Oznacza to, że w firmie, w szkole, czy w więzieniu ludzie aktywnie przyczyniają się do tworzenia sukcesów, jak i ograniczających ich samych" (Kostera 2005: 35).

Przytoczone podręcznikowe sformułowania cytowanej już wielokrotnie Kostery dobrze ukazują główne rysy postmodernistycznego podejścia do zagadnień kultury organizacyjnej i ukazują przestrzeń dla analizy kapitału kulturowego organizacji. Przestrzeń tę wyznaczają takie prace, jak autorstwa Gideona Kundy (1992, zob. także Kostera i Śliwa 2012) ukazujące niebezpieczeństwa związane z zarządzaniem kulturą (chodzi o techniki zrządzania popularne na początku lat 90. XX wieku, polegające na formułowaniu przez zarząd norm i wartości firmy), które ostatecznie prowadzi do zakłamania oraz zachowań obronnych członków organizacji, czy badania Arlie Russell Hochschild (np. 2003) dotyczące komercjalizacji życia intymnego zarówno w domu, jak i w pracy.

Dla problematyki kapitału kulturowego organizacji, istotny jest również inny aspekt postmodernistycznego podejścia do zarządzania. Zwolennicy tego nurtu wskazują, iż dziś organizacje można spotkać praktycznie wszędzie. Tę wszechobecność organizacji proponują uznać za charakterystyczną cechę współczesnego świata. Organizacje wyznaczają oraz realizują wiele celów społecznych, ekonomicznych czy politycznych, takich jak: kontrola społeczna, rozwój gospodarczy, obrona czy edukacja. Pełnią również ważną rolę w życiu ludzi, w którym nie ma możliwości ucieczki od organizacji. Organizacje pomagają zaspokoić na przykład takie potrzeby człowieka, jak potrzeby osiągnięć przynależności czy przyjaźni. Słowem, podkreślają postmoderniści, „rzeczywiście (dzisiejszy świat - uwaga T.O) jest światem organizacji (Kociatkiewicz i Kostera 2012b: 867, autorzy przywołują poglądy Gibsona Burrella, Charlesa Perrowa i Karla E. Weicka $\mathrm{z}$ podaniem informacji bibliograficznych). Jeśli więc organizacja jest kulturą, a świat zapełniony organizacjami, to kapitał kulturowy organizacji przestaje być problemem tylko menedżerów. Zaś krytykę rzeczywistości organizacyjnej, która rozwinęła się w atmosferze postmodernistycznej, można uznać za element bogatej tradycji - kontynuowanej także współcześnie - różnorodnych nurtów krytyki społecznej. Dla świata biznesu rozpoczęli tę tradycję romantycy, boleśnie rozczarowani faktem, iż większość współczesnych im właścicieli firm okazywała się zaprzeczeniem mitu dobrego przedsiębiorcy, którego literacki obraz zaprezentował np. Wiktor Hugo w Nędznikach (Salmi 2010).

$\mathrm{Z}$ takiej perspektywy proponuję spojrzeć na postmodernizm jako na kulturową atmosferę sprzyjającą krytycznym ujęciom problematyki zarządzania. Pomijam więc $\mathrm{w}$ mojej pracy, choć $\mathrm{w}$ pełni szanuję, precyzyjne rozróżnienia podawane przez Sułkowskiego (2012), na przykład między paradygmatem postmodernistycznym a paradygmatem radyklanego strukturalizmu. Tą drugą nazwą cytowany autor określa działania poznawcze środowiska „Critical Management Study”, czyli konkretnej odmiany krytycznych ujęć w naukach o organizacji, 
rozwijającej się od lat 90. ubiegłego stulecia i zadaniem Sułkowskiego - korzystającej z inspiracji neomarksizmu (Sułkowski 2012).

Empirycznych argumentów, uzasadniających szeroko rozumiany krytyczny nurt nauk o zarządzaniu, dostarcza sukcesywnie Hoopes (2004), którego badania z dziedziny historii biznesu skłoniły do stwierdzenia, iż kultura organizacyjna deklarowana w organizacji zazwyczaj nie jest głębsza niż „na jeden cal”, a na przykład okrzyczane na początku obecnego stulecia jako bardzo nowoczesne zarządzanie wiedzą istniało już od czasów Taylora. Trudno nie podzielać lęku zwolenników orientacji postmodernistycznej przed zideologizowaniem problematyki kultury w obszarze zarówno teorii jak i aktywności menedżerskiej. Świadomość tych zagrożeń oraz wypracowanie sposobów ich demaskowania, czy - mówiąc bardziej precyzyjnie, zgodnie z terminologią omawianej pobieżnie orientacji - dekonstrukcji tych zagrożeń stanowią niezbywalne osiągnięcie postmodernizmu w zarządzaniu także dla problematyki kapitału kulturowego organizacji. Wśród wspomnianych intelektualnych narzędzi analizy, diagnozy oraz dekonstrukcji znalazła się na przykład antropologia organizacji, podejście retoryczne, a także badanie tego, co przeszłość czyni z organizacją i co organizacja czyni ze swoją przeszłością, czyli podejście związane z „historycznym zwrotem" w zarządzaniu, który stanowi podstawowe tło metodologiczne niniejszej pracy i którego omówieniu poświęcam rozdziały III i IV (Kostera 2005, Booth i Rowlinson 2006) ${ }^{39}$.

Perspektywa historiograficzna, którą przyjąłem w prezentowanej pracy, każe nie spieszyć się z ostateczną interpretacją zjawisk najnowszych. Dlatego też nie czuję się kompetentny by oceniać czy tylko podsumować aktualny stan problematyki kultury organizacyjnej, choćby wyłącznie w kontekście obecności w niej wątków kapitału kulturowego. Ośmielam się jedynie zasygnalizować pewne tendencje. Jedną z nich wyznacza prawdopodobnie rozwój zarządzania międzykulturowego. Interesującym przykładem wyrosłej na tym gruncie koncepcji, interesującej z perspektywy podjęcia implicite, ale wyraźnie problematyki posłuszeństwa w organizacji jest typologia kultur organizacyjnych zaproponowana niedawno przez Naadima Yousafa (2011, także Rahmati, Darouian i Ahmadinia 2012). Biografia autora łączy arabskie korzenie z długoletnim doświadczeniem życia na Zachodzie. Za główne kryterium swej typologii Yousaf uznał stosunek organizacji do konfliktów. Wyróżnił w ten sposób:

- Kulturę Odłączną (wyobcowaną) - pokazywanie, że konflikty są obecne, jednak ważniejsze od nich są formalne zasady,

- Kulturę Demokratyczną - konflikty powinny ujrzeć światło dzienne, aby mogły być przeanalizowane i ugodowo rozwiązane,

39 Nietrudno zauważyć metodologicznego „przenikania się” paradygmatów postmodernistycznego i interpretatywno-symbolicznego w kulturowej problematyce zarządzania. Obydwa podejścia mają zbiór wspólnych technik badawczych oraz wspólnych badaczy. 
- Kulturę Antagonistyczną (przeciwstawną) - słowo „powinno być” jest tu słowem-kluczem, a zasada „brak kontaktu albo mało kontaktu” może być sposobem na uniknięcie dysonansu poznawczego w sytuacji konfliktu.

\subsubsection{Kultowość korporacyjna jako aplikacja do problematyki kapitału kulturowego organizacji koncepcji kultury organizacyjnej w ujęciu Hofstedów}

David Arnott (2000), profesor zarządzania strategicznego na Baptystycznym Uniwersytecie w Dallas (USA), zwrócił przed kilkunasty laty uwagę na korzyści, jakie przynieść może dla analizy organizacji biznesowych sięgnięcie po dorobek badań nad kultami, stanowiącymi dotąd przedmiot zainteresowania głównie religioznawstwa oraz psychologii społecznej. Zdaniem wspomnianego autora, aktualnie większość, jeśli nie wszystkie organizacje for-profit cechuje pewien poziom „kultyzmu korporacyjnego” (ang. corportae cultism). Chodzi tu o swoisty, niedostrzegany dotąd przez specjalistów zarządzania, aspekt kultury firm, który już dawno został zidentyfikowany jako specyficzna cecha niektórych grup religijnych lub parareligijnych, popularnie, choć bardzo nieprecyzyjnie nazywanych sektami. W swej podstawowej - dla omawianej problematyki pracy Kulty korporacyjne: zdradliwy powab organizacji 'wszystko-konsumujacych' (ang. Corporate Cults: The Insidious Lure of the All-Consuming Organization) Arnott wprowadza między innymi określenie cultedness. Pojęcie to odpowiadające polskiemu terminowi „kultowość”, moim zdaniem bardziej precyzyjnie niż wspomniany „kultyzm”, oddaje istotę koncepcji amerykańskiego badacza, szczególnie gdy chodzi o konieczność przekładu. Dlatego też stosunkowo często wspominam o „kultowości” w wykładach i tekstach przeznaczonych dla polskiego odbiorcy (Ochinowski 2004, $2006 \mathrm{i}$ in.).

Arnott, wykorzystując ustalenia Philipa Zimbardo, wskazuje, iż każdy kult, a więc także kult korporacyjny (czy może właśnie kultowość jako aspekt kultury organizacyjnej - uwaga T.O.) cechują następujące trzy wymiary:

- poświęcenie się pracownika dla organizacji i jej ideologii,

- charyzmatyczne przywództwo,

- odseparowanie pracownika od innych społeczności poza środowiskiem pracy

(Arnott 2000 za Zimbardo i Hartleyem 1985).

Co warto podkreślić, kultowość według amerykańskiego badacza, ma charakter subiektywny, „rozgrywa się” w umyśle każdego pracownika i może być badana poprzez odpowiedzi na pytania kwestionariuszowe. Konsekwentnie Arnott skonstruował „Test badający kult” (The Cult Test). Jego poszczególne części pozwalają uchwycić wymienione wcześniej 3 aspekty omawianego zjawiska.

Jak już wspomniałem, zdaniem autora Corporate Cults... elementy kultowości mogą zauważać członkowie wielu organizacji nastawionych na zysk. Jednak 
w niektórych firmach cechy te stają się tak nasilone, iż stwarzają poważne zagrożenie dla pracowników. Przejawia się to przede wszystkim poprzez radykalne zakłócenie równowagi między pracą a życiem osobistym. Firma staje się nie tylko „drugim domem”, ale nieraz wręcz domem jedynym, chciałoby się powiedzieć „domem totalnym”. Arnott podkreśla również, że organizacje „wysokokultowe" opierają się na istotowo niesprawiedliwej relacji pracodawca-pracobiorca. Przedsiębiorstwa opisywanego typu otrzymują od pracowników dobra ekonomiczne - czas i zdolności, dając w zamian dobro nieekonomiczne - zaspokojenie potrzeby afiliacji przez przynależność organizacyjną, którego dystrybucja nic liderów nie kosztuje. Organizacja staje się więc coraz bogatsza, jej pracownicy zaś coraz biedniejsi z punktu widzenia ekonomii rozumianej jako „nauka o dystrybucji rzadkich zasobów” (ang. scarce resources). Przy czym profity firmy są wyłącznie krótkotrwałe. W szerszej perspektywie czasowej „zarządzanie przez wysoką kultowość” stanowi typowy przykład rabunkowej gospodarki zasobami ludzkimi.

Proces ten David Arnott wyjaśnia poprzez odwołanie się do sześciu wymiarów badania kultury organizacyjnej znanych z koncepcji Geerta Hofstede'a (2000, 278). Kult korporacyjny występuje wtedy, gdy dana organizacja ujawnia duże nasilenie: (1) orientacji na zachowanie procedur (wiąże się to z ograniczeniem do minimum możliwości wyboru sposobu wykonywania obowiązków pracowniczych; zdaniem Arnotta właśnie możliwość wyboru działania jest podstawowym kryterium odróżniającym firmy niekultowe od kultowych), (2) troski o produkcję (niesie to za sobą omówione już wcześniej przedkładanie interesu organizacji nad dobro pracowników), (3) przynależności (liczy się to, kim pracownik jest wobec firmy, a nie to, co robi), (4) zamknięcia systemu (ta cecha wyraża się przede wszystkim poprzez wysokie wymagania stawiane kandydatom, którzy chcieliby pracować w organizacji oraz poprzez „nieprzemakalność” informacyjną firmy wobec podmiotów zewnętrznych), (5) ścisłej kontroli oraz (6) normatywności (co oznacza między innymi dbanie bardziej o wierność zasadom ustalonym przez kierownictwo niż o efekt końcowy działań pracowników, jak również przekonanie, iż wspomniane zasady są ważniejsze od życia jednostki).

Zainteresowanie amerykańskiego badacza kultem korporacyjnym wynika przede wszystkim ze świadomości tych zagrożeń. Stąd wyraźnie interwencyjny charakter jego prac i silnie emocjonalny podtytuł najważniejszej z nich (cytowany już przeze mnie wcześniej). Arnott odwołuje się głównie - choć nie pisze o tym wprost - do tego nurtu badań religioznawczych i psychospołecznych, który zajmuje się „kultami destrukcyjnymi”. Pomija przy tym jeden z aspektów studiów nad kultowością, moim zdaniem bardzo istotny dla zarządzania. Od czasów prac klasyków religioznawstwa aż po współczesne ustalenia tej dziedziny wiedzy, ruchy kultowe - w przywoływanych tu analizach nazywane „sektami” (wspomniany termin dla anglojęzycznego czytelnika ma znacznie bardziej neu- 
tralny wydźwięk niż dla odbiorców polskich) - uważa się za istotne środowiska innowacyjności. Na przykład Ernst Troeltsch już przed wielu laty zauważył, iż „klasy niższe (stanowiące rezerwuar społeczny dla sekt) realizują rzeczywiście twórcze działania" (cyt. za Finkem i Wittberg 2000: 155). To właśnie sekty dostarczają podstaw dla „wszystkich wielkich ruchów religijnych. Kanadyjski socjolog Sam Reimer (2003) poprzez rozległe badania empiryczne zanegował konieczność związku między przynależnością do klas niższych a predyspozycjami do działalności w grupach kultowych. Być może więc środowiska o charakterze kultu przyciągają nie tylko i nie tyle ludzi zmarginalizowanych, ile raczej osoby silnie kontestujące zastaną rzeczywistość społeczną, czyli szeroko rozumianych innowatorów. Z kolei Roger Finke i Patricia Wittberg wykazali (2000) na przykładzie historii Kościoła katolickiego, iż niezwykłą żywotnością charakteryzuje się instytucja, która potrafi utrzymać w swych ramach spontanicznie powstające sekty oraz wykorzystać ich dynamikę (a także kontestację) do własnych reform. Takie zjawisko cytowani socjologowie nazwali zdolnością instytucji do „organizacyjnej odnowy pochodzącej z wewnątrz” (ang. Organizational Revival Within). Jeśli wierzyć Peterowi Druckerowi, że nie należy przesadzać z różnicami między zarządzaniem strukturami kościelnymi i zarządzaniem na przykład siecią sklepów, to nic nie stoi na przeszkodzie, by przytoczone wyżej ustalenia religioznawców wykorzystać jako narzędzia poznawcze wspomagające innowacyjność firm. Z takiej perspektywy koncepcja Davida Arnotta każe postawić problematyce twórczości w organizacjach dwa istotne pytania.

Pierwsze dotyczy kwestii kryteriów oceny działań innowacyjnych. Bo przecież może się zdarzyć, iż szef danej firmy uzna za przewagę konkurencyjną właśnie oparcie zarządzania personelem o opisaną wyżej niesprawiedliwą dystrybucję dóbr między pracodawcą a pracownikami. Jeśli taka opcja przyniesie wzrost zysków firmie, to czy można w tym wypadku mówić o działaniach innowacyjnych? Poza aspektem etycznym pojawia się czysto „efektywnościowa” kwestia, na ile i na jak długo „rabunkowa gospodarka” zasobami ludzkimi rzeczywiście zapewnia sukces rynkowy?

Ściśle wiąże się z tym druga kwestia dotycząca kosztów społecznych innowacyjności. Chodzi tu zarówno o koszty, jakie ponoszą osoby zatrudnione przez firmy „wysokokultowe”, jak i o sens funkcjonowania przedsiębiorstw tego typu w danej społeczności lokalnej czy narodowej. Przynajmniej w państwach rozwiniętych gospodarczo pytania o to, czy opłaca się tolerować firmy efektywne, ale na przykład manipulatorskie, stawiane są coraz głośniej (Csikszentmihályi 2003).

Poruszane problemy nie dotyczą jednak tylko liderów światowej gospodarki. Kult korporacyjny wydaje się bowiem być zjawiskiem międzykulturowym. Od 2001 roku prowadzę (w porozumieniu z Davidem Arnottem) badania nad występowaniem wspomnianego fenomenu w Polsce (Ochinowski i Grzywacz 2003a, b, c, Ochinowski i Grzywacz 2004, Ochinowski 2005 i 2006). Ze względu 
na wywołujący silne emocje przedmiot tych prac osobami zbierającymi dane są studenci. Potencjalnie obniża to oczywiście wiarygodność wyników, ale zarazem zwiększa możliwości dotarcia do różnorodnych organizacji. Z tych samych powodów jedyne kryterium doboru firm stanowi ich dostępność. Jako narzędzie badawcze wykorzystywana jest polska wersja „Testu badającego kult”40.

W 2009 roku przy dużym udziale studentów Wydziału Zarządzania przeprowadziłem badania normalizacyjne na ogólnopolskiej próbie 1875 studentów zarządzania i kierunków pokrewnych przy zachowaniu doboru losowego uczelni ${ }^{41}$. Wyniki zostały zamieszczone w tabeli 1.

Tabela 1. Porównanie amerykańskich i wstępnych polskich norm testu badającego kultowość dla sumarycznego wyniku ogólnego (,połączone konstrukty korporacyjnej kultowości”)

\begin{tabular}{|c|c|c|c|c|}
\hline Kwartyle & Opis wyniku wg Arnotta & $\begin{array}{c}\text { Wyniki } \\
\text { USA }\end{array}$ & $\begin{array}{l}\text { Kategorie } \\
\text { wyników }\end{array}$ & $\begin{array}{l}\text { Wyniki } \\
\text { polskie }\end{array}$ \\
\hline 1 & Wysokokultowy & $20-39$ & \multirow{2}{*}{ Wysokokultowy } & \multirow{2}{*}{$20-52$} \\
\hline 2 & Kultowy w pewnym stopniu & $40-59$ & & \\
\hline 3 & Dość niezależny & $60-79$ & Średniokultowy & $53-65$ \\
\hline 4 & Indywidualista & $80-100$ & Niskokultowy & Powyżej \\
\hline
\end{tabular}

Źródło: Arnott (2000: 171) i badania własne.

Polskie normy okazały się bardzo zbliżone do amerykańskich. Porównanie to prezentuje również tabela 1 . Na marginesie należy zauważyć, iż było ono nieco utrudnione ze względu na pewną niekonsekwencję. Arnott (2000) mianowicie przedstawił normy dla poszczególnych wymiarów (konstruktów) w trójpodziale na wyniki wysokie, średnie i niskie, natomiast dla ogólnej sumy (to jest dla wskaźnika „połączonych konstruktów”) zastosował kwartyle, wprowadzając 4 kategorie wyników: „wysokokultowy” (ang. highly culted), „kultowy w pewnym stopniu” (ang. somewhat culted), „dość niezależny” (ang. pretty independent) $\mathrm{i}$,indywidualista” (ang. maverick) ${ }^{42}$. Przy opracowaniu wstępnych polskich norm w naszym zespole posłużyliśmy się w każdym wypadku skalą stenową, dzieląc wyniki na wysokie, średnie i niskie również dla ogólnego wskaźnika kultowości.

40 Program częściowo był finansowany z funduszów na badania własne Wydziału Zarządzania UW. W latach 2001-2005 koordynował go ze mną Waldemar Grzywacz. Na różnych etapach opracowania wyników wiele skorzystałem z uwag Mariana Dobrzyńskiego i Andrzeja Wierzbickiego oraz naszych kolegów z prowadzonych przez wymienionych profesorów zespołów: Zakładu Psychologii Organizacji Wydziału Zarządzania UW i Pracowni Badania Dziejów Myśli Społecznej i Politycznej Instytutu Historii PAN.

41 Polska została podzielona na 4 części. W każdej z nich dobór poszczególnych uczelni był losowy.

42 Jak wyraźnie widać, nazwy tych kategorii wprowadzają już do interpretacji poszczególnych poziomów kultowości badanej osoby. 
Podobieństwo polskich norm do amerykańskich jest dosyć rzadkim zjawiskiem w naukach społecznych. Najprostszym wyjaśnieniem tej zbieżności w naszym przypadku wydaje się założenie, iż kultowość ma charakter międzykulturowy. Możliwe jest jednak, iż wspomniane podobieństwo świadczy o jakimś stopniu „amerykanizacji” zarządzania w Polsce. Jak wstępnie wykazała Paulina Kurek (2005) w pracy magisterskiej przygotowanej pod moim kierunkiem, polskie podręczniki zarządzania wydają się - trudno na razie powiedzieć w jak dużym zakresie $^{43}$ - powielać kategorie amerykańskie.

Badania przeprowadzone w latach 2001-2002, 2003-2004, 2008, 2012 i 2013, obejmujące w sumie koło 140 firm $^{44}$ pozwoliły stwierdzić, iż w Polsce występuje zjawisko kultu korporacyjnego (zazwyczaj około 25\% organizacji ujawniło wysoki poziom kultowości). Ma ono jednak specyficzne, regionalne „oblicze”, ujawniające ciągłość poprzez ponad 10 lat badań, mimo zmieniających się warunków ekonomicznych. Zarysowała się bardzo wyrazista, znacznie ważniejsza niż to zakładał Arnott (na podstawie doświadczeń amerykańskich) rola charyzmatycznego lidera w działających na terenie Polski organizacjach o dużym nasileniu kultowości. Natomiast „rozmyciu” uległ wymiar „odseparowanie od społeczności”. Ponadto wyodrębniły się „nowe”, być może specyficzne dla warunków transformacji aspekty kultu korporacyjnego, takie jak: „ważna rola szefa”, „praca jako centralny element satysfakcji życiowej i podstawa poczucia tożsamości pracownika”, „sakralizacja misji firmy”, „silne więzi między pracownikami i przywiązanie do firmy” oraz „motywacja pozafinansowa”45.

43 Cytowana praca opierała się na porównawczej analizie treści rozdziałów poświęconych kulturze organizacyjnej w podręcznikach mających polską wersję językową, a pochodzących z różnych krajów (Niemcy, Francja, USA i Polska). W zakresie wspomnianej problematyki podobieństwo podręcznika polskiego i amerykańskiego okazało się uderzające.

44 Starałem się nie dopuścić do tego, aby więcej niż raz wyniki tej samej firmy zostały poddane analizie na przestrzeni czasu, ale oczywiście, przy metodologii „detektywistycznej” mogło się to zdarzyć.

45 Wyniki testu Arnotta były poddawane analizie skupień za pomocą taksonomii wrocławskiej. Przypomnę, iż polega ona na konstrukcji dendrytu, czyli podzbioru lub podzbiorów zmiennych uporządkowanych według linii łamanej rozgałęziającej się. Łamana ta nie zawiera łamanych zamkniętych. Łączy ona wszystkie obiekty należące do analizowanego zbioru zmiennych. Długości „wiązadeł” dendrytu zależą od odległości (mierzonych siłą współczynnika korelacji) pomiędzy odpowiednimi parami zmiennych. Dendryt umożliwia nieliniowe uporządkowanie zmiennych. Za najlepsze takie uporządkowanie nieliniowe danego zbioru zmiennych autorzy metody (Florek, Steinhaus i in.) uznali sytuację dla którego dendryt ma najmniejszą długość (Nowak 1990 i in.).

Zgodnie z wytycznymi Brzezińskiego (1985) i Gębarskiego (1968) podstawą analizy taksonomii wrocławskiej jest macierz uzyskana za pomocą współczynnika wielokrotnej korelacji (każdego pytania z każdym). Na podstawie macierzy wyznaczone zostają główne związki pomiędzy poszczególnymi pytaniami ankiety czy elementami wypowiedzi swobodnych. Mówiąc bardziej szczegółowo, metoda taksonomii wrocławskiej polega na realizacji kolejno następujących czynności: 
W toku testowania zasięgu omawianego zjawiska pojawiło się także szereg kwestii wymagających dalszych analiz. Najważniejsza z nich dotyczyła pytania o kryteria precyzyjnego odróżnienia „destrukcyjnych” od „niedestrukcyjnych” form kultowości w organizacjach for profit. Pozwoliłoby to między innymi na klasyfikację oraz ocenę różnych typów innowacyjności firm „zarządzanych przez kult".

Ponadto zagadnienie kultowości poszerza problematykę radzenia sobie ze stresem w organizacji, szczególnie takim, który ma charakter ukryty (pracownicy firm wysokokultowych wydają się nie ujawniać, przynajmniej na poziomie deklaracji, szczególnie wysokiego natężenia stresu; jak dotąd jednak to zjawisko badane było tylko pośrednio).

Chodzi więc o to, jak przetrwać w środowisku pracy o dużym natężeniu kultowości?

Zazwyczaj w literaturze poświęconej kultom pokazywane są metody uwolnienia się od organizacji tego typu lub rozpoznania kultowości i unikania jej. Podobne wskazówki podaje Arnott (2000). Poświęcony im rozdział jego cytowanej już wielokrotnie pracy nosi tytuł: „Jak uniknąć przynależności do organizacji kultowej w przyszłości?” Amerykański badacz proponuje jako sposoby „uodpornienia się” na kultowość korporacyjną między innymi takie strategie, jak określanie własnej definicji sukcesu i uświadamianie sobie tego, która sfera życia jest dla osoby dokonującej tej analizy najważniejsza. Wiąże się z tym postulat poszukiwania satysfakcji życiowej nie tylko poprzez pracę, ale także w rodzinie i społeczności lokalnej; naśladowania u innych osób tylko wybranych cech oraz dokonywanie okresowej rewizji oceny własnej wartości, biorąc za punkt odniesienia inne organizacje a nie swoje miejsce pracy. Arnott radzi również kontrolowanie tak zwanego pędu do stapiania się. Oznacza to dbałość o równowagę między tym co indywidualne, i tym co zbiorowe, a także uniezależnianie poczucia własnej wartości wyłącznie od realizacji celów organi-

- tworzy się macierz wzajemnych korelacji wszystkich grupowanych zmiennych,

- w każdej kolumnie należy zaznaczyć najwyższą bezwzględną wartość korelacji,

- wyodrębnia się pary zmiennych, których wartości korelacji zostały dwukrotnie podkreślone (zmienne te stanowią „rdzeń” treści skupień),

- w wierszach wyznaczonych przez wyżej wymienione zmienne należy odnaleźć wszystkie podkreślone wartości korelacji,

- zidentyfikowane $\mathrm{w}$ ten sposób następne zmienne należy dołączyć do wspomnianych w poprzednim punkcie par.

Warto podkreślić, iż taksonomia wrocławska wymusza tworzenie skupień wokół dwóch pozycji ankiety czy kategorii wydobytych z narracji swobodnej, połączonych najsilniejszymi wartościami współczynnika korelacji w obrębie danego zgrupowania zmiennych. Jest to istotne ograniczenie omawianej metody, wymagające szczególnej ostrożności na etapie interpretacji wyników. Ewa Lebiedowicz opracowała algorytm wykonania procedur taksonomii wrocławskiej za pomocą programu SPSS na przykładzie obliczeń wyników testu Arnotta. 
zacyjnych. W praktyce, zdaniem Arnotta, ograniczanie wspomnianego „pędu” można osiągnąć poprzez kilkakrotne w ciągu życia zmienianie pracy czy nawet kariery, znajdywanie wartości indywidualnych a nie takich, które są powszechne wśród członków organizacji kultowych, a także pamiętanie o prawdzie, iż żadna instytucja nie może zaspokoić wszystkich potrzeb osoby ludzkiej. Jeśli jest się w organizacji kultowej, to Arnott widzi tylko jedno wyjście: należy starać się opuścić to środowisko. Kolejną radę amerykańskiego badacza stanowi - wydawałoby się zdroworozsądkowa - sugestia, aby ćwiczyć myślenie, czyli przekraczać postrzeganie rzeczywistości w kategoriach „czarno-białych” (chodzi tu o odrobinę dialektyki), budować związki z otoczeniem poprzez jak najszersze dzielenie się swoją fachową wiedzą, oraz uświadomić sobie podstawową niesprawiedliwość istotowo związaną z każdą organizacją kultową. Chodzi o to - warto powtórzyć raz jeszcze - iż w firmach tego typu pracownik oddaje dobra wyczerpywalne, takie jak zdolności i czas. W zamian otrzymuje dobra niewyczerpywalne, jak na przykład zyskanie poczucia przynależności (pracodawca nie ponosi tu żadnych kosztów).

Pracownikowi, który ma świadomość, że jest „zanurzony w kultowości”, Arnott proponuje analizę powodów zgadzania się na taki stan rzeczy. Można to osiaggnąć poprzez zrobienie tak zwanego indeksu swoich potrzeb i dążeń, pozwalającego jednostce uzmysłowić sobie dynamikę jej relacji z organizacją, ze szczególnym uwzględnieniem elementów problemowych. Następnym krokiem, według amerykańskiego badacza, powinno być dążenie do tego, by mieć w pracy poczucie kontroli swojego losu i sensowności działań zawodowych (dają ją krótkoterminowe, możliwe do precyzyjnego określenia cele). Wreszcie cytowany autor proponuje używanie wiedzy o kultowości do poszukiwania organizacji, w których nie występuje nasilony kult korporacyjny. Odrębnej analizy i dyskusji wymaga sprecyzowanie, które z rad Arnotta mają zastosowanie tylko w USA, a które można zaadoptować na przykład do polskich warunków.

Rady te, co warto raz jeszcze podkreślić, dotyczą profilaktyki oraz wyzwalania się spod wpływu organizacji kultowych. Trudno natomiast znaleźć w literaturze strategie dla tych, którzy z różnych względów dłużej lub krócej zmuszeni są pozostać pracownikami firmy o wysokim nasileniu kultu korporacyjnego. Chodzi o ludzi, którzy nie mogą zmienić pracy na przykład z powodu skali bezrobocia, co w sposób oczywisty charakteryzuje obecną polską rzeczywistość.

$\mathrm{Z}$ pomocą mogą tu przyjść - co może zaskakiwać praktyków zarządzania - badania historyczno-psychologiczne, które podejmują analizę doświadczeń osób mających za sobą przetrwanie w organizacjach totalnych, często o charakterze kultowym. Jak to zwykle bywa w naukach społecznych, dobrze jest na początku poszukiwań poznawczych zaproponować modele odwołujące się do sytuacji skrajnych. Najbardziej znany przykład takiego podejścia stanowi bardzo popularna również w zarządzaniu koncepcja koherencji sformułowana 
przez Aarona Antonowskiego Toutes proportions gardées (1995), ten sposób myślenia kontynuują analizy, które z doświadczenia historycznego starają się wydobyć elementy uniwersalne, mogące być przydatne również w warunkach współczesnej firmy. Dla problematyki kultu korporacyjnego planuję takie analizy w przyszłości.

Najwyraźniej zagadnienie kultowości ma więcej wspólnego z kwestią władzy i posłuszeństwa, niż sensu stricto problematyką religii. W ewidentnie patologicznej postaci kultowości - w stadium „destrukcyjnego kultu korporacyjnego” - religia, czy szerzej duchowość, stanowią jedynie „retorykę firmy”. Być może „destrukcyjny kult korporacyjny” jest przykładem skrajnej instrumentalizacji, dla celów zarządzania, naturalnych potrzeb człowieka, które David Hay (2006) opisuje jako świadomość relacyjną.

Warto podkreślić, iż kult, czy raczej właśnie „kultowość”, ma charakter kontinuum. Występuje w każdej organizacji. Umiarkowane nasilenie istotnych cech kultu, to jest pewne poświęcenie się dla organizacji, traktowanie szefów jako w jakimś stopniu charyzmatycznych przywódców oraz względne odseparowanie się od innych społeczności przez pracowników wydaje się wręcz kulturowym warunkiem spójności firmy, przynosi jej zarówno integrację, jak i innowacyjność. Tylko duże nasilenie kultowości stwarza opisane wyżej zagrożenia. Nie udało mi się dotąd precyzyjne ustalić, jaki jest ten krytyczny poziom kultowości i jakie są jego uwarunkowania.

W każdym razie dbanie o integrację i kreowanie innowacyjności bez popadania w stan „kultu” proponuję uznać za ważny, empiryczny wyznacznik etyczności kapitału kulturowego organizacji, prowadzącego do możliwości stworzenia etycznego środowiska pracy. Jest to takie środowisko, dzięki któremu firmy posiadając wysoką pozycję na rynku równocześnie stwarzają pracownikom możliwość wszechstronnego rozwoju (Kisielnicki i Ochinowski 2005, por. Csikszentmihályi 2003). 
Rozdział II

\section{Kapitał kulturowy organizacji w kontekście kryzysu światowego}

\subsection{Psychologiczne i kulturowe aspekty kryzysu}

Światowy kryzys ekonomiczny ostatnich lat, którego kulminacyjny moment stanowiły zawirowania giełdowe i bankowe roku 2007, bywa bardzo interesująco sytuowany na linii „przeszłość - teraźniejszość - przyszłość”. Zdaniem niektórych naukowców, należy już myśleć o nim w kategoriach zjawisk szczęśliwie należących do historii. Inni jednak uważają, że jeśli chodzi o trudności gospodarcze, to jeszcze „wszystko przed nami”, szczególnie gdy uwagę skupi się na sytuacji Polski. I nie jest to jedyny wymiar niejednoznaczności, chciałoby się wręcz użyć potocznego terminu - „dziwności” obecnego kryzysu (Ochinowski 2011).

$\mathrm{Z}$ jednej strony jest rzeczą oczywistą, iż gospodarka światowa ma charakter sinusoidalny, dlatego też należy spodziewać się kryzysów, co u początków obecnej dekoniunktury podkreślał na przykład Richard Sennett, upatrujący globalną przyczynę zapaści ekonomicznej w zaspokojeniu zapotrzebowania na różnorodne dobra i usługi. „To zjawisko naturalne - pisał niedawno cytowany autor - ponieważ nasycenie rynku określonymi towarami powtarza się cyklicznie raz na jakiś czas" (Sennett 2008: 1). Z drugiej strony mechanizmy aktualnego kryzysu przewidzieli raczej nie ekonomiści, a przedstawiciele zgoła innych zawodów. Przede wszystkim wymienić tu należy amerykańskiego psychiatrę Peter C. Whybrowa z Uniwersytetu Pensylwania, autora słynnej już dzisiaj książki American Mania. When More Is Not Enough, opublikowanej w 2005 roku. Przywołany badacz wskazywał na nienasycenie jako główny mechanizm psychologiczny nieracjonalnych zachowań ekonomicznych Amerykanów (Whybrow 2008, Whybrow i Król 2009). W Polsce znacznie później, i wbrew jeszcze

1 Na przykład już 10.12.2010 r. warszawska Uczelnia Łazarskiego zorganizowała konferencję pod tytułem „Świat po kryzysie”. Trzy lata później, koniec kryzysu, „dekretują” w swoich wypowiedziach niektórzy urzędnicy UE. 
powszechnym optymistycznym prognozom, o podobnych zagrożeniach mówił Jerzy Szymik ${ }^{2}$, poeta, rzymskokatolicki duszpasterz i teolog z Uniwersytetu Śląskiego. Zaniepokojony zjawiskiem, które nazwał „blichtrem wokół kasy”, sformułował obawę, iż „wyobcowanie pieniądza z procesów gospodarczych oraz ogromna ilość pieniędzy wydawanych za pomocą kart płatniczych na które nie ma pokrycia, doprowadzić musi kiedyś do światowego krachu finansowego" (wg Kozackiego 2009: 1, por. Szymik, Nęcek i Białek 2009). Profesje wymienionych „proroków” obecnego kryzysu sugerowały, iż ma on przede wszystkim podłoże behawioralne, co po kilkunastu miesiącach jego trwania większość badaczy przyjęło za oczywistość (zob. np. Gärling, Kirchler, Lewis i van Raaij 2009, Shermer 2009, Stix 2009 i Strack 2009, por. polemiczne ujęcie Derbyshire'a 2009). W świetle analiz psychologicznych (choć robionych niekoniecznie przez psychologów) głównymi mechanizmami zachowań powodujących i dynamizujących aktualną zapaść gospodarczą wydają się wspomniane nienasycenie w ujęciu Whybrowa oraz analizowana przez Stephena Greenspana (2008) łatwowierność.

Centralne spostrzeżenie Whybrowa stanowi teza, iż przyczyny kryzysu tkwią w postawie „ciągle więcej, nigdy dość”. Postawę tę należy widzieć jako wyraz egoizmu, który jest nieodwracalny. Człowiek kieruje się nim instynktownie. Ściśle wiąże się z tym zbyt silne uleganie marzeniom, które prowadzi do „wirtualnego" życia na kredyt, do lawinowych zadłużeń. Gdy pryska sen, rodzi się „wielki strach”. Na przykład banki nie mogą oszacować zadłużenia, więc odmawiają pożyczek. Ostateczną konsekwencją nienasycenia okazuje się korozja zaufania (Whybrow i Król 2009).

Z kolei wspomniana łatwowierność wynika z typowo ludzkiej tendencji do wzorowania się na postępowaniu innych, zwłaszcza odnośnie do spraw, których do końca się nie rozumie. Skłonność ta sprzyja sukcesom przedsięwzięć działających według „schematu Ponziego"3 (por. Stiglitz 2010). Jest ona szczególnie silna w zwartych społecznościach, scalonych silnymi więziami etnicznymi, religijnymi i temu podobnymi. Tym między innymi tłumaczy się swoista skuteczność niedawnych działań Bernarda Madoffa ${ }^{4}$. Przeciętny człowiek jest wyczulony na oznaki oszustwa, ale następujące uwarunkowania bardzo redukują tę zdolność:

2 Przywoływane tu rozmowy z Jerzym Szymikiem opublikowane zostały w 2009 r. Jednak ich kontekst wyraźnie wskazuje, iż były przeprowadzane przed kryzysem.

3 Charles Ponzi obiecywał w latach dwudziestych poprzedniego stulecia czterdziestoprocentowy zysk ze sprzedaży i kupna kuponów pocztowych. Zysk miały generować różnice opłat pocztowych w poszczególnych krajach. Była to jedna z pierwszych piramid finansowych, która przyniosła olbrzymie straty wielu ludziom. Skuteczność (rozumiana jako łatwe pozyskiwanie naiwnych inwestorów) podobnych działań podjętych po wielu latach, na przykład przez Bernarda Madoffa, może stanowić kolejny przyczynek do kosztów „amnezji historycznej” w zarządzaniu, czy Amber Gold w Polsce.

4 Greenspan był jedną z ofiar Madoffa. 
- dystans międzyludzki,

- anonimowość,

- skomplikowane, niezrozumiałe narzędzia finansowe (Shermer 2009).

Jak wskazała na przykład Marta Klimowicz (2009) w przygotowanym przez siebie materiale internetowym ${ }^{5}$, podczas kryzysu zaobserwować można także szereg innych mechanizmów psychologicznych, występujących również „poza kryzysem", i powszechnie znanych nawet studentom pierwszych lat nauk społecznych. W warunkach globalnej zapaści ekonomicznej zjawiska te mogą jednak pełnić rolę szczególną i prowadzić do szczególnych konsekwencji behawioralnych.

Z perspektywy relacji przedsiębiorca-pracownik, jako przydatne do thumaczenia zachowań organizacyjnych podczas kryzysu, jawią się przede wszystkim klasyczne badania nad posłuszeństwem wobec autorytetu, koncepcja „grupowego myślenia" oraz nowsze prace dotyczące uwarunkowań oszustw.

Replikacja słynnego eksperymentu Stanleya Milgrama przeprowadzona kilka lat temu przez Jerry'ego Burgera (2009) z Uniwersytetu Santa Clara pokazała, że niebezpieczeństwo ulegania autorytetom, jakiemu ulec mogą zwykli, „porządni” ludzie - aż do okrucieństwa wobec podwładnych jest wciąż bliskié

Warto przypomnieć, iż z kolei syndrom „grupowego myślenia” (ang. groupthink), które opisał przed niemal czterdziestu laty Irving L. Janis z Uniwersytety Yale, przypomina o ryzyku „głupienia” grup decyzyjnych, złożonych z najlepszych fachowców, gdy działają one w izolacji oraz pod presją ważności ich decyzji. Aktywizują się wówczas mechanizmy złudzenia „megamądrości” i „megamoralności” zespołu (zob. np. Janis 1972)7.

Wreszcie niedawne eksperymenty Dana Ariely' go $^{8}$ z Duke University i MIT pokazały, iż w sytuacji zadań nastawionych na zysk finansowy, ale praktycznie niewykonalnych (bo wykonawca ma na przykład zbyt mało czasu) pojawia się umiarkowana tendencja do oszustw, szczególnie jeśli można te oszustwa

5 W chwili umieszczenia $\mathrm{w}$ Internecie był to jeden $\mathrm{z}$ pierwszych (jeśli nie w ogóle pierwszy) materiał tego typu opracowany w języku polskim. Bardziej pogłębione analizy kryzysu w oparciu o teorie i badania psychologiczne przedstawili profesorowie Grażyna Wieczorkowska-Wierzbińska, Janusz Czapiński i Tadeusz Tyszka podczas konferencji Psychologiczne aspekty kryzysu. 27.05.2009. Wydział Zarządzania UW. Konferencja ta dotyczyła przede wszystkim reakcji polskiego społeczeństwa na kryzys.

6 Warto przypomnieć, iż w oryginalnym eksperymencie Milgrama z 1961 roku próg kary niebezpiecznej dla zdrowia „uczniów” przekroczyło 82,5\% badanych postawionych w roli „nauczycieli”, działających w obecności eksperymentatora. Nieco zmodyfikowana replikacja tych badań przeprowadzona trzydzieści pięć lat później przez Burgera ujawniła $70 \%$ takich osób (Burger 2009).

7 Warto zauważyć, iż badania Janisa stanowią interesujący przykład użyteczności podejścia historycznego w psychologii organizacji (szerzej zob. Ochinowski i Pawelec 2010).

8 Pierwsze informacje na temat eksperymentów Dana Ariely'ego zyskałem dzięki felietonowi Macieja Nowickiego (2009) „Dlaczego pieniądze nie deprawują”, opublikowanemu na łamach „Europy” (wówczas dodatek do „Newseeka”) 14 lutego 2009. 
ukryć. Tendencja wzrasta, gdy jawnie oszukuje ktoś identyfikowany jako „swój”9, a także gdy osoba wystawiona na pokusę oszustwa nie ma bezpośredniego kontaktu z pieniędzmi, które są zastąpione przez instrumenty finansowe (Ariely i Zetter 2009) ${ }^{10}$.

Szerszy kontekst uwarunkowań mogących wyzwalać wymienione wcześniej mechanizmy zachowań w dobie kryzysu wyznacza znany już od dawna wśród badaczy, ale trudno przebijający się do świadomości praktyków działań ekonomicznych, skrajnie nieprzewidywalny charakter funkcjonowania giełd (łącznie z tymi największymi) oraz innych znaczących dla gospodarki światowej instytucji finansowych, co trafnie oddaje tytuł polskiego tłumaczenia pracy na ten temat pióra Nassima Nicholasa Taleba (2006) Ślepy traf. Rola przypadku w sukcesie finansowym.

Odnośnie do giełdy, zjawiskiem dobrze tłumaczącym jej wahania okazuje się „efekt Pigmaliona”, a więc zmiana oczekiwań, motywacji i pewność siebie graczy giełdowych pod wpływem wiadomości, choćby o statusie plotki z wiarygodnego źródła. Na zasadzie „owczego pędu” tak regulowane zbiorowe zachowania inwestycyjne prowadzą do „samospełniającego się proroctwa”. Nadzieje, oczekiwania czy wizje (fałszywe bądź prawdziwe) decydują o działaniach uczestników rynku (Wung i Hui 2006). W wyniku silnego zapośredniczenia życia ekonomicznego przez media wspomniana „wiarygodność” źródła często ma charakter kreacji dokonanej przez znaczące stacje telewizyjne, gazety lub/i elektroniczne nośniki informacji. Prowokacyjna teza Howarda Kurtza $(2001)^{11}$, iż telewizja, internet oraz prasa przemieniają współczesny Wall Street w pewną odmianę Hollywood, zyskuje coraz więcej potwierdzeń empirycznych (zob. np. Nofsinger 2010).

Jak wykazał Edward Chancellor (2001), wspomniane uwarunkowania behawioralne powtarzają się w dziejach kolejnych baniek spekulacyjnych (może $\mathrm{z}$ wyjątkiem roli mediów, lawinowo narastającej w ostatnim czasie). Brak pamięci historycznej wśród praktyków i analityków życia gospodarczego może więc oznaczać ograniczenie możliwości radzenia sobie z kryzysami. Rodzi też nieuzasadnione nadzieje wobec narzędzi czysto ekonomicznych. Na marginesie zupełnie innych zagadnień radykalnie opisał ten problem polski historyk Paweł Wieczorkiewicz:

„Czy ekonomia jest nauką? Powszechnie uważa się, że tak, ale ja mam pewne wątpliwości. Gdyby ekonomia była nauką, stosunki gospodarcze rozwijałby się normalnie i nie mielibyśmy ciągłych kryzysów wybuchających z nie do końca

$9 \quad$ W cytowanych eksperymentach jawnie oszukujący pomocnik eksperymentatora miał na sobie koszulkę uniwersytetu, którego studentami były osoby badane.

10 Badani otrzymywali żetony, które później mogli wymieniać na pieniądze.

11 Kurtz (2001) pisze o kreowaniu tak zwanych gwiazdorów giełdowych, których rekomendacje uważane są za niepodważalne, aczkolwiek zazwyczaj mają niewiele większą wartość niż plotki na temat gwiazd filmu czy estrady. 
jasnych powodów. Ekonomia jest żywiołowa i trudno ją zaplanować, określić do końca metodami matematycznymi, bo podlega także nastrojom społecznym, opinii publicznej" (Osica, Sowa i Wieczorkiewicz 2009: 24) ${ }^{12}$.

Nic więc dziwnego, iż również przyszłość ostatniego kryzysu jest praktycznie nieprzewidywalna. Ma (czy miał) on charakter wybiórczy, niejednokrotnie na zasadzie wspomnianego „Ślepego trafu” (choć oczywiście nie zawsze) dotykał poszczególne branże czy regiony. Również w naszym kraju jest silnie zapośredniczony przez media (w kontekście analizy psychologicznej zwróciła uwagę na ten czynnik Grażyna Wieczorkowska-Wierzbińska 2009). Ponadto przedsiębiorcy i menedżerowie (podobnie jak reszta społeczeństwa) działający na terenie Polski muszą stawić czoła jeszcze jednemu uwarunkowaniu, które dotyka wszystkich aktorów gospodarek peryferyjnych. Chodzi o poczucie braku poczucia sprawczości. „Ten kryzys nas wreszcie też dopada - pisał wiosną 2009 roku Władysław Balicki (2009: 14) - Za co? Za niewinność” (Ochinowski 2011).

Amerykańskie subprimes w USA były ewidentnym „wyzwalaczem” ostatniego kryzysu, który przyniósł rok 2007. Ze względu na wspominany wcześniej „brak pamięci” dotykający nie tylko współczesnych menedżerów, ale także klientów instytucji finansowych, warto uwypuklić oczywistość, iż chodziło o to, że przedstawiciele bankowi dawali kredyty hipoteczne osobom, które nie miały zdolności kredytowej. Przyznawanie kredytów tego typu w wyżej opisanej sytuacji jest ewidentnym działaniem na niekorzyść kredytobiorców, ponieważ bank nie przejmuje się, jak i z czego taka osoba spłaci kredyt, liczy się tylko to, że odsetki z kredytu zasilą konto danego banku. Liczba takich sytuacji rosła, doprowadzając do powstawania instytucji, które wykupywały wierzytelności. W pewnym momencie bańka spekulacyjna pękła, a wiele banków zakończyło swoją działalność na rynku.

Polski ekonomista działający w Szwajcarii, Paul H. Dembinski (2009, 2011, 2013) zalicza ten „punkt zapalny” kryzysu skumulowanego w 2007 roku do znacznie szerszego zestawu zjawisk, które nazywa „finansjalizacją”. Chodzi o bezprecedensowy rozrost sektora finansowego powodujący radykalną zmianę strukturalną światowej gospodarki. Proces ten trwający od mniej więcej dwudziestu lat zyskał rzeczywiste zainteresowanie analityków dopiero po pierwszej fali ostatniego kryzysu. Jeden z najgłębszych przejawów finansjalizacji stanowi, zdaniem Dembińskiego (2013), „handel obietnicami”, działalność praktyków ekonomii zawieszona między teraźniejszością a przyszłością, swoiście „wykorzeniona z czasu" w przeciwieństwie do tradycyjnych relacji kupiec-klient. Dramat subprimes, w perspektywie refleksji cytowanego finansisty, byłby więc szczególnym przykładem wspomnianego „handlu obietnicami”.

12 Jest to cytat z publikacji prof. Wieczorkiewicza, której ostateczne przygotowanie przerwała jego śmierć. Nie chciałbym dopuścić do tego, by przytoczony cytat stał się powodem do dyskusji na temat poglądów o naukowości ekonomii, czy historii. Pochodzi on z pracy popularyzatorskiej dopuszczającej przecież sformułowania publicystyczne. 
Warto podkreślić, że publikacje Dembińskiego (2009, 2011, 2012, 2013), a szczególnie działalność stworzonego przez niego think tanku Observatoire de la Finance uwypuklają ścisły związek finansów z problematyką aksjologiczną, niezależnie do kryzysu. Cytowany badacz zachęca do przyjrzenia się bardzo interesującej, jego zdaniem, przestrzeni poznawczej (ze złożonymi implikacjami dla życia ludzi) w obrębie trójkąta „finanse - gospodarka - wartości”. Kryzys skumulowany w 2007 roku tylko wyostrzył trafność perspektywy przyjętej przez analityków pokroju Dembinskiego. Umieszcza on diagnozowane przez siebie procesy w perspektywie historycznej, ale szuka przede wszystkim konsekwencji dzisiejszych. Interesuje go geneza obecnych procesów. Wyraźnie więc myślenie Dembińskiego zaliczyć można do „przestrzeni intelektualnej” historii organizacyjnej.

Finansjalizacja jest dla cytowanego badacza najnowszą (choć, powtórzę, tylko późno zauważoną przez analityków, ale trwającą już od około dwudziestu lat) konsekwencją działań tak zwanych napędowych sił globalizacji (Ochinowski 2004, Ochinowski i Kseba 2013).

Paul H. Dembinski wyróżnia 3 główne siły napędowe globalizacji, znacznie starsze od niej samej, nadal aktualne oraz warunkujące jej - oczywiście globalny - sukces. Dembinski mówi o: (1) instrumencie, (2) duchu i (3) katalizatorze globalizacji.

(1) Rolę instrumentu globalizacji odgrywa postęp technologiczny, rozumiany jako rozwój technologii informacyjnej, który radykalnie modyfikuje relacje „,człowiek - otoczenie fizyczne i społeczne". Proces ten rozpoczęty skonstruowaniem telegrafu, posiada swój punkt krytyczny w postaci wynalezienia internetu.

(2) Duchem globalizacji jest według Dembinskiego etos wydajności. Zdaniem cytowanego autora stanowi on współczesną pochodną weberowskiego ducha kapitalizmu. Aktualnie omawiane zjawisko opiera się na następujących zasadach, które zdominowały „globalną” świadomość społeczną:

„Uwzględnia się wyłącznie konsekwencje dotyczące decydenta; »więcej« musi być zasadniczo preferowane w stosunku do »mniej«; uwzględnia się wyłącznie zdarzenia, które da się wyrazić w kategoriach wartości, generujące wartość dodaną, a tym samym oddziałujące na PKB (reszta życia społecznego, zdarzenia, które nie pozostawiają śladu ekonomicznego, po prostu NIE ISTNIEJĄ)" (Dembinski 2003, 53).

Współczesna „kariera” etosu wydajności ma charakter procesu intelektualnego, który trwa od końca XIX wieku i polega na zmianach treści oraz hierarchii społecznie akceptowanych wartości.

Termin „etos wydajności”, użyty przez Dembinskiego, wyraźnie wymaga doprecyzowania. Wzrost wydajności robotników był przecież, co warto przypomnieć, głównym celem taylorowskiej szkoły naukowego zarządzania. I trudno byłoby zaprzeczyć faktowi, że cel ten został osiągnięty. Wydajność pracy robotników zachodnich w XX wieku wzrosła 20-krotnie. Kontekst koncepcji 
Dembinskiego wskazuje, iż duch globalizacji powinien być bardziej precyzyjnie, niż to zrobił cytowany autor, określony jako „etos efektywności ekonomicznej”. Tak też robię w dalszej części niniejszej pracy ${ }^{13}$.

(3) Z kolei rolę katalizatora globalizacji spełnia, zdaniem ekonomisty z Fryburga, mit zwany również ideałem (Dembinski 2003 używa także terminu credo) „społeczeństwa otwartego”. Jego treść wyznacza znana idea Karla Poppera (1993) o społeczeństwie, w którym jednostki mają prawo do własnych decyzji, co sprzyja inicjatywie, posiadają możliwość przemieszczania się w strukturze społecznej i są równe na starcie do konkurencji, a działania władzy z kolei są bardzo ograniczone. Ideał ten przeniesiony na gospodarkę zaowocował procesem związanym z coraz bardziej dominującą rolą aktywności gospodarczej w poszczególnych społeczeństwach i otwartością na konkurencję. Proces ten trwa od końca II wojny światowej (Dembinski 2003, Bugaj, Dembinski i Jankowiak 2001).

W tej perspektywie proponuję spojrzeć na opisany przeze mnie wcześniej kult korporacyjny jako na jeden $\mathrm{z}$ niekoniecznych, ale możliwych kulturowych aspektów globalizacji, stanowiących nieoczekiwany rezultat jednej z sił napędowych procesów globalizacyjnych, to jest etosu efektywności ekonomicznej.

Jako „miękkie” hipotezy do dalszych badań przedstawiam potencjalne zmienne pośredniczące między etosem efektywności ekonomicznej a możliwymi przejawami wysokiego natężenia kultowości korporacyjnej. Zmienne te, dotyczące elementów świadomości zbiorowej, opisuję jako tak zwaną mentalność kultową, którą uważam za jeden z aspektów kulturowych czasów globalizacji. $\mathrm{Na}$ pierwszym etapie badań poświęconych identyfikacji wspominanych zmiennych proponuję analizę treści nośników szeroko rozumianej kultury popularnej.

Mentalność kultowa, usprawiedliwiającą zarządzanie typu kultowego, charakteryzują, moim zdaniem, 3 cechy główne i 5 szczegółowych.

Cechy gtówne mentalności kultowej:

1) Dogmat: „efekt ponad wszystko”. Tę potoczną „prawdę” uważam za wskaźnik bezpośredniej obecności w świadomości zbiorowej siły napędowej globalizacji, nazywanej przez Dembińskiego $(2001,2003)$ - jak referowałem wcześniej - etosem wydajności, a którą bardziej precyzyjnie niż zrobił to cytowany ekonomista należałby określić jako etos efektywności ekonomicznej lub zysków nadzwyczajnych.

2) Skrajnie instrumentalne traktowanie rzeczywistości ${ }^{14}$. Chodzi tu o potoczne przekonanie, iż wszystko (łącznie z ludzką naturą, przyrodą, zasadami społecznymi itp.) można zmienić. Trzeba tylko wynaleźć odpowiednią technologię. Ekstremalne przejawy opisywanych postaw stanowią różnego rodzaju

13 Na ten problem zwrócił mi uwagę Tadeusz Oleksyn, profesor SGH.

14 Pomysł wprowadzenia tej cechy zawdzięczam Tomaszowi Sikorskiemu. 
działania grup fundamentalistów, zagrażających bezpieczeństwu ludzi często w skali globalnej (poddaje je psychologicznej analizie np. Lifton 1999; najbardziej spektakularnym przykładem skutków myślenia fundamentalistycznego stały się oczywiście wydarzenia z 11 września 2001 roku).

3) Dopuszczenie manipulacji, jako regulatora stosunków międzyludzkich. $\mathrm{Na}$ społeczną akceptację dla zachowań manipulacyjnych, jako specyficznej cechy współczesności, zwracają uwagę różni badacze, również ci, którzy dalecy są od postawy kasandrycznej. Kilka lat temu opinie te lapidarnie sformułował psychiatra Andrzej Jakubik (1997, 57-58), pisząc:

„Autor Il principe (Machiavelli - uwaga T.O.) z pewnością nie przewidywał, że wywodzące się od jego nazwiska instrumentalne zachowania makiawelistyczne, oprócz przypadków niewątpliwej patologii (...), będą obecnie przypisywane znacznie szerszej grupie jednostek, nie wykazujących zaburzeń osobowości. Istniejące we współczesnym świecie relacje międzyludzkie sprzyjają bowiem powszechnemu kształtowaniu się postaw egocentrycznych i manipulacyjnych (...), tym bardziej, iż w życiu codziennym okazują się niezwykle skutecznym sposobem realizacji własnych celów".

Cytowany badacz przywołuje w kontekście swojej wypowiedzi m.in. słynną książkę Josefa Kirschnera (1994) Manipulować - ale jak?, która była reklamowana za pomocą sloganu „żyć odważnie”. Innym przykładem opisywanej tendencji może być symptomatyczny fakt, iż jedno z diagnostycznych pytań skali psychologicznej Mach IV opracowanej 40 lat temu przez Christie i Geisa do badania makiawelizmu, dotyczyło stosunku wobec eutanazji (zgoda na eutanazję nieuleczalnie chorych stanowiła wskaźnik tendencji makiawelistycznych uważanych za ewidentną patologię ${ }^{15}$ ).

Cechy szczegótowe mentalności kultowej:

1) Mieszanie różnych wymiarów rzeczywistości. W kontekście globalizacji szczególnie interesujące jest pomieszanie sfery sakralnej z ekonomiczną (np. używanie argumentów religijnych lub pseudoreligijnych jako bezpośrednich elementów systemów motywacji do pracy, opisywanie bogactwa niemal w kategoriach zbawienia itp.).

2) Tajemniczość zamiast tajemnicy. Rezygnacja z uznania, iż istnieją ostatecznie niepoznawalne elementy rzeczywistości. Zamiast tego proponowanie kolejnych etapów wtajemniczenia, które można osiągnąc pod okiem doświadczonych „guru” (np. zarządzania, por. Micklethwait i Wooldridge 2000).

3) Ideowość à la carte ${ }^{16}$. Dowolny i skrajnie eklektyczny wybór różnych treści z różnych tradycji ideowych, bez zwracania uwagi na spójność logiczną.

15 Wspomniana pozycja brzmiała następująco: „Ludzie cierpiący na nieuleczalne choroby powinni mieć możliwość wybrania bezbolesnej śmierci” (cyt. za Pospiszyl 1985: 253).

16 Termin ten jest parafrazą sformułowania zaproponowanego przez francuskiego myśliciela Lewisa „religijność à la carte”, które rozpowszechniła prasa w latach 90 . XX wieku. 
Dotyczy to nie tylko systemów religijnych, ale również kulturowych wzorców życia codziennego, systemów naukowych itd. itp. Być może uprawnione jest wręcz mówienie o totalnym synkretyzmie współczesności.

4) Szafowanie naukowością i „naukowością”. Z jednej strony chodzi o różnego typu nadużycia autorytetów naukowych (manipulowanie wynikami badań, nie zawsze rzetelnie przeprowadzonymi, powoływanie jako ekspertów osób posiadających tytuły naukowe bez względu na ich szczegółowe kompetencje, swoista magia studiów MBA i in.). Z drugiej strony coraz bardziej wyraźny staje się fenomen popularności pseudonauki (zob. np. Bainbridge 2003). Przejawem szafowania zarówno naukowością jak i „naukowością” jest również fakt, że wiele teorii zarządzania odniosło sukces finansowy (to znaczy przyniosło dochody autorom lub popularyzatorom) zanim poddane zostało weryfikacji naukowej, która w wielu wypadkach wykazywała ich bezwartościowość. Ofiarami wspomnianego „sukcesu” zostają oczywiście odbiorcy „usług doradczych” opierających się na tego rodzaju teoriach (Micklethwait i Wooldridge 2000).

5) Totalna komercjalizacja. Przekonanie, iż dosłownie wszystko daje się sprzedać lub kupić. Spektakularnym tego przykładem jest książka - światowy besteller - Dala Carnegiego pod tytułem Jak zdobyć przyjaciót i zjednać sobie ludzi. Dosłowne jej potraktowanie sugeruje przecież, że przypadkowo napotkana osoba nie ma szans - musi zostać przyjacielem kogoś, kto skorzysta $\mathrm{z}$ usług wspomnianego autora...

Przytoczone zmienne ze względu na skrótowy charakter ich opisania mogą sprawiać wrażenie wartościujących. Jest to jak najdalsze od moich intencji. Służyć one mają jedynie realizacji słynnej tezy Barucha Spinozy: „Nie dziwić się, nie potępiać, zrozumieć”. Być może mentalność kultowa okaże się zmienną kulturową pomocą do zrozumienia ewolucji efektywności ekonomicznej wydajności w stronę finansjalizacji (Ochinowski 2004).

Analiza artefaktów jako nośników mentalności zbiorowej wymaga oczywiście osadzenia w konkretnym kontekście zachowań i reakcji na atmosferę kryzysową. Wstępny materiał empiryczny dotyczący właśnie tego aspektu prezentuje następny podrozdział.

\subsection{Zachowania organizacyjne menedżerów w czasach kryzysu}

Wspólnie z Leszkiem Dubickim i Piotrem Gołaszewskim ${ }^{17}$ przeprowadziłem jakościowy zwiad badawczy dotyczący zachowań właścicieli firm i menedżerów

17 Leszek Dubicki, z wykształcenia ekonomista, przygotowuje pracę doktorską w SGH, gościnnie prowadzi zajęcia dla studentów WZ UW; Piotr Gołaszewski, absolwent WZ 
wysokiego szczebla wobec pracowników podczas pierwszej fazy obecnego kryzysu gospodarczego na terenie Polski. Badanie zostało przeprowadzone metodą „detektywistyczną”. Od zimy 2008 do początków maja 2009 dwóch ,informatorów kluczowych"18 rejestrowało (zbierając relacje, a częściowo także drogą obserwacji uczestniczącej) wspomniane zachowania właścicieli małych i średnich przedsiębiorstw oraz menedżerów oddziałów międzynarodowych korporacji w Polsce lub dużych polskich firm. Jakościowy model relacjonowanych poszukiwań podyktowany został celem badawczym. Wobec bardzo różnicowanych przejawów kryzysu chodziło bowiem nie o nakreślenie uśrednionego obrazu reakcji kierownictwa firm, ale o wyodrębnienie wzorów zachowań organizacyjnych, wzorów choćby jednostkowych, ale możliwych do opisu na poziomie dobrych lub złych praktyk (Ochinowski 2011).

„Detektywistyczna” formuła prezentowanego pilotażu sprawiła, iż niemożliwe było zarówno ujawnienie jakichkolwiek informacji pozwalających na identyfikację firm poddanych badaniu, jak i zastosowanie ustrukturyzowanych technik opracowania zdobytego materiału. Pod dyskusję czytelników niniejszym podany jest więc jedynie wynik czysto intuicyjnej analizy jakościowej19.

Wstępny zbiór zachowań organizacyjnych (trudno oczywiście powiedzieć, w jakim stopniu wyłącznie jednostkowych), wyłaniających się z opisanych badań pilotażowych wygląda następująco:

\section{Sektor MŚP}

\section{Korozja zaufania - i tak od dawna deficytowego}

Ten rodzaj zachowań organizacyjnych podejmowanych przez szefów firm wobec kryzysu polega na kreowaniu wrażenia (być może także/lub wyłącznie uleganiu kreacji medialnej20), że „każda firma jest tak naprawdę w złej kondycji i tylko kwestią czasu jest wyjście tego faktu na światło dzienne". Tworzy się w ten sposób swoiste „błędne koło”. Na przykład żądanie skrócenia okresu regulowania płatności stwarza trudności płatnikowi, a gdy one występują, osoba wymagająca szybszego niż dotąd spełniania zobowiązań finansowych utwierdza się w opinii, że firma płatnika ma ukryte problemy. Jak wyraźnie widać, ewidentnie występująca w tej sytuacji „samospełniająca się przepowiednia”

UW, prowadzi zajęcia w Uczelni Łazarskiego. Obydwaj są wieloletnimi praktykami biznesu.

18 Byli to refleksyjni praktycy biznesu, zawodowo oraz towarzysko silnie zakorzenieni w badanych środowiskach.

19 Zgodnie z logiką metodologii jakościowej ogłoszenie wyników jest dopiero początkiem ich interpretacji poprzez kolejne dyskusje. Autor niniejszego tekstu i jego współpracownicy bardzo na te dyskusje liczą.

20 Oddzielnych badań wymaga sprawdzenie czy, a jeśli tak to w jakim stopniu media rzeczywiście popularyzowały lub/i popularyzują przytoczone przeświadczenie. 
oczywiście źle wpływa na zaufanie między kontrahentami. Warto poprzez dalsze badania sprawdzić, na ile do relacji między przedsiębiorstwami można odnieść wewnątrzorganizacyjne analizy Hansa Rämö (2004), który empirycznie ukazał, iż zaufanie w pracy jest czymś kruchym i zmiennym w czasie. Wymaga komunikacji, która opiera się na wykorzystaniu odpowiednich momentów do tego, by zachować się sprawiedliwie. Zaś głównymi wrogami zaufania są asymetryczne stosunki władzy i sztywna kontrola czasu.

\section{* Polaryzacja korupcji}

Z jednej strony pojawia się zmasowane kupowanie przetargów (to oczywiście tylko wrażenie $\mathrm{z}$ nieustrukturyzowanej obserwacji), z drugiej strony zaobserwować można nową, trudną do spotkania przed kryzysem postawą wyrażającą się w następującym uzasadnieniu odrzucenia oferty korupcyjnej: „nie opłaca nam się kupować przetargu, bo drogo nas będzie kosztował serwis”.

\section{* Zwalniać, zwalniać, Mocium Panie!}

Zwolnienia szybkie i bez namysłu (także finansowego), takie jak na przykład zwolnienie świetnego pracownika sprzedaży, bo trzeba robić oszczędności, mimo istnienia innych alternatyw. W analizach decyzyjnych podejmowanych przez osoby odpowiedzialne za firmę liczy się nie człowiek, nawet nie pracownik, który może przynieść zysk po kryzysie, ale wyłącznie pensja rozumiana wąsko jako obciążenie finansowe. „Czarnowidztwo” radykalizujące decyzje o zwolnieniach.

Trudno tu nie zauważyć działania mechanizmów decyzyjnych, które Daniel Kahneman i Amos Tversky opisali w postaci teorii perspektywy. Warto przypomnieć, że wspomniana, chyba najsławniejsza z koncepcji psychologicznych stosowanych do świata gospodarki (jej sformułowanie było przecież głównym powodem uhonorowania Kahnemana Nagrodą Nobla z ekonomii w 2002 roku $^{21}$ ) wskazuje między innymi na następującą prawidłowość: gdy alternatywy decyzji finansowej formułowane są w kategoriach unikania strat, to rośnie tendencja do ryzykowania (zob. np. Hens i Bachmann 2010 oraz Tyszka 2010; bezpośrednie odniesienia do obecnego kryzysu: Stix 2009, Tyszka 2009 i Czapiński 2009; o neurochemicznym podłożu tendencji do ryzyka zob. Fox i Poldrack 2008, por. Zweig 2008).

\section{Na Ludwika XIV (firma to ja)}

W ramach tego wzoru zachowań organizacyjnych właściciel firmy szybko zauważa niebezpieczeństwo kryzysu i szybko „idzie na ostro”. Stawia pracow-

$\overline{21}$ Tversky już wówczas nie żył. 
ników wobec następującego wyzwania: „nie zwiększycie wydajności, to będzie po was...”. Skrajny przypadek realizacji opisywanej strategii behawioralnej spowodował odejście wszystkich pracowników „póki jeszcze czas” - znaleźli sobie zatrudnienie gdzie indziej). W konsekwencji firma dostawała zlecenia, ale nie było komu ich realizować, bo został tylko szef i sekretarka. Jest to więc przypadek świetnego wyczucia rynku przez właściciela przedsiębiorstwa, ale znacznie gorszego wyczucia pracowników.

\section{* Od dawna wiecie, na czym stoimy}

Warunkiem budowania w ten sposób relacji przedsiębiorca-personel jest „prehistoryczna” (to znaczy rzeczywiście respektowana jeszcze przed kryzysem) zasada, że pracownicy są informowani o sytuacji przedsiębiorstwa. W konkretnym przypadku zaobserwowanym podczas zwiadu badawczego, który tu referuję, szef jednej z firm - gdy zaczął odczuwać działanie kryzysu - powiedział szczerze zatrudnionym, iż zrobi wszystko, żeby nie zwolnić nikogo i nie obniżyć pensji. Informował też pracowników o rzeczywistej kondycji przedsiębiorstwa. Nie dotrzymał obietnicy dotyczącej poziomu wynagrodzenia. Mimo to szczere postawienie sprawy wobec pracowników spowodowało, że firma - w okresie objętym badaniem - dość dobrze prosperowała. Zachowane też zostały dobre relacje w zespole. Pracownicy zgodzili się na niższe pensje, bo cenniejsze było dla nich pozostanie w firmie niż zachowanie dotychczasowego poziomu płac. Zarząd przedsiębiorstwa zastosował też technikę, którą najbardziej adekwatnie określa przymiotnik „sprytna”. Nigdy nie zostało powiedziane, kto może zostać zwolniony, więc ludzie pomagając firmie, pomagali także sobie, a przy okazji ratowali tych enigmatycznych, „którzy mieli odejść”.

\section{Nic, co ludzkie..., i to od dawna}

Ten wzór zachowań organizacyjnych bezwzględnie uwarunkowany jest wcześniejszym zainteresowaniem kierownictwa równowaga praca-życie u podwładnych. Przy takiej atmosferze w organizacji, gdy przychodzi kryzys, to pracownicy sami pytają się o sytuację firmy. By tak się jednak stało, zatrudnieni muszą znać sytuację firmy, ale wraz z interpretacją i pokazaniem modelu dobrej i złej przyszłości. Jeżeli w firmie panuje zaufanie, to takie modele traktowane sa poważnie, a nie jako „straszaki”. Sprawa poziomu wynagrodzenia schodzi wówczas w świadomości pracowników na drugi plan. Panuje względna zgodność co do tego, że teraz zaczyna się walka o sam fakt utrzymania miejsc pracy w tym przedsiębiorstwie.

Warto zauważyć, iż dwa ostatnie z przytoczonych wzorów zachowań organizacyjnych czasu kryzysu wskazują na użyteczność historii organizacyjnej także rozumianej wąsko w ,wewnątrzfirmowym” wymiarze. 


\section{Korporacje}

* Zwalniać? nie zwalniać? - oto jest pytanie!!!

Dla menedżerów wielu korporacji podstawowym problemem na przestrzeni miesięcy objętych badaniem stała się kwestia zwolnień, co zdaniem „informatora" można było zaobserwować w większości przedsiębiorstw. Wpłynął na to fakt, że od dłuższego czasu (lata 2006-2008) występował rynek pracownika, szczególnie gdy chodziło o wykwalifikowaną kadrę i gospodarczo rozwinięte rejony. Jeszcze do połowy 2008 roku częsty temat rozmów kadry menedżerskiej stanowiły kłopoty z obsadą stanowisk, częste odejścia doświadczonych pracowników „podkupywanych” przez inne firmy, wymagania płacowe i pozapłacowe oraz spadająca dyscyplina pracy. Powodem reakcji stresowych członków kierownictwa oddziałów korporacji było zapewnienie kadry do wykonania danego zadania oraz zapewnienie jakości wykonanej pracy. Lepiej więc było „przytrzymać” pracownika, pomimo faktu, że nie był „przodownikiem” i miał ciągłe roszczenia, niż zostać bez nikogo z listą zadań do wykonania.

I w takiej sytuacji przyszedł czwarty kwartał 2008 roku. Przyniósł on następującą kolejność zadań wykonywanych przez menedżera:

1) zbudowanie scenariusza odnośnie do przychodów w roku 2009. Właściciele chcą wiedzieć, jakie są przewidywania kierownictwa oddziałów na terenie Polski. Pamiętać przy tym należy, że wspomniani właściciele często kierują koncernami na zachodzie Europy, gdzie już kilka miesięcy wcześniej rozpoczął się spadek popytu i cięcie kosztów. Naturalnym oczekiwaniem właścicieli jest więc ostrożne podejście do przychodów i redukcja kosztów;

2) a więc koszty... Skreślane są w pierwszej kolejności wszelkie premie, wyjazdy integracyjne, darmowa kawa i herbata oraz szkolenia;

3) zaczyna się budżetowanie poszczególnych działów przedsiębiorstwa, a w ramach tego budżetowania dostosowanie budżetu płac do przewidywanych przychodów. W pierwszej kolejności do zwolnienia wskazywani są najsłabsi, o mniejszym zaangażowaniu i dużych oczekiwaniach.

Często okazuje się jednak, że te redukcje mogą być niewystarczające (przecież w przewidywaniach przychodów menedżerowie muszą być ostrożni, aby nie posądzono ich o nieracjonalny optymizm lub o brak umiejętności kontroli kosztów). Menedżerowie przyglądają się krytycznie, czy średni poziom wynagrodzeń w przedsiębiorstwie nie jest nazbyt „rozbuchany”. Pojawia się dylemat: czy „tniemy” już również spośród tych średnich, czy też wszystkim zaczynamy obniżać wynagrodzenie. Dylemat trudny, bo obniżenie wynagrodzenia jest zawsze demotywujące, szczególnie w przypadku najlepszych. Ale z drugiej strony jest chęć uratowania miejsc również dla tych średnich. Najczęściej w takiej sytuacji zwalnia się jednak tych średnich... A po następnych dwóch miesiącach presja nie słabnie i mimo wszystko obniża się wynagrodzenia przynajmniej części 
z tych najlepszych. Ale po jakimś czasie... i to okazuje się niewystarczające, a dodatkowo pojawia się refleksja: już jest źle, planowane wyniki finansowe już są słabe. A może to właśnie teraz byłby najlepszy moment, aby dokonać radykalnej restrukturyzacji w firmie? Z jednej strony właściciele będą zadowoleni, że aktywnie dostosowuje się firmę do trudnej sytuacji rynkowej, z drugiej strony sami menedżerowie widzą konieczność radykalnych zmian. Jeśli zaś przy tych zmianach będą jakieś dodatkowe straty, to i tak nikt nie oczekuje teraz dobrych wyników. Najważniejsze jest jedynie zachowanie płynności. A jeśli restrukturyzacja się uda, to będzie można dynamicznie powalczyć z konkurencją...

Dokonuje się restrukturyzacji: zamyka działy, które wydawały się dotąd niezbędne, zwalnia menedżerów, bez których wydawało się, że firma nie może istnieć. Te wszystkie działania i czynności związane są z silnymi stresorami. Pojawia się twarda walka pomiędzy poszczególnym członkami kadry zarządczej o uratowanie własnych pozycji ale też posad i wynagrodzeń dla „swoich” pracowników. Wśród personelu zaczynają krążyć plotki przypominające reakcje histeryczne, daleko wykraczające poza rzeczywiste plany redukcji. Wszystko to rodzi szereg zasadniczych pytań: jak w takiej sytuacji zachowują się menedżerowie? Jak powinni się zachowywać? Czy jest w ogóle możliwość znalezienia dobrego, złotego środka?

„Prawdę mówiąc to są te momenty, w których do głosu dochodzą zakodowane systemy wartości, zasady, a nawet, mówiąc górnolotnie, własne zrozumienie pojęć dobra i zła. Lub braku takich refleksji. Najciekawsze jest to, że właściwie nikt o tym nie rozmawia (...). Nikt nie stawia tezy, co jest naszym zdaniem dobre, a co złe. Na zebraniach i w czasie kłótni przedstawia się wyliczenia, tłumacząc, co jest konieczne dla firmy, ale zauważalne jest, że wielu prowadzi wojnę walcząc o to, co (...) uważa za dobre"22.

Jako najkrótszy komentarz do opisanych w tym punkcie zachowań organizacyjnych jawi się parafraza klasycznego zbioru studiów przypadków z „Harvard Business Review” na temat dylematów menedżerskich: „Gdy dobrzy ludzie robią złe rzeczy...”23, „Bliższa ciału koszula”.

To strategia behawioralna występująca u szefów korporacji międzynarodowych polegająca na zamykaniu działów w tańszej Polsce, by dać pracę „u siebie na Zachodzie", nawet gdy to się nie opłaca z finansowego punktu widzenia.

* A może jednak inaczej...?

- outplacement uwzględniający zarówno możliwości firmy, jak i potrzeby pracowników,

22 Dosłowny cytat opinii informatora kluczowego.

23 Oryg. When Good People Behave Badly. What Will You Do? 2004. Boston: Harvard Business School Press. 
- elastyczne formy zatrudnienia, w tym sabbatical leave ${ }^{24}$.

\section{Wzór zachowań organizacyjnych niezależny od wielkości firmy}

\section{- Okazja czyni redukcje}

Załatwianie „porachunków” z powołaniem się na kryzys. Należałoby tu wymienić przykłady działań odwetowych, po prostu złośliwych itp. Jednak miały one charakter na tyle szczegółowy, że mogłoby to grozić identyfikacją obserwowanych przez nas firm, czego chcę uniknąć.

Przy wszelkich ograniczeniach badań pilotażowych o charakterze jakościowym, bez popełniania błędu nieuzasadnionych uogólnień, nie sposób jednak nie zauważyć, iż przytoczony zwiad badawczy wyraźnie wskazuje na nieco głębszy niż tylko behawioralny (rozumiany wąsko) wymiar zachowań organizacyjnych w warunkach kryzysu. Istotna problematyka tych zachowań wydaje się dotykać poziomu wartości, a szczególnie wartości moralnych ${ }^{25}$. Następny podrozdział poświęcę więc właśnie tej problematyce (Ochinowski 2011).

\subsection{Moralny nurt dyskusji wokół kryzysu światowego}

Ostatnio - ale, co należy podkreślić - jeszcze przed globalną zapaścią gospodarczą - w dyskusjach na temat relacji etyka-biznes pojawił się względnie nowy nurt myślenia. Dość niespodziewanie dla prawie niepodzielnie do niedawna panującego relatywizmu, kolejne, prowadzone niezależnie od siebie badania psychologów i religioznawców pokazują, iż mimo wszystko istnieje ponadkulturowy, ogólnoludzki zestaw norm moralnych (zob. np. Seligman 2005, Damon 2004, Küng, 2002, 2005). Wydaje się on skupiać wokół złotej zasady: „nie rób drugiemu, co tobie niemiłe” (w wersji anglosaskiej: „rób to, co chcesz, żeby inni tobie robili”). Z takiej perspektywy mówi się raczej o „etyce w biznesie”, a nie o „etyce biznesu” i podejmuje badania nad funkcjonowaniem wspomnianych ogólnoludzkich norm moralnych na terenie działalności biznesowej (Kisielnicki i Ochinowski 2005, Ochinowski i Kseba 2013).

Pewne wątki związane $\mathrm{z}$ takim właśnie kontekstem wartości podjęli również cytowani wcześniej autorzy pierwszych behawioralnych analiz kryzysu, gdy formułowali postulaty zaradcze. I tak w eksperymentach Ariely'ego wystąpiła zmienna znacząco zmniejszająca tendencję do oszukiwania. Była to manipulacja eksperymentalna polegają na poproszeniu badanych, by przed przystąpieniem

24 Długoterminowe płatne nieobecności pracownika w firmie.

25 Zgodnie z logiką badań jakościowych wniosek ten ma charakter hipotetyczny. Na jego sformułowanie mógł mieć wpływ fakt, iż wszystkie osoby zaangażowane w opisany pilotaż szczególnie interesują się problematyką relacji wartości etycznych i działań biznesowych. 
do rozwiązywania zadań powtórzyli Dekalog. Czynność ta w sposób istotny statystycznie zmniejszała ilość oszustw niezależnie od światopoglądu badanych (Ariely i Zetter 2009). Shermer (2009: 24) komentując pracę Greenspana (2008), odwołuje się po prostu do zdrowego rozsądku czytelnika, apelując o swoistą „czujność” wobec oszukańczych recept na poradzenie sobie z problemami finansowymi: ,jeśli coś wygląda zbyt dobrze, żeby było prawdziwe, to na pewno nie jest prawdziwe". Burger (2009) wykazał, iż empatyczna troska i wysiłek skierowany na samokontrolę nieco różnicuje ${ }^{26}$ skłonność do „okrutnego posłuszeństwa”. Whybrow radzi szukać punktów oparcia „pozakryzysowych”. Wskazuje na oczywistą, choć często zapomnianą w toku działań biznesowych tezę, że warto pracować nad polepszeniem relacji z bliskimi (Whybrow i Król 2009). Nadaje to na przykład problematyce równowagi praca-życie (a nawet szerzej, zagadnieniu praktyk przedsiębiorczych respektujących reguły zrównoważonego rozwoju), rys tyleż aksjologiczny, co jednocześnie pragmatyczny.

Następne lata przyniosły dalsze rozwinięcie perspektywy aksjologicznej w interpretacjach kryzysu. Stwierdzenie Alaina Touraine'a (2013: 95) z jego najnowszej książki Po kryzysie (oryg. francuski Après la crise, Paris 2010), iż „nauki społeczne powinny priorytetowo potraktować sprawę stworzenia nowej etyki, będącej wyrazem postaw moralnych w określonych sytuacjach społecznych"27 dobrze oddaje klimat tej nadal aktualnej, choć toczącej się nie od dziś dyskusji wokół globalnych zaburzeń gospodarczych, które przyniósł rok 2008.

Nie dziwi więc praktycznie nikogo, że do istotnych źródeł ostatnich zaburzeń światowej gospodarki zalicza się łamanie ogólnoludzkich norm etycznych oraz kierowanie się przez decydentów ekonomicznych i konsumentów takimi przypadłościami ludzkiej psychiki, które tradycja wielkich religii określa jako namiętności bądź żądze ${ }^{28}$. Przy czym obecnie pojęcia tego rodzaju używane są przez znacznie szersze grono niż tylko przywódców duchowych czy teologów. Na przykład filozoficzne pytanie Vaclava Havla o to, ,jaki sens ma wzrost” (cyt. za Sedláčkiem 2012: 243) skierowane u początków kryzysu do ekonomistów, nie wzbudziło wśród tych ostatnich protestu, że były prezydent Czech miesza porządki nauk ${ }^{29}$. Odpowiadając na nie, rodak i doradca ekonomiczny Havla, Tomáš Sedláček (2012) ${ }^{30}$ obszerny rozdział swej Ekonomii dobra i zta poświęcił dziejom ludzkiej chciwości, którą to tematyką poprzedził bezpośrednią analizę

$26 \mathrm{~W}$ badaniu Burgera nie była to różnica istotna statystycznie. Można mówić jedynie o pewnej tendencji.

27 Tłum. M. Frybes.

28 Przedmiotem często burzliwych sporów pozostaje oczywiście problem, kto łamał te normy i folgował czyim namiętnościom w sposób wyzwalający kryzys.

29 Inną kwestią jest, znacznie przekraczającą ramy niniejszego rozdziału, w jakiej mierze środowiska ekonomistów uznały pytanie Havla za ważne wyzwanie poznawcze.

30 Sedláček jako ekonomiczny doradca Havla mógł być intelektualnym inspiratorem cytowanego pytania. 
kategorii postępu w myśli i praktyce gospodarczej (zob. także Sedláček, Orrel i Chlupatỳ 2012, por. np. Dembinski 2011). W tym kontekście przywoływał idee Arystotelesa jako klasyka „filozofii środka”, który już u zarania myśli europejskiej za największą z ludzkich wad uważał brak umiaru (zob. Strocka 2012). Warto przy tym przypomnieć, że taki fundament aksjologiczny Zachód dzieli z innymi kręgami cywilizacyjnymi. Przed laty pokazał to na przykład tajwański intelektualista John Ching Hsiung Wu (1975, I wyd. 1953) poprzez analizę podobieństwa katolickiej cnoty pokory i analogicznych wartości cenionych przez filozofię taoizmu. Jak przypomniał ostatnio Adrew Ross Sorkin (wnikliwy kronikarz krachu, którego kumulację przyniósł 2007 rok), jeśli chodzi o deficyt pokory, to wśród głównych graczy odpowiedzialnym za gospodarcze turbulencje nic, lub prawie nic się nie zmieniło (Sorkin i Woś 2013).

Przytoczone, wyłącznie przykładowo, treści dyskusji nad ostatnim kryzysem ekonomicznym, wyraźnie pokazują, iż przywrócił on - co sygnalizowałem wcześniej - światowej opinii publicznej, także opinii ekonomistów i specjalistów od zarządzania, problematykę aksjologiczną. Mówiąc metaforycznie, stał się „dramatycznym argumentem” popierającym wcześniejsze, to jest „przedkryzysowe" tezy niektórych badaczy o istnieniu uniwersalnego zestawu wartości, które konstytuują etykę biznesu na poziomie głębszym niż, istotne przecież, różnice międzykulturowe. Pomijając szczegóły wymagające odrębnego opracowania, warto podkreślić, iż wspomniane wartości koncentrują się wokół obecnej w większości kultur światowych przytoczonej już „złotej zasady”: „rób, to co chcesz, żeby ludzie tobie robili" (Seligman 2005, Peterson i Seligman 2004, Damon 2004).

W nieopublikowanym jeszcze opracowaniu Monika Strocka (2012) przeprowadziła wstępną analizę aksjologicznych wątków bestsellerowej książki Josepha E. Stiglitza (2010) Freefall. Free Markets and the Sinking of the Global Economy (Swobodny upadek. Wolny Rynek i tonięcie globalnej gospodarki). Warto podkreślić, iż Swobodny upadek napisał ekonomista wrażliwy także na moralne problemy gospodarki, jeden z nielicznych, którzy przewidzieli światowe załamanie skumulowane w 2007 roku, obdarzony zarówno głęboką wiedzą, jak i „duchem sprawiedliwości" (tak ocenia Stiglitza Touraine 2013). Zdaniem Strockiej (2012) Stiglitz wskazał na następujące aksjologiczne przyczyny ostatnich globalnych trudności gospodarczych:

1) triumf chciwości nad rozwagą (mówi o tym już tytuł szóstego rozdziału Avarice Triumphs Over Prudence książki Stiglitza Freefall America Free Markets and the Sinking of the World Economy - por. cytowana wcześniej książka Sedláčka 2012, której amerykańskie wydanie ukazało się rok po omawianej publikacji Stiglitza 2010);

2) wypieranie tradycyjnych wartości właśnie przez chciwość i konsumpcjonizm (por. Sedláček, 2012: 240, używający w tym kontekście syntetycznego 
spostrzeżenia: „Konsumpcja działa jak narkotyk”); „triumfowi” chciwości i konsumpcji towarzyszy kryzys moralny;

3) eliminacja zaufania $z$ relacji interpersonalnych, wyraźnie obecna choćby w sekurytyzacji odpowiedzialnej za powstanie „toksycznych aktywów”31. Właśnie sekurytyzacja była, zdaniem Stiglitza, bezpośrednią przyczyną kryzysu;

4) powszechne dążenie do zysku (co samo w sobie nie jest złe), nieraz jednak „za wszelką cenę" (co już na ogół jest złe);

5) zmiana perspektywy z długo- na krótkoterminową między innymi w odniesieniu do celów, które stawiane są kadrze zarządzającej. Owa zmiana łącząca się ze wspomnianym wcześniej nadwartościowym traktowaniem „zysku za wszelką cenę" powoduje powstanie problemu podejmowania nadmiernego ryzyka przez gospodarczych decydentów na różnych poziomach oraz trudności z ustaleniem, jaki podmiot jest odpowiedzialny za określone działania w dłuższym okresie.

Cytowany wcześniej Touraine (2013: 92) następująco podsumowuje moralistyczne poglądy Stiglitza na przyczyny kryzysu z 2008 roku:

„Powodem (...) tych błędów (które doprowadziły do załamania gospodarki światowej - uwaga T.O.) jest sytuacja, w której wielkie zasady i sprawiedliwe idee niewiele znaczą wobec działań schlebiających danej populacji, zachłyśniętej życiem ponad stan i rozdartej pychą panowania nad światem, podczas gdy od dawna uczestniczy ona, mniej lub bardziej świadomie, w tworzeniu warunków do wybuchu nowej bańki spekulacyjnej (tym razem bańki subprimes)"32.

Przywoływane już kilkakrotnie opracowanie Moniki Strockiej (2012) uwypukla pesymizm Stiglitza, jeśli chodzi o możliwość spontanicznej zmiany na lepsze w zakresie opisywanych problemów. Przywrócenie globalnemu społeczeństwu takich wartości jak zaufanie, myślenie perspektywiczne czy rozwaga i odpowiedzialność nie nastąpi samoistnie, zdaje się przekonywać czytelnika autor Freefall (Stiglitz 2010).

Podobnie cytowany już Sedláček w rozmowie z matematykiem Davidem Orrelem i publicystą Romanem Chlupatỳm (2012) uważa, iż kryzys skumulowany w 2007 roku jest jeszcze zbyt mały by skłonić środowiska ekonomiczne do porzucenia wiary w postęp redukcjonistycznie mierzony wskaźnikami PKB oraz w modelowanie matematyczne, które często stosuje się czysto mechanistycznie. Sedláček i Orrel wydają się sugerować, iż wspomniane przekonania stanowią „ideologiczne paliwo” kryzysu (choć cytowani autorzy nie używają wprost takiej metafory).

31 Chodzi o sytuację, w której strony (pożyczkodawcę i pożyczkobiorcę) nie łączą relacje, a informacje o określonym kredycie hipotecznym ujęte są w danych statystycznych.

32 Tłum. M. Frybes. 
Touraine (2013: 92) uznając poznawcze kompetencje Stiglitza, przypisuje równocześnie zasadnicze ograniczenie jego refleksji, które można by nazwać „błędem odpersonalizowania”. „Ten wybitny ekonomista (mowa oczywiście o autorze Swobodnego upadku - uwaga T.O.) (...) zdaje się w sposób nieunikniony popełniać ten sam błąd, który często zarzuca się socjologom: przeciwstawianie ogólnych idei zimnym siłom, zasad strategiom, ideałów interesom"33. Takie ujęcie, zdaniem cytowanego francuskiego socjologa, sprawia, iż analizy Stiglitza nie pozwalają znaleźć odpowiedzi na pytanie, dlaczego zaszły procesy warunkujące kryzys. Trudno też w oparciu o Swobodny upadek formułować praktyczne rekomendacje działań poprawiających stan gospodarki po 2008 roku. Przynajmniej częściowo uwagi Touraine’a można odnieść także do poglądów Sedláčka i Orrela.

Podstawową szansę na rozwiązanie problemów kryzysu, które trafnie uchwycili Stiglitz oraz inni analitycy, widzi Touraine w podjęciu aktywności, także gospodarczej, przez aktorów (używając socjologicznego znaczenia tego terminu) świadomych swej podmiotowości. Tacy aktorzy są zdolni do podejmowania wspólnych działań oraz do budowania, czy raczej rekonstrukcji wzajemnych relacji w oparciu o zasady inne niż te, które są obecnie dominujące wśród graczy rynkowych nadwartościowo traktujących „zysk ponad wszystko”. Określenie „bycie świadomym swej podmiotowości” jest dla Touraine'a równoznaczne ze stwierdzeniem „bycie świadomym swoich praw”. Chodzi przede wszystkim „o prawo istot ludzkich do bycia uznanymi za jedynych sędziów swoich własnych wyborów, to znaczy do bycia uznanymi za podmioty będące nosicielami praw" (Touraine 2013: 93-94). Przy czym, gdy Touraine pisze o prawie człowieka „do bycia uznanym za jedynego sędziego własnych wyborów”, to nie wyraża tym samym skrajnego indywidualizmu i subiektywizmu moralnego, który wyjmowałby spoza osądu społecznego na przykład działania przestępców. Chodzi tylko o świadomość aktorów, iż mają oni prawo decydowania o swoich działaniach także w sferze gospodarczej, i nie są deterministycznie podporządkowani „prawom rynku jako instytucji ponoć bardziej racjonalnej niż decyzje ludzi czy całość gospodarki oraz wszyscy ludzie".

„Idei podmiotu - pisze dalej Touraine - nie sposób jednak zredukować do obrony praw człowieka. Składają się na nią wszystkie elementy składowe ludzkiego bytu, które mogą zostać uznane za uniwersalne, poczynając od rozumu (który potrafi zdefiniować prawdę wolną od wszelkich ideologii religijnych czy politycznych), a kończąc na przeżytych doświadczeniach i tradycjach" (Touraine 2013: 94).

Taka perspektywa powoduje radykalną zamianę zainteresowania nauk społecznych. Przedmiotem badań przestaje być jednostka i jej potrzeby, a staje się właśnie podmiot i jego prawa.

33 Przekład M. Frybes. 
Touraine (2013: 173) zwraca też uwagę na wzrost znaczenia państwa narodowego w dobie kryzysu (choć nie zapomina równocześnie o postępującej utracie części skutecznego działania przez tę strukturę), gdyż „każdy naród i każdy region pragnie być lepiej broniony przed konsekwencjami kryzysu światowego, zabiegając zarazem o ochronę własnej przeszłości, własnego dziedzictwa, języka i pamięci”34. Jednak francuski badacz nie wiąże wzrostu znaczenia państwa z faktem, iż to właśnie państwo narodowe stanowi ostatni bastion (nawet jeśli słaby i dysfunkcjonalny) obrony praw obywatelskich w świecie zdominowanym przez korporacje. Zdaniem Michella Billiga (2008), to właśnie fakt, iż instytucje i procedury państwa narodowego (jak na przykład wybory) chronią choćby minimum swobód demokratycznych jego obywateli decyduje o tym, że teza o zmierzchu państw narodowych nie ma obecnie pokrycia w rzeczywistości. W dobie globalizacji znaczenie państw narodowych, postrzeganych przez ludzi jako struktury chroniące (lepiej lub gorzej) demokrację wręcz wzrasta (Billig 2008, por. Hoopes 2011) $)^{35}$.

Możliwość rzeczywiście podmiotowych działań Touraine (2013) przypisuje takim ludziom jak aktywiści ruchów walczących o prawa kobiet oraz ruchów ekologicznych, które przejmują obecnie funkcje związków zawodowych czasów industrializacji. Ci „nowi aktorzy”, by użyć określenia zaproponowanego przez Touraine'a (2013) potrzebują jednak ulepszenia swej organizacji oraz wsparcia instytucjonalnego, by skutecznie przeciwstawiać się obecnej wersji globalnego rynku.

Nie sposób tu nie przypomnieć, iż omawiany francuski socjolog był przed laty głównym autorem zespołowej analizy fenomenu pierwszej „Solidarności” (z lat 1980-1981), wykazując, iż stanowiła ona raczej ruch społeczny, a nie związek zawodowy w tradycyjnym rozumieniu tego terminu (Touraine $\mathrm{i}$ in. 2010). Wznowienie przywołanego studium trzy lata temu, a więc równocześnie z publikacją oryginału Po kryzysie można uznać (nawet jeśli zbieżność dat jest przypadkowa) za kolejny wątek dyskusji wokół kryzysu skumulowanego w 2007 roku, tym razem oparty na dawniejszych, ale też kryzysowych, polskich doświadczeniach.

W kontekście mojej pracy jeszcze jeden wątek formułowanych przez Touraine'a rad przeciwko kryzysowi zasługuje przynajmniej na zasygnalizowanie. Francuski socjolog podkreśla fakt, że „mimo krytyk, Shumpeterowskie pojęcie przedsiębiorczości (podkreślenie T.O.) ma jednak wielką zaletę polegającą na uznaniu centralnego miejsca wynalazczości i twórczości w analizie ekonomicz-

34 Tłum. M. Frybes.

35 Interesująca byłaby dyskusja tezy Billiga o znaczeniu państw narodowych z koncepcją rozrastania się ponadnarodowej klasy kapitalistycznej (zob. np. Kostera i Śliwa 2012). Kwestia ta jednak znacznie przekracza zakres niniejszej pracy. Odkładam więc ją na przyszłość. 
nej”, które to elementy wyznaczają centrum („samo serce” jak pisze Touraine 2013: 94) aktywności nastawionych na podmiot.

Bardziej optymistycznie (jak przystało na jednego z twórców tak zwanej psychologii pozytywnej) niż Touraine widzi możliwości współczesnego świata biznesu Martin Seligman (2011). Wierzy on, że można zmienić mentalność głównych graczy globalnego rynku poprzez modyfikację studiów menedżerskich. Przywołany amerykański psycholog proponuje zajęcia z zakresu rozpoznawania tego, co stanowi najważniejszą wartość dla poszczególnych jednostek i grup oraz proponuje - nie tylko zarządzającym podmiotami gospodarczymi - uodparnianie się na kryzys dzięki praktycznemu wykorzystaniu koncepcji „rozkwitania” (ang. flourishing). Chodzi o zjawisko opisane operacyjnie przez Felicię Hopper i Timothy'ego So w 2009 roku wyrażające się swoistym stanem dobrostanu, dobrego samopoczucia ujawnianego przez jednostki, grupy i szersze społeczności (łącznie z narodami). Aby można było mówić o występowaniu „rozkwitania”, dany podmiot musi zadeklarować przejawianie wszystkich cech podstawowych i minimum trzech cech dodatkowych tego fenomenu. Sa one następujące (podaję za Seligmanem 2011):

\section{cechy podstawowe:}

1. pozytywne emocje,

2. zaangażowanie,

3. poczucie sensu, celu;

\section{cechy dodatkowe:}

1. poczucie wartości siebie,

2. optymizm,

3. sprężystość (ang. resilience),

4. witalność,

5. autodeterminacja,

6. pozytywne relacje interpersonalne.

Seligman (2011) zdroworozsądkowo zwraca uwagę, iż - jeśli chodzi o główne cechy stanu „rozkwitania” - o ile kryzys powoduje emocje negatywne, to nadal zaangażowanie oraz poczucie sensu może „pozostawać w mocy” dla każdego człowieka (wspomniane wymiary są od siebie niezależne). Szczegółową rolę cech dodatkowych jako czynników radzenia sobie przez jednostki i szersze zbiorowości z warunkami zaburzeń gospodarczych na razie pomijamy. Wymaga ona oddzielnego opracowania.

Już teraz jednak można wskazać „osiowe” cechy swoistego modelu przedsiębiorczości, czy szerzej - aktywności gospodarczej i/bądź społecznej zarysowanego zarówno przez Touraine'a jak i Seligmana. Model ten zawiera postulat wartości, które w świetle proponowanego tu ujęcia prac cytowanych autorów konstytuują kapitał kulturowy organizacji i stanowią ramy dla dobrych praktyk. 
Najwyraźniej wspominane cechy dają sprowadzić się do trzech: (1) pomiotowości, (2) relacyjności i (3) zakorzenienia.

Podmiotowość - rozumiana jest zgodnie z przytaczanym wcześniej określeniem Touraine'a.

Relacyjność - rozumiana jest jako współdziałanie oraz umiejętność budowania pozytywnych stosunków międzyludzkich, co zakłada koncepcja „rozkwitania”. Jak pokazał na przykład David Hay $(1998,2006,2007)$, naturę relacyjną ma również poczucie sensu, które, ujmując rzecz psychologicznie, polega na braniu odpowiedzialności za kogoś lub coś bądź przynależności do kogoś lub czegoś radykalnie większego ode mnie. Cytowany już wielokrotnie Dembinski (2011 i 2013) jeden z głównych sposobów zmniejszania negatywnych skutków niesionych przez finansalizację widzi we wspieraniu relacji (osobowych i zakorzenionych w czasie, mających swoją historię), które przeciwstawia transakcjom (krótkotrwałym, anonimowym i niewymagającym zaufania). Właśnie zamiana relacji na transakcję według tego polsko-szwajcarskiego ekonomisty należy do podstawowych symptomów strukturalnych przemian światowej gospodarki, które spowodowały kryzys (por. opinia George'a Sorosa przytaczana przez Sennetta 2010).

Zakorzenienie - będące pochodną zaangażowania (szczególnie, choć nie tylko, na poziomie lokalnym, może chodzić też o zaangażowanie w rodzinę, w jakieś sprawy, w obronę kogoś, w realizację celów itp.), służy podmiotowej aktywności (np. Lewicka 2013, Ochinowski i Kseba 2013).

Tradycyjnie literatura przedmiotu przypisuje wymienione trzy cechy przedsiębiorczości społecznej (zob. np. Wilkin ${ }^{36}$ 2008, Frączek, Hausner i Mazur 2012 oraz Ochinowski 2010), warto jednak potraktować je szerzej, jako „osie” modelu antykryzysowego działalności kapitału kulturowego organizacji. Znajdują one coraz więcej zrozumienia na kartach literatury przedmiotu, zarówno zachodniej jak i polskiej poruszającej wprost znaczenie w zarządzaniu poszczególnych z wymienionych zasad (zob. np. Izquierdo i Vicedo 2012, Chaves i Monzon Wilkin 2008, Motyka i Pawlak 2012, Praszkier i Nowak 2012).

W mojej pracy traktuję wspomnianą triadę jako fundament kapitału kulturowego organizacji, który wyłania się z dyskusji okołokryzysowych. Źródeł kapitału opartego na triadzie „podmiotowość - relacyjność - zakorzenienie” szukam w ideach i praktykach pochodzących z tradycji przedsiębiorczości na terenie Polski. Taką perspektywę uzasadnia historia organizacyjna, wyłaniający się od kilkunastu lat obszar badań i refleksji organizacyjnej łączący przeszłość ze współczesnością i przyszłością praktyk zarządzania. Właśnie historii organizacyjnej poświęcam dwa następne rozdziały.

36 Kategorię „,zakorzenienie” wprowadziłem do niniejszej pracy za Jerzym Wilkinem (2008: 17), który propaguje wspieranie „gospodarki społecznie zakorzenionej”. 


\section{Rozdział III}

\section{Historia organizacyjna w naukach o zarządzaniu}

\subsection{Znaczenie kultury organizacyjnej i pamięci organizacyjnej dla rozwoju nurtu historycznego w zarządzaniu}

\subsubsection{Wątki historyczne w kulturze organizacyjnej}

Zainteresowanie perspektywą historyczną w dziedzinie nauk o zarządzaniu przyniósł przede wszystkim postmodernizm, począwszy od początku lat 90 . ubiegłego stulecia. Jednak już znacznie wcześniej problematyka kultury organizacyjnej pełniła rolę „pasa transmisyjnego” zainteresowań historycznych na obszarze teorii organizacji (Carroll 2002, Booth i Rowlinson 2006). Początek „złotego okresu” kultury organizacyjnej, który, co warto przypomnieć, przypadł na lata 80 . XX wieku, to także czas działań nowego pokolenia historyków organizacji. Przestali oni ograniczać badania przeszłości na potrzeby zarządzania do wąsko rozumianej historii przedsiębiorstw lub poszukiwań archiwalnych tego typu, tak jak to miało miejsce dotąd. Zwłaszcza zorientowane praktycznie prace poświęcone kulturze organizacyjnej wyraźnie wskazywały istotne znaczenie postrzegania dziejów organizacji biznesowych (wraz z otoczeniem społecznym) dla ich efektywnej teraźniejszości.

Takim ujęciom poznawczym szczególnie sprzyjały, co nie może dziwić, postmodernistyczne modele kultury organizacyjnej, które mniej więcej dekadę później po wspomnianym wcześniej „kulturowym boomie lat 80 .” zadomowiły się wśród teoretyków organizacji.

$\mathrm{Z}$ perspektywy rozwoju badań historycznych dla potrzeb zarządzania najcenniejsze w postmodernistycznym nurcie było uznanie kategorii „kultura” za „metaforę rdzenną”, umożliwiającą rozumienie organizacji po prostu jako kultury. Taka perspektywa poznawcza bardzo sprzyjała interdyscyplinarnym przedsięwzięciom badawczym, skupionym na problematyce kultury w zarządzaniu. 
Warto jednak podkreślić, że dużą część dotychczasowej wiedzy o kulturze organizacyjnej, zgromadzonej także przed i „obok” nurtu postmodernistycznego, przedstawiciele teorii i praktyki zarządzania zaczerpnęli z innych dziedzin humanistyki czy nauk społecznych. Kulturą organizacyjną zajmowali się, wprost lub pośrednio, często luminarze danych dyscyplin, jak na przykład antropologowie Clifford Geertz oraz Ward Hunt Goodenough, socjolog Emile Durkheim czy psychologowie społeczni Leon Festinger i George Kelley. Przy czym w zarządzaniu nierzadko zapomina się o założeniach wymienionych nauk, czerpiąc $\mathrm{z}$ nich wybiórczo te treści na temat kultury, które wydają się być przydatne do zwiększenia efektywności działań biznesowych. Niemniej jednak, także w obszarze myśli menedżerskiej panuje duża różnorodność znaczeń i kontekstów dotyczących kultury organizacyjnej (Hartnell, Ou i Kinicki 2011 oraz Kostera 2007, 2010, 2011 i in.). W naturalny sposób znalazło się też miejsce dla kontekstu historycznego.

Najbardziej radykalne ujęcie problematyki organizacyjnej z perspektywy możliwości włączenia do nauk o zarządzaniu studiów historycznych zaproponowali w 1993 roku późniejszy współautor referowanego już „Prospektu” Michael Rowlinson oraz John Hassard. Ich zdaniem kultury organizacyjne należy traktować jako „wymyślone tradycje” poszczególnych przedsiębiorstw, podobnie do tradycji kreowanych przez narody (cyt. za Booth i Rowlinson 2006: 11).

Inni badacze zwracali uwage na ścisły związek między historią a misją, tożsamością i spójnością organizacji, ukazywali praktyczne znaczenie tej pierwszej jako nośnika wiedzy menedżerskiej i temu podobne. Stopniowo analizy historyczne przenikały do centrum badań nad zarządzaniem.

Za swoiste ukoronowanie opisywanego skrótowo mariażu zainteresowania przeszłością z problematyką kultury organizacyjnej uznać można, moim zdaniem, twierdzenie ${ }^{1}$ autorstwa Karla E. Weicka z jego znanej wśród zachodnich badaczy zarządzania książki Sensemaking in organizations (1995). Wspomniany teoretyk organizacji każe widzieć historyka w każdym menedżerze, ponieważ „każdy podejmujący decyzję jest tak dobry, jak dobra jest jego pamięć” (Weick 1995: 184-185, cyt. za Boothem i Rowlinsonem 2006: 11). „Ten jest człowiekiem decyzyjnym, kto rozumie dany wynik i retrospektywnie konstruuje historię, która jak się wydaje doprowadziła do niego" (do wyniku - uwaga T.O.; Weick 1995: 184). Na kartach innej pracy cytowany badacz podkreśla, iż podstawę nadawania sensu w organizacji stanowi „spoglądanie wstecz”, by znaleźć kryteria nadające się do zastosowania w teraźniejszości (Weick 2001, podaję według sformułowań Kostery i Śliwy 2012: 251). W ten sposób Weick dotyka centralnej funkcji poznawczej historii organizacyjnej, jak pokażę to nieco dalej.

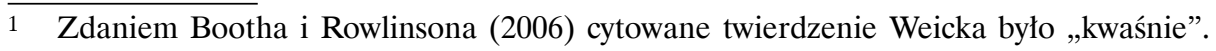




\subsubsection{Pamięć organizacyjna}

Przytoczony w poprzednim paragrafie cytat z pracy Weicka dotknął zagadnień, które bywają zaliczane do kultury organizacyjnej, a zarazem, przede wszystkim ostatnio, są traktowane jako odrębny dział zainteresowań badaczy zarządzania. Chodzi o problematykę pamięci organizacyjnej. Stanowi ona szczególnie „żyzne pole” uprawiania historii organizacyjnej. Zdaniem Craiga E. Carrolla (2002) już lata dziewięćdziesiąte ubiegłego stulecia przyniosły prace związane ze zmienną: „pamięć organizacyjna”, odznaczające się wyjątkowo wysokim (jak na tamten okres naukowych tendecji w zarządzaniu) poziomem refleksji, czy raczej autorefleksji teoretycznej o charakterze historiograficznym² ${ }^{2}$

Jednak szczególne uściślenie relacji między historiografią a analizami pamięci organizacyjnej nastąpiło po zmianie dominującego paradygmatu badania tej drugiej z poznawczego na społeczny. Jeszcze na początku lat 90. XX wieku John P. Walsh i Gerardo Riviera Ugnson twierdzili, iż „pamięć społeczna dotyczy zmagazynowanych informacji z historii organizacji, które mogą być przeniesione tak, by miały udział w obecnych decyzjach" (Walsh i Ugnson 1991: 61, pełny zapis bibliograficzny tej pracy zob. przypis 23, cyt. za Boothem i Rowlinsonem 2006: 11). Początkowo przytoczone określenie było uważane przez naukowców zajmujących się zarządzaniem za fundamentalne. Jednakże krytyka użyteczności dla badań organizacyjnych takiego modelu pamięci organizacyjnej jako „magazynu”, zwane przez niektórych przeciwników co najmniej statycznym, spowodowała zwrócenie się ku koncepcjom pamięci zbiorowej, rozwijających inspiracje płynące z prac Maurice'a Halbwascha. Obecnie jedną z autorek, w której pracach poszukują inspiracji przedstawiciele „studiów nad pamięcią organizacyjną" (ang. organizational memory studies - OMS) - wyodrębnianych na Zachodzie jako oddzielna subdyscyplina zarządzania dzięki przytoczonej wcześniej pracy Walsha i Ugnsona - jest polsko-brytyjska uczona Barbara A. Misztal (Uniwersytet w Leicester, Wielka Brytania). Jej zdaniem badania dotyczące pamięci społecznej „przede wszystkim koncentrują się na społecznych aspektach pamiętania i na rezultatach tego społecznego doświadczenia, to jest na reprezentacji przeszłości w całym zestawie idei, różnych rodzajów wiedzy, praktyk kulturowych, rytuałów i pomników, poprzez które ludzie wyrażają swoje postawy wobec przeszłości i które konstruują ich relacje z przeszłością" (Misztal 2003: 6³,

2 Carroll przytacza w tym kontekście dwie publikacje: Casey A., 1997, Collective memory in organizations. In: Advances in Strategic Management 14: Organizational Learning and Strategic Management, red. nauk. J. Walsh, A. Huff, 111-51, Greenwich, CT: JAI Press oraz Walsh J.P. i G.R. Ungson, 1991, Organizational memory, Academy of Management Review 16: 57-91.

3 Chodzi o pracę: Misztal B.A., 2003, Theories of social remembering, Milton Keynes: Open University Press. 
cyt. za Rowlinsonem, Boothem i in. 2009: 71). Dzięki zetknięciu się teoretyków organizacji z taką perspektywą teoretyczną pamięć organizacyjna będzie mogła być bardziej niż dotąd analizowana w społecznym i historycznym kontekście, a działania badawcze OMS zostaną „uhistoryczniane”. Mogą one stać się wręcz jedynym z głównych obszarów rozwoju historii organizacyjnej, jak sugerują to Michael Rowlinson, Charlse Booth, Peter Clark, Agnès Delahaye i Stephen Procter (2009), autorzy artykułu Social Remembering and Organizational Memory opublikowanego przed dwoma laty na łamach „Organizations Study”4. Moim zdaniem tekst ten, będący wynikiem współpracy międzynarodowego, interdyscyplinarnego zespołu, opublikowany w czasopiśmie dostępnym w większości szkół biznesu na świecie, można uznać za sygnał otwarcia się (lub co najmniej otwierania się) także głównego nurtu nauk o zarządzaniu na problematykę związaną z historią organizacyjną.

Rok przed opublikowaniem cytowanego artykułu, Roos Poole 5 , porządkując obszar wspomnianej problematyki, wskazał na dyskusyjność niektórych, potocznie i nie tylko potocznie, przyjmowanych za oczywiste rozróżnień związnych z różnymi rodzajami pamięci. Między innymi podkreślił on społeczne aspekty pamięci indywidualnej. Za Halwbashem przypomniał, iż to, co pamięta pojedynczy człowiek, w dużym stopniu zależy od wspomnień, zdjęć oraz innych artefaktów dostarczanych mu przez przyjaciół, członków rodziny i innych znaczących ludzi. Bez wsparcia, a także bez potwierdzenia ze strony otoczenia społecznego, zapamiętane przez jednostkę fakty, osoby bądź przedmioty stopniowo ulegają zapomnieniu. Co więcej, terminy w jakich opisujemy, a także przypominamy sobie różne wydarzenia $z$ naszego życia formowane są przez język, konwencje i wartości charakterystyczne dla grup społecznych do których należymy. Pamięć jednostki, podobnie jak inne doświadczenia, jest więc „ustrukturyzowana konceptualnie" (ang. conceptually structured). Do halbwashowskich argumentów dotyczących społecznego charakteru pamięci indywidualnej, Poole dodał jeszcze jeden. Wskazał mianowicie na nieoczywiste konsekwencje bezspornego faktu, że często wspomagamy swoją pamięć korzystając z zapisów na zewnętrznych nośnikach informacji, takich jak notatniki, laptopy i temu podobne. Oznacza to, iż nasza pamięć w znacznym stopniu polega na dostępie do zewnętrznych reprezentacji minionej rzeczywistości. Przy czym reprezentacje te mają tak samo społeczny, zbiorowy charakter jak rytuały czy pomniki tradycyjnie uważane za „magazyny” pamięci zbiorowej. Konkludując, Poole sugeruje, iż różnica między pamięcią indywidualną a zbiorową ma charakter raczej kontinuum niż „przepaści”. Z kolei, nie negując w tym wypadku oczywistych różnic między

4 Termin „historia organizacyjna” nie występuje wprost w tekście tego artykułu, ale został wybrany przez autorów jako jedno ze słów-kluczy identyfikujących jego treść.

5 Poole R., Memory, history and the claims of the past, „Memory Studies”, nr 1, 2008, s. 149-166. Dziękuję autorowi za przesłanie mi swojego tekstu. 
historią jako nauką a pamięcią zbiorową, cytowany badacz zwraca uwagę na funkcjonalne podobieństwa obydwu sposobów „dotykania” przeszłości. Zarówno historia naukowa, jak i pamięć opierają się na dążeniu do prawdy, domaganiu się prawdy (ang. claim to truth) jako horyzontu swych dążeń. Zaś prawda o przeszłości - tu przywołuje Poole tradycje myślenia o pamięci jednostkowej rozwijane na przykład przez Fryderyka Nietzschego i stosuje je do zagadnień pamięci zbiorowej - pociąga za sobą konkretną odpowiedzialność za dziedzictwo tej przeszłości. Pamięć więc zarówno pojedynczego człowieka, jak i zbiorowa, oraz ta zweryfikowana przez historyków - naukowców, ma wymiar przede wszystkim moralny, a nie tylko czysto poznawczy. W takiej perspektywie główną funkcją pamięci zbiorowej jest formułowanie pewnych wymagań, jakie przeszłość niesie teraźniejszości (ang. claims of the past). Funkcja ta ma więc charakter normatywny. Pamięć zbiorowa informuje obecne pokolenia o ich odpowiedzialnościach wobec przeszłości. Może być potwierdzona lub zanegowana przez historię naukową, ale nie powinna być uważana za gorszą wersję wizji dziejów. Jak mi się wydaje, Poole, nie pisząc o tym wprost, wyraźnie dopuszcza też możliwość, iż pamięć zbiorowa może w niektórych przypadkach bardziej prawdziwie niż jej naukowy odpowiednik reprezentować przeszłość.

Perspektywa intelektualna zaproponowana przez cytowanego badacza wyraźnie stwarza impuls do wzbogacenia zarządzania o perspektywę historyczną, a także ukazuje, iż może on pełnić zarazem funkcje poznawcze, jak i wartościujące (Ochinowski 2009b).

\subsection{Geneza historii organizacyjnej i jej ewolucja}

\subsubsection{Kształtowanie się kultury organizacyjnej jako interdyscyplinarnego obszaru badań organizacyjnych}

Mniej więcej od początku bieżącego stulecia próbę kompleksowej analizy przeszłości dla potrzeb zarządzania stanowi historia organizacyjna, którą jej zwolennicy zazwyczaj umieszczają w obszarze teorii organizacji (Booth i Rowlison 2006). Jak dotąd określana jest ona operacyjnie, poprzez wskazywanie poszczególnych prac, wprost lub pośrednio dotykających problematyki historycznej w zarządzaniu. Według cytowanych już Bootha i Rowlinsona (2006) podstawy tej dziedziny nauk o organizacji określił na początku obecnego stulecia amerykański medioznawca Craig E. Carroll, wówczas doktorant Uniwersytetu Teksańskiego (Austin, USA). Historię organizacyjną nazywa on „wyłaniającym się polem badawczym, które przekracza intelektualne domeny i kontynenty" (Carroll 2002: 556). Do wspomnianych domen Carroll zaliczył retorykę, studia kulturowe, komunikację w biznesie, socjologię oraz zarządzanie strategiczne. 
Wymienienie retoryki na pierwszym miejscu nie musiało być przypadkowe. Sugeruje przynależność (choć trudno określić jak głęboką) historii organizacyjnej do szerokiego nurtu retorycznego w badaniach dotyczących człowieka i społeczeństwa, o którym wspominałem w rozdziale pierwszym niniejszej pracy.

W każdym razie retorykę, ale także inne dziedziny wymienione wcześniej za Carrolem (2002) reprezentowało ponad dwustu członków z trzydziestu pięciu krajów świata, których szybko po powstaniu skupiła lista dyskusyjna „OrgHistory”, zainicjowana przez Carrola najprawdopodobniej wiosną $2000 \mathrm{roku}^{6}$. Anons dotyczący listy zawierał informację, że jest ona skierowana do osób „zainteresowanych naukowo-historycznym wymiarem życia organizacji - włączając związki tego wymiaru z cyklami życia organizacji, strukturą wewnętrzną, kadencją organizacji, nostalgią, ciągłością organizacji i tożsamością organizacyjną, teorią instytucji, uprawomocnianiem organizacji (ang. legitimacy - T.O.), zarządzaniem wrażeniem i prawdopodobnie także z przedsiębiorczością" (Carroll 2000).

Również od początku bieżącego stulecia odbywały się na różnych konferencjach panele poświęcone historii organizacyjnej. Carroll (2002) wyróżnił spośród nich konferencję Akademii Zarządzania (Toronto, 2000) oraz Piątą Konferencję na temat Reputacji Korporacyjnej, Tożsamości i Konkurencyjności (Paryż, 2002). Cytowany badacz uznał zwiększanie się liczby uczestników listy dyskusyjnej, udane panele oraz inne przejawy „współmyślenia” dotyczącego historii w zarządzaniu, obserwowane u naukowców z różnych dziedzin i krajów, za wiarygodne wskaźniki wzrostu zainteresowania historią organizacyjną. Tłumaczył tę tendencję przede wszystkim nastrojami przełomu tysiącleci sprzyjającymi autorefleksji zarówno jednostek, jak i organizacji oraz rozwojem mediów, a szczególnie baz internetowych i czasopiśmiennictwa biznesowego, których to rozwój doprowadził do znacznego upublicznienia zasobów archiwalnych firm. Organizacje zaczęły „głośniej” niż dotychczas definiować się „nie tylko w kategoriach tożsamości, ale także w kategorii historii " (Carroll 2002: 556).

Wcześniejszą „historię historii organizacyjnej” Carroll (2002) widzi jako sekwencję nakładających się na siebie kilku faz.

Początkowo historia organizacji (w liczbie mnogiej) zajmowała wyłącznie specjalistyczne grono historyków biznesu oraz archiwistów, niespecjalnie zainteresowanych kwestiami metodologicznymi czy teoretycznymi. Była więc, jak zdaje się sugerować cytowany medioznawcza, wąsko rozumianą historią biznesu.

Jak już pisałem wcześniej, nowe pokolenie badaczy uprawiających historię organizacyjną pojawiło się $\mathrm{w}$ związku z modą na kulturę organizacyjną (lata osiemdziesiąte XX wieku). Naukowcy ci, według surowego osądu Carrolla

6 E-mail Carrolla do Bootha, informujący o powstaniu listy nosił datę 8 kwietnia 2000. Jest on do dziś dostępny w internecie (Carroll 2000).

7 W oryginale: „terminie tożsamości” i „terminach historii” (in term of indentity [...] in terms of history). 
(2002: 557), mimo stopniowego podejmowania refleksji historiograficznej, nadal jednak byli „zbyt zorientowani na zarządzanie”, a ponadto nadal zbyt mało zajmowała ich teoria oraz metodologia. Generalnie postulaty różnych autorów (wśród których Carroll wymienia wspomnianego już obszernie Zalda), którzy mniej więcej od początku lat dziewięćdziesiątych ubiegłego stulecia wyzwali do wysiłku na rzecz konstruowania bardziej adekwatnych niż dotychczas używane podstaw dla historii organizacji, pozostawały bez echa. Badacze podejmujący tego typu prace, ze wspomnianymi już wyjątkami studiów nad pamięcią organizacyjną oraz nad ewolucją tożsamości organizacyjnej w czasie, byli zorientowani przede wszystkim praktycznie.

Za przełomowy moment Carroll uważa publikację na łamach „Human Relation” - prestiżowego czasopisma „głównego nurtu zarządzania” - przytaczanej już przeze mnie analizy różnych wersji dziejów firmy Cadbury pióra Rowlinsona i Hassarda. Tekst ten pod prowokacyjnym tytułem Wymyślanie kultury organizacyjnej: historie historii Cadbury (The invention of corporate culture: A history of the histories of Cadbury), zamieszczony w 46 numerze wspomnianego periodyku z 1993 roku, zawierał między innymi sugestię, iż historycy biznesu generalnie „nie lubią podejmowania kwestii teorii i metod” (Carroll 2002: 557). Właśnie owa krytyka, zadaniem Carrolla, zapoczątkowała proces wyodrębniania się historii organizacyjnej jako oddzielnego obszaru badań.

Sześć lat później duńscy naukowcy Cang Sen Ooi i Esben Karmark podczas konferencji w Kopenhadze poświęconej relacji między analizą dyskursu a naukami społecznymi, sprecyzowali różnice między historią biznesu a historią organizacyjną. Charakterystyczne, iż ich referat, zresztą prawdopodobnie nigdy nieopublikowany, opierał się, podobnie jak przytaczany wcześniej artykuł Rowlinsona i Hassarda, na konkretnych badaniach. Tym razem chodziło $\mathrm{o}$ aktualizuję historii w tak zwanych złotych duńskich czasach z wykorzystaniem przykładu firmy Lego (Carroll 2002).

Ooi i Karmark wskazali różnice między celami oraz obszarami badań historii biznesu i historii organizacyjnej. Sugerują oni, iż pierwszą należy widzieć jako przejaw tradycyjnej praktyki historiograficznej (często bezrefleksyjnej) dążącej do realizacji „obiektywnych” studiów nad przeszłością. Natomiast historia organizacyjna, „która łączy teorię organizacyjną, retorykę i historiografię, jest bardziej (niż historia biznesu - T.O.) zainteresowana strategicznym zawłaszczaniem przeszłości” (ang. the strategic appropriation of the past) (Carroll 2002: 557).

Powyższy cytat zawiera, moim zadaniem, najbardziej precyzyjne jak dotąd, aczkolwiek wyłącznie funkcjonalne określenie historii organizacyjnej.

Historię organizacyjną, zdaniem jej zwolenników, odróżniają od historyków biznesu cele badawcze. Skupieni na „obiektywnej” przeszłości historycy biznesu zajmują się wyłącznie jej prezentowaniem oraz interpretowaniem. Historyków organizacyjnych interesuje natomiast problem, jak „obecne warunki wpływają na 
rzeczywistą reprezentację przeszłości” (Carroll 2002: 557). Zajęcie się „historią samą w sobie" (praktyka historyków biznesu) rodzi tendencję do skrajnych ujęć zagadnienia ciągłości versus nieciaggłości dziejów. Z takiej perspektywy historia uznawana jest za cykliczną lub wręcz przeciwnie - za po prostu nieprzewidywalną. Przesunięcie punktu zainteresowania badawczego na procesy „zawłaszczania historii” (co właśnie robią historycy organizacyjni) rodzi pytanie: ,jak inspiracje przywołane z przeszłości kształtują przyszłe warunki” (Carroll 2002: 558). W świetle historii biznesu przeszłość wzywa do opisania „co rzeczywiście się zdarzyło". Natomiast historia organizacyjna uważa przeszłe doświadczenia za „zasoby do wyartykułowania” (ang. a resorce for articulation, Carroll 2002: 558) ${ }^{8}$.

Ooi i Kremer ukazują istotną konsekwencję teoretyczną rozwoju historii organizacyjnej. Otóż powoduje ona konieczność zmierzenia się także przez badaczy zarządzania $\mathrm{z}$ jednym $\mathrm{z}$ najważniejszych problemów historiograficznych o charakterze metodologicznym - czy raczej głębiej - epistemologicznym. Chodzi oczywiście o zagadnienie obiektywizmu w naukowym poznawaniu dziejów. Duńscy naukowcy przypominają idealny model badań historycznych, który ma prowadzić do obiektywnej reprezentacji przeszłości. Możliwe jest to jednak tylko wtedy, gdy istnieje pełne udokumentowanie badanego wycinka dziejów. Problem polega na tym, że taka sytuacja nigdy nie ma miejsca. Dokumentacja dostępna badaczowi zawsze ma charakter wybiórczy. Niektóre informacje można zdobyć tylko za pośrednictwem wspomnień świadków, a ci często stają się niedostępni z różnych powodów. Zasoby archiwalne również nie są wieczne. Ulegają zapomnieniu, są przenoszone czy niszczone. Nawet jeżeli ocaleją w stanie idealnym, to i tak „nieuchronnie zniknie kontekst, który je stworzył” (Carroll 2002: 558). Nie należy się więc dziwić, że „intencjonalne artykułowanie historii jest zawsze selektywnie konstruowane i dlatego też nie jest obiektywne lub 'nienaruszone"' (Ooi i Karmark 1998: 2-3, cyt. za Carrollem 2002: 558).

Trudno powiedzieć, na ile cytowani badacze są wyznawcami poznawczego relatywizmu. Carroll zdaje się prezentować dość zrównoważone stanowisko. Przytacza pogląd Petersona, iż „prawda” związana z materialną egzystencją, szczególnie taką, która się nie zmienia, ostatecznie „kontroluje doświadczenie”. Równocześnie jednak sięga do następującej tezy Gioi, Shulzta i Corleya: „aczkolwiek fakty się nie zmieniają, to ich znaczenie zmienia się zawsze" (źródło obydwu cytatów: Carroll 2002: 558).

Narracje organizacji stanowią ciekawy przykład precyzyjnie ilustrujący opisaną „dwoistość” teraźniejszych obrazów przeszłości. Carroll (2002) pisze wręcz

8 Jako źródło tej, pozwolę sobie raz jeszcze podkreślić - podstawowej moim zdaniem charakterystyki historii organizacyjnej Carroll (2002) podaje, obok opisanego referatu Ooia i Kramarka także publikację: O' Connor, E. (2000), Plotting theorganization: narrative as a construct for studying change, „Journal of Applied Behavioral Science”, Vol. 36, No. 2, pp. 174-192. 
o procesie ciągłego „przepisywania”, któremu wspomniane narracje podlegają. Zmieniają się wraz z upływem czasu tematy, bohaterowie, wątki treściowe czy waga poszczególnych spraw tworzących zawartość korporacyjnych opowieści snutych przez właścicieli, menedżerów, pracowników, przez i dla samych siebie, jak i szeroko rozumiany jej krąg odbiorców. Zwolennicy historii organizacyjnej wyciągaja z opisanej sytuacji praktyczne konsekwencje badawcze. Od strony metodologicznej preferują podejście, które Carroll (2002: 558) nazywa retoryczno-historycznym. Pozwala ono szukać odpowiedzi na liczne problemy dotyczące relacji historia-teraźniejszość organizacyjna. Wchodzą tu w grę szczegółowe pytania badawcze typu , jak historia zakotwicza i usprawiedliwia teraźniejsze działania? jak legitymizuje ona nowe roszczenia organizacyjne za pomocą starych? jak buduje nowoczesną i starą chwałę?” (Carroll 2002: 558).

$\mathrm{Z}$ perspektywy czasu można przyznać, iż działania poznawcze Carrolla podjęte na początku naszego stulecia rzeczywiście stanowią „kamień milowy” w rozwoju historii organizacyjnej, co bez przesadnej skromności sugerował już wówczas sam autor. Cytowane przeze mnie propozycje teoretyczne zawarł on na stronach wstępu do specjalnego numeru periodyku „Organizational Change Management" (a więc kolejnego, przywoływanego w kontekście rozwoju historii organizacyjnej pisma „głównego nurtu” zarządzania). Carroll gościnnie redagował wspomniany numer zatytułowany Strategiczne użycie przesztości i przysztości $w$ zmianie organizacyjnej. Właśnie tam opublikowane artykuły Carroll określił „kamieniem milowym” badań nad historią organizacyjną. A były to teksty prezentujące etnograficzne studia na temat znaczenia przeszłości organizacji dla jej członków w teraźniejszości, analizy procesów organizacyjnych rozgrywających się „z tyłu” - na zapleczu oficjalnych historii korporacyjnych czy empiryczne odpowiedzi na pytanie, dlaczego takie, a nie inne historie prezentowane są na pierwszym miejscu (Carroll 2002, Ooi 2002, Booth i Rowlinson 2006).

Generalnie Carroll (2002) jako redaktor wspomnianego numeru monograficznego „JoOChM” i autor jedynego w tym zbiorze czysto teoretycznego artykułu uporządkował, a także dał nowe impulsy dla teorii historii organizacyjnej, a na poziomie bardziej szczegółowym wskazał związki tej dziedziny badań z zarządzaniem zmianą oraz uściślił jej relacje z problematyką tożsamości organizacyjnej. Przy czym tożsamość organizacyjną proponował ujmować narracyjnie, jako zjawisko nieustannie zmieniające się.

Trudno nie zauważyć, iż cytowany artykuł Carrolla stanowi ukłon historyków organizacyjnych w kierunku prac Barbary Czarniawskiej. Amerykański medioznawcza proponował rozwinąć bliskie Czarniawskiej ujęcie organizacji jako „podmiotów snujących opowieści” (ang. story-telling organizations) i przyjąć model „organizacji opowiadających dzieje” (ang. history-telling organizations) ${ }^{9}$,

$\overline{9}$ Nieprzetłumaczalna na język polski gra słów angielskich: story i history. 
co pozwala uchwycić sposoby „strategicznego użytkowania historii” (Carroll 2002: 559). Można wtedy poddać analizie na przykład proces stygmatyzacji organizacji przez ich historię, ograniczającą alternatywne szanse rozwoju.

Carroll jednak nie zapomina również o praktycznym wymiarze studiów nad „zawłaszczaniem” przeszłości organizacji. Jego zdaniem, dzięki „historii organizacyjnej, której istnienie zauważał już w niektórych pracach powstałych na początku obecnego stulecia ${ }^{10}$ (sugerując, że możemy także odwrócić ten proces stygmatyzacji historii - T.O.) poprzez poszerzenie spectrum naszych możliwości - możemy użyć naszych wyobrażeń przyszłości do przekształcenia wyobrażeń przeszłości, możemy nadać nową formę przeszłości w bardziej wartościowych (dla nas - T.O.) terminach, możemy przeformułować przeszłość w budzące zainteresowanie wyobrażenia lub interpretacje, które mogą stać się właśnie tak rzeczywiste, autorytatywne i inspirujące, jak te, których bezwiednie używamy do kierowania swoim życiem" (Carroll 2002: 559).

\subsubsection{Historia organizacyjna jako przejaw historycznego zwrotu w naukach o zarządzaniu}

Od 2006 roku zwolennicy perspektywy historycznej w obszarze zarządzania posiadają własne pismo naukowe o zasięgu międzynarodowym, kwartalnik „Management and Organizational History” (M\&OH) wydawany siedem lat przez SAGE, ostatnio (2013 r.) przejęty przez wydawnictwo „Taylor \& Francis Group".

Po czterech latach od sformułowania przez Carrolla cytowanych wcześniej tez, Booth i Rowlinson (2006), na podstawie analizy trendów naukowych oraz praktyki badawczej, dzielili się w pierwszym numerze wspomnianego periodyku odczuciem, iż historia organizacyjna, tak jak rozumial ją amerykański medioznawca, faktycznie stała się samodzielną dziedziną badań. Zjawiska intelektualne na terenie nauk społecznych, oczywiście ze szczególnym uwzględnieniem zarządzania, które zadaniem przywołanych autorów potwierdzają ich intuicję, to ogólnie rzecz biorąc historyczny zwrot „szturmujący” teorię organizacji, a także wznosząca się ,fala” refleksji na temat odpowiedniego stylu pisania o organizacjach w ujęciu historycznym, wzrost zainteresowania badaczy organizacji pracami filozofów historii i wreszcie proces dotyczący dość szczegółowego zagadnienia,

10 Carroll (2002) powołuje się tu na prace: Gioia D.A., Schulz M. i Corley K.G. (2000), Organizational indentity, image and adaptive instability, „Academy of Management Review", Vol. 25, No. 1, 63-81; McWhinney W. i Batista J. (1988), How remythologizing can revitalize organizations, „Organizational Dynamics”, 46-58 oraz Paalumäki A. (2000), „Time and organizational indentity: discourses of the past and the future as constructor of the organizational self", referat prezentowany na IV Międzynardowej Konferencji na temat Dyskursu Organizacyjnego, The Management Centre, King's College, London. 
mianowicie pojawienie się potencjalnych, dość licznych związków między problematyką kultury organizacyjnej i pamięci organizacyjnej. Spośród programów badawczych, za różne warianty wykorzystania perspektywy, którą wyznacza historia organizacyjna Booth i Rowlinson uznali przywoływane już przeze mnie artykuły z monograficznego numeru „Organizational Change Management” (2002) pod redakcją Carrolla, a także wcześniejsze prace, takie jak innowacyjne wykorzystanie metafory dramaturgicznej przez Boya do studiów nad korporacją Disneya (1995) oraz wieloletnie badania niemieckiego naukowca Kielera (z lat 1989-1998) dotyczące genezy i ewolucji nowożytnych wzorów organizacji formalnych. Ostatnie wymienione przedsięwzięcie dało impuls do rozpoczęcia debaty nad historycznym kontekstem rozwoju fenomenu organizowania się.

Cytowani już wielokrotnie brytyjscy badacze Booth i Rowlinson (2006), z których pierwszy jest redaktorem naczelnym „Management and Organizational History”, omówili zjawisko „historycznego zwrotu w teorii organizacji” na początku dziesięciopunktowego tekstu, zatytułowanego po prostu „Prospekt”, który otwiera pierwszy numer wspomnianego periodyku, a który najwyraźniej uznać można za podstawowy jak dotąd manifest poznawczy zachęcający do dyskusji o potrzebie wzbogacenia myśli menedżerskiej przez zwrócenie się ku doświadczeniom przeszłości.

Zdaniem Bootha i Rowlinsona mówienie o „historycznym zwrocie” uzasadniają poglądy teoretyków organizacji, sukcesywnie apelujących o poznawcze zwrócenie się ku przeszłości, takich jak: Mayer Zald, Alfred Kieser, Gibson Burrell, Stewart Clegg czy Roy Jacques. Ten dobór nazwisk dobrze ilustruje częsty związek występujący między apelami o „więcej wrażliwości historycznej” a krytycznym nurtem badań nad zarządzaniem. Wymienieni autorzy są bez wątpienia czołowymi przedstawicielami rzeczonego krytycznego nurtu, stanowiącego najbardziej wyrazisty przejaw postmodernizmu na terenie nauk o organizacjach. Równocześnie, niektórzy od dość dawna, promują zjawiska, które dziś tworzą „historyczny zwrot”.

I tak na przykład Mayer Zald (2002: 381, cyt. za Boothem i Rowlinsonem 2006: 7) zarzuca szkołom biznesu „odcięcie się od myślenia humanistycznego”.

Podobnie Gibson Burrel uważa, iż kadrze tychże wydziałów pozwolono na ucieczkę „od jakiekolwiek wrażliwości na problemy podnoszone przez nauki humanistyczne".

Konsekwentnie, zdaniem Roya Jacquesa, (1996: viii, 190, cyt. za Boothem i Rowlinsonem 2006: 7) „perspektywa historyczna” „dostarcza krytycznie refleksyjnej wizji dobrego społeczeństwa".

Scharakteryzowana przez Booth i Rowlinsona intelektualna atmosfera „historycznego zwrotu" wywołuje szereg zagadnień szczegółowych, którym poświęcone są pozostałe punkty „Prospektu”. 
Chodzi o następujące zagadnienia (numery paragrafów pokrywają się z oryginalnym tekstem):

(2) Metody historyczne i style naukowego pisania o przesztości w kontekście teorii organizacji. Booth i Rowlinson ukazuja potrzebę zintensyfikowania epistemologicznej refleksji nad praktyką badania przeszłości dla potrzeb teorii organizacji z uwzględnieniem tak kluczowych zagadnień, jak problematyka metod badawczych, statusu źródeł czy właśnie stylu pisarstwa historycznego. Autorzy dyskutują historiograficzne napięcie między podejściem dokumentarnym i narracyjnym, zachęcają do refleksyjnego stosowania różnych rozwiązań metodologicznych, zaś konkludując, określają swój cel jako „promocję zarówno 'dobrze poinformowanych' pod względem historycznym prac w obrębie teorii organizacji, jak i badań należących do dziedziny historii, a jednocześnie 'dobrze poinformowanych' przez teorię organizacji” (Booth i Rowlinson 2006: 9).

(3) Filozofia historii $i$ teoretycy historii. Autorzy referowanego „Prospektu” są zdania, że zarówno metodologiczna refleksja, jak i różnego typu eksperymenty metodologiczne $\mathrm{z}$ historią $\mathrm{w}$ teorii organizacji prowadzą do konieczności zmierzenia się z podstawowymi problemami współczesnej historiografii podejmowanymi na kartach prac najbardziej znaczących współczesnych filozofów i teoretyków naukowego poznawania przeszłości. Booth i Rowlinson proponują sięganie do myśli Haydena White'a, Michela Foucaulta, Paula Ricoeura, Davida Carra oraz Deirdry McCloskey. Jako centralne zagadnienie metahistoryczne w kontekście związków badania dziejów z teorią organizacji, jawi się kwestia ciągłości bądź nieciągłości historii. Omawiany punkt „Prospektu” kończy się wskazaniem na retoryczne ujęcie tego problemu proponowane przez Deirdrę McCloskey, która definiując dzieje jako „historię przez nas opowiadaną”, uważa, że „ciągłość i nieciaggłość historii są narracyjnymi sztuczkami, które można wybierać ze względu na ich wartości (dosł. cnoty - T.O.) dla opowiadania" (cyt. za Boothem i Rowlinsonem 2006: 10).

W dalszej części „Prospektu” jego autorzy omawiają szereg szczegółowych punktów, które najwyraźniej określają pole praktyki badawczej oraz edukacyjnej „historycznego nurtu”. Są one następujące: (4) kultura organizacyjna i pamięć społeczna (chodzi o historyczne wymiary tych zjawisk, co omówiłem w paragrafie poprzedniej części niniejszej pracy), (5) historia organizacyjna jako rodząca się oddzielna subdyscyplina zarządzania, (6) historia biznesu a teoria organizacji (wzajemne związki), (7) etyka biznesu w historii (chodzi o „sens i etykę zachowań biznesowych z przeszłości”, Booth i Rowlinson 2006: 5), (8) metanarracje na temat kapitalizmu korporacyjnego, które zogniskowała przede wszystkim „historiograficzna debata dotycząca rozwoju kapitalizmu i współczesnego modelu korporacji”, w zachodniej literaturze przedmiotu rozpoczęta pracami Alfreda Chandlera (Booth i Rowlinson 2006: 5), (9) związki historii myśli menedżerskiej z edukacją na wydziałach zarządzania (dosłowny 
tytuł tego punktu brzmi: „Historia zarządzania i edukacja w zakresie zarządzania”) i (10) relacje zachodzące między szkołami biznesu a wzrostem społecznego zainteresowania historią (zachodnia historiografia określa badanie roli historii w różnych kręgach społecznych mianem „historii publicznej”, ang. Public History, taki też tytuł nosi ostatni, przed podsumowaniem, punkt „Prospektu”).

Kolejne numery „Management and Organizational History” od początku powstania w znacznym stopniu monitorują, a zarazem inspirują procesy związane $\mathrm{z}$ historycznym zwrotem w zarządzaniu. Obecnie kwartalnik wydawany jest pod redakcją jego współzałożyciela Michaela Rowlinsona, przy współpracy Roya Stagera Jacquesa.

Droga badawcza Jacquesa dobrze ilustruje „historyczny zwrot” w dziedzinie nauk o organizacji. Ten amerykański profesor zarządzania (ostatnio związany z Massey University w Nowej Zelandii), a także praktyk biznesu początkowo zajmował się zagadnieniami pracy opartej na wiedzy. Niektóre aspekty wspomnianego obszaru poszukiwań poznawczych doprowadziły Jacquesa do badań dotyczących genezy wiedzy menedżerskiej, które zaowocowały książką Produkowanie pracowników (Manufacturing the Employee, 1996). Warto podkreślić, że stanowiła ona aplikację filozoficznych propozycji Michela Foucaulta do badania „ukrytych” dziejów wiedzy menedżerskiej. Zawierała krytykę uniwersalizmu zarządzania oraz propagowała podejście historyczne, jako intelektualne narzędzie kreowania krytycznej, refleksyjnej wizji „dobrego społeczeństwa”. Nic dziwnego, że Jacques, już na łamach pierwszego numeru M\&OH wyraźnie zaliczony został do głównych przedstawicieli „historycznego zwrotu” (Booth i Rowlinson 2006). Jako autor drugiego obok „Prospektu” programowego tekstu tego periodyku, pod tytułem Historia, historiografia oraz badania nad organizacjami: wyzwanie i potencjat (History, historiography and organization studies: The challenge and the potential) Jacques z perspektywy głównego nurtu zarządzania oceniał nowe czasopismo, formułując dla niego dwa podstawowe cele:

- udział w budowaniu dialogu między historią biznesu i naukami o organizacji (ang. organizational studies), dziedzinami, które dotąd niewiele łączyło,

- pobudzanie świadomości przedstawicieli „głównego nurtu” dotyczącej tego, że perspektywa historyczna odgrywa istotną rolę w rozumieniu procesów zarządzania.

Zdaniem Jaquesa (2006), do realizacji powyższych zadań konieczne jest stworzenie środowiska, które skupiałoby się wokół praktyki aktywnego dyskutowania oraz nauczania historiografii w kontekście szeroko rozumianej problematyki menedżerskiej. Jako porównawczy przykład takiej intelektualnej społeczności Jacques przywoływał swoisty ruch zwolenników intelektualnej mody na kulturę organizacyjną z lat osiemdziesiątych ubiegłego stulecia (wielokrotnie już wspomniany na kartach niniejszej pracy). Jacques konsekwentnie rozwijający swe zainteresowanie przeszłością jako ważnego narzędzia pogłębiania teorii 
organizacji, a także humanizacji stosunków w firmie (np. Rowlinson, Jacques i Booth 2009, Jacques i Hobson 2009), po kilku latach wziął współodpowiedzialność za kwartalnik $\mathrm{M} \& \mathrm{OH}$, a tym samym za rozwój historii organizacyjnej.

Z kolei do intelektualnych osiągnięć Rowlinsona, na którego publikacjach w znacznym stopniu opiera się niniejszy rozdział, warto dodać fakt, iż badacz ten nadał historyczną orientację Szkole Biznesu i Zarządzania Uniwersytetu Queen Mary w Londynie, kierowanej przez niego od 2004 roku. Tę jednostkę akademicką najwyraźniej można uznać za jeden z najważniejszych, jeśli nie główny ośrodek rozwoju historii organizacyjnej na świecie. O tym, że jest to rozwój o zasięgu światowym, świadczy choćby międzynarodowy skład zespołu redakcyjnego $\mathrm{M} \& \mathrm{OH}$. Obejmuje on przede wszystkim naukowców brytyjskich i amerykańskich, ale także z Francji, Norwegii, Finlandii, Holandii, Kanady, Australii, Nowej Zelandii, Izraela i Turcji. Booth, twórca kwartalnika oraz jego pierwszy redaktor naczelny pozostaje członkiem redakcji. Jak dotąd nikt nie reprezentuje we wspomnianym gronie ani historiografii, ani nauk o zarządzaniu krajów Europy Środkowo-Wschodniej.

Do niedawana też nie było na łamach omawianego kwartalnika publikowanych prac obejmujących problematykę Europy Środkowo-Wschodniej. Sytuację tę zmieniła Polka - Martyna Śliwa, teoretyk organizacji, bezpośrednio zainteresowana historią organizacyjną (szczególnie w kontekście transformacji postsocjalistycznej, przez krajowych autorów nazywaną raczej postkomunistyczną, oraz migracji) pracująca na Uniwersytecie w Essex ${ }^{11}$. W 2011 na łamach $\mathrm{M} \& \mathrm{OH}$ Martyna Śliwa wraz z Becky Taylor zaprezentowała wyniki analizy 25 historii życia Polaków, spośród których 8 przebywało podczas badań na emigracji w Wielkiej Brytanii, 8 wróciło do kraju po uprzedniej emigracji, a 9 nigdy nie migrowało. Autorki wykorzystały szerokie znaczenie terminu „migracja”, określając nim zarówno przemieszczenia ludzi wewnątrz danego państwa (migracja wewnętrzna), jak i poza nim (migracja zewnętrzna). Dążyły do uchwycenia biograficznych znaczeń obydwu rodzajów migracji w odniesieniu do trajektorii życia zawodowego. Interesowały je wyjazdy Polaków przed 1989 rokiem i po nim, a także przed wejściem naszego kraju do Unii Europejskiej w 2004 roku i po nim. Dane do badań Śliwa i Taylor uzyskały za pomocą historii mówionej, wykazując, iż metoda ta pozwala na uchwycenie złożonej, zależnej od wielu przypadkowych zmiennych, a zarazem trwającej w czasie relacji między migracją a wyborami związanymi z przebiegiem pracy zarobkowej. Migracja okazała się bowiem - z perspektywy biograficznej - nie tyle pojedynczym wydarzeniem, ile częścią względnie długotrwałej historii osobistej (zarówno jednostki jak i kilku

11 Polskim czytelnikom znana jest ona przede wszystkim jako współautorka (obok Moniki Kostery) cytowanego wielokrotnie podręcznika Zarzadzanie w XXI wieku. Jakość, twórczość, kultura, Warszawa 2012. 
pokoleń rodzin) i zawodowej. Ponadto do zrozumienia rzeczywistości społecznej zarówno socjalistycznej, jak i postsocjalistycznej bardzo przydatne poznawczo, jeśli nie wręcz konieczne, jest sięgnięcie do przeżyć ludzi, którzy doświadczyli życia w obydwu z nich.

Trudno oprzeć się wrażeniu, że wypłynięcie polskiej, czy szerzej środkowoeuropejskiej problematyki na „szerokie wody” historii organizacyjnej, poprzez losy migrantów zarobkowych, stanowi pewnego rodzaju odblask słynnej publikacji Floriana Znanieckiego i Williama Thomasa The Polish Peasant in Europe and America z lat 1918-1920, które zapoczątkowało zarówno międzynarodową karierę Znanieckiego, jak i wersji socjologii „Z czynnikiem humanistycznym”, którą on zainicjował. Tym bardziej, że Śliwa i Taylor wykorzystały metodologię historii mówionej. Znaniecki zaś należy do niewątpliwych jej prekursorów.

Ostatnio wspomniana polska badaczka z Essex opublikowała na łamach M\&OH tekst metodologiczny dotyczący historii mówionej w zarządzaniu (Śliwa 2013). Ukazał się on pośród innych artykułów tematycznego numeru poświęconego podsumowaniu wyzwań z zakresu metodologii stojących aktualnie przed historią organizacyjną. Być może więc Śliwa okaże się twórczą kontynuatorką „polskiego" sposobu uprawiania badań historyczno-społecznych, który przed laty zainicjował Znaniecki, i będzie go szerzyć w problematyce zarządzania.

$\mathrm{M} \& \mathrm{OH}$ konsekwentnie publikuje prace badawcze o nastawieniu historycznym, obejmujące tematyką praktycznie wszystkie działy zarządzania „i okolic” (jest to także marketing, badania operacyjne, finanse i rachunkowość, systemy informacyjne, ekonomię polityczną i in.). Redaktorzy nie stawiają ograniczeń co do okresu dziejów będącego przedmiotem zainteresowania potencjalnych autorów, od starożytności do czasów współczesnych. Starają się też, by tematyka czasopisma obejmowała jak najbardziej zróżnicowane kręgi geograficzne oraz społeczne.

W zakresie problematyki metodologicznej omawiane pismo ma wyraźne, czemu trudno się dziwić, nastawienie interdyscyplinarne. Zastanawia się nad nowymi rozwiązania warsztatowymi dla historii biznesu (np. Taylor, Bell i Cook 2009), jest też otwarte na możliwości adaptacji do potrzeb analiz organizacji, podejść badawczych różnych działów historii, ze szczególnym uwzględnieniem historii kultury i historii społecznej (np. M\&OH 2011), jak również sięga po inne dyscypliny wiedzy, nawet tak odległe od metodologii historii, jak na przykład neurofizjologia (Corbet 2008).

Jednocześnie M\&OH (2011) nie zaniedbuje refleksji historiograficznej, szczególnie szukając inspiracji w nowych nurtach naukowej analizy praktyki badań przeszłości, czy filozofii tejże. Jako przykłady warto podać choćby teksty poświęcone myśli Foucaulta (Mckinlay 2006), hermeneutyce (Maielli 2007; Taylor, Bell i Cook 2009) i Waltera Benjamina (monograficzny numer 8 z. 1, 2012), podejściu feministycznemu (Philips i Riepin 2010, oraz inne artykuły z numeru 5 z. 3-4, 2010) czy historii konceptualnej (Costea, Crump i Holm 
2006 oraz Andersen 2011). Autorów tego czasopisma zajmuje też wspomniana już wcześniej teoria postkolonialna (Srinivas 2012 i Decker 2013), która stanowi jeszcze jeden lącznik między historią organizacyjną a krytycznym nurtem zarządzania (por. Kostera i Śliwa 2012).

We wrześniu 2011 roku Centrum Historii Zarządzania Uniwersytetu Londyńskiego Queen Mary, a więc główny ośrodek historii organizacyjnej na świecie, zorganizowało warsztat pod tytułem „Jakościowe metody historyczne w badaniach z zakresu zarządzania i organizacji”. Główne wątki wymiany myśli zostały opublikowane dwa lata później na łamach $\mathrm{M} \& \mathrm{OH}$. Zarówno wspomniany warsztat, jak i będące jego pokłosiem artykuły powstały w celu wymiany szczegółowych doświadczeń między tymi, którzy mieli już do czynienia z metodami historycznymi oraz, tak bardzo jak to możliwe, w celu demistyfikacji wspominanych metod. Główną intencję organizatorów wyznaczały starania, aby omawiane przedsięwzięcie stało się pierwszym krokiem do stworzenia praktycznego kompendium metod historycznych w zarządzaniu. „Zagadnieniem wspólnym dla wszystkich działań podejmowanych podczas warsztatu było zaakceptowanie faktu, iż podejście historyczne jest wartościowe i w pewnym stopniu »wspiera « debaty filozoficzne o naturze historii, oraz, że istnieje potrzeba zapewnienia praktycznego przewodnictwa dla tych, którzy chcą stosować podejście historyczne w praktyce" (Musacchio Adorisio i Mutch 2013: 105). Konsekwentnie Rowlinson i Hassard (2013) na podstawie jakościowej i ilościowej analizy bibliograficznej publikacji biznesowych z lat 1991-2010 (55 artykułów zajmujących się historią) opisali tendencje zawarte w praktyce badaczy zarządzania zainteresowanych przeszłością. Jak się okazało, wśród tych naukowców dominują analizy ilościowe. Ponadto rzadko przeprowadzają oni badania archiwalne oraz preferują historię najnowszą. Jako praktyczną radę autorzy zalecają wykorzystanie socjologicznej teorii neoinstytucjonalnej do wzbogacenia warsztatu historyka organizacji. Aby było to skuteczne, zdaniem Rowlinsona i Hassarda, konieczne jest spełnienie trzech postulatów:

1) stosowanie $w$ toku badań przeszłości na potrzeby zarządzania bardziej rygorystycznie niż to ma miejsce dotąd, metodologii wypracowanej przez historyków, szczególnie jeśli chodzi o krytykę źródeł;

2) wzbudzenie zainteresowania pierwotnymi źródłami dokumentów, które dobrze znają historycy biznesu, takimi jak: protokoły, kartoteki zarządu, raporty wewnętrzne i memoranda;

3) „eksport” teorii na obszar analizy przeszłości, a nie, jak to jest powszechne dotąd, ilustrowanie teorii za pomocą danych historycznych.

Zgodnie z dialogiczną atmosferą „historycznego zwrotu” inni uczestnicy omawianego warsztatu między innymi wykazywali brak możliwości w pełni naukowego badania archiwów, choćby ze względu na fakt, iż ich zwartość w znacznym stopniu zależy od właścicieli (Decker 2013), postulowali powrót 
historyków biznesu do podstawowych pytań historiografii (Belli, Taylor 2013), dyskutowali użyteczność metod wizualnych przy analizie historycznej (Kokki, Jönsson 2013) i dzielili się doświadczeniem w zakresie stosowania historii mówionej (Śliwa 2013). Charakterystyczne, iż wśród zagadnień interesujących inspiratorów warsztatu na Uniwersytecie Londyńskim Queen Mary najwyraźniej nie znalazły się najnowsze kwestie teoretyczne podnoszone obecnie przez niektórych historiografów, takie jak posthumanistyczna wersja historii (pisanie dziejów także z perspektywy przyrody nieożywionej) czy przejście od „ery świadectwa” do „ery kryminalistyki” (nacisk na materialne dowody, na rzeczy w toku badań historycznych, Domańska 2013). Wyraźnie widać więc nowy etap rozwoju historii organizacyjnej skoncentrowany wokół praktyki badawczej. Być może właśnie „zwrot historyczny” okaże się jedną z empirycznych odpowiedzi na zarzut formułowany przez niektórych naukowców, iż krytyczny nurt zarządzania „wykazuje się również ograniczoną skutecznością pragmatyczną, ponieważ niewiele jest znaczących projektów badawczych realizowanych" na jego gruncie (Sułkowski 2012: 250).

Warto w kontekście powyższego przypomnieć ideę podkreślaną przed laty przez Bootha i Rowlinson (2006) na łamach „Prospektu”, że dalekie od ich intencji - wyrażonych przede wszystkim za pomocą cytowanej już przeze mnie dziesięciopunktowej agendy - byłoby określanie granic bądź wykluczanie innych, niż proponowane przez nich, rozwiązań w zakresie „historycznego zwrotu” w naukach o organizacji. Zachęcali więc do szukania różnorodnych inspiracji czy propozycji, zarówno teoretycznych jak i metodologicznych.

Do tego rodzaju przykładów - powstałych na bardzo różnych obszarach badawczych i mogących wzbogacić warsztat historyka organizacyjnego - należy propozycja David Ahlstroma, Davida Lamonda i Zhujuna Dinga (2009), by w teorii zarządzania oraz edukacji menedżerskiej wykorzystywać wątki organizacyjne niesione przez najnowsze dzieje wojskowości.

Jako studium przypadku tego rodzaju autorzy poddali analizie doświadczenia I wojny światowej pod kątem funkcjonowania przekonań (które, co warto przypomnieć, dobrze zna poznawcza psychologia organizacji) o „nieuchronności” wyników podejmowanych działań, a także wybranych zagadnień systemu organizacyjnego i przywództwa.

Okres II wojny światowej posłużył im do krytycznego spojrzenia na zjawisko „wygrywania poprzedniej wojny”, grożące także współczesnym menedżerom. Ahlstrom i współpracownicy przytaczają szereg innych przykładów wojennych wydarzeń historycznych „testujących” różnorodne problemy zarządzania.

Z kolei dzieje japońskiego ataku na Pearl Harbor mogą wzbogacić wiedzę o roli zaskoczenia oraz o fenomenie „myślenia grupowego” (który został przecież sformułowany na podstawie metody archiwalnej), a wojna wietnamska może stać się źródłem nowych informacji na temat eskalacji zaangażowania. 
Przy czym relacje nauki o zarządzaniu z historią militarną nie są wcale jednokierunkowe. Badacze dziejów militarnych XX wieku również mogą twórczo skorzystać z ustaleń na przykład teorii organizacji przy planowaniu swych badań oraz interpretacji ich wyników.

Dla obydwu stron najważniejsze jest, konkludują Alhstrom, Lamond i Zhujun, by wykorzystywać krytyczne analizy faktów, a nie wypełnione fikcją opowieści. Historia wojskowości przypomina więc historykom organizacyjnym, iż pomimo całego subiektywizmu, którym obciążona jest każda rekonstrukcja przeszłości, istnieje hierarchia narracji historycznych wyznaczana przez staromodne dążenie do ustalenia ,jak mogło być naprawdę”.

Interesującego uzasadnienia użyteczności historycznych studiów nad organizacjami dostarcza pośrednio amerykański naukowiec - badacz dziejów zarządzania Richard Marens (2005), propagując kategorię „wyczucia czasu”, bądź raczej „charakterystycznych cech danego czasu” (timing), czyli uwarunkowań dziejowych popularności (lub niepopularności) idei zdobywających dominująca pozycję (lub marginalizowanych) w praktyce menedżerskiej niezależnie od ich merytorycznej wartości.

Richard Marens analizuje z tej perspektywy losy katolickiej nauki społecznej. Podstawowy dla genezy wspomnianej doktryny dokument, encyklika papieża Leona XIII, Rerum Novarum znalazła silny, praktyczny oddźwięk w środowiskach odpowiedzialnych za gospodarkę tamtego okresu, czyli przełomu XIX i XX wieku (Marens 2005, zob. także Burleigh 2011b i Anderson 2009). Niecało sto lat później porównywalne gatunkowo idee Jana Pawła II pozostawały zupełnie na marginesie działań biznesowych (zob. także blok materiałów polskiej edycji magazynu „Forbes”, pod znaczącym tytułem Dekalog biznesu pisat kto inny, wydany po śmierci papieża Polaka). Zdaniem Marensa, analogiczne badanie historycznych uwarunkowań pomoże wyjaśnić współczesne trudności, jakie napotyka na przykład recepcja projektu zarządzania opartego o interesariuszy (stakeholder management), pomimo iż stanowi on zestaw idei, charakteryzujących się ,imponującym rodowodem, etycznym ugruntowaniem i atrakcyjnością dla praktyki” (2005: 298).

Uogólniając przytoczone studium przypadku, Marens proponuje, aby generalnie przy analizie idei biznesowych nie pomijać historycznego studium warunków, które są konieczne do ich realizacji. Powodzenie jakichkolwiek propozycji zmian zależy w takim samym stopniu od możliwości i uwarunkowań, jak od etycznego wydźwięku i logicznej spójności rozwijanych idei. Praktykę biznesowej innowacyjności znacząco może więc wspomóc „historyczne zrozumienie tego, skąd (dana koncepcja - dopisek T.O.) pochodzi oraz jakie przeszkody napotkała" (Marens 2005: 298).

Niezależnie jednak od pluralizmu środowisk mających swój wkład do historii organizacyjnej powstanie w 2006 roku kwartalnika „Management and Organiza- 
tional History" proponuję uznać za kolejny etap rozwoju omawianej dyscypliny, świadczący o osiągnięciu przez nią pewnego stopnia jeśli nie naukowej, to przynajmniej środowiskowej dojrzałości. Istotnym brakiem pozostaje nieobecność tego periodyku w podstawowych elektronicznych zbiorach literatury fachowej, na czym cierpią oczywiście przede wszystkim peryferyjne (z perspektywy globalizacji) ośrodki akademickie.

Charakterystyczną cechę $\mathrm{M} \& \mathrm{OH}$ stanowi przyjęte przez jej redaktorów szerokie rozumienie podstawowych kategorii przedmiotowych, określających zakres zainteresowań czasopisma, to jest „zarządzania”, „organizacji” oraz „organizowania się”. „Organizacja jest interpretowana szeroko - głosi anons wydawniczy (M\&OH 2011) - włączając jednostki administracji publicznej oraz niekapitalistyczne formy organizacji społecznych i gospodarczych, podobnie jak podmioty biznesowe". Warto przypomnieć, iż taka intencja przyświecała również „założycielskiemu”, jeśli chodzi o historię organizacyjną, artykułowi Carrolla (2002), zaś wcześniej dla całego zarządzania jako dyscypliny naukowej, propagował ją, przy różnych okazjach, Peter Drucker. Historia organizacyjna jawi się więc także jako platforma wymiany doświadczeń między różnymi typami życia organizacyjnego, doświadczeń interpretowanych z perspektywy przeszłości, ale nie tylko w przeszłości aktualnych.

Na zakończenie niniejszej, wstępnej prezentacji „historycznego zwrotu” jako tła rozwoju historii organizacyjnej warto zauważyć, iż sympatia jego promotorów do krytycznego nurtu zarządzania najwyraźniej jest odwzajemniona. Świadczą o tym wypowiedzi i/lub działania prominentnych akademików związanych $\mathrm{z}$ postmodernizmem $\mathrm{w}$ naukach o organizacji.

Nie przez przypadek przywoływany już wcześniej Roy Jacques przyjął, co warto przypomnieć, obowiązki współredaktora „Management and Organizational History". Tekst pióra Rowlinsona, tegoż Jaquesa i Bootha (2009) poświęcony historii organizacyjnej, która stanowi propozycję podejścia badawczego w ramach „historycznego zwrotu”, wszedł do kolejnej edycji oxfordzkiego podręcznika krytycznego zarządzania, The Oxford Handbook of Critical Management Studies (Alvensson i Wilmott 2009).

Z kolei wspominana już Barbara Czarniawska (2010: 14), polska profesor zarządzania działająca obecnie w Szwecji, na kartach książki Trochę inna teoria organizacji, wymieniając za Ianem Hackinkgiem stopnie zaangażowania w poznawaną rzeczywistość dostępne badaczowi zarządzania o duszy konstruktywisty, na pierwszym miejscu stawia analizy historyczne, „gdzie celem badań jest rekonstrukcja, tj. dokumentacja przebiegu określonego procesu konstrukcji”.

Dużą część IX rozdziału, poświęconego procesom zapominania w organizacjach, Czarniawska (2010: 139) opiera na przykładzie reform z czasów starożytnego Rzymu, które porównuje do prób odgórnego reformowania gospo- 
darki PRL przed 1980 rokiem. Autorka tę konfrontację „ponad tysiącleciami” kończy następującą konkluzją: „Efekty rzymskich i polskich reform okazały się diametralnie różne i zarazem bardzo podobne. Różniły się tym, że rzymskie reformy wprowadzily skuteczny system kontroli, a polskie zupełnie nie. Podobny był rezultat końcowy: udane reformy rzymskie zdławiły gospodarkę cesarstwa, nieudane reformy polskie dobiły nieefektywną polską gospodarkę. Czy jest zatem możliwe, aby reformy rzeczywiście coś ulepszyły?". Odpowiadając na to pytanie, Czarniawska „wraca” do współczesności, pisząc: „czas na przykład ze Szwecji”. Odpowiedź sygnalizowana tytułem jednego z podrozdziału przywołanej tu części podręcznika Reformy jako sposób bycia znacznie wykracza poza zakres mojej pracy, dlatego ją pomijam. Istotne z punktu widzenia niniejszych rozważań jest natomiast podane przez autorkę uzasadnienie tego, że dokonuje uogólnień ważnych dla współczesnej praktyki menedżerskiej na podstawie zestawienia odległych od siebie przypadków historycznych. Reinterpretuje więc w perspektywie zarządzania ustalenia historyków bardzo różnych epok. Czarniawska używa w tym kontekście zdroworozsądkowej argumentacji, bez sztucznego racjonalizowania swych wyborów poznawczych, co zresztą generalnie cechuje pisarstwo naukowe cytowanej badaczki, łączące wysoki poziom erudycji z prostotą wywodu.

Odniesienia do historii starożytnego Rzymu oraz PRL-u autorka Troche innej teorii organizacji poprzedza odżegnaniem się od pokusy uniwersalizmu. „Nie mam zamiaru proponować uniwersalnych teorii i wszechobowiązujących wniosków" - pisze, by następnie, pomijając znaną jej dobrze historiograficzną debatę o statusie poznawczym i ontologicznym faktów z przeszłości, stwierdzić po prostu - „ale trzeba zauważyć, że wiele trafnych obserwacji dotyczących procesów organizowania sformułowano dużo wcześniej”. Powodów aktualności wspomnianych spostrzeżeń Czarniawska nie wiąże z możliwością istnienia „niezmiennej natury ludzkiej” bądź „istoty organizowania” (cudzysłowy cytowanej autorki), bo obydwu kategoriom polsko-szwedzka badaczka przypisuje status wyłącznie konstruktów kulturowych. Zaś przyczyną aktualności historycznych obserwacji dotyczących zarządzania jest „raczej ludzka dola i nieustanne wysiłki, żeby nadać jej sens - również organizując” (Czarniawska 2010: 135). Wyzwania, z którymi zmierzyć musi się człowiek, okazują się więc, zdaniem Czarniawskiej, stałymi na przestrzeni dziejów, a tak sformułowane stanowisko poznawcze, które pozwolę sobie nazwać uniwersalizmem sytuacyjnym (zakłada bowiem ostateczną transhistoryczność sytuacji określających wspomnianą „człowieczą dolę"), jedyną formą uniwersalizmu dopuszczalną przez postmodernistyczne nurty w naukach o organizacji. Jednocześnie wspomniany uniwersalizm sytuacyjny byłby poznawczą granicą konstruowania czy raczej dekonstrukcji przeszłości, chroniąc przez to „historyczny zwrot” jako intelektualny nurt zarządzania przed niemożliwością powiedzenia „niczego o niczym” jak przed laty, logicznie, choć 
nie bez ironii pisał Ernest Gellner (1997) wskazując na ostateczne konsekwencje radykalnego postmodernizmu.

U Czarniawskiej zwraca uwagę uznanie za uniwersalne także dążenie człowieka do nadawania sensu swemu losowi. Zaś organizowanie rozumiane właśnie jako konstruowanie rzeczywistości badaczka uznaje za jedno z działań sensotwórczych. Stanowi to chyba najbardziej nobilitujące kulturowo określenie zarządzania, jakie znalazłem w literaturze przedmiotu.

Poglądy Czarniawskiej (2010) wyznaczają interesującą perspektywę poznawczą dla „historycznego zwrotu”. „Uniwersalizm sytuacyjny” oraz założenie o stałym w czasie dążeniu człowieka do nadawania sensu swej doli pozwalaja spojrzeć na badanie przeszłości dla potrzeb zarządzania jako na poszukiwanie modelowych sytuacji wyzwań, które mogą okazać się aktualne i dziś (przy unikaniu oczywiście błędu prezentyzmu), zaś doświadczenie przeszłych pokoleń (szeroko rozumianych organizatorów i odbiorców ich działań) uznać za źródło dobrych lub złych praktyk, przede wszystkim sensotwórczych. Takie podejście realizowane przez różnych badaczy zainteresowanych historią zarządzania, by wymienić choćby Chrisa Lowneya (2011), którego koncepcję omawiam dalej, jest teoretycznym fundamentem badań i analiz przeszłości podejmowanych przeze mnie $\mathrm{w}$ niniejszej pracy.

Jednocześnie coraz bardziej aktualne staje się pytanie, czy „historyczny zwrot" zawsze wiązać się musi z postmodernizmem. Na przykład Kazimierz Doktór (2011), jeden z polskich zagorzałych przeciwników wspomnianej orientacji, zresztą krytykujący ją przy użyciu (nomen omen) iście postmodernistycznej dawki ironii, wyraźnie dowartościowuje perspektywę historyczną, gdy pisze o najnowszym modelu menedżera transgranicznego. Warto jednak pamiętać, że postmodernizm był tu pierwszy.

\subsection{Specyfika i funkcje poznawcze historii organizacyjnej w naukach o zarządzaniu}

\subsubsection{Uniwersalizm i prezentyzm - historiograficzne problemy teorii organizacji}

Centralną kwestię historiograficzną „historycznego zwrotu” w zarządzaniu którego uszczegółowienie stanowi historia organizacyjna - wyznacza, zdaniem cytowanych już wielokrotnie Bootha i Rowlinsona (2006), problem uniwersalizmu i prezentyzmu. Przywoływany przez nich Zald wskazuje, iż właśnie one są charakterystycznymi cechami nauk społecznych uprawianych przez pracowników szkół biznesu. Cechy te wyraża nastawienie badaczy na poszukiwanie ogólnych i abstrakcyjnych praw. W rezultacie „nauka społeczna odcina się sama od 
historii" (zwrot Zalda cytowany za Boothem i Rowlinsonem 2006: 6). Skutkiem uniwersalizmu jest punkt widzenia, według którego współczesne teorie organizacji mają zastosowanie „zawsze i wszędzie”, tłumaczą wszystkie zjawiska organizacyjne niezależnie od specyfiki społeczeństwa i czasu, w którym zjawiska te występują. Z kolei konsekwencję prezentyzmu stanowi charakterystyczna retoryka sprawozdań z badań, sugerująca, iż są one realizowane w „nieskontekstualizowanej, rozciągniętej w czasie teraźniejszości” (zwrot Zalda cytowany za Boothem i Rowlinsonem 2006: 6). Zdaniem Zalda, prezentyzm zaprzecza uniwersalizmowi. Stopień wspomnianego zaprzeczenia określa częste u przedstawicieli zarządzania przekonanie, iż teraźniejszość jest „okresem bezprecedensowej zamiany, zwiastującej świt nowej ery" (Booth i Rowlinson 2006: 6). Zazwyczaj jednak przekonania tego nie popiera się stosownym rozpoznaniem precedensów historycznych. Uogólniając, można mówić o „retorycznym pomyśle uprzywilejowania teraźniejszości, niezwiązanej z przeszłością i rozciągniętej w czasie" Booth i Rowlinson 2006: 6). Przy czym roszczenie to, jak zwracają uwagę Booth i Rowlinson, występuje wśród naukowców od bardzo dawna.

Cytowani autorzy proponują nazwać prezentyzm i uniwersalizm „podejściem do przeszłości według Flinstonów i Simpsonów”. Przywołują tu oczywiście znaną, również kilku pokoleniom polskich widzów kreskówkę „Między nami Jaskiniowcami” (ang. The Flintstones), w której ludzie epoki żelaza niczym nie różnią się od przedstawicieli społeczeństwa amerykańskiego XX wieku. Serial bawi licznymi anachronizmami, takimi jak na przykład bożonarodzeniowe występy bohaterów mające miejsce tysiące lat przed narodzinami Chrystusa. „Metoda Flistonów i Simsonów” przeniesiona na teren zarządzania rodzi przekonanie, iż problemy organizacyjne od początku świata są takie same, jak współczesne.

Booth i Rowlinson przytaczają określenie uniwersalizmu sformułowane przed laty przez cytowanego już Roya Jacquesa, jednego z pierwszych historyków myśli menedżerskiej, który poddał krytyce wizję zarządzania jako „zbioru uniwersalnych, wiecznych prawd" przeciwstawiając jej narracyjną historię stosunków w pracy ograniczoną geograficznie do USA.

Na kartach swej książki Produkowanie pracowników: wiedza o zarządzaniu od XIX do XXI wieku (1999, ang. Manufacturing the employee: management knowledge from the 19th to 21st centuries) zauważył on, iż uniwersalizm oznacza przedstawianie zarządzania jako „ciagłej nici biegnącej przez cywilizację” (cytat ze strony 19 omawianej pozycji podaję za Boothem i Rowlinsonem 2006: 6). Nawet Biblia dla uniwersalistycznych teoretyków organizacji zawiera warte cytowania kwestie organizacyjne. Przytoczoną charakterystykę uniwersalizmu na terenie zarządzania rozwija, również cytowany przez Bootha i Rowlinsona, Simon Down, który do ważnych cech uniwersalistycznego podejścia zalicza częste ,akcentowanie ciąłości nad zmianą” (Down 2001: 402, cyt. za Boothem i Rowlinsonem 2006: 6). Trudno nie zauważyć, iż w ten sposób myśl organiza- 
cyjna zostaje wzbogacona (lub obciążona, jak zapewne uważają krytycy „historycznego zwrotu") o dyskusje od lat zajmujące historiografów i historiozofów, ze szczególnym uwzględnieniem kwestii wyjątkowości versus powtarzalności wydarzeń dziejowych. Down, a za nim Booth i Rowlinson piszą zresztą o tym wprost, przywołując potoczne sformułowania wspomnianej kontrowersji. I tak uniwersalizm można uznać za poznawczą konsekwencję ideologii niesionej przez powiedzenie „nic nowego pod słońcem” (łac. nihil novi sub sole). Jedynie za półprawdę uważał to sformułowanie Milton Friedman, dla równowagi identycznie traktując przeciwstawne cytowanemu powiedzenie „historia lubi się powtarzać”.

Nawiasem mówiąc, sięgnięcie na łamach „Management \& Organizational History" do klasycznej pracy Friedmana Esseys in positive economics z 1966 roku przypomina, iż orientacja historyczna znacznie wcześniej niż w zarządzaniu zadomowiła się wśród nauk ekonomicznych. Zagościła tam zresztą na wyraźne życzenie samych ekonomistów. Jak wskazywał to choćby nestor polskich historiografów Stanisław Grabski (2003), powstanie historii gospodarczej stanowiło interesujący precedens w dziejach nauk humanistycznych, gdy jedna z dziedzin wiedzy (ekonomia) wywołała rozwój - poprzez wyodrębnienie nowej subdyscypliny - innej (to jest historii). Być może podobnym precedensem będzie rozwój historii organizacyjnej „na życzenie” zarządzania. Choć tu pole poznawcze jest już częśsiowo zagospodarowane przez historię biznesu oraz historię przedsiębiorczości (zob. np. Lipartito 1995, Taylor, Beck i Cook 2009, Amatori i Colli 2011, Jones, van Leeuwen i Broadberry 2012 oraz Landes, Mokyr i Baumol 2010). Relacjom między wymienionymi obszarami badań a historią organizacyjną poświęcę oddzielne miejsce w następnych podrozdziałach.

Wracając do rozważań nad prezentyzmem i uniwersalizmem, w omawianym tekście programowym Bootha i Rowlinsona warto zwrócić uwagę na myśl, iż druga ze wspomnianych ideologii może być użyteczna jako przeciwwaga twierdzenia o braku ciągłości między przeszłością i teraźniejszością. Trzeba jednak zdawać sobie sprawę z grożących przy tym uproszczeń. Cytowany już Down ilustruje te intelektualne zagrożenia przykładem badań obciążonych „metodologicznym grzechem pierworodnym" właśnie ze względu na bezkrytyczne wykorzystanie uniwersalizmu. Chodzi o studia nad inicjatywami gospodarczymi w starożytnej Grecji, traktowanymi jako rodzaj przedsiębiorstw międzynarodowych. Dla realizacji tak określonego tematu badacze wykorzystują perspektywę poznawczą współczesnego zarządzania międzykulturowego oraz stosują język opisu charakterystyczny dla kapitalizmu korporacyjnego. Wspomniane operacje intelektualne zawierają założenie, iż organizacje gospodarcze starożytnych Greków (a może także wszystkie inne na przestrzeni dziejów) były pewnymi formami kapitalizmu. Z kolei pociąga to za sobą bardziej szczegółową tezę, mającą już wprost konsekwencje metodologiczne, że starożytne przedsiębiorstwa międzynarodowe posiadały kształt nadający się do analizy za pomocą koncepcji 
Michaela Portera. A to - konkluduje Down - jest nie do obrony. Przytoczony krytycznie przez cytowanego autora pogląd metodologiczny można by przyjąć jedynie przy założeniu, że zasady rynkowe istniały zawsze, co jednak wymaga zignorowania szerokiej gamy danych zgromadzonych przez historię intelektualną oraz historiografię starożytności.

Booth i Rowlinson (2006) zalecają jednocześnie ostrożność wobec inspirowanej marksizmem krytyki powszechności praw rynku. Krytyka ta bowiem opiera się na również uniwersalistycznym, choć konkurencyjnym wobec wcześniej opisanego, założeniu Karola Marksa dotyczącym walki klas.

„Metoda Flinstonów i Simpsonów”, czyli mieszanka uniwersalizmu z prezentyzmem tworzy obrazy zmyślonych organizacji, funkcjonujących „w niedatowanej, rozciągniętej w czasie teraźniejszości' (Booth i Rowlinson 2006: 7). Jest to zjawisko podobne do obrazu fikcyjnego miasteczka Springfield z ,Jaskiniowców", które nie sposób umiejscowić na terenie któregokolwiek stanu USA. Podobnie prezentystycznie, jak wspomniane wcześniej organizacje, wygląda najbardziej chyba znany bohater przywoływanej kreskówki, Burt Simpson. Nigdy się nie starzeje. Zawsze pojawia się $\mathrm{w}$ teraźniejszości, niezależnie od liczby wcześniejszych epizodów z jego udziałem. Jak ukazuje cytowana przez Bootha i Rowlinsona przywoływana już Czarniawska, podobnie zmyślone organizacje często prezentują badania organizacyjne. Organizacja „może nie istnieć, a jednocześnie wszystko, co mówi się na jej temat, może być prawdą", to znaczy „może być wiarygodne w świetle innych tekstów” (cyt. za Boothem i Rowlinsonem 2006: 7). Autorzy omawianego przeze mnie „Prospektu” wydają się więc sugerować, iż niektóre przynajmniej współczesne studia nad organizacjami przypominają ,postmodernistyczny pastisz”, jakim jest obraz filmowej siedziby „Jaskiniowców”, czyli zmyślonego Springfield.

„Historyczny zwrot - konkludują Booth i Rowlinson (2006: 7) - problematyzuje uniwersalizm i prezentyzm. Podnosi on kwestię zakresu, w jakim organizacje oraz badania organizacyjne powinny być »uhistorycznione«, to jest umieszczone w specyficznym, historycznym kontekście".

Omawiane podejście rodzi szereg istotnych pytań, pomijanych przez zwolenników „metody Flinstonów i Simpsonów”. Uogólniając sugestie Bootha i Rowlinsona, można je wyrazić następująco, pamiętając, że są to tylko przykłady:

- kiedy powstały poszczególne formy działalności gospodarczej? (na przykład czy wspominane w „Prospekcie” przedsiębiorstwo międzynarodowe narodziło się w starożytnej Grecji? Można to pytanie sformułować także inaczej: czy przedsiębiorstwo funkcjonujące w starożytnej Grecji było tą samą formą działalności gospodarczej, która jest specyficzna dla kapitalizmu doby globalizacji?),

- które formy aktywności gospodarczej znane z przeszłości można wiarygodnie porównywać ze współczesnymi? W jakich przypadkach jest to możliwe? 
(na przykład w jakim przypadku bezpośrednie inwestycje zagraniczne (ang. foreign direct investment) realizowane na przełomie XIX i XX wieku, czyli podczas „pierwszej odsłony” globalizacji, są porównywalne z tymi, które znamy obecnie na przełomie XX i XXI stulecia?),

- a w kategoriach teraźniejszości, jak bardzo nadają się do generalizacji ustalenia badań etnograficznych poczynionych na podstawie sfabularyzowanej i przypuszczalnie typowej organizacji? (2006).

\subsubsection{Specyfika historii organizacyjnej w świetle jej funkcji poznawczych}

Uproszczenia „metody Flinstonów i Simpsonów” nie niwelują jednak przekonywujących, możliwych do naukowej identyfikacji przez badaczy przeszłości, przypadków „poprzedników” niektórych wydarzeń charakterystycznych dla współczesnego kapitalizmu. Na przykład prace takich wiodących historyków gospodarczych jak Kevin H. O'Rourke, Nial Ferguson, czy mniej znany Barry Eichengreen, pozwoliły ustalić, iż pod pewnymi względami maksymalny jak dotąd poziom globalizacji, rozumianej jak najbardziej zgodnie ze nowoczesnymi kryteriami, miał miejsce na przełomie XIX i XX wieku. Została ona zahamowana przez wybuch I wojny światowej. Kwestią sporną pozostaje dla historyków jedynie rola imperializmu podczas wspomnianej, „pierwszej odsłony" globalizacji.

Historia organizacyjna może też wnosić swój wkład w rozwój historii bezprzymiotnikowej. Przykład takiego wpływu dotyczący historii powszechnej przyniosły ostatnio rozwijające się prężnie badania po pierwszej fali kryzysu 2007 nad finansową stroną przeszłości, co już sygnalizowałem wcześniej. Patricia M. McGoldrick (2013) z lodyńskiego Middlesex Univeristy poddała analizie niedawno odtajnione dokumenty National Archives, które pokazują, że rząd brytyjski w czasie II wojny światowej (wspomniane archiwalia obejmują lata 1941-1943) prowadził szczegółowy monitoring transakcji realizowanych przez główne agendy finansowe Państwa Watykan. Zdaniem cytowanej badaczki operacje te mogą rzucić nowe światło na dyskutowane do dziś, nie tylko przez historyków, zachowania papieża Piusa XII podczas działań wojennych. Jak się okazuje, Watykan inwestował wówczas bardzo duże sumy nie tylko w pomoc humanitarną, ale także znacząco wspierał amerykański przemysł wojenny. „Finansowa historia II wojny światowej - pisze Luca M. Possati (2013: 57), komentując badania McGoldrick - jest jeszcze terra incognito, którą niewielu uczonych zaczęło studiować. To, co mamy przed oczami, wystarczy jednak, by zrezygnować $\mathrm{w}$ rekonstrukcji faktów z pospiesznych ocen i poglądów podyktowanych przez ideologię". Ostatnie z przytoczonych spostrzeżeń Possatiego, gdy wyrwać je z konkretnego kontekstu dyskusji nad Piusem XII, staje się wskazaniem istotnej funkcji analiz historycznych także w zarządzaniu. 
Wracając do myśli Bootha i Rowlinsona (2006), warto podkreślić, iż cytowani autorzy zwracają uwagę na fakt, że „,zwrot historyczny” poza wszystkim intensyfikuje także krytyczną i etyczną refleksję dotyczącą nauk o zarządzaniu. Nowe ujęcia takich zagadnień jak rasa, płeć (gender) czy seksualność podejmowane ostatnio, bądź nieco wcześniej przez teoretyków organizacji, także powinny pociągnąć za sobą historyczne konceptualizacje. Jako przykład Booth i Rowlinson (2006) wskazują na poszukiwania Anshumana Prasada, który nadzieje na pogłębienie analizy przyczyn globalnego zróżnicowania miejsc pracy wiąże $\mathrm{z}$ teorią postkolonialną.

Autorzy cytowanej już wielokrotnie magna charta omawianej opcji intelektualnej, czyli „Prospektu”, nie poprzestają na wynikającej z niego krytyce dotychczas dominującego nurtu myśli menedżerskiej. Za Bellem Üsdikenem i Alfredem Kielerem wyróżniają oni trzy postawy poznawcze umożliwiające teoretykom organizacji i zarządzania zintensyfikowanie zainteresowań przeszłością.

Pierwsza z nich nosi nazwę „suplementarysta” (ang. supplementarist). Zwolennik takiego podejścia to badacz, który patrzy na teorię organizacji z perspektywy przedstawiciela nauk społecznych. W takim ujęciu czynniki historyczne są jedynie dodawane jako jedne $\mathrm{z}$ wielu innych zmiennych, takich jak na przykład „kultura narodowa”. Zgodnie z taką perspektywą teoretyczną zadaniem historii jest tylko uzupełnianie istniejących teorii organizacji.

Druga postawa badaczy zarządzania wobec przeszłości według Üsdikena i Kielera to „integracjonista” (ang. integrationist). Polega ona na podjęciu wysitków poznawczych zmierzających do wzbogacenia teorii organizacji poprzez rozwijanie jej związków z naukami humanistycznymi, jednak bez całkowitego porzucenia wspomnianej wyżej „orientacji społecznej”. Wśród potencjalnych „partnerów” dla badań organizacyjnych wymieniana jest właśnie historia, a obok niej literaturoznawstwo i filozofia. Poznawczy cel „integracjonistów” wyznacza dążenie do zintegrowania historii i teorii organizacji. Kieler preferuje takie właśnie podejście.

Natomiast Booth i Rowlinson (2006: 8) w znacznym stopniu utożsamiają się z trzecią postawą - „reorientacjonisty” (ang. reorientationist), która niesie ze sobą „bezkompromisową krytykę istniejących teorii organizacji ze względu na ich ahistoryczną orientację". Takie podejście wyraża przekonanie, iż właściwy „historyczny zwrot” wymaga reorientacji teorii organizacji. Kierunek wspomnianego przewartościowania powinien być zgodny z postulatami formułowanymi przez krytyczny nurt w zarządzaniu i studia genderowe (gender studies).

W niniejszej książce staram się łączyć postawę interakcjonisty i reorientacjonisty.

Booth i Rowlinson (2006) kończą konstytutywny dla obecnego kształtu historii organizacyjnej fragment „Prospektu” wyraźną (choć przedstawioną pośrednio) sugestią, iż dwa główne jej filary to: (1) badania, rygorystyczne 
pod względem metodologii oraz (2) podsumowujące prace badawcze przeglądy historiograficzne, stanowiące istotny przyczynek do dalszego rozwoju omawianego obszaru zainteresowań poznawczych jako samodzielnej subdyscypliny teorii organizacyjnej.

Charakterystyczne, iż prace badawcze, przytaczane przez cytowanych autorów, a jeszcze bardziej publikacje $\mathrm{z}$ dziedziny historiografii na które się powołują, często są znacznie starsze niż „założycielski” artykuł Carrolla (2002). Jedne i drugie pochodzą z lat dziewięćdziesiątych (to głównie badania) oraz osiemdziesiątych (przede wszystkim przeglądy historiograficzne) dwudziestego wieku, ale znalazła się wśród nich również klasyczna dla zachodniej historiografii poruszającej problematykę menedżerską książka Reinholda Bendixa Praca $i$ wtadza $w$ przemyśle: ideologie zarzadzania $w$ procesie industrializacji (Work and authority in industry: Ideologies of management in the course of industrialization) nosząca datę wydania 1956 (!). Najwyraźniej więc historia organizacyjna zalicza się do dziedzin o stosunkowo krótkiej historii i względnie długiej prehistorii. Warto pogłębiać analizę tej prehistorii, będącej, zgodnie z sugestiami Carrolla (2002), Bootha i Rowlinsona (2006) nośnikiem inspiracji na dziś.

Niewątpliwie pogłębianie to powinno dotyczyć „czasu i przestrzeni” tak, by historia organizacyjna, dyscyplina z natury swej krytyczna, sama nie uległa stygmatyzacji myślą „ulubionych” przez badaczy okresów czy hegemonistycznych centrów naukowych.

Przykładem idei rozwijanych „na peryferiach” globalizacji mogą być poglądy polskiego historyka, działającego przede wszystkim w okresie międzywojennym - Feliksa Konecznego, dotyczące roli przedsiębiorczości i handlu w dziejach, skutkujące oryginalną praktyką badawczą oraz interpretacyjną. Ich szczegółowy wykład wymaga jednak analizy historiograficznej tej części dorobku krakowskiego uczonego. Sukcesywnie ją przeprowadza Katarzyna Błachowska z Instytutu Historycznego UW.

Globalny charakter zarządzania międzykulturowego powoli przywraca do łask, aczkolwiek niebezkrytycznie, także historiozoficzne dokonania Konecznego. Jak się wyraźnie okazuje, użytecznych narzędzi analizy działań biznesowych z ogólnoświatowej perspektywy dostarcza koncepcja cywilizacji sformułowana jeszcze przed II wojną światową przez wspomnianego krakowskiego historyka (Koneczny 1935/1997, zob. także Skoczyński 1997 i 2003). Dziś jest ona znana bardziej za granicą niż w Polsce. Według Konecznego, cywilizacja to pewien sposób (metoda) ułożenia życia społecznego. Kluczową rolę odgrywają w nim takie elementy jak: dobro, prawda, piękno, zdrowie i dobrobyt, zwane „pięciomianem”. Na cywilizację składają się między innymi stosunek do czasu, relacja między prawem prywatnym a publicznym, źródła prawa oraz poczucie narodowe.

Według wspomnianego badacza nie istnieje jedna droga rozwoju cywilizacji. Wynika to z faktu, że różne społeczeństwa wyznaczają sobie różne cele. Tym, 
co najbardziej je różnicuje, jest koncepcja dobra oraz sposobów jego realizacji. Koneczny uważał, że nie da się połączyć cywilizacji, które są odmienne od siebie pod względem moralnym. Dziś ta teza wymaga oczywiście dyskusji oraz empirycznej weryfikacji. Z kolei częścią składową cywilizacji jest kultura, a w zasadzie różnorodne kultury, które mimo swego zróżnicowania składają się na jedną całość - na cywilizację właśnie. Wyraźnie korzystał z myśli Konecznego, choć nigdy się wprost na niego nie powołując, Samuel P. Huntington (zob. Skoczyński 2003).

Natomiast na poziomie teorii zarządzania zmaganie się ze zjawiskiem marginalizacji zarówno jeśli chodzi o światową historiografię, jak i nauki o zarządzaniu, wymagałoby dowartościowania polskiej tradycji myśli menedżerskiej bez wpadania w niebezpieczeństwo megalomanii narodowej. Niedawno zmarły amerykański historyk John Mee już na początku lat 60. ubiegłego stulecia zwrócił uwagę, iż „harmonogram” autorstwa Karola Adamieckiego, narzędzie do diagnozy produktywności pracowników było wcześniejsze od analogicznego rozwiązania spopularyzowanego w świecie jako „diagram” Henry'ego Gantta. Fakt ten przytoczył Daniel A. Wren (1972) na kartach swej Ewolucji myśli menedżerskiej (ang. The Evolution of Managment Thought), podręcznika historii nauk o zarządzaniu należącego do kanonu tej dziedziny. Wren (1972) opisał paradoks historyczny polegający na tym, że diagram Gantta spopularyzowany przez Wallace'a Clarka legł u podstaw europejskiego „ruchu produktywności”, który był traktowany jako eksport idei z USA mimo znacznie wcześniejszych działań Adamieckiego. Autor Ewolucji myśli menedżerskiej widział tu analogie do losów osiągnięć francuskiego ojca zarządzania Henri'ego Fayola i konkludował: „Mówiąc krótko, naukowe zarządzanie zdobyło uznanie Europy i tłumaczenia płynęly w tym kierunku, ale nie vice versa. Taylor zaćmił Fayola, a Gantt został przyjęty przed Adamieckim; przemysłowy klimat w Europie był gotowy na idee naukowego zarządzania, ale dopiero inne czasy przyniosły Europie rozpoznanie jej własnych synów" (Wren 1972: 181). Trudno powiedzieć, czy dla dziedzictwa Adamieckiego czasy te w ogóle nadeszły poza krótkim przedziałem lat międzywojennych. Techniczne propozycje autora „diagramu” oczywiście należą już od dawna wyłącznie do historii, ale niektóre, wstępne jak dotąd analizy, sugerują, iż polski inżynier zaproponował także ideowe, czy szerzej sensotwórcze (parafrazując przytoczone wcześniej przeze mnie sugestie Czarniawskiej, 2010) podstawy działań menedżerskich alternatywne wobec tayloryzmu. Być może są one warte dzisiaj uwagi nie tylko historyków (zob. np. Bomabała 2006 oraz Czech 1980 i 2009). Na oddzielne badanie zasługuje także fakt, iż polska myśl menedżerska, której rozwój przerwany został przez II wojnę światową i jeszcze silniej przez stalinizm (Czech 1999, 2009 i in.) odradzała się - mimo cenzuralnych ograniczeń - już od lat 50. ubiegłego wieku, ale niekoniecznie przez nawiązanie do tradycji Adamieckiego. Uważany za twórcę współczesnej 
polskiej terminologii menedżerskiej, autor mającego osiem wydań podręcznika Organizacja i zarzadzanie (ostatni przedruk 1981 r.) i wielu innych znaczących publikacji, wcześniej dyrektor w rodzinnej fabryce zaliczanej do czołowych polskich przedsiębiorstw, Jan Zieleniewski zaproponował teoretyczne oparcie nauk dotyczących organizacji na prakseologii Tadeusza Kotarbińskiego. Warto zbadać, na ile ten nurt myślowy zadomowił się wśród polskich badaczy i menedżerów.

Jest on do dziś twórczo rozwijany na przykład przez część środowiska Centrum Etyki Biznesu (CEBI) Akademii Koźmińskiego i Instytutu Filozofii i Socjologii PAN w Warszawie, stanowiącego ośrodek o skali międzynarodowej. W 2012 roku Centrum organizowało V Światowy Kongres Etyki Biznesu (ISBEE). Na czele tej instytucji od wielu lat stoi Wojciech Gasparski (np. 2000, Gasparski i Pszczołowski 1983), gorący zwolennik prakseologicznego nurtu myśli menedżerskiej oraz propagowania jej na świecie. Tradycja Adamieckiego, przynajmniej w Polsce od czasu do czasu również wychodzi poza ścisły zakres historii zarządzania. Na przykład przywoływany już Bombała (2006) zaproponował kilka lat temu etykom biznesu, by przyjrzeli się bliżej idei harmonii duchowej, zawartej w pracach twórcy „harmonogramu”. Cytowany wcześniej Czech (2009), profesor Uniwersytetu Ekonomicznego w Katowicach, swą obszerną monografię życia i dokonań Adamieckego kończy sugestią, iż bohater jego pracy był prekursorem interdyscyplinarnego podejścia do problematyki menedżerskiej, jak również zarządzania informacją. Autor wspomnianej książki konsekwentnie analizuje także dorobek innych zapomnianych luminarzy zarządzania w Polsce Józefa Lisaka, Piotra Drzewieckiego, Aleksandra Rothera i Edwina Hauswalda, umiejscawiając ich wysiłki na tle zachodniej myśli i praktyki menedżerskiej (np. Czech 1983, 1984, 1999, 2005, 2012). Podobnie jak Gasparski, Czech publikuje studia poświęcone polskiej problematyce także po angielsku, przeciwstawiając się tym samym wspomnianej na początku niniejszego akapitu marginalizacji również grożącej środowiskom naukowym. Dzięki badaniu tradycji instytucji kształcących menedżerów oraz organizacji branżowych (np. Czech 1997, 2008) cytowany naukowiec de facto styka się twórczo z historią organizacyjną, tak jak jest ona rozumiana $\mathrm{w}$ niniejszej książce (szczególnie zob. następne podrozdziały). Last but not least autor monografii o Adamieckim rozwija swe badawcze zainteresowanie przeszłością jako pracownik Zakładu Zarządzania Innowacjami Katedry Zarządzania Przedsiębiorstwem wspomnianego wcześniej śląskiego uniwersytetu, a więc w stałym kontakcie poznawczym $\mathrm{z}$ wyzwaniami menedżerskiej współczesności. Biorąc pod uwagę przywołane tu przeze mnie informacje, uznać należy Czecha za głównego przedstawiciela „historycznego zwrotu" na terenie polskich nauk o zarządzaniu, aczkolwiek dalekiego, jak się wydaje, od perspektywy postmodernistycznej.

Cytowany badacz, zachowując w pełni oryginalność swych zainteresowań, przypomina stylem pracy naukowej Zbigniewa Martyniaka (1936-2002), wielo- 
letniego profesora Akademii Ekonomicznej w Krakowie (obecnie Uniwersytet Ekonomiczny) ${ }^{12}$. Martyniak łączył analizę i popularyzację najnowszych trendów zarządzania z rekonstrukcją tradycji tej dziedziny, również przypominając polskie osiągnięcia. Poświęcił na przykład oddzielną monografię Stanisławowi Bieńkowskiemu (1882-1958), pionierowi nauki i praktyki zarządzania w naszym kraju, równocześnie zwolennikowi jej humanistycznego nurtu, a Karola Adamieckiego i znacznie mniej znanych Piotra Drzewieckiego (1865-1944) oraz Franciszkę Józefę Joteyko (1866-1928) zaliczył do grona prekursorów nauk organizacji i zarządzania, obok Taylora, Gantta, Fayola i Mayo (Martyniak 1983, 1989). Wśród pozycji bibliograficznych Martyniaka ważne miejsce zajmują zarówno Nowe metody i koncepcje zarzadzania (2002), jak i Historia myśli organizatorskiej (2002).

Być może więc jest szansa na powtórzenie się - tym razem w przypadku historii organizacyjnej - sytuacji z początku XX wieku, gdy problematyka historii gospodarczej, dzięki wysiłkom przede wszystkim jednego uczonego Franciszka Bujaka (1875-1953), „ukształtowała się u nas - wprawdzie - z pewnym opóźnieniem w stosunku do Zachodu i na wzór niemiecki”, ale zaowocowała dość szybko oryginalną polską szkołą uprawiania tej dziedziny wiedzy (Grabski 2000: 146, Madurowicz-Urbańska 1976, 1999 i in.). Szkoła ta zachowała zresztą aktualność praktycznie do dziś, głównie dzięki dokonaniom naukowym i organizatorskim Heleny Madurowicz-Urbańskiej (1918-2008) na Uniwersytecie Jagiellońskim (Franaszek 2000).

W każdym razie publikacje reprezentowane przez prace Martynika i Czecha' ${ }^{13}$ stanowić mogą „polski głos” dotyczący miejsca historii organizacyjnej w ramach teorii organizacji lub innych dyscyplin zajmujących się zarządzaniem. Nadal bowiem miejsce to pozostaje kwestią sporną.

Børre Nylehn (2011) wychodząc od historycznej analizy obszaru badań, nazywanego w literaturze angielskiej „studiami nad organizacjami” (organizational study), ukazuje jego radykalną segmentację, która sprawia, że w praktyce badawczej i menedżerskiej wręcz trudno dziś mówić o teorii organizacji jako spójnej całości. Naukowcy utożsamiają się raczej ze szczególowymi dyscyplinami, które uprawiają. Na przykład teoria organizacji rozwijana przez badaczy norweskich wydaje się być podzielona na siedem segmentów: (1) segment zarządzania; (2) tak zwany segment college'u (eklektyczna wiedza z zarządzania i organizacji, którą wykładają nauczyciele collegów, można więc tu mówić o segmencie propedeutyki nauk o organizacji); (3) segment psychologiczny; (4) segment socjologiczny; (5) segment związany z Action Reserach (koncepcją

12 Na prace Martyniaka zwrócił mi uwagę Marian Dobrzyński, profesor w Katedrze Psychologii i Socjologii Zarządzania WZ UW.

13 Na UJ w pewnej przynajmniej mierze podobny do cytawnego badacza styl uprawiania nauk o zarządzaniu rozwija aktualnie Piotr Górski (zob. np. 2005, 2007, 2008). 
sformułowaną przez Einara Thorsruda i dotyczącą kształtowania warunków pracy w organizacji, które sprzyjają wysokiej jakości działań zatrudnionych); (6) segment nauk politycznych oraz (7) segment Business Administration.

W USA różne dziedziny zainteresowań naukowców zajmujących się światem szeroko rozumianego biznesu prowadzą do różnorodności w ramach jednego obszaru poznawczego, czyli teorii organizacji. Norweska sytuacja jest inna. Odmienne zainteresowania skutkują działaniem poszczególnych grup akademickich w separacji. Stąd Nyhlen mówi nie o różnych specjalizacjach (polach badawczych) składających się na jedną dziedzinę, ale właśnie o oddzielnych segmentach, które miewają także tendencję do wewnętrznego różnicowania się (dotyczy to na przykład segmentu psychologicznego). Mogą też się tworzyć nowe segmenty. Nyhlen uważa tę sytuację za naturalną i sprzyjającą rozwojowi nauk o organizacji. Należy więc je traktować bardziej jako zbiór różnorodnych dyscyplin przez analogię do kategorii „nauki społeczne” niż jako ściśle określoną dziedzinę badań. „Można coś stracić przez próby osłabiania wkładu poszczególnych tradycji, tak by rozwinąć bardziej jednolitą naukę o organizacji” (Nyhlen 2011: 246).

Spostrzeżenia Nyhlena (2011) stwarzają szansę na intelektualną przestrzeń dogodną dla rozwoju historii organizacyjnej. Niezależnie od tego, czy na przykład w Polsce spełni się wariant amerykański czy raczej norweski, atmosfera autonomii pozwoliłaby na stopniowe wyłonienie się tradycji historycznej ubogacającej nauki o organizacji.

Podsumowując dotychczasowe rozważania zaprezentowane na kartach niniejszego rozdziału, proponuję określić historię organizacyjną jako względnie autonomiczny segment (lub „pole”) nauk o zarządzaniu, nasycony refleksją historiograficzną, badający to, co przeszłość czyni organizacjom i jej otoczeniu oraz co organizacje czynią z przeszłością (swoją i swego otoczenia).

Potoczny termin „czyni/czynią” użyty tu intencjonalnie sygnalizuje możliwość objęcia zainteresowaniem badawczym otwartego zbioru relacji przeszłość-teraźniejszość (a także przyszłość) organizacyjna, takich jak wzajemne warunkowanie, intepretowanie, zawłaszczanie $\mathrm{i}$ wiele innych.

Proponowane określenie historii organizacyjnej uznaję za robocze i stanowiące podsumowanie dotychczasowych, niedługich przecież procesów wyodrębniania się omawianego obszaru zainteresowań poznawczych. Nie dążę więc do sztucznej precyzji, zgodnie z uwagą Andrzeja Półtawskiego, iż aczkolwiek jest bardzo ważne, by dbać o ścisłość i uporządkowanie prezentowanych myśli, to jednak zbyt duże skupienie się na tym aspekcie grozi „wylaniem dziecka z kąpielą”. „Dlatego - konkluduje wspomniany filozof - cenię także tych myślicieli, którzy mają coś istotnego do powiedzenia, nie operując przy tym odpowiednio ścisłymi pojęciami, ściśle opracowanym językiem" (Półtawski, Bagiński i in. 1996: 174; por. Półtawski, Ziemiec i Maciejczak 2013). Reprezentantem 
takich właśnie „myślicieli” są, moim zdaniem, badacze uprawiający historię organizacyjną na obecnym etapie jej rozwoju.

Podstawowe cele badawcze historii organizacyjnej postuluję określić za pomocą dwóch następujących obszarów problemowych:

- wydobywanie $z$ przeszłości biznesowej dobrych praktyk (szczególnie na poziomie sensów możliwych do nadania działaniom określanym jako organizowanie) przydatnych współcześnie i w przyszłości jako intelektualne narzędzia optymalizacji działalności gospodarczej oraz szeroko rozumianej aktywności menedżerskiej,

- identyfikowanie zbioru niewykorzystanych lub zapomnianych możliwości w zakresie szeroko rozumianej działalności organizacyjnej oraz identyfikacja korzeni tych możliwości, a także uwarunkowań ich ograniczeń.

Funkcjonalne znaczenie historii organizacyjnej precyzyjnie oddaje sformułowanie użyte przez Anielę Kiełbicką (2003: 13): „Stawianie (...) pilnych postulatów badawczych (w dziedzinie historycznych organizacji - dopisek T.O.) jest jak najbardziej uzasadnione, w szczególności w świetle potrzeb praktyki gospodarczej, szukającej w tradycji oparcia dla swego rozwoju i postępu".

Przytoczone stwierdzenie, które pochodzi z monografii cytowanej autorki na temat dziejów krakowskiej Izby Przemysłowo-Handlowej w latach 1850-1950 - czyli lokalnej organizacji przedsiębiorców „,padło z dala od głównych nurtów dyskusji wokó1 „historycznego zwrotu”. Jest zatem sygnałem, że historia organizacyjna jako filozofia „użytkowania” przeszłości jest bliska (choćby intuicyjnie) znacznie szerszemu gronu badaczy, niż mogłyby się to wydawać na podstawie przykładów przytaczanych przez jej zdeklarowanych zwolenników.

\subsection{Relacje człowiek-organizacja jako problem badawczy historii organizacyjnej}

\subsubsection{Historyczny aspekt funkcjonowania człowieka w organizacji}

Wśród centralnych problemów badawczych, specyficznych dla historii organizacyjnej, Booth i Rowlinson (2006) umieszczają kwestię „uhistoryczniania subiektywności”, czyli studiowania historyczności koncepcji opisujących subiektywne aspekty funkcjonowania jednostek, organizacji i generalnie obszaru zarządzania. Często wspomniane koncepcje uważane są świadomie lub nieświadomie, także przez naukowców, za ponadczasowe. Cytowani autorzy przytaczają liczne prace badawcze związane z tą problematyką, jak „ukryte” dzieje wiedzy menedżerskiej; kulturowe i polityczne uwarunkowania uzasadnień (ang. rationality) w dziejach myśli poświęconej zarządzaniu, uzasadnień konkretyzowanych poprzez koncepcje poszczególnych ról zawodowych, na przykład roli inżyniera; historyczne gra- 
nice stosowalności abstrakcyjnych kategorii zarządzania wynikające $\mathrm{z}$ ich genezy; czy periodyzacja dyskursu organizacyjnego i menedżerskiego na podstawie analiz bibliometrycznych ${ }^{14}$. Nie brak w obrębie sygnalizowanego obszaru badań także prac poświęconych subiektywności rozumianej dosłownie, to jest koncepcjom dotyczącym psychiki uczestników „organizacyjnej gry” na przestrzeni dziejów.

Moim zdaniem, sztandarowym przykładem realizacji badawczej tego typu, o dużym znaczeniu dla psychologów organizacji, a zarazem dobrze ilustrującej możliwości historii organizacyjnej jest studium historyczności stresu pióra Tima Newtona (1995). Naukowiec ten podjął polemikę z rozpowszechnioną „ideą człowieka epoki żelaza cierpiącego we współczesnym biurze” (Newton 1995: 22). Idea ta wyraża przekonanie, iż mechanizmy stresu zostały zaprogramowane u człowieka na wczesnych etapach ewolucji. Są biologicznie dziedziczonymi strategiami reagowania wobec wyzwań typowych dla nieskomplikowanych społeczeństw pierwotnych. Dlatego okazują się nieadekwatne w obliczu stresorów, które niesie złożona współczesność. Newton wykazał wątłość argumentacji przemawiającej na rzecz takiego stanowiska. Wbrew pozorom okazuje się ono bliższe potocznym „teoriom” stresu rozpowszechnianym przez popularne massmedia (które to „teorie” również poddał analizie) niż naukowemu dyskursowi. Koncepcja „człowieka epoki żelaza” ignoruje bowiem empiryczny dorobek antropologów kulturowych, wyraźnie pokazujący, iż społeczeństwa preindustrialne były tak samo skomplikowane jak są te po przemianach modernizacyjnych. Ponadto opiera się ona na uproszczonej wersji darwinizmu, bezkrytycznie obarczając winą za współczesne kłopoty biologiczną ewolucję instynktów, rzekomo pozostającą daleko w tyle za wyzwaniami nowoczesności. Krytykowana przez Newtona pespektywa zakłada też, że złożoność obecnego społeczeństwa stanowi nieunikniony skutek ewolucji człowieka oraz gwałtownego rozwoju narzędzi i technologii. Według Newtona ludzie mają więc „niewielki udział w reprodukcji tego społeczeństwa. Jedynie co mogą zrobić, by złagodzić nieuchronny stres, to zając się modyfikacją 'niefortunnego dziedzictwa instynktów', którym zostali obarczeni przez ewolucję" (Newton 1995: 23). Zdaniem Newtona, popularność koncepcji „człowieka epoki żelaza” wynika przede wszystkim z jej zgodności z intuicją laika oraz z korzyści psychicznych, jakie dają uproszczenia. Nawiasem mówiąc, trudno oprzeć się spostrzeżeniu, iż krytykowane przez Newtona podejście nadal jest rozpowszechnione, szczególnie wśród psychologów ewolucyjnych, mimo że od opublikowania jego analiz minęło ponad piętnaście lat.

Newton i jego współpracownicy zaproponowali alternatywne ujęcie stresu w pracy jako zjawiska, które jest specyficznym elementem współczesności. Stanowi swoisty „emocjonalny produkt” społecznych i politycznych (w sensie polityki firmy) cech pracy oraz życia $w$ organizacji. Takie przeformułowanie

$\overline{14}$ Booth i Rowlinson (2006) podają szczegółową bibliografię tych badań. 
problematyki stresu pozwala na spojrzenie z perspektywy innej niż determinowała to koncepcja „człowieka epoki żelaza” na możliwości, zarazem na odpowiedzialność jednostki w zakresie radzenia sobie (Newton, Handy i Fineman 1995, Booth i Rowlinson 2006).

Reasumując, Tim Newton dokonał krytycznej analizy koncepcji dotyczącej wybranej „zmiennej subiektywnej” pod kątem ahistoryczności, wzbogacił związaną z tą zmienną problematykę o wymiar historyczny, podnosząc tym samym naukowy poziom dyskusji, zaproponował alternatywną konceptualizację zjawiska, a także wskazał praktyczne i społeczne konsekwencje obydwu podejść. Pracę jego uznać można za modelowy przykład realizacji zadań historii organizacyjne (Ochinowski 2012b).

\subsubsection{Koncepcje badań historycznych dotyczących relacji człowiek-organizacja}

Kompleksowe, teoretyczne i praktyczne rozwiązania dla tej dziedziny badań, właśnie w kontekście uhistorycznienia subiektywności, zaproponowali na łamach czasopisma „Business History” Huseyin Leblebici i Nina Shah (2004) z amerykańskiego Uniwersytetu Illinois w Urbana-Champaign. Określili oni możliwe trzy „wyjściowe” ideologie badaczy dotyczące „brania na poważnie” relacji między historią a naukami organizacyjnymi. Pierwsze ujęcie zakłada, iż poszukiwania teoretyczne i badawcze specjalistów od zarządzania tylko implicite dotykają materii historycznej. Zdaniem Leblebiciego i Shah taki pogląd zarówno zawęża rozumienie zjawisk organizacyjnych, jak i utrudnia „zaprzężenie" historii do rozwoju zarządzania. Na przeciwnym krańcu ideowym (ujęcie drugie) leży radykalne przekonanie o zupełnym ignorowaniu przez teorie oraz badania organizacyjne perspektywy historycznej, co stanowi poważny problemem, bowiem „nie może być nauki społecznej bez historii” (Leblebici i Shah 2004: 353). W takim przypadku cała wiedza o organizacji powinna być pisana na nowo z uwzględnieniem czynników dziejowych. Trzecie stanowisko nawołuje, by określić „terytorium”, na którym historia spotyka nauki o zarządzaniu. Takie rozwiązane umożliwia wzajemne wzbogacanie się przez obie dziedziny bez zdominowania drugiej strony. Leblebici i Shah (2004: 355) proponują, by konkretny cel poznawczy wyznaczał obszar problematyki organizacyjnej otwarty na historię. Chodzi o rozumienie „temporalnej natury organizacji oraz roli, jakie w nich pełnią społeczni agenci (social agents)", co sprowadza się do rozumienia „wzorów zmiany i ciągłości w życiu organizacji”. By tak określony cel zrealizować, przedstawiciele zarządzania potrzebują nie tylko demaskowania ahistoryczności uniwersalistycznych wątków teorii organizacji, ale przede wszystkim interpretacji tego, jak „aktorzy dziejów orientują swe intencje i działania wobec wydarzeń historycznych”. Przy takich zadaniach poznawczych, zbędne 
jest według omawianych amerykańskich badaczy, zbyt intensywne zajmowanie się spornymi kwestiami historiografii, takimi jak opozycje między teorią i historią, opisem i wyjaśnianiem, wyjaśnianiem przyczynowym i podejściem narracyjnym, dedukcją i indukcją, czy nawet długie filozoficzne debaty na temat istotności alternatywnych metod bądź teorii. Wystarczyć ma integrowanie metod i koncepcji historycznych z organizacyjnymi wokół przedstawionego wcześniej celu poznawczego. „Innymi słowy - piszą cytowani autorzy - potrzebujemy naturalnie (intrisically) historycznych teorii, obejmujących zarazem wyjaśnianie i opis" (Leblebici i Shah 2004: 355). Nasuwa się tu refleksja, jak rozpoznać owe „naturalnie historyczne teorie” i jak sprawdzić, czy rzeczywiście spełniają one jednoczenie funkcje opisowe i wyjaśniające bez głębszego namysłu z wykorzystaniem historiografii oraz przy zamknięciu się na jej nowe, oczywiście nie zawsze użyteczne, ale warunkujące dyskusję, koncepcje. Jak wreszcie, bez uciążliwych i czasem nawet jałowych dyskusji, osiągnąć rzeczywisty rozwój teorii i metod szczególnie na interdyscyplinarnym z natury terenie badań? Odpowiedzi na te pytania pozostają jak na razie tajemnicą Leblebiciego i Shah, której zgłębienie znacznie przekraczałoby zakres niniejszej publikacji. Jedynie więc sygnalizuję istnienie również zdystansowanego do historiografii nurtu współpracy nauk o zarządzaniu z historią. Cytowani autorzy widzą nawiązanie tej współpracy przede wszystkim poprzez sformułowanie odpowiednich pytań. Stawiają przy tym nauce o przeszłości dość wygórowane warunki: „(...) jeśli historia nie będzie w stanie podjąć niektórych spośród najważniejszych kwestii dyskutowanych w teorii organizacyjnej, nie da rady być efektywna". Dla reprezentowanej przez siebie dziedziny wiedzy są już bardziej wyrozumiali: „Tak samo, jeśli teoria organizacyjna po prostu będzie uznawać historię za dłuższą wersję studium przypadku, nie będzie możliwe przyciągnięcie uwagi poważnych historyków zainteresowanych historią organizacji” (Leblebici i Shah 2004: 356).

Leblebici i Shah (2004) podają szczegółowy przykład rozwiązań teoretycznych i opartych na nich badań spełniających opisane wyżej standardy. „Zapraszają" historię do udziału w jednej z najważniejszych debat w obszarze socjologii organizacji, to jest dyskusji dotyczącej relacji podmiotowe sprawstwo - struktura (agency - structure debate). Jest to kwestia cyklicznie zajmująca socjologów, szczególnie modna w społecznych badaniach organizacyjnych na przełomie ubiegłego i obecnego stulecia. Streścić ją można za pomocą następującego pytania:

„Czy życie organizacji jest determinowane przez niemożliwe do opanowania strukturalne ograniczenia (nośniki przymusu, ang. constraints) czy też jest aktywnie kreowane poprzez strategiczne działania agentów organizacji, to jest przez zarządzanie?" (Leblebici i Shah 2004: 359).

Kluczowe zagadnienie, warunkujące sposób rozwiązania powyższego problemu, według Leblebiciego i Shah, stanowi koncepcja podmiotowego sprawstwa. Dominujące nurty współczesnej socjologii amerykańskiej uważają je za habitu- 
alne (nawykowe), powtarzalne i zrozumiałe samo przez się. Wśród teoretyków organizacji przytoczony pogląd podzielają neoinstytucjonaliści oraz zwolennicy podejścia ekologicznego.

Leblebici i Shah przyjmują inne rozwiązanie, uznając, że „podmiotowa sprawczość człowieka może być ujmowana teoretycznie jako 'temporalnie osadzony proces społecznego zaangażowania, oparty na informacjach z przeszłości (w swym habitualnym aspekcie), ale także zorientowany ku przyszłości (jako zdolność do osadzania nawyków z przeszłości i projektów na przyszłość w kontekście nieprzewidzianych cech danego momentu'). W ramach takiej konceptualizacji podmiotowego sprawstwa historia staje się integralną częścią rozwoju teorii, która łączy podmiotowe sprawstwo, strukturę i działanie" (Leblebici i Shah 2004: 359).

Teoretyczny pomysł Leblebiciego i Shah polega na wyróżnieniu trzech konstytutywnych elementów podmiotowego sprawstwa:

1. wymiaru powtarzalnego (iterational dimension), czyli wybiórczego reprodukowania przez podmiot, ze względu na aktualne potrzeby społeczne, znanych z przeszłości wzorów mentalnych i zachowaniowych. Wymiar ten jest opisywany przede wszystkim w pracach socjologicznych. Socjologowie organizacji będący zwolennikami wspomnianego wcześniej neoinstytucjonalizmu podkreślają, iż trwałość organizacji stanowi wynik nie tyle sankcji, ile właśnie ,zsocjalizowanych oczekiwań” (Leblebici i Shah 2004: 359);

2. wymiaru projekcyjnego (projective dimension), który dotyczy wyobrażeniowego kreowania nowych możliwości na przyszłość. Stanowi przedmiot zainteresowania przede wszystkim psychologii oraz antropologii i jest typowym tematem fenomenologicznych sposobów ujmowania rzeczywistości. Literatura biznesowa de facto mówi o tym wymiarze sprawczości podmiotowej, gdy podkreśla znaczenie kreowania nowych możliwości jako determinanty sukcesu menedżerskiego. Rozpoznawanie sposobów, poprzez które przeszłe doświadczenia zostają wyobrażeniowo włączone do procesów wspomnianej kreatywności wyznacza, zdaniem cytowanych amerykańskich badaczy, owocny teren współpracy poznawczej teorii organizacji i teorii. Nasuwa się jednak uwaga, że przytoczone tu przez Leblebiciego i Shah szczegółowe problemy wymagają raczej typowego warsztatu psychologa, czy też - gdy odniesie się je do organizacji - socjologa niż historyka, nawet jeśli byłyby to historyk organizacyjny wprawiony w analizie „zawłaszczania historii”;

3. wymiaru praktyczno-oceniającego (practical-evaluative dimension) polegającego na zdolności aktora społecznego do formułowania praktycznych i oceniających osądów na temat możliwych dróg aktywności. Wspomniane osądy stanowią odpowiedź na różnorodne dylematy, niejasności i temu podobne wyzwania chwili. „Ten wymiar - piszą Leblebici i Shah (2004: 361) - jest specjalnie istotny dla historii organizacyjnej, w świetle której aktorzy dokonują 
poznawczych, moralnych i estetycznych osądów jako części swej świadomości praktycznej”. Zdaniem autorów opisany wymiar sprawczości podmiotowej generalnie pomijają socjologowie oraz teoretycy organizacji. Jak więc widać, para amerykańskich badaczy wyraźnie przypisuje historii organizacyjnej funkcję upodmiotowienia aktorów teorii i praktyki organizacyjnej.

Z perspektywy swego modelu Leblebici i Shah (2004: 361) oczekują od historii organizacyjnej pomocy przy analizie „skomplikowanych współzależności między strukturami a sprawczością podmiotową wewnątrz ram temporalnych". Konstytutywnym elementem wspomnianych „ram” wydają się być „skale czasowe" (time scales) - czyli przekonania odnośnie do interwałów określających „długość życia” poszczególnych zjawisk - które różnicują wymienione wymiary sprawczości podmiotowej i łączą się z różnymi rodzajami narracji. Cytowani badacze wykorzystali sformułowany przez siebie model przy badaniu procesów powstania, transformacji i regeneracji inkubatorów biznesu (Leblebici i Shah 2004). Warto przypomnieć, iż podobne do opisanych wysiłki konceptualizacji podmiotowości człowieka z uwzględnieniem czynników historycznych podejmowali znacznie wcześniej, stosując odmienne niż socjologiczna perspektywy teoretyczne, zwolennicy współpracy badawczej historii i psychologii Robert Jay Lifton oraz McKilan Runyan. Generalnie propozycje te stanowią przyczynek do konceptualnego pogłębienia wspomnianej już funkcji historii organizacyjnej, jaką jest „uhistorycznianie subiektywności”, godzien oddzielnej analizy przekraczającej jednak ramy niniejszej pracy.

„Uhistorycznianie subiektywności”, jako jeden z głównych tematów historii organizacyjnej każe wspomnieć także o innych, nieco podobnych próbach realizacji tej problematyki, to jest podejmowanej od czasu do czasu współpracy badawczej psychologii i historii. Znane mi projekty instytucjonalnego uprawiania szeroko rozumianej historii psychologicznej zostały zarzucone wobec trudności natury organizacyjnej (zob. np. Ochinowski i Pawelec 2010, Ochinowski 2002 i 2012b). Być może jednak należy im się miejsce w obszernym zbiorze intelektualnych inspiracji historii organizacyjnej. Być może też mogą być dziś pomocne jej przedstawicielom. Obecnie czytelnik ma do dyspozycji tylko odosobnione badania, bądź co najwyżej systematyczne prace podejmowane przez indywidualnych badaczy przeszłości albo psychologów.

Spośród nich nie sposób pominąć doskonale również w Polsce znanego Efektu Lucyfera Philipa Zimbardo (2008), publikacji ważnej także dla problematyki zarządzania. Należy ona do grona tych niewielu publikacji psychologicznych, które zachowując w pełni swój akademicki charakter, wywołały szeroką dyskusję nie tylko wśród przedstawicieli dziedziny macierzystej, ale również innych nauk oraz wśród reprezentantów szeroko rozumianej humanistyki, a także wykształconych laików (zob. np. Minitz 2008, Rhead 2009, Kreuger, Salamucha 2009 i Grzegorek 2009). Z jednej strony Zimbardo poddaje wielostronnej analizie 
krytycznej swój słynny Stanfordzki eksperyment więzienny, który przeprowadził latem 1971 roku, zwracając między innymi uwagę na historyczne uwarunkowania uzyskanych wówczas wyników i ich interpretacji. Podrozdział omawianej książki, pod znaczącym w kontekście naszych rozważań tytułem Stanfordzki Eksperyment Więzienny a duch tamtych czasów może być zwiastunem zerwania z tradycją wielu „koncepcji psychologii społecznej, które - jak krytycznie ocenia to Michael Billig (2008: 50) - uważają zmienne psychologiczne za byty uniwersalne, a nie produkty historycznie skonstruowane". $\mathrm{Z}$ drugiej strony, pod koniec swej książki Zimbardo, co już wcześniej sygnalizowałem, przedstawia opracowaną wraz z Zeno Franco roboczą taksonomię heroizmu oraz oparty na niej motywacyjny, wielowymiarowy model heroizmu. Te propozycje teoretyczne wyrastaja $\mathrm{w}$ znacznym stopniu $\mathrm{z}$ analizy historycznych postaci, wybranych $\mathrm{z}$ literatury przez Zimbardo i Franco jako przykłady osób heroicznych (Ochinowski 2012b).

Sięgając do innych niż eksperymentalne modelów badań psychologicznych, warto zauważyć, iż na przykład pojawiająca się co jakiś czas wśród metodologów sugestia wykorzystywania teorii cech (choć niekoniecznie konkretnej teorii cech, zob. np. Art i De Fruyt 2001) przy analizie materiałów historycznych znajduje od czasu do czasu realizacje badawcze. Jeden z tego typu przykładów zaprezentowali kilka lat temu Anthony J. Mayo i Nitin Nihria z Harwardzkiej Szkoły Biznesu, autorzy tłumaczonej również na język polski pracy Czas rekinów. Liderzy amerykańskiego biznesu XX wieku'15 (2007). Poszukując cech „liderów biznesu” opracowali oni metodologię wyłaniania osób zasługujących na to miano. Projekt, który był realizowany od 2001 roku, wynikał z założenia, iż historia biznesu nie jest zbyt doceniana w edukacji menedżerskiej. Mayo i Nihira postanowili więc „zapoczątkować tworzenie kanonu liderów biznesu”. Skonstruowali listę 1000 „legend biznesu” (zaliczając do niej dyrektorów generalnych - CEO i założycieli firm), która powstała na podstawie następujących kryteriów (Mayo i Nihira 2007: 18):

- kandydaci musieli być założycielami lub dyrektorami generalnymi firmy z siedzibą w USA co najmniej przez 5 lat miedzy rokiem 1900 a 2000,

- kryteria finansowe oparte zostały na trzech wskaźnikach: stosunku wartości rynkowej do wartości księgowej (tzw. wskaźnik $q$ Tobina), wskaźniku rentowności aktywów oraz wzroście wartości rynkowej. Wobec niekompletnych danych (szczególnie z odleglejszej historii) autorzy zastosowali wielowarstwowe podejście do analizy finansowej, wykorzystując szereg innych wskaźników i baz danych. Na liście legend biznesu znalazły się osoby, które co najmniej przez cztery lata $\mathrm{z}$ rzędu uzyskiwały najlepsze wyniki w zakresie przynajmniej jednego z wymienionych trzech głównych wskaźników, to jest osiągnęły to, że ich firmy znalazły się wśród $10 \%$ najwyżej ocenianych

$\overline{15}$ Tłum. A. Żak i J. Mikołajczyk, Wydawnictwo Helion, Gliwice 2007. 
przedsiębiorstw w danym roku (3/4 osób z ostatecznej listy 1000 liderów nie spełniło wspominanych kryteriów finansowych),

- ocena wpływu danej postaci na społeczeństwo, na firmę, bądź na społeczeństwo i firmę. To kryterium było dla autorów decydujące. Powstało ono w wyniku obfitego przeglądu materiałów biograficznych i rankingów biznesowych pochodzących z czasopism „Fortune”, „Forbes”, „Time”, „Wall Street Journal”, „New York Times”, encyklopedii biznesowych i innych źródeł. Autorzy brali pod uwagę następujące wskaźniki jakościowe:

- zasługi dla amerykańskiego biznesu, takie jak: otwieranie nowych rynków, tworzenie branż, przyczynianie się do postępu w technologii lub w metodach zarządzania (szczególnie ważny był dla autorów wpływ kandydatur w kontekście czasów, w których żyli);

- fakt, że dorobek danych osób oparł się próbie czasu lub/i otwierały one nowe możliwości przed innymi.

W celu zredukowania puli kandydatów na liderów biznesu Mayo i Nohira przeprowadzili ankietę wśród siedmiu tysięcy przywódców biznesowych. Respondenci byli proszeni o ocenę kandydatów jako kanonu przywódców biznesowych wraz z uzasadnieniem wyborów. Powstała w ten sposób zweryfikowana empirycznie lista cech liderów biznesu.

Ubocznym efektem wspomnianej ankiety była możliwość wyodrębnienia na podstawie odpowiedzi respondentów trzech archetypów przywódców biznesowych: przedsiębiorcy, menedżera i lidera. Z końcowej listy autorzy wykluczyli tych kandydatów, którzy w swej działalności łamali prawo (Ochinowski 2012b).

Podsumowując przedstawioną charakterystykę metodologii Mayo i Nihri, warto zwrócić uwagę, iż wyniki ich prac otwiera obszerna lista przedsiębiorców, menedżerów i liderów pierwszego dziesięciolecia XX wieku, na której znaleźli się między innymi: Henry Ford, John Rockefeller (zaliczeni do grona przedsiębiorców) oraz John. F. Morgan (w gronie menedżerów). Z kolei biznesowych przywódców ostatniej dekady ubiegłego stulecia, która chronologicznie kończy omawiany projekt, reprezentują między innymi: Jeffrey P. Bezos (Amazon) i Jerry Yang (Yahoo) - jako przedsiębiorcy, John Pepper (Procter\&Gamble), Lee R. Raymond (Exxon Mobil Corporation) i Richard M. Rosenberg, (Bank of America Coroporation) - w kategorii menedżerów oraz Louis V. Gerstner Jr (IBM) - jako lider. Dla polskiego świata biznesu na razie brak tego typu precyzyjnej klasyfikacji. Określenie elit biznesu okazuje się w naszych warunkach zadaniem niełatwym. Podjąłem takie starania w ramach projektu „Elity o historii”, który przygotował zespół Pracowni Dziejów Myśli Społecznej i Politycznej PAN pod kierunkiem Andrzeja Wierzbickiego (2009)16. Kryteria

16 Projekt zyskał pozytywną opinię merytoryczną recenzenta KBN, jednak z konkluzją, że nie będzie finansowany, co uniemożliwiło jego realizację. 
elitarności skonstruowane w odniesieniu do przedstawicieli polskiego biznesu były inspirowane wspomnianą pracą Mayo i Nohiry (2007). Stanowią więc przykład pomocniczej roli analiz historycznych przy rozwiązywaniu problemów badawczych osadzonych we współczesności.

Pilotażowe wywiady, jakie przeprowadziłem z wybranymi losowo pracownikami Wydziału Zarządzania UW, nie przynosiły żadnych odpowiedzi, lub co najwyżej odpowiedzi bardzo niejasne. Na przykład jedna z nich sugerowała, iż elity biznesu tworzą osoby, które „kręcą interesy” w znaczeniu obracania bardzo dużą ilością pieniędzy (rzędu wielu milionów) i ze znacznym wpływem na polską gospodarkę.

Krzysztof Jasiecki (2002 i 2007), najbardziej chyba konsekwentny badacz elit biznesu w naszym kraju, przestrzega przed zbyt mechanicznym przenoszeniem wzorów z krajów wysokorozwiniętych. Panuje w nich bowiem dość duże ujednolicenie różnych sektorów działalności gospodarczej. Polską, czyli raczej postkomunistyczną specyfiką, jest natomiast duże zróżnicowanie kultury organizacyjnej różnych grup przedsiębiorstw. Zdaniem Jasieckiego, elita biznesu stanowi bogatą część społeczeństwa powstałą w wyniku transformacji gospodarczej. Tak rozumianą elitę obejmującą osoby, które zajmują kluczowe pozycje w organizacjach gospodarczych o dużej skali działania, tworzą przede wszystkim szefowie wielkich korporacji. Są oni głównymi rywalami tzw. oligarchów. Wśród wspomnianych wielkich przedsiębiorstw do czołowych graczy Jasiecki zalicza na pierwszym miejscu spółki z udziałem Skarbu Państwa, następnie filie korporacji zagranicznych (co stanowi kolejną komplikację wyboru kandydatów do wspomnianego wcześniej, niezrealizowanego projektu IH PAN), a później dopiero przedstawicieli rodzimego kapitału. Cytowany autor wskazuje też na potencjalnie ważną rolę organizacji skupiających ludzi biznesu (choć w wywiadzie z 2007 roku oceniał ich aktualną działalność dość krytycznie).

Jak się wydaje, inne propozycje określenia elity biznesu w Polsce są znacznie mniej precyzyjne niż rozważania Jasickiego. Na przykład w początkowym okresie polskiej transformacji po 1989 roku, Janusz Sztumski (1995: 13) odwoływał się do potocznego rozumienia tego terminu: „na ogół uważa się, że elity to po prostu grupy ludzi zajmujących czołowe pozycje w zinstytucjonalizowanych strukturach gospodarczych, społecznych, politycznych i innych, jakie istnieją w danym społeczeństwie lub w badanej społeczności. Są to osoby nazywane niekiedy także 'prominentami' w różnych sferach życia społecznego".

Uwzględniając propozycje przytoczonych autorów i związane z nimi liczne niejasności, zaproponowałem następujące uproszczone kryteria doboru kandydatów do próby reprezentującej (choć niekoniecznie reprezentatywnej w statystycznym tego słowa znaczeniu) elitę biznesu w Polsce:

1. osoby wymieniane w rankingu miesięcznika „Forbes” jako liderzy polskiego biznesu od początku polskiej edycji tego magazynu (od 2005 roku) oraz 
w rankingu tygodnika „Wprost” najbogatszych ludzi w Polsce (z tego samego okresu). Chodzi o osoby pojawiające się przynajmniej dwukrotnie w obydwu rankingach (przy czym przynajmniej raz w pierwszej dziesiątce rankingu „Forbsa”), lub przynajmniej dwukrotnie w pierwszej piątce rankingu „Forbsa”;

2. szefowie polskich firm zajmujących czołowe miejsca (pierwsze dziesięć firm polskich) na liście największych firm Europy Środkowej w ostatnim roku (Raport: Ranking Central Europe Top 500, firmy Delloite i dziennika „Rzeczpospolita”);

3. szefowie organizacji biznesowych wchodzących w skład Polskiej Rady Przedsiębiorczości;

4. szefowie firm ważnych w Polsce z szeroko rozumianych przyczyn społecznych (np. ludzie biznesu zaproszeni do prowadzonej w 2009 roku przez „Gazetę Wyborczą” ankiety na temat początków firm, szefowie firm odznaczeni Medalem Solidarności Społecznej itp.).

Przytoczone przykłady i im podobne (zob. np. Ochinowski 2012) traktuje jako wyraz nadziei, iż „ziemią obiecaną” współdziałania badawczego historyków i psychologów stać się może właśnie historia organizacyjna. 
Rozdział IV

\section{Historia organizacyjna i praktyka zarządzania w przedsięwzięciach badawczych}

\subsection{Koncepcja historii organizacyjnej w ujęciu Theodore'a Zeldina i jej implikacje dla zarządzania organizacją}

\subsubsection{Intelektualny projekt Theodore'a Zeldina wykorzystania przeszłości dla teraźniejszości organizacyjnej}

Rozbudowany projekt wykorzystania przeszłości do wzbogacenia teraźniejszości biznesowej, wyraźnie realizujący cele „uhistorycznienia subiektywności”, choć nie używający tego terminu, stał się udziałem brytyjskiego historyka urodzonego w 1933 roku Theodore'a Zeldina (1994/1998, 1999, 2001, Trinca 1998, Snowman 1999, Wylie i Zeldin 2000, Chapman, Radcliffe i Zedlin 2004 oraz Oxford Muse 2010, zob. Ochinowski 2012b). Jego prace nie były dotąd kojarzone $\mathrm{z}$ historią organizacyjną. Posiadają jednak wiele konstytutywnych cech tej perspektywy poznawczej i - co w kontekście menedżerskiego kultu sukcesu wcale nie jest najmniej ważne - stanowią przykład „spełnionego snu”. Zeldin bazując na własnych doświadczeniach badawczych (przede wszystkim dotyczących dziejów Francji, które przyniosły mu zasłużone uznanie naukowe), dokonał oryginalnej reinterpretacji ogromnego zbioru danych obejmujących dzieje powszechne w najszerszym tego słowa znaczeniu na temat, również szeroko rozumianej, „uhistorycznionej subiektywności”. Interesowały go geneza oraz ewolucja dziejowa, poprzez doświadczenia różnych cywilizacji, wybranych aspektów życia osobistego, ze szczególnym uwzględnieniem emocji. Skupił się na zmiennych, szczególnie jego zdaniem interesujących dla współczesnego człowieka. Chciał przede wszystkim zrekonstruować możliwości w zakresie stosunków interpersonalnych i szerzej, odnoszące się po prostu do „sztuki życia” zagubione poprzez zawirowania dziejów. Tak powstała, chyba najsłynniejsza dotąd 
publikacja Zeldina (1994/1998) An Intimate History of Humanity ${ }^{1}$ (pierwsze wydanie 1994), której polski przekład ukazał się pod dosłownie przetłumaczonym, lecz wyraźnie niezręcznym tytułem Intymna historia ludzkości (1998) i niestety bez źródeł bibliograficznych przytaczonych przez autora w oryginale książki. Założenia przyświecające wspomnianej pracy dobrze oddają następujące cytaty, dające przy okazji próbkę eseistycznego stylu autora:

„Jedynie znajomość historycznych doświadczeń ludzkości może oszczędzić człowiekowi przykrości rozczarowania” (Zeldin 1998: 83).

„Obecnie trzeba wykorzystać na nowo skamieliny historii do zbudowania dróg prowadzących tam, dokąd chcemy się udać" (Zeldin 1998: 62).

„Można się czuć wyobcowanym w swym własnym mieście, ale ma się przodków na całym świecie" (Zeldin 1998: 59).

Uzasadniając ostatnie z przytoczonych twierdzeń, Zeldin sugeruje, iż z perspektywy badań historycznych bliższy współczesnemu człowiekowi Zachodu jest na przykład Marco Polo (1254-1324) ze swoimi podróżniczymi pasjami niż przez całe życie nieopuszczający najbliższej okolicy mieszkańcy Bigouden, bretońskiej wsi I połowy XIX wieku. Również atmosfera chińskiego miasta Zhang Zang (Hangzhou) z okresu wypraw Marco Polo, zawiera więcej elementów podobnych do tych, którymi żyją mieszkańcy obecnych metropolii, niż to, co historycy ukazali na temat życia w Wenecji tego samego czasu. Przy czym cytowany autor przynajmniej pośrednio świadomy jest ryzyka, jakie niesie rozwijanie wspomnianych przykładowo analogii. „Wszystko, co składa się na pamięć przeszłości, skąpane jest, a często zatopione w nostalgii, dumie oraz w najrozmaitszych iluzjach i namiętnościach" (Zeldin 1998: 63). Zeldin jednak z całym przekonaniem ryzyko to podejmuje, by wypełnić istotną jego zdaniem lukę edukacji społecznej. „W historii nauczanej w szkołach nie kładzie się jednak nacisku na takie związki i nie wskazuje na fakty z przeszłości, które mają dla współczesności największe znaczenie" (Zeldin 1998: 59).

Nietrudno zauważyć, że perspektywa poznawcza sugerowana przez Zeldina zawiera takie cechy charakterystyczne dla historii organizacyjnej jak krytycyzm wobec zastanych praktyk intelektualnych (w tym wypadku związanych z uprawianiem i popularyzacją nauk o przeszłości), refleksję historiograficzną (choć na kartach Intymnej historii ludzkości raczej marginalną jeśli chodzi o tezy formułowane wprost, silnie obecną jednak implicite) oraz analizę, a przede wszystkim

1 Już wcześniej podobną tematykę Zeldin rozwijał w pięciu tomach Historii francuskich pasji (History of French Passions).

2 Polski czytelnik nie mógł być raczej świadom wielu odcieni znaczenia przymiotnika „intymny” jakie przybierał on w ciągu dziejów, często kulturowo kojarzony z indywidualnością, a wcale niekoniecznie tylko ze sferą seksualności. Dogłębnie Zeldin (2000) analizuje ten problem, na co zwróciła uwagę M. Gawin (2007), jedna z nielicznych polskich badaczek przeszłości, która zauważyła pracę Zeldina. Szkoda, że polski wydawca nie wykorzystał faktu, iż angielskie intymacy można tłumaczyć na kilka sposobów. 
intencjonalne rozwijanie „zawłaszczania” przeszłości dla potrzeb współczesnego człowieka. U cytowanego polihistora wspomniane „zawłaszczanie” ma charakter pragmatyczny, ukierunkowane jest na wskazanie konkretnych merytorycznych treści, które, zdaniem autora, mogą przydać się obecnie mieszkańcom Zachodu do doskonalenia „sztuki życia”. Warto też raz jeszcze podkreślić łączenie przez Zeldina eseistycznego sposobu pisania, bardzo sprzyjającego popularyzacji prezentowanych treści, $\mathrm{z}$ solidnym fundamentem historiograficznym ujawnianym zresztą czytelnikowi, poprzez następujące po każdym rozdziale wykazy publikacji źródłowych (jak już wspomniano, zostały one niestety pominięte przez polskiego wydawcę).

Intymna histora ludzkości zawiera wątki bezpośrednio związane z problematyką organizacyjną. Na przykład charakteryzując zjawisko wzrostu znaczenia w stosunkach międzyludzkich szacunku kosztem władzy, Zeldin wskazuje, że proces ten współcześnie zainicjowały środowiska biznesowe, co nota bene stanowi interesującą tezę polemiczną wobec poglądów cytowanego przeze mnie często historyka biznesu Jamesa Hoopesa (2004)³.

Przy omawianiu zagdanienia kontaktów międzycywilizacyjnych Zeldin zwraca uwagę czytelnika przede wszystkim na zasadnicze bariery komunikacyjne, co wydaje się zbliżać go do wspomnianych wcześniej Konecznego (1935/1997) i Huntingtona (2006). Odmiennie jednak niż wymienieni autorzy, Zeldin uważa, że przczyny tych problemów nie są natury aksjologicznej, ale leżą jedynie w złożoności odmiennych cywilizacji, przekraczającej możliwości poznawcze jednostki.

„Trzeba by żyć wielokrotnie dłużej, niż żyje się przeciętnie, by móc poznać nawet niewielki ułamek myśli - pisze cytowany badacz na temat kontaktów człowieka Zachodu z cywilizacją Chin - którą pozostawili po sobie chińscy mędrcy, uczeni, aforyści i poeci, i która byłaby interesująca dla nas, współczesnych. Rodzi frustrację, że nie można pisać o nich przez cały czas, tak wielką przyjemność stanowi studiowanie ich zwodniczych twierdzeń” (Zeldin 1998: 497).

Ostatecznie jednak Zeldin nie podziela pesymizmu Konecznego i Huntingtona. Wykorzystując swą erudycję historyczną, podsuwa on także współczesnym biznesmenom zainteresowanych przedsięwzięciami międzynarodowymi praktyczne rozwiązanie z przeszłości. Mianowicie przypomina fakt wykorzystywania przez Brytyjczyków do zarządzania interesami imperium na terenie Chin, po wygranej wojnie opiumowej, osób, które dziś należałoby nazwać „agentami kulturowymi”. Byli to Chińczycy zainteresowani zachodnią edukacją swoich dzieci, posługujący się łamaną angielszczyzną i porzucający niektóre narodowe obyczaje nieakceptowane przez ludzi Zachodu (Zedlin pisze o zwyczaju krępowania córkom stóp), a jednocześnie świadomie zanurzeni w swojej kulturze.

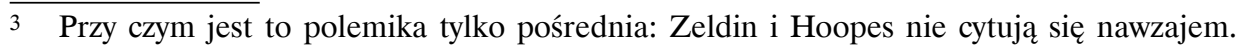


Wspomnieni „agenci” łączyli świadczenie usług dla zachodniego kapitalizmu z silnym nacjonalizmem.

Natomiast z ogólnej perspektywy w cytowanej pracy razi arbitralność sądów tego badacza, brak uzasadnienia wyboru takich a nie innych publikacji źródłowych, dyskusji prezentowanych interpretacji oraz ogólnie głębszej refleksji na temat opozycji fakt-narracja, szczególnie pożądanej przy wkraczaniu na tak nowe metodologicznie i merytorycznie obszary wykorzystywania wiedzy o przeszłości, jak to ma miejsce u brytyjskiego polihistora. Spełnienie wymienionych standardów niekoniecznie musiałoby się odbyć kosztem zmiany eseistycznego stylu pisania, atrakcyjnego dla szerokiej grupy odbiorców. Ułatwiłoby za to zauważenie prac Zeldina przez promotorów historii organizacyjnej, jak myślę, z dużą korzyścią poznawczą dla obu stron.

W każdym razie wspomniane wady Intymnej historii ludzkości nie zaszkodziły popularności intelektualnej jej autora. Przetłumaczona na wiele języków omawiana praca zaliczona została do zbioru prestiżowych publikacji, które zdaniem brytyjskich wydawców, najlepiej oddawały humanistyczny dorobek ludzkości przełomu tysiącleci. Reedycja Intymnej historii ludzkości w serii milenijnej wyraźnie pokazuje, iż jej autor był jednym z twórców atmosfery zainteresowania przeszłością, która, zdaniem Carrolla (2002), co warto raz jeszcze przypomnieć, walnie przyczyniła się do rozwoju historii organizacyjnej na początku obecnego stulecia (Ochinowski 2012b).

\subsubsection{Postulaty Theodore'a Zeldina dla praktyki zarządzania}

Dla samego Zeldina analiza dziejów jako źródła „sztuki życia” znacznie wcześniej niż przytaczane sukcesy stała się okazją do szerokiego zainteresowania rzeczywistością pracy, w tym także światem biznesu. Zeldin spojrzał na miejsca wykonywania zawodu, jako na obszar rozwoju możliwości jednostki ludzkiej. Nie krył swych ideologicznych, choć popartych interpretacją doświadczenia przeszłości, założeń, iż współczesny biznes powinien ewoluować w stronę humanizacji, zarówno jeśli chodzi o relacje z klientami, jak i wewnątrz organizacji. Rzeczywistą naturę współczesnych miejsc pracy Theodore Zeldin badał w latach dziewięćdziesiątych ubiegłego stulecia jako kierownik programu „Przyszłość pracy" (The Future of Work), który zyskał wsparcie Komisji Europejskiej. Integralną część tego projektu, nastawionego na wykreowanie nowego modelu działalności biznesowej, były rozmowy w miejscu pracy z zatrudnionymi na temat czynników sprawiających, że tradycyjne organizacje nie są postrzegane przez pracowników jako satysfakcjonujące. Zdaniem Zeldina, pozwalają one wykorzystać zaledwie 20-25\% możliwości pracujących tam osób. Dlatego też pracodawcy powinni tak organizować stanowiska pracy, aby podwyższyć ten odsetek, jednocześnie dając podwładnym okazję stania się lepszymi ludźmi 
i większego niż dotychczas zaangażowania w realizację zadań zawodowych. Do osiągnięcia wspomnianego celu konieczne jest, według cytowanego historyka, przywrócenie podstawowej umiejętności społecznej, jaką stanowi „sztuka dobrej konwersacji”, zapomniana przez szefów współczesnych firm i organizacji. Sztuka dobrej konwersacji to coś znacznie głębszego niż proste komunikowanie się między sobą. To umiejętność wczuwania się w drugą osobę, wnikania w jej myśli i uczucia. W warunkach pracy jest to trudne, choćby z tego powodu, że ludzie często nie czują się tam swobodnie i nie zachowują naturalnie. Częste uczucie odczuwane na płaszczyźnie zawodowej stanowi strach. Tym bardziej więc rozmowę w pracy zaliczyć należy do jej istotnych elementów, a dobrą rozmowę, wręcz do kluczowych. Większość szefów firm i przełożonych badanych przez Zeldina zalicza umiejętność dobrej rozmowy do swoich najważniejszych kompetencji zawodowych, od której zależą także inne umiejętności. Podstawowe cechy dobrej konwersacji cytowany badacz formułuje następująco:

- taka rozmowa nie powinna być wykładem, przemówieniem, czy monologiem kierowanym do wszystkich, „podejmując dobrą rozmowę, należy szukać w każdej sytuacji raczej tego, co łączy, niż tego, co dzieli z rozmówcą",

- słuchając z uwagą swojego rozmówcy, należy próbować dowiedzieć się o nim jak najwięcej (na przykład po sposobie mówienia, akcencie, żargonie jakiego używa). Taka wiedza pozwoli prowadzącemu dobrą konwersację na sformułowanie najlepszej odpowiedzi, adekwatnej do sytuacji, problemu ale i osobowości rozmówcy.

Pośrednie przesłanie koncepcji dobrej rozmowy stanowią wartości rodzinne 4 . Humanizacja miejsca pracy powinna doprowadzić do tego, że relacje rodzinne członków firmy będą inspirować - również te, które dotyczą relacji ze współpracownikami czy klientami. W wyniku tego typu rozmowy kierownik może dowiedzieć się o rzeczywistych, głęboko ludzkich zainteresowaniach swych podwładnych, bez „wchodzenia z butami” w ich prywatność.

Uogólniona metoda dobrej rozmowy nosi nazwę audytu humanistycznego. Zeldin stosował ją przy realizacji rozmów podczas projektu „Przyszłość pracy”. Zaleca ją również do codziennego stosowania w firmach. Audyt humanistyczny umożliwia pogłębienie relacji międzyludzkich w pracy, a zarazem pomaga ujawnić nowe kompetencje pracowników, które mogą przydać się także do realizacji celów firmowych. Na przykład w trakcie prawdziwej konwersacji może okazać się, że ktoś z pracowników świetnie potrafi łagodzić konflikty w swojej rodzinie. Być może te jego kompetencje negocjacyjne będzie można wykorzy-

4 Możliwość takiej interpretacji koncepcji Zeldina zawdzięczam Jarosławowi Kleczkowi, filozofowi, socjologowi i przedsiębiorcy, współautorowi publikacji szkoleniowych, wieloletniemu uczestnikowi prywatnych seminariów dotyczących „ludzkiego oblicza” zarządzania, które miałem przyjemność prowadzić w Warszawie przez około dziesięć lat dla studentów różnych uczelni i przedstawicieli biznesu. 
stać przy kontaktach z trudnymi klientami lub do rozwiązywania konfliktów między pracownikami.

„To proste - wyjaśnia Zeldin, jak przeprowadza audyt humanistyczny Rozmawiam z nimi o wszystkich aspektach ich życia, o ich życiu osobistym, o aspiracjach..., o sprawach niemierzalnych. Przykład: rozmawiam z szefem sprzedaży w dużej korporacji zajmującej się sprzedażą wysyłkową... Po trzech godzinach rozmowy wyznał mi, że zawsze chciał być aktorem... Został skuszony do korporacji poprzez świetne zarobki, bonusy, samochód służbowy... ale czuje się więźniem... dlaczego nie stworzyć mu w miejscu pracy warunków, namiastki działań teatralnych? Wbrew pozorom teatr i sprzedaż mają dużo wspólnego" (Zeldin i Wylie 2000)5.

Cel rozwijania swoistej kultury organizacyjnej opartej na dobrej rozmowie, brytyjski historyk określił zaś następująco:

„Czy mamy się spodziewać, że będziemy bardziej zaangażowani w naszą pracę? Musimy »unieważnić« wykonywane zawody, pracę. Unieważnić różnicę pomiędzy pracą a czasem wolnym. Największą pomyłką ostatniego stulecia było zaprzęgnięcie ludzi do podłej pracy, dając im w zamian czas wolny poza nią... Teraz musimy walczyć o to, abyśmy pracowali, nie mając świadomości, że to co robimy, jest pracą" (Zeldin i Wylie 2000).

Przytoczone propozycje Zeldina tylko pozornie mogą wydawać się oczywiste. Nieoczywista była przede wszystkim jego diagnoza podstawowych braków współczesnego zarządzania ludźmi. Co najważniejsze, świat biznesu z zainteresowaniem odniósł się do koncepcji brytyjskiego polihistora. Zeldin zaczął być zapraszany na konsultacje przez wiele decyzyjnych osób, reprezentujących najwyższe szczeble kierowania firmami $\mathrm{z}$ sektora finansów, prawa, ochrony zdrowia, IT, doradztwa, transportu, produkcji, projektowania, reklamy oraz organizacji rządowych i międzynarodowych. Stał się członkiem „Nowego Trustu Mózgów" tworzonego przez BBC i Międzynarodowego Forum Ekonomicznego. Wierny aż do emerytury podstawowemu miejscu swej działalności akademickiej, to jest St. Antony's College w Oxfordzie (któremu nadał kształt interdyscyplinarnego ośrodka studiów podyplomowych i którym, jako dziekan, kierował przez czternaście lat), jako badacz i uczony zaangażował się także w programy z zakresu przywództwa dla wyższej kadry zarządzającej prowadzone przez inną oxfordzką jednostkę, Templenton College. Był profesorem wizytującym kilkunastu uczelni na świecie. Paryska Szkoła Biznesu (HEC) obdarzyła go tytułem doktora honoris causa.

Na marginesie warto wspomnieć, iż Zeldin sformułował również koncepcję reformy nauczania uniwersyteckiego, które poddał otwartej krytyce, przede wszystkim ze względu na sztywność programów akademickich. Tradycyjne

$\overline{5}$ Ten i kolejny cytat pochodzą z przekładu D. Gochno. 
nauczanie i konsultowanie prac brytyjski historyk zaproponował zastąpić ideą „Superuniwersytetu” przyszłości. Ma to być instytucja zapewniająca studentom kontakt z praktyką uprawiania ziemi i produkowania przedmiotów, zawierająca elementy „szkoły przetrwania”, umożliwiająca tworzenie sztuki i piękna oraz angażowanie się w wolontariat, słowem dostarczająca słuchaczom (czy raczej powinno się napisać „uczestnikom”) wyposażenie potrzebne do tego, by „przeżywać lepsze życie, bardziej służące spełnieniu” (Snowman 1999: 27).

W celu wspomagania rozwoju i aplikacji bliskich mu idei, wśród których, co warto raz jeszcze podkreślić, istotne miejsce zajmuje dążenie do reformy świata biznesu, Zeldin powołał fundację „Oxford Muse”. Jest jej prezesem.

Historia, jako dziedzina wyznaczająca określony sposób myślenia, stanowi, zdaniem cytowanego brytyjskiego badacza, filozofa i reformatora, intelektualne źródło jego zaangażowań. Podczas realizacji wspomnianego projektu „Przyszłość pracy”, skrajnie zorientowanego przecież na teraźniejszość i przyszłość, Zeldin deklarował:

„Jestem historykiem, w tym sensie, że niezmiennie myślę o tym, jak rzeczy doszły do miejsca, w którym są i jakie lekcje możemy z tego wyciągnąć. Ostateczny cel stanowi odkrycie, co człowiek może zrobić ze swoim jednostkowym życiem - dokąd powinniśmy stąd pójść" (Snowman 1999: 26).

Trudno nie zauważyć współbrzmienia powyższej wypowiedzi z podstawowymi elementami ideologii oraz zadań badawczych historii organizacyjnej, tak jak je widzą Carroll (2002) czy Booth, Rowlinson i Jaques (2009). Szczególnie użyteczne (w sensie dosłownym, a także użyteczności poznawczej) wydaje się przedyskutowanie dziś na nowo swoistej propozycji teoretycznych ram dla analiz w zakresie „uhistoryczniania subiektywności”, za które uznać można podstawy cytowanego programu „Przyszłość pracy”, następująco sformułowanej przed laty przez Zeldina.

„Główny impuls historii ludzkości stanowi poszukiwanie przez jednostki partnerów, kochanków, guru lub bogów. Spotkania z obcą osobą, ideą lub sytuacją formują indywidualne życie i nadają mu kierunek. Gdy spotyka się dwoje ludzi, wtedy powstaje możliwość, że połączą się by stworzyć coś, co nie istniało wcześniej, właśnie tak, jak w badaniach naukowych często występuje połączenie idei z dwóch dyscyplin, które inicjuje odkrycie (...). Jest prawdą, iż wielu ludzi ma wąski krąg znajomych i tendencję do przyjmowania jedynie tego, co popiera ich istniejące opinie. Jednak strach, stanowiący główną przeszkodę przed zamianą, jest stale zmniejszany przez spotkania, które obracają nieznane w znane, nawet jeśli nowe rodzaje strachu pojawiają się, by zająć miejsce starych" (Zeldin 1999: 1633).

Pośród różnorodnych wątków, które niosą ze sobą, idee Zeldina zwracają także uwagę na istotny potencjał intelektualny historii organizacyjnej, pośrednio sygnalizowany przez jej promotorów, a jednak, jak się wydaje, niewyrażany dotąd 
wprost. Chodzi o możliwość poszukiwania w przeszłości wzorów dobrych praktyk dla obecnych działań biznesowych przy wystrzeganiu się oczywiście błędu prezentyzmu ${ }^{6}$. Zgodnie z zarysowaną wcześniej logiką historii organizacyjnej jej docelowa użyteczność powinna mieć kontekst współczesny. Zaś bezpośrednio do sformułowania omawianego tu celu poszukiwań poznawczych przyczyniło się rozumienie historii lapidarnie wyrażone przez Bohdana Cywińskiego jako nauki nie o tym jak było, ale o tym jak bywa ${ }^{7}$ (Ochinowski 2012b).

\subsection{Heroiczne przywództwo w ujęciu Chrisa Lowneya}

\subsubsection{Analiza koncepcji Chrisa Lowneya w kontekście historii organizacyjnej}

Interesującego przykładu „zawłaszczenia” przeszłości dla potrzeb współczesnego zarządzania dostarcza dostępna od niedawna na polskim rynku wydawniczym praca Chrisa Lowneya Heroiczne przywództwo. Tajemnice sukcesu firmy istniejacej ponad 450 lat (2011) ${ }^{8}$. Autor, wcześniej członek zakonu jezuitów, a następnie przez siedemnaście lat jako dyrektor zarządzający różnych oddziałów banku J.P. Morgan \& Co na świecie, wchodził także w skład zarządu wspomnianej korporacji. Podczas praktyki menedżerskiej uświadomił on sobie, początkowo na zasadzie - jak sam pisze (2011: 9) - mglistego przypomnienia, iż metoda „360 stopni”, którą firma Lowneya swego czasu wprowadzała jako „absolutne novum' i „najlepszą praktykę” była de facto znana jezuitom około 435 lat wcześniej. Idąc tym tropem, Lowney - wówczas dyrektor Morgana ustalił zasadnicze podobieństwo między swoim bankiem a wspomnianym zakonem z początków jego działalności, polegające na konieczności efektywnego radzenia sobie przez obydwie organizacje $\mathrm{z}$ otoczeniem złożonym i nieustannie zmieniającym się 9 . Uwzględniając oczywiście uwarunkowania historyczne oraz skrajnie różne misje porównywanych instytucji, Lowney (2011: 11) doszedł do wniosku, że Ignacego Loyolę oraz jego współpracowników można uznać za osoby, których „podejście do kształtowania pomysłowych, gotowych na podjęcie ryzyka, ambitnych, elastycznych oraz myślących globalnie ludzi przynosito

6 Pod pojęciem „prezentyzmu” rozumiem tu mechaniczne używanie doświadczeń z przeszłości jako „wzorów” tłumaczących zjawiska współczesne i odwrotnie. Dalsza część niniejszego rozdziału zawiera historiograficzne rozwinięcie tego terminu.

7 Sformułowania tego Cywiński użył w rozmowie ze mną w 2001 roku.

8 Oryginał wydany w 2003 roku pod tytułem Heroic Leadership. Best Practices from a 450-year-old Company that Changed the World.

9 Chodzi więc o otoczenie nazwane przez Druckera turbulentnym, co polski tłumacz (Łukasz Malczak) poświęconej temu problemowi książki wspomnianego autora przełożył jako „burzliwe”. 
efekty". Konsekwentnie prezentowany praktyk zarządzania zrealizował projekt odpowiadający na pytanie ,czego szesnastowieczni zakonnicy mogliby nauczyć (...) światowców z XXI wieku, na temat przywództwa oraz radzenia sobie ze złożonymi i stale zmieniającymi się okolicznościami?” (Lowney 2011: 11). Wyniki wspomnianych badań pozwoliły Lowneyowi opracować model „heroicznego przywództwa", którego istotę stanowi kultura organizacyjna oparta na czterech zasadach (wartościach): heroizmie, pomysłowości, miłości i samoświadomości ${ }^{10}$. Jak się wydaje, opisywana praca zarówno wpisała się w aktualne trendy badawcze, jak i odpowiedziała na niektóre przynajmniej potrzeby biznesu, wzmocnione przez ostatni kryzys ekonomiczny.

Jako przykład warto zauważyć, iż naukowe badanie heroizmu podjął ostatnio (również posługując się metodą historyczną) wspomniany już nestor psychologów społecznych Philip Zimbardo ${ }^{11}$.

Z kolei Mark Bandsuch, Larry Pate i Andjeff Thiel (2008: 99) przywołują wykonane przez Lowneya analizy samoświadomości przy konstruowaniu własnego modelu ,przywództwa opierającego się na zasadach” modelu mającego służyć odbudowie zaufania interesariuszy w świecie biznesu.

Steven Hein (2008), przygotowując krytyczny przegląd aktualnych prac na temat relacji filozofii i duchowości z przywództwem biznesowym, zaliczył książkę Lowneya do „neofilozoficznego" nurtu tej problematyki. Prezentację Heroicznego przywództwa na Uniwersytecie Transamerykańskim w Puerto Rico wsparła gazeta propagująca wiedzę biznesową „Caribbean Business”. I nie ma podstaw by uznać to za odosobniony przypadek (Ochinowski 2012b).

Znacznym ograniczeniem pracy Lowneya, a szczególnie możliwości jej oddziaływania na świat biznesu stanowi zjawisko, które polski filozof Michał Heller (2006) nazwa strukturalną niestabilnością języka. Chodzi o zakładany przez tradycyjne (nota bene dziś już krytykowane, ale przy opisie wspomnianego fenomenu nadal użyteczne) modele komunikacji, oparte na wyróżnianiu trzech koniecznych elementów każdej strony porozumiewania się: komunikatu, nadawcy i odbiorcy. W idealnej sytuacji, którą umożliwiają tylko języki formalne, odbiorca powinien rozumieć komunikat tak samo jak nadawca. Poza językami formalnymi chodzi o przybliżone rozumienie komunikatu.

„A więc powinno być tak, że mała zmiana znaczenia w komunikacie ze strony nadawcy, prowadzi do małej zmiany znaczenia w rozumieniu komunikatu przez odbiorcę. Jeżeli taka sytuacja zachodzi, mówimy, że komunikat (lub język, w jakim został on wyrażony) posiada własność (strukturalnej) stabilności.

10 Poprzez cytowany projekt Lowney poszukiwał, jak już pisałem, tzw. dobrych praktyk. Jednak ich źródło upatrywał nie tylko w sukcesach, ale także w porażkach analizowanej organizacji. Za ważną przyczynę kasaty jezuitów w XVII wieku uważa on brak innowacyjności ówczesnej zakonnej „centrali”.

11 Do tej kwestii powrócę w dalszej części niniejszego rozdziału. 
Ale mogą istnieć - i faktycznie często istnieją - komunikaty (języki), które tej własności nie mają. Nawet mała zmiana znaczenia, zamierzona przez nadawcę, może pociągnąc za sobą dużą zmianę w rozumieniu tego znaczenia przez odbiorcę. A inne (i to inne w dużym stopniu) zrozumienie jednego terminu przez odbiorcę pociaga za sobą, na zasadzie reakcji łańcuchowej, lawinę kolejnych niezrozumień dalszych terminów. Pierwsze zniekształcenie narasta coraz bardziej. Komunikat taki (lub język) jest (strukturalnie) niestabilny. Nadawca i odbiorca nie są w stanie porozumieć się ze sobą" (Heller 2006: 113).

Koncepcja „heroicznego przywództwa” operuje przynajmniej dwoma spośród czterech dla niej kluczowych terminami, które bardzo trudno ując za pomocą terminologii typowej dla współczesnej psychologii organizacji: „heroizm” i „miłość”. Jak sygnalizowałem wcześniej, pierwsze z tych pojęć aktualnie operacjonalizuje na gruncie psychologii społecznej Phillip Zimbardo. Trudniej wygląda sytuacja drugiego terminu. Sukcesywnie próby wyrażenia miłości, kluczowej kategorii chrystianizmu, w języku modernistycznym, dającym „paszport" do świata nauk społecznych, podejmowane przez takich autorów jak John C.H. Wu (1941/1999) czy Carl Anderson (2008/2009) wydają się interesować wyłącznie wąskie grona tak zwanych intelektualistów katolickich - bądź co najwyżej nieco szersze kręgi - intelektualistów zainteresowanych duchowością ${ }^{12}$. Książka Lowneya stwarza okazję przypomnienia znacznie wcześniejszego przypadku zainteresowania menedżerskim doświadczeniem jezuitów ze strony badaczy. Isabella Selega Csíkszentmihályi (1988), żona Mihály'ego Csíkszentmihályi (2005), odkrywcy zjawiska „przepływu” (czy „uskrzydlenia”, ang. flow), szukając historycznych kontekstów tego fenomenu wskazała, iż szesnastowieczną dynamikę oraz sukces zgromadzenia Ignacego Loyoli można tłumaczyć właśnie warunkami sprzyjającymi przeżywaniu przepływu, wspomaganymi przez zakonną regułę. Dziś „przepływ” coraz intensywniej wchodzi „na teren” zarządzania ludźmi. Na przykład stanowi podstawę działań personalnych w firmie telekomunikacyjnej „Ericsson”. Jest także jednym z kluczowych elementów projektów „Good Work” i „Good Business”, realizowanych od 15 lat jako empiryczne poszukiwanie łączników między etyką a wysokim poziomem wykonania działań biznesowych (Ochinowski 2010, 2011). Program studiów doktoranckich prowadzonych przez Mihály'ego Csíkszentmihályi (2011) wśród swych podstawowych celów obejmuje szkolenie psychologów organizacji (Ochinowski 2012b).

12 Na marginesie warto zauważyć, iż być może jest to symptom szerszego zjawiska. Niestabilność języków generalnie wydaje się stanowić jeden z głównych czynników zniechęcających historyków i teoretyków organizacji do podjęcia szerszej współpracy. 


\subsubsection{Psychologia pozytywna jako potencjalny partner poznawczy historii organizacyjnej}

Wspomniany na zakończenie poprzedniego paragrafu program studiów doktorskich dotyczy psychologii pozytywnej, względnie nowego ${ }^{13}$ nurtu badań i refleksji, który sam w sobie wydaje się być interesującym „partnerem” dla historii organizacyjnej, przynajmniej jeśli chodzi o „uhistorycznienie subiektywności”. Jak pisali przed laty Martin P. Seligman i Mihály Csíkszentmihályi (2000) w deklaracji założycielskiej tego podejścia psychologia pozytywna koncentruje się na naukowym badaniu pozytywnych emocji, zaangażowaniu i poczuciu sensu, czyli tych trzech aspektów ludzkiego życia, które uszczegółowiają zjawisko potocznie określane dość niepraktycznym dla badaczy terminem „szczęście”. Psychologowie pozytywni stawiają sobie za cel mierzenie, klasyfikowanie oraz budowanie wspomnianych trzech fenomenów. Chodzi więc z jednej strony o dowartościowanie pozytywnych stron funkcjonowania człowieka, z drugiej zaś o ich precyzyjne, naukowe badanie oraz formułowanie empirycznie uzasadnionych wskazań praktycznych. Przy czym naukowość czy nawet empiryczność rozumiana jest w ramach psychologii pozytywnej przede wszystkim jako dyscyplina myślenia i poznawania rzeczywistości. Co do konkretnych rozwiązań metodologicznych zauważyć można interesujące zróżnicowanie opcji, raczej rzadkie wśród przedstawicieli innych nurtów psychologii. I tak na przykład Seligman (2007) dużą wagę przypisuje „złotym standardom” badań psychologicznych, takim jak stosowanie opracowanych psychometrycznie narzędzi pomiaru oraz wykorzystanie eksperymentów, badań podłużnych (wieloletnich $\mathrm{z}$ tą samą grupą badanych), doboru losowego i grup kontrolnych, w których wykorzystuje się efekt placebo. Jednak już drugi z „ojców założycieli” psychologii pozytywnej ${ }^{14}$, opisywany przeze mnie Csíkszentmihályi (2004) prezentuje nieco bardziej „miękkie” stanowisko metodologiczne:

13 Środowiska rozwijające i propagujące psychologię pozytywną obchodziły przed kilku laty jej dziesięciolecie (1998-2008). W Polsce jubileusz ten rozpropagowała (także wśród nieprofesjonalistów) „Rzeczpospolita”, publikując w wydaniu z 19.11.2008 blok materiałów poświęcony wspomnianemu nurtowi myśli psychologicznej. Niekiedy „narodziny” psychologii pozytywnej przesuwane są o dwa lata „w przód” i wiązane z artykułem Martina E.P. Seligmana i Mihaly'ego Csíkszentmihályiego z 2000 roku, który był za oficjalną proklamacją rozwoju tego nurtu. Aktualnie działa również na terenie naszego kraju pierwsza Katedra Psychologii Pozytywnej, kierowana przez prof. Ewę Trzebińską w Szkole Wyższej Psychologii Społecznej. Trzebińska (2008 i nast.) jest też autorką pierwszego polskiego podręcznika psychologii pozytywnej.

14 Ewa Trzebińska (2008) do grona twórców psychologii pozytywnej zalicza oprócz Seligmana i Csíkszentmihályi także Eda Dienera oraz Charlesa Richarda „Ricka” Snydera. 
„Z upływem lat zacząłem sobie zdawać sprawę z ograniczonego zastosowania liczb, logiki i statystyki, jednak te wczesne doświadczenia ${ }^{15}$ skutecznie uodporniły mnie przeciw skłonności do popadania w przesądy, uprzedzenia i irracjonalność. Obecnie mój stosunek do metod empirycznych jest taki sam, jak Churchila do demokracji: możliwe, że to bardzo zły system, ale wszystkie inne są jeszcze gorsze" (Csíkszentmihályi 2004: 44).

Warto też podać jako przykład jeszcze trochę innego traktowania naukowości w ramach psychologii pozytywnej, przetłumaczoną kilka lat temu na język polski książkę Jonathana Haidta Szczęście. Od mądrości starożytnych uczonych po koncepcje wspótczesne $(2007)^{16}$, której autor z równą powagą podchodzi do wyników najnowszych badań empirycznych, jak i do ustaleń filozofów na przestrzeni dziejów. Zresztą praktyka badawcza oraz rozsiane po różnych publikacjach wypowiedzi cytowanych wcześniej twórców psychologii pozytywnej pokazują, iż podejście Haidta również dla nich nie jest obce.

Można zauważyć, że generalnie psychologia pozytywna dowartościowuje dziedzictwo kulturowe (rozumiane globalnie) jako inspirację, a także „surowiec” do badań psychologicznych. Ma to oczywiście istotne znaczenie dla poszukiwań poznawczych związanych z „uhistorycznianiem subiektywności”. Charakterystyczne dla warsztatu psychologów pozytywnych jest poszukiwanie w materiałach historycznych uniwersalnych potencjałów psychicznych jednostki ludzkiej oraz możliwości budowania tych potencjałów i wykorzystywania ich w wymiarze zarówno indywidualnym jak i społecznym (zob. np. Peterson i Seligman 2004, Seligman 2002/2005) oraz eksploracja historycznych korzeni zjawisk odkrywanych w toku badań psychologicznych (np. wspomnianego zjawiska flow czy też zoperacjonalizowanej przez Haidta kategorii szczęścia ${ }^{17}$ ). Jak widać, współpraca między historykami i psychologami pozytywnymi realizuje się przede wszystkim na terenach historii idei i historii kultury, co może wzbogacić o te obszary także historię organizacyjną. Csíkszentmihályi wprost stwierdza, iż psychologia pozytywna stanowi rodzaj naukowej promocji tez, które już znacznie wcześniej zawierały religijne i filozoficzne dzieła światowej tradycji. Dziś jednak mało kto utwory te czyta, zaś książki psychologiczne jak najbardziej tak (Seligman i Csíkszentmihályi 2000). Wspomniany trop wyznacza jeszcze jedno zadanie dla historii organizacyjnej. Nic nie stoi na przeszkodzie, by stała się ona także narzędziem hellerowskiej „,stabilizacji języka” w dialogu między doświadczeniem przeszłości a potrzebami (Ochinowski 2009a).

15 Csíkszentmihályi formułuje cytowany pogląd jako podsumowanie swoich wspomnień związanych z kontaktami z myśleniem naukowym w dzieciństwie.

16 Tytuł oryginału The Happiness Hypothesis: Finding Modern Truth in Ancient Wisdom (2006). Autorem polskiego przekładu jest Agnieszka Nowak.

17 Zob. cytowaną już pracę Haidta (2007). 


\subsection{Tradycje przedsiębiorczości jako dziedzina badań historii organizacyjnej na przykładzie prac Kordiana Tarasiewicza}

\subsubsection{Stan badań nad dziejami przedsiębiorczości w Polsce}

Jeden z obszernych tematów historii organizacyjnej wyznaczają dzieje przedsiębiorczości. Ma on szczególne znaczenie w kontekście materiału empirycznego niniejszej pracy, to jest tradycji zarządzania przedsiębiorstwami rozwijanymi w przeszłości na ziemiach polskich. Szczególnie interesujące w tym kontekście są te prace historyczne, które niejako w uzupełnieniu do działań środowisk naukowych, piszą sami praktycy biznesu lub ich potomkowie, a więc osoby naturalnie łączące teraźniejszość i przyszłość biznesową z przeszłością. Zazwyczaj analizują oni tę przeszłość właśnie z myślą o przyszłości swej branży lub ogólnie działalności gospodarczej. Są więc „zadomowieni” w historii organizacyjnej, choć nie używają tego terminu.

Wspomniany przejaw twórczości historiograficznej poddaję w tym rozdziale analizie na podstawie pojedynczego przypadku: dorobku polskiego przedsiębiorcy - Kordiana Tarasiewicza. Tradycję zarządzania w jego firmie omawiam dalej (zob. par. 6.2). Sylwetkę Tarasiewicza jako historyka przedsiębiorczości umieszczam na tle zarysu historiograficznego tej dziedziny badań w naszym kraju.

W porównaniu z dorobkiem dziejopisarstwa krajów zachodnich, w których historia przedsiębiorczości doczekała się już (obok dziejów myśli menedżerskiej) nawet publikacji podręcznikowych (zob. np. Landes, Mokyr i Baumol 2010 oraz Landström i Lohrke 2011), naukowa rekonstrukcja tradycji, czy szerzej, przeszłości działań przedsiębiorców na terenie Polski, jest dość wątły. Według opinii Ryszarda Kołodziejczyka (1968), sformułowanej przed wielu laty, do tego w warunkach PRL-owskiej cenzury, przed II wojną światową informacje dotyczące dziejów społeczności polskich przedsiębiorców („,polskiej burżuazji", jak pisał wówczas cytowany autor) miały zazwyczaj charakter treści rozproszonych na kartach monografii poszczególnych osób lub instytucji. Wydaje się też, iż pewne dane na wspomniany temat można znaleźć w pracach poświęconych dziejom gospodarczym czy historii pracowników, to jest klasy robotniczej, poczynając od badań Aleksandra Wóycickiego $(1922,1927)$. Zarówno jednak to przypuszczenie, jak i przytoczona opinia Kołodziejczyka wymaga oddzielnej weryfikacji. Poznawczymi we wspomnianym kierunku są na przykład podejmowane aktualnie przez Katarzynę Błachowską (2011) analizy wątków dotyczących przedsiębiorczości w pracach Feliksa Konecznego, które wspomniałem już wcześniej ${ }^{18}$.

18 Na razie pomijam problematyką dziejów przedsiębiorczości wśród ziemian, która posiada już dość pokaźną literaturę, nadal jednak oczekującą na analizę historiograficzną. 
Obecny, raczej mało zaawansowany, co już podkreślałem, etap refleksji historiograficznej nad dziejami polskiej przedsiębiorczości zdaje się jednak sugerować, iż po 1945 roku, mimo panowania ustroju niechętnemu przedsiębiorczości, rozwijała się ona jednak, choć przeważnie na marginesie realizacji innych, bardziej „bezpiecznych ideologicznie” tematów badawczych. I tak na przykład pewne treści dotyczące początków przedsiębiorczości w Polsce czytelnik znajdzie, podobnie jak wcześniej u Wóycickiego ${ }^{19}$, na kartach Początków klasy robotniczej Niny Assorodobraj (1946).

Niezależnie od panującej wówczas ideologii wspomniany już Koneczny (1946-1949/2006) próbował rozwijać proprzedsiębiorczą publicystykę, obficie wykorzystując odniesienia historyczne. Była to już jednak tylko publicystyka zaawansowanego wiekiem i marginalizowanego przez władze PRL-u badacza dziejów, publicystyka dotycząca spraw aktualnych, sięgająca jedynie po przykłady z przeszłości.

Od wczesnych lat pięćdziesiątych ubiegłego wieku ważnym ośrodkiem dynamizującym badania nad historią polskiej przedsiębiorczości stał się warszawski Instytut Historii PAN. Zdaniem cytowanego już Kołodziejczyka (1993), to właśnie tutaj, mimo trwania apogeum stalinizmu, środowisko młodych historyków skupionych wokół Witolda Kuli podjęło tematykę dziejów „ludzi interesu” pod nazwą „dzieje burżuazji w Polsce”. „Całe ówczesne seminarium doktorskie Kuli - wspominał po latach Kołodziejczyk (1993: 7) - tkwiło w tej problematyce i dzięki temu mogliśmy wówczas studiować dzieje polskiego Unternehmertum $^{20}$, na tle przemian cywilizacyjnych w społeczeństwie polskim”. Najbardziej konsekwentnie spośród przedstawicieli tego środowiska rozwijał wspomnianą problematykę właśnie przywoływany już przeze mnie wielokrotnie Ryszard Kołodziejczyk (1957, 1962, 1963, 1968, 1993 i in.). Warto wskazać w jego dorobku choćby pracę Bohaterowie nieromantyczni. O pionierach kapitalizmu w Królestwie Polskim (1961), która starała się wypełnić zarówno cele czysto poznawcze, jak i edukacyjne, próbując przełamać stymulowane przez funkcjonariuszy systemu politycznego czasów PRL-u niepamięć społeczną oraz negatywną stygmatyzację postaci tego typu. „Zatytułowałem ją 'Bohaterowie nieromantyczni' chcąc w ten sposób wyróżnić to środowisko od dominującej przez cały wiek dziewiętnasty tradycji romantycznej. W tamtym czasie nie było sprawą łatwą kreowanie na

19 Podobieństwo perspektywy badawczej Wóycickiego i Assorodobraj nie umniejsza w niczym oryginalności metody i ustaleń tej drugiej. Praca Assorodobraj stanowi przykład ujęcia problematyki dziejów przedsiębiorczości „od drugiej strony”, poprzez pryzmat historii robotników bądź innych grup społecznych, których badanie było w czasach PRL-u mile widziane. Zbigniew Romek z IH PAN zwrócił mi uwagę, iż taka strategia była świadomie podejmowana przez niektórych badaczy, zainteresowanych „niewygodną” dla władz państwowych tematyką i przez to zmuszonych do zmagań z komunistyczną cenzurą. Trudno powiedzieć, czy był to przypadek Assorodobraj.

20 Po polsku ,przedsiębiorczość”. 
bohaterów narodowych ludzi interesu: kupców, bankierów i przemysłowców, określanych, aż do niedawna mianem wyzyskiwaczy i krwiopijców. Starałem się wówczas ratować od niepamięci przed polskim czytelnikiem owych pionierów nowoczesności. Nazwałem ich pionierami i bohaterami nieromantycznymi, chociaż sam miałem świadomość, że de facto i oni byli na wskroś romantyczni, zgodnie z duchem epoki, w której żyli. Inna kwestia, że ułatwiały mi te poczynania znane bankructwa oraz finansowe niepowodzenia moich bohaterów" (Kołodziejczyk 1993: 2-3). Cytowany historyk wskazuje, iż środowisko Kuli stało się inspiracją dla szeregu przedsięwzięć badawczych pogłębiających omawianą problematykę, zarówno w samym Instytucie, jako poza nim, by przykładowo wymienić choćby prace przywoływanego już przeze mnie Ireneusza Ihnatowicza (1971). Zgłębianie dziejów polskiej przedsiębiorczości zyskało też tradycje poza stolicą ze szczególnym uwzględnieniem silnych ośrodków stworzonych przez badaczy łódzkich i poznańskich. Gdy w 1993 roku Kołodziejczyk (1993) podsumowywał stan polskiej historiografii poświęconej omawianym zagadnieniom, to podkreślał zarówno zapóźnienie w stosunku do prac zachodnich, jak i dynamiczny rozwój naznaczony już liczącymi się osiągnięciami. Planuję niedługo podjąć weryfikację przytoczonej opinii, po kolejnych dwóch dekadach od czasu jej sformułowania.

Z późniejszych badawczych realizacji problematyki dziejów polskiej przedsiębiorczości nie sposób pominąć, oprócz pojawiających się sukcesywnie biografii poszczególnych „ludzi interesu”, na przykład uwag historyka Tomasza Szaroty (1995, 2011), dotyczących działań przedsiębiorczych uwikłanych w codzienność mieszkańców stolic europejskich czasów okupacji hitlerowskiej. Publikacje Szaroty mają walor porównawczy. Jego książka poświęcona okupacyjnej codzienności głównych miast Europy znacznie mniej zajmuje się przedsiębiorczością niż jego znana praca poświęcona „dniu powszedniemu” wyłącznie okupowanej Warszawy.

Przejawy dynamicznego rozwoju drobnych przedsięwzięć gospodarczych po wyzwoleniu stolicy spod hitlerowskiej okupacji zaliczył do wartych odnotowania elementów „pamięci warszawskiej odbudowy” Jan Górski (1972, 1990), choć dotykał tej problematyki, przynajmniej w publikacjach, dość marginalnie ${ }^{21}$ i - z konieczności spowodowanej przez główny zakres jego zainteresowań (najnowsza historia Warszawy) - wyłącznie na poziomie lokalnym.

Ogólnopolskim dziejom przedsiębiorczości po 1944 roku poświęcone były dwa programy Ośrodka „Karta”: „Na marginesie: prywatna inicjatywa 1945-1989" (realizowany wspólnie z Fundacją Bankową im. Leona Kronenberga w latach 1998-2001, dokumentujący przez zbieranie relacji wszelkie formy pry-

21 Wspomniane badania Górskiego powstawały przed 1989. Mogły więc tu zaważyć względy cenzuralne. 
watnej inicjatywy czasów PRL-u) oraz „Przedsiębiorczość po polsku” (wystawa przygotowana na zlecenie Polskiej Agencji Przedsiębiorczości w 2012 roku, a wcześniej wspólne wydawnictwo obydwu instytucji w 2010 roku). Pierwszy z wymienionych projektów przyniósł ograniczony liczebnie, ale wartościowy merytorycznie zbiór świadectw losów „prywaciarzy” poddanych presji państwa gospodarki planowej. Przede wszystkim dotyczą one szykan, heroicznego często oporu wobec nich oraz na ogól przegranej przed „finałem” (Gluza 2004: 6). Ze zrozumiałych względów (było to pierwsze przedsięwzięcie badawcze „oddające głos” prywatnym przedsiębiorcom czasów PRL-u) niewiele miejsca pozostało na ich kartach dla opisów dobrych praktyk, czy chociażby uchwycenia, do dziś pozbawianej naukowej analizy, dynamiki przedsiębiorczości polskiej pierwszych lat powojennych, o której literacko pisał Leopold Tyrmand w Zlym i którą nostalgicznie wspomniał w Dzienniku 1954, a także dla analogicznego (choć jak się wydaje na mniejszą skalę, niż wspomniane wcześniej) zjawiska po 1956 roku (Knyt i Wancerz-Gluza 2004). Drugi wspomniany projekt skupiał się przede wszystkim na prywatnych działaniach gospodarczych Polaków po przemianach roku 1989, poprzednie okresy traktując bardzo skrótowo, a czas przed 1945 rokiem pomijając zupełnie (Bertram i Kowalczyk 2010). Warto jednak podkreślić, iż trudny do przecenienia, obszerny materiał źródłowy dotyczący dziejów polskiej przedsiębiorczości różnych okresów czeka na badaczy w Archiwum Mówionym Ośrodka „Karta”, gdzie jest sukcesywnie uzupełniany. Zarówno źródła, jak i opracowania ważne dla tej tematyki publikuje też kwartalnik „Karta”.

Ostatnio (w 2012 roku) próbę kompleksowej kontynuacji historycznej analizy polskich tradycji przedsiębiorczości podjął zespół dawnej Pracowni Badania Dziejów Myśli Społecznej i Politycznej IH PAN, wcześniej przez wiele lat działający pod kierownictwem Andrzeja Wierzbickiego, obecnie istniejący jako nieformalna grupa historiograficzna w ramach Pracowni Badania Dziejów Inteligencji. Środowisko to, którego działania organizuje aktualnie Zbigniew Romek, tradycyjnie obok badaczy z Instytutu Historycznego PAN skupia również pracowników Instytutu Historycznego UW, Wydziału Zarządzania tejże uczelni oraz innych ośrodków. Projekt autorstwa tego grona, zatytułowany „Polska myśl historyczna i polityczna XIX-XX w. o rodzimej przedsiębiorczości”, odnosił się do takich zagadnień jak: (a) relacje między polskością a przedsiębiorczością w historiograficznej myśli charakterologicznej doby porozbiorowej; (b) »krzyżowanie się« idei związanych z przedsiębiorczością występujących w myśli socjalistycznej i katolicyzmie społecznym przełomu XIX i XX wieku; (c) źródła przedsiębiorczości społecznej na przykładzie idei spółdzielczości w kręgu Towarzystwa Kooperatystów (1906-1939); (d) osiagnięcia myśli ekonomicznej i technicznej w refleksji historycznej oraz publicystyce Feliksa Konecznego, a także (d) obraz inicjatywy prywatnej w propagandzie doby PRL-u. Projekt ten niestety został uznany przez zespół doradczy Rady Narodowego Programu Rozwoju 
Humanistyki za niezgodny z zasadniczymi celami tego Programu, a co za tym idzie - wykluczony z procedury konkursowej umożliwiającej dofinansowanie.

Oddzielnej analizy wymaga obecność (lub jak się wydaje raczej nieobecność) wątków historycznych (dotyczących polskich doświadczeń) na kartach podręczników przedsiębiorczości. Wydana niedługo po II wojnie światowej publikacja tego typu Istota i przedmiot nauki o przedsiębiorstwie pióra Antoniego Skowrońskiego (1949), zawiera obszerną charakterystykę polskiego przedsiębiorcy w perspektywie historycznej. Była to charakterystyka bardzo krytyczna, co, jak się wydaje, częściowo mogło wiązać się z okresem wydania omawianej publikacji. Autor, sam mający doświadczenie jako kierownik przedsiębiorstwa ${ }^{22}$, pisał, iż generalnie „przedsiębiorca europejski na schyłku XIX wieku nie dorównywał swym horyzontem myślowym zmianom gospodarczym i technicznym zachodzącym na świecie. To samo można powiedzieć o przedsiębiorcy w Polsce. Był to przeważnie doświadczony technik, bardzo często cudzoziemiec, ulegający spolszczeniu" "23. Skowroński wymieniał tylko jedną zaletę swoich poprzedników na ziemiach polskich: „dużą dozę wytrwałości w pracy”. Pisał natomiast o wielu niedostatkach kompetencyjnych, takich jak:

- „brak należytego wyczucia szerokich obowiązków społecznych”,

- „zasklepienie się całkowicie w zawziętej walce konkurencyjnej” i nastawienie wyłącznie na maksymalizację zysku,

- brak uwzględnienia szerszego aspektu społecznego w stosunku do pracowników (tu jednak, przyznawał Skowroński, zdarzały się niewielkie wyjątki),

- a przede wszystkim brak odpowiedniego wykształcenia ekonomicznego, zarówno ogólnego i niewystarczająca „naukowa ${ }^{24}$ znajomość zjawisk występujących w przedsiębiorstwie”, a co za tym idzie nieumiejętność użycia do myślenia o działalności gospodarczej kategoriami „kalkulacji maszynowej i zasad organizacji”.

Taki zaś niewykształcony teoretycznie kierownik przedsiębiorstwa przypomina w okresie panowania wysokiego standardu technicznego i skomplikowanego systemu gospodarczego „kapitana statku bez wykształcenia nawigacyjnego” (Skowroński 1948: 89-90). Przedsiębiorcy zaczynali więc działalność bez odpowiedniego przygotowania i „nawet w dziedzinie technicznej” musieli polegać na własnej pomysłowości. Zresztą, zdaniem Skowrońskiego, takim samym wyzwaniom stawiali czoła wszyscy przemysłowcy amerykańcy i europejscy.

22 Informacja o tej działalności Skowrońskiego pochodzi z roku 1965 i nie precyzuje, kiedy autor Istoty i przedmiotu nauki o przedsiębiorstwie prowadził firme//firmy, ani jaki to był podmiot/były podmioty gospodarczy/gospodarcze (Lipiński 1965).

23 Taka sytuacja, czyli większościowy udział cudzoziemców w tworzeniu przedsiębiorczości na ziemiach polskich jest faktem, który trudno byłoby podważyć. Niekoniecznie jednak trzeba go interpretować jako słabość naszej kultury, ostatecznie wybieranej przecież przez większość wspomnianej grupy jako docelowa (szerzej o tym zob. par. 3.5).

24 Najwyraźniej Skowrońskiemu chodziło o tayloryzm. 
Cytowany autor negatywnie oceniał też polskiego przedsiębiorcę okresu międzywojennego. Skowroński uważał, iż zasady zarządzania wynikające z nauki o organizacji zaczęły się przyjmować na terenie naszego kraju - i to też w stopniu ograniczonym - dopiero po wizycie Wallace'a Clarka, który między innymi zorganizował warszawskie przedsiębiorstwo Lilpopa, Raua i Loewensteina zajmujące się budową wagonów ${ }^{25}$. Był to początek lat 30 . ubiegłego stulecia. Zaś znaczący rozwój firm polskich, oparty na osiągnięciach zachodnich nauk o zarządzaniu, przyniosła dopiero poprawa sytuacji ekonomicznej kraju i uporządkowanie legislacji działalności gospodarczej tuż przed II wojną światową (Skowroński 1948).

Skowroński (1948) zarzucał więc polskim przedsiębiorcom z przeszłości brak fachowej wiedzy i kompetencji menedżerskich. Konsekwentnie, aby zlikwidować niedostatki tak negatywnie ocenianego dziedzictwa, autor wszystkie swoje powojenne publikacje poświęcił regułom nowoczesnego zarządzania przedsiębiorstwem. Oprócz cytowanego przeze mnie często podręcznika, gdy tylko pojawiły się ku temu możliwości, wydał książkę poświęconą głównym zagadnieniom funkcjonowania małego przedsiębiorstwa przemysłowego (1958), a po kilku następnych latach Nowoczesne zasady organizacji przedsiębiorstwa (1965) uznane za pierwsze tego typu opracowanie na rynku polskim (Lipiński 1965) ${ }^{26}$. Początkowo książka ta miała zawierać także część historyczną (omówienie klasycznych zasad organizacji), która ostatecznie pozostała w maszynopisie. Bez dotarcia do tego maszynopisu trudno powiedzieć, czy zawierał on wątki dotyczące dziejów polskiej przedsiębiorczości. Do innych publikacji Skowrońskiego należą Ekonomika przedsiębiorstwa - zasady organizacji przedsiębiorstwa (1968), Metody podejmowania decyzji w przedsiębiorstwie (1969), zawierające historyczny zarys rozwoju metod kontroli kierowniczej, ale bez polskich odniesień oraz Nowoczesne kierunki zarzadzania i szkolenia w przedsiębiorstwie (1969). Warto przy tym zauważyć, iż Antoni Skowroński, oddany orędownik nowoczesności w zarządzaniu, posiadający tytuł doktora, najlepiej zauważony został wchodząc na rynek publikacji naukowych opracowaniem historii myśli ekonomicz-

25 Sprawozdanie z tych prac opublikował po angielsku Międzynarodowy Instytut Naukowej Organizacji w 1933 roku (Skowroński 1948).

26 Ta ocena książki Skowrońskiego, wyrażona przez luminarza polskiej ekonomii Edwarda Lipińskiego we wstępie do wspominanej publikacji dotyczyła oczywiście czasów im współczesnych, to jest po 1956 roku. Pierwszy, nowoczesny na swoje czasy, polski podręcznik ekonomiki przedsiębiorstwa, jak inaczej Lipiński nazywał omawianą dziedzinę, wydał tuż przed wybuchem II wojny światowej Józef Lisak pod tytułem Ekonomia jednostkowa (1939, zob. także Czech 1997 i 1999). Później, pod koniec lat czterdziestych była oczywiście omawiana Istota i przedmiot nauki o przedsiębiorstwie samego Skowrońskiego, o czym zresztą Lipiński (1965) pośrednio wspominał. „Pierwszeństwo” książki Nowoczesne zasady polegało więc na próbie przedstawienia czytelnikowi polskiemu najnowszego ówczesnego stanu wiedzy, która od czasu cytowanych prac radykalnie się zmieniła w dość szczegółowych zakresach i możliwościach jej aplikacji. 
nej. W 1928 roku poznański „Skład Główny Geberthner i Wolf” wydał jego pracę poświęconą Władysławowi Ochenkowskiemu (1840-1908), polskiemu ekonomiście przełomu XIX i XX wieku. Poglądy tego lwowskiego profesora Skowroński (1928: 204) interpretował jako wyraz prądu myślowego mającego na celu „zharmonizowanie kierunku liberalnego i społecznego w programie umiarkowanej interwencji państwowej”. Wskazywał, iż analizowana koncepcja była wprawdzie zależna od myśli zachodniej, co jednak nie zmienia faktu, iż stanowiła głęboko przemyślaną i naukowo uzasadnioną próbę syntezy dwóch odmiennych perspektyw ekonomicznych. Skowroński (1928: 204) podkreślał ponadto, iż ,jest ona niejako wyrazem całego życia autora, w którym każde jego poczynanie było dążeniem do syntezy".

Trudno nie zauważyć faktu, iż historyczna praca późniejszego propagatora najnowszych rozwiązań w zarządzaniu była jego dialogiem z problemami współczesności ${ }^{27}$. Nietrudno też odnaleźć podobieństwa zawartych w niej myśli do późniejszej drogi naukowej autora, co pokazuje choćby tematyka zasygnalizowanych przeze mnie publikacji Skowrońskiego. Wszystkie są wyrazem poszukiwań przez autora nowoczesnych sposobów pracy efektywnego przedsiębiorcy, zdolnego do uogólniającej refleksji i wrażliwego na problematykę społeczną. Przypadek Antoniego Skowrońskiego zasługuje więc na oddzielne opracowanie (które uwzględni także uwarunkowania historyczne, w jakich przyszło rozwijać swe poglądy omawianemu przedsiębiorcy oraz teoretykowi przedsiębiorczości) dotyczące możliwych związków zainteresowania przeszłością i innowacyjnością zarazem.

Powrócę teraz do zagadnień dziejów polskich przedsiębiorców zamieszczonych na kartach podręczników dla ich współczesnych następców. Nieco odmienny w stosunku do wersji Skowrońskiego obraz przeszłości zarysował prawie dziesięć lat przed nim Józef Lisak (1939, II wyd. 1946), autor wydanej tuż przed II wojną światową Ekonomii Jednostkowej, która była pierwszą na rynku polskim nowoczesną publikacją z zakresu zarządzania przedsiębiorstwem (zob. Czech 1997, 1999). Józef Lisak - doktor UJ i organizator edukacji ekonomicznej na Górnym Śląsku - tylko marginalnie, pośrednio zasygnalizował swoje poglądy dotyczące historycznych korzeni polskich przedsiębiorców. Przy okazji omawiania dziejów tak zwanych stosunków pracowniczych (relacji pracownik-pracodawca) stwierdził polemicznie wobec także do dziś panujących poglądów: „błędnym jest mniemanie, jakoby ostatni wiek przyniósł zaczątki

27 Być może taką naturę ma każda dobra książka historyczna. Pomijam tu przypadki publicystycznego czy ideologicznego nadużywania historii do celów doraźnych. Gdy Skowroński publikował cytowaną pracę o Ochenkowskim (koniec lat 20. XX wieku), problematyka interwencjonizmu państwowego była bardzo aktualna także w Polsce. Na marginesie warto zauważyć, że poszukiwanie syntezy liberalizmu i interwencjonizmu nie jest odległe także od treści niektórych dyskusji dotyczących kryzysu gospodarki światowej 2007. 
przemysłu w Polsce i jakoby Polska królewska była krajem wyłącznie rolniczym" (Lisak 1939: 251). Tradycje przemysłowe naszego kraju Lisak (1939: 255) odnajduje już we wzmiankach z Kroniki Polski Wincentego Kadłubka, a wspomnianą ewolucję stosunków pracowniczych na polskich ziemiach, którą krótko omawia aż do 1918 r., kończy konkluzją, iż były one wtedy u nas nie najlepsze, ale „podobnie zresztą było i za granicą”. Główna trudność Polaków odzyskujących niepodległość polegała na tym, że gdy w innych krajach potrzebne były tylko reformy, oni zmuszeni byli budować przemysł od podstaw i to jeszcze „budować z tak fatalnych dziedzictw lat minionych”. W cytowanej pracy Lisaka (1939) uwagi z zakresu historii dotyczą tylko zarządzania ludźmi. Dalsze analizy dorobku cytowanego autora powinny wykazać, na ile te spostrzeżenia dotyczące uwarunkowań historycznych moża rozszerzyć także na całą tradycję przedsiębiorczości na terenie Polski. Trudno mi wskazać współczesne przykłady tego typu. Symptomatyczne mogą być tutaj prace naukowe i dydaktyczne Beaty Glinki z Wydziału Zarządzania Uniwersytetu Warszawskiego. O ile publikacja habilitacyjna tej uczonej Kulturowe uwarunkowania przedsiębiorczości w Polsce (Glinka 2008) zawierała odniesienia do tradycji polskiej przedsiębiorczości, choć tylko za pośrednictwem dziejów literatury, to już najnowszy podręcznik jej autorstwa i Svetlany Gudkovej Przedsiębiorczość (2011) ogranicza treści historyczne do obecności problematyki związanej z przedsiębiorczością w dziejach myśli ekonomicznej. Z kolei zachodni, przetłumaczony na język polski podręcznik - książka Roberta B. Mellora z zespołem (wyd. pol. 2011, oryg. ang. 2009) Przedsiębiorczość, zawiera wprawdzie historyczne przykłady firm, ale tylko w dwóch zaledwie przypadkach sięgają one czasów wcześniejszych niż ósma czy dziewiąta dekada ubiegłego stulecia.

Edukacyjny walor dziejów „ludzi interesu”, o który walczył przed laty Kołodziejczyk, staje się więc wyraźnie dziś zagubiony. Na kartach prac polskich autorów chlubnym wyjątkiem pozostaje firma Andrzeja Blikle, dość często analizowana przez badaczy i popularyzatorów zarządzania, bardziej jednak w perspektywie jej aktualnych osiągnięć niż tradycji (jeden $\mathrm{z}$ ostatnich przykładów zob.: Woźniak 2012).

Porzucając kwestię treści podręczników, ale nie związaną z nimi problematykę, warto zauważyć, iż wspominane wcześniej badania powstałe w środowisku Kołodziejczyka, malujące jednoznacznie pesymistyczny obraz polskiego przedsiębiorcy z przeszłości przedstawiony przez Skowrońskiego (1948), znalazły dla lat międzywojennych kontynuację dopiero ostatnio. Chodzi przy tym o perspektywę ogólnopolską.

Prace badawcze ograniczone do dziejów przemysłowców Warszawy, Łodzi, Poznania czy Krakowa rozwijają się bowiem dość dynamicznie i kumulatywnie. Biorąc pod uwagę tylko przykład problematyki warszawskiej, można wyróżnić trzy wyraźne płaszczyzny rekonstrukcji dziejów przedsiębiorczości lokalnej. 
Pierwszą wyznaczają prace sensu stricto naukowe, choć niekoniecznie powstające w ramach formalnych instytucji badawczych. Przez długi okres głównym ich ośrodkiem była, mniej więcej od końca lat 50. ubiegłego stulecia, Sekcja Historii Warszawy Towarzystwa Miłośników Historii oraz utworzona w 1968 roku Pracownia Badania Dziejów Warszawy Instytutu Historii PAN, później działająca jako Komisja Badania Dziejów Warszawy. Z obydwoma środowiskami związane są prace Mariana Marka Drozdowskiego (np. 1976 i wiele innych, był on wieloletnim kierownikiem wspominanych podmiotów), który pomiędzy różnymi wątkami swych zainteresowań varsavianistycznych, ze szczególnym uwzględnieniem międzywojnia, znalazł także miejsce na wzmianki o stołecznej przedsiębiorczości a także prace wspomnianego już Jana Górskiego (np. 1990), dotykającego badawczo problematyki spontanicznego „wybuchu” drobnych inicjatyw gospodarzy na ulicach Warszawy po wyzwoleniu kolejnych jej części spod okupacji hitlerowskiej. Wspomniane środowiska promowały także publikacje dotyczące wyłącznie dziejów warszawskiej przedsiębiorczości, czego przykładem są omawiane dalej prace Kordiana Tarasiewicza.

Obecnie inicjatywę badania omawianej problematyki wyraźnie przejęły instytucje społeczne, takie jak Fundacja „Cultus” merytorycznie animowana przez Tadeusza Władysława Świątka i Rafała Chwiszczuka czy Stowarzyszenie „Nasz Norblin”, którego koordynatorem jest Krzysztof Wittels, potomek założyciela znanej warszawskiej spółki „Norblin, Bracia Buch i T. Werner”. Obydwie organizacje realizują różnorodne projekty, dotyczące - jako głównego lub pobocznego przedmiotu zainteresowania - dziedzictwa stołecznych przedsiębiorców. Wykorzystują one między innymi techniki historii wizualnej, lącznie ze stronami internetowymi (zob. np. Chwiszczuk 2006, a szczególnie „Made in Warszawa" 2008). Reprezentatywnym przejawem dokonań badawczych omawianych środowisk są publikacje niezależnego varasavianisty wspomnianego Tadeusza Władysława Świątka, który współpracuje zarówno z „Cultusem”, jak i z „Naszym Norblinem”. Dzieje poszczególnych warszawskich przedsiębiorstw prezentował on już i prezentuje nadal w swoich pracach na temat przeszłości poszczególnych dzielnic czy obszarów miasta (np. 2006, Świątek i Chwiszczuk 2012). Przede wszystkim jednak jest on autorem kluczowej dla badacza historii działań gospodarczych na terenie stolicy monografii Rody warszawskie (Świątek 2007, zob. także Markiewicz i in. 2010). Większość rodzin badanych przez Świątka zajmowało się przedsiębiorczością na przestrzeni od XVIII do XX wieku. Cytowana książka stanowi więc istotny przyczynek do alternatywnej, obok historii politycznej, militarnej i kulturowej, wizji dziejów miasta, uzupełniającej wspomniane perspektywy poprzez biografie rodzinne. Prace Świątka, aczkolwiek osadzone w lokalności, zawierają często informacje istotne dla historii organizacyjnej, a także gospodarczej znacznie przekraczające obszar samej tylko Warszawy. Na przykład przy okazji opisu aktywności 
na naszym rynku Towarzystwa Akcyjnego Telefonów Cedergren i Zakładów Oświetleniowych Philipsa cytowany autor analizuje efektywne działania władz Polski międzywojennej, dotyczące zabezpieczenia krajowych interesów wobec obcego kapitału. Pierwsza z wymienionych firm, szwedzka, zajmująca się telefonią i istniejąca w Warszawie od 1901 roku, dwadzieścia cztery lata później stała się przedsiębiorstwem wyłącznie polskim. Z kolei umowa dotycząca Philipsa, który wchodził do naszego kraju na początku drugiej dekady ubiegłego wieku, gwarantowała, iż „ponad 50\% akcji nowej inwestycji miała należeć do państwa polskiego oraz prywatnych udziałowców krajowych" (Świątek 2007: 122). Na oddzielną dyskusję, sprowokowaną właśnie przez historię organizacyjną, zasługuje brak tego typu klauzuli podczas powrotu omawianej firmy do Polski po 1989 roku. Prace Świątka (2007, 2012, także Markiewicz i in. 2010) stanowią również ciekawy materiał do analizy procesów dobrowolnej inkulturacji dużej części cudzoziemców, wśród nich luminarzy polskiej przedsiębiorczości, którzy stawali się „Polakami z wyboru”. Problemu tego, wymagającego oddzielnej analizy, dotykam w dalszej części niniejszej książki (zob. rozdz. V, podrozdz. 5.1.).

Druga płaszczyzna rekonstrukcji dziejów lokalnej przedsiębiorczości na przykładzie Warszawy to wynik poszukiwań poznawczych historycznie zorientowanych publicystów. Dużo materiałów tego typu zawierały klasyczne już dziś prace Jerzego Kasprzyckiego (Kasprzycki i Stępień 1971 i nast., Kasprzycki 2000 i nast., zob. także kontynuacje: Kasprzycki i Majewski 2006, Zieliński i in. 2012) oraz Olgierda Budrewicza (zob. szczególnie 1990, także 1964, 1966, 2008 i 2009 i in.). Dziś skłaniają one między innymi do konstatacji, iż niestety szereg przejawów przedsiębiorczych działań warszawiaków z przeszłości, zauważonych przez publicystów, nie doczekało się dotąd uwagi profesjonalnych historyków i pozostają ciekawostką pozbawioną krytycznego opracowania. Obecnie podobną tematykę kontynuują na przykład wspomniany już Rafał Chwiszczuk (2006), Stanisław Milewski (2010), a przede wszystkim Magdalena Stopa, która oprócz serii książek o starych kamienicach i ich mieszkańcach, publikacji wiernych duchowi Pożegnań warszawskich Kasprzyckiego wydaje także szereg książek poświęconych wyłącznie tradycjom warszawskiego rzemiosła oraz drobnej przedsiębiorczości (Stopa i Brykczyński 2007, Stopa 2010, Stopa i Capani 2012). Warto wykorzystać je jako materiał do analiz zarówno historyków, jak i teoretyków organizacji.

W jeszcze większym stopniu niż autorskie opracowania publicystów, przedmiotem uwagi badaczy przeszłości i teraźniejszości biznesu powinny stać się dziennikarskie utrwalenia historii mówionej. Stanowią one moim zdaniem trzecią płaszczyznę ujmowania tradycji przedsiębiorczości lokalnej. Dla historii organizacyjnej są rodzajem źródła, nie tylko z powodu niedostatku archiwaliów (nieco szerzej o historii mówionej w zarządzaniu zob. par. 6.1., rozdz. VI niniejszej pracy). Obecnie obszerny projekt tego typu finalizuje Justyna Krajewska 
(2013). Głównym kryterium jej zainteresowania są autobiografie zakorzenione w stolicy. Autorka zdobyła między innymi tak unikatowe opowieści, jak narracje Władysława Matkowskiego - jednego z ostatnich pracowników firmy „Pluton”, Tomasza Gesslera, potomka lwowskiej firmy „Baczewski” restytuującego aktualnie działalność wspomnianego przedsiębiorstwa w Polsce, Zygmunta Gebethnera, przedstawiciela rodu znanych księgarzy czy Jana Jabłkowskiego, który nie tylko od lat intensywnie działa w zakresie przywrócenia krajobrazowi Warszawy „Domu Braci Jabłkowskich”, ale także wykorzystuje doświadczenie swoich przodków do zarządzania innowacyjnym instytutem badawczo-wdrożeniowym ${ }^{28}$. Do ustaleń Krajewskiej kilkakrotnie odwołuję się na kartach prezentowanej pracy ${ }^{29}$. Choćby przytoczone przykłady jej rozmówców pokazują, iż wspomniany projekt, aczkolwiek „warszawski”, to niesie także wątki znacznie przekraczające wymiar lokalności.

Wracając na poziom ogólnokrajowy, warto podkreślić, iż niedawno została opublikowana praca Marii Barbasiewicz Ludzie interesu w przedwojennej Polsce (2013) - pionierska analiza działań gospodarczych 14 polskich przedsiębiorców prowadzących duże i mniejsze przedsięwzięcia w okresie międzywojnia. Autorka pracy opisała zróżnicowaną grupę reprezentantów branży finansowej, odlewniczej, chemicznej, spożywczej (wyroby czekoladowe), browarniczej, garbarskiej, tkackiej i mediów, kierując się przekonaniem, iż „często wiemy więcej o przemysłowcach i fabrykantach końca XIX wieku niż o przedsiębiorcach dwudziestolecia” (Barbasiewicz 2013: 10). Charakterystykę działalności tych ostatnich osadziła na szerokim tle historii gospodarczej tamtych lat. Dokonała też pewnych porównań. Jej zdaniem, na przykład dyspozycje osobowościowe, które sprzyjały sukcesom bohaterów omawianej książki, to „rzutkość, odwaga, wiedza, umiejętność lawirowania wśród zmieniających się okoliczności gospodarczych i politycznych, także szczęście i pewna bezwzględność" (Barbasiewicz 2013: 11). Badaczka przeszłości pokusiła się też w tym kontekście o publicystyczną generalizację, twierdząc, że nic się zmieniło do dziś jeśli chodzi o funkcjonalne znaczenie wymienionych cech także na współczesnym rynku. Za wspólny dla analizowanych przez siebie, subiektywnie wybranych przedsiębiorców międzywojnia Barbasiewicz (2013: 400) uznała stosunek do wyzwań zawodowych, który charakteryzował „przede wszystkim dbałość o wizerunek firmy, wykorzystywanie koniunktury i umiejętność konfrontacji z biznesowymi przeciwnościami" oraz specyficzne relacje z pracownikami charakteryzujące się połączeniem wysokich wymagań i pewnej opieki socjalnej, zróżnicowanej

28 Jan Jabłkowski, syn Feliksa Jabłkowskiego, ostatniego właściciela „Domu Braci Jabłkowskich", jest dyrektorem Przemysłowego Instytutu Automatyki i Pomiarów PIAP w Warszawie.

29 Serdecznie dziękuję Autorce za udostępnienie mi jej książki będącej aktualnie (lato 2013) w trakcie procesu wydawniczego. 
zależnie od kondycji przedsiębiorstwa oraz osobistego poczucia odpowiedzialności właściciela za podwładnych. Równocześnie cytowana autorka przestrzega przed generalizowaniem ostatniej z wymienionych charakterystyk. Przypadki bezwzględnego wyzysku zatrudnionych oraz braku troski o ich bezpieczeństwo też należą do dziejów polskiej przedsiębiorczości lat międzywojennych, co potwierdza część krytyki formułowanej przez Skowrońskiego (1948).

Konwencja wydawnicza niestety wymusiła na autorce omawianej publikacji rezygnację z przypisów. Nie powinno to jednak wprowadzać czytelnika w błąd co do wartości poznawczych Ludzi interesu w przedwojennej Polsce. Książka Barbasiewicz (2013) jest pracą historyczną, opartą na bogatym materiale źródłowym, choć zgodnie z tradycją historiografii anglosaskiej napisaną tak, by „była do czytania”. Braki w zasobach dokumentów archiwalnych badaczka zrównoważyła wykorzystaniem literatury wspomnieniowej, opracowań badaczy i miłośników dziejów regionalnych, kontaktami z rodzinami opisywanych przedsiębiorców oraz różnymi formami historii mówionej. „Zbieranie tych informacji - można porównać do gromadzenia pojedynczych puzzli układanki. Trzeba mieć detektywistyczne skłonności, by pisać o ludziach interesu Drugiej Rzeczypospolitej” - podsumowuje Barbasiewicz metodologię swej pracy (2013: 10). Przytoczona konkluzja nadal jest aktualna także dla innych okresów i tematów z dziejów polskiej przedsiębiorczości.

\subsubsection{Kordian Tarasiewicz jako historyk dziejów przedsiębiorczości}

W zarysowanej $\mathrm{w}$ poprzednim paragrafie sytuacji warto moim zdaniem spojrzeć nieuprzedzonym okiem na próby pisarstwa historycznego, podejmowane przez niektórych polskich praktyków prywatnej działalności gospodarczej. Próby te, aczkolwiek zazwyczaj skupione na wąskiej problematyce dziejów firm autorów lub ich przodków bądź przyjaciól, pisane z pozycji wykształconych laików, stanowią zarówno przyczynek do wątłego nurtu badania tradycji rodzimej przedsiębiorczości, jak i są okazją uwzględnienia także polskich doświadczeń w „historycznym zwrocie” w zarządzaniu.

Obydwa wspomniane aspekty egzemplifikuje w niniejszym paragrafie działalność przedsiębiorcza oraz dziejopisarska Kordiana Tarasiewicza ${ }^{30}$ (ur. 1910). Jest on wnukiem założyciela i synem kolejnego właściciela, a sam był ostatnim

30 Podwaliny niniejszego podrozdziału stanowią rozmowy, które prowadzę z Kordianem Tarasiewiczem od czerwca 2010 roku, uzupełnione dokumentami z archiwum domowego tegoż i z Archiwum Miasta Warszawy oraz publikacjami naukowymi, popularyzatorskimi i wspomnieniowymi: Tarasiewicza (1971, 2009 i 2011), Drozdowskiego i Tarasiewicza (1964), Ihnatowicza (1971), Budrewicza (1990), Poznańskiej (1993), Machlejd (2010) i Stopy (2010). Ważnym źródłem jest także strona internetowa Kordiana Tarasiewicza www. tarasiewicz.info 
dyrektorem Palarni Kawy „Pluton”, działającej na terenie Warszawy w latach 1882-1950. Od 1934 do 1950 roku (kiedy to firmę zlikwidowały władze PRL-u) kierował nią właśnie Kordian Tarasiewicz (zob. par. 6.2. rozdziału VI niniejszej pracy). Lata stalinowskie były dyrektor palarni kawy przetrwał jako pracownik drobnych firm prywatnych, pralni chemicznej, a następnie wytwórni kauczuku, która została wchłonięta przez Centralę Przemysłowo-Handlową „Inco”. Wówczas były dyrektor „Plutona” został dyrektorem handlowym ostatniego z wymienionych przedsiębiorstw (1953-1956). „Odwilż” w 1956 roku także Kordianowi Tarasiewiczowi zwiększyła możliwości wyboru miejsca pracy. W 1959 roku stał się on członkiem zarządu „Libelli”, spółki założonej przez środowisko warszawskiego Klubu Inteligencji Katolickiej. Od 1965 do 1977 roku, gdy firma służyła KiK-owi, był jej dyrektorem naczelnym. Po dziesięciu latach i kolejnych zmianach własnościowych Kordian Tarasiewicz wrócił do „Libelli” jako członek Rady Nadzorczej, a na wiele lat jako przewodniczący tej struktury, prowadząc wspomnianą działalność do 2002 roku. Zarówno w „Inco”, jak i w „Libelii”” konsekwentnie kontynuował tradycję „Plutona”. Obecnie, mimo przekroczenia stu lat, nestor warszawskich przedsiębiorców czynnie rozwija zainteresowania życiem politycznym i gospodarczym. Między innymi współpracuje z Centrum im. Adama Smitha. Okazjonalnie przekazuje swoje doświadczenie także studentom Wydziału Zarządzania i Wydziału Stosowanych Nauk Społecznych Uniwersytetu Warszawskiego.

Od końca lat 50. ubiegłego stulecia Kordian Tarasiewicz pisze oraz sukcesywnie publikuje artykuły i książki o charakterze wspomnieniowym, popularyzatorskim a także sensu stricto historycznym. Zresztą te pierwsze, o czym nieco szerzej wspomnę dalej, także wnoszą swój wkład do polskiej historiografii czasów najnowszych. Zaś u genezy tych ostatnich zawsze leży osobiste doświadczenie autora. Początek działalności pisarskiej Kordiana Tarasiewicza wyznacza jego opracowanie Kronika domu Grzybowska 37. nr hip. 37, wyróżnione na konkursie zorganizowanym przez Prezydium Rady Narodowej m.st. Warszawy w 1961 roku. Pięćdziesiąt dwa lata później jako oddzielną książkę opracowanie to opublikowało Wydawnictwo VEDA (Warszawa 2013). Po wspomnianej nagrodzie sukcesywnie następowały publikacje artykułów na łamach „Biuletynu Polskiego Związku Tenisowego” „Stolicy”, „Mówią Wieki”, „Kroniki Warszawy”, „Rocznika Warszawskiego”, a także w pracach zbiorowych zarówno wspomnieniowych, jak i naukowych. Do dziś Tarasiewicz jest autorem lub współautorem dziesięciu książek ${ }^{31}$. Napisał również monografię swej rodzinnej firmy (1971) oraz opracowanie analizujące branżę herbaciano-kawową na ziemiach polskich w perspektywie historycznej z uwzględnieniem aspektów obyczajowych (Tara-

31 Cztery z nich dotyczą problematyki tenisowej (ze szczególnym uwzględnieniem dziejów tej dyscypliny sportu). 
siewicz 2009). Popularyzatorskiemu ujęciu tej problematyki cytowany autor poświęcił oddzielną publikację Przygody $z$ kawa $i$ herbata (Tarasiewicz 2001). Najbardziej znaną książką Kordiana Tarasiewicza okazała się autobiografia Cały wiek $w$ Warszawie. Wydana dwukrotnie, była głównym argumentem dla jury nagrody literackiej im. Witolda Hulewicza, które w 2011 roku przyznało warszawskiemu przedsiębiorcy Wielką Nagrodę „za pracę jego życia dla Polski zwieńczoną" właśnie wspomnianą publikacją. Ostatnio (2013) bohater niniejszego podrozdziału opublikował na zamówienie Wydawnictwa PWN kolejną książkę: Zapach świeżej kawy w opracowaniu naukowym niżej podpisanego. $\mathrm{W}$ porównaniu $\mathrm{z}$ poprzednimi pracami, w tej rozwinięte są wątki związane z zarządzaniem, a jej część integralną stanowi wybór wspomnień pracowników.

Prace osób pokroju Kordiana Tarasiewicza, czyli doświadczonych biznesmenów, a jednocześnie wykształconych laików, którzy opanowali podstawy warsztatu badawczego historyka, stanowią istotne uzupełnienie naszkicowanej przeze mnie sytuacji. $\mathrm{Z}$ jednej strony nadają one dziejom przedsiębiorczości walor osobisty i praktyczny zarazem, a z drugiej pokazują wręcz instrumentalną aktualność dawnych doświadczeń dla ludzi dzisiaj podejmujących przedsięwzięcia gospodarcze. I dotyczy to zarówno publikacji sensu stricto historycznych, jak i wspomnień, mających istotną wartość źródłową (zob. Szarota 2010). W wypadku prac Tarasiewicza, o czym pisałem już wcześniej, granice między wspomnianymi rodzajami pisarstwa są płynne. Autobiografię autor kończy następującą uwagą o swej monografii „Plutona”, uwagą która dobrze ilustruje wcześniejsze stwierdzenia z tego akapitu:

„Okazało się też, że moja książka (Kawa po warszawsku - dopisek T.O.) miała odniesienia jak najbardziej współczesne. Otóż leżąca na tej samej, co moja żona, sali w szpitalu pani usłyszawszy nasze nazwisko zapytała, czy jesteśmy rodziną autora Kawy po warszawsku. Opowiedziała, że jej mąż, chcąc się przekwalifikować z urzędnika na przedsiębiorcę, poszedł na Wydział Zarządzania Uniwersytetu Warszawskiego, gdzie profesor poradził mu, aby - jeśli chce zostać przedsiębiorcą - przestudiował ... Kawę po warszawsku. Nie będę ukrywał, że autorowi miło coś podobnego usłyszeć” (Tarasiewicz 2010: 297).

Nie znając zaleceń wspomnianego profesora, którego tożsamości nie udało mi się dotąd ustalić, realizuję od kilku lat na tymże Wydziale Zarządzania UW, studium przypadku wykorzystujące jedenasty rozdział książki Caly wiek $w$ Warszawie zatytułowany Praktyka $w$ Plutonie $i$ kierowanie firma. Ta część autobiografii Kordiana Tarasiewicza opisuje jego działania przedsiębiorcze z lat trzydziestych ubiegłego stulecia. Przytoczone wspomnienia, wzbogacone o inne informacje źródłowe ${ }^{32}$, pozwalają na skonstruowanie użytecznego dydaktycznie wstępu do

32 Poza Calym wiekiem... przy konstrukcji i realizacji wspomnianego studium przypadku wykorzystuję także Kawę po warszawsku, moje rozmowy z autorem z lat 2010-2102 oraz materiały prasowe dotyczące „Plutona”. 
takich zagadnień jak kultura organizacyjna, społeczne otoczenie organizacji, zarządzanie przedsiębiorstwem, zarządzanie zmianą i zarządzanie kryzysowe ${ }^{33}$.

Wspominana już wielokrotnie Kawa po warszawsku stanowi, co warto raz jeszcze podkreślić, główną pracę Kordiana Tarasiewicza, sensu stricto historyczną. Ostatecznie została opublikowana w 1971 roku, jednak wyraźnie była owocem wieloletnich zainteresowań autora tradycjami rodzinnej firmy, a także, szerzej, dziejami polskiej przedsiębiorczości. Już podczas II wojny światowej dyrektor „Plutona” zainicjował pisanie wspomnień przez pracowników ${ }^{34}$. Pieczołowicie dbał też o archiwum przedsiębiorstwa, które jednak uległo znacznemu zniszczeniu. Ocalałe z wojennej pożogi dokumenty Tarasiewicz przechował w archiwum domowym, a część stopniowo deponował w Archiwum Miasta Stołecznego Warszawy i w Bibliotece Narodowej. Dziś, niestety, nie wszystkie archiwalia można tam odnaleźć35.

Do podjęcia szerszych prac historycznych byłego dyrektora „Plutona” ośmieliła varsavianistyczna nagroda za Kronike domu Grzybowska $37 \mathrm{nr}$ hip. 1050 (1961 rok). Pomysł napisania dziejów swej firmy Kordian Tarasiewicz przedstawił Witoldowi Kuli, a więc osobie chyba najbardziej wówczas kompetentnej w zakresie historii przedsiębiorczości. Ten znany badacz zakwestionował jednak możliwości poznawcze biznesmena, argumentując, iż monografia przeszłości firmy wymaga warsztatu profesjonalnego historyka. Tarasiewicz znalazł dla swych zamiarów intelektualne wsparcie wśród varsavianistów. Poznany na forum Towarzystwa Miłośników Historii Marek Marian Drozdowski zachęcił bohatera niniejszego szkicu, by ten zrealizował pomysł napisania historii „Plutona”. Pierwszym etapem naukowej współpracy obydwu zainteresowanych był wspólny artykuł Rozwój przemystu Warszawy w latach 1918-1939, opublikowany na łamach „Rocznika warszawskiego” w 1964 roku. Po następnych siedmiu latach Gospodarczy Instytut Wydawniczy, oficyna założona przez byłą Izbę Przemysłowo-Handlową, znana z tematyki handlowo-przemysłowej, wydała Kawę po warszawsku jako pięćdziesiąty czwarty tom varsavianistycznej

33 Po realizacji jednej $\mathrm{z}$ pierwszych wersji tego studium przypadku otrzymałem od studenta informację, iż istnieje strona internetowa K. Tarasiewicza. Tak zaczęła się moja bezpośrednia współpraca $\mathrm{z}$ nestorem warszawskich przedsiębiorców. Warto przytoczyć reakcję jednego z moich młodszych kolegów - wykładowców: Michał Mijal, który po uczestnictwie w realizacji studium przypadku „Plutona” zwrócił mi żartobliwie uwagę, że niepotrzebnie podkreślam, iż opisuję sytuację sprzed II wojny światowej. Zarówno bowiem ówczesne problemy, jak i rozwiązania przyjmowane przez Tarasiewicza są jak najbardziej aktualne.

34 Wspomnienia pracowników pisane na prośbę właściciela firmy są oczywiście obciążone cechami „historii dworskiej”. Jednak Tarasiewicz traktuje je przede wszystkim jako źródło nieznanych sobie faktów, lub poszerzenia wiadomości na temat różnych wydarzeń z dziejów przedsiębiorstwa, a nie jako nośniki opinii czy ocen. Fragmenty tych relacji ukazały się w wydanej w marcu 2013 roku książce Zapach świeżej kawy.

$35 \mathrm{Z}$ niewiadomych przyczyn zaginęła teczka Tarasiewicza w Bibliotece Narodowej. 
serii Instytutu Historii PAN - Biblioteki Historycznej im. Tadeusza Korzona. Publikacja opierała się na trzech rodzajach źródeł: na archiwaliach domowych autora i dokumentach z licznych archiwów instytucjonalnych, na literaturze przedmiotu oraz na wspomnieniach i spisanych relacjach pracowników „Plutona" różnych szczebli, od robotników i sprzedawców po członków kierownictwa firmy. Taką różnorodność materiałów Tarasiewicz wykorzystywał dla potrzeb większości swoich publikacji, łącznie z pracami autobiograficznymi. Te ostatnie różniły się od książek czy artykułów o zacięciu naukowym jedynie stopniem świadomej subiektywności autora. Nawet bowiem w omawianej monografii „Plutona” Tarasiewicz wolny jest od pozytywistycznego dążenia do „obiektywizmu za wszelką cenę”. „Mimo rzetelnego wysiłku, aby praca (Kawa po warszawsku - uwaga T.O.) była możliwie obiektywna, trudno było autorowi uniknąc spojrzenia subiektywnego, wynikającego z osobistego zaangażowania wieloletnią pracą w przedsiębiorstwie" (Tarasiewicz 1971: 6).

Cytowana praca wyraźnie więc nawiązuje - przy czym chodzi o nawiązanie oczywiście mimowolne, niejako „antycypacyjne” - do modelu „badania zaangażowanego" (ang. advocasy research), który ponad dziesięć lat po ukazaniu się dziejów „Plutona” zaproponował amerykański psychohistoryk Robert Jay Lifton (1983 i 1986, zob. także Grzywacz i Ochinowski 2003). Podstawę wspomnianego stanowiska metodologicznego stanowi „zasada wyartykułowanej subiektywności”. Badacz świadomy własnego subiektywizmu ma łączyć zaangażowanie ideowe $\mathrm{z}$ odpowiednim stopniem bezstronności. Pierwszy z wymienionych elementów, osobiste zaangażowanie czy raczej zaangażowania, które zadaniem autora danej pracy badawczej mogą wpływać na proces poznawania rzeczywistości, powinny być ujawnione czytelnikowi. Zaś „odpowiedni stopień bezstronności" zyskuje się poprzez respektowanie metodologii badań - w wypadku modelu Liftona, jak i prac Tarasiewicza - chodzi o metodologię badań historycznych. O spełnienie tego standardu Tarasiewicz zadbał, korzystając przy pisaniu Kawy po warszawsku z pomocy varsavainstki Hanny Szwankowskiej. W ostatecznej redakcji dziejów „Plutona” udział wziął również inny historyk Warszawy - Jan Kosim. Omawiana publikacja stanowi przykład monografii historycznej zrealizowanej z perspektywy - równocześnie - zaangażowania i dystansu (por. Ochinowski 1998). Jak większość prac Tarasiewicza, wyraźnie posiada ona cechy takiego przedstawienia rzeczywistości, które filmoznawcy nazywają „dokumentalizmem osobistym”. Przy czym chodzi tu o najbardziej podstawowe znaczenie tego terminu wiązane z twórczością Stana Braghage'a, który ,przez wiele lat amatorską kamerą $8 \mathrm{~mm}$ kręcił w swoim domu w Colorado filmy pokazujące jego samego, żonę, dzieci, przyjaciół, zwyczajne zdarzenia z jego własnego życia” (Przylipiak 2011: 22, zob. także Pitrus 2011).

Autor Kawy po warszawsku zastrzegał, że ponieważ „nie jest historykiem i poruszając się w sferze problemów historycznych jako amator traktuje swoje 
opracowanie jako referat materiałowy do dziejów warszawskiego przemysłu i handlu" (Tarasiewicz 1971: 6). Jednak podczas pisania omawianej książki jakby zapomniał o cytowanej obiekcji. Dzieje firmy „Pluton” Tarasiewicz osadził na szerokim tle procesów politycznych, społecznych, obyczajowych i gospodarczych $^{36}$, szczególnie jeśli chodzi o czas do I wojny światowej, co właśnie zdaniem cytowanego autora wyróżnia nowoczesną syntezę od opracowań przyczynkarskich. Ważne uzupełnienie kontekstu działania „Plutona” stanowiło także obfite wprowadzenie do omawianej publikacji problematyki konsumpcji kawy w Polsce na przestrzeni dziejów. Wreszcie wielostronna monografia warszawskiej firmy, właśnie ze względu na specyfikę dziejów tego miasta ma znaczenie wykraczające poza studium pojedynczego przypadku. Zniszczenia wojenne i powojenne infrastruktury prywatnego biznesu stolicy, a także związanej z nim dokumentacji sprawiły, iż każda monografia historyczna na ten temat urasta do rangi cennych znalezisk, analogicznych do zdobyczy archeologa. Autor Kawy po warszawsku był tego świadom, podejmując się pracy nad tą publikacją ${ }^{37}$. Bez przesadnej pewności siebie uważał „opisanie działalności firmy »Pluton «, ściśle związanej z dziejami miasta” za, jak to nazywał „mały przyczynek dokumentacji” w zakresie rekonstrukcji dziejów gospodarczych Warszawy.

Trudno się oprzeć refleksji dotyczącej wspomnianego wcześniej „przesunięcia” badawczych działań Kordiana Tarasiewicza z obszaru historii gospodarczej na teren varsavianistyki, stanowiącej - w przeciwieństwie do zainteresowań seminarium Witolda Kuli - raczej niszową, swoiście lokalną dziedzinę poznawania przeszłości. Ograniczyło to znacznie recepcję prac bohatera niniejszego szkicu, także wśród profesjonalnych historyków. Jednocześnie jednak być może pozwoliło ochronić jego publikacje wydawane jeszcze w PRL-u przed radykalnymi ingerencjami cenzury. Kawa po warszawsku wydaje się być książką praktycznie wolną od koncesji na rzecz państwowej ideologii. Jest przecież udokumentowaną źródłowo pochwałą prywatnej przedsiębiorczości, a w swych końcowych partiach bez ogródek opisuje zniszczenie firmy przez stalinowski reżim. Omawianą monografię „Plutona” opublikowano na początku dekady gierkowskiej, a więc okresu pewnego przyzwolenia ideologicznego na umiar-

36 Tarasiewicz między innymi przytacza historię Polaka Jana Kulczyckiego, który po otrzymaniu od Jana III Sobieskiego zdobytych na Turkach zapasów kawy miał założyć pierwszą wiedeńską, a zarazem pierwszą środkowoeuropejską kawiarnię (1683). Božidar Jezernik twierdzi (1999/2011: 193), powołując się na ustalenia Karla Teply'ego, że jest to legenda, która jednak „na zawsze weszła do wiedeńskiej tradycji”. W latach trzydziestych ubiegłego wieku miała miejsce wręcz dyskusja na temat pisowni nazwiska wspomnianego bohatera, a nawet na temat jego narodowości.

37 We Wstepie do Kawy po warszawsku Kordian Tarasiewicz wspomniał tylko o zniszczeniach wojennych. Jednak faktograficzna opowieść zamykająca książkę o zniszczeniu „Plutona” przez stalinowski reżim nie pozostawia wątpliwości, iż autor dobrze zna również straty zadane warszawskiemu, a także szerzej, polskiemu biznesowi po wojnie. 
kowaną pochwałę gospodarki kapitalistycznej ${ }^{38}$. Równocześnie jednak nadal obowiązywał oficjalny sentyment dla pewnych symboli lat stalinowskich, na przykład poprzez nadawanie nazw ulic czy patronów szkół rodem z pierwszego dziesięciolecia PRL-u. W każdym razie zaryzykuję przypuszczenie, iż to przede wszystkim niszowości należy zawdzięczać fakt, iż Kawa po warszawsku mogła się ukazać w takim kształcie, że do dziś nie straciła na wartości ani dla praktyków biznesu, ani dla badaczy przeszłości.

Po latach były dyrektor „Plutona” powtórzył schemat pisarstwa historycznego ze swej pierwszej książki na kartach publikacji Kawa $i$ herbata na ziemiach polskich. Handel, konsumpcja, obyczaje (2009). Tu również autor wykorzystał trojakie źródła: materiały drukowane, archiwalia oraz wspomnienia i własne doświadczenia. Omawiana książka ma charakter szkiców historycznych. W chwili opublikowania była ona pierwszą w Polsce pracą poświęconą genezie oraz ewolucji konsumpcji kawy i herbaty na terenie naszego kraju, a także przemianom w branży. Szeroko uwzględniała kwestie obyczajowe związane z wymienionymi używkami. Kawę i herbatę... można porównać do eseju słoweńskiego etnolga Božidara Jezernika (1999/2011) Kawa, który w oryginale ukazał się dziesięć lat przed omawianą tu książką Tarasiewicza, ale prawie trzy dekady później, niż Kawa po warszawsku, również, co już podkreślałem, dotykająca spraw kultury i obyczaju konsumpcji kawy. Zresztą warto wspomnieć, iż polskiemu czytelnikowi książka Jezernika została udostępniona dopiero w 2011 roku dzięki przekładowi Joanny Pomorskiej dla wydawnictwa Czarne.

Kawę $i$ herbate na ziemiach polskich... opublikowała Oficyna Wydawnicza SGH, a więc uczelnia, na której studia autor przerwał przed laty, by zając się prowadzeniem firmy. $Z$ kolei ostatnio uznanie ze strony środowiska historycznego zdobyła autobiografia Kordiana Tarasiewicza. Cytowany już Tomasz Szarota (2010) w drugim, najnowszym wydaniu swej monografii Okupacyjnej Warszawy dzień powszedni wskazał na Caly wiek $w$ Warszawie jako na podstawowe źródło do badania dziejów stołecznej burżuazji czasów II wojny światowej.

Kordian Tarasiewicz inspiruje także innych do rekonstruowania dziejów przedsiębiorczości. W latach 60. ubiegłego stulecia zachęcił grupę żyjących jeszcze wówczas przemysłowców przedwojennej Warszawy i ich współpracowników, by napisali historię stołecznych przedsiębiorstw prywatnych. Powstałe w ten sposób kilkadziesiąt studiów przypadków zostało zdeponowane w Muzeum Historycznym Miasta Stołecznego Warszawy. W roku akademickim 2013/2014 rozpocznę, we współpracy z Tadeuszem W. Świątkiem, prace redakcyjne nad tym zbiorem źródeł zmierzające do jego wydania.

38 Marcin Wolniewicz z IH PAN zwrócił mi uwagę, iż początek dekady gierkowskiej charakteryzował się oficjalną tendencją do dowartościowania tradycji „pracy u podstaw" zamiast kultywowania ideowej spuścizny powstań. Wspomniana atmosfera mogła oczywiście sprzyjać publikacji takich książek jak Kawa po warszawsku. 
Warto uwadze badaczy przeszłości i teraźniejszości działań gospodarczych polecić również historię mówioną, którą tworzy bohater niniejszego podrozdziału, poprzez liczne wywiady i innego typu wypowiedzi, ze szczególnym uwzględnieniem obszernej relacji dla Archiwum Historii Mówionej Ośrodka „Karta” 39.

Różnorodne świadectwa składane przez Kordiana Tarasiewicza rysują między innymi, czy raczej przede wszystkim, wielowymiarowy obraz firmy „Pluton” na przestrzeni sześćdziesięciu lat jej istnienia od końca XIX wieku do czasu apogeum stalinizmu. Perspektywa historyczna pokazuje omawianą palarnię kawy jako przedsiębiorstwo rodzinne, któremu przyszło funkcjonować w bardzo burzliwych czasach, które mężnie stawiało czoła kolejnym kryzysom, a którego właściciele oraz kierownicy efektywnie poszukiwali równowagi między działalnością firmową i życiem rodzinnym, między biznesem i kulturą, między efektywnością przedsiębiorstwa i działaniem na rzecz jego otoczenia społecznego, między sukcesem rynkowym i troską o pracowników, między ciągłością i innowacyjnością, między intuicją praktyków i ustaleniami nauk dotyczących zarządzania. W tych właśnie wymiarach autobiograficzna perspektywa Kordiana Tarasiewcza może wzbogacić polską i nie tylko polską historiografię dziejów przedsiębiorczości o nowe kierunki analiz, zaś dla współczesnych biznesmenów stać się źródłem dobrych praktyk. Warto też pomyśleć o intelektualnej współpracy badaczy przeszłości z teoretykami i praktykami zarządzania wokół zagadnień, których przykładem są dzieje „Plutona”. Ci pierwsi mają kompetencje, by uchronić tych drugich od błędu prezentyzmu oraz wyjaśnić im kontekst różnych rozwiązań gospodarczych, otrzymując w zamian aparat pojęciowy, wiedzę i doświadczenie biznesowe konieczne do interpretacji takiego właśnie materiału historycznego. Stwarza to wygodne poznawczo pole rozwoju badań w ramach „historycznego zwrotu" na terenie zarządzania nie tylko ograniczone do naszego, lokalnego „podwórka”.

\subsubsection{Podsumowanie ujęcia historii organizacyjnej w niniejszej pracy}

Rekapitulując zaprezentowane dotąd wątki dotyczące historii organizacyjnej, Carroll (2002), a za nim inni badacze oraz teoretycy, ukazali wspomnianą dziedzinę jako interdyscyplinarny obszar badań, naukowej refleksji i zastosowań, czerpiący koncepcje zarówno z teorii organizacji, jak z szerszego spectrum nauk społecznych i humanistycznych (Booth i Rowlinson 2006). Jest ona „dzieckiem” praktyki badawczej, ale stała się oddzielną subdyscypliną dopiero wtedy, gdy została wzbogacona o namysł historiograficzny. Można ją uznać za przejaw dość niespodziewanej „inwazji” historiografii na teren zarządzania, a więc maria-

39 Większość tych narracji dostępna jest na stronie internetowej Kordiana Tarasiewicza. Relacja dla „Karty” została nagrana w 2007 roku (zob. Archiwum... 2007). 
żu typowo teoretycznej nauki kojarzonej przede wszystkim z akademickością i dziedziny także naukowej, ale stanowczo uprawomocniającej swój rozwój wymiarem użyteczności. Wbrew pozorom jednak historiografię oraz zarządzanie łączy głębokie podobieństwo. Obydwie dyscypliny stanowią w swej istocie teoretyczny namysł nad praktyką (praktyką badania przeszłości w wypadku historiografii i praktyką menedżerską, jeśli chodzi o zarządzanie). Należą do sfery praxis, rozumianej za Arystotelesem jako rodzaj wiedzy, której ostatecznym celem jest działanie. Gdy rozwiną wspólpracę, jak proponuje to historia organizacyjna, mogą stać się efektywnym narzędziem dla refleksyjnego praktyka.

Inny charakterystyczny rys historii organizacyjnej stanowi jej istotowa dyskursywność, a mówiąc precyzyjniej - dialogiczność. Wyodrębnienie się omawianej subdyscypliny jest jednym z przejawów krytycznego nurtu zarządzania, zarówno w sensie metodologicznym, jak i ideologicznym. Do grona jej „matek” zalicza się także retorykę. Specyfika charakteryzowanej dziedziny badania przeszłości została pierwotnie określona poprzez opozycje wobec jej „starszej siostry”, tradycyjnej historii biznesu (zob. poglądy Ooia i Kremarka podzielane przez Carrolla 2002). Historia organizacyjna służy między innymi krytyce ahistoryczności różnych koncepcji dotyczących teorii organizacji (szczególnie zob. poglądy Bootha i Rowlinsona 2006). Jednakże nie przebywa tylko w świecie abstrakcji. Choćby potencjalnie pomaga demaskować na przykład opisaną wcześniej stygmatyzuję historią organizacji i jej członków, czy praktyki kreowania oficjalnych wersji dziejów przedsiębiorstwa służące sprawowaniu władzy na terenie korporacji. Zwolennicy historii organizacyjnej z zasady „patrzą na ręce” każdej władzy i tej symbolicznej, kreującej naukowe mody w zarządzaniu, i tym całkiem realnym, kierującym poszczególnymi firmami światem biznesu czy polityki naukowej. W takim sensie historia organizacyjna, respektując metodologiczne standardy naukowości (czego strzegą jej związki z historiografią), może pełnić funkcje krytyki społecznej, stawać po stronie pokrzywdzonych, być nośnikiem apelu „źle ma się kraj”, by sięgnąć do słynnego tytułu ideowego testamentu Tony'ego Jundta (2010). Na koniec warto raz jeszcze podkreślić za Carrollem (2002) konstruktywny potencjał historii organizacyjnej. Wskazując sposoby przewartościowania obrazu przeszłości, zarówno jednostek, jak i organizacji, podsuwa tym samym i jednym i drugim praktyczne narzędzia podnoszenia efektywności działania, a także jakości życia.

Jak wyraźnie widać, historia organizacyjna, podobnie do współczesnej socjologii, z której przecież także pochodzi, nie jest nauką values free, wolną od wartości. Nasuwa się hipoteza wymagająca oczywiście precyzyjnych weryfikacji, iż omawiana subdyscyplina realizuje model „badania zaangażowanego” (ang. advocacy research), sformułowany przed laty przez Roberta Jaya Liftona dla potrzeb analiz dotyczących ludzkich wymiarów doświadczeń dziejowych. Istotę wspomnianego modelu stanowi zasada wyartykułowanej subiektywności: badacz 
świadomy własnego subiektywizmu ma łączyć zaangażowanie ideowe (które wprost artykułuje na kartach swej pracy) z odpowiednim stopniem bezstronności. Spełnienie tego drugiego warunku zapewnia po prostu respektowanie metodologii badań (Lifton 1985, 1987, Strozier i Flynn 1992).

Oczywiście jak każda struktura myślowa, historia organizacyjna może stać się miejscem idei czy działań niegodziwych ${ }^{40}$. Jednak zakorzenienie w krytycznym nurcie zarządzania oraz spory „ładunek” historiografii, będącej „strażnikiem” naukowego krytycyzmu, zdają się minimalizować niebezpieczeństwo wypaczeń na jej obszarze, wypaczeń dotyczących zarówno nierzetelności badawczej czy ideologicznych interpretacji, jak i odstąpienia od zarysowanej wcześniej funkcji społecznej. Historia organizacyjna jest z gruntu antyuniwersalistyczna i antyprezentystyczna. Formułowane przez jej przedstawicieli „recepty” nie zwierają roszczeń hegemonistycznych. Autorefleksja i wewnętrzny krytycyzm należą do istoty omawianej dziedziny badania przeszłości. Być może więc rozwój historii organizacyjnej stanie się - w ograniczonym choćby stopniu - zwiastunem odrodzenia dyskusji naukowych, których stopniowe zanikanie boleśnie odczuwają nie od dziś ludzie zatroskani stanem nauk społecznych, włącznie z zarządzaniem (Furedi 2008, Micklethwait i Wooldridge 2000). Historia organizacyjna, ujmowana szeroko również jako pewna propozycja intelektualna, ma szansę odegrać rolę promotora Habermasowskiej idei „demokratycznego dyskursu” pośród badaczy społeczeństwa i kultury. Logika charakteryzowanej subdyscypliny teorii zarządzania, a szczególnie podejmowany przez jej przedstawicieli namysł nad problemem obiektywności poznana historycznego, stanowiącego zawsze rodzaj hermeneutyki, dobrze współbrzmi ze znanym przekonaniem Habermasa, iż interpretacja rozumiejąca nabiera charakteru obiektywnego, gdy powstaje w toku otwartej dyskusji z udziałem wielu badaczy w warunkach „idealnej sytuacji komunikacyjnej”, nieraz tłumaczonej jako „idealna sytuacja mówienia” (zob. np. Wielecki 2012: 161). Wspomniana „idealna sytuacja komunikacyjna" wymaga zaś, co warto przypomnieć, całkowitej swobody wypowiedzi, równej pozycji dyskutantów oraz braku nacisków zewnętrznych i argumentów pozamerytorycznych. Do takiej dyskusji wyraźnie wydają się zachęcać sztandarowi zwolennicy historii organizacyjnej, by wspomnieć choćby raz jeszcze Bootha i Rowlinsona (2006) apelujących o jak najszerszy, interdyscyplinarny

40 Zdaję sobie sprawę, iż termin „niegodziwe” wymaga doprecyzowań poprzedzonych dyskusją znacznie przekraczającą zakres niniejszego podrozdziału. Korzystam w tej sytuacji z pomocy, którą oferują - dość niespodziewane wobec prawie niepodzielnie do niedawna panującego relatywizmu - wyniki prowadzonych niezależnie od siebie badań psychologów i religioznawców sprzed kilku lat, pokazujące, iż mimo wszystko istnieje ponadkulturowy, ogólnoludzki zestaw norm moralnych (zob. np. Seligman 2005, Damon 2004, Küng 2005). Wydaje się on skupiać wokół złotej zasady: „nie rób drugiemu, co tobie niemiłe”. $\mathrm{Z}$ takiej perspektywy za niegodziwe uznaję wszelkie działania potencjalnie lub realnie naruszające wspomniany kod. 
dyskurs wokół opisywanych przez siebie badań oraz propozycji teoretycznych bądź, bardziej generalnie, styl pisarstwa naukowego dominujący na łamach „Management and Organizational History”.

Wyłącznie taki też charakter - zaproszenia do dyskusji - ma niniejsza książka. Przedłożone czytelnikowi analizy, wnioski czy interpretacje kryją nieśmiała ambicję autora, by stały się one jedynie (lub aż) inspiracją dyskursu wokół jednego aspektu organizacyjnej historii i organizacyjnej teraźniejszości, to jest kapitału kulturowego organizacji w perspektywie tradycji polskiej przedsiębiorczości. Prezentuję więc materiał podwójnie przeciwstawiający się marginalizacji w zarządzaniu. Proponuje on źródła benchmarkingu powstałe na prowincji globalizacji i wśród niewielkich podmiotów gospodarczych (z wyjątkiem Biura Odbudowy Stolicy), zgodnie z parafrazą spostrzeżenia jednego z zachodnich socjologów, iż „prawdziwe życie rozgrywa się w małych firmach” oraz zdroworozsądkowo pojmowanym faktem, że większość korporacji zaczynała jako małe przedsiębiorstwa i w tamtym czasie często lokuje swoje założycielskie mity. 
Rozdział V

\section{Wpływ ideowego dziedzictwa przedsiębiorczości na kapitał kulturowy organizacji}

\subsection{Kulturowe wzorce przedsiębiorcy powstałe na ziemiach polskich}

\subsubsection{Lokalne mity proprzedsiębiorcze a problem początków nowoczesnego kapitalizmu na ziemiach polskich}

Problematykę kapitału kulturowego miejsca pracy i kapitału organizacji, tak jak jest on rozumiany w niniejszej publikacji, bezpośrednio łączą mity proprzedsiębiorcze, czyli funkcjonujące na danym obszarze geograficznym wzorce efektywnych działań gospodarczych oraz ich podmiotów (szczególnie osobowych), rozpowszechniane przez literaturę, sztukę, film i inne nośniki kultury (łącznie z popularną), a także publicystykę i wspomnienia. Zarówno niosą one ze sobą etos (rozumiany jako „apel o wartości”) aktora gry rynkowej, jaki przypisują określone sensy organizacjom biznesowym (Ochinowski 2012a).

$\mathrm{W}$ niniejszym rozdziale interpretuję wspomniane proprzedsiębiorcze wzorce kulturowe za pomocą kategorii mitu rozumianego za Michelem de Certeu (1990/2008: 135) jako „fragmentaryczny dyskurs łączący się z różnorodnymi praktykami jakiegoś społeczeństwa, który wyraża je w sposób symboliczny"1. Mity proprzedsiębiorcze powstawały zazwyczaj w czasie narodzin nowoczesnej formy kapitalizmu ${ }^{2}$ na danym obszarze i do dziś są rozpowszechnianie/utrwalane przez różne nośniki kultury, przykładowo wymienione już wcześniej. Są więc interesującym przedmiotem badań dla historii organizacyjnej jako ideologiczny, a także retoryczny „łącznik” między przeszłością, a teraźniejszością

Przekład K. Thiel-Jańczuk.

2 To jest takiego, który związany był z procesami modernizacji zapoczątkowanymi przez XVIII-wieczną Anglię. 
i przyszłością. Są łącznikiem retorycznym, bowiem zakorzenione w przeszłości dostarczają argumentów do oceny obecnych i przyszłych potencjałów ludzi oraz organizacji z danego obszaru.

W naszym kraju, co być może jest charakterystyczne także dla innych (może tylko niektórych) państw Europy Środkowo-Wschodniej, pytanie o kulturowy wzorzec wspominanego rodzaju pociąga za sobą zasadniczy problem, czy generalnie przeszliśmy przez doświadczenie modernizacji, na którym mógłby zapuścić korzenie lokalny mit proprzedsiębiorczy?

„Nie wytworzył się rodzimy polski kapitalizm”, pisał przed laty Feliks Koneczny (1921: 579). Przy czym wówczas wileński historyk przyjmował bardzo szerokie, kulturowe, a zarazem stricte finansowe rozumienie kapitalizmu. Chodziło mu o sytuację, w której ,pieniądz był [by] nie tylko końcem przedsiębiorstwa jako zysk za pracę i zabiegi, ale żeby bywał na odwrót także początkiem przedsiębiorstw, jako narzędzie do uzyskiwania dalszych zysków coraz większych" (Koneczny 1921: 578).

Rozpoczynające niniejszy rozdział zdanie Konecznego, konsekwentnie pojawiało się i pojawia się nadal w pracach większości historyków gospodarczych, niezależnie od ich orientacji ideowej czy metodologicznej. Analiza historiograficznej „kariery” wspomnianego przekonania znacznie przekracza zakres tematyczny niniejszej książki. Teraz warto wskazać jedynie swoiste, ,ukoronowanie" dziejów omawianej tezy, które niedawno pojawiło się na kartach literatury fachowej. Jacek Kochanowicz (2010) w pracy, którą redagował wspólnie z Mirosławą Marody i która umieszcza problematykę historyczną w kontekście kulturowej problematyki współczesnej gospodarki, przywołał bowiem ostatnio badania Witolda Kuli (1955) i jego współpracowników z lat 50. XX wieku. Zdaniem Kochanowicza wynik owych studiów, który, mimo czasu powstania oraz opublikowania raczej nie wspierał tez dogmatycznego marksizmu, do dziś jest aktualny i pokazuje, że jeszcze w XVIII wieku na polskich ziemiach „śladów jakiegokolwiek kapitalizmu trudno było się doszukać” (Kochanowicz 2010: 39). Dalej cytowany historyk pisze jednak o grupie społecznej mieszkańców Rzeczpospolitej przedrozbiorowej, która szybko przyswoiła sobie wartości, a także praktyki kapitalistyczne ${ }^{3}$. Chodzi oczywiście o Żydów. Kochanowicz (2010) wyraźnie wyklucza ich jednak z grona pionierów kapitalizmu w Polsce, podkreślając odrębność kulturową omawianej społeczności. A szkoda. Cytowany Koneczny (1921: 579) znacznie wcześniej ujmował ten problem bardziej konsekwentnie: „Nie wytworzył się rodzimy polski kapitalizm, a więc Żydzi stali się naszymi kapitalistami”.

3 Na początku omawianego fragmentu swej pracy Kochanowicz (2010) stwierdza, iż Żydzi byli grupą społeczną „potencjalnie kapitalistyczną” na ziemiach polskich. Jednak jego dalsza charakterystyka tej grupy wyraźnie pozwala pominąć przymiotnik „potencjalnie”. 
Warto przypomnieć, iż podobną rolę zaczęli odgrywać na ziemiach polskich przedstawiciele także innej grupy narodowej - Niemcy. Wciąż nie przebił się do potocznej świadomości, nawet czytelników prac historycznych, fakt, iż niemieccy osadnicy byli znaczącymi promotorami rozwoju nowoczesnej gospodarki naszego kraju szczególnie od czasów Augusta III (zob. np. Kriegseisen 1998, Staszewski 2010, Świątek in. 2010), co stanowi przesłankę do rewizji obrazu czasów saskich (Bartkiewicz 1998; w zakresie rozwoju myśli ekonomicznej Skoczyński 2010 za Skrzypkiem 2000).

Za swoistą kwintesencję kulturowego opisu znaczenia Niemców dla modernizacji polskich ziem uznać można kilkadziesiąt lat późniejsze słowa Ksawerego Druckiego-Lubeckiego - ministra skarbu w Królestwie Polskim, które entuzjastycznie przytoczył Stanisław Wasylewski (1962/2010: 314) na kartach swej znanej książki Życie polskie w XIX wieku ${ }^{4}$ stanowiącej interesujący przykład pogranicza literatury pięknej oraz publicystyki historycznej, a więc publikacji szczególnie predestynowanej do konstruowania mitów: „Sto pięćdziesiąt tysięcy rąk roboczych przybyło z Niemiec, i mimo podnoszonych zastrzeżeń, że może to być groźne na przyszłość, daje wyraz przekonaniu, że to import fachowego rzemieślnika przyczyni pomyślności przemysłowi polskiemu, a przybysze ulegną powolnej asymilacji”.

Omawiane przemówienie sejmowe Lubeckiego dotyczyło powstania przemysłowej Łodzi, a więc stanowiło jeden z pierwszych elementów retorycznych, które z czasem stworzą model „lodzermenscha” opisujący swoisty typ łódzkiego przedsiębiorcy, przede wszystkim niemieckiego lub żydowskiego pochodzenia ${ }^{5}$. Jak wskażę dalej, model ten był obecny także na innych obszarach dawnej Rzeczypospolitej, ale treściowo mniej lub bardziej oscylował wokół „łódzkiego kanonu".

Wspomniany mit skonstruowała, a także rozpowszechniła literatura piękna (zwłaszcza polska i żydowska) oraz wspomnieniowa (głównie pisana przez autorów pochodzenia niemieckiego lub Niemców). Spory udział w jego utrwaleniu miała również publicystyka. Literacka wyrazistość mitów „lodzermensch” była i jest znacznie większa od mitów powstałych w Wielkopolsce, w zaborze austriackim i później - w czasach II Rzeczpospolitej.

4 Publikację tę Wasilewski przygotowywał przez dużą część okresu międzywojennego. Uzupełniał ją w latach 1941-1946. Nie ukończył prac związanych z przygotowaniem do druku omawianej książki, która ostatecznie doczekała się wydania dzięki zabiegom redaktorskim Zbigniewa Jabłońskiego, niemal dziesięć lat po śmierci autora. Nowe jej wydanie ukazało się w 2008, dodruk dwa lata później (Tazbir 2010).

5 Pomijam tu sugestię Lubeckiego na temat asymilacji obcych przybyszów do Łodzi, która wymaga oddzielnej uwagi. Warto podkreślić, iż w rzeczywistości cytowany fragment jest dość swobodną interpretacją przemówienia Lubeckiego. Wasilewski na przykład bardzo zawyża liczbę niemieckich osadników. Zwrócił mi na to uwagę Andrzej Wierzbicki z Instytutu Historii PAN. 
Wątpliwości, czy mity proprzedsiębiorcze oparte na modelu „lodzermenscha” można przypisać polskiej tradycji kulturowej, rozwiewają ustalenia zarówno historyków „bezprzymiotnikowych”, jak i badaczy dziejów literatury. Z jednej strony warto przytoczyć choćby Piotra Wandycza (1992/1995: 23), który prezentując zachodniemu czytelnikowi dzieje Europy Środkowo-Wschodniej i szukając specyficznych wyróżników tego regionu znalazł między innymi podstawy do następującego, bardzo radykalnego poznawczo stwierdzenia: „Inną cechą charakterystyczną dla Europy Środkowo-Wschodniej, a pod wieloma względami wręcz wyjątkową w tej skali zjawiska, była obecność Niemców i Żydów oraz wzajemne oddziaływanie między nimi a lokalnymi narodowościami”6.

$\mathrm{Z}$ drugiej strony, wprawdzie polska nowożytna, nasycona ideologią sarmacką nie wypracowała także w czasach narodzin kapitalizmu rodzimych wzorów proprzedsiębiorczych, to jednak właśnie eklektyzm tej kultury, tolerancyjność i otwartość na wpływy zagraniczne okazały się silnym magnesem przyciagającym także ludzi interesu z różnych krajów, ze szczególnym uwzględnieniem, co warto raz jeszcze podkreślić, właśnie Żydów i Niemców (o przytoczonych tu cechach kultury staropolskiej zob. np. Maliszewski 2010 i Mincer 2009).

Warto przy tej okazji wspomnieć, iż jak dotąd uznawany za jeden z dwóch najbardziej efektywnych w skali globalnej model wielokulturowości, aplikowany z sukcesem w Australii, ,wyszedł spod ręki” Polaka - socjologa Jerzego Zubrzyckiego ${ }^{7}$. Model ten zakłada, iż takie czynniki jak podział pracy, wspólnie dzielone codzienne doświadczenia oraz inne przejawy „codziennej współzależności” są silniejszym spoiwem społecznym niż wspólnota pochodzenia. Zubrzycki, który doradzał australijskiemu rządowi, świadomie wykorzystał - do rozwiązywania jak najbardziej współczesnych problemów - doświadczenia Pierwszej Rzeczypospolitej, to jest Polski XV-XVIII wieku (Pakulski 2011: 50).

Na postawienie swoistej „kropki nad i” w kwestii „polskości” proprzedsiębiorczego mitu opartego na modelu „lodzermenscha” pozwalają choćby spostrzeżenia Laury Quercioli Mincer (2009: 437), autorki eseju o literaturze jidysz włączonego, jako integralna część do Historii literatury polskiej pióra włoskich znawców przedmiotu (Marinelli 2009): „Niezbędną przesłanką obecności tego rozdziału w książce poświęconej historii literatury polskiej jest założenie o otwartym charakterze polskiej kultury, będącej wyrazem społeczeństwa dynamicznego, zdolnego akceptować wielość przekonań i wiar religijnych. Z tej

Przekład T. Wyrozumski.

7 Drugi ze wspomnianych modeli zrealizowany został w Quebecku (Pakulski 2011). Zubrzycki do dziś w literaturze anglojęzycznej na temat międzykulturowości traktowany jest jako ważny punkt odniesienia. Dyskutuje się, również krytycznie, na przykład kwestię, czy jego propozycje są adekwatne wobec wyzwań aktualnej fali emigracji na Zachód z krajów islamskich (Poynting i Mason 2008). Obecnie doświadczenie Pierwszej Rzeczpospolitej proponuje zaaplikować do zarządzania międzynarodowego w UE Siewierski (2010). 
perspektywy także literatura polska w języku hebrajskim i jidysz stanowi część piśmiennictwa polskiego: $\mathrm{z}$ racji pokrewieństwa tematów, postaci, krajobrazów, odwołań do tych samych wydarzeń historycznych. Na koniec, z powodu matrycy kulturowej samych autorów, na ogół żydowskiej i polskiej jednocześnie lub żydowskiej w jej charakterystycznej polskiej odmianie"8.

Nic chyba nie stoi na przeszkodzie by proprzedsiębiorcze mity oparte na kulturowym modelu „lodzermenscha” uznać właśnie za wyraz doświadczeń przede wszystkim żydowskich i niemieckich (może także rosyjskich) przedsiębiorców, ale „w charakterystycznej polskiej” odmianie tych doświadczeń. Zaś ścieranie się, często pociągające za sobą skrajnie silne emocje, negatywnych i pozytywnych klisz niesionych przez różne odmiany tego mitu, warto potraktować nie tylko jako wyraz problemów etnicznych, ale także jako świadectwo zmagań kultury polskiej wobec wyzwań kapitalizmu.

Mity te interpretuję $\mathrm{w}$ kontekście kapitału kulturowego miejsca pracy (Lamont 1992, Lothart 2002) jako lokalny odpowiednik aksjologicznej (czyli dotyczącej wartości) podstawy, którą stanowiły moralizmy: ekspresywny i ascetyczny, (jak założyłem w rozdziale pierwszym, podrozdział 1.1.) znanego powszechnie mitu american dream, czyli idei „od pucybuta do milionera”, postawy, którą - również powszechnie - uważa się za „kulturowe paliwo” globalnego rozwoju amerykańskiej wersji kapitalizmu, a co za tym idzie związanych z tą wersją rodzajów kulturowego kapitału organizacji (Ochinowski 2012c).

Wiele na to wskazuje, choć teza jest dopiero na początku weryfikowania jej na drodze badawczej, iż wspomniany sen był nie tylko śniony, ale i efektywnie realizowany daleko od USA, a także niezależnie od amerykańskich wpływów, bo znacznie wcześniej niż zyskały one globalne znaczenie. Warto szukać więc lokalnych korzeni kulturowego kapitału miejsca pracy.

Podstawę wspomnianej, nieśmiałej tezy stanowi zaproponowana tu przyczynkarska na razie reinterpretacja proprzedsiębiorczych mitów, które zrodziły się na ziemiach polskich przełomu XIX i XX stulecia. Reinterpretuję treść tego mitu w duchu kulturowego kapitału miejsca i kulturowego kapitału organizacji, sięgając do literatury pięknej i wspomnieniowej ${ }^{9}$,

\footnotetext{
Przekład. M. Woźniak.

9 Niniejszy rozdział, jak i oczywiście cała książka, napisana jest przez człowieka nie posiadającego żadnych kompetencji krytyka ani historyka literatury. Jako typowy herbertowski „barbarzyńca w ogrodzie” abstrahuję od istotnej problematyki gatunków czy konwencji literackich. Jedynie rekonstruuję - podkreślam raz jeszcze - na poziomie przyczynkarskim - treści dotyczące szeroko rozumianego (niekonieczne związanego z Łodzią, o czym dalej) kulturowego wzorca przedsiębiorcy zawartego we wspomnieniach oraz utworach literatury pięknej, których akcja odnosi się do ziem polskich (rozumianych jako obszar określony przez granice I Rzeczypospolitej), bądź do emigrantów lub zesłańców z tych ziem pochodzących, od połowy XIX wieku do 1939 roku i które są dzisiaj dostępne dla przeciętnego inteligenckiego użytkownika bibliotek publicznych.
} 
wykorzystując tezę amerykańskiej ekonomistki i badaczki dziejów gospodarczych, a także profesora retoryki Deirdre McCloskey (np. 2001), iż nic tak dobrze jak twórczość pisarzy nie pomaga rozumieć, „kalibrować” rzeczywistość ekonomiczną. Tym bardziej jest to przecież prawdziwe w doniesieniu do kulturowego aspektu tej rzeczywistości (Ochinowski 2012a).

Jako metodologiczne przyzwolenie na włączenie rozdziału o mitach literackich do publikacji z zakresu zarządzania traktuję narratywizm zainicjowany i rozwijany w obszarze badań organizacyjnych przez Barbarę Czarniawską (np. 2012). Cytowana uczona także wprost rozwija tezę o ścisłych związkach między fikcją literacką a zrządzaniem, szczególnie (choć nie wyłącznie) na podstawie powieści kryminalnych. Znaczną estymą naukowców cieszy się w omawianym kontekście Sherolck Holmes. Czarniawska przeprowadziła analizę tej postaci jako literackiej figury badacza z zakresu nauk o organizacji, a Kociatkiewicz i Kostera jako wzorzec menedżera zmagającego się z tak zwanym racjonalnym nurtem w zarządzaniu (Czarniawska 2010, Kociatkiewicz i Kostera 2012b).

\subsubsection{Konteksty znaczeniowe proprzedsiębiorczych mitów związanych z metaforą "lodzermenscha"}

Wielokulturowość opisywanej tu grupy mitów ${ }^{10}$ nie przeszkadza temu, iż do popularności jego kanoniczej wersji, to jest wzorca „lodzermenscha” szczególnie przyczynił się polski pisarz. Chodzi oczywiście o Władysława Reymonta i jego Ziemię obiecanq, powieść z 1899 roku (Ochinowski 2012a). Najczęstszy sposób odbioru wspomnianej powieści każe widzieć w niej czarną wersję obrazu łódzkiego człowieka interesu. Takie ujęcie zdawał się sugerować już sam Reymont w liście do Jana Lenartowicza z 1896 roku: „Rozrost miasta, fortun, interesów $\mathrm{z}$ iście amerykańską szybkością, psychologia tych napływających tłumów po żer, mieszanie się ich i przenikanie, i urabianie w jeden typ tak zwany lodzermensch, oddziaływanie tej ssawki, polipa jaką jest Łódź na cały kraj” (cyt. za Woźniakiem 1998: 32).

Warta oddzielnej analizy, znacznie przekraczającej możliwości niniejszej pracy, ale konieczna tu do zasygnalizowania jest triadyczna pod względem narodowym konstrukcja „lodzermenscha” na kartach Ziemi Obiecanej. „W postaciach Maxa Bauma, Moryca Welta i Karola Borowieckiego, na zasadzie symbiozy dopełniały się stereotypy żydowskiej inwencji, niemieckiej racjonalności i polskiego dynamizmu. Elementem wspólnym był kult kapitału nakazujący

10 Szerzej na temat „lodzermenscha” zob. przede wszystkim monograficzny numer miesięcznika „Tygiel”, 4-5, 1998, poświęcony właśnie tej problematyce. Spośród historyków omawianą matrycę kulturową analizuje, ale tylko w jej negatywnej konotacji, Stefan Pytlas (1994). Sporo wspomnieniowych odniesień do „lodzermenscha” zawiera antologia tekstów o historycznej Łodzi opublikowana niedawno na łamach kwartalnika „Karta” (Zespół red. „Karty” 2013). 
przechodzić do porządku dziennego nad skrupułami moralnymi w imię globalnego szczęścia, które jest tuż tuż. Bez względu na intencje Reymonta, który o polskiej Ziemi Obiecanej pisał z ironią i goryczą, jego książka przyczyniła się do wzbogacenia etosu Lodzermenscha o pierwiastki polskie"11.

Krzysztof Woźniak (1998) proponuje, by rozróżniać dwie wersje mitu „lodzermenscha". Ta literacka, zazwyczaj negatywna, charakteryzuje swego bohatera jako osobę zdegradowaną, która zdradza własne korzenie, a służy wyłącznie dwóm wartościom: sukcesowi i pieniądzu. Z kolei pamięć zbiorowa łódzkich robotników przypisuje „lodzermenschowi” zgoła odmienne cechy: przede wszystkim pracowitość, zaradność, ale także wrażliwość społeczną, wyrażająca się na przykład poprzez opiekę nad dzielnicami robotniczymi, aptekami, szkołami, żłobkami i temu podobnymi instytucjami.

Jednak również literacka, a szczególnie reymontowska postać omawianego wzorca, dopuszcza różnorodną lekturę, nie tylko nasyconą negatywną oceną. I tak na przykład Monika Adamczyk-Grabowska (1998: 89) następująco odczytuje przesłanie Ziemi obiecanej: „odejście od tradycji (...) prowadzi do nieszczęść, a nawet zguby, ale z drugiej strony sztuczne zatrzymywanie czy zapobieżenie zmianom jest niemożliwe" 12 .

Z przytoczoną interpretacją świetnie koresponduje fragment cytowanego przeze mnie wcześniej listu Reymonta: „Rozrost miasta, fortun, interesów z iście amerykańską szybkością - (podkreślenie T.O.)”. Przytoczony cytat stanowi kolejną przesłankę ośmielającą do potraktowania proprzedsiębiorczego mitu opartego na modelu „lodzermenscha” jako nasz lokalny, peryferyjny odpowiednik american dream.

Zresztą taka sugestia ma już pewne pośrednie poparcie w tak zwanej literaturze faktu, formie pisarstwa oscylującej przecież między realistycznym, nieraz nawet protoempirycznym opisem rzeczywistości a mitotwórstwem. Uporczywie propagowana przez Szewacha Wiessa potrzeba rekonstrukcji międzynarodowych karier emigrantów żydowskich z ziem polskich (szczególnie entuzjastycznie sformułowana przez tegoż autora ostatnio na łamach „Rzeczpospolitej”: „Żydzi z Polski podbili świat!"13) znalazła swą częściową realizację w pracach Andrzeja Krakowskiego (2011) oraz zbiorowej pod reakcją Kamili Żyto i Marcina Pieńkowskiego (2011) poświęconych dużemu znaczeniu właśnie przedstawicieli tej społeczności dla rozwoju Hollywood, również od strony zarządzania, nie wyłączając innowacyjności. Pierwszy z wymienionych badaczy pokusił się

11 Uwaga Andrzeja Wierzbickiego z Instytut Historii PAN do pierwszej wersji niniejszego tekstu (wiosna 2012, notatka w maszynopisie). Cytowany badacz jest także autorem sformułowania „triadyczna pod względem narodowym konstrukcja lodzermenscha”.

12 Adamczyk-Grabowska (1998) bliźniacze przesłanie przypisuje powieści Bracia Aszkenazy.

13 „Izrael narodził się w Polsce”. Z prof. Szewachem Wiessem rozmawia Piotr Zychowicz, PlusMinus, dodatek do „Rzeczpospolitej”, 24-25.09.2011, P16. 
wręcz o próbę uogólnienia zespołu cech dających polsko-żydowskim emigrantom przewagę konkurencyjną nad innymi grupami przy budowaniu „fabryki snów”. Krakowski (2011: 13) wymienia ich lepsze wykształcenie w stosunku do pozostałych nacji traktujących Amerykę jako szansę na poprawę bytu; przypisywanie umiejętności przeżycia, dostosowaniu się do nowych warunków oraz szukaniu niezauważonych przez konkurencję możliwości, większego znaczenia niż więzom rodowym (np. nazwisku); humanizm i humanitaryzm, przejawiający poprzez działalność filantropijną, gdy fortuna została już zdobyta; zdolność podejmowania ryzyka, związaną z niewesołymi widokami na powrót do miejsca urodzenia („Nikt na nich nie czekał, najwyżej służba w carskim wojsku i kolejne represje"), empatię jako pochodną doświadczenia różnorodnych okrucieństw i dającą im niejako naturalnie status twórcy, a także fakt, iż „pomimo wszystko, zawsze czuli się patriotami i z dumą przypominali światu, skąd przyszli. Szkoda trochę, że bez wzajemności”. Ostatnia sugestia wymaga oczywiście rozwinięcia przekraczającego problematykę mojej książki (por. np. pracę Biskupskiego (2010/2011) $)^{14}$, którą można odczytywać po części polemicznie wobec zacytowanego poglądu Krakowskiego z 2011).

W każdym razie dzięki Krakowskiemu (2011) powstała propozycja - warta zainteresowania badaczy - operacyjnego opisu kompetencji „lodzermenscha” (i to zweryfikowanych przez konkurencję międzynarodową), symbolizujących pewien typ przedsiębiorcy, który oczywiście nie musiał być związany z Łodzią.

W niniejszym rozdziale używam rozbudowanego terminu: „mity proprzedsiębiorcze oparte na modelu "lodzermenscha"'. Termin ten oznacza zbiór cech przedsiębiorcy oraz - choćby pośrednio - cech realizowanych przez niego przedsięwzięć, powstały na ziemiach wyodrębnionych granicami I Rzeczypospolitej i opowiadany bądź „śniony” przez mieszkańców różnych jej regionów. Najbardziej wyrazista wersja tego mitu powstała w Łodzi. Tę właśnie wersję określam jako „model lodzermenscha”.

To miasto Łódź szczególnie przyciągało ludzi o wspomnianych zdolnościach, być może pomagało je rozwijać, a przynajmniej w pewnym okresie stwarzało alternatywę dla emigracji. Proponuję więc wrócić do źródłowego znaczenia omawianego mitu.

Wyraźnie w perspektywie american dream, choć nie używając tej kategorii, czyta Ziemię obiecanq Jerzy Grohman (1998), potomek lódzkich fabrykantów. Zwraca on uwagę na fakt, iż u Reymonta lodzermensch jest poza wszystkim także sprawnym „człowiekiem interesu”15. A sam model, jego zadaniem,

14 Polski wydawca opatrzył książkę Biskupskiego wstępem o wyraźnym wydźwięku antysemickim. Nie może to jednak obciążać autora, który o tym nie wiedział i pisemnie zażądał wyjaśnień (zob. dyskusję na ten temat dostępną w internecie).

15 Dosłownie Grohman (1998) mówi o dwóch obliczach lodzermenscha u Reymonta, z których jedno to właśnie „sprawny człowiek interesu”. 
powstał z uogólnienia doświadczeń łódzkich przedsiębiorców ${ }^{16}$, ludzi pochodzenia najczęściej nie polskiego, cechujących się pewnymi zdolnościami inicjatyw gospodarczych i pracowitością, będących patriotami lokalnym, wobec kraju co najwyżej lojalnymi. Grohman (1998: 37) uzupełnia tę charakterystykę, realistycznym stwierdzeniem, iż „zdarzali się wśród nich szachraje”. Reymontowski obraz lodzermenscha cytowany autor jednocześnie wzbogaca o informacje na temat działalności kulturowej (mecenatu) i filantropijnej omawianej grupy. Zaś we wspomnieniach o własnej łódzkiej rodzinie o niemieckich korzeniach przytacza on przykład panien Treker, które były typem „ewangelicznej uczciwości, solidności we wszystkim, w każdym calu" (Spodenkiewicz 2006: 7417). Wyraża też przekonanie, że ogólnie wśród jego krewnych - protestantów żywy był etos Ewangelii. Przy czym sam Grohman odrzuca weberowską tezę o protestanckich korzeniach kapitalizmu, wskazując, iż ten sposób uprawiania biznesu narodził się w katolickiej Florencji, a drugim jego ośrodkiem była również katolicka Belgia (Spodenkiewicz 2006).

Interesujące świadectwo o niemieckiej „gałęzi” lodzermenschów z początków I wojny światowej, a więc pod koniec największej świetności tej formacji, zostawił na kartach swoich wspomnień znany polski przemysłowiec Andrzej Wierzbicki (2001: 187, cytowane wspomnienie dotyczy 1915 roku) „Pierwsza rzecz, o jakiej przekonaliśmy się, to bezwzględnie polskie oblicze Łodzi. Jeżeli wśród części przemysłowców łódzkich, wywodzących się z Niemiec, trwały jeszcze przed wojną pewne sentymenty niemieckie, polityka okupantów, od samego początku konsekwentnie i nieubłaganie dążąca do zniszczenia polskiego przemysłu włókienniczego, przyszłego konkurenta przemysłu niemieckiego, gruntownie je wykorzeniła. Zrozumieli, że zwycięstwo Niemiec to zagłada dla nich i solidaryzowali się bez zastrzeżeń ze społeczeństwem polskim. Jako wytrawni organizatorzy i administratorzy rozwinęli szeroką działalność w miejscowym Komitecie Obywatelskim”.

Zgoła inaczej publicystycznie zgeneralizowany typ lodzermenscha opisywał dwadzieścia dwa lata później Józef Mackiewicz (2002: 77, cytat z reportażu pierwotnie drukowanego na łamach „Słowa”, 1937, 53):

„Lodzermensz, pisany przeze mnie umyślnie na sposób spolszczony jest specjalnym typem, jeśli nie rasą. Łódź, która powstała tak niedawno, składała się pierwotnie z kilkunastu rodzin niemieckich. Do Niemców przypętali się okoliczni mieszkańcy, a więc Polacy. Później z Rosji jęli najeżdżać ludzie, rozumiejący się na interesie. Wtedy, oczywiście, zjawili się Żydzi. Z tej mieszaniny powstał typ człowieka predestynowanego do życia dla pieniędzy. Można powiedzieć: mię-

16 Grohman (1998) proponuje zaliczyć do lodzermenschów także majstrów i urzędników. Pomijam ten wątek wymagający odrębnej dyskusji.

17 Serdecznie dziękuję Mikołajowi Katusowi za zwrócenie uwagi na wspomnienia Grohmana (Spodenkiewicz 2006) i zdobycie ich dla mnie. 
dzynarodowiec, kosmopolita, gdy się uda wyjechać za granicę, pacyfista w interesach, rydzo-śmigłowiec w kawiarni, zetzeciak w pracy - oto Lodzermensz".

Obraźliwy ton każde zaliczyć przytoczony fragment reportażu do nielicznych wypowiedzi Mackiewicza, co do których prawdziwa jest sugestia Władysława Boleckiego (2007), że lepiej byłoby, gdyby nie powstały.

Patrząc szerzej, słowa te reprezentują dość liczny zbiór jednoznacznie negatywnych opinii o „lodzermenschu” wychodzących spod pióra różnych autorów, w różnych okresach, a których wypowiedzi tutaj pomijam ${ }^{18}$. Zgodnie z zaproponowaną przeze mnie na początku niniejszego podrozdziału interpretacji można w nich widzieć wyraz polskich lęków, choć występujący także w innych krajach, przed wyzwaniami kapitalizmu.

Jeśli nie brać pod uwagę oceniającej warstwy tekstu Mackiewicza, to wyraźnie widać, że utrwala on również takie kompetencje reprezentantów omawianego mitu, jak orientacja międzynarodowa, zdolność przystosowania się do warunków robienia kariery za granicą (por. np. wspomniane wcześniej sukcesy polskich Żydów w Hollywood) oraz - to pewna nowość nie ujmowana przez przytaczanych dotąd przeze mnie autorów - pacyfizm dotyczący działalności biznesowej.

Na szczęście jednak felieton Mackiewicza nie jest ostatnim literackim obrazem „lodzermenscha”. W 1935 roku wyszło polskie tłumaczenie napisanej niemal dwadzieścia lat wcześniej powieści austriackiego pisarza Józefa Rotha Hotel Savoy ${ }^{19}$. Autor, który kilkakrotnie odwiedzał i lubił nasz kraj - czego literackie świadectwo zostawił jego przyjaciel Józef Wittlin (1949/1991) - wielobarwnie przedstawił sylwetki polskich Zydów zamieszkujących Łódź przełomu wieków. Nawet pobieżne przyjrzenie się choćby niektórym $\mathrm{z}$ nich pozwala dostrzec różne oblicza „lodzermenscha”.

Boolmfield, właściciel tytułowego hotelu uosabia pewną wersję spełnionego mitu. Nie mieszka już w Łodzi, tylko do niej przyjeżdża od czasu do czasu, oczekiwany niczym Mesjasz. „Pan nie zna Bloomfielda? - dziwi się jeden z bohaterów Hotelu Savoy - Bloomfield jest dzieckiem tego miasta, jest miliarderem w Ameryce. Całe miasto woła: 'Bloomfield przyjeżdża!' Ja rozmawiałem z jego ojcem, tak jak z panem tu rozmawiam, żebym tak zdrów był” (Roth 1924/2002: 2920).

Na miejscu „robi interesy” Febus Böhlaugu, de facto zarządzający kapitałem żydowskiej Łodzi i władający finansami pod nieobecność Bloomfielda. Człowiek

18 Część z nich przytaczają częściowo uczestnicy dyskusji „Lodzermensch - historia i mit”, którą zorganizowała i opublikowała pod takim właśnie tytułem redakcja „Tygla Kultury” (1998, 4-5: 28-38).

19 Serdecznie dziękuję Darii Treli, doktorantce Wydziału Polonistyki UW za pomoc w opracowaniu Hotelu Savoy dla potrzeb niniejszej pracy. Jednak poziom moich interpretacji zupełnie jej nie obciąża.

20 Przekład tego i następnych przytoczonych fragmentów Hotelu Savoy Rotha - I. Berman. 
sukcesu, do którego się nie przyznaje. Skąpy nawet wobec krewnych, nieustannie skarży się na brak gotówki. Jego przesadzone narzekanie to jednak także świadectwo niezwykłej wrażliwości duszy lodzermenscha na puls gospodarczej koniunktury w wymiarze zarówno makro- jak i mikroekonomicznym.

„Interesy w ogóle nie idą w tych czasach - twierdzi Böhlaugu, co warto podkreślić mówiący tak o epoce łódzkiej prosperity przed I wojną światową - Gdy byłem mały, dostawałem obwarzanek z makiem za pół kopiejki, teraz chleb kosztuje dziesięć kopiejek, dzieci - na psa urok - dorastają i potrzebują pieniędzy, Aleksander chciał, by codziennie dostawali kieszonkowe" (Roth 1924/2002: 12).

I wreszcie Abel Glanz, drobny ciułacz, który łączy zmysł artystyczny z finansowym. Sufler w małym teatrze, marzący o karierze reżysera, póki co handluje walutą. Częsty gość Febusa Böhlaugu'a. Realistycznie opowiada o swoim „sposobie na życie", a jednocześnie puentuje jeden z najważniejszych, jeśli w ogóle nie najważniejszy rys mentalności lodzermenscha: „Nie jest łatwo handlować walutą (...) Trzeba ryzykować życie - to jest żydowskie przeznaczenie (...) To jest zaczarowana sprawa" (Roth 1924/2002: 37).

Nawisem mówiąc, trudno oprzeć się wrażeniu, iż cytowany fragment również od strony formalnej odkrywa duszę „lodzermenscha” oraz - a może szczególnie - jego uboższych krewniaków. Chodzi o umiejętność mądrościowych uogólnień, naturalnie puentujących opisy codziennego zmagania się z rzeczywistością wolnego rynku. Nie tylko więc na terenie małych miasteczek, jak pisał Słonimski, ale także w bogatej Łodzi, szewc bywał poetą, a zegarmistrz (czy handlarz walutą) filozofem ${ }^{21}$.

Oprócz wymienionych przeze mnie jedynie przykładowo pojedynczych bohaterów, Hotel Savoy utrwalił także atmosferę łódzkiej ulicy przełomu XIX i XX stulecia, zaludnioną ludźmi wspomnianego właśnie typu, różniących się statusem materialnym czy osiąganymi sukcesami, ale złączonych wspólnym sposobem myślenia, a także działania wobec wolnorynkowej rzeczywistości. „Wędrowałem dalej, widziałem czarne grupki chyżych Żydów w kaftanach, słyszałem głośne szepty, powitania, energiczne słowa i długie przemówienia - pióra, procenty, chmiel, stal, węgiel, cytryny; wszystko to latało, wyrzucane z warg w powietrze, wycelowane w uszy" (Roth 1924/2002: 10).

Nic dziwnego, że Hotel Savoy stał się obecnie „literackim artefaktem” łódzkiego Festiwalu Wielu Kultur. Trudno oprzeć się w tym kontekście marzeniu, by przywołana powieść spełniła także podobną rolę przy okazji konferencji lub codziennej akademickiej edukacji poświęconej tożsamości polskiego biznesu.

Po latach szczególnie „niemieckie oblicze” (choć nie tylko niemieckie) lodzermenscha odżyło na kartach wspomnień Karola Dedeciusa (2008), „europejczyka z Łodzi”, jak sam siebie nazywał. Cytowany tłumacz i eseista wraca

$\overline{21}$ Zob. wiersz A. Słonimskiego, Elegia miasteczek żydowskich. 
do początków dziewiętnastowiecznej prosperity ziemi łódzkiej, gdy po zaliczeniu przez rząd Królestwa Polskiego stolicy tego regionu do grupy miast przemysłowych, wobec świetnych warunków naturalnych, sprzyjających produkcji włókienniczej, opisywany obszar stał się miejscem szybkiego osiedlania wielu przedsiębiorców z różnych rejonów Niemiec i dzisiejszych Czech. Jako przykłady Dedecius (2008: 18) wymienia ${ }^{22}$ Ludwika Meyera, Karola Scheiblera, Roberta Biedermana, Gotloba Eisterta, Fryderyka Wilhelma Schweikerta, Jana Heinzela, Franciszka Kinderamana, Józefa Karola Horaka, Markusa Kohna i Kalmana Poznańskiego, „którzy z biegiem czasu zbudowali całe mnóstwo małych i większych manufaktur i fabryk, przyczyniając się do niesłychanego rozkwitu miasta”. Niemiecki pisarz, sam pochodzący z rodziny urzędnika miejskiej administracji, a więc obserwujący typowych „lodzermenschów” z bliskiej, ale jednak pewnej odległości, kreśli bardzo wyważony ich portret. Wykazuje się przy tym trafnym wyczuciem, czym, kulturowo rzecz biorąc, jest przedsiębiorczość, a nawet ogólniej, szeroko rozumiany biznes. Dedecius nie kryje z jednej strony podziwu dla dynamiki i rozmachu działań łódzkich przemysłowców, rozumie ich chęć bogacenia się, która jednocześnie sprzyjała rozwojowi miasta, z drugiej zaś strony jest świadom patologii wspólistniejących, zdaniem autora w sposób konieczny, z wymienionymi wcześniej procesami. Tak powstało chyba jedno z piękniejszych, a równocześnie realistycznych syntetycznych ujęć modelu „lodzermenscha”: „Niektórzy zaczynali od krosna tkackiego, a pięćdziesiąt lat później byli panami imperium przemysłowego, zatrudniającego tysiące robotników. Mieszkali w pałacach jak książęta, budowali osiedla robotnicze, utrzymywali szkoły, kościoły, teatry, szpitale, zakładali stowarzyszenia artystyczne i muzyczne, dorabiali się miliardowych majątków, co było oczywiście z pożytkiem i dla miasta. Zaczęła się złota epoka niegdysiejszej wsi, a później drugiego co do wielkości po Warszawie miasta w Polsce. Łódź, zdaje się z rozrzewnieniem o tym opowiada. Ale oczywiście tam, gdzie jest tyle wielkich fabryk i pałaców, muszą też istnieć nędza i bezprawie" (Dedecius 2008: 18)"23.

Trudno się oprzeć wrażeniu, wymagającemu oczywiście fachowych analiz, iż zdanie Dedeciusa o karierze wsi, która na tyle stała się tak atrakcyjna dla obcych, przedsiębiorczych przybyszów, że dzięki nim szybko urosła do rangi lokalnej metropolii, można traktować również za swoistą metaforę w ogóle udziału Polski w procesach modernizacji.

Dedecius, pochodzący z rodziny niemiecko-czeskiej, miał podczas łódzkiego dzieciństwa przyjaciół, prócz przedstawicieli wymienionych narodowości, także wśród Żydów i Polaków. Właśnie międzykulturowy rys „lodzermenscha” (którą to cechę zdawał się charakteryzowany „typ” dzielić z resztą obywateli opisywa-

22 Dedecius nie podaje imion wymienianych przemysłowców. Dla potrzeb niniejszego tekstu zidentyfikowałem tych przedstawicieli rodów, którzy jako pierwsi przybyli do Łodzi.

23 Przekład S. Lisiecka. 
nego miasta), stanowi, zdaniem autora cytowanych pamiętników, podstawowy wyznacznik Łodzi lat międzywojennych i wcześniejszych.

Podobnie charakteryzuje żydowskich przedsiębiorców przełomu XIX i XX wieku Isaak Bashevis Singer. Aczkolwiek bohaterowie jego utworów działają raczej na terenie Warszawy i małych miasteczek (brat noblisty upodobał sobie Łódź), to pewne cechy działaczy gospodarczych reprezentujących polskich Żydów wydają się na tyle „lokalnie uniwersalne”, że pozwalam sobie je zaliczyć także do literackich wyrazów, szeroko, w tym wypadku wręcz archetypicznie ujętego proprzedsiębiorczego mitu opartego na modelu „lodzermenscha”.

Maks Mordche, bogaty żydowski przedsiębiorca z Ameryki Południowej, bohater powieści Szumowiny, rozgrywającej się na początku XX wieku, po śmierci syna i wobec innych kłopotów osobistych szuka ukojenia poprzez powrót do Polski. Na pytanie warszawskiego pomocnika rabina „Czy mógłby Pan tutaj prowadzić swe interesy?” - odpowiada bez wahania: „Mój interes jest dobry wszędzie" (Singer 1991/1992: 7324). Nieco wcześniej, w latach względnej gospodarczej prosperity Kongresówki, rozgrywa się inny utwór przywołanego noblisty - Spuścizna, który rozpoczyna nadzieja wyrażona przez Daniela Kaminera, umierającego dostawcy dla rosyjskich garnizonów, iż jego wnuk Sasza, poprowadzi interesy dziadka. „Daniel Kaminer już dawno się zorientował, że Sasza zna życie i ludzi, i ma obrotny język. Możliwe, że zdradza talent do interesów. Wnuk wdał się w rodzinę Kaminerów” (Singer 1969/1997: 925). Nadzieje te zostają zresztą szybko spełnione tuż po śmierci nestora rodu. „Okazało się, że chłopiec ma iście żydowski zmysł do interesów. Tak szybko się wszystkiego nauczył, że wprawił ludzi w zdumienie" (Singer 1997: 10).

$\mathrm{Na}$ kartach tej samej powieści Singer uchwycił również inny rys mitów żydowskiego przedsiębiorcy, to jest napięcie między efektywnym przyjęciem rynkowych reguł gry a przywiązaniem do judaistycznej tradycji, która w Spuściźnie zaznaczała się jako charakterystyczna dla chasydyzmu swoista abnegacja spraw materialnych.

To napięcie, mieniące się różnymi barwami poszczególnych odmian religii mojżeszowej, przechowała także literacka mitologia małych żydowskich miasteczek (sztetł) wbrew obecnemu również na jej kartach nurtowi przeciwstawiania prowincjonalnych miejscowości jako środowisk nieskalanej tradycji miejskim molochom niosącym pogoń za zyskiem. Choćby pobieżny przegląd postaci zaludniajacych obydwie literackie przestrzenie pokazuje, iż mentalność przedsiębiorcy czy handlarza z małego miasteczka wcale nie musiała być istotowo odmienna od psychiki klasycznego „lodzermenscha” przy oczywistej różnicy w zasobności kieszeni obydwu.

24 Przekład L. Nicpan.

25 Przekład I. Wyrzykowska. 
Mosze-Awrum, właściciel niewielkiego zakładu szewskiego, ojciec głównego bohatera płockiej powieści Symcha Symchowicza Pasierb nad Wista pełnej ewidentnych odniesień autobiograficznych, bardzo mocno przeżywa fakt, iż nadeszły ciężkie czasy i trudno jest utrzymać rodzinę, dać wypłatę czeladnikom oraz zmusić dłużników, by oddali należności. Kamasznika ogarnia wielki smutek, staje się agresywny wobec żony. Napięcie mija, gdy Mosze-Awrum wpada na pomysł - po swoistej, przeprowadzonej myślowo „analizie” lokalnego rynku - założenia restauracji. Ta inicjatywa przynosi spodziewany zysk, ale mocno utrudnia całej rodzinie w nim zaangażowanej świętowanie szabatu. Powstały dyskomfort staje się jednym z czynników powodujących emigrację córki właściciela lokalu do Palestyny. Jednak nie tylko problemy bytowe motywują przedsiębiorcze działania Mosze-Awruma. Gdy nadchodzi zima hamująca funkcjonowanie restauracji, ojciec głównego bohatera Pasierba nad Wista wraca do pracy kamasznika. Oczywiście robił to, by nie marnować pieniędzy zarobionych latem, ale także dlatego, że „poza tym nie lubił siedzieć bezczynnie (...). Głównym celem tej bieganiny było zabicie zimowej bezczynności i zarobienie kilku dodatkowych złotych" (Symchowicz 1994/2005: 78-7926).

Podobną „dywersyfikację ryzyka” podejmował nieco wcześniej, w innym miasteczku (ukraińskie Woronki) ojciec innego bohatera, innej powieści autobiograficznej Szołem Alejhema $Z$ jarmarku rozgrywającej się na Ukrainie. Reb Nachum Wewik, „uważany w mieście za największego bogacza (...) Był właścicielem nieruchomości, dostarczał buraków do cukrowni, dzierżawił miejscową pocztę, handlował zbożem, przewoził ladunki berlinkami na Dnieprze, zajmował się wyrębem lasów, handlem wołami, ale dochody czerpał przede wszystkim ze sklepu z Manufakturą" (Alejchem 1989: 3027). Jak zwrócił na to uwagę Bal Machszowes, jeszcze w większym stopniu szkicowany tu archetyp Żyda - multiprzedsiębiorcy uosabiał u Alejchema Menachema Mendela, „Luftmensch”, „wczoraj makler giełdowy, dzisiaj swat, jutro kupiec leśny, pojutrze agent ubezpieczeniowy (...). Żyje jakby w gorączkowym śnie" (cyt. za BelisLegisem 1989: 20).

Przykład Mendla pokazuje równocześnie, iż swobodne przyjęcie przez Żydów z polskich ziem rynkowych reguł gry nie „skazywało ich” samo przez się na sukces ${ }^{28}$. Tu najprawdopodobniej leży główna różnica między mitem „lodzermenscha", a american dream.

26 Przekład M. Domański.

27 Przekład M. Friedman.

28 Jak zwróciła mi na to uwagę Joanna Nalewajko-Kulikov z Zakładu Historii Idei i Dziejów Inteligencji w XIX-XX wieku IH PAN ten pesymistyczny, czy raczej realistyczny rys, analizowany przeze mnie mit zawdzięcza archetypowi „Żyda pechowca” (Szmiel) charakterystycznemu dla literatury jidysz w Europie Srodkowo-Wschodniej. 
Już podczas dziewiętnastowiecznej prosperity, przywołany Mosze Mendel reprezentuje „biednych ludzi bujających w obłokach”, którzy „nie mogli pojąć, dlaczego zostali wyrzuceni z kapitalistycznego pociągu" (Belis-Legis 1989: 8). Dramat bohatera Aleihema gęstnieje i staje się społecznym, jeśli czytelnik sięgnie po literaturę opisującą sytuację po I wojnie światowej, gdy niepodległość Polski spowodowała zamknięcie rosyjskich rynków dla produktów „lodzermenschów".

Jednym z najbardziej przejmujących symboli tego zjawiska pozostanie niewątpliwie obraz śmierci przedsiębiorcy ściśle powiązanej z głębokim kryzysem jego miasta, nakreślony przez Izraela Joszuę Singera (brata wspominanego wcześniej noblisty) na kartach Braci Aszkenazych: „Łódź się załamała (...) Król Łodzi Maks Aszkenazy, próbował wraz z miastem wrócić do życia. Lecz były to tylko silne konwulsje ciężko chorego, jakby rozbłyskująca, migocząca świeca przed zgaśnięciem. Nic się nie udało sklecić z połamanych skorup królestwa Aszkenazego. Pękło i rozpadło się ono wraz z miastem, podobnie jak wraz z nim się narodziło. Pewnej późnej godziny nocnej pękło również serce Maksa Aszkenazego. Jak bez powietrza nie mógł Aszkenazy oddychać w mieście pozbawionym dymu" (Singer 1998: 743 i 749). Trudno o bardziej wyrazistą metaforę losu biznesmena w warunkach ekonomicznego kryzysu. To także niewątpliwy przyczynek do dyskusji nad uniwersalnymi wątkami mitu „lodzermenscha”.

Dynamiczne włącznie się Żydów, także tych żyjących na polskich ziemiach, w procesy modernizacji zaowocowało, co warto przypomnieć, radykalnym wyjściem „poza getto”. Nie tylko wobec obywateli Łodzi, ale także wobec mieszkańców prowincjonalnych „sztetlów” prawdziwy jest opis zjawiska, które starszy Singer (Izrael Joszua) utrwalił na kartach cytowanej powieści: „niezależnie od wszystkich innych konsekwencji proces modernizacji niesie dla Żydów także ściślejsze włączenie się w rytm powszechnej historii. Nigdy nie byli z niego, co jasne, wykluczeni. Teraz wszakże ich związki ze światem żydowskim znacznie się zacieśniają" (Prokop-Janiec 1998: 13).

To przecież o małomiasteczkowych bohaterach Alejchema pisał Salomon Belis-Legis (1989: 15-16), że często ujawniają nerwowość, bo „Są dziećmi epoki, która nie ma czasu, która spieszy się nie wiadomo dokąd (...). Szołem Alejchem trzymał rękę na pulsie życia swojej epoki, a masy żydowskie w wyniku swej skomplikowanej sytuacji były najczulszym jej barometrem”.

Dynamiczne „wyjście poza getto” ze znacznie większym bagażem doświadczeń kapitalistycznej przedsiębiorczości niż mieli inni mieszkańcy ziem polskich (poza oczywiście Niemcami) w kontekście splotu innych uwarunkowań, których choćby wspomnienie znacznie przekraczałoby tematykę niniejszej pracy, przynosiło powszechnie znane, dramatycznie trudne problemy dotyczące relacji Żydów i ich nieżydowskiego otoczenia. Zasygnalizuję tylko tę kwestię, przytaczając głos 
opublikowany ostatnio na łamach „Midrasza” w dyskusji nad książką Grzegorza Krzywca Szowinizm po polsku. Przypadek Romana Dmowskiego podkreślający, iż konflikt ekonomiczny między rodzącym się pod koniec XIX wieku polskim drobnomieszczaństwem a ustabilizowanym już drobnomieszczaństwem żydowskim stanowił jeden z głównych czynników popularności myśli endeckiej29. Jak się też wydaje, pełna analiza złych stosunków między Polakami a Żydami sprzed koszmaru Holocaustu, nie jest możliwa bez opracowania także materiałów w języku jidysz, choćby tych, które zawierają zbiory Żydowskiego Instytutu Historycznego, niepoddanych jeszcze naukowej analizie, o czym mówił niedawno na łamach prasy nowy dyrektor tej Instytucji Paweł Śpiewak ${ }^{30}$.

Jednak ekonomiczne relacje polsko-żydowskie nie musiały być i (jak pokazuje choćby działalność Zrzeszenia Importerów Kawy i Herbaty z lat 30. ubiegłego wieku, o której piszę w rozdziale VI, podrozdział 6.2. niniejszej pracy nie zawsze były) wyłącznie złe. Rozdział ten pozostaje w obrębie problematyki mitu, może więc uwypuklić mityczne „potencjały mniejszościowe” kreujące wzór nie tylko konfliktowych relacji między przedstawicielami różnych kultur szeroko rozumianego biznesu. Niech nośnikiem wspominanych treści pozostanie na przykład pan Malczyk, polski klient restauracji ojca bohatera cytowanej powieści Symchowicza, wspomagający biedne żydowskie dziecko. „Malczyk był przedsiębiorcą budowlanym i po długim letnim dniu pracy lubił godzinami przesiadywać w restauracji Mosze-Awruma nad kuflem piwa i rozmawiać z każdym, kto mu się nawinął. Dobrze zaznajomiony ze Starym Testamentem, z uznaniem i szacunkiem wypowiada się o Żydach - ludziach Przymierza, z których pochodził Pan Jezus. Współczuł »Gilgulowi«, kilka razy zabrał go do fryzjera na podcięcie włosów i często kupował mu jedzenie" (Symchowicz 1994/2005: 6531).

Warto więc może zreinterpretować proprzedsiębiorcze mity oparte na modelu „lodzermenscha” zgodnie z apelem wygłoszonym przy zupełnie innej okazji przez Christiana Krausego: „Historii nie można zawrócić. Jednak konsekwencje, które jesteśmy gotowi z niej wyciągnąć dla naszej teraźniejszości i dla przyszłości naszych dzieci, są dla nas nowym wyzwaniem ${ }^{32}$ (Ochinowski 2012a).

Taka perspektywa skłania do przypomnienia jeszcze jednej kulturowej odmiany omawianych mitów, to jest takiej, która uosabia tradycje przedsiębiorczości

29 Przytoczną opinię zawierał „Głos z Sali”. Tego typu dyskusje same w sobie są mitotwórcze. Nie podejmuję tu sprawy historycznego uzasadnienia wspomnianej opinii.

30 Żyd przestaje się źle kojarzyć. Rozmowa Mazurka z Pawłem Śpiewakiem, PlusMinus, dodatek do „Rzeczpospolitej”, 26.11.2011. Pobrano z: http://www.rp.pl/artykul/365403,760279. html [08.01.2012].

31 Przekład M. Domański.

32 Fragment kazania wygłoszonego przez Christiansena 8 września 2002 w Świdnicy. Był on wówczas prezydentem Światowej Federacji Luterańskiej, cyt. wg albumu Adama Bujaka (2007), „Swiatowe dziedzictwo. Polska na liście UNESCO”, Kraków, Biały Kruk, s. 249. 
rosyjskiej czy - szerzej - czerpiącej z wartości prawosławia ${ }^{33}$. Rozwijana na ziemiach Królestwa Polskiego w warunkach represji carskiego zaborcy wydaje się ona (co nie może oczywiście wywoływać zdziwienia) znacznie bardziej zapomnianą, a zarazem obarczoną negatywnymi stereotypami niż opisane wcześniej odmiany żydowska i niemiecka.

$\mathrm{Na}$ kartach polskiej literatury pięknej rosyjska przedsiębiorczość XIX wieku jest „obecna” przede wszystkim... przez nieobecność. Sytuację tę symbolizuje choćby już do dawna „punktowane” przez historyków literatury milczenie Reymonta o Rosjanach - mieszkańcach Ziemi obiecanej (zob. np. Kielak 2013). Wcześniej podobnie Prus, cieszący się przecież zasłużoną sławą wnikliwego obserwatora Warszawy ${ }^{34}$ na kartach Lalki „nie widział” jaskrawych kolorów szyldów sklepowych narzuconych przez zaborcę (stanowiących sposób zwalczania nastroju żałoby Polaków po powstaniu styczniowym) oraz ich dwujęzyczności. Konsekwentnie świat prawosławnych warszawiaków pozostał przez tego autora „nieprzedstawiony” (Mikołejko 201335).

Rosyjski element proprzedsiębiorczych mitów opartych na modelu lodzermescha pozostaje również niepodjętym dotąd tematem badawczym. Uwaga Wiktorii Śliwowskiej sformułowana podczas niedawnej konferencji „Polska-Rosja, nowe horyzonty” dotyczy także sfery przedsiębiorczości: „tak naprawdę temat 'Rosjanie w Polsce w dobie zaborów' czeka na kompleksowe opracowanie, (...) w dalszym ciąu czekamy na odpowiedź, jak traktowano Rosjan: czy rzeczywiście panował wobec nich cały czas ostracyzm, czy byli przyjmowani w polskich domach, (...) ile było małżeństw mieszanych (poza arystokracją) itd. Słowem, co należy do sfery mitu, a co nie" 36 .

Interesująca badawczo byłaby na przykład analiza funkcjonowania na ziemiach polskich - zarówno w przestrzeni realnej, jak i mitologicznej - dwóch

33 W niniejszym rozdziale ograniczam się jedynie do tradycji rosyjskiej. Jednak na przykład Paweł Przeciszewski (2011) wspomina serbskich i greckich kupców przebywających na stałe w Warszawie w XVIII, związanych z bizantyjską odmianą prawosławia. Ich ślad ośmiela do poszukiwania także takiego archetypu lodzermenscha, który sięga korzeniami aż do średniowiecznego Biznacjum, gdzie działalność przedsiębiorczą pośrednio nobilitował choćby Mikołaj Kabasilas (Tatakis 2012, o znaczeniu cesarstwa bizantyńskiego w historii gospodarczej zob. np. Sheprad 2013). Obecnie sukcesorami tradycji tej grupy przedsiębiorców w Polsce są Grecy, przede wszystkim prowadzący działalność gastronomiczną, których aktywność analizuje aktualnie z perspektywy kapitału kulturowego Mehmet Ali Ozcobanlar, doktorant Wydziału Zarządzania UW.

34 Zob. np. Noc z „Lalka Prusa, „Wprost”, 18.05.2012. Dostępne w: www.wprost.pl/ ar/323200/Noc-z-Lalka-Prusa/ [pobrane 09.04.2013].

35 Trudno się natomiast zgodzić z Mikołejko (2013), że Lalka przemilcza także światy żydowski i protestancki (por. np. Maręga b.r.w.).

36 Podaję za relacją Ałły Marteńczyk (2012), A wśród prelegentów same znakomitości, Sami o sobie, dodatek do „Przeglądu Prawosławnego”, nr 12, 2012, s. 54-55. W przypadku problematyki rosyjskiego lodzermenscha do analitycznej pracy pozostaje także rekonstrukcja mitu i ewentualnych sposobów jego funkcjonowania. 
typów przedsiębiorcy charakterystycznych, zdaniem Heiko Haumanna (1993: 34) dla Rosji doby uprzemysłowienia. Cytowany badacz zaproponował przed laty wyróżnienie dwóch grup przedsiębiorców rosyjskich:

a) Moskaeurów, którzy „zakładali (...) fabryki z notesem w ręku” i zaczynali „od drobnego przedsiębiorstwa przemysłu tekstylnego lub spożywczego, pozostającego w silnym związku z lokalnym rolnictwem i handlem",

b) „Petersburskich biurokratów” czyli inżynierów, techników i dawnych urzędników stających na czele nowoczesnych zakładów przemysłowych i związanych z nimi banków, a także przedsiębiorców dysponujących nikłymi zasobami kapitałowym i równie niewielkimi możliwościami zbytu na wolnym rynku, co powodowało ich silne uzależnienie „od hojnej pomocy państwowej”37.

Równie ciekawe wydaje się zbadanie, czy na polskie ziemie (i jeśli tak, to w jakim stopniu) przenikały aksjologiczne postulaty działalności biznesowej formułowane przez przedstawicieli odrodzenia rosyjskiej myśli prawosławnej przełomu XIX i XX wieku. Jeden z czołowych reprezentantów tego fermentu ideowego, który dramatycznie przerwała bolszewicka rewolucja 1917 roku, Dmitrij Filosofow znalazł później schronienie w Polsce (Przeciszewski 2011). Trudno jednak dziś, przynajmniej jak dotąd, powiedzieć, na ile jego samego i towarzyszących mu przedstawicieli rosyjskiej emigracyjnej inteligencji interesowały sprawy przedsiębiorczości. Niemniej jednak warto pamiętać, iż praca niekwestionowanego lidera „Srebrnego wieku” religijnej myśli w Rosji, jak nazywają wspomniany okres historycy kultury, Sergiusza Nikołajewicza Bułgakowa (1871-1944) Filozofia gospodarki (ros. Fitosofia chozajstwa, pierwsze wydanie 1912 rok) zaliczana jest do prekursorskich w literaturze światowej książek dotyczącej dziedziny, która dużo później zyskała miano „etyki biznesu” (zob. Paprocki 2011) ${ }^{38}$. Przywołany myśliciel, zarówno poprzez wykształcenie jak i działalność dydaktyczną związany z zagadnieniami ekonomicznymi poświęcił

37 Warto zwrócić uwagę, iż „geograficzne” wyznaczniki typów rosyjskich przedsiębiorców wyróżnionych przez Haumanna (1993) mają znaczenie wyłącznie metaforyczne. I tak na przykład „Petersburscy biurokraci” działali nie tylko wokół Petersburga, ale także na południu Carstwa Rosji, w Zagłębiu Donieckim (chodzi więc o dzisiejszą Ukrainę) i w Krzywym Rogu. W takim samym sensie piszę o lodzermenschu, jako o mitologicznym wzorze przedsiębiorcy, który równie dobrze mógł działać na obszarze samej Łodzi, jak i Warszawy czy małych miasteczek ukraińskich.

38 Cenne wskazówki dotyczące ideowych podstaw rosyjskiego wzoru lodzermenscha zawdzięczam ks. Henrykowi Paprockiemu z Katedry Teologii Prawosławnej Uniwersytetu w Białymstoku i Seminarium Prawosławnego w Warszawie, który na gruncie polskim kontynuuje myśl religijną Srebrnego Wieku rosyjskiego prawosławia. Ekonomiczne poglądy Bułgakowa pomogła mi poznać Lena Artemenko, stypendystka Programu Rządu RP dla Młodych Naukowców w roku akad. 2012/2013. Swój wkład wniosły także Anna Leszczyńska i Jewienia Karczenko uczestniczki wykładu ogólnouniwersyteckiego „Historyczny sukces. Zapomniane tradycje polskiej przedsiębiorczości” (UW, semestr zimowy 2012/2013). Wszystkim tym Osobom serdecznie dziękuję. 
im sporą część dorobku pisarskiego. Posiłkując się filozofią Friedricha Schellinga, Bułgakow propagował wizję gospodarki jako działania podmiotu, który określał jako economic man zależny w konkretnym kształcie swej aktywności od danej epoki, a także od wyznania religijnego. Na przestrzeni długiej historii prawosławia, przeważało rolnictwo. Słabo rozwijał się kapitał i przemysł. Autor Filozofii gospodarki wiązał to z faktem, że działalność zawodowa rolni$\mathrm{ka}$, naturalnie zwrócona ku przyrodzie oraz jej tajemnicom, bardziej sprzyja stosunkom religijnym niż praca $\mathrm{w}$ fabryce. Jednak rozwój form gospodarczych stanowi proces, którego konieczność warunkuje wola gospodarcza jednostki ludzkiej. Takie spojrzenie ściśle wydaje się łączyć z bułgakowskim rozumieniem produkcji jako „aktywnego wpływu podmiotu na przedmiot lub osoby na naturę” przez co jednostka „obiektywizuje swoje cele” (Bułgakow 1990: $\left.76^{39}\right)$. Dziewiętnastowieczne procesy industrializacji i urbanizacji stanowiły dla cytowanego myśliciela rodzaj gospodarczej konieczności. Skoro nie można jej uniknąć, to należy ją tak przeobrazić duchowo, by ośrodki eksploatacji człowieka - jakimi były niewątpliwie w swej większości ówczesne przedsiębiorstwa - stały się miejscami wspólnej pracy, a służenie żądzom winno zostać przemienione w posługę chrześcijańskiej miłości. Poglądy Bułgakowa legły u podstaw prawosławnego poglądu na kumulację kapitału, która nie może stawać się celem samym dla siebie. Powinna służyć dobru wspólnemu, ponieważ jej podmiot (przedsiębiorca) jak każdy człowiek ma naturę wspólnotową (Bułgakow 1990 i 1992, Paprocki 2011). Zdaniem Henryka Paprockiego (2011: 1) nie była to tylko teoria. „Przykładami moga być tutaj prawosławni kupcy i przemysłowcy, którzy fundowali szpitale, szkoły a nawet gromadzili dzieła sztuki, żeby później przekazać je całemu narodowi. Właśnie z tego typu działalności powstało Muzeum Sztuki imienia Aleksandra Puszkina w Moskwie”. Przy czym warto podkreślić, iż tradycja prawosławna docenia znaczenie dążenia do zysku w aktywności gospodarczej, uznając takie nastawienie za oczywiste. Na przykład wypowiedzi jednego z największych autorytetów religijnych Rosji, św. Serafina z Sarowa (1759-1833, kanonizowanego przez Cerkiew Prawosławną w 1903), które zapisał (bądź sparafrazował - jak chcą niektórzy badacze) Mikołaj Aleksandrowicz Motowiłow, zawierają wręcz sugestię, by życie duchowe miało podobną strukturę i intensywność do działań przedsiębiorczych skoncentrowanych wokół zysku. „Opowiem Panu o sobie, o ubogim Serafinie. Pochodzę z kurskich kupców i kiedy nie byłem w monasterze, bywało, że handlowaliśmy towarem, który daje najwięcej zysku. Tak samo i Pan powinien postępować (chodzi o realizację celów duchowych - uwaga T.O.), jak w sprawach duchowych, których sens nie polega na tym, żeby tylko handlować, ale na tym, żeby

39 Przekład L. Artemenko. 
osiągnąć jak największy zysk" (św. Serafin z Sarowa 2008: 64-6540). Trudno nie zauważyć pokrewieństwa aksjologicznego - ale realizowanego na poziomie konkretnych zachowań - rosyjskiego wzoru przedsiębiorcy z naszkicowanymi przeze mnie wcześniej żydowskim i niemieckim archetypem „lodzermenscha”. Równie trudno szerzej zidentyfikować obecność rosyjskiej odmiany omawianego etosu na ziemiach polskich. Literackimi nośnikami modelu „lodzermenscha” o prawosławnej duszy pozostają dwaj powieściowi kupcy, roztaczający opiekę nad Polakami - zesłańcami syberyjskimi. Pierwszy to Suzin z Lalki Prusa cierpliwie inspirujący działalność przedsiębiorczą Wokulskiego. Drugi to - przy zachowaniu wszelkich proporcji warunkowanych różnicą klasy przywołanych książek - Naszkin, drugoplanowy bohater Tajemniczej wyprawy Tomka, którego autor książki, Alfred Szklarski uczynił przyzwoitym, choć chciałoby się napisać nieprzyzwoicie bogatym biznesmenem wspierającym skazanego na katorgę młodego Polaka Zbyszka Karskiego, a także innych zesłańców, nawet wbrew polityce władz swojego kraju. Przy czym warto zauważyć, iż „przyzwoitość” Naszkina bezkonfliktowo szła w parze z realizacją celów ekonomicznych, dzięki zatrudnianiu wykształconych sybiraków.

„- Nie przypuszczałem, że zesłańcy mogą uczestniczyć w przyjęciach u syberyjskich bogaczy - zauważył Tomek ${ }^{41}$ nieufnie mierząc ją ${ }^{42}$ wzrokiem. - Nie taki więc diabeł straszny, jak go malują!

- To tylko dzięki wpływom wszechwładnego tutaj Naszkina. On jest spokrewniony z moją matką. Na wieść o aresztowaniu wyjednał, by zesłano mnie do Nerczyńska. Pracuję w jego przedsiębiorstwie.

- Hm, jeśli tak, to naprawdę przyzwoicie postąpił - powiedział Tomek. - Czy on zatrudnia również innych zesłańców?

- Tak, przecież to przeważnie inteligentni ludzie. Na Syberii brak umiejących czytać i pisać. Ja studiowałam w Moskwie medycynę.

- Ciekawe, słyszałem, że są trudności w przyjmowaniu zesłańców do pracy.

- Naszkin dorobił się fortuny, nawet gubernator mile widzi go u siebie. Carska administracja na Syberii pławi się w wódce, a na to przecież trzeba pieniędzy. Kto ma czym płacić, może sobie na wiele pozwolić" (Szklarski 2007: 136).

W każdym razie rosyjski wątek proprzedsiębiorczego mitu opartego na modelu „lodzermenscha”, choćby tylko lekko naszkicowany ubogaca jeszcze wielobarwność kulturową omawianego wzorca i wzbogaca jego źródła aksjologiczne.

$40 \quad$ Przekład H. Paprocki.

41 Tomek Wilmowski, bohater fikcyjny, główna postać serii młodzieżowych książek Alfreda Szklarskiego.

42 Chodzi tu o rosyjską sybiraczkę, jak się później okazało miłość Zbyszka Karskiego. 
W takiej perspektywie kwintesencją rozważań o przedsiębiorcy „z prowincji świata” stać się może refleksja Dedeciusa (2008: 354-35543), sugerująca, iż wspominany mit należało czytać jako wyrosłą na polskich ziemiach opowieść o życiu i przedsięwzięciach biznesmena, mniej lub bardziej świadomego napięcia między „czynnikiem ludzkim” a walką o zysk, bez wątpienia umiejącym sprostać wyzwaniom globalizacji44. „Łódzkiej szkole przede wszystkim zawdzięczam wychowanie do współżycia i współpracy z ludźmi różnych narodowości, różnego wyznania, różnego pochodzenia, różnych poglądów. Miastu mojej młodości, Łodzi, zawdzięczam również właściwy stosunek do pracy, do codziennych obowiązków i odpowiedzialności (do tej pory nie znoszę nieróbstwa i brakoróbstwa - u siebie). A ponadto bezcenne doświadczenie koleżeństwa, radości życia, „niepróżnujące próżnowanie”45.

Podsumowując, proprzedsiębiorcze mity wyrosłe z modelu „lodzermenscha” zawierają takie elementy treściowe jak: (1) wrażliwość na puls gospodarczej koniunktury (spośród bohaterów literackich kompetencję tę reprezentował np. Febus Böhlaugu), (2) świadomość ryzyka i tajemniczości finansów np. (Abel Glanz), (3) partyzancki kapitalizm jako społeczne otoczenie biznesu (zob. np. łódzką ulicę z powieści Rotha), (4) globalną mobilność (np. Maks/Mordche z „Szumowin” I.B. Singera), (5) dywersyfikację ryzyka (np. bohaterowie Szołem Alejchema) oraz (6) problematykę równowagi „praca-życie”, ze szczególnym uwzględnieniem napięcia między efektywnym przystosowaniem się do reguł rynkowych a wiernością tradycji religijnej (zob. np. powieści I.B. Singera czy Pasierb nad Wista Symchowicza). Swoje spełnienie mit ten łączył z (7) dużym sukcesem finansowym (np. Bloomfield), równocześnie zawierając sporą dozę (8) realizmu, aż do opisów zupełnej klęski (np. Maks Aszkenazy z powieści I.J. Singera, Ochinowski 2012a).

Warto sprawdzić, czy mityczny „lodzermensch” odróżnił się choćby częściowo w polskiej przedsiębiorczości lat 90 . XX w.

43 Przekład S. Lisiecka.

44 Warto przypomnieć, iż „lodzermensch” jako typ biznesmena został uformowany i przeżywał swoje „złote czasy” właśnie w okresie pierwszej fali globalizacji, uważanej jak dotąd za najsilniejszą (por. omówienie tej sprawy w III rozdziale, podrozdział 3.2. niniejszej pracy, tamże wskazówki bibliograficzne).

45 Nieoczekiwana dla mnie pośrednia sugestia Dedeciusa (2008), by do mitu lodzermenscha włączyć kategorię „otium” jest na tyle interesująca, iż wymaga oddzielnej dyskusji znacznie przekraczającej rozmiary niniejszego, z natury swej szkicowego rozdziału. Planuję dyskusję taką podjąć w przyszłości. Tu tylko zasygnalizuję obecność atmosfery otium także w przytoczonym cytacie z powieści Szklarskiego. Fragmenty jej akcji kluczowe dla problematyki mojej pracy rozgrywają się przecież na przyjęciu u syberyjskiego potentata, przy zaproszeniu także zesłańców. Zauważenie tego faktu, jak i przydatności przygód Tomka Wilmowskiego do analiz o wzorcu przedsiębiorczości zawdzięczam anonimowemu uczestnikowi dyskusji internetowej na stronie „Gazety Wyborczej”. 


\subsection{Lokalne mity proprzedsiębiorcze jako źródło inspiracji dla współczesnego biznesu}

\subsubsection{Lokalne mity proprzedsiębiorcze a problemy globalizacji}

Powstaje oczywiście pytanie dotyczące „korzyści”, jakie może dać zajmowanie się proprzedsiębiorczym mitem opartym na modelu „lodzermenscha” w kontekście współczesnych problemów biznesu.

Jeden z potencjalnych pożytków sięgania po dziewiętnastowieczne mity proprzedsiębiorcze wyznacza problematyka globalizacji. Warto przypomnieć, że prace takich wiodących badaczy dziejów gospodarczych jak Kevin H. O’Rourke, Niall Ferguson czy mniej znany Barry Eichengreen, pozwoliły ustalić, iż obecny charakter globalizacji, rozumianej zgodnie ze współczesnymi nam kryteriami, jest zakorzeniony w czasach przełomu XIX i XX wieku. Została ona zahamowana przez wybuch I wojny światowej. Warto więc raz jeszcze podkreślić, iż „lodzermensch” jako specyficzny model biznesmena został uformowany i przeżywał swój ideologiczny rozkwit właśnie w okresie pierwszej fali globalizacji, uważanej jak dotąd za najsilniejszą. Treści ideowe zawarte w micie z tamtej epoki mogą się okazać aktualne i dziś. Bo i dziś globalizacja niesie wyzwania kulturowe podobne do tych sprzed wieku. Jako przykład warto wskazać choćby napięcie między dążeniem do zysku a respektowaniem wartości religijnych czy związane z tym zaburzenie równowagi między kosmopolitycznych charakterem praktyk współczesnego kapitalizmu a potrzebą zakorzenienia w lokalnych tradycjach. Zdaniem nie tylko Huntingtona, ta druga $\mathrm{z}$ wymienionych kwestii stanowi obecnie jeden z głównych problemów zarządzania międzykulturowego.

Dlatego też warto podjąć badania porównawcze analogiczne do „lodzermenscha” archetypów kulturowych z różnych krajów, regionów oraz cywilizacji ${ }^{46}$.

Mity proprzedsiębiorcze oparte na tym modelu, przeanalizowane w niniejszym rozdziale są prawdopodobnie wspólnym dziedzictwem całego regionu Europy Środkowo-Wschodniej47.

$\mathrm{Z}$ innych tradycji europejskich (ale należących raczej do obszaru prowincji niż centrum kapitalizmu), nasuwają się na myśl działania artystyczne i poglądy znanego architekta Antoniego Gaudiego (1852-1926), który łączył wierność lokalnej tożsamości, a także uniwersalne wartości katolicyzmu z przyjaźnią wobec kultury rynku. Warto przypomnieć, iż ten Katalończyk, zakochany w swej małej ojczyźnie, jest aktualnie kandydatem na ołtarze Kościoła katolickiego. Zarazem jednak jego - może nie najbardziej oryginalny, ale jedyny oficjalnie

46 Pomysł ten zawdzięczam Larsowi Derlischowi, doktorantowi Wydziału Zarządzania UW.

47 Zwrócił mi na to uwagę Maciej Górny z Zakładu Historii Idei i Dziejów Inteligencji w XIX-XX wieku IH PAN. 
nagrodzony przez władze Barcelony (w której Gaudi lokował niemal wszystkie prace) - projekt to Casa Calvet, dom mieszkalny oraz służący „prowadzeniu interesów”. Znacząca jest również wieloletnia przyjaźn Gaudiego z Euesebi Güelleem, katalońskim przemysłowcem, który cenił wybitnego architekta przede wszystkim za „syntezę geniuszu artystycznego i zaangażowania społecznego" (Zrebst 1992/2010: 25). Logika historii organizacyjnej ośmiela, by w tym kontekście postawić pytanie badawcze o związki między doświadczeniem historycznym, które symbolizuje Gaudi, a trwającym do dziś dynamizmem przedsiębiorczości Katalończyków zarówno w ich ojczyźnie, jak i na emigracji (Lafuente, Vaillant i Rialp 2006 oraz Vaillant i Lafuente 2007) ${ }^{48}$.

Odwrotny kierunek analizy, to jest od niespodziewanych sukcesów we współczesności do poszukiwania ich korzeni w tradycji kulturowej, sugerują osiągnięcia środowiska biznesmenów związanych z turecką prowincją Anatolia. Od początku lat 80. ubiegłego stulecia bardzo dynamicznie rozwijają oni średnie przedsiębiorstwa, które zyskały już znaczącą pozycję eksportową na rynkach światowych i są uważane za główną siłę sprawczą sukcesu gospodarczego Turcji ostatnich dziesięcioleci. W połowie lat 90 . XX wieku firmy te zaczęły być przez dziennikarzy i badaczy nazywane „anatolijskimi tygrysami” przez analogię do „azjatyckich tygrysów”, to jest Honkongu, Korei Południowej i Tajwanu, określanych tak ze względu na napędzającą rozwój tych krajów konkurencyjność produkowanych tam produktów, szczególnie charakterystyczną dla lat 70. ubiegłego stulecia. Jako źródło swych sukcesów omawiani „ludzie interesu" z tureckiej prowincji oraz obserwatorzy ich działań wskazują między innymi tradycje kultury muzułmańskiej. „Anatolijskie tygrysy” chętnie przywołują islam, niekiedy widząc w nim wręcz aksjologiczne podstawy specyficznej odmiany ekonomii (niektórzy obserwatorzy szkicowanego tu fenomenu mówią o „islamskim weberianiźmie”), zrzeszają się w muzułmańskich związkach pracodawców (Ozcobanlar 2013 i Sromin 2008). Zdaniem cytowanego już przeze mnie Mehmeta Ali Ozcobanlara (2013: 7) „ducha” „anatolijskich tygrysów” uformowały takie wartości jak „,zaufanie, solidarność i lojalność. Te trzy komponenty znalazły się w centrum sukcesu rozwojowego regionu Anatolii. Głębokie islamskie korzenie Anatolii, związki ze wspólną kulturą społeczności islamskich,

48 Na dynamizm przedsiębiorczości katalońskiej diaspory w Kanadzie zwrócił mi uwagę Erji Furuyama z Uniwersytetu Nihonabshi Gakkon (Japonia). Mehmet Ali Ozcobanlar planował podjąć analizę kapitału kulturowego Katalończyków w swojej pracy doktorskiej na Wydziale Zarządzania UW. Jednak hermetyczność tej społeczności spowodowała, że po wstępnym rozpoznaniu problematyki, zrealizowanym podczas półrocznego pobytu w ramach programu wymiany „Erasmus” (semestr zimowy 2012/2013), wspomniany doktorant zrezygnował z tego tematu, uznając, iż jest bardzo trudny do wykonania dla osoby „, zewnątrz”, nie znającej języka katalońskiego. Przytoczony przypadek ukazuje zasadniczą barierę utrudniającą badania porównawcze nad lokalnymi mitami proprzedsiębiorczymi. 
sufizm jako system wiary oraz wiejskie pochodzenie przeciwdziałały niezgodzie między anatolijskimi przedsiębiorcami i dlatego też aktywność ekonomiczna raptownie rozwijała się (...)" na terenie omawianego regionu ${ }^{49}$.

Z kolei Daleki Wschód zawiera na przykład tradycje taoistyczne, które zadaniem Danny Lama i Cala Clarka (1994) w znacznym stopniu uformowały tajwańską wersję „partyzanckiego kapitalizmu” (ang. guerrilla capitalism). Właśnie „partyzancki kapitalizm” - na który złożyły się takie elementy jak: (1) agresywna, wręcz zuchwała pogoń za możliwościami „robienia biznesu”, (2) skrajna elastyczność w szybkiej realizacji nawet drobnych zleceń, (3) zwrócenie uwagi na jakość i standardy (quality and design), (4) ryzykowne licytowanie, (5) działanie w ramach kompleksowych sieci podwykonawców oraz (6) tylko wybiórcze śledzenie najlepszych spośród uregulowań rządowych i wynikających z prawa międzynarodowego, takich jak przepisy dotyczące własności intelektualnej - miał zdaniem cytowanych autorów znacznie bardziej warunkować sukces tajwańskiej małej i średniej przedsiębiorczości niż wpływ państwa. A właśnie te podmioty, warto przypomnieć, stanowiły główną siłę napędową gospodarki Republiki Chińskiej od początku jej istnienia i sprawiły, iż Tajwan, początkowo zacofana i biedna, a do dziś przeludniona oraz izolowana politycznie wyspa, spektakularnie wdarł się do grona gospodarczych „tygrysów Azji”. Z kolei przyczynę umożliwiającą rozwój „partyzanckiego kapitalizmu” Lam i Clark upatrują w czynnikach kulturowych, ze szczególnym uwzględnieniem wartości taoistycznych. To właśnie małe świątynie taoistyczne, zarządzane przez świeckich do dziś pełnią na Tajwanie także rolę ośrodków budowania kapitału społecznego wspierającego przedsiębiorczość (np. Zeldin 1998).

Być może też cechy cywilizacji afrykańskiej, a szczególnie jej kolektywizm rodzinny i sąsiedzki, witalizm oraz wrażliwość na rytm, wytworzyły - zapewne w tradycji oralnej - swoiste, nieznane Zachodowi mity proprzedsiębiorcze niepozbawione ładunku konkurencyjności. Szczególnie wspomniany kolektywizm, standardowo uważany przez zachodnich obserwatorów za hamulec rozwoju ekonomicznego państw afrykańskich, wcale przecież nie musi pełnić takiej roli (por. na przykład pracę Dołęgowskiego, Czerniaka i Siewierskiego 2012 o znaczeniu wartości wspólnotowych w rozwoju gospodarczym, także Hay 2006).

\subsubsection{Lokalne mity proprzedsiębiorcze a postkolonializm we współczesnym zarządzaniu}

Opisywane mity, czy raczej różne ich lokalne odmiany, mogą pełnić rolę intelektualnego remedium na etnocentryzm, od którego nie są wolne także

49 Cytowany Mehmet Ali Ozcobanlar aktualnie analizuje kapitał kulturowy przedsiębiorczości anatolijskich tygrysów w ramach swojej pracy doktorskiej na WZ UW, porównując go, co już sygnalizowałem, z bizantyńską wersją wspomnianego kapitału. 
niektóre korporacje międzynarodowe. Zazwyczaj takie nastawienie grozi pomijaniem prawdziwych wartości innych kultur (także wartości istotnych dla rozwijania efektywnego biznesu). Przypomina to o niezwykłej żywotności mitu determinizmu kulturowego w naukach społecznych i ekonomicznych. Karierę tego przekonania rozpoczęła w 1904 roku słynna Etyka protestancka $i$ duch kapitalizmu pióra Maxa Webera. Warto przypomnieć, iż zdaniem tego socjologa, u źródeł kapitalizmu leży aktywność ludzi wyznających religię protestancką. Religia oraz idący za nią określony typ kultury ma więc ściśle wyznaczać szanse danego społeczeństwa na sukces gospodarczy. Tezę tę historycy, a także badacze gospodarki dyskwalifikowali wielokrotnie przede wszystkim za przesadne przypisywanie znaczenia tylko jednemu czynnikowi przy tłumaczeniu procesów ekonomicznych oraz faworyzowanie tylko jednej formacji kulturowej. Kwintesencję wspomnianych krytyk zawiera na przykład ironiczne stwierdzenie Normana Davisa (1998: 547), który wskazuje, iż w odpowiedzi Weberowi „można by równie dobrze zapytać, dlaczego protestancki Bóg tak hojnie wyposażył swoich wyznawców w złoża węgla kamiennego".

Niemniej jednak determinizm kulturowy zachowuje niezwykłą żywotność. W latach 60. ubiegłego stulecia część amerykańskich naukowców obwiniała konfucjanizm za biedę w Azji. Mniej więcej po następnej dekadzie, wobec sukcesów gospodarczych „azjatyckich tygrysów"50 te same środowiska chwaliły prorynkowe zalety tej samej kultury konfucjańskiej (Sorman 2009).

Z kolei nasze stulecie otwierała książka Lawrence'a Harrisona i Samuela P. Huntingtona (2000/2003) Kultura ma znaczenie: jak wartości wptywaja na rozwój społeczeństw, której autorzy „starają się przekonać czytelnika, że wszystkie biedne kraje i kultury cierpią z powodu niedoskonałości kulturowych, które nie pozwalają im wyjść z ubóstwa" (Wilk i Cligget 2011: 171).

Jednym z przejawów etnocentryzmu stanowi niewątpliwie zjawisko myślenia postkolonialnego, którego opis powstał w ramach szerokiego nurtu teorii postkolonialnej popularnej obecnie w naukach społecznych. Wspomniana teoria (por. rozdział III, podrozdział 3.2. niniejszej pracy), za Boothem i Rawlisonem (2006)) jako o jednej z konceptualnych nadziei zwolenników historii organizacyjnej, mówiąc najogólniej, dotyczy mentalnego konserwowania podziału na centra i peryferie typowe dla stosunków kolonialnych (zob. także Kostera i Śliwa 2012). Ironicznie lapidarny opis tych ostatnich zaprezentowali na kartach swej relacji ze zwiedzania świata dwaj przedwojenni polscy podróżnicy Tadeusz Perkitny i Leon Mroczkiewicz. Gdy odwiedzali oni w 1928 roku Senegal, wówczas kolonię francuską, rzucił się im w oczy specyficzny, „kulturalny podział własności”: „Tak złudne, nędzne i przemijające dobra doczesne, jak gmachy, sklepy

50 Chodzi oczywiście o bardzo dynamiczny wówczas rozwój gospodarek Japonii, Korei Południowej i Tajwanu. 
banki, pałace i wille należą do białych. Zaś dobra tak wspaniałe, wprost przez Boga dane i wieczne, jak słońce, niebo, morska woda i piasek są własnością czarnych. Czyżby mogło być zresztą inaczej w kolonii?” (Perkitny 2009: 100).

Dziś po upływie wielu lat radykalnych zmian na gospodarczej mapie świata sarkastyczne spostrzeżenie podróżników z Polski nadal jest aktualne jako symbol podstawowej pokusy czyhającej na zachodniego biznesmena, który przekracza granice własnej kultury, poszukując rynków zbytu lub personelu taniej siły roboczej. Oczywiście jest to „pokusa” czyhająca w myśleniu oraz spostrzeganiu świata.

Teoria postkolonialna, demaskująca te pokusy, wydaje się stanowić dogodne narzędzie intelektualnego „uhistorycznienia” zarządzania i to nie tylko w krajach zachodnich czy tak zwanych rozwijających się.

Polska slawistka pracująca na teksańskim Uniwersytecie Rice zastosowała omawianą koncepcję najpierw do tropienia wątków imperialnych na kartach literatury rosyjskiej, od czasów carskich, poprzez okres ZSRR, aż po postsowiecką współczesność, a następnie zaproponowała przenieść kategorię postkolonializmu z literaturoznawstwa do analizy współczesnego życia politycznego na przykładzie funkcjonowania Polski jako członka Unii Europejskiej. Z tej perspektywy wspomniany postkolonializm polega na przystosowywaniu działań danego kraju wyłącznie do racji hegemonów (najsilniejszych państw) zamiast formułowania i artykułowania własnych interesów. Zerwanie z takim myśleniem przez polityków reprezentujących państwo niehegemonistyczne jest ważnym krokiem ku normalności zgodnej z demokratycznymi regułami gry (Thompson 2000, Thompson i Memphes 2007, Nowicka 2007) ${ }^{51}$. Wprost do badania najnowszych dziejów Polski zastosowała teorię postkolonialną Ewa Domańska (2008), ukazując jej użyteczność przy analizie obrazów PRL-u. Nic nie stoi na przeszkodzie by wykorzystać omawianą koncepcję także w praktyce biznesowej i badaniach przedsiębiorczości.

Nietrudno znaleźć przecież w biznesie międzykulturowym praktyki wynikające z myślenia postkolonialnego. Przykładem niech będzie zakończony przed kilku laty proces o mobbing przeciwko prezesowi firmy Lafarge wytoczony przez Polaków - członków zarządu tego przedsiębiorstwa ${ }^{52}$.

Wcześniej podobnego rodzaju, choć nie tak spektakularnego rodzaju trudności doświadczyło środowisko warszawskiej firmy „Daewoo FSO” pod zarzą-

51 Zupełnie pomijam problem wykorzystywania koncepcji Ewy Thompson i generalnie kategorii postkolonializmu w politycznych dyskusjach współczesnej Polski.

52 Jak potwierdził wyrok uznający pretensje skarżących (potwierdzony także przez francuskich prawników) wspomniany prezes używał zwrotów typu „wielkie gówno” na określenie czteroletniej pracy Polaków, ironiczne mówił o „polskiej logice myślenia” czy „polskiej inteligencji”. Zlecał on dyrektorowi finansowemu obliczania kosztów utrzymania prywatnego domu prezesa spółki, ironiczne stwierdzając, że dyrektor mógłby także skosić trawnik przed domem prezesa. 
dem koreańskim (1997-2004). Wyraźne przejawy mentalności postkolonialnej zagranicznych zarządców fabryki przejawiały się następująco:

- przekazywanie polskim robotnikom i inżynierom wiedzy oraz doświadczenia technicznego, które już posiadali,

- niektóre elementy nowego systemu zarządzania jakością kojarzyły się w Polsce z czasami PRL-u, choć Koreańczycy istotnie usprawnili zarządzanie fabryką,

- zdarzały się wypadki agresji fizycznej wobec pracowników ze strony koreańskich menedżerów,

- nie respektowano przywiązania Polaków do 8-godzinnego dnia pracy,

- nie brano pod uwagę faktu, że w Europie relacje zawodowe mają charakter bardziej poziomy (np. w Polsce ważna rola związków zawodowych i nieformalnych powiązań), niż to jest w azjatyckim systemie wartości.

Nastroje wśród pracowników dobrze oddawało powiedzenie polskich robotników FSO z tamtych czasów: „Przeżyliśmy czerwonych (to jest władze PRL), przeżyjemy i żółtych"53.

Okazuje się, iż u podstaw przytoczonych tu przykładowo przejawów „myślenia postkolonialnego" leżą stereotypy formowane przez brak wiedzy historycznej między innymi współczesnych biznesmenów z krajów zachodnich. Dobrze ilustrują to zjawisko, za pomocą szczegółowych przykładów, następujące wypowiedzi dwóch historyków brytyjskich:

„Zanim dwanaście milionów Afrykanów porwano i sprzedano w nowym świecie jako niewolników, głównymi ofiarami niewolnictwa byli Słowianie. To od nazwy tego ludu (slav) pochodzi angielska nazwa „niewolnik” (slave) ${ }^{54}$. Sło-

53 Cytowany slogan, który usłyszałem w autobusie w pobliżu FSO, skłonił mnie do przeprowadzenia zwiadu badawczego metodą wywiadów z ,informatorami kluczowymi” wśród polskich menedżerów FSO Daewoo, którzy pracowali pod tzw. pierwszym zarządem koreańskim. Te nieustrukturyzowane wywiady przeprowadziłem, przy udziale Marcina Tygielskiego, wówczas studenta IPSiR, w 2006 roku. Niektóre z wyników moich rozmów przedstawiam powyżej. Moim informatorem był Andrzej Łowicki, refleksyjny praktyk zarządzania, wieloletni dyrektor transportu w FSO, absolwent WZ UW, który wspó1pracuje ze mną przy zbieraniu materiałów do społecznej historii wspomnianego przedsiębiorstwa.

54 Teza przytoczona przez Zedlina jest obecnie uważana przez historyków i filologów za naukowo nieuzasadnioną. Niemiej jednak dobrze oddaje ona potoczne myślenie przeciętnego „człowieka Zachodu”. Przyjmuje się wprawdzie wersję, że rzeczywiście w X wieku w Europie Zachodniej słowo servus [niewolnik] zostało zastąpione przez sclavus, pochodzące od Sclavus, czyli Słowianin. Przyniosło to trwałą zmianę językową (por współczesne niem. Sklave, fr. l'esclave, i ang. slave). Tymczasem wspomnę pojawienie się terminu sclavus było związane $\mathrm{z}$ tym, iż pod koniec $\mathrm{X}$ i na początku następnego stulecia zachodnioeuropejskie targi niewolników zapełniły się „towarem słowiańskim”. Niewolnicy stanowili główny „towar” wczesnośredniowiecznych kupców z Europy Zachodniej wymienny na srebro konieczne do handlu ze Wschodem. Znaczący udział w tym procederze miały także kraje słowiańskie. I co najistotniejsze, głównymi dostawcami słowiańskich nie- 
wian, łapanych przez Rzymian, chrześcijan, muzułmanów, wikingów i Tatarów, sprzedawano na całym świecie. I słowo Słowianin zaczęło oznaczać cudzoziemca. (...) Bliżej naszych czasów, gdy Słowianami zaczęli rządzić tyrani i lud ten nie przejawiał nadziei na wyzwolenie, niektórzy doszli do ponurego wniosku, że najwidoczniej w charakterze ludzi słowiańskiego pochodzenia tkwi coś, co skazuje ich na niewolnictwo. Ale taki wniosek został wyprowadzony z fałszywych przesłanek" (Zeldin 1994: 15).

„Wyrobiono sobie obraz Europy Wschodniej jako dziwacznego tworu, ponieważ nic o niej nie wiedziano. Bo niby skąd można było się czegokolwiek dowiedzieć? Przypominam sobie czasy, gdy studiowałem w Cambridge, a potem wykładałem w Oksfordzie. Wtedy coś takiego jak historia Polski, Czech czy Węgier w ogóle nie istniało. Historia krajów Europy Wschodniej pojawiała się jedynie jako element tzw. soviet studies i była ważna jedynie na tyle, na ile wiązała się z historia Związku Sowieckiego (...). I aby to zmienić, trzeba bardzo dużo czasu i wysiłku. Obraz polskiego hydraulika, który kradnie prace miejscowym (...) wpisuje się w te tradycje. Dziś dochodzi do tego jeszcze strach Zachodu przed globalizacją - przed niepewnym jutrem, nieszczelnymi granicami, delokalizacją, konkurencja nowych gospodarek. Otwarcie na Wschód stanowi w oczach Zachodu element tej serii zdarzeń” (Judt 2007).

Zestawione wyżej wypowiedzi nie wymagają oczywiście komentarza i odnoszą się także do biznesowych problemów nie tylko Europy Wschodniej.

Sławomir Magala, polski profesor zarządzania międzynarodowego na Uniwersytecie Erazma w Rotterdamie, wobec niebezpieczeństw etnocentrycznego determinizmu kulturowego proponuje menedżerom perspektywę wyznaczaną przez kompetencje międzykulturowe (2011: 259-260 i 2006: 67-68), „które staramy się stworzyć w naszych działaniach naukowych, edukacyjnych i konsultingowych, takie, które coraz więcej ludzi rozbudowuje w trakcie niezliczonych interakcji, oraz takie, które śledzimy za pomocą nowych struktur konceptualnych i modeli teoretycznych (...)”, tak by „stworzyć parlament subkultur, w którym można będzie negocjować różnice, a opcje jasno przedstawiać pełnemu pasji rządowi i organizacji wykonawczej kształtowanej przez interesy władzy. Na dłuższą metę właśnie o to chodzi w kompetencji międzykulturowej. Wyrasta ona w cieniu władzy i pasji”.

Problematyka kompetencji międzykulturowych stanowi nowy, tworzący się jeszcze dział zarządzania. Zdaniem Magali (2011), ta dziedzina znajduje swe miejsce między teorią organizacji, rozwojem organizacji, zarządzania zasobami ludzkimi i badaniami komunikacji, utrzymując ścisły związek z szeregiem innych nauk humanistycznych i społecznych, takich jak socjologia, antropolo-

wolników na rynki Europy Zachodniej i arabskie byli sami Słowianie (por. nowożytne niewolnictwo w Afryce, Barański 2012). 
gia kulturowa, psychologia społeczna czy ekonomia kulturowa, by wymienić tylko niektóre. Nawiasem mówiąc, trudno nie zauważyć podobieństwa zarówno strukturalnego, jak i funkcjonalnego między kompetencjami międzykulturowymi i historią organizacyjną.

Literacki rodowód mitu typu „lodzermensch” wskazuje na użyteczność literatury jako narzędzia uczenia kapitału kulturowego i trenowania kompetencji międzykulturowych.

Podsumowując, mam nadzieję, iż badania przyczynkarsko zrealizowane i sugerowane w niniejszym rozdziale, dotyczące kulturowej warstwy nieamerykańskiego american dream będą pomocne w rozwoju międzykulturowej edukacji proprzedsiębiorczej oraz optymalizacji działań biznesowych pozbawionych myślenia postkolonialnego czy innych form etnocentryzmu. Zaś prowincjonalne (w stosunku do centrów globalizacji) tradycje przedsiębiorczości, w tym także polskie, przeniknięte duchem „lodzermenscha” będą miały szanse stać się elementami kompetencji międzykulturowych i kapitału kulturowego organizacji, który wyłania się z okołokryzysowych dyskusji55.

Następny podrozdział poświęcony jest „Nowej Kulturze Pracy”, ideologii działań biznesowych, która ponad 50 lat temu była przez swoich twórców intencjonalnie formułowana jako „polski głos” w dyskusji wspominanego typu. Wtedy chodziło o kryzys spowodowany II wojną światową. Tamte propozycje wartości i praktyk konfrontuję $\mathrm{z}$ wyzwaniami obecnej sytuacji około kryzysowej.

\subsection{Idee środowiska Nowej Kultury Pracy (1945-1948) i ich współczesne aplikacje}

\subsection{1. Środowisko „Tygodnika Warszawskiego" 1945-1948 (wybrane aspekty)}

W Polsce poszukiwanie konceptualizacji, a tym bardziej realizacji wspomnianego w ostatnim rozdziale części pierwszej niniejszej pracy kapitału kulturowego organizacji, wykorzystującego ideową triadę „podmiotowość - relacyjność - zakorzenienie” wydają się nadal „wołaniem na puszczy”, szczególnie wobec rozpowszechnionych u nas poglądów skrajnie liberalnych, sięgających być może aż „socjopatycznego egoizmu”, jak to z publicystyczną przesadą ostatnio ujął (cytując jednak doniesienia z badań) Rafał Woś (2013), dziennikarz „Dziennika Gazety Prawnej”. Przypadki zachowań organizacyjnych, respektujących podmiotowość, relacyjność i zakorzenienie oczywiście się zdarzają, ale są do uchwycenia przede wszystkim przez analizy jakościowe, których wyników z natury rzeczy nie

55 Chodzi oczywiście o kryzys finansowy 2007. 
da się uogólniać (uchwycił je na przykład zwiad badawczy opisany w ostatnim rozdziale pierwszej części niniejszej pracy). Takie podejście zainteresowane wyłącznie wąsko rozumianym zyskiem wydaje się stanowić sytuację typową dla głównych tendencji globalnego świata pracy, co z krytycznym niepokojem konsekwentnie analizuje od kilkunastu lat Richard Sennett (2006, 2009, 2010 i 2012). Cytowany socjolog jedną z przyczyn takiego stanu rzeczy widzi w zerwaniu z tradycjami kultury organizacyjnej łączącej efektywność firmy i dbałość o podstawowe prawa, a także potrzeby pracownika (zob. szczególnie Sennett 2010, Ochinowski i Kseba 2013).

Tym bardziej może być więc interesujące przypomnienie współczesnym aktorom działalności gospodarczej, szczególnie tym, którzy są zainteresowani „szerszym zrozumieniem swojego biznesu”56 (Amatori i Colli 2011: ii), iż na terenie prowincjonalnego kraju Europy Środkowej - to jest Polski - już przed pięćdziesięciu laty idee wyraźnie, choć nie wprost, nawiązujące do wspomnianej triady „podmiotowość - relacyjność - zakorzenieni” jako podstawy dobrych praktyk przedsiębiorczych rozwiało środowisko skupione wokół „Tygodnika Warszawskiego", zapominanego dziś stołecznego pisma środowisk inteligenckich, artystycznych, a także związanych z przedsiębiorczością̧7. Co istotne, „Nowa Kultura Pracy” - taki był tytuł koncepcji - nabierała kształtu w kontakcie z praktyką gospodarczą przynajmniej części jej autorów. Niestety, procesy stalinizacji kraju prowadzące także do zniszczenia przez represje prezentowanego czasopisma sprawiła, iż ten projekt efektywnej, a zarazem „ludzkiej” przedsiębiorczości nigdy nie wyszedł poza formułę publicystycznego pomysłu (Ochinowski 2010).

Program „Nowej Kultury Pracy” został zarysowany przede wszystkim na łamach redagowanej przez Jerzego Brauna i Tadeusza Kudlińskiego (Biełaszko 2007) wkładki do „Tygodnika Warszawskiego”, ukazującej się nieregularnie w latach 1947-4858. Stanowil on forum dyskusji nad gospodarką i problemami pochodnymi rozwijanej w środowisku wywodzącym się z konspiracyjnej organizacji „Unia”, która podczas II wojny światowej skupiła szerokie kręgi inte-

56 Do takich „refleksyjnych praktyków” adresowana jest historia biznesu.

57 Tomasz Sikorski i Marcin Kulesza (2013) z Instytutu Historii i Stosunków Międzynarodowych Uniwersytetu Szczecińskiego opublikowali ostatnio obszerny wybór publicystki „Tygodnika Warszawskiego” opatrzony naukowym opracowaniem i poprzedzony wstępem stanowiącym ważny przyczynek do monografii tego środowiska. Wyraźnie więc opinia o zapomnieniu wspomnianego pisma, przynajmniej wśród badaczy, ma szansę stać się nieaktualna.

58 Oprócz dodatku, także w innych miejscach „Tygodnika Warszawskiego” ukazywały się artykuły poświęcone ekonomii, gospodarowania zasobami naturalnymi czy też dotyczące prawa własności. Obok zagadnienia pracy były to tematy gospodarcze najczęściej omawiane na łamach tego czasopisma. Ich wybór dotyczący także problematyki ekonomicznej zawiera wspomniana publikacja Sikorskiego i Kuleszy (2013). 
ligencji różnych opcji ideowych, zainteresowanej budowaniem programów dla Polski powojennej. Zróżnicowanie ideowe wspomnianego kręgu nie zmieniało jednak faktu, iż istotna część jego znaczących przedstawicieli była intencjonalnie zakorzeniona w katolickiej nauce społecznej, twórczo, często niestandardowo ją interpretując, a w niektórych aspektach także rozwijając (Wiszniewski 1998).

„Unia” mająca charakter struktury ideowo-wychowawczej powstała w roku 1940, na skutek połączenia kilku mniejszych ugrupowań ruchu oporu przeciw okupantowi hitlerowskiemu. W ramach tej organizacji powstało szereg mniej lub bardziej realistycznych koncepcji odbudowy różnych sektorów państwa ze zniszczeń wojennych (Wiszniewski, 1998 i Bujak 1988). Z powodu bardzo szerokiego zakresu zagadnień podejmowanych przez działaczy „Unii”, powstały w jej ramach różne piony: „Unia Kobiet”, „Unia Społeczna”, „Unia Kultury”, „Unia Młodych” a także, co najistotniejsze z punktu widzenia niniejszego artykułu, „Unia Pracy”. Właśnie ta struktura stała się ścisłym środowiskiem narodzin ideologii „Nowej Kultury Pracy”, ostatecznie sformułowanej już po wojnie (Braun 1981, Bujak 1988 i Strocka 2012).

Po 1945 roku część działaczy „Unii” posługiwało się wspomnianym już „Tygodnikiem Warszawskim” (ukazującym się w latach 1945-4859) w celu promowania swoich poglądów. Przez pierwszych kilka tygodni tygodnikiem kierował Zygmunt Wądołowski, później, aż do zamknięcia pisma, Zygmunt Kaczyński, przy dużym udziale wspomnianego wcześniej Jerzego Brauna (A.G. 1946). Zarówno Wądołowski, jak i Kaczyński byli księżmi rzymsko-katolickimi. W piśmie przeważała - przy zachowaniu szerokiego pluralizmu dyskusji - orientacja chrześcijańsko-demokratyczna ${ }^{60}$. Nie było ono jednak organem żadnej struktury kościelnej (Ochinowski i Kseba 2013).

Trzon środowiska tygodnika stanowili, co już sygnalizowałem, byli działacze i sympatycy Unii, oraz Stronnictwa Pracy, ówczesnej partii chrześcijańskodemokratycznej, starającej się, przynajmniej w pierwszych latach powojennych, oficjalnie działać na polskiej scenie politycznej. Zresztą środowiska te nie były rozłączne. Unia dość szybko, już podczas okupacji hitlerowskiej stała się organizacyjnie częścią Stronnictwa Pracy. Po 1945 roku grupa byłych unionistów podjęła działalność polityczną w Stronnictwie Pracy (Braun, 1981). Warto jednak raz jeszcze podkreślić, iż „Tygodnik Warszawski” miał charakter względnie otwarty, dając szansę publikowania dość zróżnicowanych poglądów.

59 Zamknięcie „Tygodnika Warszawskiego” po niecałych trzech latach ukazywania się było wyłącznie represją władz stalinowskich, nie miało żadnego uzasadnienia ekonomicznego. Większość dziennikarzy trafiła do stalinowskich więzień.

60 Dla ścisłości warto zauważyć, iż podczas krótkiego okresu redagowania pisma przez Wądołowskiego, wśród autorów dominowały osoby związane z opcją narodowo-demokratyczną. Część z nich pisała dla „Tygodnika” także później (Chrzanowski, 1997). 
Jego redaktorem naczelnym przez większość krótkiego czasu ukazywania się pisma był, jak już pisałem, ksiądz Zygmunt Kaczyński (1894-1953), przed II wojną światową dyrektor Katolickiej Agencji Informacyjnej i działacz chrześcijańskich związków zawodowych, podczas okupacji członek polskich władz na Uchodźctwie (ostatecznie jako minister wyznań religijnych i oświecenia publicznego w rządzie Mikołajczyka). Redagowanie „Tygodnika...” przypłacił śmiercią w więzieniu, poddany represjom politycznym (zob. np. Paczkowski 1991).

Spośród dwóch wymienionych przeze mnie wcześniej redaktorów wkładki „Kultura i praca” Jerzy Braun (1901-1975), typ intelektualisty - pasjonata, filozof (zob. Wiśniewska-Rutkowska 2004, Braun 2006) zainteresowany przede wszystkim światem idei, nie miał większej styczności z praktyką przedsiębiorczą, choć był autorem koncepcji tak zwanej gospodarki dynamicznej61 oraz publikacji na jej temat (Łętocha 20006 i Gołaszewski 2010). Pełnił niewątpliwie rolę przywódcy ideowego grupy „Tygodnika...”. Więziony przez stalinowski reżim (1945/1946 i 1948-1956) później wyjechał do Rzymu, gdzie zmarł (Łętocha 2006 i Otwinowska 1999).

Drugi redaktor dodatku „Kultura i Praca”, Tadeusz Kudliński (1898-1990) łączył twórczość pisarską (jako autor powieści, opowiadań, szkiców i wspomnień) oraz pasję teatrologiczną (jako recenzent, historyk i popularyzator teatru, a także organizator profesjonalnych i amatorskich scen) z pracą w krakowskim oddziale Banku Gospodarstwa Krajowego (podczas okupacji hitlerowskiej był de facto polskim dyrektorem tego oddziału). Podobnie jak inni „tygodnikowi” koledzy on także przeszedł gehennę więziennych kazamatów (lata 1949-1955), po której szczęśliwie wrócił do aktywnej działalności pisarskiej (Gołaszewski 2010, Kudliński 1984 i 1992).

Warto wspomnieć, iż Kudliński był przed II wojną światową autorem między innymi powieści Wygnańcy Ewy (1932), jednego z nielicznych polskich utworów literackich poświęconych Wielkiemu Kryzysowi lat 30. ubiegłego stulecia. Z jednej strony na jej kartach opisał przekraczanie podstawowych norm moralnych przez „ludzi interesu” różnego kalibru i kierujących się różnymi motywami. Z drugiej strony rozpacz ofiar kryzysowej nędzy. Obu tym zjawiskom przeciwstawił ascetyczną wersję chrześcijańskiej świętości, jako nośnika buntu, ale także nadziei. Poprzez postać Świerszcza Tadeusz Kudliński przedstawił wspomniany ideał świętości również jako świadectwa takich wartości jak ofiara i przebaczenie.

Według deklaracji samego pisarza, bohater ten był wzorowany na postaciach katolickich świętych (Jesionowski 1936). Jednak niekonwencjonalne zachowanie Świerszcza, do złudzenia przypominające wręcz zaburzenia psychiczne, czyni go bliskim prawosławnej tradycji „szaleńców”, „jurodiwych”, którzy „wyśmie-

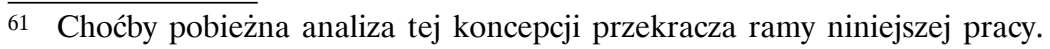


wając" wszelkie formy stereotypowej moralności opartej na zasadach (...)”, potwierdzają „nadrzędną wartość osoby”, niosą wolność dającą powody do obaw współczesnym dyktaturom, są „niekończącą się troską o ludzką tożsamość” (Ware 2003: 235 i 211, ostatnie stwierdzenie stanowi fragment przytoczonej przez Ware'a wypowiedzi Cecil Collins).

Nie posiadam kompetencji krytyka literackiego, ani znawcy tradycji religijnych, trudno więc mi wyrokować, na ile to skojarzenie jest uprawnione ${ }^{62}$. W każdym razie uwypukla ono dopuszczalną chyba interpretację przesłania powieści Kudlińskiego, iż katastrofizm ${ }^{63}$ kryzysu wymaga niekonwencjonalnych odpowiedzi także na płaszczyźnie moralnej i duchowej. Warto byłoby więc wznowić Wygnańców Ewy jako literacki głos w aksjologicznej dyskusji na temat sytuacji radykalnych problemów ekonomicznych, przydatny także po 2008 roku ${ }^{64}$, oczywiście przy uwzględnieniu różnic historycznych ${ }^{65}$.

Po 1945 roku punktem wyjścia dla twórców „Nowej Kultury Pracy” była także sytuacja kryzysowa (Ochinowski i Kseba 2013). Wtedy chodziło oczywiście o świadomość poważnych zniszczeń, których Polska doznała w czasie II wojny światowej. Zasadnicza różnica między środowiskiem „Tygodnika Warszawskiego" a większością ówczesnego społeczeństwa polegała na tym, że

62 „Szaleńcy chrystusowi”, ,jurodiwi” to typowe dla rosyjskiego prawosławia postacie (często później ogłaszane świętymi), które przez pozornie zaburzone zachowanie w różnych okresach historycznych radykalnie zwracały uwagę społeczeństwu bądź/i rządzącym na wartości religijne. Podobnie zachowujących się ludzi ma wśród swoich świętych także Kościół Katolicki. Ekumeniczną, autorską interpretację „jurodiwości” zaproponowała Catherine de Hueck Doherty (2012), widząc w niej radykalną postawę kontestacji między innymi wobec zjawisk, które obecnie, Dembinski (2011 i 2013), o czym już pisałem, nazywa finansjalizacją. Cytowana książka de Heck Doherty (2012) nie dotyczy ostatniego kryzysu. Po raz pierwszy opublikowana prawdopodobnie w 1993 roku, powstała na podstawie pism i refleksji autorki zmarłej osiem lat wcześniej. Jej główne prace, mające charakter przede wszystkim medytacji, powstawały sukcesywnie mniej więcej od połowy XX w.

63 Warto zauważyć, posługując się elementarną wiedzą historyczno-literacką, że katastrofizm, będący konwencją typową dla europejskiego pisarstwa lat 30 . XX w. powstał między innymi jako kulturowa odpowiedź na Wielki Kryzys i niewątpliwie dostarczał perspektywy adekwatnej do jego opisu.

64 Zresztą zdaniem krytyków i historyków literatury powieść broni się także pod względem literackim. Wprawdzie początkowo była niedoceniona. Kudliński wydał ją sam. Wkrótce jednak dostał właśnie za Wygnańców Ewy Związkową Nagrodę Literacką, prestiżowe wyróżnienie przyznawane w Polsce międzywojennej. Powieść ta ma oryginalną strukturę wielowątkową, jest utworem symultaneistycznym, by użyć języka teorii literatury, co upodabnia ją do osiągnięć takich pisarzy zachodnich jak John Dos Passos oraz Jules Romains. Podkreśla się również „głębokość motywacji społecznej i filozoficznej” Wygnańców Ewy oraz „konkretną rzeczowość w przedstawianiu świata” (Kwiatkowski 1990: 231, Kudliński 1984).

65 Na nieporównywalnie trudniejszą sytuację ludzi dotkniętych kryzysem lat 30. ubiegłego wieku, w porównaniu ze skutkami wydarzeń finansowych roku 2008 zwraca uwagę na przykład Seligman (2011). 
zamiast „załamywać ręce” nad stanem poszczególnych sfer życia Polaków, grupa ta postrzegała sytuacje „po zniszczeniach” przede wszystkim jako możliwość budowania od nowa, ale w sposób racjonalny i innowacyjny. Do tej idei często powracali autorzy „Nowej Kultury Pracy”, podkreślając możliwości, jakie niesie budowa od zera:

„W miastach zniszczonych otwierają się największe możliwości stworzenia warunków nowych, z góry przemyślanych i podyktowanych wizją doskonałej architektury społecznej i ekonomicznej” (Braun, 1947).

Ważne były zniszczenia materialne, bo swoim ogromem uniemożliwiały ludziom powrót do normalności, ale patrząc szerzej, ważniejsze było, zdaniem przedstawicieli tej grupy ideowej, odbudowanie tego, co dość pompatycznie nazywali „duchem narodu” i zasad, jakimi naród powinien się kierować, uwzględniając te czynniki, które mogą przynieść społeczeństwu prawdziwą, długofalową korzyść.

Całe środowisko silnie wierzyło, że u podstaw każdego działania gospodarczego leży jakaś koncepcja pracy. Właśnie takie założenie spowodowało, iż pracy poświęcono wiele przemyśleń. Był to oczywiście przejaw tradycyjnej katolickiej nauki społecznej, nadającej pracy kluczowe znaczenie dla zrozumienia współczesności przynajmniej od czasów papieża Leona XII66. Wśród założeń programowych „Nowej Kultury Pracy” leżało przekonanie, że nawet tak głęboki kryzys jak okres wojny daje szansę odnowy moralnej (Wiszniewski, 1998). Na łamach „Tygodnika Warszawskiego”, można było znaleźć choćby taką opinię: „Stanęliśmy na przełomie dziejów, widzimy to i czujemy wszyscy. Straszliwy kataklizm wojenny, bezmiar zniszczeń i przelanej krwi, masowy upadek moralności wśród ludzi - to dopiero jego etap pierwszy. Na etapie drugim, mającym nie tylko odbudowywać, ale i z gruntu niejedno przebudować, trudności się mnożą. Czy niewiadome Jutro będzie rzeczywiście lepsze, a ideał sprawiedliwości wcieli się w życie bez wykoślawień? I czy powszechna tęsknota ludzkości za trwałym pokojem przestanie wreszcie być niezniszczalną utopią?" (Od Redakcji, 1945).

Dużo później jeden z liderów omawianego środowiska, Jerzy Braun, wprost użył kategorii kryzysu przy opisie znaczenia II wojny światowej dla naszego kraju: „W latach 1939-1946 Polska przeszła przez Scyllę i Charybdę jednego z największych kryzysów w jej dziejach. Można go porównać chyba tylko z okresem rozbicia dzielnicowego i najazdów Mongołów, z potopem wojen kozackich i szwedzkich oraz kataklizmem rozbiorów i upadku powstania 1794 roku" (Braun 1981: 124).

Opisywane interpretacje można - per analogiam i przy zachowaniu wszelkich proporcji - traktować jako publicystyczny model zagrożeń i szans czasów

$66 \quad \mathrm{Z}$ pozakonfesyjnej literatury przedmiotu na polskim gruncie zob. przede wszystkim analizy pióra Marcina Króla (2006 i in.). 
kryzysu. Warto zatem przyjrzeć się być może użytecznym także na początku dwudziestego pierwszego wieku rozwiązaniom proponowanym przez twórców „Nowej Kultury Pracy” (Ochinowski i Kseba 2013).

\subsubsection{Spółdzielnia „Źródło”. Szkic do historycznego studium przypadku firmy consultingowej (1945-1948)}

Wśród osób tworzących środowisko „Tygodnika Warszawskiego”67 zdecydowanie najpełniej reprezentował praktykę biznesową Stanisław Wiktor Bukowski (1896-1976), jeden z zapomnianych nestorów zarządzania na terenie Polski, prawdopodobnie współpracownik Karola Adamieckiego, przez wiele lat zatrudniony w polskim oddziale Philipsa, później, podczas okupacji hitlerowskiej niezależny kupiec, po 1945 roku działacz Stronnictwa Pracy i struktur samorządowych ${ }^{68}$. Był specjalistą - a wspomnienia o nim uprawniają także do dodania określenia „pasjonatem” - w zakresie systemów sprzedażowych, reklamy oraz naukowej organizacji pracy (Hoppe 1972, Skibińska i Bukowska 1980, Turowski 1989 i 1991, Kudliński 1992, Gołaszewski 2010, Bujak 1988, Sikorski i Kulesza 2013). Tę ostatnią, zgodnie z zasygnalizowaną wcześniej ideologią swego środowiska, traktował on jako czynnik uwielokrotniający „efekty codziennego wysiłku twórczego" (Król 1980; 464). Kierując się takim właśnie spojrzeniem na funkcje zarządzania, a równocześnie realizując ściśle pragmatyczne cele, Bukowski zorganizował przedsiębiorstwo pod nazwą Spółdzielnia „Źródło”,

67 Wśród niewymienionych przeze mnie publicystów omawianego czasopisma byli m.in. Kazimierz Studentowicz - główny ekspert ekonomiczny tego środowiska, Adam Grabowski - redaktor działu ekonomicznego „Tygodnika...” oraz księża Aleksander Wóycicki - nestor katolickiej nauki społecznej w Polsce, propagator, a także praktyk spółdzielczości, gorący zwolennik praw pracowniczych, ze szczególnym uwzględnieniem ośmiogodzinnego dnia pracy, przed II wojną światową uczestnik prac Międzynarodowej Organizacji Pracy z ramienia polskiego rządu i Stefan Wyszyński - zaangażowany propagator katolicyzmu społecznego, znawca problemów społecznych, późniejszy prymas Polski. Sprawami świata pracy interesował się również wspominany już przeze mnie ks. Zygmunt Kaczyński, redaktor naczelny „Tygodnika Warszawskiego” przez większość część krótkiego okresu jego istnienia. Kaczyński, znany przede wszystkim jako dziennikarz, m.in. przed II wojną światową działał na forum chrześcijańskich związków zawodowych. W „Kolumnie Młodych” „Tygodnika...” publikował swoje artykuły Wiesław Chrzanowski używający wówczas pseudonimu Andrzej Żur (zob. np. Chrzanowski 2005 oraz archiwalne numery „Tygodnika Warszawskiego” 1945-1948).

68 Zaraz po II wojnie światowej Bukowski wszedł do Zarządu Stronnictwa Pracy, jako działacz tej partii został członkiem Krajowej Rady Narodowej, gdzie między innymi z pasją bronił inicjatywy prywatnej. 26.09.1946 roku złożył legitymację poselską na znak protestu przeciw działaniom władz stalinowskich powodujących rozbicie ruchu chrześcijańsko-demokratycznego w Polsce. Od początku kwietnia do końca listopada 1948 roku Bukowski był dyrektorem Wojewódzkiego Związku Zrzeszeń Prywatnego Handlu i Usług w Lodzi oraz Zrzeszenia Prywatnego Handlu i Usług miasta Łodzi (Bujak 1988, Turowski 1989, Skibińska i Bukowska 1989, Sikorski i Kulesza 2013, Akta S. Bukowskiego...). 
świadczące usługi doradcze o bardzo szerokim spektrum. Wśród wspominanych pragamatycznych celów, przyświecających omawianemu przedsiębiorcy przy zakładaniu firmy, wymienić należy chęć utrzymania spójności konspiracyjnego środowiska inteligentów, głównie akademickich współpracujących podczas okupacji z organizacją „Unia” oraz danie im możliwości zarobkowania w warunkach powojennego kryzysu. Zarówno w czasie jego powstania, jak i dzisiaj „Źródło" należałoby zaliczyć do sektora MŚP. Założyciel przedsiębiorstwa, twórczo wykorzystując idee „banków wiedzy”, które poznał przed II wojną na zachodzie Europy, zgromadził wokół siebie ekspertów z wielu dziedzin, dosłownie „od A do Z": od architektów po zoologów (tak prawdopodobnie głosił, trudno nam dziś powiedzieć, na ile był to jedynie slogan reklamowy firmy). Celem Bukowskiego (1951: 160), zgodnie ze sformułowaniami, które przypisał mu później autor propagandowej broszury dotyczącej postawienia między innymi twórcy „Źródła” przed stalinowskim sądem, było stworzenie „instytucji (...) uniwersalnej - jak to nazwano, żywej encyklopedii - która grupując z jednej strony odpowiedni zespół pracowników umysłowych, przede wszystkim profesorów uniwersytetu, docentów, specjalistów z różnych dziedzin wiedzy teoretycznej i praktycznej, stworzyłaby dla nich warsztat pracy i możliwość zużytkowania tej części wiedzy, której inaczej wyeksploatować nie są w stanie, a z drugiej strony dała społeczeństwu placówkę, w której tanim kosztem można by zdobyć wszelkie wiadomości, np. z dziedziny praktycznej - o przepisach technicznych dla różnych fabrykacji itp.”.

Bukowski zakładał, że w początkowym etapie statutowe działania spółdzielni będą finansowane przez jej członków. Szybko jednak okazało się, iż przedstawiciele świata akademickiego oraz pozostali członkowie nie dysponują odpowiednimi funduszami. Ostatecznie założyciel „Źródła” dostał dwie pożyczki z kręgów „Unii” (1945 rok), a później Stronnictwa Pracy (1947). Wynosiły one kolejno 500 i 300 dolarów, co stanowiło niewielkie sumy jak na potrzeby działania omawianej spółdzielni. Pieniądze te jednak umożliwiły funkcjonowanie „Źródła”, skutecznie uzupełniając wkład finansowy udziałowców. Poprzez prasę rozreklamowana została możliwość uzyskania różnorodnych porad za bardzo przystępną cenę. Firmą kierował profesjonalny zarząd. Na przykład zastępca dyrektora Alfred Schlichting przeszedł do „Źródła” z Banku Gospodarstwa Krajowego (gdzie współpracował ze wspomnianym wcześniej Tadeuszem Kudlińskim, który najwyraźniej namówił kolegę na tę zmianę pracy). Być może taką samą praktykę zawodową miał dyrektor omawianej spółdzielni. Na razie udało się jedynie ustalić jego nazwisko: Wollen (Kudliński 1992). Jak pisał w swoich wspomnieniach cytowany wielokrotnie Tadeusz Kudliński (1992: 147), pracownicy „Źródła” odpowiadali „na napływające zamówienia czy to teoretyczne czy praktyczne. I szło to wcale nieźle". Poza Krakowem, gdzie Spółdzielnia miała siedzibę przy Rynku Głównym 32, planowano tworzenie oddziałów terenowych 
(Poznań, inne rejony Krakowa itd.) oraz zespołów tematycznych. Dość krótko funkcjonowała filia warszawska, przy ul. Nowogrodzkiej. Bukowski, chcąc rozszerzenia działań „Źródła” na całą Polskę, kontaktował się w tej sprawie z zarządami miast, związkami zawodowymi oraz innymi instytucjami. Najwyraźniej opór przedstawicieli tych struktur hamował rozwój omawianej spółdzielni. Warto podkreślić, iż „Źródło” spełniało ważne funkcje społeczne. Stosunkowo tanio udostępniało know-how szerokiemu gronu odbiorców, propagowało innowacyjność, realizowało efektywną współpracę świata akademickiego i praktyków różnych dziedzin. Realizując formę spółdzielni, omawiane przedsiębiorstwo opierało się na zasadzie współwłasności wszystkich uczestników przedsięwzięcia, współfinansowaniu i współodpowiedzialności za jego losy. Zbliżało to „Źródło” do współczesnych nam firm konsultingowych, coraz częściej rozwijających partnerstwo z kluczowymi pracownikami (Gołaszewski, 2010). Warto też zauważyć, iż Bukowski już w 1945 roku angażował do doradztwa inteligentów w większości niezwiązanych z biznesem. Sześć lat później James Allen, współzałożyciel Allen \& Hamilton, przy ocenie kompetencji kandydatów na współpracowników przesunął główny punkt zainteresowania $\mathrm{z}$ doświadczenia biznesowego na zdolności analityczne, co uważa się za istotny przełom w sposobie zatrudniania konsultantów („Historia firm konsultingowych” 2010).

Bukowski nie miał jednak żadnych szans szerzej przedyskutować swoich doświadczeń, a tym bardziej skonfrontować ich z dokonaniami światowymi. Europę Środkową szczelnie oddzielała od Zachodu „żelazna kurtyna”. A w 1948 roku stalinowskie władze zniszczyły „Źródło” za pomocą sfingowanych zarzutów, aresztując i skazując na horrendalnie duże wyroki pozbawienia wolności członków kierownictwa firmy. Sam Bukowski po ośmiu latach ciężkiego więzienia (1948-1956) na tyle stracił zdrowie, iż nie był już w stanie kontynuować żadnej działalności gospodarczej (Wróbel 2005, Ochinowski 2011).

$\mathrm{Na}$ obecnym etapie badań trudno jednoznacznie ocenić efektywność „Źródła”. Paradoksem jest, iż najwięcej wiadomości zawiera o tej inicjatywie propagandowa publikacja dotycząca procesu członków Stronnictwa Pracy („Sojusznicy...” 1951), czyli „,nośnik informacji” z natury zakłamany. Nie sposób więc także precyzyjnie stwierdzić, na ile „Źródło” realizowało zasady „Nowej Kultury Pracy", choć wydaje się, że chociaż częściowo tak (zob. Gołaszewski 2010, Strocka, Gołaszewski i Dreilich 2012). W każdym razie omówiona przeze mnie spółdzielnia Bukowskiego określała podstawowy kontekst praktyki biznesowej, obok doświadczeń bankowych Kudlińskiego i jego kolegów, interferującej z publicystyką na temat przedsiębiorczości, którą rozwijał przez „Tygodnik Warszawski”, przede wszystkim, poprzez wkładkę „Kultura i Praca”.

Oddzielnego opracowania, znacznie przekraczającego ramy niniejszej pracy, wymaga analiza programu „Nowej Kultury Pracy” w świetle historii idei biznesowych z uwzględnieniem także najnowszych trendów. Jest to istotne poznawczo 
zadanie na przyszłość. Tu sygnalizuję tylko fakt, iż współczesny nam czytelnik tekstów „Tygodnika Warszawskiego” (1945-1948) spotyka w nich zarówno konsekwencje uwarunkowań historycznych (co oczywiste) ${ }^{69}$, jak i tezy, które wydają się nie tracić aktualności także dla współczesnego przedsiębiorcy. Przy czym obydwie $\mathrm{z}$ wymienionych cech mają na przykład sztandarowe postulaty praktyczne autorów skupionych wokół „Kultury i pracy”, to jest zastąpienie maksymalizacji zysku jego optymalizacją oraz wprowadzenie płacy rodzinnej. Każda z tych koncepcji wymaga dyskusji znacznie przekraczającej zakres niniejszej pracy, a także aktualny stan wiedzy jej autora. Są więc tu tylko zasygnalizowane w kontekście współczesnej praktyki przedsiębiorczej na przykładzie firmy sektora MŚP, sieci przedszkoli „Biedroneczka” (Ochinowski 2011, por. Łętocha 2006).

\subsubsection{Ideologia "Nowej Kultury Pracy” a funkcjonowanie sieci przedszkoli „Biedroneczka”}

Firma „Biedroneczka”70 powstała w roku 2002. Była małym niepublicznym przedszkolem, którego lokal stanowił dom na terenie podwarszawskiego

69 Na przykład przywiązanie omawianego środowiska do firm rodzinnych i warsztatów rzemieślniczych wynikało nie tylko z tradycyjnie katolickiego poglądu. Taka była po prostu wówczas struktura pracy na naszym kontynencie. Jak zauważa Hartmut Kaelble (2010: 53) „Do tego praca w Europie około 1950 r. była często pracą rodzinną - głównie w gospodarstwach chłopskich, warsztatach rzemieślniczych, handlu detalicznym i transporcie".

70 Firma „Biedroneczka” działa od 2002 roku. Niniejszy podrozdział stanowi zakończenie ważnego etapu - wciąż jednak wyłącznie przyczynkarskich - badań nad treścią oraz możliwościami aplikacyjnymi projektu „Nowej Kultury Pracy”. U ich początków znalazło się moje wieloletnie zainteresowanie „Tygodnikiem Warszawskim”. Zainteresowanie to długo miało charakter raczej pozanaukowy. Wynikało ze swoistej „ambicji lokalnej”: stołeczny tygodnik katolików wydawany w pierwszych latach powojennych, niemal równocześnie z krakowskim „Tygodnikiem Powszechnym”, nie tylko nie przetrwał burzliwych dziejów, ale też został kompletnie zapomniany. Podczas jednej z nieudanych prób wznowienia warszawskiego tytułu Dariusz Piętka (obecnie pracownik Instytutu Filozofii UKSW) zwrócił niżej podpisanemu uwagę na proeuropejskość treści wspomnianego pisma oraz ich potencjalnej wartości jako źródła intelektualnej inspiracji dla współczesnej problematyki Unii Europejskiej. Taka perspektywa poznawcza zaowocowała wspólnym opracowaniem Tomasza Ochinowskiego i Jerzego Jagodzińskiego. Już wcześniej, pierwszy z wymienionych, robiąc kwerendę „Tygodnika Warszawskiego” dla potrzeb zupełnie innej problematyki (zob. Ochinowski 2005), przypadkowo natrafił na wkładkę „Kultura i Praca”. Tak poznał koncepcję „Nowej Kultury Pracy”, którą starał się rozpropagować oraz poddać pod dyskusję studentów Wydziału Zarządzania UW, włączając ją zarówno do treści dydaktycznych, jak również do tematyki prac zaliczeniowych. W roku akademickim 2007/2008 praktyczną stroną przywołanej ideologii zainteresował się Piotr Gołaszewski, uczestnik prowadzonego przeze mnie seminarium magisterskiego, prywatny przedsiębiorca z sektora MŚP. Jako właściciel firmy „Biedroneczka” podjął on eksperyment naturalny typu leraning by doing, aplikując wybrane elementy „Nowej Kultury Pracy” w swoim przedsiębiorstwie, równocześnie badając opinie studentów zarządzania na temat 
Ursusa odziedziczony przez Piotra Gołaszewskiego, współzałożyciela i do dziś współwłaściciela. Od 2006 przedsiębiorstwo ma charakter spółki. Przekształcenie to znacznie zdynamizowało rozwój „Biedroneczki”. Obecnie (stan na rok 2013) jest ona małą siecią dwóch przedszkoli mieszczących się w profesjonalnie wyposażonych budynkach oraz dysponujących placami zabaw. Zatrudnia ogółem 27 osób (w 2006 roku było szesnastu pracowników), którzy opiekują się łącznie około setką przedszkolaków. Specyfika branży sprawia, czemu trudno się dziwić, że wśród zatrudnionych są same kobiety. Rotacja pracowników od czterech lat praktycznie nie przekracza poziomu jednej osoby rocznie. Niewielkie są również wahania zarówno kosztów, jak i zysków dzięki dość stałej i przewidywalnej liczbie klientów. Zmienność wspominanych czynników wiąże się przede wszystkim z podejmowaniem przez kierownictwo firmy dodatkowych inicjatyw, takich jak na przykład popołudniowe, dodatkowe zajęcia dla dzieci z zakresu ceramiki itp. „Biedroneczka” generuje roczne obroty wynoszące według deklaracji współzałożyciela około 700 000-900 000 złotych.

Omawiana sieć przedszkoli nigdy nie stanowiła jedynego źródła zarobkowania dla głównego właściciela. Stąd też grupie założycielskiej stosunkowo łatwo było przyjąć założenie, zgodne z ich przedsiębiorczą ideologią, iż na pierwszym miejscu działalności „Biedroneczki” mają stać potrzeby dzieci. Dochód stanowił zawsze kwestię istotną, ale wtórną. Omawiana sieć przedszkoli stosunkowo szybko zdobyła dobrą opinię w środowisku lokalnym, czego świadectwem są zarówno pozytywne sądy wypowiadane przez rodziców, jak i wskaźniki praktyczne: zapełnione listy przyjęć oraz rezerwacje miejsc dla dzieci na kolejne lata. Choć sytuacja przedszkola wydawała się więc dobra, i to praktycznie od samego początku, Gołaszewski i jego współpracownicy odczuwali, iż firmie brakuje elementów filozofii biznesu, które wyznaczałyby standardy, a nawet sposoby zachowań wobec bieżących wyzwań. W odpowiedzi na ten stan - jak już pisałem - po zetknięciu się z pomysłami „Tygodnika Warszawskiego”, Gołaszewski podjął decyzję, by stopniowo wprowadzać na terenie „Biedroneczki”

jej aktualności (Gołaszewski 2010). Po mniej więcej dwóch latach trwania eksperymentu, wstępnej analizie poddała go cytowana już przeze mnie Monika Strocka (2012), poprzez zwiad badawczy polegający na pogłębionym wywiadzie ze wspomnianym Piotrem Gołaszewskim, który w międzyczasie samodzielnie podejmował usystematyzowaną autorefleksję jako współautor prezentacji i tekstów poruszających omawianą problematykę (np. Ochinowski i Gołaszewski 2011, 2012, Strocka, Gołaszewski i Dreilich 2012). Również niżej podpisany przy okazji innych publikacji stara się konfrontować „Nową Kulturę Pracy" z aktualnymi zagadnieniami działań gospodarczych, by przytoczyć choćby przykład społecznej odpowiedzialności biznesu (Ochinowski 2011), czy wyzwania kryzysu (por. Ochinowski i Gołaszewski 2012). W lutym 2013 Agnieszka Kseba dokonała krytycznego opracowania i uzupełnienia (poprzez kolejną kwerendę „Tygodnika Warszawskiego” oraz rozmowę z Gołaszewskim) zwiadu badawczego Strockiej. Ten etap przyczynkarskich badań nad „Nową Kulturą Pracy” wyznaczył empiryczne treści niniejszego podrozdziału (Ochinowski i Kseba 2013). 
zasady „Nowej Kultury Pracy” (Ochinowski i Kseba 2013, Strocka 2012, Gołaszewski 2010 oraz rozmowy T. Ochinowskiego i A. Kseby z P. Gołaszewskim, 2008-2013).

W dalszej części niniejszego podrozdziału zarysuję główne - według mnie (wybrane z perspektywy obecnych potrzeb zarządzania) - elementy ideologii „Nowej Kultury Pracy” oraz aplikacje niektórych z nich realizowane na terenie „Biedroneczki”. Szczegółowe zagadnienie postulowane przez publicystów „Tygodnika Warszawskiego” systematyzuję, a zarazem reinterpretuję przez propozycję przyporządkowania ich do kategorii „,podmiotowość - relacyjność - zakorzenienie" (por. Ochinowski i Kseba 2013, Gołaszewski 2010, Ochinowski i Gołaszewski 2011 i 2012, Strocka, Gołaszewski i Dreilich 2012 i Strocka 2012).

\section{Podmiotowość}

\section{A. Personalistyczna koncepcja pracy jako aktu twórczego}

Autorzy koncepcji „Nowej Kultury Pracy” formułowali szereg propozycji zamiany w postrzeganiu pracy, którą uznali za typowe dla potocznej świadomości społeczeństwa swoich czasów (czytelnikowi pozostawiamy decyzję na ile polemiczny ton przyjęty przez publicystów „Tygodnika Warszawskiego” odnośnie do tej problematyki miałby uzasadnienie także dzisiaj).

Po pierwsze proponowali oni, aby odrzucić wizję pracy zawężoną jedynie do wysiłku fizycznego czy też umysłowego. Należy raczej zwrócić uwagę - podkreślali - na naturę pracy jako aktu poznawania zarówno siebie samego, jak i możliwości, które otaczają jednostki ludzkie. Dopiero taka zmiana w percepcji codziennych zajęć jest warunkiem skutecznej reformy gospodarczej kraju. Szczególnie ważne wyzwanie stanowi przemiana mentalności dotyczącej pracy dwóch grup społecznych: polskiej inteligencji oraz robotników. Zestaw poglądów na pracę, któremu przypisywali głębokie znaczenie motywacyjne (w wymiarze ogólnospołecznym), cytowani publicyści określali roboczo jako mit kultury pracy, ewentualnie mit potęgi pracy, a później jako „nową kulturę pracy”.

Przy czym termin „mit” interpretowali wyraźnie antropologicznie, nadając mu równocześnie przede wszystkim pozytywne konotacje, traktując go jako „pomost między faktycznym a możliwym dzięki swej niezwykłej sile wynikającej z zespolenia pierwiastków racjonalnych wyznaczających i uzasadniających cel, to jest pożądana rzeczywistość oraz intuicyjnych, pobudzających wyobraźnię, które dają impuls do działania" (Łętocha 2006: 238).

Mit pracy miał być więc wizją tego, jak powinna być ona traktowana, wizją, do której należy dążyć. Wyznaczał i wizualizował cele zarówno dla jednostek, jak i całego społeczeństwa czy rządu. Realia powojenne skłaniały do tworzenia takich właśnie pozytywnych mitów w różnych dziedzinach. 
Twórcy „Nowej Kultury Pracy” podkreślali jednak, iż mit, choć ujmowany przez nich w wymiarze przede wszystkim pozytywnym, może stać się narzędziem niszczącym. Jest to zależne od wartości tego, co ma być efektem końcowym starań, do których mit wzywa. Wiele z dużej ilości, często antagonistycznych mitów proponowanych społeczeństwu zawiodło. Omawiane środowisko odrzucało każdą wizję ideologiczną, z której prędzej czy później wyłania się obraz sensu życia człowieka sprowadzony do zaspokajania potrzeb materialnych. Uznawano, że takie wytyczanie celu społeczeństwu prowadzi ostatecznie jego członków do dwóch form istnienia, jako konsumentów lub producentów, bez możliwości pozostawania twórczymi, indywidualnymi jednostkami.

Odpowiednio pojmowana praca, wyznaczająca podstawowy wymiar codziennych zajęć, jest gwarantem budowy takiego ustroju gospodarczego państwa, który pozwoli uniknąć błędów dotychczasowych rozwiązań (cytowani publicyści mieli tu na myśli przede wszystkim liberalizm i socjalizm w wersjach, jakie znali ówcześnie, to jest po 1945 roku; krytykowali obydwie formacje ideowe i ustrojowe zgodnie z typowym dla tamtego czasu postulatem katolickiej nauki społecznej poszukiwania „trzeciej drogi”, dziś mającym znaczenie jedynie historyczne).

Przedstawiciele omawianego środowiska wielokrotnie podkreślali „społeczne wyzwolenie pracy”. Chodziło o to, aby zmniejszać na tyle, na ile to będzie możliwe takie zagrożenia, jak nieróbstwo, czy też brak zainteresowania i zrozumienia znaczenia pracy dla człowieka. Zamiast wspominanych negatywów należy zaszczepić społeczeństwu poczucie godności pracy.

Człowiek winien być twórczy w tym, co robi, a także dynamiczny. Jednostka ludzka może twórczość i dynamizm działania osiągnąć, realizując dwie postawy. Pierwsza z nich to „optymizm kreacjonistyczny”, czyli wiara w możliwość przebudowy siebie samego, a później także całego społeczeństwa. Druga postawa, nazwana przez twórców omawianej koncepcji „dynamizmem kulturalno-ekonomicznym" oznacza zaangażowanie w postawione sobie cele przy wierności zasadom, z których cele te wynikają.

Tak realizowana praca winna w pierwszym rzędzie zapewnić wszystkim warunki egzystencji umożliwiające swobodny udział w dobrach kulturalnych.

„Nowa Kultura Pracy” nie kontestowała całkowicie dotychczasowego dorob$\mathrm{ku}$ ekonomii. Uznawała za słuszne wiele $\mathrm{z}$ obowiązujących teorii gospodarczych, nadając im jednak wymiar antropologiczny - dostrzegający w działaniach gospodarczych po pierwsze człowieka. Praca powinna być postrzegana jako akt twórczy bez względu na to, przez kogo jest wykonywana i jak ważna jest społecznie. „Trudno bowiem wyobrazić sobie pracę bez minimalnego choćby udziału samorzutności twórczej i trudno sobie wyobrazić jakąśs formę twórczości, która nie wymagałaby pewnego nakładu pracy" (Braun b.d.w: 10).

Ważnym postulatem zbudowanym na powiązaniu rozwoju pracy i kultury jest powstanie modelu człowieka typu homo creator. Człowieka świadomego, 
twórcy i pracownika w jednym. Istota ludzka bez względu na wykonywaną pracę, zakres jej odpowiedzialności i stopień szacunku społecznego, jakim cieszy się dany zawód, nie ogranicza swojego bytu jedynie do parania się takim czy innym zajęciem. Przypadki takie są jednostkowe. W cyklu całego życia jednostki ludzkiej praca, pomimo iż potrafi zajmować ogromną część czasu, jest tylko jednym z wielu elementów. Niemniej jednak, właśnie ze względu na to, iż jest ona bardzo ważnym czynnikiem ludzkiego życia, nie powinna być traktowana jedynie jako żmudny obowiązek czy środek pozyskania funduszy. Podstawowym błędem, przed którym ostrzegali autorzy „Nowej Kultury Pracy”, było podejmowanie przez jednostkę ludzką takiego zajęcia i wykonywanie go w taki sposób, iż człowiek pozbawia się poczucia sensu swojej pracy. Błędem jest także - co dotyczy pracodawców - takie organizowanie przestrzeni i zasad zajęć pracowników, które uniemożliwia im odczuwanie satysfakcji w ramach swoich działań. „Dokonujące się stopniowo wyzwalanie pracy prowadzi do przyszłej jej harmonizacji z kulturą. W coraz większym stopniu winna być ona nasycana pierwiastkami piękna, gdy tego bowiem brak, odczuwana jest jako przekleństwo, nieznośne jarzmo" (Braun 2003: 217, cytowana praca została napisana w 1942 r.).

W świetle „Nowej Kulturze Pracy” praca ma charakter dwubiegunowy. Jeden z biegunów to wkład pracownika, kształtowanie przez niego postawy wobec pracy. Drugi biegun to oddziaływanie pracy na człowieka, kształtowanie siebie poprzez pracę. Gdyby wprowadzić w życie podane propozycje, „można by tedy przeniknąć pracę pierwiastkiem osobistej twórczości i radości życia, gdyby ludzkość uświadomiła sobie jej związek z duchowym postępem jednostki, z tworzeniem samego siebie" (Braun 1947c: 6).

Aplikacja w „Biedroneczce”. Realizacja idei „pracy jako aktu twórczego” przejawia się w „Biedroneczce” nie tylko na poziomie motywowaniu pracowników, ale też i rodziców, którzy powierzają placówce swoje dzieci. Właściciele dbają, aby zachęcać rodziców do podejmowania działań mających na celu rozwijanie więzi między nimi i ich dziećmi. Służy temu stwarzanie możliwości rodzicom angażowania się w różnego typu wydarzenia, takie jak występy czy pokazy organizowane przez dzieci.

Zdaniem Gołaszewskiego, postulat pracy jako aktu twórczego spełniają też rozmowy rodziców z pracownikami, opiniowanie działalności przedszkola, ze szczególnym uwzględnieniem oceny podejścia personelu do dzieci, oraz stymulowanie rodziców do tego, by wysuwali własne pomysły. Pojawienie się ostatnio (dane z wiosny 2013) sporej grupy rodziców, którzy nie wykazują praktycznie żadnej inicjatywy wobec przedszkola Gołaszewski uznał za wskaźnik poważnego kryzysu, z jakim zmierzyć się musi jego firma. Zjawisko to, jego zdaniem, uderza przede wszystkim $\mathrm{w}$ personel. Wychowawczynie były bowiem przyzwyczajone do tego, iż dostają od większości rodziców dzieci z „Biedroneczki” informacje 
zwrotne. Obecnie rodzice przestali ich udzielać. Personel „Biedroneczki” poczuł się w tej sytuacji zdezorientowany.

Jeśli chodzi o motywowanie pracowników, to także oni mają możliwość uczestnictwa w życiu firmy, w sposób podobny do tego, który oferowany jest rodzicom. Organizowane są spotkania, podczas których we własnym gronie właściciele i pracownicy mają możliwość wzajemnego wymieniania się spostrzeżeniami, zgłaszania swoich uwag i pomysłów. Kierownictwo przedszkola zwraca szczególną uwagę na to, aby pracownicy wychodzili z inicjatywą, by „dawali coś od siebie”. Podczas wspomnianych spotkań rozmawia się także o obawach i wątpliwościach pracowników. Dzięki temu diagnozowanie danego problemu następuje tak szybko jak to możliwe i z uwzględnieniem punktu widzenia samego pracownika, co zwiększa możliwości rozwiązania go. Takie działania pomagają również wzajemnie poznać się wszystkim zaangażowanym w przedszkole. Zdaniem Gołaszewskiego, wspomniane proste procedury zarządzania personelem potwierdzają potoczne przekonanie, że praca z ludźmi, których się zna, jest zarówno znacznie przyjemniejsza, jak i łatwiejsza (np. trafniej dobiera się sposoby motywowania pracownika) niż w przypadku anonimowości w relacji kierownictwo-podwładni.

\section{B. Optymalizacja zysku w miejsce jego maksymalizacji}

Chyba najbardziej odważną propozycję „Nowej Kultury Pracy” stanowił postulat zastąpienia zysku maksymalnego optymalnym.

Pojęcie to wymaga pewnych wstępnych wyjaśnień. Jeżeli właściciel firmy z jednej strony traktuje wykres zysku jako funkcję o stałym wzroście, a z drugiej strony oszacowuje poziom comiesięcznych kosztów, to łatwo odnajdzie punkt, w którym zyski pokryją się z kosztami. Optymalizacja zysku oznacza rezygnację z powiększania zysku w nieskończoność.

W założeniu twórców „Nowej Kultury Pracy” zysk optymalny ma realizować dwa cele: (1) pokrycie bieżących kosztów działań przedsiębiorcy czy też jego codziennego życia (i jego rodziny), a także (2) zapewnienie środków na zrównoważony rozwój firmy. Rozwój ma zapewnić właśnie nadwyżka ponad wspominany punkt pokrycia się kosztów i zysków.

Nastawienie nie na maksymalizację zysku lecz na jego optymalizację ma sprawić, iż praca może być realizowana w wymiarach czasowych, które pozwalają na godne życie uczestnikom organizacji, a także zapewniają i właścicielom firmy i pracownikom czas na „korzystanie” z życia. Rozwój produkcji czy też przedsiębiorstwa powinien więc uwzględnić także inne niż czysto materialne potrzeby ludzkie i koniecznie być z nimi zharmonizowany.

Aplikacja w „Biedroneczce”. W zasadzie nastawienie na optymalizację zysku implicite istniało $\mathrm{w}$ organizacji od początku, jeszcze przed intencjonalnym wprowadzeniem zasad „Nowej Kultury Pracy”. Nadal w omawianym przed- 
siębiorstwie zysk zajmuje ważne, ale nie pierwsze miejsce na liście priorytetów. Gołaszewski deklaruje kierowanie się maksymą, że „na tym biznesie nie zarabia się milionów”.

Istotna dla polityki finansowej przedszkola jest dbałość o to, by wszystkie przychody placówki były na tyle wysokie, aby możliwe było pokrycie kosztów jej działania oraz wynagrodzeń pracowniczych. Wynika to z humanistycznej orientacji deklarowanej przez współwłaściciela: na pierwszym miejscu stawiany jest człowiek, niezależnie od tego, czy chodzi o małe dziecko, czy pracownika.

Pensje właścicieli jak i pracowników trudno określić jako wysokie na tle konkurencyjnych jednostek, jednak właśnie to, jak dotąd, pozwoliło na stabilizację oraz zabezpieczenie środków „na trudniejszy czas”. Przy czym wysokość wynagrodzeń wydaje się być adekwatna do potrzeb pracowników. Wskaźnikiem pozwalającym na takie przypuszczenie może być duża liczba chętnych do pracy w „Biedroneczce”.

Według ideologii „Nowej Kultury Pracy” szacunek jako element atmosfery przedsiębiorstwa ma uzasadnienie ekonomiczne. Dlatego, jeśli celem zarządzających będzie zysk optymalny oraz traktowanie ludzi z szacunkiem, to wtedy pracownicy będą przykładać się do wykonywania powierzonych im zadań, których jakość realizacji będzie wyższa, niż przy braku odczuwania szacunku. Gołaszewski ma nadzieję, iż taka zależność między szacunkiem wobec pracowników a poziomem ich pracy występuję $\mathrm{w}$ jego placówce.

W branży prywatnych przedszkoli wyższa niż u konkurencji jakość świadczenia usług jest dość wyraźnie zauważalna przez klientów - płatników, czyli rodziców. Zadowoleni z usług danej placówki po pierwsze - decydują się na stałe posyłanie tam swoich dzieci, a po drugie - mogą rekomendować przedszkole, co w rezultacie zwiększa zapisy na kolejne lata, a tym samym gwarantuje przychody. Ostatnio (wiosna 2013) tę zależność, rejestrowaną dotąd przez właścicieli „Biedroneczki”, poważnie zaczyna zakłócać pauperyzacja rodzin w Polsce oraz dość agresywna polityka oświatowa preferująca przedszkola samorządowe i państwowe kosztem obniżenia standardów opieki nad dziećmi (wzrasta ilość miejsc, jakie oferują placówki samorządowe i państwowe, uzyskana przez zwiększanie wielkości grup dziecięcych, a towarzyszy temu redukcja personelu pomocniczego).

Nadal jednak opisywanej firmie daleko do utraty płynności finansowej. Nadwyżka zysku ponad całością kosztów przeznaczana jest na dalszy rozwój przedsiębiorstwa oraz pracowników, włączając zarząd.

\section{Postulat płacy rodzinnej}

Twórcy „Nowej Kultury Pracy” proponowali dość radykalną reinterpretację myślenia o płacy, przekraczając stereotyp jedynie wynagradzania za wykonane czynności. Postulowali, by płacę traktować także jako czynnik uwzględniający 
osobistą sytuację pracownika oraz przełożenie tej sytuacji na potrzeby społeczeństwa i państwo. Kontynuując jedną z tradycji ideologicznych katolickiej nauki społecznej, proponowali wprowadzenie, a przynajmniej „przymierzenie się” do wprowadzenia „płacy rodzinnej”.

Aplikacja w „Biedroneczce”. Element zainspirowany ideą płacy rodzinnej stanowią starania kierownictwa placówki o rozeznanie prywatnej sytuacji, a w razie potrzeby względne dostosowanie sposobu wykonywania pracy do ich potrzeb. Efektem tego typu działań jest praktycznie zerowa rotacja w omawianej firmie. Pracownicy nie chcą odchodzić i deklarują wysokie przywiązanie do przedsiębiorstwa. Efektem ubocznym wspomnianych rozwiązań jest nieco mniejsza wydajność poszczególnych osób, ale i tak poziom ich zaangażowania zadowala kierownictwo. Dla działania w powyższy sposób ważne jest, co już podkreślałem, poznanie pracowników i ich sytuacji rodzinnej. Stąd istotne są opisane przeze mnie wcześniej spotkania, czy nawet podejmowane przez kierownictwo próby nawiązywania relacji na zasadzie bardziej koleżeńskiej niż według standardowego wyobrażenia stosunku „pracodawca-pracownik”. Oczywiście takie relacje buduje się dosyć długo i próby ich tworzenia nie są wynikiem wywiadu przeprowadzanego podczas rozmowy kwalifikacyjnej, co byłoby łamaniem prawa pracy. W opisywanym przedszkolu stawia się na długoletnią współpracę.

Żadna $\mathrm{z}$ opiekunek przedszkola nie jest jednocześnie zatrudniona w innym miejscu. Można by pomyśleć, że trzyma je tu brak pracy na rynku, czy brak wykształcenia. W rzeczywistości osoby zatrudnione w przedszkolu mają wyższe wykształcenie, duże doświadczenie i co chyba najważniejsze - jak wynika zarówno z rozeznania kierownictwa, jak i z opinii rodziców - dobre, z perspektywy pedagogicznej, podejście do dzieci. Były też propozycje pracy dla przedszkolanek ze strony rodziców. Zdarzało się, że chcieli, aby pracowały one dla nich jako nianie. Pracownice „Biedroneczki” jednak odrzucały te propozycje. Może to oznaczać, że czują się one związane ze swoim miejscem pracy, że uważają się za współpracowników, ale też to, iż finansowo są w takiej sytuacji, że nie muszą zmieniać miejsca pracy. Jeśli jednak się zdarza, że komuś potrzebny jest tak zwany zastrzyk gotówki, przedszkole pomaga w następujący sposób: aktywa, które należą do placówki są dostępne dla jego pracowników. W razie potrzeby dana osoba może poprowadzić dodatkowo płatne zajęcia i zarobić dodatkowe pieniądze. Te zajęcia to na przykład logopedia, ceramika, plastyka. Są one tańsze niż „na mieście” i zdarza się, że korzysta z nich najczęściej rodzeństwo przedszkolaków. W „Biedroneczce” organizacją takich zajęć zajmuje się „Żuczek” - firma działająca przy przedszkolu.

„Biedroneczka” stara się, by pensje pracowników można było uznać za godziwe (stosowane są indywidualne oceny motywacji finansowej w ramach stałych rozmów z pracownikami). Warto jednak zauważyć, iż poszczególni pracownicy spędzają stosunkowo mało czasu w placówce ze względu na dość dużą liczbę 
opiekunów, co pozwala na intensywniejszą rotację w trakcie dnia i zapewnienie pracownikom czasu na alternatywne zajęcia lub odpoczynek.

Równie ważny element z perspektywy postulatu płacy rodzinnej w praktyce „Biedroneczki” to wspomaganie rozwoju życia rodzinnego pracowników. Zatrudnianie młodych kobiet wiąże się z akceptacją zajścia w ciążę, na co firma powinna być przygotowana. Wcześniejsze, negatywne podejście założycieli firmy do takiej sytuacji skutkowało trudnościami w relacjach z pracownikami oraz destabilizacją działań pracowniczych. Natomiast jasne zadeklarowanie przez kierownictwo akceptacji potrzeb prokreacyjnych zatrudnionych osób pozwoliło zbudować środowisko pracy, w którym kobiety czują się pewnie, a co najważniejsze z punktu widzenia firmy, taka postawa doprowadziła do dużej lojalności pracowników. W wielu sprawach osoby zarządzające firmą mogą liczyć na uczciwość i otwartą postawę pracowników, co pozwala na planowanie nie tylko najbliższej przyszłości i rozwoju przedsiębiorstwa. Taka atmosfera zaowocowała na przykład podczas pierwszej fali ostatniego kryzysu (2007). Pracownicy sami przyszli do głównego właściciela by przedyskutować działania antykryzysowe.

\section{Relacyjność}

\section{A. Postulat wspótpracy ludzi kultury z przedsiębiorcami i pracownikami}

Za konieczny warunek wprowadzenia w życie zasad „Nowej Kultury” jej twórcy uznali współdziałanie środowisk kultury i pracy. Zadaniem tych, którzy posiadają wiedzę i pomysły, jak lepiej i sprawniej może przebiegać praca, jest udostępnianie wspominanej wiedzy i pomysłów szerokiej części społeczeństwa, bo tylko tak można mówić o zrównoważonym rozwoju społeczeństwa czy kraju. Zależność wymienionych grup ma prostą strukturę: „warstwa intelektualna nic nie jest w stanie zmienić w otaczającym ją bycie bez pośrednictwa pracy mas ludowych. Ale i na odwrót cała ich siła fizyczna byłaby bezradna, gdyby nie nauczyła ich technika, jak się ujarzmia naturę" (Braun 2003: 69). Istotne miejsce we wspomnianej relacji odgrywa, zdaniem inicjatorów „Nowej Kultury Pracy”, sztuka, która ,jest postacią kultury najbliższą życiu, wytwarza uczuciowy obraz świata wartości, działający jako dźwignia duchowego postępu" (Wspólnota kultury i pracy... 1947: 21). W pojęciu sztuki autorzy koncepcji „Nowej Kultury Pracy” łączyli zarówno to wszystko, co określić można wyżynami działań artystów, jak i piękno prac artystów ludowych, aż po działania indywidualnych „laików sztuki”, wyrażające się w dbaniu o dom i jego najbliższą okolicę. Szczególnie podkreślali właśnie ten zwyczajny wymiar sztuki dostępny dla każdego, kto tylko zechce być uczestnikiem, kreatorem piękna lokalnego. Synteza pracy i kultury ma właśnie przynosić, jako jeden z ubocznych produktów tego połączenia, powstawanie „sztuki codzienności”. Bez względu na to, czy chodzi o estetyczne budownic- 
two czy też o zadbany ogród, istotą pozostaje aranżacja najbliższego otoczenia człowieka, a tylko świadomość podmiotu ludzkiego jest w stanie zdecydować o tym, jak duże starania poczyni on, aby żyć estetycznie. Jak pisali autorzy „Nowej Kultury Pracy”, chodzi o „wygląd życia przez włączenie sztuki w świat codziennych wytworów pracy - rzemiosła, wytwórni, handlu, reklamy itd."

Aplikacja w „Biedroneczce”. Właściciele i „Biedroneczka” starają się, by firma w swoim działaniu kierowała się także i tą zasadą. Nie zawsze jest to bezpośrednia współpraca z ludźmi kultury, ale sporo inicjatyw przedszkola wiąże się z kulturą i sztuką (w jak najszerszym rozumieniu tych terminów). Na przykład organizowane są konkursy tańca dla przedszkolaków. Z jednej strony służą one dobrej zabawie i rywalizacji, ale inny cel także realizowany poprzez tę inicjatywą stanowi rozwój dziecka poprzez taniec. Dla dzieci jest to możliwość poznawania nowych osób, odnajdywania się w nowych sytuacjach, a te umiejętności na pewno pomagają na kolejnych szczeblach ścieżki edukacyjnej. Może się zdarzyć tak, że dziecko, idąc do nowej szkoły, spotyka tam rówieśnika, którego poznało na konkursie tańca. Taka sytuacja na pewno podnosi poczucie bezpieczeństwa i pewności siebie u dziecka. Dla przedszkoli z kolei jest to możliwość nawiązania współpracy z otoczeniem społecznym, która może owocować podejmowaniem kolejnych inicjatyw oraz realizacji wspólnych celów. W przedszkolu organizowane są również na przykład sympozja poświęcone omówieniu problemów pozyskiwania funduszy przez takie placówki.

Dodatkowo w ramach zajęć dzieci odwiedzają muzea, teatry z okolicy przedszkola.

Przedszkole wprowadziło projekt „wycieczka do mojego miejsca”. W ramach zajęć organizowane są wycieczki do miejsc, w których mieszkają poszczególne przedszkolaki. Czasami okazuje się, że kilkoro dzieci mieszka obok siebie. Wycieczki te stwarzają oczywiście możliwość poznania przez przedszkolaków najbliższej okolicy swojego miejsca zamieszkania i społeczności lokalną. W praktyce społeczność lokalna jest tu pojmowana głównie jako osoby starsze, które mają dużą wiedzę na temat historii danego miejsca i mogą coś o tym przekazać dzieciom.

\section{B. Wspomaganie instytucji rodziny w przezwyciężaniu trudności i docenianie jej wartości}

Autorzy „Nowej Kultury Pracy” o rodzinie, szczególnie licznej rodzinie, pisali, iż jest „dla narodu idącego w przyszłość wartością bezcenną, a wysiłek jej utrzymania i wykształcenia musi być traktowany jako swego rodzaju poświęcenie dla dobra publicznego" (Braun b.d.w). Podkreślali oni wielokrotnie, że rodzina stanowi podstawową komórkę życia, a jej bezpieczeństwo powinno być kluczowe dla osób sprawujących władzę. „Waga tej instytucji jest tak wielka dla życia narodu, iż winien nad nią zostać rozciągnięty parasol ochronny" (Braun 1985: 79). 
Konsekwentnie wśród podstawowych zadań społecznych „Nowej Kultury Pracy” publicyści „Tygodnika Warszawskiego” zdecydowanie podkreślali znaczenie rodziny, wymieniając następujące priorytety, które postulowali traktować łącznie: „stworzenie najzdrowszych i najdogodniejszych warunków pracy, wypoczynku i życia rodzinnego nierozerwalnie" (cyt. za Ochinowskim i Gołaszewskim 2012: 16).

Równie wyraźnie stawiano sprawę trudności, z jakimi boryka się kobieta, prowadząc dom i opiekując się rodziną, (co było istotną bolączką polskiego społeczeństwa lat 40. ubiegłego wieku; warto sprawdzić na ile aktualną także dzisiaj). Postulowano konieczność zmian w tej kwestii, wymieniając wśród założeń „Nowej Kultury Pracy”: „usprawnienie gospodarstwa domowego, zwłaszcza kobiecego pod kątem umożliwienia domownikom, a szczególnie kobiecie, wypoczynku i korzystania z kultury" (O nową kulturę pracy 1947: 6).

Aplikacja w „Biedroneczce”. Jak już sygnalizowałem, kierownictwo firmy nie skupia się tylko na samych pracownikach, ale także bierze pod uwage potrzeby ich rodzin. Świadczą o tym takie elementy zarządzania firmą, jak system „sieci poleceń” oraz funkcjonowanie Funduszu Ratunkowego, nawiązującego do instytucji płacy rodzinnej.

Fundusz Ratunkowy polega na tym, że gdy ktoś z zatrudnionych osób znajdzie się $\mathrm{w}$ trudnej sytuacji wymagającej wsparcia, może skorzystać z pomocy finansowej, opartej na zasadach podobnych do funkcjonowania SKOK-u.

System „sieci poleceń” opiera się na fakcie, że pracownicy posiadają zarówno wysokie kwalifikacje zawodowe, jak i odpowiednie podejście do dzieci. Stąd też, co warto raz jeszcze powtórzyć, zdarzały się próby „podkupienia” pracowników przez rodziców, żeby zatrudnić ich jako nianie. Opiekunki z „Biedroneczki”, przypomnijmy, jednak odrzucały te propozycje.

Osoby zatrudnione w omawianych przedszkolach bez problemu mogłyby dostać pracę $\mathrm{w}$ innych placówkach. Co więcej, często też pracownicy znają nawzajem swoje rodziny, wiedzą, kto się czym zajmuje i w jakiej jest sytuacji. Jeśli więc okazuje się na przykład, że ktoś potrzebuje stolarza, a mąż jednej z pracownic trudni się tym fachem, często dochodzi do polecania go jako potencjalnego wykonawcy danego zlecenia. Polecający podejmuje pewne ryzyko, w pewnym stopniu bierze na siebie odpowiedzialność za osobę, którą poleca. W praktyce jest to jednak o tyle bezpieczny system, że poziom danej znajomości zazwyczaj okazuje się wystarczająco głęboki, a dodatkowo jedną z wartości kultywowanych w „Biedroneczce” stanowi zaufanie kierownictwa do wspólpracowników. Stosunki pomiędzy pracodawcą a pracownikami w omawianej firmie oparte są na lojalności. Z relacji współzałożyciela „Biedroneczki” wyłania się specyficzne rozumienie kategorii „lojalność”, którą można określić jako „lojalność organizacyjna". Jej podstawę stanowi przestrzeganie przez pracowników zasad zapisanych w regulaminach oraz szeroko rozumiana lojalność wobec dzieci. W „Biedroneczce” chodzi także o dawanie z siebie „czegoś więcej”, czyli 
np. pomysłów na działania wychowawcze i ogólnie dotyczących funkcjonowania przedszkola. Takie inicjatywy pracowników rzeczywiście występują.

Organizacja działania „Biedroneczki” nastawiona jest na wspomaganie opiekuńczych i wychowawczych funkcji rodzin klientów, nieraz nawet wbrew samym rodzicom. Jak deklaruje główny właściciel, Gołaszewski, jego sieć ma renomę „trudnego przedszkola”, ponieważ w odniesieniu do pewnych fundamentalnych (jego zdaniem) kwestii prorodzinnych kierownictwo nie chce podejmować negocjacji z rodzicami (opiekunami) dzieci zapisanych do „Biedroneczki”. Tak było na przykład w anegdotycznym przypadku pewnej matki, która domagała się, żeby placówka mogła być otwarta do 20.00 , ponieważ wtedy po dziecko mogłaby przychodzić... niania. Odpowiedź właściciela nie pozostawiała żadnych wątpliwości: taka sytuacja jest wykluczona. Był to więc krok ku uświadomieniu rodzicom, by więcej czasu poświęcali swemu dziecku, poparty realnym ramami działania placówki - ustaleniem godziny zamknięcia przedszkola na godzinę 17.30.

\section{Zakorzenienie}

\section{A. Racjonalne zarządzanie dobrami lokalnymi}

Uczestnicy dyskusji nad „Nową Kulturą Pracy” uwypuklali między innymi potrzebę sensownego eksploatowania zastanej przez człowieka natury. Podkreślali, że dobra naturalne otaczające wieś czy miasto są potencjalnym źródłem dochodu, a dochód ten spożytkowany wedle zasady racjonalnego podziału może stanowić środek wzrostu kulturalnej zamożności lokalnego społeczeństwa. Budowanie wspólnej infrastruktury, także sportowej i rekreacyjnej nie tylko służy miejscowym producentom i wykonawcom, ale i pozostawia trwałe dobra użyteczne dla grupy ludzi zamieszkujących wspólnie okolicę. Pisano o „budowaniu podstaw egzystencji zbiorowej”, która występuje, gdy „miasto (wieś), jego zarząd i jego aktywni obywatele przechodzą świadomie od chaosu przedsiębiorczości indywidualnej do świadomego wyboru najważniejszej i podstawowej dla swego bytu funkcji gospodarczej, która może nie tylko zapewnić ludziom minimum utrzymania, ale i doprowadzić postępowo do ogólnej zamożności" (cyt. za Gołaszewskim i Ochinowskim 2012: 13).

Aplikacja w „Biedroneczce”. Przedszkole działając według wybranych zasad „Nowej Kultury Pracy” intencjonalnie przyczynia się do zwiększania dobrobytu społeczności lokalnej. Działania na jej rzecz to na przykład wspomniana już wcześniej organizacja konkursu tańca dla przedszkolaków z różnych placówek. Celem takich akcji jest nie tylko rywalizacja, ale przede wszystkim integracja środowiska przedszkolnego. W ten sposób dzieci poznają się nawzajem, a te relacje mogą być korzystne także długofalowo, gdy dzieci znajdą się w nowym środowisku, jakim jest na przykład szkoła podstawowa. 
Inne inicjatywy tego typu to wystawiane tradycyjne jasełka, gdzie publicznością są nie tylko dzieci $\mathrm{z}$ innych grup, ale też rodzice, ludzie $\mathrm{z}$ sąsiedztwa przedszkola i przyjaciele przedszkola. Często są to imprezy, podczas których różne firmy sponsorują nagrody, catering itp. Jeszcze inne działania tego typu to współpraca $\mathrm{z}$ dziennymi domami opieki. $\mathrm{W}$ ramach takiej współpracy dzieci wychodzą na spacery razem ze starszymi osobami. Spotkania te przynoszą korzyść dla dzieci, ale też dla tych osób. W „Biedroneczce” organizowane są też, co warto powtórzyć, na przykład sympozja, w celu omówienia tego, jak przedszkola mogą pozyskiwać fundusze.

Warto też wspomnieć o jednej z inicjatyw, którą podjął sam personel omawianej placówki - inicjatywy nastawionej na dbanie o lokalne środowisko naturalne: na niektóre spacery dzieci zabierają przyrządy do zbierania śmieci i sprzątają okolicę.

\section{B. Własność prywatna jako osiągnięcie i zarazem zobowiązanie}

Wtórnym efektem pracy, szczególnie tej wykonywanej solidnie, jest prędzej czy później pojawiająca się własność. Jej wymiar może być ogromnie zróżnicowany, od nieruchomości (domu, mieszkania), po drobne elementy codziennego użytku. Ze względu na silne połączenia pracy i własności, podkreślane tradycyjnie między innymi przez katolicką naukę społeczną, także ten czynnik nie mógł zostać pominięty w ideologii „Nowej Kultury Pracy”. Od początku powstawania omawianego projektu, dyskutantów wspomnianego środowiska zajmowała relacja pracy i własności. Ich zdaniem, sytuacja jest wtedy optymalna, gdy własność stanowi wynik uczciwej pracy wykonywanej możliwie wedle zasad „Nowej Kultury Pracy”. Trudność cytowanym publicystom sprawiało natomiast wypracowanie jednolitego stanowiska wobec kwestii, jak należy traktować własność prywatną, jaki powinien być jej wymiar i na ile własność prywatna powinna być tylko prywatna. Podkreślić trzeba, iż odrzucali oni z całą mocą wszelkie koncepcje zniesienia własności prywatnej.

Tak jak praca, tak też własność - podkreślano - posiada podwójny charakter. Na pełen wymiar własności składa się jej część indywidualna i społeczna. Precyzując ten drugi aspekt, oczekiwano, iż posiadacz własności będzie używał jej w taki sposób, aby oczywiście zapewnić sobie byt, nawet znacznie lepszy niż innym, ale pod warunkiem dzielenia się ze społeczeństwem tym, co jego własność przynosi jemu. Fundamentem takiego sposobu myślenia było założenie, iż posiadacz nabył swój majątek, nie posługując się jedynie sobą samym, ale przy udziale na przykład dóbr naturalnych, które są własnością całego narodu, a tym samym skoro zaczerpnął z dobra ogółu, to część powstałej wartości przynależy do społeczeństwa. Chodzi więc znowu o tradycyjnie rozwijane przez katolicką naukę społeczną rozróżniane prawo posiadania i używania własności 
(por. np. Konstytucja Gaudium et spes jeden z podstawowych dokumentów Soboru Watykańskiego II).

Aplikacja w „Biedroneczce”. Istotnym elementem, który uległ zmianie $\mathrm{w}$ funkcjonowaniu omawianej sieci przedszkoli wraz z coraz to głębszym przekonaniem właścicieli do „Nowej Kultury Pracy”, było uwzględnienie interesu społecznego. Od początku środowisko lokalne stanowiło istotny punkt odniesienia dla kierownictwa firmy, jednak oficjalne przyjęcie zasady odpowiedzialności wobec społeczeństwa pozwoliło m.in. na podjęcie ryzyka obniżenia kosztów związanych z oddaniem dziecka do przedszkola (bez straty na jakości). Sytuacja taka pozwoliła szerszej grupie niezamożnych na korzystanie z usług „Biedroneczki”. Rozsądna kalkulacja ceny spowodowała szybki i pełny nabór. Kluczowa okazała się tu akceptacja zasady zysku optymalnego. Do dziś omawianą sieć przedszkoli charakteryzuje jeden $\mathrm{z}$ niższych poziomów cen proponowanych przez tego typu prywatne placówki w warszawskiej dzielnicy Ursus.

\section{Preferencje dla drobnej przedsiębiorczości i spółdzielczości}

Model praktyki gospodarczej wynikającej z „Nowej Kultury Pracy” jej autorzy nazwali „gospodarką dynamiczną”. Nie wgłębiając się w nieistotne dziś szczegóły, chodzi o oparcie działań przedsiębiorczych w skali kraju na dwóch filarach. Pierwszy z nich stanowiły firmy (jak byśmy powiedzieli dzisiaj) średnie i małe: „średni i drobny posiadacz jest nierozerwalnie związany z losem narodu i państwa, czego nie można powiedzieć o wielkim kapitale, lotnym jak piasek i wobec narodu obojętnym" (Braun 1947b: 3).

Programowanie przestrzeni gospodarczej, jakiego podjęli się autorzy „Nowej Kultury Pracy", wymagało wskazania nie tylko idealnych modeli budowania poszczególnych podmiotów ekonomicznych, ale także rzeczywistego oparcia propozycji na istniejących już elementach. Potrzebne było jasne wskazanie, jaka forma prawno-organizacyjna jest tą, która możliwie najlepiej stanie się rusztowaniem do budowy sprawnej gospodarki. Jak już wcześniej można było dostrzec, większą wagę przywiązywano do średnich i drobnych uczestników rynku ze względu na ich intensywniejsze powiązanie ze społecznością lokalną, a tym samym ze społeczeństwem w ogóle. Konflikt między kapitałem a pracą, do dziś przecież aktualny, nie istniał w małych, rodzinnych zakładach czy warsztatach, obecnie powiedzielibyśmy firmach. Za pierwszy filar gospodarki dynamicznej uznawano właśnie taką drobną inicjatywę gospodarczą. Twórczą, silnie powiązaną z lokalnymi potrzebami i nie obojętną na sytuację otaczającej ją społeczności. Warto przy tej okazji zauważyć, iż obecnie w przekonaniu niektórych ekonomistów, teoretyków gospodarczych, ale szczególnie przedstawicieli biznesu, to właśnie drobne przedsiębiorstwa są kluczowe dla realizacji idei zrównoważonego rozwoju. 
Obok małych firm, twórcy „Nowej Kultury Pracy” afirmowali jeszcze jedną formę działalności, która już samą formą wewnętrznej organizacji spełniała wiele postulatów środowiska „Tygodnika Warszawskiego”. Chodziło o spółdzielnie. Ich siłę, zdaniem omawianego środowiska, stanowi konieczność odejścia od indywidualistycznego ujęcia działań gospodarczych, a w ich miejsce powołanie twórczego i zgodnego współdziałania. Na tym właśnie polegała istota założeń proponowanego dynamizmu działań przedsiębiorczych.

Aplikacja w „Biedroneczce”. Omawiana organizacja jest typowym przykładem efektywnej działalności gospodarczej sektora MŚP. Dla głównego właściciela bardzo ważna jest większa dbałość zarówno o biznes, a tym samym o klientów, jak i pracowników niż ma to miejsce w przypadku dużych korporacji. Przykłady przytoczone w niniejszym tekście świadczą o tym, że stosunkowo mała organizacja ma sporo możliwości w podejmowaniu wspólnych działań łączących przedszkole i społeczność lokalną.

Przy przedszkolu funkcjonuje wspomniana już firma „Żuczek”, umożliwiająca pracownikom dodatkowe zarobkowanie. W pewnym zakresie rozwija ona zarysowane wcześniej walory spółdzielczości, choć nie przyjęła takiej formy organizacyjnej.

\section{Codzienność jako „przestrzeń" rozwoju Nowej Kultury Pracy}

Zdaniem twórców omawianej propozycji ideologicznej zmiana w myśleniu o pracy wymaga zakorzenienia postulowanej nowej wizji w codzienności życia człowieka, rozszczepiającej się na zróżnicowane dziedziny. „Nowa Kultura Pracy"proponuje zatem podział życia na poszczególne sfery, w ramach których postulowano konkretne praktyki. Publicyści „Tygodnika Warszawskiego” wspomniane sfery określali mianem „odcinków działania”. Wyszczególnili sześć kluczowych odcinków: (1) praca, (2) dom, (3) nauka, (4) oświata, (5) sztuka i (6) gospodarka. Elementy te razem tworzyły spójny całokształt dziedzin, na które człowiek ma wpływ, a z drugiej strony dziedziny te, już ukształtowane, wpływają na los i życie kolejnych pokoleń. Analiza konkretnych praktyk dla poszczególnych sfer postulowanych przez „Nową Kulturę Pracy”, przekracza ramy niniejszego podrozdziału. Wrócę natomiast do tych zagadnień w rozdziale następnym. Dla praktyki przedsiębiorczości ważna jest natomiast podstawowa, ogólna zasada zawarta w omawianym projekcie: potrzeba ścisłych relacji między „kluczowymi odcinkami” według zasady wzajemnego wspomagania i transferu doświadczeń na poziomie codzienności.

Aplikacja w „Biedroneczce”. Program edukacyjny „Biedroneczki” daleko wybiega poza wąsko rozumianą opiekę nad dziećmi „gdy rodzice pracują”. Chodzi w nim przede wszystkim o jak najlepsze zapoznanie dzieci ze światem oraz wpojenie przedszkolakom od najmłodszych lat podstawowych wartości 
ogólnoludzkich. Do tych elementów aksjologicznych właściciele placówki zaliczyli także patriotyzm lokalny, realizowany przede wszystkim poprzez praktyki codzienności.

Jak już sygnalizowałem, przedszkole wprowadziło zajęcia mające na celu poznawanie środowiska lokalnego. Dzieci odwiedzają muzea, teatry i temu podobne. Inne przykłady takich działań to również już omawiane: „wycieczka do mojego miejsca" oraz odwiedziny dziennych domów pobytu dla osób starszych. W ten sposób dzieci poznają historię Ursusa, której skarbnicą są ci ludzie. Innym celem odwiedzin domów opieki jest przyzwyczajenie dzieci do kontaktu ze starszymi osobami, kształtowanie szacunku do osób starszych i pokazanie ich roli w społeczeństwie. Dla niektórych dzieci daje to możliwość zyskania „przyszywanych dziadków”, ponieważ dzieci często albo mają dziadków w innych miastach (skąd imigrowali ich rodzice), albo żyją w rodzinach, w których przedstawiciele poprzedniego pokolenia już zmarli. Wspomniane spotkania są też chętnie podejmowane przez samych pensjonariuszy domów opieki. Przedszkolaki wystawiały przedstawienia o historii Ursusa w takich placówkach. Wspomniane przedstawienia zostały później przeorganizowane tak, aby mogły je zobaczyć również inne osoby ze społeczności lokalnej.

Nie zawsze edukacja tego typu spotyka się ze zrozumieniem rodziców. Jednak względnie niska cena przedszkola implicite sprzyja pedagogizacji dorosłych.

Prezentowana analiza ma strukturę otwartą. Jest relacją z poszukiwań w obszarze historii idei przedsiębiorczych jako źródła dobrych praktyk na dzisiejszy czas kryzysu. Wspierające te poszukiwania wieloetapowe badanie jakościowe, dotyczące eksperymentalnej aplikacji wspomnianych idei przez współwłaściciela jednego z warszawskich przedsiębiorstw danego sektora, oczywiście niczego nie przesądza. Wymaga krytycznego pogłębienia, a przede wszystkim dyskusji.

Trzy zawarte postulaty, podobnie jak wcześniej omówione, należące do głównych elementów ideologii „Nowej Kultury Pracy”, dotyczą społecznego otoczenia organizacji. Wymagają one przetestowania na znacznie szerszym obszarze niż pojedyncza firma. Na razie przedstawię więc jedynie ich treść. Chodzi o problematykę dochodu narodowego, wychowania i nauczania przedsiębiorczości oraz zagadnienia jedności państw Europy.

Koncepcja dochodu narodowego. „Nowa Kultura Pracy” prezentowała radykalnie odmienne podejście do zagadnienia dochodu narodowego niż to, którego także dziś uczą się studenci uczelni ekonomicznych i biznesowych, a którego filozofię dobrze oddaje encyklopedyczne określenie: „dochód narodowy jako produkt narodowy netto wyrażony w cenach czynników produkcji” (zob. np. Encyklopedia $P W N$ ). Treściom zawartym w przytoczonej definicji ideolodzy „Nowej Kultury Pracy” zarzucali dość marginalne traktowanie człowieka. Sami natomiast proponowali, by rozumieć dochód narodowy jako „stałe zmniejszanie się energii wydatkowanej przez jednostkę, naród, ludzkość na utrzymanie 
się w bycie, czyli stałe zwiększanie się zapasu energii, którą możemy użyć na twórczość duchową". Chodziło więc o zysk wypracowywany przy wykorzystaniu odpowiednich narzędzi przez całe społeczeństwo. Zasoby ludzkie powinny być połączone $\mathrm{z}$ wykorzystaniem zasobów naturalnych w taki sposób, by wzrastała wydajność pierwszego z wymienionych elementów. To z kolei pozwala oszczędzać czas, który może być przeznaczony na inną działalność przedsiębiorcy, w tym także na odpoczynek (Strocka, Gołaszewski i Dreilich, 2012).

Wychowanie i nauczanie przedsiębiorczości. Celem wychowania, według twórców „Nowej Kultury Pracy”, jest „,wydobycie różnorodnych dyspozycji tkwiących w duszy dziecka, ukształtowanie pełnej osobowości, żyjącej zarówno życiem zewnętrznym, jak i wewnętrznym, przyrodzonym i nadprzyrodzonym” (Braun 1947d: 1). Pierwotne oraz nienaruszalne prawa w zakresie wychowania ma co nie może dziwić w świetle przedstawionych wcześniej elementów ideologów „Nowej Kultury Pracy” - rodzina.

Generalnie „Nowa Kultura Pracy” duży nacisk kładła na edukację. Jej twórcy postulowali, aby w celu uczenia dzieci samodzielności już na poziomie szkoły podstawowej pozwalać uczniom na podejmowanie decyzji dotyczących zarówno ich samych, jak i placówki oświatowej. Jako sposób osiagnnięcia tego celu omawiani publicyści wskazywali wprowadzenie w szkołach wysokiego stopnia samorządności. Taki system wychowania i edukowania miał spowodować, że dzieci już od najmłodszych lat będą nabywać umiejętności niezbędne do aktywnego uczestnictwa w życiu lokalnych grup społecznych oraz będą zdobywać kompetencje z zakresu przedsiębiorczości (Strocka, Gołaszewski, Dreilich, 2012, Ochinowski i Kseba 2013).

\section{Idea unionizmu}

Ideologia „Nowej Kultury Pracy” dotykała również jeszcze szerszych podmiotów społecznych niż wymienione. Na przykład wyraźnie zawierała wątki, które uznać można za korzenie intelektualne współczesnej narracji o Unii Europejskiej. Podczas II wojny światowej środowisko intelektualistów podziemnego pisma „Kultura Jutra”, stanowiącego, co warto przypomnieć, wojenny poprzednik „Tygodnika Warszawskiego”, było jedną z grup rozwijających wówczas ideę unionizmu. W tym wypadku chodziło o projekt urządzenia porządku powojennego na zasadach federacyjnych, przy poszanowaniu uniwersalnych norm moralnych i czerpaniu bezpośrednich inspiracji z chrystianizmu. Projekt ten z jednej strony nawiązywał do polskich, szeroko rozumianych tradycji unionistycznych, poczynając od unii polsko-litewskiej, z drugiej był bardzo bliski ideom Ojców Założycieli Unii Europejskiej. Po II wojnie światowej myśli te znalazły poczesne miejsce na łamach „Tygodnika Warszawskiego”. Wyraźnie więc Polska była wśród krajów, w których nowoczesna dyskusja o zjednoczeniu Europy zaczęła 
się dość wcześnie. Niestety, co warto raz jeszcze podkreślić, panująca wówczas rzeczywistość polityczna uniemożliwiła wspomnianej grupie opiniotwórczej kontakt z Zachodem Europy. Warto przypomnieć, iż po trzech latach działalności liderzy grupy, wraz ze swym głównym inspiratorem Jerzym Braunem, zostali na wiele lat zamknięci w więzieniu. Gdy w 1957 roku ogłaszano Traktaty Rzymskie, pozostali przy życiu polscy unioniści dopiero od kilku, czy kilkunastu miesięcy byli poza więzieniem i prawie nikt, nie tylko w Europie, ale i w Polsce o nich nie słyszał. Temat ten oczywiście tylko sygnalizuję do oddzielnego opracowania.

Już jednak w niniejszym podrozdziale widać wyraźnie, że, jak to zapowiadałem, dzisiejszy czytelnik tekstów „Tygodnika Warszawskiego” (1946-1948) spotyka w nich zarówno konsekwencje uwarunkowań historycznych, jak i tezy, które wydają się nie tracić aktualności także dla współczesnego przedsiębiorcy czy menedżera. Z perspektywy problematyki kulturowego kapitału organizacji szczególnie warte uwagi, mimo swego publicystycznego i miejscami idealistycznego charakteru, wydają się te elementy ideologii „Nowej Kultury Pracy”, które wyraźnie, choć niekoniecznie wprost, nawiązują do triady „podmiotowość relacyjność - zakorzenienie”. Sugestię tę zdaje się potwierdzać porównawcza analiza treści projektu „Nowej Kultury Pracy” z przykładowym współczesnym programem dotyczącym etyki biznesu.

\subsubsection{Nowa Kultura Pracy jako ideowa poprzedniczka programu "Good Work"}

Wzięcie pod uwage projektu „Good Work” jako potencjalnej odpowiedzi na ideowe wyzwania sytuacji współczesnego biznesu usprawiedliwiają przynajmniej trzy przyczyny.

Po pierwsze - analizy funkcjonowania idei społecznej odpowiedzialności biznesu wyraźnie wskazały na konieczność poszukiwania precyzyjnych jej wskaźników, sięgających głębiej niż tylko poziomu PR firmy oraz związania tej problematyki z praktyką zrównoważonego rozwoju (Bernatt, Bogdanienko i Skoczny 2011).

Drugą przyczynę stanowi swoisty zwrot aksjologiczny obserwowany od pewnego czasu w zarządzaniu jakością. Coraz częściej do świadomości zarówno praktyków, jak i teoretyków biznesu dociera prawdziwość starej tezy Richarda Kocha (1994/97: 95): „Jakość nie jest sprawą technik, choć niektóre z nich (...) mogą stanowić dobry punkt wyjścia do zmiany zachowań. Jakość tkwi w sercach i umysłach pracowników" (por. np. Csíkszentmihályi 2002).

Wreszcie, o czym pisałem wielokrotnie, obecny kryzys ekonomiczny skłania do zwrócenia się ku rozwiązaniom, które łączą pragmatyzm z aksjologią.

Projekt „Good Work” początkowo (i nadal jest taki w swej istotnej części) sprowadzał się na poziomie operacyjnym do poszukiwania osób, które łączą 
ekspercki poziom wykonywania pracy ze świadomością służenia szerszym społecznościom.

Zainicjowali go przed ponad piętnastu laty Howard Gardner, Mihaly'ego Csikszentmhályi i William Damon (Gardner, Csikszentmihályi Damon 2001, Fischman, Solomon, Greenspan i Gardner 2004, Gardner 2007 i 2010, Good Work... 2011, zob. także Strocka, Derlisch i Gołaszewski 2012). Dotąd zebranych zostało ponad 1200 uzasadnionych empirycznie przypadków przedstawicieli różnych profesji, osób uzdolnionych zawodowo, a jednocześnie myślących o skutkach swoich prac i o odpowiedzialności wobec różnych punktów odniesienia, takich jak: stawiane sobie cele, rodzina, przyjaciele, rówieśnicy, koledzy, misja lub sens wykonywanego zawodu, instytucje, z którymi są związani, szerszy świat (łącznie z przyszłymi pokoleniami), może to być Ziemia lub Bóg.

Jak wykazały badania cytowanych autorów i ich współpracowników, charakterystyczne cechy osób realizujących model „Good Work” wyznaczają $\mathrm{z}$ jednej strony bardzo wysokie poczucie satysfakcji z wykonywanej pracy, przejawiające się poprzez stosunkowo częste doświadczenie zjawiska flow (przepływu), z drugiej zaś przeżywanie, również względnie licznych, dylematów moralnych.

Dylematy etyczne w pracy nie są oczywiście zagadnieniem nowym ani wyjątkowym, jednak należy zwrócić uwagę na to, jak piszą autorzy projektu „Good Work", iż działamy obecnie w specyficznych warunkach. W warunkach trudnych i często nieprzewidywalnych, w których nowe technologie zasadniczo zmienity poczucie czasu i przestrzeni. $\mathrm{W}$ warunkach, w których siły rynkowe, również w administracji mają bezprecedensowe znaczenie we współczesnym świecie i czasami działają destruktywnie na ludzi i społeczeństwa. Obecnie niewiele jest znaczących czynników (jeśli w ogóle jakieś są) stanowiących realną przeciwwagę sił rynkowych.

Jeszcze innym, bardzo ważnym zagrożeniem czyhającym na osoby realizujące „Good Work” jest stres, dotykający każdego, niezależnie od wykonywanego zawodu. Szybko zmieniające się technologie, innowacyjne wynalazki, nowe przepisy prawne, ciaggle inne oczekiwania społeczeństwa, powodują stres zarówno u producentów, jak i konsumentów.

Osoby realizujące „Good Work” wypracowały jednak pewne strategie efektywnego rozwiązywania dylematów etycznych, strategie mające, jak się wydaje, charakter uniwersalnych dobrych praktyk.

Ci, którzy łączą wysoką efektywność wykonania pracy z etyką, stając w obliczu dylematu moralnego, rozważają (kolejno) trzy główne kwestie:

1. Zgodność ewentualnej decyzji z misją wykonywanego zawodu. Misja jest tu rozumiana jako to, co decyduje o specyfice danej profesji, jest jej sensem.

2. Zgodność ewentualnej decyzji ze standardami wyznaczanymi przez pracę osób które decydent uważa za wzór. 
3. Zgodność ewentualnej decyzji z poczuciem tożsamości decydenta - poczucie „bycia sobą” i wartości, których nie można przekroczyć.

Istota każdego ze wspomnianych tu kryteriów podejmowania decyzji w warunkach dylematu moralnego zgodnie ze standardami "Good Work” przedstawia się następująco:

\section{Misja}

Każdy zawód ma swoją misję, wyrażającą się w zaspokajaniu określonych potrzeb społecznych, z wykorzystaniem właściwych i specyficznych dla tego zawodu kompetencji, a także w przyczynianiu się do większego dobrostanu ludzi. Ideałem jest, gdy misja jest na tyle atrakcyjna, że przyciaga człowieka do wykonywania danego zawodu i ułatwia jego samorealizację, a także przetrwanie trudnych chwil i konfliktów.

\section{Standardy}

Standardy w kontekście „Good Work” mają prowadzić do wysoce profesjonalnej i etycznej realizacji misji danego zawodu. Każda profesja ma swoje standardy, których przestrzegania oczekuje od jej adeptów. I tak na przykład, od prawników oczekuje się, że będą sprawiedliwi, o wysokim poziomie moralności, będą bronić naszych interesów najlepiej jak potrafią w każdych okolicznościach. Nauczyciele mają dawać osobisty przykład - być kulturalni, świetnie wykształceni, dobrze traktować uczniów, unikać prywatnych kontaktów z nimi.

\section{Tożsamość}

Istotne jest tu w szczególności osobiste przekonanie o tym, kim jesteśmy, co dla nas i dla mnie jest najważniejsze, jakie wyznaję wartości. To również całościowa wizja człowieka jako pracownika, mieszkańca miasta, kraju, mieszkańca tej planety. Centralnym elementem poczucia tożsamości jest osobista moralność. Wyznacza ją granica (przyjęta przez daną jednostkę), której dany człowiek nie chce przekraczać w konkretnej sytuacji wyboru. Tożsamość to również mocne i słabe strony, sfera motywacyjna. Wszystko to, co dana osoba preferuje i to, czego nie lubi. Jednak najgłębszy wymiar poczucia tożsamości wyznacza, według autorów projektu „Good Work”, właśnie poczucie moralności.

W nurcie tego projektu Csikszentmhályi (2003) przeanalizował grupę firm dobrze prosperujących na rynku, a których szefowie starają się kreować etyczne środowisko pracy, czyli takie, w którym jednostki ludzkie mogłyby urzeczywistniać swoje potencjały. Cytowany badacz nadał przedsiębiorstwom spełniającym wspomniane kryteria etykietę „Good Business”. Praktyczny wskaźnik tego, czy 
dana organizacja zarządzana jest metodą „Good Business”, stanowi możliwość przeżywania przez pracowników „przepływu”.

Analiza dobrych praktyk organizacji realizujących tę metodę pozwoliła wyodrębnić następujące ich cechy charakterystyczne:

\section{Pełna mocy wizja wykraczająca poza własne ,ja"}

Cele stawiane przez założycieli i kierownictwo są korzystne nie tylko dla firmy, ale też dla innych ludzi. Są to cele, w które mogą być zaangażowani podwładni i współpracownicy. Cele, które sprawiają, że pracownikom chce się je realizować nie tylko z poczucia obowiązku. Takie cele zmieniają pracownika z egocentryka w człowieka chcącego wzrastać, kontaktować się z innymi, współpracować.

Istnieją trzy główne motywy, dzięki którym menedżerowie realizują szerszą perspektywę zarządzania:

- dawanie z siebie wszystkiego,

- pomaganie innym,

- budowanie lepszego świata.

Jeśli te motywy (lub któryś z nich) są realizowane w organizacji, to może ona stać się czymś więcej niż tylko miejscem wypełniania obowiązków, stosowania procedur, zarabiania pieniędzy czy pomnażania zysków. Będzie organizacją, której pracownicy mają poczucie, że działają dla dobra innych.

\section{Specjalne zasady zachowań organizacyjnych:}

- duże znaczenie zaufania, które wynika z szacunku dla pracowników,

- organizacja jest skupiona na osobowym rozwoju swoich członków,

- dostarczanie możliwości przeżywania przepływu w miejscu pracy.

Najważniejszą i podstawową zasadą etycznego zachowania się w organizacji jest kwestia zaufania, z którą związany jest szacunek. Jeżeli jakaś grupa ludzi współpracuje ze sobą nad danym projektem, a współpraca oparta jest na szacunku i zaufaniu, daje się wtedy odczuć wielce satysfakcjonujące poczucie wspólnoty. Etyczne przywództwo to także szczera troska o osobisty rozwój każdego z pracowników.

Ważnym aspektem jest niepozbawianie pracownika zwyczajnej radości z pracy, z dobrze wykonywanych zadań. Nawet realizacja małych, cząstkowych celów sprawia radość, kiedy daje się z siebie wszystko. Aby to uzyskać, warto pamiętać żeby:

- formułować jasne cele,

- zadania były dobrze dopasowane do umiejętności pracownika.

Jeżeli te dwa punkty nie zostaną spełnione, to pracownik może stracić inicjatywę i kreatywność. Bardzo ważne jest również stworzenie tzw. autotelicznego środowiska, które „Good Work” gwarantuje wszystkim pracownikom:

- dobry przepływ informacji; informacje zwrotne,

- jasne zasady, granice i oczekiwania, 
- poczucie kontroli wewnętrznej,

- atmosferę sprzyjającą koncentracji na bieżącym zadaniu,

- modę na motywację wewnętrzną,

- stawianie sobie nowych wyzwań.

\section{3. „Produkt, który służy rodzajowi ludzkiemu”}

Każdy z pracowników danej organizacji powinien zdawać sobie sprawę z tego, w jaki sposób jego firma pomaga lub może przyczynić się do polepszania życia ludzi. Szczególnego znaczenia nabiera aspekt misji w kontekście urzędów i pracowników służby cywilnej. Oprócz przełożonych, również wszyscy pracownicy wykonawczy powinni regularnie dokonywać bilansu. Czy moja praca przynosi więcej szkody czy korzyści ludziom (współpracownikom, klientom)? Jeśli okazuje się, że bilans wychodzi stale na minus i nie potrafię tego naprawić, być może jest to sygnał, że urząd po prostu nie jest miejscem dla mnie.

Zdaniem Csikszentmihályia (2003) zarządzanie zasobami ludzkim w organizacji realizującej „Good Business” wyznaczane jest przez następujące cele:

1) kształtowanie fizycznego środowiska pracy, czyli dopasowanie go do potrzeb pracowników, przyjazne miejsca gdzie można odpocząć, wystrój, który odzwierciedla całą filozofię firmy;

2) budowanie emocjonalnego środowiska pracy, w którym kierownictwo reprezentuje postawę, że praca powinna być traktowana poważnie, ale nie jest jednak sednem życia;

3) umożliwianie pracownikom wolnego, swobodnego poruszania się i działania. Pracownicy mają wpływ na decyzje związane bezpośrednio z ich pracą;

4) umożliwienie pracownikom realizacji celów, obowiązków i zadań. Są one jasno wytyczone, są zgodne z misją urzędu. Bardzo silna i nieustannie podtrzymywana świadomość celowości swoich działań. Dopasowanie zadań do umiejętności pracowników, czyli osiągnięcie równowagi pomiędzy umiejętnościami a trudnością zadania;

5) umożliwianie komunikacji opartej na zaufaniu. Sprzężenie zwrotne, czyli proste pytanie: „Jak mi idzie?” Komunikacja z pracownikami nie tylko w obrębie własnego oddziału;

6) sprzyjanie personalnemu rozwojowi pracownika;

7) unikanie tworzenia sytuacji stresujących, wywołujących napięcie.

Warto wspomnieć prowadzone także w obszarze projektu "Good Work” analizy Damona (2004), który na podstawie pogłębionych wywiadów z czterdziestoma ośmioma przedstawicielami kadry kierowniczej różnych firm sformułował tezę o istnieniu „moralnej przewagi konkurencyjnej” (ang. the Moral Advanatage). Wspomniane badania wpisują się w coraz silniej słyszalny w zarządzaniu nurt myślenia, już przeze mnie wspominany kilkakrotnie, zakładający istnienie uniwersalnego zestawu wartości konstytuujących etykę biznesu na poziomie 
głębszym niż istotne przecież różnice międzykulturowe (por. Kung 2002, Seligman 2005 i 2011).

Jeśli to podejście jest uzasadnione, to warto podjąć poszukiwania poza amerykańskimi wersjami perspektywy wyznaczanej przez projekt "Good Work” lub nawet poza amerykańskich jej „poprzedników ideowych” (antecedencji). Przyczynić się to może do rozwoju międzykulturowego ujęcia społecznej odpowiedzialności biznesu.

Charakter przyczynkarskiego zbliżania się do tego celu ma porównanie programu „Good Work” z jednym przypadkiem teorii i praktyki biznesowej wyrosłej niezależnie od amerykańskiego pomysłu, to jest polskiego projektu „Nowej Kultury Pracy”, który wypełnił treść niniejszego podrozdziału.

W celu przetestowania pokrewieństwa treściowego obydwu programów etycznego biznesu została przeprowadzona po moim kierunkiem analiza pól semantycznych ich głównych idei skupiona wokół słów kluczy: „praca”, „biznes” oraz „menedżer i pochodne"71.

Analiza pól semantycznych słowa-klucza „praca” zasugerowała podobieństwo między koncepcjami „Good Work” i „Nowej Kultury Pracy” na poziomie podstawowych wartości ludzkich (poczucie sensu, uczciwość), które obie koncepcje łączą z pracą. Obydwie koncepcje również ściśle łączą etyczny wymiar pracy z jej efektywnością. Harmonię między tymi elementami zgodnie uznają za podstawowy wyznacznik dobrych praktyk biznesowych. Przy czym „Good Work" wydaje się koncepcją bardziej optymistyczną i indywidualistyczną niż „Nowa Kultura Pracy”. Ta druga z kolei bardziej niż „Good Work” podkreśla wartość pracy jako podstawy działań ekonomicznych czy nawet budowy tzw. ustroju gospodarczego.

Obydwie koncepcje przeciwstawiają sensowną pracę z poczuciem przykrej konieczności i przymusu.

71 Wspomniana analiza przebiegała według następujących kroków: (1) przygotowane zostały - przeze mnie przy współpracy z Pauliną Pachowską i Piotrem Gołaszewskim - syntetyczne prezentacje (w formie esejów) założeń Projektów „Good Work” i „Nowej Kultury Pracy"; (2) obydwie prezentacje zostały poddane analizie pól semantycznych. Analizę wykonali studenci pierwszego roku Wydziału Zarządzania UW w ramach zaliczenia części badawczej przedmiotu „elementy socjologii”. Pełnili oni rolę sędziów kompetentnych. Każde słowo klucz dla obydwu prezentacji analizowało niezależnie od siebie przynajmniej trzech sędziów. Dany element treściowy był brany pod uwagę przy interpretacji wyników, jeśli wskazało na niego przynajmniej dwóch sędziów. Sędziowie przeszli przeszkolenie $\mathrm{w}$ zakresie stosowania analizy pól semantycznych pod kierunkiem moim i Moniki Strockiej. Analiza została dokonana w ciągu dwóch ostatnich tygodni maja 2012 pod kierunkiem Moniki Strockiej. Rolę sędziów kompetentnych pełnili: Agata Trzonkowska, Mateusz Błąkała, Emilia Kubiak, Magdalena Wiench, Mateusz Popowski, Dawid Chyła, Paulina Olszewska, Beata Duda, Agata Piędzia, Rafał Stankiewicz, Igor Rychlik i Katarzyna Kopyt. 
Zarówno „Good Work”, jak i „Nowa Kultura Pracy” podkreślają relatywny charakter pracy; to, że może przynosić zarówno szkody, jak i korzyści. „Nowa Kultura Pracy” ujmuje tę kwestię bardziej szczegółowo niż „Good Work”.

Obydwie koncepcje koncentrują się na etycznym środowisku pracy. „Good Work” nastawione jest na identyfikację tego środowiska. „Nowa Kultura Pracy” ma charakter bardziej postulatywny. Apeluje o kształtowanie etycznego środowiska pracy, np. poprzez zmianę mentalności społeczeństwa.

Analiza semantyczna słowa klucza „biznes” nie wnosi nic nowego do powyższej charakterystyki. Zarówno „Good Work”, jak i „Nowa Kultura Pracy” ściśle wiążą działalność biznesową z pracą, stąd podobne są asocjacje, opozycje, działania przez i działania na. Oczywiście są one tu bardziej operacyjne i bardziej szczegółowe niż w wypadku pracy. Jednak to wymaga oddzielnej analizy, którą planuję podjąć w przyszłości. Jedynym elementem treściowym wyraźnie dodanym przy słowie kluczu „biznes” jest podkreślenie w obydwu koncepcjach znaczenia biznesu dla podnoszenia jakości życia. W tym aspekcie koncepcje różnią się tylko terminologią, spowodowane tym, że „Nowa Kutura Pracy” jest dużo starsza niż „Good Work” i powstała w innym kręgu kulturowym.

Analiza pól semantycznych zbiorczego słowa klucza „kierownik, właściciel, biznesmen, menedżer" w świetle obydwu koncepcji jest punktem wyjścia konkretnych wskazań etycznych dla kadry kierowniczej przedsiębiorstwa. Są one następujące: dawanie z siebie wszystkiego, pomaganie innym, budowanie lepszego świata (kategorie z programu „Good Work”), innowacyjność pracowników, godne życie, kultura rozwoju (kategorie z „Nowej Kultury Pracy”).

Podobnie jak w wypadku analizy pól semantycznych terminu „praca”, także w wypadku „menedżera i pochodnych” „Good Work” mocniej niż „Nowa Kultura Pracy" podkreśla aspekt diagnostyczny (jest koncepcją wyrosłą z identyfikacji konkretnych środowisk biznesowych realizujących tę koncepcję), zaś „Nowa Kultura Pracy” jest bardziej postulatywna (była przecież konkretną ideologią wtórnie dopiero sprawdzoną w praktykach gospodarczych).

W toku omawianej analizy szczególnie wyraźnie ujawniły się dwa ogólne podobieństwa między porównywanymi projektami. Zarówno dla „Good Work”, jak i dla „Nowej Kultury Pracy” jedną z kluczowych kategorii działań biznesowych stanowi odpowiedzialność zarówno wobec zewnętrznego, jak i wewnętrznego środowiska firmy. Podobne w wypadku obydwu programów jest rozumienie pracy jako twórczej aktywności dostarczającej głębokiej satysfakcji.

Podsumowując, analiza pól semantycznych podstawowych treści koncepcji „Good Work” i „Nowej Kultury Pracy” wykonana dla trzech słów kluczy: „praca”, „biznes” oraz „menedżer i pochodne” pozwala przyjąć hipotezę o zasadniczym aksjologicznym podobieństwie tych koncepcji mimo, iż powstały one w różnym czasie oraz różnych warunkach zarówno kulturowych, jak i ekonomicznych. Różnią się też zasadniczo metodologią. „Good Work” jest rodzajem 
teorii ugruntowanej wynikłej z badań empirycznych rzeczywistości biznesowej, „Nowa Kultura Pracy” była koncepcją powstałą w wyniku przemyśleń teoretycznych oraz analiz historii idei. Dopiero wtórnie została przetestowana przez praktyki przedsiębiorcze. Mimo tych różnic $-\mathrm{z}$ punktu widzenia historii idei biznesowych - i przy przyjęciu wspomnianych odmienności czasowych, można więc uznać, iż „Nowa Kultura Pracy” była „treściową poprzedniczką” (antecedencją) programu „Good Work”.

Niniejszy rozdział wykorzystywał analizę treści literackich, analizę archiwalną oraz technikę learnig by doing. Następny ukazuje użyteczność odmiennej niż zastosowana tutaj perspektywy metodologicznej do analizy praktyk pochodzących z tradycji zarządzania jako nośnika kapitału kulturowego współczesnej organizacji. Wykorzystują na różne sposoby historię mówioną, choć powstały także na podstawie poszukiwań archiwalnych. Podrozdział 6.1. jest analizą historiograficzną badań prowadzonych za pomocą zbierania relacji ustnych. Podrozdział 6.2. opiera się na historii mówionej „w praktyce”. Dla treści podrozdziału 6.3. historia mówiona była punktem wyjścia. 
Rozdział VI

\section{Kapitał kulturowy w wybranych praktykach z tradycji polskiej przedsiębiorczości}

\subsection{Historia mówiona odbudowy Warszawy w ujęciu Jana Górskiego a metodologiczne problemy badania zarządzania ludźmi w organizacji}

\subsubsection{Historia mówiona jako metoda badawcza}

Od strony metodologicznej użytecznym łącznikiem między problematyką kultury i pamięci organizacyjnej a historiografią, które to połączenia, przypomnę, należą do istoty „Zwrotu historycznego" na terenie zarządzania, wydaje się być historia mówiona, czyli, mówiąc najogólniej, naukowe wykorzystanie relacji. Dość dobrze znają ją badacze przeszłości, a chętnie też sięgają po nią analitycy organizacji ${ }^{1}$.

Wykorzystując nieco pretensjonalną metaforę, pozwolę sobie zaryzykować stwierdzenie, iż pod wieloma względami historia mówiona przypomina samochód terenowy, zwany pieszczotliwie „gazikiem”. Wehikuł o podejrzanym pochodzeniu, wstyd się w nim pokazać na eleganckich ulicach, pochłania bardzo dużo energii, ale tylko on umożliwia podróże po niedostępnych dla innych pojazdów trasach i bezdrożach, a także dostarcza użytkownikowi silnych przeżyć, trudnych do porównania z czymkolwiek innym. Lączy zainteresowaniem sobą ludzi różnych profesji i różnych generacji. Będąc właśnie taką, historia mówiona (ang. oral history ${ }^{2}$ ) - niezależnie czy traktowana jako specyficzna

1 Choć ci drudzy do niedawna raczej nie używają jej nazwy, do wyjątków należy cytowany już przeze mnie artykuł Śliwy z 2013 roku, pisany, przypomnę, w kontekście historii organizacyjnej.

2 Por. np. inną propozycję językową sformułowaną przez Elżbietę Tabakowską (1998), tłumaczkę Europy Normana Davisa. Używa ona terminu opisowego „historia ustnego 
metoda czy jako subdyscyplina nauk o przeszłości - stanowi jeden z ciekawszych problemów epistemologicznych. $Z$ jednej strony znajduje się ona $w$ centrum aktualnych dyskusji metodologów, zaś z drugiej sięga do odległych tradycji. Zdaniem Paula Richarda Thompsona (1990) omawiana perspektywa poznawcza była w ogóle pierwszym rodzajem refleksji nad dziejami. Odegrała istotną rolę choćby w rozwoju kultury starożytnego Rzymu i starożytnego Izraela ${ }^{3}$. Powstanie współczesnej formy historii mówionej jako metodologii zbierania danych wspomniany Thompson wiąże z monumentalną pracą Julesa Micheleta z Sorbony Historia Rewolucji Francuskiej (fr. Histoire de la Revolution française; 7 tomów, wydanych w latach $1847-1853^{4}$, zob, Thompson 1990).

Jednak szczególne zainteresowanie omawianym podejściem do badań rozpoczęło się pod koniec lat 60 . XX wieku wśród uczonych zachodnioeuropejskich zajmujących się najnowszymi dziejami społeczeństw5 ${ }^{5}$ Zaciekawienie to wydawało się trwać około trzy dekady, by nieco opaść na przełomie tysiącleci i ostatnio wybuchnąć z nową siłą. Ostatnie zdanie, aczkolwiek mające charakter wyłącznie publicystycznego uogólnienia, da się jednak podeprzeć faktami. Na przykład choćby pobieżne wykorzystanie wyszukiwarki „Google”, sugeruje, iż ostatnio odbywa się na świecie rocznie co najmniej kilka, jeśli nie kilkanaście konferencji poświęconych historii oralnej. Dotyczy to także naszego kraju (zob. np. Wagner i Wiślicz 2008, Woźniak 2010). Przed pięciu laty trzydniowe, wielowątkowe obrady na Uniwersytecie Jagiellońskim zatytułowane „Oral History. The Art of Dialogue” (8-10 listopada 2007), zainaugurował gościnny wykład Allesandro Portelliego - nestora metodologów omawianego sposobu badań.

Rodzimą tradycję rozwoju tego podejścia reprezentują tak znane, także w skali międzynarodowej, działania badawcze, jak prace wspomnianego już

przekazu”. W polskiej literaturze przedmiotu funkcjonują również nazwy: „historia ustna” i „historia mówiona”. Przywołując poglądy różnych historyków, będę zamiennie stosował terminy używane przez każdego z nich.

3 Zob. np. Thompson (1990) oraz Eliach i Gurewitsch (1996). Jako inny wczesny przykład historii oralnej w szerokim, kulturowym znaczeniu, warto wskazać na przykład Odyseję. Być może nawet jej właśnie należałoby przyznać chronologiczne pierwszeństwo (zwrócił na to uwagę Andrzej Wierzbicki podczas dyskusji w Pracowni Dziejów Myśli Społecznej i Politycznej IH PAN, marzec 2008). Tradycja ustna odegrała istotną rolę w rozwoju kultury nawet tak silnie związanej z pismem jak chińska (zob. np. J.C.H. Wu, Ponad Wschodem i Zachodem. Autobiografia chińskiego konwertyty, Warszawa 1994, por. W.S. Morton i Ch.M. Lewis, Chiny. Historia i kultura, Kraków 2007).

4 Michelet, pisząc dzieje rewolucji francuskiej traktował dokumenty archiwalne wyłącznie jako jedno z wielu wartościowych źródeł. Sięgał do własnej pamięci (urodził się w Paryżu, jedenaście lat po zburzeniu Bastylii) oraz zbierał sprawozdania ustne i rekonstruował historie życia bezpośrednich uczestników analizowanych wydarzeń (zob. także Włodarek i Ziółkowski 1990).

5 Tosh 1991 (wznowienie 2006). W niniejszej publikacji pomijam kwestię wyjaśnienia przyczyn tego zainteresowania. 
wcześniej twórcy polskiej szkoły historii gospodarczej Franciszka Bujaka oraz Floriana Znanieckiego. Przy czym, co warto przypomnieć, obydwaj uczeni wykorzystywali historię oralną do zgłębiania problematyki, która z powodzeniem dziś zmieściłaby się $\mathrm{w}$ tematyce zarządzania ${ }^{6}$. O znanych powszechnie pracach Znanieckiego wspominałem już wcześniej (zob. paragraf 3.1. „Geneza historii organizacyjnej i jej rozwój”). W tym miejscu warto przypomnieć, iż dla Bujaka (1976) monografie miejscowości, choć intencjonalnie skupione tylko na teraźniejszości, były ważnym krokiem ku rozwijanej później przez niego historii gospodarczej. Cytowany polski klasyk tej dziedziny dziejopisarstwa, gdy we wczesnym okresie swej pracy naukowej (chodzi o przełom XIX i XX wieku) przygotowywał wspomniane monografie gospodarczo-społeczne, to cenił rozmowy z mieszkańcami analizowanych miejscowości na równi z materiałem dokumentacyjnym. Zauważył przy tej okazji wartość dialogicznych form zbierania relacji ustnych: „Wnet jednak przekonałem się, że lepiej jest prowadzić protokół zeznań osób przesłuchiwanych po kilka razem. Taki zbiorowy wywiad okazał się ściślejszy i szybciej prowadzący do celu; co jeden powiedział, to inni uzupełniali lub prostowali; w razie sprzeczności parę pytań wskazywało mi, za którym zdaniem pójść należy” (Bujak 1976: 319, przedruk tekstu z 1927 r.). Wyraźnie Bujak zidentyfikował też znaczenie osobistego zaangażowania informatorów w proces zbierania wywiadów do celów naukowych, wskazując przy tym pośrednio na empatyczny charakter i wręcz interwencyjne funkcje monografii wykorzystujących informacje mówione. Rozmówców traktował on jako osoby bardziej kompetentne w swoich sprawach niż badacz, a więc, używając terminologii współczesnej etnografii, jako „informatorów kluczowych”. „Oczywiście taktowne obejście tak ze starszymi, jak z młodzieżą, tak z Żydami, jak i z chrześcijanami dopomagało mi bardzo. Odkryłem przy tym, że bardzo pożyteczne jest budzenie zainteresowania rozmówców dla ich własnych spraw celem pouczenia mnie, nieświadomego, albo częściowo nieświadomego, ale współczującego z nimi i pragnącego dopomóc w ich biedzie" (Bujak 1976: 322). Warto podkreślić, iż cytowane opinie pochodzą z autorefleksyjnego tekstu Bujaka pod tytułem Drogi mojego rozwoju naukowego. Jak pisałem już w części niniejszej pracy poświęconej historii organizacyjnej, trudno oprzeć się wrażeniu kontynuacji „polskiej” tradycji korzystania z relacji ustnych, oczywiście w nowym kontekście metodologicznym, przez prace Śliwy $(2011,2013)$, dotyczące historii mówionej „na usługach” zarządzania. Nie wiem, czy cytowana autorka zetknęła się z publikacjami Bujaka. Nie wydaje się to być najistotniejsze. Na uwagę zasługuje fakt, iż jej obydwa teksty na łamach „Management and Organizational History”, a szczególnie drugi pod tytułem Uczyć się stuchania: refleksje badacza organizacji

6 Na te tradycje historii mówionej w polskiej historiografii zwrócił mi uwagę Andrzej Wierzbicki podczas wspomnianej już dyskusji w Pracowni Dziejów Myśli Społecznej i Politycznej IH PAN, marzec 2008. 
na temat stosowania historii mówionej, ma oczywisty charakter autorefleksyjny. Przy czym jest to autorefleksyjność, która przeszła doświadczenie postmodernizmu i różnorodnych współczesnych dyskusji metodologicznych. Chodzi więc o autorefleksyjność świadomą samej siebie ${ }^{7}$, a nawet traktowaną jako podstawowy wymóg etyczny uprawiania historii mówionej. U podstaw takiego ujęcia omawianej problematyki leży przekonanie, które Śliwa wydaje się podzielać z Gluckiem i Patai'em, iż „oddziaływanie badacza w toku procesu badawczego jest kluczowym elementem etyki badań" (Śliwa 2013: 188). Cytowana autorka proponuje też strukturyzację autorefleksji osoby zbierającej relacje mówione według następujących dwóch wątków:

- uczenie się, czego badacz nie chciał słyszeć i dlaczego tego nie chciał słyszeć,

- refleksja nad tym, czego badacz słuchał (czego tak naprawdę dotyczyły jego rozmowy z respondentami).

Jako kategorię podstawową dla autorefleksji badacza, uprzednią wobec przytoczonych, można powiedzieć „technicznych” kwestii, Śliwa (2013) proponuje spojrzenie na wywiad służący historii mówionej jako sytuację wymiany, która dotyka poziomu intymności obydwu uczestników procesu badawczego Chodzi o zachowanie zasady wzajemności oraz „podziału autorytetu”. Zarówno badacz, jak i jego rozmówca mają prawo do „słuchania i opowiadania” sobie wzajemnie historii każdego z nich. Dla badacza pojawia się w tym kontekście również kwestia „perspektywizmu”, by wrócić do zapomnianej nieco kategorii sformułowanej niegdyś przez Williama McKinleya Runyana (1985). Prowadzący wywiad ma bowiem okazję, co podkreśla Śliwa (2013), nie używając terminu „perspektywizm”, do podjęcia refleksji nad tym, jak różne historie własnego życia on sam opowiada w zależności od słuchacza. Podobne założenie o głębokości i zarazem selektywności pamięci i poczucia ,ja” powinien on przyjąć, gdy słucha historii swego rozmówcy. Najwyraźniej więc historia mówiona wpisuje kapitał kulturowy organizacji oparty na triadzie „podmiotowość - relacyjność - zakorzenienie" do swej metodologii.

Cytowane postulaty etyczne, a zarazem metodologiczne dotyczące autorefleksji w procesie zbierania wypowiedzi ustnych, ośmielają do przywołania jeszcze jednej analogii między doświadczeniem Bujaka i współczesnych badaczy. Dobrze zrealizowany program historii mówionej powinien prowadzić do konkluzji, którą nestor historii gospodarczej w Polsce podsumował w jednym ze swych wczesnych przedsięwzięć naukowych: „W czasie tej pracy dokonał się we mnie zestrój moralny: dojrzałem jako uczony i jako obywatel” (Bujak 1976: 120).

$\overline{7}$ Tekst Śliwy oparty jest na jej dzienniku prowadzonym podczas badań. 


\subsubsection{Rozmowy Jana Górskiego z kierownictwem odbudowy Warszawy i ich implikacje dla zarządzania ludźmi w organizacji}

W tym paragrafie zilustruję użyteczność omawianej perspektywy badawczej dla historycznego zwrotu w naukach o organizacji za pomocą przykładu mniej znanego niż publikacje przywołanych wcześniej luminarzy polskiej humanistyki, ale zarazem znacznie głębiej niż one zakorzenionego w zagadnieniach organizacyjnych. Chodzi o badania Jana Górskiego, warszawskiego historyka, socjologa i publicysty, który szeroko sięgał do doświadczeń świadków i uczestników historii przy pracy nad syntezą dziejów stolicy pierwszych lat po II wojnie światowej8. Wspomniany autor zapraszał kierownictwo odbudowy Warszawy, architektów i urbanistów oraz inne osoby odpowiedzialne za omawiane przedsięwzięcie, zarówno do dyskusji w Pracowni Dziejów Warszawy IH PAN (o której pisałem wcześniej), jak i do współtworzenia seryjnego wydawnictwa „Studia Warszawskie", którego zeszyty poświęcone czasom PRL-u wówczas redagował. Swoich rozmówców prosił także o opinię na temat pisanych przez siebie tekstów. Wśród osób zapraszanych przez Górskiego byli zarówno przedstawiciele ówczesnej nomenklatury komunistycznej, jak i osoby prezentujące postawę bardziej lub mniej niezależną wobec władz państwowych, by wymienić choćby (w gronie tych drugich) Stanisława Jankowskiego, słynnego „cichociemnego” o pseudonimie „Agaton” z czasów okupacji hitlerowskiej, po II wojnie architekta Biura Odbudowy Stolicy, czy Stanisława Szwalbego, działacza spółdzielczego o orientacji PPS-owskiej (Szwankowska 2002, Ochinowski 2009b).

Zdaniem Hanny Szwankowskiej (2002) varsavianistki przez wiele lat wspó1tworzącej wspomnianą Pracownię Dziejów Warszawy IH PAN, można wręcz mówić o warsztacie badawczym dotyczącym dziejów stolicy po 1944 roku, który Górski zaczął organizować w wymienionej jednostce. Jednym $\mathrm{z}$ ważnych elementów tego warsztatu były właśnie dyskusje z zaproszonymi gośćmi. „Nad koncepcjami tych opracowań (na temat dziejów Warszawy powojennej - uwaga T.O.), później ich roboczymi fragmentami, toczyły się na piątkowych zebraniach Pracowni w Instytucie (Pracowni Dziejów Warszawy IH PAN - uwaga T.O) twórcze i bardzo ożywione dyskusje. Przychodzili architekci - projektanci Warszawy »nowej« $\mathrm{i} »$ zabytkowej«, kierownicy $\mathrm{i}$ organizatorzy odbudowy Warszawy, odbudowy w szerokim znaczeniu tego słowa, prezydenci i ci, co z trudem dźwigali jej kulturę" (Szwankowska 2002: 108).

Już prawdopodobnie w pierwszym referacie, związanym $\mathrm{z}$ planowaną monografią, to jest $\mathrm{w}$ wystąpieniu na dorocznym spotkaniu varsavianistów

8 Górski nie używał terminu „historia mówiona”, choć jego rozmowy z przedstawicielami kierownictwa odbudowy Warszawy po 1945 wyraźnie należą do jej obszaru badań. 
(Radziejowice $1968^{9}$ ) Górski przywołał dokument z zakresu historii mówionej, a mianowicie prelekcję Mariana Spychalskiego z okazji dwudziestolecia wyzwolenia Warszawy ${ }^{10}$. Koncepcja drugiego zeszytu „Warszawy Stolicy Polski Ludowej”, który stanowił XIV tom Studiów Warszawskich, zawierającego opracowania, materiały i przyczynki do planowanej syntezy historii stolicy, została przed publikacją poddana dyskusji, w której uczestniczyli także przedstawiciele kierownictwa odbudowy, formułujący szereg uwag faktograficznych i źródłowych oraz oceniających materiały. Z metodologicznego punktu widzenia, szczególnie interesujące wydaje się przypomnienie opinii Romana Piotrowskiego, byłego szefa Biura Odbudowy Stolicy, który „podkreślał konfliktowość procesu odbudowy", co pomimo używania przez cytowanego przedstawiciela ówczesnej nomenklatury charakterystycznej „nowomowy”, miało wydźwięk „nieprawomyślny”, jeśli pamiętać o obowiązującym do końca PRL-u lirycznym obrazie ${ }^{11}$ dźwigania stolicy z ruin ${ }^{12}$. „Odbudowę Warszawy - mówił Piotrowski - trzeba widzieć jako proces konfliktowy, przebiegający w okresie rewolucji socjalnej, proces, w którym występowały poglądy rewolucyjne i zachowawcze" (cyt. za Górskim 1972: 14). Świadkowie historii okazali się więc też stroną w jej interpretacji. Streszczenie wspomnianej dyskusji Górski zamieścił we „Wstępie” do omawianego tomu ${ }^{13}$. W ten sposób zdawał się sugerować również historiograficzne znaczenie historii mówionej, wyraźnie znaczące także w kontekście zarządzania ludźmi w organizacji.

9 Właśnie w 1968 roku Jan Górski został przyjęty do IH PAN z zadaniem napisania syntezy dziejów odbudowy stolicy jako kolejnego tomu historii Warszawy. Wcześniej pracował on w redakcji „Życia Warszawy”. Odszedł z dziennika wraz z innymi kolegami na znak protestu „przeciw bredniom i nieprawości” (wg opinii Stefana Bratkowskiego, cyt. za Szwankowską, 2002: 107-111, cyt. ze s. 108). Zmieniona wersja referatu Górskiego z Radziejowic została opublikowana pt. Warszawa wspótczesna w perspektywie historycznej, jako rozdział zbioru prac Górskiego (1973b).

10 Chodzi oczywiście o wkroczenie wojsk radzieckich i LWP do opuszczonej przez hitlerowców Warszawy 17 stycznia 1945 r. Streszczenie wystąpienia Spychalskiego zostało opublikowane na łamach „Kwartalnika Historycznego”: tekst niepodpisany, Marszatek M. Spychalski w TMH, z. 3, 1965, s. 757, a następnie w wersji znacznie rozszerzonej i przejrzanej przez prelegenta: Problemy wyzwolenia $i$ odbudowy Warszawy. Spotkanie $z$ marszatkiem Marianem Spychalskim, z. 1, 1966, s. 55-68.

11 Zapożyczam tu znaną metaforę Jana Strzeleckiego.

12 Jest to tym bardziej interesujące, iż jak piszą Jerzy S. Majewski i Tomasz Markiewicz (1998: 19), „Roman Piotrowski, szef BOS-u, później w latach pięćdziesiątych minister budownictwa, członek PPR miał wyznaczoną rolę 'pasa transmisyjnego' poglądów swojej partii do liczącego ponad 1000 osób kolektywu pracowniczego. biura, którym kierował". Pamięć o pełnionej w czasie odbudowy roli „rewolucjonisty” okazała się więc dla tego działacza komunistycznego, relacjonującego po latach swoje doświadczenia, silniejsza niż obowiązująca przez te wszystkie lata oficjalna wersja bezkonfliktowej odbudowy Warszawy.

13 Spotkanie miało miejsce w Pracowni Dziejów Warszawy IH PAN, czerwiec 1970 (zob. Górski 1972). 
Ponadto na szczególne podkreślenie zasługuje fakt, iż Górski uwzględniał również dialogiczny charakter omawianego podejścia do poznawania dziejów najnowszych (nic nie stoi na przeszkodzie, by uwagę tę przenieść także na „najnowsze dzieje” firmy i jej otoczenia społecznego) W trzecim tomie Warszawy Stolicy Polski Ludowej zamieścił opracowanie pod tytułem $O$ zniszczeniach, odbudowie i przyszłości Warszawy, stanowiące zapis dyskusji zorganizowanej w lutym 1972 roku przez SARP („wespół z Komitetem Pokoju”) z udziałem osób zaangażowanych bezpośrednio po wojnie w kierowanie odbudową stolicy oraz varsavianistów. Okazała się ona wielogodzinną debatą, w znacznym stopniu złożoną z konfrontowania „na gorąco" relacji o odbudowie i rozbudowie Warszawy. Sam Górski przyjął rolę osoby doprecyzowującej przedmiot sporu oraz bronił wartości wspomnianej dyskusji jako źródła (Górski 1973a, 199014).

Autor Warszawy w latach 1944-1999 relacje, dokumenty oraz opracowania naukowe traktował jako „trzy człony jednego procesu poznania społecznego” (Górski 1981: 390). Postulował, by stosunkami między „poznaniem przez uczestnictwo" a „poznaniem naukowym” rządziła zasada wzajemnej kontroli i uzupełniania, nie zaś sprzeczności. Ponadto refleksja Górskiego nad wspomnieniami świadków dotykała także problemu ich subiektywizmu, w sposób daleki jednak od przypisywania mu wyłącznie negatywnej roli, zniekształcającej poznanie, co stosunkowo często sugerowali niektórzy spośród innych historyków (zob. Ochinowski 2008). „Spotkania z budowniczymi Warszawy wielokrotnie potwierdzały myśli, że nie ma sztywnego podziału na poznanie przez uczestnictwo i poznanie naukowe, albowiem zapis pamięci uczestników bywa niezmiernie cennym źródłem wiedzy. Niejednokrotnie jednak wynosiłem z tych spotkań wrażenie, że trudna nasza historia współczesna odbiła się na psychice i emocjonalności budowniczych tego miasta w bardzo nieprosty sposób" (Górski 1981: 179).

Niespodziewanie dla piszącego te słowa Górski (1990: 16-17), w pracy będącej ukoronowanych jego badań nad pierwszymi latami powojennej stolicy, to jest habilitacji pt. Warszawa 1944-1949. Odbudowa - być może pod wpływem krytyki15 - nieco zdystansowal się od historii mówionej: „Bardzo rzadko jednak sięgam w tej książce do spisanych przeze mnie relacji uczestników odbudowy. Rozmowy z nimi były dla mnie ważną inspiracją, konfrontowaną jednak z zapisem dokumentalnym".

Nie jest wykluczone, iż przytoczony spadek entuzjazmu varsavianisty do źródeł mówionych choćby po części wynikał z faktu, iż warunki peerelowskiej

14 Tę drugą publikację $\mathrm{w}$ porównaniu z pierwszą znamionuje znaczny spadek entuzjazmu autora do historii mówionej. W dalszej części niniejszego rozdziału nieco szerzej omawiam ten problem.

15 Górski wspomina recenzję wydawniczą Franciszka Ryszki, który zarzucił brak uzasadnienia doboru świadków. 
cenzury uniemożliwiały autorowi pełny opis konfliktowego charakteru czasów odbudowy16. Górski (1990: 17) wspomniał o tym dość oględnie: „Miałem też świadomość tego, że między uczestnikami odbudowy zachodziły kontrowersje, których na kartach tej książki nie ukrywam, ale i nie przeceniam. Obok różnic merytorycznych często występowały konflikty kompensacyjne, skoro decyzje w sprawie Warszawy były coraz bardziej scentralizowane, a wpływ różnych grup, osób i środowisk zależał w znacznym stopniu od sugerowania rozwiązań Bolesławowi Bierutowi”.

I tak historia mówiona, nawet pętana przez cenzurę (co niewątpliwie wpłynęło także na dobór rozmówców przez Górskiego i wypowiadane w toku dyskusji sądy) zakłóciła sielankowy czy raczej właśnie liryczny obraz odbudowy Warszawy obowiązujący w oficjalnej historiografii PRL-u' ${ }^{17}$ (Ochinowski 2009b).

Trudno nie wskazać analogii do ustaleń cytowanego już wcześniej Kundy (1992) o represyjnym i ideologicznym charakterze budowania „silnej kultury organizacyjnej" w niektórych współczesnych firmach. Demistyfikacyjna potencjalnie rola historii organizacyjnej posługującej się historią mówioną wydaje się w tym kontekście niepodlegająca dyskusji. Chodzi przecież o szansę przeniesienia kapitału kulturowego opartego na triadzie „podmiotowość - relacyjność - zakorzenienie" z poziomu korporacyjnej retoryki (a więc traktowania wspomnianej triady jako narzędzia kontroli) na poziom rzeczywistych relacji międzyludzkich $\mathrm{w}$ firmie, tam gdzie taka sytuacja ma miejsce. W aspekcie koncepcji zarządzania pomocne może być tu na przykład „konfliktowe” ujęcie kultury organizacyjnej zaproponowane przez Yousafa (2011) o czym pisałem wcześniej (zob. par. 1.3. niniejszej pracy).

Historiografia choćby tylko dotycząca tak szczegółowego tematu, jak ten podjęty przez Górskiego, może przez analogię, uwrażliwić menedżerów i badaczy organizacji na głębokość oporu, jaki czeka próba wspomnianej demistyfikacji nie tylko w samej firmie, ale także na poziomie ideologii czy wręcz niektórych wersji nauk o zarządzaniu. Warto bowiem zasygnalizować, iż pogłębioną analizę konfliktowego charakteru odbudowy stolicy podjęli historycy dopiero na przełomie wieków, a temat nadal daleki jest od pełnego opracowania. Przy czym najważniejsze (jeśli nie jedyne książkowe) publikacje na ten temat Jerzego S. Majewskiego i Tomasza Markiewicza Warszawa nie odbudowana (1998); Jerzego Kochanowskiego, Piotra Majewskiego, Konrada Rokickiego i Tomasza Markiewicza, Zbudować Warszawe piękna... (2003) oraz Jerzego Kochanowskiego (red.), W połowie drogi. Warszawa między Paryżem a Kijowem (2006) - opierają się przede wszystkim (co zrozumiałe w związku z nieubłaga-

16 Por. opinia Szwankowskiej (2002).

17 Praca habilitacyjna Górskiego „przeleżała” w wydawnictwie aż do 1990 roku i ukazała się dwa lata po śmierci autora. 
nym upływem czasu) na archiwaliach i wprawdzie obficie oddają głos świadkom epoki, ale tylko głos zapisany w dokumentach.

Nadal też zdarzają się prace, raczej popularnonaukowe niż sensu stricto badawcze, kontynuujące liryczną wersję opowieści o odbudowie stolicy. Jako przykład podać można album autorstwa Marka Kwiatkowskiego „Warszawa - z ruin do życia" (Warszawa 2007), który sprowokował następującą refleksję recenzenta tygodnika „Stolica”: „Przeglądając album, można ulec kojącemu serce złudzeniu, że przedwojenna Warszawa rzeczywiście trwale odrodziła się, a komunizmu nigdy nie było..." (J.Z. 2008: 54).

To samo, per analogiam do zarządzania zasobami ludzkimi znaleźć można w niektórych pracach lub wypowiedziach autorytetów z tej dziedziny, gloryfikujących kontrolę i „ślepe zaangażowanie” (zob. np. dziś już klasyczne krytyki tych tendencji w pracach Micklethwaita i Wooldridge'a 2000 oraz Haigha 2004).

Zresztą metodologiczną przestrzeń do współpracy historii i zarządzania, szczególnie zarządzania ludźmi w kontekście kapitału kulturowego organizacji (choć cytowany autor nie używał tych terminów), naszkicował również Górski (1964) poprzez sformułowany w pierwszej połowie lat 60. publicystyczny postulat, by rozwijać „historię ludzką”, to jest taką, która powinna ujmować dramat jednostek i społeczeństw wyrażający się poprzez ich dokonania, rozczarowania, nadzieje, spełnienia. Zdaniem cytowanego badacza czasy najnowsze cechuje zasadnicza sprzeczność między optymistycznym dążeniem pojedynczych osób oraz mas ludzkich do politycznej aktywności, rozwoju demokracji i celów temu podobnych, a rozczarowaniem, które dotyka człowieka w zetknięciu z bezduszną rzeczywistością różnorodnych struktur czy procesów dziejowych, przywołujących myśl o determinizmie. Właśnie uchwycenie tej sprzeczności poprzez badania stanowić ma istotę „historii ludzkiej”.

Górski wyraźnie podkreślał, iż nie chodzi tu o problem zmiany źródeł, lecz pytań stawianych źródłom. Niemniej jednak autor Historii powszechnej i osobistej znacznie rozszerzał, w porównaniu z tradycyjną historiografią, zakres materiałów dostarczających danych badaczowi przeszłości. Na przykład praca Pamięć warszawskiej odbudowy. Antologia, związana przecież z szeroko rozumianą problematyką zarządzania, stanowiąca autorski przykład realizacji projektu „historii ludzkiej”, zawierała bardzo zróżnicowany zestaw tekstów, między innymi analizy socjologiczne oraz literaturę piękną (Górski 1972). Trudno nie zauważyć tu analogii do aktualnych nurtów w zarządzaniu, a szczególnie w jego odmianie krytycznej (por. Kostera i Śliwa 2012).

Bez obaw o nadinterpretację można znaleźć w omawianym zarysie koncepcji także potencjalne miejsce dla problemów z zakresu zarządzania, choć jak już pisałem, autor nie wymieniał ich wprost. Górski był bowiem zdecydowanym przeciwnikiem zbyt daleko posuniętej specjalizacji dyscyplin humanistycznych. Uważał, iż prowadzi ona do zaniku funkcji zespalającej różne dziedziny wie- 
dzy, którą to funkcję przypisywał właśnie kulturowym naukom o człowieku. Przesadnemu rozdrobnieniu „społeczeństwa specjalistów” cytowany autor próbował zaradzić poprzez rozwój kultury historycznej, stanowiącej według niego podstawę szeroko rozumianej humanistyki. Celowi temu służyła zorganizowana właśnie przez Jana Górskiego oraz Janinę Leskiewiczową i Janusza Sztetyłłę sekcja Kultury Historycznej Towarzystwa Miłośników Historii. W ciągu kilkuletniej bardzo aktywnej działalności sekcji (1985-1989), przerwanej śmiercią głównego inspiratora, odbyło się szereg spotkań dyskusyjnych gromadzących przedstawicieli różnych dziedzin. Interesujące byłoby sprawdzić, czy pośród zabierających głos na tym forum historyków, badaczy literatury, teatrologów, socjologów czy publicystów nie zabrakło osób mniej lub bardziej bezpośrednio związanych z zarządzaniem. Byli nimi przecież też zapraszani do Instytutu Historii przedstawiciele kierownictwa odbudowy stolicy.

Wracając do historii mówionej, dotyczącej sporów o sposób odbudowy stolicy, to przynajmniej w jednym aspekcie nadal jest historią żywą, rozwijaną według modelu antropologicznego niemal w stanie czystym. Chodzi o działalność Stowarzyszenia Osób Objętych Dekretem Warszawskim „Dekretowiec”. Członkowie stowarzyszenia między innymi zbierają relacje oraz organizują konferencje prasowe, których celem jest przebicie się do opinii publicznej z problemem trwających do dziś skutków dekretu Bolesława Bieruta sprzed ponad $60 \mathrm{lat}^{18}$. Osobiste wspomnienia wykorzystywane przy tego typu wysiłkach jako merytoryczna podstawa argumentacji stanowią interesujący i warty dalszych badań przykład historii mówionej w jej funkcji normatywnej, przypominającej społeczeństwu o odpowiedzialności za przeszłość, o czym pisał wspominany we wcześniejszych rozdziałach Pool (2008, zob. np. Grabiński 2008).

Pokazują też, razem z omówionymi wcześniej badaniami Górskiego, w jaki sposób sięganie do relacji świadków służyć może dekonstrukcyjnym, a zarazem sensotwórczym funkcjom historycznych analiz dla potrzeb współczesnego zarządzania. Autor Warszawy w latach 1944-1949... tę sensotwórczą funkcję organizowania starał się najwyraźniej ujawnić poprzez tropienie mitów, które uważał za zawierający w sobie dużą siłę element rzeczywistości zarówno z dawnych lat jak i obecnej. Zdaniem cytowanej już Szwankowskiej (2002) Górski identyfikował mit czasów odbudowy Warszawy poprzez źródła publicystyczne i literackie (por. Górski 1972a), zaś mitu stolicy mu współczesnej poszukiwał za pomocą analizy ankiety prasowej, którą na przełomie lat 1968/1969 opublikowało „Życie Warszawy”19 (por. Górski 1972b). Stanowiła ona główną część interdyscyplinarnych

18 Chodzi o dekret z 1945 roku odbierający grunty na terenie stolicy prywatnym właścicielom. Zob. stronę prowadzoną przez wspomniane stowarzyszenie. Dostępna w: www. dekretowiec.pl [ 16.06.2008].

19 Analogiczną ankietę opublikowano też na łamach „Trybuny Robotniczej”, by zebrać opinie mieszkańców Śląska i Zagłębia o Warszawie. 
badań zrealizowanych wspólnie przez Instytut Histori PAN, Instytut Socjologii UW oraz redakcję „Życia Warszawy” i Towarzystwo Miłośników Warszawy (Nowakowski i in. 1972). Wypowiedzi niemal 1400 respondentów spośród mieszkańców stolicy skłoniły Górskiego do wskazania takich rdzennych elementów mitu warszawiaka końca lat. 60. ubiegłego stulecia, jak patriotyzm lokalny budowany przede wszystkim na doświadczeniach wojennych oraz dość niska samoocena wynikająca z obserwacji współczesności (Górski 1972b, Ochinowski 2009b).

Jak więc widać, tropienie konfliktowych rys na obrazie organizacji (historycznej lub współczesnej), co umożliwia przede wszystkim historia mówiona, nie kłóci się z poszukiwaniem mitów (czemu również może służyć historia mówiona). W pracach Górskiego było to raczej przeciwstawianie mitowi propagandowemu mitów społecznych, choć też przecież identyfikowanych w warunkach cenzury. A ten drugi rodzaj mitu też zawierać może (prawdopodobnie zazwyczaj zawiera) treści wzajemnie wobec siebie konfliktowe, jak chociażby przytoczona wcześniej duma z przeszłości i krytyka wobec siebie współczesnego wyrażona przez respondentów o ankiety badającej obraz warszawiaka sprzed pół wieku.

Na zakończenie warto zwrócić uwagę na jeszcze jeden aspekt metodologiczny analizowanych prac Górskiego. Otóż właśnie funkcje dekonstrukcyjne uprawianej przez niego historii mówionej (dekonstrukcyjne wobec „wielkich narracji” ówczesnej oficjalnej historiografii), były realizowane, pomimo iż grono rozmówców warszawskiego badacza stanowili „ludzie władzy organizacyjnej, członkowie kierownictwa odbudowy stolicy”. Nie jest to częsty wypadek w stosowaniu historii mówionej. Jak przypomnieli ostatnio Sjoerd Keulen i Ronald Kroeze (2012), demokratyczny charakter tej perspektywy badawczej sprawia, iż liderzy organizacji niechętnie są zapraszani przez badaczy do udzielania wywiadów (także dla potrzeb zarządzania). Szefostwo ma przecież wiele innych okazji, by się wypowiedzieć. Takie ujęcie sprawy zubaża jednak możliwości historii mówionej. „Dopuszczenie do głosu” liderów organizacji przynosi bowiem przynajmniej cztery korzyści, nie tylko poznawcze:

1. wypowiedzi przedstawicieli kierownictwa często mają znaczenie archiwalne, dają okazję zapisu informacji, którym inaczej groziłoby unicestwienie;

2. pozwalają na naukowe wykorzystanie historii mówionej do badania przywództwa;

3. właśnie demokratyzm historii mówionej wymaga „dopuszczenia do głosu” także liderów; inaczej mogą czuć się wykluczeni z opisu historii firmy, poczuć, iż ważna część ich życia została zagubiona, co grozi wręcz przeżyciem traumatycznym;

4. historia mówiona często ma znaczenie terapeutyczne, którego waga w przypadku liderów nie podlega dyskusji (por. Keulen i Koreze 2012).

Następny podrozdział niniejszej pracy opiera się na historii mówionej, która powstała w wyniku trzyletnich rozmów autora niniejszej pracy ze wspomnia- 
nym już wielokrotnie Kordianem Tarasiewiczem, byłym dyrektorem średniego przedsiębiorstwa, a zarazem osoby będącej przez kilkadziesiąt lat jednym z liderów swojej branży. Wykorzystanie relacji wspomnianej osoby do analizy tradycji przedsiębiorczości w naszym kraju jako nośnika kapitału kulturowego dla współczesnych organizacji ma szczególne uzasadnienie. Kordian Tarasiewicz jest najstarszym polskim przedsiębiorcą. Obecnie (2013 r.) ukończył 103 lata. Nadal pozostaje czynnym refleksyjnym praktykiem (jego prace dotyczące historii przedsiębiorczości poddałem historiograficznej analizie $\mathrm{w}$ paragrafie 1.6, w rozdziale I). Udziela porad biznesowych oraz wypowiedzi dla historyków, badaczy zarządzania, studentów i dziennikarzy. Aktualnie jest inicjatorem powołania organizacji zrzeszającej potomków warszawskich przemysłowców, kupców i rzemieślników, nastawionej przede wszystkim na wspieranie młodych przedsiębiorców.

\subsection{Dobre praktyki zarządzania $w$ branży zdominowanej przez małe i średnie przedsiębiorstwa na przykładzie doświadczeń Palarni Kawy „Pluton” (1882-1950)}

\subsubsection{Wstępna charakterystyka firmy „Pluton”}

W niniejszym rozdziale proponuję spojrzeć przez pryzmat problematyki kapitału kulturowego na wybrane doświadczenia menedżerskie „Burżua oświeconych" - mieszczańskiego środowiska, które funkcjonowało na terenie Warszawy pod koniec XIX wieku. Byli to głównie mali i średni przedsiębiorcy (biorąc pod uwagę obecne kryteria wielkości firm). Charakteryzowali się tym, iż „zarówno $\mathrm{w}$ filantropii, w mecenacie, jak $\boldsymbol{i} w$ sposobach uktadania stosunków z robotnikami (podkreślenie T.O.) manifestowali postawy nowe"20. Ireneusz Ihnatowicz (1971: 164) jako reprezentantów tej właśnie grupy „Ludzi interesu” wymienił rodzinę Tarasiewiczów, właścicieli Palarni Kawy „Pluton” (1882-1950).

Była to firma średniej wielkości o zasięgu ogólnopolskim²1, zajmująca się przygotowaniem i sprzedażą palonej kawy oraz jej surogatów ${ }^{22}$. W jej skład wchodziła (oprócz obsługi administracyjnej) palarnia kawy, sklepy, których w szczytowym okresie rozwoju firmy (lata międzywojenne) było 28 , a także grupa przedstawicieli handlowych, rozbudowana po 1934 roku, gdy dyrektorem

20 W porównaniu z liderami warszawskiego biznesu poprzedniej generacji.

21 Przed I wojną światową firma działała na obszarze zaboru rosyjskiego. Miała też sklep w Kijowie (od 1911 r.).

22 W ciągu swej historii „Pluton” okresowo zajmował się też innym asortymentem (z małymi wyjątkami spożywczym), ale zawsze służyło to wyłącznie wzmocnieniu głównego nurtu działalności biznesowej lub - w sytuacjach ostrych kryzysów - było jej substytutami. 
został właśnie Kordian Tarasiewicz. W 1924 roku omawiana firma wchłonęła swego głównego krajowego konkurenta, przedsiębiorstwo „Kawa 'Molinari”” Wiktora Matyjewicza (zmarłego w 1917 roku).

Na początku XX wieku „Pluton” zatrudniał 62 pracowników. W okresie międzywojennym liczba zatrudnionych wzrosła do ok. 100, by podwoić się podczas okupacji hitlerowskiej. Dokładna liczba pracujących dla „Plutona” czasów II wojny światowej jest trudna do ustalenia. Oficjalna lista płac z tego okresu obejmuje ok. 250 osób, ale część stanowili przedstawiciele świata kultury i inne postacie znaczące społecznie. Ich fikcyjne zatrudnienie było formą pomocy udzielanej przez „Pluton”.

Również podczas okupacji hitlerowskiej „Pluton” prowadził własną kawiarnię „Fregata” (przez okres 2-3 lat od 1940 roku, Strzeżek 2012). Wcześniej współpracował z restauracjami i kawiarniami, dostarczając swoje produkty.

Powstanie Warszawskie przerwało działalność firmy, stopniowo jednak wznawianą w miarę zbliżającego się końca wojny.

Już od końca 1945 roku powtórnie funkcjonowała palarnia. W okresie powojennym liczba zatrudnionych nie przekroczyła 35 (dane dotyczące 1947 roku, najlepszego dla „Plutona” na tym etapie funkcjonowania firmy), by ostatecznie spaść do 21 (pod koniec 1949 r.).

Omawiane przedsiębiorstwo okresowo ściśle współpracowało z zagranicznymi firmami tej branży, takimi jak niemiecka „Kawa Hag” (1908-1914 jako wyłączne przedstawicielstwo, a w okresie międzywojennym na zmienionych zasadach) oraz belgijska „Cafesa” S.A. (przez pewien czas od 1932 roku). Firma była w okresie międzywojennym wyraźnym liderem środowisk branżowych w Polsce. Podczas wojny „Pluton” wszedł w spółkę z fabryką marmolady „Płudy”, co przyniosło znaczącą modernizację tej drugiej wytwórni oraz przyczyniło się do rozwoju upraw warzyw i owoców na terenach dzisiejszej Białołęki. Ścisła współpraca została też nawiązania z Towarzystwem Przemysłowym „Lawina” (produkcja słodyczy), a po Powstaniu Warszawskim uruchomiono oddział „Płud” w Radoniach k. Grodziska Mazowieckiego. W poszukiwaniu sposobów przetrwania po 1945 roku „Pluton” realizował też biznesowe relacje z różnymi przedsiębiorstwami, takimi jak np. z fabryka soków owocowych A. Matuszewskiego w Płocku. Zawsze jednak dla właścicieli „Plutona” najważniejszym asortymentem pozostawała kawa.

Tuż przed szczytowym okresem rozwoju branżowego firmy (dane z 1934 roku) przedsiębiorstwo miało udział w ponad $10 \%$ rynku polskiego rynku kawowego i w 25\% warszawskiego. Udział ten sukcesywnie wzrastał. Wybuch wojny udaremnił dokładne określenie ile wynosił ostatecznie. Doświadczenie „Plutona” ze szczególnym uwzględnieniem dobrych praktyk wypracowanych w „przestrzeni” firmy wyznacza główną treść niniejszego podrozdziału. Przewodnikiem po tym terytorium będzie Kordian Tarasiewicz, co warto przypomnieć, wnuk założyciela, 
syn kolejnego właściciela i ostatni dyrektor „Plutona” (w latach 1934-1950)23. W drugiej części tej pracy pisałem o nim jako o historyku przedsiębiorczości (zob. par. 2.6). Zdaję sobie sprawę, iż działalność pojedynczej firmy staje się wyraźna jedynie na tle konkurencji i innych relacji biznesowych. Jednak również do problematyki niniejszego rozdziału odnieść można cytowaną wcześniej opinię Barbasiewicz (2013), iż historykowi polskiej przedsiębiorczości (i to nie tylko okresu międzywojennego, jak pisze przywołana autorka) potrzebny jest zmysł detektywistyczny. Na obecnym etapie badań wspomniane tło jestem w stanie jedynie zasygnalizować na przykładzie wybranych przypadków, dalekich zresztą od kompletnego i bezbłędnego opracowania (więcej danych zob. w przypisach do: Tarasiewicz 2013b) ${ }^{24}$.

\subsubsection{Specyfika branży herbaciano-kawowej w Polsce (połowa XIX w. - połowa XX w.)}

Firma „Pluton” należała do branży herbaciano-kawowej. W kapitalistycznej formie branża ta rozwijała się na ziemiach polskich mniej więcej od lat 30 .

23 Podwaliny niniejszego rozdziału stanowią rozmowy, które prowadzę z Kordianem Tarasiewiczem od czerwca 2010 roku (od dwóch lat przybrały one formę regularnych, cotygodniowych spotkań) uzupełnione dokumentami z archiwum domowego tegoż i z Archiwum Miasta Warszawy oraz publikacjami naukowymi, popularyzatorskimi i wspomnieniowymi: Tarasiewicza (1971, 2009 i 2011), Drozdowskiego i Tarasiewicza (1964), Ihnatowicza (1971), Budrewicza (1990), Steinborna (1979), Poznańskiej (1993), Machlejda (2010) i Stopy (2010). Ważnym źródłem informacji jest także strona internetowa Kordiana Tarasiewicza www. tarasiewicz.info. Wyniki wspomnianych rozmów z lat 2010-2013 zostały opublikowane przez Wydawnictwo Naukowe PWN w książce K. Tarasiewicza Zapach świeżej kawy, Warszawa 2013, pod moją redakcją naukową. Stanowi ona publikację źródła z zakresu historii mówionej, na podstawie którego powstał, jako kolejny poziom interpretacji doświadczenia z przeszłości, niniejszy podrozdział. W zbieraniu relacji Kordiana Tarasiewicza i naukowej redakcji wspomnianej książki współpracowała ze mną Agnieszka Kseba. Wcześniej spory udział w dokumentowaniu wspomnień byłego dyrektora Palarni „Pluton” miały Joanna Zdanowska i Monika Strocka.

O nadal początkowym etapie poznawania dziejów polskiej przedsiębiorczości świadczyć może choćby fakt, iż niektóre szczegółowe informacje tam zawarte już po kilku miesiącach od wydania omawianej publikacji wymagają uzupełnień lub korekt. Na przykład w przypisie 44 podałem, że inż. Jan Arnold pełnił funkcję zastępca członka Zrzeszenia Importerów Kawy i Herbaty. Sprawozdanie... tej organizacji na rok 1937 wymienia go wśród władz, ale jako członka Komisji Rewizyjnej.

Wspomniane niedoskonałości nie obciążają oczywiście osób, które przyczyniły się do zebrania danych na temat tradycji firm branży herbaciano-kawowej w Polsce dla potrzeb zarówno Zapachu świeżej kawy, jak i niniejszej pracy. Byli to uczestnicy moich wykładów ogólnouniwersyteckich i monograficznych w roku akademickim 2012/2013 dotyczących historii biznesu: Joanna Kowalczyk, Michał Śliwiński, Małgorzata Kasińska, Mateusz Michalski, Wiktora Jasinowski, Jakub Kopczyński, Paweł Murtynowski, Michał Pluta i Aleksander Awdziejczyk. W tej samej kwestii zechcieli też pomóc inni studenci UW: Marta Czapnik, Krzysztof Mańkowski i Wojciech Różycki. Wszystkim tym osobom serdecznie dziękuję. 
połowy XIX wieku, gdy rozpoczął się proces przenikania rosyjskiego handlu herbatą do Królestwa Kongresowego. Szczyt osiągnęła w okresie międzywojennym, w połowie XX wieku przeżywając dramatyczną przerwę tradycji większości przedsiębiorstw spowodowaną stalinowską ,walką o handel”. Przy czym segment kawowy rozpoczął dynamiczny rozwój nieco później od herbacianego. Punktem krytycznym było powstawanie palarni kawy. Pierwszą z nich na ziemiach polskich, co warto raz jeszcze przypomnieć, była działającą od 1882 firma „Pluton”. Z kilku przynajmniej względów tradycje przedsiębiorczości sektora kawy i herbaty są szczególnie interesujące w kontekście kapitału kulturowego tworzących go organizacji biznesowych na ziemiach polskich (Loza 1939, Herbaczyńska 2007, Metter 2009, Diatłowicka 2010, Leski 2009).

Po pierwsze - wspomniana branża posiadała swój mit założycielski. Ruch kawiarniany w Europie Środkowej miał zapoczątkować Polak Franciszek Kulczycki, uczestnik wyprawy wiedeńskiej Jana III Sobieskiego. Jemu właśnie monarcha ofiarował zdobyte na Turkach zapasy kawy, prawdopodobnie jako wyraz uznania dla zasług na polu bitwy. Mając takie zasoby produktowe, Kulczycki w 1683 roku założył kawiarnię w Wiedniu. Berlin będzie czekał na swoją pierwszą kawiarnię prawie pięćdziesiąt następnych lat (do 1721 roku). Historia o założycielu pierwszej kawiarni na terenie naszej części Europy jest żywa do dzisiaj - jak się jednak wydaje, bardziej w Wiedniu i we Lwowie - z którego to miasta, lub jego okolic, według jednej z wersji miał pochodzić Kulczycki - niż w Warszawie. Dla Austriaków bohater przytaczanej historii nazywał się Georg Franz Kolschitzy, niektóre publikacje piszą też o Francisu Kotchizkim alias Kotlenskim. Był tłumaczem w armii tureckiej, który w 1683 roku znalazł się na terenie oblężonego Wiednia. Na ochotnika przedzierał się kilkakrotnie przez linie tureckie do obozu sojuszników i z powrotem, przynosząc przy tej okazji wiedeńczykom wieści będące dla nich „wielkim moralnym wsparciem” (Jezernik 2011: 188-189). W pamięci mieszkańców stolicy Austrii funkcjonuje on zazwyczaj jako Polak pochodzący z Galicji. Są jednak wersje przywoływanej opowieści, które twierdzą, iż był on Serbem czy wręcz mityczną postacią skupiającą w jednej biografii losy czterech Ormian. Również Ukraińcy widzą w nim swego rodaka o nazwisku Kolshethsko. Ostatnio wiedeński historyk Karl Teply odebrał Kolschitzkiemu rolę założycielską pierwszej kawiarni na terenie tego miasta. Przytoczona teza stanowi kolejny etap dyskusji wokół omawianej postaci, która wybuchła w latach 30. ubiegłego wieku. Niestety, najwyraźniej nie biorą w niej udziału polscy historycy. „Jednak postać właściciela kawiarni Kolschitzkiego, bez względu na fakty historyczne, na zawsze przeszła do wiedeńskiej tradycji. W drugiej połowie XIX wieku jedną z ulic, które przecinają Favoritengasse, nazwano jego imieniem - Kolschitzkygasse. W 1885 roku właściciel kawiarni na budynku stojącym przy skrzyżowaniu tych ulic na fasadzie domu ustawił rzeźbę Kolschitzkiego „(...), a sama kawiarnia z czasem została 
nazwana jego imieniem" (Jezernik 2011: 193). Warto zauważyć, iż przytaczane przez Jezernika ożywienie pamięci o Kulczyckim przypadło na okres, w którym powstawanie palarni kawy rozpoczęło nowoczesny etap rozwoju branży. Zaś w latach 30. XX wieku, gdy wiedeńczycy toczyli cytowaną wcześniej dyskusję, czyli podczas kolejnego ożywienia mitu, Kordian Tarasiewicz wypuścił na rynek polski kawę paczkowaną (co było wówczas nowością, niezwiązaną z tą dyskusją), a jeden z trzech jej gatunków - „Kawiarniana” - ozdobił wizerunkiem Franciszka Kulczyckiego.

Po drugie - branżę herbaciano-kawową na ziemiach polskich, aczkolwiek stworzoną i rozwijaną przez kupców różnych narodowości, niemal zmonopolizowały firmy krajowe. Podczas dwudziestolecia międzywojennego jedyne przedsiębiorstwo tego segmentu, będące oddziałem podmiotu zagranicznego, liczące się na naszym rynku stanowiła spółka Juliusz Meinl S.A. z siedzibą początkowo w Krakowie, później w Warszawie. Macierzysta, austriacka firma „Juliusz Meinl” działała na terenie Wiednia od 1862 roku. Wtedy pierwszy sklep w centrum tego miasta otworzył Juliusz Meinl - nazywany w historii korporacyjnej „Juliuszem Meinlem I" (1824-1914). W sklepie handlowano towarami kolonialnymi. Pierwsza palarnia kawy Meinla powstała w 1891 roku przy ulicy Neustifgasse. Dziś materiały internetowe firmy zawierają nieprawdziwą informację, że była to pierwsza palarnia kawy w Europie. Trudno jednoznacznie stwierdzić, komu rzeczywiście należy się chronologiczne pierwszeństwo, jednak trzeba zauważyć, iż opisywana austriacka palarnia powstała 9 lat później niż analogiczna warszawska inicjatywa Tarasiewiczów (w 1882 roku).

Jeszcze przed I wojną światową Meinl miał kilkaset sklepów w różnych częściach Austro-Węgier. Pod koniec XIX wieku otworzył filie detaliczne na terenie Galicji. Po odzyskaniu niepodległości przez Węgry, Czechosłowację i inne państwa Europy Środkowo-Wschodniej zorganizowano odrębne spółki, które działały jako firmy krajowe, tworzące holding. Stał się potentatem regionu Europy Środkowej. Posiadał tam około 500 sklepów. Już od czasów zaborów „Meinl” był obecny także w niektórych miastach polskich. Szczególnie intensywną ekspansję na nasz rynek rozpoczął po koniec lat 20. XX wieku. W 1934 firma posiadała w Polsce już około 20 sklepów. „Pluton” traktował ją jako swego głównym konkurenta. Jednym z pierwszych działań Kordiana Tarasiewicza po objęciu funkcji dyrektora rodzinnej palarni kawy była wizyta w wiedeńskiej centrali „Meinla”, którą odbył z przyjacielem i współpracownikiem Adamem Kamińskim (w 1934 roku).

Do przewag konkurencyjnych austriackiej firmy na polskim rynku w okresie międzywojennym należały trzy elementy: duży kapitał, szeroki asortyment oferowanych produktów oraz wyszkolenie personelu.

Kapitał „Meinla” powiększał się dzięki temu, że spółki krajowe uzyskiwały możliwość obniżenia podatków przez zadłużanie się w centrali lub zawyżanie 
cen, po których centrala sprzedawała swoje towary. Praktyki tego typu budziły zastrzeżenia polskich handlowców; „Meinl” oferował swoim klientom oprócz kawy również herbatę, kakao, olej, wino, czekoladę i wafle. Wzorując się na swym głównym konkurencie, Kordian Tarasiewicz także planował w ostatnim okresie przed 1939 rokiem poszerzyć zakres sprzedawanych towarów. Okazało się to jednak niemożliwe bez przebudowy sklepów „Plutona”. Pomysł został więc odłożony na przyszłość. Zniweczył go wybuch wojny. Jednak - paradoksalnie - przydał się podczas okupacji hitlerowskiej, gdy firma Tarasiewiczów pozbawiona szerszych możliwości produkcji i sprzedaży kawy musiała zająć się innym asortymentem.

Personel zatrudniony u „Meinla” był bardzo dobrze wyszkolony, ale oprócz wyszkolenia istotnym jego atutem były także inne innowacje w zarządzaniu zasobami ludzkimi. Austriacka firma wprowadziła na przykład wyłącznie męski personel sklepowy, co było wówczas nowością. Kordian Tarasiewicz również na zasadzie eksperymentu zaczął zatrudniać mężczyzn w sklepach. Do czasu wybuchu II wojny światowej jeden z nich zaczęli prowadzić tylko dwaj sprzedawcy.

Po Anschlussie Austrii (1938) „Meinl” stał się w rzeczywistości firmą niemiecką. Nie zaprzestał jednak rozbudowy swojej sieci. Podczas okupacji hitlerowskiej na terenie Polski sklepy tego przedsiębiorstwa otrzymały status Nür für Deutsche („tylko dla Niemców”). Sprzedawały luksusowe produkty spożywcze. W niektórych wspomnieniach wojennych ukazywane są jako jeden z symboli dostatku okupanta.

Członkowie założycielskiej rodziny Meinl do dziś współuczestniczą w działalności firmy. Obecnie przedsiębiorstwo pod nazwą „Julius Meinl Coffee” działa globalnie, na terenie 70 krajów świata. W swym asortymencie ma kawę, herbatę oraz dżemy z naturalnych, kandyzowanych owoców. Niedawno wróciła też na rynek polski. Jej przedstawiciel w 2012 roku złożył wizytę Kordianowi Tarasiewiczowi.

Inną formułę utrzymania się na polskim rynku po 1918 roku niż „Meinl” przyjęła niemiecka firma „Kaiser's Kaffee-Geschäft”, istniejąca od 1880 roku. W 1971 roku stała się ona częścią Tengelmann Group. Dziś funkcjonuje pod nazwą „Kaiser's Tengelmann”. Jej twórcą był Josef Kaiser (1862-1950), który odziedziczył po rodzicach sklep kolonialny. W okresie międzywojennym (a także wcześniej) prawdopodobnie główną siedzibą przedsiębiorstwa (lub jedną z głównych jego filii) był Gdańsk („Kaiser’s Kaffee-Geschäft” powstał w niemieckiej miejscowości Viersen). Na polskich terenach należących wówczas do II Rzeszy - Pomorza i w rejonie poznańskim - „Kaiser” miał swoje sklepy już przed I wojną światową, gdy generalnie rozbudowywał ich sieć. Odzyskanie niepodległości przez Polskę skomplikowało sytuację firmy wobec dość silnych nastrojów antyniemieckich na terenach, na których funkcjonowała ona w naszym kraju. Aby zaradzić tym trudnościom, nie chcąc zrażać polskich konsumentów 
niemiecką nazwą firmy, założona została w Gdyni spółka „Wielkopolski Skład Kawy” z Francem Baushem, ówczesnym właścicielem „Kaisera” jako członkiem zarządu. We wspomnianą inicjatywę bardzo zaangażował się Władysław Smoleń, pochodzący ze Lwowa absolwent wiedeńskiej Akademii Handlowej, posiadający tytuł doktora. W Gdyni mieszkał od 1927 roku. Rozwinął tam szeroką działalność kupiecką. Współtworzył większość przedsiębiorstw ważnych dla gdyńskiego portu. Był gorącym zwolennikiem zdynamizowania importu przez Gdynię. Proponował naśladowanie rozwiązań sprawdzonych w sąsiednim Gdańsku, takich jak tworzenie niewielu, ale silnych spółek, które zajmowałby się sprawami importu w Gdyni, przeniesienie do tego miasta z Warszawy centrów administracyjnych odpowiedzialnych za import oraz aktywizację importową Gdyńskiej Izby Przemysłowo-Handlowej.

„Wielkopolski Skład Kawy” bardzo odpowiadał wspomnianym poglądom Smolenia, które utrwalił później na kartach wydawnictwa Import towarów kolonialnych przez porty polskie (była to treść referatu zaprezentowana przez autora podczas V Naukowego Zjazdu Instytutu Bałtyckiego, który w 1939 wydrukował ten tekst). W opisywanej firmie Smoleń miał udział większościowy. Aktywnie działał też w samorządzie przedsiębiorców. Od 1937 roku był członkiem zarządu Zrzeszenia Importerów Kawy i Herbaty, do którego wrócę. Pełnił też funkcję wiceprezesa gdyńskiej Izby Przemysłowo-Handlowej (jako wiceprezes Sekcji Handlowej Izby) oraz członka Zarządu Związku Towarzystw Kupieckich na Pomorzu (być może był wiceprezesem także tej organizacji).

Podczas okupacji hitlerowskiej po wybuchu II światowej został zamordowany przez Niemców w trakcie akcji eksterminacyjnej polskiej inteligencji na Pomorzu w lasach piaśnickich koło Wejcherowa (1939/1940).

W 1939 r. firma „Kaiser’s Kaffee-Geschäft” miała ponad 1900 filii. Przed II wojną światową, wcześniej niż polskie przedsiębiorstwa branży kawowej, wprowadziła rodzaj umów „franchisingowych”. Później tą drogą poszedł „Wedel”, a za nim „Pluton”. „Kaiser” także stosował dzierżawę.

W końcowym okresie II wojny światowej kierownictwo firmy „Pluton” przewidywało, iż wobec klęski Niemiec otworzą się „możliwości gdańskie”. W maju 1945 roku, zaraz po zakończeniu działań wojennych, szefostwo firmy otrzymało wiadomość, iż zniszczeniom nie uległy palarnia herbaty po firmie „Waysyly Perloff” w Oliwie oraz palarnia kawy we Wrzeszczu, dawniej właśnie przedsiębiorstwo „Kaiser's Kaffee-Geschäft”. Kierownictwo „Plutona” podjęło decyzję, żeby oprzeć działalność przedsiębiorstwa na nieruchomościach gdańskich, bowiem budynki firmowe w Warszawie były bardzo zniszczone. By osiagnnąc ten cel wystąpiono do Ministerstwa Aprowizacji i Handlu z wnioskiem o wydzierżawienie wspomnianych poniemieckich obiektów. Już wcześniej szefostwo „Plutona” złożyło w Ministerstwie Handlu Zagranicznego notatkę „na temat roli, jaką mogą odegrać przedwojenne firmy zajmujące się han- 
dlem zagranicznym w Gdańsku, który był już polskim miastem” (Tarasiewicz 2010: 221). Skutkiem tych działań była delegacja z Ministerstwa Aprowizacji, która zaproponowała Kordianowi Tarasiewiczowi, jako dyrektorowi „Plutona”, przejęcie firm niemieckich, ale pod nadzorem Zjednoczenia Producentów Namiastek Kawy i Surogatów Cykorii we Włocławku. Pismo Ministerstwa z dnia 30 maja 1945 roku mianowało Tarasiewicza tymczasowym zarządcą obydwu wymienionych poniemieckich nieruchomości, z zastrzeżeniem, iż Zjednoczenie będzie pośrednio kierować tymi przedsiębiorstwami. Stwarzało to niejasną sytuację dla „Plutona”, jednak jego szefostwo kierowało się nadzieją, że po upływie pewnego czasu powstanie możliwość ubiegania się o wydzierżawienie lub kupno „Kaiser's Kaffee-Geschäft”. Do Wrzeszcza pojechała część kadry menedżerskiej i pracowników „Plutona”. Rozpoczęli oni żmudny proces zabezpieczenia obiektów oraz przygotowań do rozpoczęcia produkcji. Teraz jednak ani władze państwowe, ani „Zjednoczenie Producentów...” nie przejawiały żadnego zainteresowania tą działalnością, nie mówiąc już o jakiejkolwiek pomocy. Żeby zabezpieczyć pieniądze na wynagrodzenia robotników Kordian Tarasiewicz zmuszony był zaciągnąć kredyt, za który kierownictwo „Plutona” odpowiadało osobiście. Otrzymanie tego kredytu było możliwe tylko dlatego, że podczas okupacji hitlerowskiej firma udzieliła zabezpieczenia Państwowemu Bankowi Rolnemu i obecnie była winna stosunkowo niedużą sumę. Wspomniane ryzyko poszło jednak na marne, przynajmniej jeśli chodzi o Gdańsk. Wobec widocznego braku możliwości powiązania byłego „Kaisera” z „Plutonem”, przedsiębiorstwo Tarasiewicza zrezygnowało z działalności nad Bałtykiem i skupiło się na odbudowie firmy w Warszawie.

Wreszcie trzecią, najbardziej tradycyjną drogę opanowania polskiego rynku, w porównaniu ze wskazanymi wcześniej, przyjęła jeszcze jedna niemiecka firma branży kawowej: „Paul Nachtigal Kaffeerösterei-Grossbetrieb”. Funkcjonowała ona od 1897 roku na terenie Gdańska. Dysponowała tam dużą palarnią kawy. W okresie międzywojennym obejmowała ekspansją handlową między innymi Wielkopolskę. Generalnie region ten zdominowany był wówczas przez przedsiębiorstwa gdańskie omawianej branży. Pokonywały one wielkością kapitału małe firmy polskie. „Nachtigal” („Słowik”) praktycznie zalewał tamtejszy rynek kawą w opakowaniach 125-gramowych, odpowiadających wagą funtowi (co wychodziło naprzeciw przyzwyczajeniom klientów z byłego zaboru pruskiego). W dawnej Kongresówce kawę sprzedawano wyłącznie na wagę. „Pluton” kierowany przez Kordiana Tarasiewicza, chcąc zdobyć pozycję także na terenie Wielkopolski (miał tam sklep w Poznaniu), wprowadził towar opakowany o takiej samej gramaturze, jak produkty „Nachitgala”. Operacja się udała. Kupcy wielkopolscy nazwali kawę Tarasiewiczów „polskim słowikiem”, co wyrażało względne ich odwrócenie się od oferty niemieckiej. Plany wprowadzenia przez „Plutona” takich samych opakowań w całej Polsce udaremniła II wojna światowa. 
Pod koniec II wojny światowej właściciel i personel „Nachtigala” uciekli z Gdańska. Przedsiębiorstwo zostało przeniesione do Hoykenkamp w Saksonii, gdzie funkcjonowało do roku 1980.

Interesującym tematem dla badacza $\mathrm{z}$ dziedziny historii organizacyjnej są rzadsze niż przykładowo opisane wcześniej, ale jednak mające miejsce na przestrzeni międzywojnia, ekspansje handlowe w odwrotnym kierunku, z Polski na rynek niemiecki. Kordian Tarasiewicz zrelacjonował jeden taki przykład dotyczący Gdańska. Zdobywanie wspomnianego obszaru przez polskich przedsiębiorców było wspierane przez Ministerstwo Spraw Zagranicznych. Sytuację tę wykorzystał Alfred Jurzykowski, który wcześniej nie zajmował się ściśle branżą herbaciano-kawową. Miał w Warszawie dom handlowy. Założył on na terenie Gdańska firmę „A. Jurzykowski, Import - Eksport” i handlował towarami kolonialnymi. Nie wiadomo, czy przedsiębiorstwo to rzeczywiście działało, choć pisał o nim Przewodnik po Gdańsku, który tuż przez II wojną światową wydała dla Polaków Polska Macierz Szkolna. Być może Jurzykowski właśnie w związku ze wspomnianą firmą nawiązał lub uściślił kontakty biznesowe, które zaowocowały jego późniejszymi sukcesami. Po wzięciu udziału w Kampanii Wrześniowej (był oficerem rezerwy) Alfred Jurzykowski pozostał na emigracji. Przebywał w USA, a następnie, od 1950 roku zajmował się uprawą kawy i handlem nią na terenie Ameryki Południowej. W 1953 roku został menedżerem znanej niemieckiej firmy samochodowej Mercedes Benz. Zdaniem Kordiana Tarasiewicza był także jej udziałowcem. Zdobył dużą fortunę. Stał się znanym filantropem. Jego Fundacja finansowała między innymi budynek biblioteki Polskiego Instytutu Naukowego w Nowym Yorku (PIASA) oraz znaną nagrodę literacką Nagrodę Fundacji Alfreda Jurzykowskiego. Laureatów tej nagrody z Polski Jurzykowski odnajdywał za pośrednictwem między innymi Kordiana Tarasiewicza, którego znał wcześniej dzięki branży herbaciano-kawowej. Sygnalizowane tu wątki biografii przedsiębiorcy, na razie przechowywane głównie przez historię mówioną, są, jak pisałem wcześniej, interesującym wyzwaniem dla badacza zarządzania zorientowanego historycznie 25 .

Po trzecie, jak już sugerowałem, branża kawowo-herbaciana na ziemiach polskich opierała się o małe i średnie przedsiębiorstwa, często rodzinne, z czasem wielopokoleniowe oraz miała charakter międzykulturowy. W 1935 roku na terenie Polski funkcjonowało 255 sklepów z kawą i herbatą. Branżowa organizacja Zrzeszenie Importerów Kawy i Herbaty, skupiająca mniej więcej 90\%

25 Powyższe wątki historii życia zawodowego Alfreda Jurzykowskiego opieram głównie na relacji Kordiana Tarasiewicza (lipiec 2013) oraz stronie internetowej poświęconej Jurzykowskiemu: http://www.magazyn.pioneer.com.pl/brazylijsko-amerykanski-filantropz-polski,varia,267,10,1,pl [dostęp 20.07.2013]. W niektórych kwestiach źródła te nie są spójne. 
firm tego sektora, liczyła w 1937 roku około 200 członków, spośród których duże podmioty gospodarcze jak Spółdzielnia „Społem” czy fabryka Fuchsa stanowity zdecydowaną mniejszośćc.

Zdarzało się, iż wspominania międzykulturowość występowała w jednej firmie, szczególnie jeśli przyjąć głębszą perspektywę historyczną (niż tylko wyniki sprzedażowe ostatniego roku). Przykładem takiego przedsięwzięcia może być „Krajowa Hurtownia Herbaty, d. M. Szumilin, Sp. Akc.”. Jej założycielem był Nikolaj [Mikołaj] Szumilin pochodzący ze zubożałej rodziny kupieckiej w Biełewie. Praktykę zdobywał w Mińsku, gdzie w sklepie kolonialnym pracował jako chłopiec na posyłki. Poznał go tam właściciel jednego z warszawskich sklepów tej branży (przy Palcu Teatralnym) i zaprosił do współpracy (w 1832 roku). „Pracowity i uczciwy młodzieniec szybko zyskał zaufanie warszawskiego pryncypała, który z czasem pomógł mu się usamodzielnić, pożyczając pieniądze" (Steinborn 1979: 34). Szumilin założył w 1840 roku wielobranżowy sklep w Lublinie (sprzedający akcesoria cerkiewne, samowary, cukier z trzciny i herbatę). Około 1870 roku przeniósł swoje przedsięwzięcie do Warszawy. Wyczuwając koniunkturę, zajął się mieszaniem i paczkowaniem herbaty. Jego syn Dymitr (po śmierci ojca w 1878 roku przejął przedsięwzięcie) przekształcił firmę w paczkarnię herbaty. Sprzedawał własne mieszanki herbaciane pod nazwą „M. Szumilin”. Jako małe przedsiębiorstwo Szumilin nie był uznawany za groźną konkurencję dla rosyjskich firm panujących wówczas na rynku herbacianym Warszawy („Popow”, „Perłow”, „Wysocki”). Na początku XX w. Dytmir Szumilin, który prowadził równolegle także inne przedsięwzięcia biznesowe przyjął do spółki Mieczysława Kutznera (był on farmaceutą z Poznania). Wspólnik posiadał duże zdolności organizacyjne. Firma zmieniła nazwę na „Towarzystwo M. Szumilin”. Paczkarnia herbaty została zmodernizowana. Stopniowo zyskała range jednego $\mathrm{z}$ wiodących przedsiębiorstw branżowych na ziemiach polskich. Podczas I wojny właściciele firmy musieli opuścić Warszawę (Kutzner, jako obywatel pruski był wysiedlony). Zapasy herbaty zostały jednak zabezpieczone przez pracowników i dzięki temu uratowały się. Mimo tego, po powrocie właścicieli sytuacja firmy nie była jasna. Zdaniem Kutznera warunki ekonomiczne i polityczne nie wróżyły dobrze na przyszłość. Z kolei Szumilin chciał zachowania ciągłości marki. Na przeszkodzie planom kontynuacji przedsięwzięcia stanęły braki kapitałowe. Szumilin i Kutzner przekształcili więc przedsiębiorstwo w spółkę z ograniczoną odpowiedzialnością pod nazwą „Krajowa Hurtownia Herbaty, dawniej T-wo M. Szumilin”, dopuszczając zewnętrznych udziałowców (w roku 1920). Kierownictwo objął wspomniany Mieczysław Kutzner, który później, w latach 30. XX w. był prezesem Stowarzyszenia Przemysłowców Herbacianych. W 1921 roku firma stała się spółką akcyjną. Działania te nie przyniosły spodziewanych korzyści. Szczególne problemy stwarzał brak własnych fachowców branżowych po śmierci Dymitra Szumilina w 1922 roku. 
W drugiej dekadzie okresu międzywojennego „Krajowa Hurtownia Herbaty” została zmodernizowana dzięki dynamicznej działalności menedżerskiej Adama Steinborna (pochodzącego z rodziny protestanckiej o chlubnych polskich tradycjach patriotycznych, pracownika firmy od ok. 1928 roku, dyrektora od 1938), który doskonale znał mentalność niemiecką i pozyskał również kontakty zagraniczne. Przedsiębiorstwo cieszyło się na rynku dobrą opinią, a jego najbardziej znanym towarem była herbata „nr 20”. Rosły obroty. Rozbudowywała się sieć przedstawicieli handlowych. „Było to możliwe dzięki wprowadzeniu nowoczesnych metod handlu (kwalifikacje fachowe, stała kontrola rynku, modernizacja paczkarni, reklama) oraz dzięki najściślejszemu przestrzeganiu przez Zarząd firmy (...) zasad rzetelności i solidności kupieckiej” (Steinborn 1979: 371-372). Tuż przed II wojną światową „Krajowa Hurtownia Herbaty” otworzyła sklep w Poznaniu. Stała się też ważnym współpartnerem polskiego handlu zagranicznego. Była założycielem spółki „Kampania Handlu Zamorskiego” służącej pozyskiwaniu dewiz dla branży kawowo-herbacianej, prowadzącej tak poważne przedsięwzięcia eksportowe jak sprzedaż polskich samolotów do Grecji, dział przeciwlotniczych do Szwecji, lokomotyw do Maroka i in. Miała też znaczący udział w rozwoju samorządu branżowego, na przykład przy powstaniu Polskiej Centrali Importu Kawy, Herbaty i Kakao (początek lat 30. XX w.). Steinberg w imieniu środowiska przedsiębiorców zajmujących się kawą i herbatą na terenie Polski skutecznie negocjował poprawę warunków konkurencji z faworyzowanymi przez przepisy międzynarodowe ${ }^{26}$ kupcami Wolnego Miasta Gdańska. Podczas II wojny światowej zarządowi firmy udało się włączyć ją w okupacyjny system aprowizacji ludności polskiej. Pozwoliło to prowadzić dalej działalność Krajowej Hurtowni Herbaty (stała się Rejonową Hurtownią Aprowizacyjną), co chroniło pracowników przed wywiezieniem na roboty w głąb Rzeszy, przedsiębiorstwo przed likwidacją, a jego personelowi dawało spore możliwości poruszania się samochodem. Firma prowadziła rozbudowaną działalność społeczną, często o charakterze konspiracyjnym (pomoc żywnościowa i pieniężna dla różnych grup, w tym także dla Żydów, udział w ratowaniu „dzieci Zamojszczyzny” i in.) oraz związaną z walką zbrojną Polskiego Państwa Podziemnego. Na terenie przedsiębiorstwa działa Armia Krajowa. Znajdował się tam skład broni. Adam Steinborn między innymi na zlecenie wywiadu akowskiego zdobywał istotne dla polskiego Podziemia informacje poprzez rozmowy z szefem warszawskiego Sicherheitsdienstu (organu niemieckiego wywiadu) Ernstem Kahem ${ }^{27}$. Podczas Powstania Warszawskiego firma prowadziła bezpłatną kuchnię. Ostatecznie

26 Dziś nie można odtworzyć szczegółów tej faworyzacji ani jej podstaw prawnych (Szymański 2013).

27 SS-Sturmbannfuhrer Ernst Kah był szefem Wydziału III (SD). Określany mianem szarej eminencji warszawskiego urzędu Sicherheitspolizei (pol. Policji Bezpieczeństwa), jako że był odpowiedzialny za najbardziej perfidne wobec Polaków operacje. 
budynki przedsiębiorstwa zostały spalone przez Niemców. Gdy wojna się skończyła, żona Steinborna próbowała wznowić Krajową Hurtownię Herbaty. Po krótkiej działalności w latach 1947-1948 okazało się to niemożliwe.

Prawdopodobnie pierwszym polskim przedsiębiorstwem branży kawowoherbacianej była firma Leona Krupieckiego, która działała na terenie Kongresówki prawdopodobnie do lat 40. XIX wieku. Jego znak firmowy „Kopernik” przejęło później Warszawskie Towarzystwo Handlu Herbatą „A. Długokęcki i W. Wrześniewski SA" działające od 1913 lub 1914 roku początkowo w formie kooperatywy (chodzi o rodzaj spółdzielni). Firmą tą kierowali Antoni Długokęcki (jako przewodniczący zarządu), Władysław Wrześniewski i Kazimierz Jaskólski. Po 1918 roku „Warszawskie Towarzystwo...” przekształciło się w spółkę akcyjną o charakterze komandytowym. Prowadziło sklepy w Warszawie (przynajmniej 4) i Wilnie. Zdobyło duże uznanie klientów na terenie Polski o czym świadczy na przykład wspomnienie Władysława Pakulskiego (wg relacji Pawła Martynowskiego 2013). „Herbata z Kopernikiem” była reklamowana za pomocą sloganu „Jeśliś znawcą, nie laikiem - pij herbatę z Kopernikiem”. Opisywane przedsiębiorstwo działało jeszcze podczas okupacji hitlerowskiej. Świadczy o tym informacja, iż Władysław Wrześniewski jako prezes Warszawskiego Towarzystwa Handlu Herbatą ufundował kapliczkę przy ul. Brackiej 23, gdzie mieścił się pierwszy sklep firmy. Jak dotąd nie udało mi się ustalić dalszych dziejów przedsiębiorstwa, chociaż warto wspomnieć, że od 2004 roku w Krajowym Rejestrze Sądowym widnieje firma „Warszawskie Towarzystwo Handlu Herbatą A. Długokęcki i W. Wrześniewski Sp. z o.o.”.

Po czwarte - kawa i herbata (szczególne ta pierwsza) w omawianym okresie (to jest do połowy XX wieku) były towarami niszowym ze względu na niski poziom spożycia obydwu tych używek na ziemiach polskich oraz fakt, iż (z wyjątkiem kawy zbożowej) ich odbiorcami były przede wszystkim bogate grupy społeczne (Tarasiewicz 2009). By zyskać perspektywę historyczną, warto zacytować opinię Kordiana Tarasiewicza sprzed kilku lat (2009: 161) - popartą danymi statystycznymi oraz kilkudziesięcioletnią obserwacją branży, że „Polska nadal jeszcze znajduje się poniżej światowej średniej, jeśli chodzi o (...) konsumpcję (kawy i herbaty - T.O.)". Równocześnie nestor handlu kawą i herbatą stwierdza, że „dziś jesteśmy świadkami, jak kultura ich konsumpcji dźwiga się z nizin powojennego półwiecza. Można nawet mówić o powolnym jej renesansie" (Tarasiewicz 2009: 160).

Dla branżowego przedsiębiorcy wieku XIX i pierwszej połowy XX wieku naszkicowane w poprzednim akapicie uwarunkowania oznaczały, iż poza tańszymi surogatami kawy (których nabywcami była uboga ludność), jego produkty trafiały do grup elitarnych, zarówno pod względem finansowym, jak i kulturowym. $\mathrm{Z}$ jednej strony był to segment konsumentów bardziej niż warstwy biedniejsze odporny na kryzysy finansowe. $Z$ drugiej jednak, co oczywiste, 
towar luksusowy mógł być łatwiej niż inne eliminowany z domowego budżetu, właśnie w wypadku kryzysu. Ponadto produkt nie cieszył się, czemu też trudno się dziwić, specjalnym wsparciem władz państwowych okresu międzywojennego. Czynniki te powodowały, że do tradycji przedsiębiorstw branży herbacianokawowej należy także specyficzne doświadczenie różnorodnego typu sytuacji kryzysowych. Tej problematyce, jako kluczowej dla kapitału kulturowego organizacji, poświęcę dalszą część niniejszego rozdziału.

Szczególny przypadek wielostronnej sytuacji kryzysowej stał się udziałem omawianej branży w Polsce na początku lat 30. ubiegłego stulecia. Był to czas Wielkiego Kryzysu, którego, co warto przypomnieć, jednym z symboli medialnych stał się obraz wyrzucania worków z kawą do morza. Równocześnie zintensyfikowała się ekspansja na rynek polski niemieckiego potentata kawowego, to jest firmy „Meinl”. Uwarunkowania prawne na poziomie międzynarodowym, które dzisiaj są już nie do odtworzenia (Szymański 2013), sprawiały, iż polscy importerzy kawy byli w okresie międzywojennych generalnie w gorszej sytuacji wyjściowej niż na przykład ich główni konkurenci z Niemiec i Wolnego Miasta Gdańska. Ogólnie rzecz biorąc, chodziło o ilość towaru, tak zwanych kontyngentów, zwolnionych przy eksporcie do danego kraju z pewnego rodzaju opłat. Polska miała prawo do mniejszych kontyngentów niż małe przecież obszarowo Wolne Miasto Gdańsk. W konsekwencji tego na przykład plantatorom brazylijskim, czyli ówcześnie głównemu eksporterowi kawy, również niezależnie od kryzysu, nie opłacało się wysyłać swego produktu do Polski. Lobbing przedsiębiorców wobec polityków, by ci podjęli działania międzynarodowe, nie przynosił efektu ${ }^{28}$.

Władze państwowe uzależniały przydział dewiz importerom od ich działalności eksportowej (Steinborn 1979). Coraz bardziej restrykcyjne stawały się polskie przepisy obciążające różnorodnymi opłatami handel międzynarodowy kawą i herbatą. Jak zanalizował to Rafał Szymański (2013), na przykład opodatkowanie celne zwiększyło się na początku lat 30. ubiegłego wieku o ponad $400 \%$ w przypadku kawy oraz o ponad $600 \%$ w przypadku herbaty w stosunku do analogicznych przepisów z połowy lat 20 . XX wieku.

Do tych wszystkich uwarunkowań doszły jeszcze idee monopolistyczne (Tarasiewicz 1971 i 2010, Steinborn 1979, Szymański 2013), dyskutowane także na łamach pasy z początku lat 30. ubiegłego stulecia (Tarasiewicz 1971, Szymański 2013). Nieco później konkretną próbę wprowadzenia monopolu sprzedaży kawy brazylijskiej do Polski podjęła holenderska firma „Hegoma”. Poważnym zagrożeniem dla branży herbaciano-kawowej okazały się przepisy z 1932 roku dotyczące warunków uzyskiwania ulgi celnej na kawę i herbatę. Uzależniały one

28 Na poziomie wiedzy, jaką obecnie posiadam, trudno powiedzieć, czy zabrakło woli, czy umiejętności negocjacyjnych u polityków. 
cenę tak zwanych świadectw kompensacyjnych związanych z otrzymywaniem wspomnianych ulg od podaży i popytu, co zakłócało równowagę gry konkurencyjnej na rynku omawianych towarów (cena zakupu świadectwa przez danego importera stawała się zupełnie od niego niezależna i de facto przypadkowa).

Wspomniane tendencje wywołały, czekający wciąż na opracowanie, ruch samoobrony kupców branży herbaciano-kawowej. W 1932 roku, jako bezpośrednia odpowiedź na wspomniane przepisy o uzyskiwaniu ulgi celnej, powstało Zrzeszenie Importerów Kawy i Herbaty R.P. Łączyło ono firmy branżowe z terenu Polski i Wolnego Miasta Gdańska. Wprowadziło wspólne rozliczenia związane ze wspomnianym problemem ulg dla swoich członków. Wspomniana organizacja działała w latach 1931-1932 oraz 1936-1939. Przerwa w jej funkcjonowaniu wynikała z powołania Polskiej Centrali Importu Kawy (PCIK) do obsługi dużej transakcji międzynarodowej, polegającej na powiązaniu sprzedaży polskich szyn kolejowych do Brazylii z eksportem kawy z tego kraju (tzw. clearing). PCIK była spółką powołaną przez importerów kawy, którzy po zakończeniu transakcji reaktywowali swoje Zrzeszenie. Tym razem jednak, ze względu na antypolską politykę władz Wolnego Miasta Gdańska, przedsiębiorcy stamtąd nie weszli do tej organizacji. Jak już pisałem, Zrzeszenie, choć przynależność do niego była zupełnie dobrowolna, gromadziło ponad $90 \%$ firm branżowych działających na terenie Polski (dane z 1937 roku). Oprócz spraw rozliczeniowych pełniło ważną rolę networkingową, powodując stopniowe lagodzenie relacji między konkurentami i stymulując wewnątrzbranżowy benchmarking, a także wyznaczając standardy handlu omawianymi towarami. Istotną cechę Zrzeszenia Importerów Kawy i Herbaty stanowiła jego międzykulturowość, mająca odbicie także w składzie zarządu (zob. Sprawozdanie... 1938). Ta wielokulturowość Stowarzyszenia przetrwała nawet wzrost tendencji nacjonalistycznych w latach 30 . XX wieku.

Jedną z nielicznych dostępnych dziś charakterystyk działania tej organizacji przedstawił Kordian Tarasiewicz (2013: 71): „Do tego Zrzeszenia należały wszystkie firmy, bez względu na ich przekonania narodowościowe, firmy żydowskie, ukraińskie i niemieckie (nie było tylko firm z Gdańska, bo ze względu na status wolnego miasta, miało ono pewne przywileje w handlu kawą). Wszystkie razem stanowiły całość, dzięki czemu mogliśmy razem bronić się przed zakusami monopolu, czy zarządzeniami, które by uderzały w branżę. To była wielka zaleta tego Zrzeszenia, że wspomniane trzy narodowości w zgodzie dbały o to, aby nie dopuścić do monopolu zagranicznego albo państwowego, bo to by było dosyć szkodliwe dla całej branży. Właśnie dzięki temu, że się ludzie nie separowali od siebie, tylko razem uzgadniali politykę, można było stawać w obronie rynku kawowo-herbacianego (...). Na początku te kontakty między konkurentami układały się dosyć trudno. Niektórzy z nich wyznawali zasadę, że konkurent to wróg. Więc zdarzało się nawet, że nie chcieli koło siebie siedzieć, ale później, gdy wszystko się rozkręciło, stosunki się polepszały". 
Liderem wspomnianego ruchu samoobrony branży herbaciano-kawowej w Polsce i inicjatorem Zrzeszenia był poprzednik Kordiana Tarasiewicza, Stanisław Hirszel (ok. 1865-1934), dyrektor „Plutona” w latach 1915-1934. Firma, którą reprezentował, sama miała spory bagaż doświadczeń zmagania się z różnorodnymi kryzysami.

\subsubsection{Niepowodzenie jako geneza firmy}

Dzieje rodzinnej inicjatywy Tarasiewiczów zaczęły się od najostrzejszej formy kryzysu, to jest od finansowej klęski. Tadeusz Tarasiewicz senior (1830-1910) pochodzący z galicyjskiej miejscowości Szczyrzyc (Sądecczyzna), zdobył wykształcenie w zakresie handlu oraz bankowości pod kierunkiem Wincentego Marcina Kirchmayera (1820-1893), znanego krakowskiego kupca, właściciela banku, działacza samorządowego, społecznego i politycznego, który wspierał finansowo powstanie styczniowe, kolekcjonera sztuki, później niemniej znanego bankruta. Nawiasem mówiąc, oddzielnej analizy wymaga fakt, na ile łączenie spraw kultury, socjalnych i narodowych z rozwijaniem biznesu, charakterystyczne dla wszystkich pokoleń właścicieli „Plutona”, założyciel firmy przejął od swego mentora. Być może też tego typu tradycje rodzinne Tarasiewiczów, dziś praktycznie niemożliwe do odtworzenia, wpłynęły na wybór właśnie Kirchmayera jako mistrza handlowego fachu.

Działalność zawodową Tadeusz Tarasiewicz rozpoczął od bankowości. Szybko jednak zdecydował się na założenie własnego sklepu. Od przełomu lat 60. i 70. dziewiętnastego wieku prowadził przy krakowskim Rynku Głównym, w domu „Pod złotą kulą” (róg ul. św. Jana) wielobranżowy „Skład Towarów Żelaznych i Norymberskich”, oferujący tak zróżnicowany asortyment, jak: sztaby żelaza, dzwony, inne metale, drut, samowary, narzędzia, później także naftę i cement ${ }^{29}$. Sklep sprzedawał również „herbatę chińską 'lądem sprowadzaną cenioną wówczas wyżej od herbat sprowadzanych drogą morską, którym zarzucano niewłaściwy sposób pakowania i niekorzystny wpływ transportu na ich jakość” (Tarasiewicz 2010: 6). Po kilku latach właściciel „Składu” założył ponadto kantor wymiany. Oprócz działalności biznesowej przyszły twórca „Plutona” miał doświadczenie także w innych rodzajach aktywności, co stało się, jak już wielokrotnie pisałem, rodzinną tradycją Tarasiewiczów i ich wspólpracowników. Opisywany nestor rodu pełnił funkcje radcy miejskiego, asesora do spraw handlowych przy Sądzie Krajowym oraz członka Wydziału Wielkiego Kasy Oszczędności. Był on także zasłużonym uczestnikiem działań Towarzystwa Dobroczynnego w Krakowie, za co instytucja ta uhonorowała go dyplomem.

29 Sklep Tadeusza Tarasiewicza był wyłącznym dystrybutorem na Austrię cementu portlandzkiego z najstarszej polskiej cementowni w Grodźcu pod Będzinem. 
W tradycji rodzinnej Tadeusz Tarasiewicz zapisał się przede wszystkim właśnie jako dobry, uczciwy człowiek, wrażliwy na potrzeby biednych, mniej natomiast jako utalentowany przedsiębiorca.

Sygnalizowana przeze mnie wcześniej szeroka dekompresja ryzyka biznesowego nie przyniosła efektu. W 1878 roku nestor rodzinnego biznesu Tarasiewiczów podpisał akt upadłości swej firmy. Po wielu latach jego wnuk, a główny bohater niniejszego rozdziału, Kordian Tarasiewicz tak interpretował przyczyny wspomnianej sytuacji: „Nie są znane okoliczności tego wydarzenia. A ja doszedłem do wniosku, że błąd mojego dziadka polegał na lokalizacji firmy. Pozornie umiejscowienie sklepu była bardzo dobre: Rynek Krakowski, na rogu ulicy Świętego Jana. Tam po drugiej wojnie światowej mieścił się 'Orbis'. To jest wspaniały punkt, na samym rogu, w sam raz na sklep. Ale wiele wyjaśnia ogłoszenie mówiące o tym jakie produkty dziadek sprzedawał. Mówi ono o nafcie, cemencie i żelazie. To nie były artykuły na Rynek, które kupują przychodzący tam ludzie. Tadeusz Tarasiewicz miał na składzie także drobne rzeczy. Wspomniane ogłoszenie mówi między innymi o herbacie, ale herbata stanowiła minimalną część asortymentu. A przede wszystkim tam był cement! Kto by cement kupował na Rynku Głównym w Krakowie? Czyli lokalizacja tego interesu dziadka była niefortunna. Bo to powinna być raczej hurtownia, gdzie samochody by podjeżdżały z cementem. A nikt przecież, pozwolę sobie powtórzyć, nie będzie handlował cementem na Rynku w Krakowie. To pewnie spowodowało, że ten interes nie poszedł" (Tarasiewicz 2012).

Upadek krakowskiego sklepu nie zakończył jednak działalności dynamicznego przedsiębiorcy. Jak po latach podawała okolicznościowa broszura wydana na trzydziestolecie „Plutona”: „Wielkie stosunki handlowe i ciaggła styczność z zagranicą zwróciły jego (przyszłego założyciela omawianej firmy - T.O.) uwagę na rozwijający się szybko przemysł palenia kawy, co nasunęło mu myśl pójścia tą drogą i założenia takiej fabryki w kraju. Po przeprowadzeniu odpowiednich studyów (pisownia oryginalna - T.O.) wybór jego padł na Warszawę, gdzie konsumpcja kawy była stosunkowo dość znaczną, a całe Królestwo Polskie stało na wysokim poziomie przemysłowym" (Pluton... 1911: 8).

Szczegółowe przyczyny zajęcia się przez Tadeusza Tarasiewicza branżą kawową nie są znane. Dziś wydają się niemożliwe do odtworzenia.

Rodzina Tarasiewiczów przeniosła się do Warszawy w roku 1880. Literacki obraz przedsiębiorczej atmosfery tego miasta na przełomie XIX i XX stulecia, przeżywającego wówczas rodzaj prosperity, tak przedstawił Isaac Bashevis Singer (1969/2007: 39) na kartach powieści Spuścizna: „Słońce przygrzewało. W Ogrodzie Saskim zakwitły bzy. Na ulicach robotnicy układali szyny pod konne tramwaje. Zrywali chodniki. Platformy dowoziły kamienie brukowe i odcinki szyn, które porządnie układano w pryzmy i stosy gotowe do użytku. Waliły 
potężne młoty. Wszędzie na Pradze, Woli, Ochocie, a nawet w centrum Warszawy, powstawały błyskawicznie nowe fabryki. Z Niemiec, Francji i Ameryki nadchodziły maszyny o tak potężnych rozmiarach, że nie sposób było pojąć, jak ludzkie umysły mogły je zaprojektować, a ludzkie ręce zmontować. Na Krakowskim Przedmieściu i Nowym Świecie zastąpiono latarnie gazowe łukowymi. Banki rozporządzały większymi kapitałami, przeto fabrykanci i kupcy dostawali pożyczki niskoprocentowe"30.

Nowa firma „Pluton” była charakterystycznym elementem singerowskiej mozaiki. Już sam jej produkt świadczył o dużej innowacyjności założyciela. I był obarczony znacznym ryzykiem. Wymagał bowiem zmiany obyczajów konsumentów. W tamtym okresie kupowano raczej surową kawę i służba paliła ją na patelni. Sprzedaż kawy palonej wydawała się korzystną ofertą. Kupujący uznawali ją za atrakcyjną, ale jednocześnie ich opór budziła wyższa cena kawy palonej w stosunku do surowej. Wspomniana różnica ceny wynikała nie tylko z potrzeby amortyzacji kosztów wyposażenia palarni, ale także z faktu, iż ziarna kawowe palone były lżejsze niż surowe. Pierwsza na ziemiach polskich palarnia kawy, zorganizowana przez Tadeusza Tarasiewicza seniora w 1882 roku, miała więc niepewną przyszłość. Jej założyciel zaryzykował po raz drugi w swej karierze przedsiębiorcy, tym razem stawiając na dość radykalną innowacyjność. Początkowo (chodzi o pierwsze miesiące, czy nawet tygodnie funkcjonowania „Plutona”) wydawało się, iż i tym razem przedsięwzięcie zakończy upadłość. „Nie wiem, czy ja nie będę musiał drugi raz zlikwidować firmę”, pisał Tadeusz Tarasiewicz senior w jednym ze swoich listów (cytat z pamięci K. Tarasiewicza 2013: 22). Jednak palarnia utrzymała się na rynku, dając materialne podstawy egzystencji dość licznej rodzinie (rodzice i pięcioro dzieci), z którą jej założyciel przyjechał do Warszawy. Mimo ryzyka biznesowego, typowego dla początkowej działalności firmy, Tadeusz Tarasiewicz senior nie zaprzestał intensywnej działalności charytatywnej także w Warszawie. Jednym z jego ostatnich wydatków tego typu była wpłata 500 rubli (co stanowiło znaczną sumę) na rzecz Domu Stowarzyszenia Robotników Chrześcijańskich w Warszawie, który powstał z inicjatywy ks. Marcelego Godlewskiego (1865-1945) znanego warszawskiego działacza chrześcijańskiego ruchu robotniczego. Dom został otwarty w 1910 roku jako prawdopodobnie pierwsza instytucja tego typu na terenie zaboru rosyjskiego. Stwarzała ona ludności robotniczej możliwość aktywności samopomocowej i kulturalnej (Otwarcie... 1910). Innowacyjność założyciela „Plutona” wyrażała się więc także $\mathrm{w}$ angażowaniu $\mathrm{w}$ innowacyjne przedsięwzięcia na rzecz szeroko rozumianego społecznego otoczenia organizacji.

$\overline{30}$ Przekład I. Wyrzykowska. 


\subsubsection{Kapitał kulturowy „Plutona” na przestrzeni dziejów firmy}

Innowacyjność oraz rys społeczny (przejawiający się także poprzez różnorodne działania na rzecz personelu firmy, których jednym z celów było budowanie zaangażowania pracowników wobec przedsiębiorstwa), a także niemal cykliczne stawiane czoła różnorakim kryzysom określało specyfikę kulturową przedsięwzięć gospodarczych (kapitał kulturowy organizacji), które można określić roboczym terminem „przyzwoity biznes warszawskich mieszczan”. Specyfikę tę precyzuję na podstawie wybranych praktyk menedżerskich z dziejów palarni kawy „Pluton”31.

Równocześnie z założeniem omawianego przedsiębiorstwa Tadeusz Tarasiewicz wysłał jednego ze swoich synów, Jana (1864-1906) na praktykę branżową do Hamburga, a po jego powrocie i osiągnięciu pełnoletności, bardzo szybko po założeniu „Plutona”, jeszcze w 1882 roku powierzył mu kierowanie firmą. Dzięki działalności Jana Tarasiewicza przedsiębiorstwo stosunkowo szybko zyskało dynamikę rozwojową. Zostało unowocześnione technologicznie i organizacyjnie. Zdaniem syna właściciela, też Jana Tarasiewicza, „ojciec (...) stworzył tę fabryczkę z papierowym kominkiem, a zostawil ją fabryką z wieloma kominami" (cyt. za Budrewiczem 1990: 258). Według zachowanych danych statystycznych „Pluton” w początkowym okresie działania przynosił 40000 rubli zysku rocznie, co było dużym osiągnięciem firmy średniej wielkości (według współczesnych nam standardów). Pozwoliło to na rozwój przedsiębiorstwa oraz inwestycję w nieruchomości. W 1902 lub 1903 roku zapadła decyzja o budowie przy ul. Żytniej w Warszawie fabryki wraz z powierzchnią mieszkalną dla dość licznej rodziny właściciela. Inwestycja została szybko zrealizowana kosztem 160000 rubli i była sukcesywnie powiększana. By zdobyć dodatkowe źródło funduszy młody właściciel „Plutona” najprawdopodobniej grał na giełdzie (z sukcesem).

31 Takie ujęcie historii organizacyjnej „Plutona” może rodzić zarzut idealizacji, tym bardziej, że działania propracownicze były głównym, sugerowanym przeze mnie tematem moich rozmów z Kordianem Tarasiewiczem (2010-2013). W ciągu trzech lat pracy nad tą problematyką szukałem różnych źródeł weryfikacji obrazu, jaki wyłaniał się z prowadzonych wywiadów. Było to utrudnione z powodu braków w zakresie dokumentacji i opracowań. W każdym razie nie znalazłem dotąd, ani w dokumentach, ani w opiniach informatorów (zarówno badaczy, jak i potomków rodzin warszawskich przedsiębiorców) danych, które podważyłyby zasadność określenia „przyzwoity biznes” w odniesieniu do funkcjonowania „Plutona”. Dalszą weryfikację moich ustaleń polecam uwadze następnych badaczy. Gwoli rzetelności metodologicznej, podkreślam, iż podczas relacjonowanych trzyletnich działań badawczych, emocjonalnie byłem „po stronie” rozmówcy, starając się jednocześnie zachować standardy krytycyzmu naukowego, tak jak tego wymaga „badanie zaangażowane" w ujęciu Roberta J. Liftona (1985, 1986, 1987, zob. także Strozier i Flynn 1992; zastosowanie do problematyki zarządzania: Ochinowski i Grzywacz 2003). 
Charakterystyczne, iż wspomniana nieruchomość nie weszła do majątku firmy, tylko pozostała własnością Jana Tarasiewicza. Chodziło o to, by nie stanowiła obciążenia finansowego dla „Plutona”. Taka praktyka rozdzielania sfery rodzinnej i firmowej stała się w przypadku omawianego przedsiębiorstwa regułą. Przy czym chodziło też o zabezpieczenie funduszy rodzinnych. Zachowały się dokumenty dotyczące bilansów. Pokazują one, iż kapitał zakładowy powiększał się co roku z zysków, więc rodzina właściciela nic nie dopłacała. Nawet poważne inwestycje finansowane były za pośrednictwem banku. Aby zachować swobodę finansową właściciele „Plutona” wypracowali następującą strategię. W przypadku zmniejszenia się zysków na skutek dekoniunktury firma nie obracała gotówką, a posługiwała się wekslami. Dzięki temu pieniądze zostawały w banku. Z kolei weksle, które wystawiali dłużnicy, nie były oddawane do banku, by nie płacić procentów. W wyznaczonym terminie dany kupiec wykupywał weksel wprost od Tarasiewiczów Zmniejszało to skutki spadku wartości pieniądza32.

W zakresie działań Jana Tarasiewicza na rzecz zatrudnionych, zachowała się informacja o organizowaniu kursów dla analfabetów oraz o propozycji właściciela, aby z okazji dwudziestopięciolecia „Plutona” w 1907 roku założyć kasę zapomogowo-pożyczkową dla pracowników, jako instrument finansowego wsparcia dla zatrudnionych. Ta druga inicjatywa została zrealizowana już po śmierci Jana Tarasiewicza, który niespodziewanie zmarł w wieku 42 lat. Zaś wspomniane kursy funkcjonowały na pewno przed I wojną światową, a być może rozpoczęły się jeszcze pod koniec XIX. Byłyby więc niemal „rówieśnikami” przedsiębiorstwa.

Śmierć Jana Tarasiewicza (jesienią 1906 roku) przyniosła poważny kryzys przywództwa w firmie. Pozostali dwaj bracia nie byli zainteresowani prowadzeniem „Plutona”. Tadeusz Tarasiewicz - junior (1863-1917) zaangażował się już wcześniej w przemysł naftowy, Michał Tarasiewicz (1871-1923) rozwijał karierę artystyczną jako wybitny polski aktor i reżyser, jeden z pierwszych w Polsce interpretatorów bohaterów dramatów romantycznych (Makomaska 1968). Konieczność zajmowania się rodzinnym przedsiębiorstwem stanowiło źródło dylematów szczególnie dla drugiego z wymienionych. Wyraźnie nie brano pod uwagę możliwości prowadzenia przedsiębiorstwa przez kobietę (Zofia siostra Tadeusza i Michała, weszła w skład władz przedsiębiorstwa, a druga z sióstr wcześnie zmarła). Założyciel firmy był już w bardzo podeszłym wieku.

Mimo wspomnianych trudności w „Plutonie”, kierowanym teraz przez Tadeusza juniora i Michała, nadal prowadzone były działania innowacyjne. Właściciele unowocześnili palarnię przez sprowadzenie odpowiednich maszyn. W latach 1912 i 1914 zakupione zostały samochody firmowe, co stawiało „Plu-

32 Taka strategia przyniosła dobre efekty podczas Wielkiego Kryzysu lat 30. XX wieku (zob. Tarasiewicz, 2010). 
tona" w awangardzie nowoczesności wśród ówczesnych przedsiębiorstw. Jeszcze bardziej innowacyjny charakter miały realizowane na przestrzeni kliku lat, aż do pierwszej wojny światowej, prekursorskie na skalę globalną próby opracowania ekstraktu z kawy. Ostatecznie plany te nie powiodły się z powodu niedostatków technologicznych wyniku prac pierwszego z wykonawców wspomnianego wynalazku (ekstrakt przygotowany przez Wiesława Wisłockiego był bardzo smaczny, ale zbyt szybko pokrywał się pleśnią) oraz nagłej śmierci drugiego (Przemysława Rakowskiego w 1915 r.). Powiodło się natomiast uzyskanie przedstawicielstwa na Królestwo Kongresowe wspomnianej wcześniej breneńskiej firmy „Kawa Hag"33 (sprzedaż kawy bezkofeinowej, 1908 roku). W 1909 odbył się finansowany z funduszów przedsiębiorstwa konkurs na plakat reklamowy „Plutona”, w którym wzięli udział znaczący plastycy warszawscy. Ustalona została obowiązująca później długo oficjalna nazwa firmy „Pierwsza Warszawska Fabryka Palenia Kawy, Cykorii i Surogatów Kawy J. i M. Tarasiewiczów”.

Jednocześnie z tego okresu pochodzą względnie szczegółowe informacje o standardach traktowania pracowników. Zrealizowany został pomysł Jana Tarasiewicza dotyczący powołania na 25-lecie przedsiębiorstwa „Kasy PożyczkowoOszczędnościowej Pracowników Fabryki Pluton” w Warszawie (1907 rok). Jej kapitał utworzyło 5\% opłat pracowników - członków Kasy, potrącanych od ich wynagrodzeń oraz $2 \%$ opłat uiszczonych przez właścicieli, także w stosunku do ich pensji. Właściciele zasilili również jednorazowo kapitał obrotowy wspomnianej instytucji równowartością jednomiesięcznego wynagrodzenia osób zatrudnionych w danym dniu przez „Plutona”. Kasa działała przynajmniej do końca I wojny światowej. Jest to charakterystyczna cecha stosunku właścicieli Palarni wobec pracowników. Działania pomocowe były realizowane tylko, gdy pojawiały się rzeczywiste potrzeby i były kończone, gdy zatrudnieni zyskiwali warunki do radzenia sobie samodzielnie. Od 1911 roku obowiązywał w „Plutonie” ośmiogodzinny dzień pracy. Według opinii Józefa Sobczyńskiego, palacza kawy, który przepracował dla omawianej firmy 40 lat, „uposażenie zaspokajało potrzeby życiowe pracowników i ich rodzin". Ponadto właściciele wypłacali zatrudnionym 15 pensji rocznie (oprócz wynagrodzeń comiesięcznych były to dodatki świąteczne oraz na zakup zimowego ubrania). „Trzeba obiektywnie stwierdzić, że w ten sposób uposażeni pracownicy nie musieli myśleć o szukaniu dodatkowych zarobków, a mogli w pełni zużytkować czas wolny od pracy na zaspokojenie swoich potrzeb kulturalnych i na odpoczynek". Cytowany Sobczyński opisuje też inne udogodnienia socjalne: „W czasie ośmiogodzinnego dnia pracy stosowane były jednogodzinne przerwy odpoczynkowe. Podczas tych przerw robotnicy łącznie z Dyrektorami uczestniczyli w grach sportowych i organizowali inne zajęcia rozrywkowe. Czas ten przeznaczony na odpoczynek był wliczany w normalny

33 Firma działa do dziś. Jest własnością amerykańskiego koncernu „Kraft Foods”. 
dzień pracy. Z przyjemnością obserwowało się całą załogę pracowniczą, która stanowiła jakby jedną dużą rodzinę i często pomagała sobie wzajemnie przy rozwiązywaniu różnych kłopotów. W ramach pomocy dla robotników dyrekcja zorganizowała bezpłatne zupy dla wszystkich zatrudnionych, które spożywano w czasie przerwy. Przy ustawionych stołach wspólnie zasiadali do posiłków robotnicy, pracownicy biura i dyrekcja. Z innych form pomocy pracownikom wymienię jeszcze tylko fakt zakupienia przez Dyrekcję losu loteryjnego (przed I wojną światową) ,z przeznaczeniem ewentualnej wygranej do podziału między wszystkich zatrudnionych" (cyt. za Tarasiewiczem 2013b: 37-38).

Jednak centralny element kapitału organizacji, który wypracowali właściciele „Plutona” jeśli chodzi o stosunek do pracowników, ujawnił się w 1914 roku, gdy firma stała się spółką akcyjną (Towarzystwem Akcyjnym według ówczesnej terminologii). Właściciele podjęli wówczas decyzję o rozdaniu akcji pracownikom. Był to pierwszy taki wypadek na ziemiach polskich (zob. Klaczkowski 1918) ${ }^{34}$. Przy czym wielkość akcji przypadająca na poszczególnego pracownika była bardzo niewielka. Kordian Tarasiewicz, po wielu latach następująco komentował wspomniane wydarzenie: „Trzeba wprawdzie zaznaczyć, że własność owych akcji, posiadanie ich przez pracowników miało - używając dzisiejszego języka - charakter wirtualny, ale był to czynnik przywiązujący ich do przedsiębiorstwa, który sobie bardzo cenili” (K. Tarasiewicz 2010: 10). „W przyszłości okazało się bardzo słuszne, żeby właśnie w taki sposób najbardziej jak można wiązać zatrudnionych z firmą. Pracownik, który miał poczucie, że jest symbolicznym, ale jednak akcjonariuszem, miał inny stosunek do pracy i do firmy, w której jest zatrudniony, do wszystkiego, co się z nią wiąże" (K. Tarasiewicz 2013: 50).

Gdy dwadzieścia lat później Kordian Tarasiewicz obejmował funkcję dyrektora „Plutona” (1934), doświadczył zjawiska, które można nazwać „transferem 'w czasie' kulturowego kapitału organizacji”.

Od wybuchu I wojny światowej przedsiębiorstwem kierował Stanisław Hirszel (ok. 1865-1934), zarówno przed, jak i po związaniu się z „Plutonem” aktywny warszawski działacz kupiecki i samorządowy, także autor artykułu o finansowaniu teatrów (być może w związku z tą problematyką poznał go Michał Tarasiewicz). Podczas I wojny światowej Hirszel był członkiem Komitetu Obywatelskiego m.st. Warszawy, pierwszego polskiego organu samorządu miejskiego przed 1918 rokiem. Jako prezes Sekcji Żywnościowej wspomnianego Komitetu, zainicjował on tak zwane Tanie Kuchnie, które oferowały obiady i herbatę dla ubogich mieszkańców miasta. Równocześnie, na prośbę wła-

34 Trudno ustalić, kto pierwszy na świecie rozdał akcje pracownikom. Różne formy udziału zatrudnionych w zyskach, łącznie z możliwością zakupu przez nich akcji firmy, eksperymentalnie wprowadzali pojedynczy przedsiębiorcy europejscy od lat 40. XIX wieku. Rozdawanie akcji pracownikom zaczęło się prawdopodobnie w USA pod koniec XIX wieku. Najwyraźniej były to jednak działania sporadyczne. 
ścicieli „Plutona”, którzy jako obywatele austriaccy musieli wyjechać w głąb Rosji, przyjął nominację od jego z nich, Michała Tarasiewicza (z którym się przyjaźnit), na stanowisko dyrektora firmy (w 1915 roku). Kierował on przedsiębiorstwem kolejne 40 lat, przeprowadzając je przez czas pierwszej wojny światowej i późniejszych kryzysów - „Nawet dywidenda była, tak że z zysków można było coś uszczknąć po końcu każdego roku” (Tarasiewicz 2013: 58). W okresie międzywojennym Hirszel stanął na czele aktywności samorządowej całej branży, budując tym samym wysoką pozycję środowiskową kierowanej przez siebie Palarni (co wspominałem już wcześniej). Pod koniec życia jednak, jak wraca pamięcią Kordian Tarasiewicz, wspomniany przyjaciel rodziny „nie miał siły, żeby nie tylko prowadzić branżę, ale jeszcze dostatecznie zajmować się rozwojem firmy. I „Pluton” trochę tak zaczął 'obrastać starością' powiedzmy”35, szczególnie jeśli chodzi o urządzenie sklepów, reklamę i wyszkolenie personelu.

Te czynniki oraz pokłosie Wielkiego Kryzysu gospodarczego przełomu lat 20. i 30. ubiegłego wieku, a także tak zwanej wojny celnej z Niemcami, sprawiły, iż gdy Kordian Tarasiewicz w 1934 roku objął po śmierci Hirszla funkcję dyrektora, zastał firmę w dość złej kondycji finansowej. „Od 1930 roku do 1935, mniej więcej o $30 \%$ spadły obroty. Zyski jeszcze były, ale bilans finansowy zaczął sytuować się na poziomie niebezpiecznym”36. „Bilans za 1934 rok wykazywał najniższy poziom sprzedaży i zysku w porównaniu do poprzednich lat (Tarasiewicz 2010: 90). Młody, wówczas 24-letni dyrektor, zdecydował się na radykalne posunięcia. Nie chciał nikogo zwalniać. Zrobił rodzaj analizy efektywności każdego z zatrudnionych i tym, którzy nie nadążali za wymaganiami współczesnego rynku, zredukował - po indywidualnej rozmowie z każdym wynagrodzenia o $20-25 \%$. Dotknęło to niektórych pracowników palarni, administracji, a przede wszystkim sklepów. „Również sobie zredukowałem pensję dyrektorską o połowę w stosunku do uposażenia Pana Hirszla"37, wspominał po latach. Przed tymi działaniami właściciele przedsiębiorstwa zwrócili się do pracowników z apelem o zrozumienie ciężkiej sytuacji firmy.

Ponadto Kordian Tarasiewicz musiał rozpocząć pełnienie funkcji dyrektorskiej od działań dyscyplinujących. Do części bogatych klientów „Plutona” kawa była dowożona samochodami. Kierowca jednego z nich przekazał Tarasiewiczowi informację, iż niektórzy pracownicy obsługujący wspomnianych indywidualnych odbiorców oszukują firmę, sprzedając dodatkowo zabieraną przez siebie kawę „na własną rękę”. Zwolnienie winnych, niezwłocznie po rozpoznaniu sprawy, stanowiło dopiero początek rozwiązania problemu. Chodziło o przyjęcie działań profilaktycznych na dłużą metę. Tarasiewicz przyjął następujące

35 Niepublikowana wypowiedź K. Tarasiewicza udzielona autorowi niniejszej pracy w 2012 r.

$36 \mathrm{Jw}$.

$37 \mathrm{Jw}$. 
rozwiązanie: „Wiedziałem, że tylko dobra organizacja pracy może zapobiec zachowaniom wspomnianego typu. Wprowadziłem więc znormalizowane worki na kawę o rozmiarze dokładnie odpowiadającym wielkości zamówień klientów, a wnoszenie jakichkolwiek innych opakowań do samochodów służbowych w czasie pracy zostało zabronione. Worki te zawierające pudełka $\mathrm{z}$ kawą, były zamknięte, a pracownicy pobierali je z szafek zamykanych na klucz. W ten sposób zażegnany został problem niebezpieczeństwa nieetycznych zachowań osób zatrudnianych przez moją firmę" (Tarasiewicz 2013: 87-88).

Warto przy tej okazji zauważyć, iż niszowy produkt, jakim była kawa w okresie międzywojennym, dostarczany najbogatszym klientom indywidualnie transportem samochodowym (przy czym chodzi przecież o towar mający charakter używki), budzi skojarzenia z dzisiejszym zarządzaniem na rynku doznań, gdzie „jednym z elementów produktu staje się pamięć. Firmie zależy więc, bardziej niż w przypadku innych form działalności rynkowej, by relacja $\mathrm{z}$ klientem była trwała i harmonijna (Kostera i Śliwa 2012: 214, autorki te referują poglądy Josepha Pine'a i Jamesa Gilmore'a na temat rynku doznań).

Mimo obniżenia pensji części pracowników, poprzedzonej koniecznością wspomnianych działań dyscyplinujących, nie nastąpił spadek morale personelu „Plutona”. A przecież zjawisko to niemal zawsze ma miejsce, gdy redukowane są wynagrodzenia. Nawet jeśli kierownictwo daje przykład. Wspomniany rodzaj radykalnego spadku nastrojów pracowników po utracie części wynagrodzenia tłumaczy choćby teoria perspektywy, znana studentom pierwszych lat nie tylko psychologii, ale i szkół biznesu (np. Kahneman 2012). W jej świetle zrozumiałe jest, iż nawet, jeśli obniżenie pensji stanowi cenę za utrzymanie pracy, to świadomość tego stanowi ważny argument, ale przede wszystkim na poziomie racjonalnym. Nie rekompensuje natomiast wystarczająco negatywnych emocji, występujących nie tylko u tych zatrudnionych, którzy zaczynają mniej zarabiać niż poprzednio. Obniżenie nastroju udziela się także innym pracownikom, rozprzestrzeniając się praktycznie na całą organizację. Zazwyczaj dla utrzymania choćby dotychczasowego poziomu wykonania pracy konieczne staje się wzmożenie kontroli ze strony menedżerów ${ }^{38}$.

W przypadku opisanych działań młodego dyrektora „Plutona” żadne z tych zjawisk nie wystąpiło.

Najprawdopodobniej ${ }^{39}$ pracownicy dali Kordianowi Tarasiewiczowi szansę, kredyt zaufania, ponieważ był bardzo młodym dyrektorem. W ten sposób,

38 Szczególnie gdy redukcja zarobków wiąże się ze zmniejszeniem wymiaru pracy, co nie miało miejsca w opisywanym przypadku „Plutona”.

39 Identyfikacja czynników, które wystąpiły wówczas w „Plutonie” i zahamowały procesy obniżenia morale pracowników zajęła około pół roku rozmów z Kordianem Tarasiewiczem, który szukał odpowiedzi także w materiałach archiwalnych swojej firmy i wspomnieniach zatrudnionych. 
zgadzając się na jego, jak sam to później określił - „dość drakońskie” kroki, wzięli odpowiedzialność za przedsiębiorstwo.

Taką postawę pracowników warunkowały ich doświadczenia, że firma nigdy ich nie oszukała, a większość zatrudnionych była z nią związana od wielu lat. Zdarzały się osoby z czterdziestoletnim stażem, podczas gdy sam „Pluton” istniał wówczas od 52 lat. Większość zatrudnianych była znacznie starsza od nowego dyrektora, który jako syn właściciela uosabiał tradycje firmy.

Drugi ważny czynnik pomagający pracownikom obdarzyć Kordiana Tarasiewicza kredytem zaufania, to fakt, iż niektórzy z nich doceniali jego innowacyjne, bardziej nowoczesne niż dotąd podejście do wielu spraw firmowych, takich jak reklama, organizacja sprzedaży itp. Ujawniło się ono już podczas odbywania stażu w „Plutonie” przez obecnego, nowego dyrektora.

Warto w tym kontekście przypomnieć badania Hansa Ramo (2004) nad naturą zaufania w pracy. W ich świetle ma ono naturę kruchą, zmienną w czasie. Wymaga komunikacji, która opiera się na wykorzystaniu przez kadrę zarządzającą odpowiednich momentów do tego, by zachować się sprawiedliwie.

Przypadek „Plutona” ukazuje możliwość bardziej trwałej niż sugeruje cytowany Ramo „kulturowej otoczki” zaufania w firmie. Tworzą ją uczciwość pracodawców, przekonanie podzielane przez pracowników, iż w ich interesie jest, aby przedsiębiorstwo nadal działało oraz dodatkowe świadczenia odpowiadające rzeczywistym potrzebom zatrudnionych, takie jak: sport, programy edukacyjne, bonusy o istotnym znaczeniu symbolicznym itp. Podstawową sprawą pozostaje zżycie się pracowników z przedsiębiorstwem. „Po prostu było silne przywiązanie pracowników do firmy - podsumował współcześnie Kordian Tarasiewicz, swoje doświadczenie z początków kierowania „Plutonem” - Obchodziło się jubileusze. Zatrudniony, który przepracował 10 lat dostawał srebrny zegarek, a za 25 lat złoty. Poza tym co roku były gratyfikacje. Zysk nie tylko akcjonariusze zabierali, ale zawsze kilkadziesiąt tysięcy złotych przeznaczaliśmy na gratyfikacje dla pracowników po skończonym roku. Więc ludzie byli zadowoleni, mieli dobre płace. No i to zdało egzamin" 40 . Takie właśnie procesy proponuję nazwać transferem 'w czasie' kapitału kulturowego organizacji.

Przytoczona wypowiedź Tarasiewicza ukazuje, iż wspomniany transfer nie tylko niesiony jest przez tradycję, ale wymaga również intencjonalnego kontynuowania dobrych praktyk. Niektóre z nich trzeba oczywiście dostosowywać do wymogów aktualnej sytuacji. Znaczenie, również w sensie skutecznego rozwiązywania problemów organizacyjnych tej „twórczej kontynuacji”, bądź raczej „inspiracji tradycją” widoczne jest szczególnie w sytuacjach kryzysowych, które są szczególnie przecież predystynowane, by być wzmiankowanymi za Ramo (2004) momentami (czy raczej przedziałami czasowymi) dobrymi do tego, by

$\overline{40}$ Niepublikowana wypowiedź K. Tarasiewicza udzielona autorowi niniejszej pracy w 2012 r. 
kadra zarządzająca zademonstrowała zachowania sprawiedliwe. Na przestrzeni dziejów „Plutona” taką szczególną okazję stworzyła II wojna światowa. Dzięki towarzyskim relacjom z kierownictwem „Philipsa”, które zostało wprzęgnięte w hitlerowski przemysł zbrojeniowy, ale pozostało wierne sympatii wobec Polaków, firma Tarasiewiczów, obok innych polskich przedsiębiorstw i podobnie jak omawiana wcześniej Krajowa Hurtownia Herbaty, zyskała możliwość przetrwania jako element systemu zaopatrzenia kartkowego. Pozwoliło to, wraz z innymi działaniami, na niezwykle dynamiczny rozwój „Plutona” podczas okupacji hitlerowskiej. Warto podkreślić, iż rozwojowi temu towarzyszyła także szeroko prowadzona przez Kordiana Tarasiewicza i jego wspólpracowników aktywność skierowana na pomoc więźniom obozów koncentracyjnych i jenieckich oraz innym potrzebującym, ze szczególnym uwzględnieniem świata kultury. Dyrektor „Plutona” był na przykład liderem spontanicznych działań warszawiaków w związku z ratowaniem „dzieci Zamojszczyzny” (1943 r., zob. Kozaczyńska 2011). Podczas Powstania Warszawskiego magazyny firmowe stały się źródłem żywności dla walczących i ludności cywilnej.

W stosunku do własnych pracowników (których obejmowały w razie potrzeby wymienione formy pomocy) Kordian Tarasiewicz podjął trzy długofalowe działania wprost inspirowane inicjatywami przodków.

I tak na wzór Kasy Zapomogowo-Pożyczkowej z I wojny została zorganizowana, adekwatna do aktualnych potrzeb, „Spółdzielnia Spożywców Pracowników firmy 'Pluton' T. i M. Tarasiewiczów” (1940-1945). Członkostwo w tej instytucji było dobrowolne. Dzięki wspominanej spółdzielni pracownicy firmy mogli kupować żywność po cenie hurtowej, a także korzystać z bezpłatnej opieki lekarskiej i bezpłatnych leków.

Edukacyjne inicjatywy kierownictwa „Plutona” podejmowane niemal od początku istnienia firmy zainspirowały Kordiana Tarasiewicza do powołania kursów dla stażystów (właśnie podczas II wojny nastąpiła zmiana pokoleniowa pracowników firmy). Kursy te prowadzone były przez kilkudziesięciu prelegentów z różnych dziedzin, takich jak: naukowa organizacja pracy, reklama, produkcja, administracja itp. Do grona wykładowców zapraszano często liczące się postacie polskiego biznesu i świata akademickiego. Na przykład tematykę reklamy realizował Stanisław Zenon Zakrzewski (1890-1976), jeden z twórców jej nowoczesnej wersji w Polsce. „Naukową organizację pracy” prowadził Władysław W. Baliński (1899-? data śmierci nieznana), znawca problematyki administracji i kierownictwa, związany z Instytutem Oświaty Pracowniczej, od 1935 roku redaktor naczelny „Przeglądu Organizacji”. Zagadnienia przemysłu spożywczego wykładał Damazy Tingler (1904-1996) jeden z twórców Centralnego Inspektoratu Standaryzacji i Eksportu Wyrobów Polskiego Przemysłu Mięsnego, po wojnie wieloletni profesor Politechniki Gdańskiej. Na wspomnianych kursach zajęcia prowadzili też przedstawiciele kadry kierowniczej 
„Plutona”. Program obejmował również zwiedzanie zaprzyjaźnionych przedsiębiorstw „Lawina” i „Płudy”. Bezpośrednim pomysłodawcą omawianej inicjatywy edukacyjnej był Jan Koelichen (1900-1963)41, wieloletni inspektor gimnazjum im. Mikołaja Reja. Po walkach w Kampanii Wrześniowej przeżył on okupację hitlerowską jako kierownik magazynu i ekspedycji „Plutona”. Był żołnierzem Powstania Warszawskiego (po II wojnie pracownikiem ZAiKS-u).

Kursy stanowiły więc jednocześnie okazję do dostarczenia młodzieży „Plutona" fachowej wiedzy, a także formę pomocy dla wykładowców, którym wojna bardzo ograniczyła możliwości ich zwykłej pracy. Poziom wspomnianych kursów sprawił, iż były nazywane „małym uniwersytetem”. Miały one rodzaj obrzędowości akademickiej z egzaminami i przyznawaniem nagród za osiągnięcia w nauce.

Wreszcie społeczne zainteresowania rodziny Tarasiewiczów kontynuowane były w „Plutonie” podczas okupacji hitlerowskiej poprzez inicjatywę stworzenia programu społecznego na okres powojenny Projekt koncentrował się wokół zagadnienia, jak przedsiębiorca mógłby wyobrażać sobie poprawę bytu pracowników. Chodziło na przykład o wprowadzenie ułatwień w kredytach mieszkaniowych, organizowanie wakacji itd. We wspomniany program, spośród osób spoza „Plutona” mocno zaangażował się Jerzy Zawieyski. Opracowanie tej problematyki powstało $\mathrm{w}$ formie pisemnej. Kordian Tarasiewicz oddał je po II wojnie jednej z pracownic „Inco”, gdy był jego dyrektorem. Do dziś wspomniane materiały nie zostały odnalezione.

Warto zasygnalizować fakt, iż intencjonalny transfer zarówno wartości, jak i dobrych praktyk z „Plutona” jego ostatni dyrektor starał się kontynuować także po zniszczeniu firmy przez władze administracyjne PRL-u podczas tak zwanej drugiej wojny o handel (1950 rok). Pracując od 1953 roku, o czym już pisałem wcześniej, na stanowiskach dyrektorskich w „Inco”, a później „Libelii”, jednocześnie dbał zarówno o zysk, jak i o pracowników. Już w czasach stalinowskich skutecznie minimalizował niedogodności prawne ograniczające możliwości zarobkowania przez kadrę zarządzającą firm prywatnych. Kordian Tarasiewicz wprowadził wówczas system patentów, zyskując dla ich autorów stały dodatek finansowy do pensji, nie lamiąc prawa gospodarczego nawet funkcjonującego w warunkach tak zwanego realnego socjalizmu (Ochinowski 2013).

Kwestią dalszych badań pozostaje sprawdzenie skuteczności kapitału kulturowego „Plutona”, także w ekonomicznych kategoriach funkcjonowania organizacji. Na razie pewne wskaźniki istnieją tylko dla okresu międzywojnia. Kredyt zaufania, który dostał od pracowników Kordian Tarasiewicz w 1934 roku, pozwolił zaoszczędzić fundusze i podjąć szereg działań naprawczych. Tak sam podsumował omawiany okres: „Niektórzy pracownicy doceniali, że coś nowego

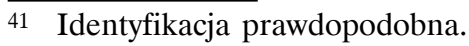


się dzieje, że podchodzę do pewnych tematów bardziej nowocześnie niż to było dotąd. Sprawa reklamy, sprawa opakowań, estetyki. Nawiązałem kontakty z projektantami, którzy byli bardzo zdolnymi grafikami polskimi tamtego pokolenia: Maciej Nowicki, Eryk Lipiński czy Jerzy Hryniewiecki. Takie sławne nazwiska zostały wciągnięte w to, żeby zmienić opakowania. Ogłosiliśmy konkurs na Wydziale Grafiki Politechniki Warszawskiej. Wygrał go Jerzy Hryniewiecki. Jego projekt „ziarnko kawy w płomieniu” funkcjonuje do tej pory. Był też szereg innych pociagnnięć: w sklepach zaczęliśmy wprowadzać nowoczesne oświetlenie neonowe, specjalne urządzenia zaprojektowali zdolni architekci. To ruszyło do przodu. Niestety trzeba powiedzieć, że nie było dużo czasu, bo w 1939 roku wybuchła wojna. Ale były to cztery lata intensywnej pracy, która dała ciekawe rezultaty" 42 . Warto dodać jeszcze zmiany zarządzania personelem wzorowane przede wszystkim na rozwiązaniach przyjętych w fabryce „Wedla” oraz wprowadzenie rodzaju franczyzy, dla chętnych chcących prowadzić własne sklepy. „Wszystkie wspomniane (...) przedsięwzięcia organizacyjne, jak wprowadzenie nowych opakowań, szkolenie pracowników i pomysłowa reklama spowodowały, że w 1935 roku obrót wzrósł o 3\%, w roku 1936 o 15\%, w 1937 o 20\%, a w 1938 o $22 \%$ w porównaniu z wynikami 1934 roku. Gdyby nie wybuch wojny w 1939 roku wyniki kształtowałyby się na poziomie lat koniunktury przed kryzysem początku lat trzydziestych" (Tarasiewicz 2010: 104).

\subsubsection{Kapitał kulturowy „Plutona” a koncepcja menedżerów transgranicznych}

Jak pisałem w pierwszym rozdziale, sięganie do przeszłości, mimo wielu oporów, bywa, także w polskich naukach o zarządzaniu uważane za zajęcie mające wartość aktualną, a nawet innowacyjną.

Interesujący przykład takiego poglądu zawiera koncepcja transgranicznej elity menedżerów, którą rozwija wspominany już wcześniej Kazimierz Doktór (2011). Autor ten wskazuje, iż wyzwania stające przed nowoczesną organizacją zdezaktualizowały takie narzędzia poznawcze, mające służyć kadrze kierowniczej, jak wielowymiarowe ujęcia stylów zarządzania wynikające $\mathrm{z}$ teorii sytuacyjnej, matryce poziomych funkcji zarządców sformułowane przez Fayola, pionowe role organizacyjne w ujęciu Mintzberga, kluczowe kompetencje czy tradycyjne ale wciąż żywotne typologie umiejętności strategicznych, taktycznych i operacyjnych. Te przykładowo wymienione za Doktorem (2011) koncepcje nie są w stanie, jego zdaniem, sprostać zadaniom, które stawia obecnie przed organizacjami skrajnie turbulentne otoczenie społeczne, by odwołać się do znanego określenia rozpropagowanego niegdyś przez Petera Druckera. Krytyczną cechę

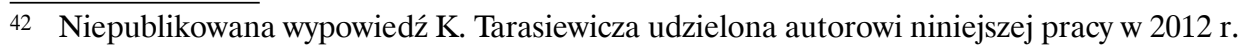


wspomnianej turbulencji stanowi oczywiście bardzo niska prognozowalność przyszłości. Doktór (2011: 159) upatruje poznawczą nadzieję na modernizację myśli i praktyki menedżerskiej w koncepcji „transgraniczności zarządców jako znaczącego elementu nowych strategii zarządzania w kulturze organizacji dla przyszłości”. Zdaniem cytowanego badacza, efekt działań transgranicznej elity menedżerów stanowi sytuacja, gdy stratedzy nie boją się ryzyka, wykonawcy pracują ponad ludzkie siły, zaś „kierownictwo opanowało trudną sztukę wymuszania posłuszeństwa i osiągania niebotycznych celów" (Doktór 2011: 160). Relacyjny aspekt opisywanej perspektywy zarządzania wyznacza funkcjonalna współpraca w „trójkącie”: właściciele - kierownicy liniowi - kierownicy sztabowi, skutkująca ograniczeniem skłonności autorytarnych u menedżerów oraz ich postawa typu „wielokulturowość to mój żywioł”, także w znaczeniu rozmaitości kultur biznesowych na terenie Polski, o których „nie śniło się” zachodnim teoretykom ${ }^{43}$.

Czynnikiem warunkującym sukcesy sygnalizowanej tu drogi zarządzania są przymioty osobiste menedżerów transgranicznych: posiadanie wizji, znajomość swoich misji, motywacja osiagnnięć, świadomość własnych kompetencji, umiejętność grania ról wynikających z wymagań rozwoju cywilizacyjnego.

I właśnie w tym aspekcie, choć nie tylko, Doktór (2011) pisze o użyteczności sięgania do doświadczeń historycznych. Wskazuje on na przykład, co już podkreślałem w pierwszym rozdziale niniejszej pracy, iż bardzo podobnym wyzwaniom menedżerskim, które dziś wymuszają transgraniczność, efektywnie stawiali czoła budowniczowie egipskich piramid czy stratedzy armii Państwa Środka z czasów powstawania Chińskiego Muru. Zaś wzorów osobowych skutecznej transgraniczności cytowany socjolog organizacji każe szukać pośród „polskich bohaterów zarządzana w biznesie" takich jak Eugeniusz Kwiatkowski, Hipolit Cegielski, Leopold Kronenberg, Izrael Kalmanowicz Poznański czy Ignacy Mościcki ze względu na stworzenie prosperity Mościc (Doktór 2011: 162).

Bez specjalnego trudu można wskazać przykłady transgraniczności także w historii rodzinnej firmy Tarasiewiczów. Przy czym doświadczenie „Plutona” pozwala wzbogacić wspomnianą koncepcję o jeszcze jedną zmienną. Menedżerowie omawianej palarni kawy konsekwentnie, co już wielokrotnie pokazywałem, łączyli efektywność oraz innowacyjność działań z prospołecznym stosunkiem do pracowników. Możliwość wyraźnego poszukiwania alternatywnych sposobów wobec tych wyłącznie stymulowanych maksymalizacją zysku - rozwijania efektywnej działalności biznesowej wydaje się być ważnym uzupełnieniem koncepcji zaproponowanej przez Kazimierza Doktóra. To nowe kryterium pozwoli też znacznie wzbogacić listę historycznych przykładów menedżerów transgranicznych $\mathrm{z}$ tradycji polskiej przedsiębiorczości.

43 Chodzi na przykład o swoistą „mieszankę” kultur kapitalizmu i naleciałości z poprzedniego systemu, zdarzającą się nadal w niektórych polskich przedsiębiorstwach lub choćby posiadających krajowe „korzenie” z czasów PRL-u. 
Warto dodać do niej choćby Jana Wedla, a także Mariana Wieleżyńskiego, Władysława Szaynocha i znowu Ignacego Mościckiego, tym razem jako współinicjatora (wraz z dwoma wcześniej wymienionymi) spółki „Gazolina”, poprzez którą realizowali oni swe ulubione hasła: „Robić! Robić!4 - „Zrobić! Zrobić!”45 - „Zarobić! Zarobić!46 (zob. np. Tarasiewicz 2010, Majcheld 2006, Wieleżyński 1985 i Bratkowski 1989). Charakterystyczną cechą proponowanych tu przykładowo „uzupełnień” listy bohaterów polskiego biznesu jest to, iż przedsiębiorcy ci łączyli efektywność oraz innowacyjność działań z prospołecznym stosunkiem do pracowników.

„Stwierdzić muszę - wspomniał po latach Kordian Tarasiewicz (2010: 96-97), główny bohater niniejszego podrozdziału - że wzorem przedsiębiorstwa przemysłowego była dla mnie ${ }^{47}$ fabryka czekolady »E. Wedel« i jej współwłaściciel i dyrektor dr Jan Wedel. Uwagę zwracała zwłaszcza świetna organizacja pracy i wystrój sklepów firmowych, poziom wykształcenia personelu, estetyka opakowań. Powszechnie znane były dobre stosunki z pracownikami i szereg udogodnień socjalnych, m.in. opieka lekarska. Sensację wzbudziła wiadomość, że firma zakupiła samolot RWD ${ }^{48}$ do przewozu pilnych przesyłek, a o pozycji firmy świadczył sklep filialny w Paryżu".

Z kolei spółka „Gazolina”, powstała przede wszystkim dla badań i innowacji, w okresie międzywojennym skutecznie przełamywała niemal monopolistyczną pozycję firm francuskich na polskim rynku naftowym. Jednocześnie zaliczyć ją należy do grona prekursorskich przedsiębiorstw na świecie, które poszukując sposobów stworzenia „ludzkich warunków pracy (...) z zachowaniem równowagi między przeciwstawnymi sobie pracą ludzką i kapitałem", rozdały akcje pracownikom, „z tym, że właściciel nie posiadał większości akcji a jedynie wraz z częścią tzw. stałych pracowników miał praktyczną większość głosów"49 (J.C. 1985: 8, Wieleżyński 1985).

Wiele danych wskazuje na to, iż podobne dążenie do równowagi między wysoką pozycją rynkową a humanistyczną postawą wobec pracowników cechowało również tak znane przedsięwzięcia biznesowe Polski okresu międzywojennego jak sklepy braci Jabłkowskich i braci Pakulskich (Jabłkowski 2005, Krajewska 2013).

Włączenie wymienionych tu przykładowo liderów firm do grupy polskich prekursorów menedżerów transgranicznych pozwala nieco skorygować wyznaczniki

44 Przypisywane Mościckiemu.

45 Przypisywane Szaynochowi.

46 Przypisywane Wieleżyńskiemu.

47 Chodzi o lata 30. XX wieku.

48 Samolot ten służył firmie Wedla także do realizacji innowacyjnych działań reklamowych.

49 Bohater niniejszego rozdziału Kordian Tarasiewicz wyraził w rozmowie ze mną wątpliwość, czy taka sytacja większościowego udziału pracowników rzeczywiście mogła mieć miejsce. 
efektywności tej kategorii zarządców. Skuteczność działań bohaterów biznesu również na naszych ziemiach niekoniecznie musiała opierać się na tym, iż wykonawcy pracowali ponad ludzkie siły, zaś „kierownictwo opanowało trudną sztukę wymuszania posłuszeństwa”, choć niewątpliwie osiągało także „niebotyczne cele" (Doktór 2011: 160).

Obecna sytuacja „okołokryzysowa” rodzi pytanie, na ile przyzwoity biznes jako rodzaj kapitału kulturowego organizacji, czy używając innej terminologii, także zaproponowanej w niniejszej pracy, działalność gospodarcza lub menedżerska oparta na triadzie podmiotowość - zaangażowanie - zakorzenienie możliwa jest do realizacji w niesprzyjającym takim rozwiązaniom społecznym otoczeniu. Bo przecież moralny nurt dyskusji o ostatnich turbulencjach gospodarki światowej świadczy o tym, że współczesna rzeczywistość globalna nie sprzyja takim modelom przedsiębiorczości, choć wydają się one konieczne jako obrona właśnie przed tymi turbulencjami. I, bez obawy popadnięcia w pompatyczność, jest to obrona samej gospodarki jak i globalnej społeczności. Chodzi więc o wykonalność zaleceń interpretatorów kryzysu przywoływanych w poprzedniej części pracy.

W takiej sytuacji pojawia się zasadne z punktu widzenia historii organizacyjnej pytanie o determinanty uprawiania „uczciwego biznesu” przez niektóre środowiska przedsiębiorców na terenie Polski od połowy XIX do połowy XX wieku. Problem ten wymaga odrębnych badań. Na razie podać można kilka odpowiedzi formułowanych przez współtwórcę oraz spadkobierców tamtego dziedzictwa.

Kordian Tarasiewicz (2013) i Jan Jabłkowski (Krajewska 2013) mówią w tym kontekście o tradycji rodzinnej. Tarasiewicz (2013) dodaje jeszcze inspiracje, jakie zawdzięczał publicystyce Polskiej Partii Socjalistycznej. Jabłkowski (2005) zwraca też uwagę na krytyczną cechę przedsiębiorców omawianego okresu, mianowicie myślenie o swojej firmie w długiej perspektywie, wielu pokoleń, zarówno przeszłych, ale przede wszystkim przyszłych. Tadeusz Władysław Świątek ${ }^{50}$ wskazuje dwa uwarunkowania nurtu ,przyzwoitego biznesu” wspomnianych lat: (1) fakt, iż większość ówczesnych przedsiębiorców z polskich ziem studiowała i praktykowała w Niemczech, gdzie miała okazję zetknąć się z mocno zaawansowaną problematyką społeczną oraz (2) ubóstwo społeczeństwa polskiego, wyznaczające specyficzny kontekst prowadzenia działalności gospodarczej. Ubogie środowiska pracowników wymagały szczególnej ostrożności ze strony pracodawców. Nigdy nie wiadomo było, jaka iskra może wywołać wybuch.

Sugestie Świątka wydaje się potwierdzać, bądź przynajmniej ilustrować, historia konkurencji między dwoma warszawskimi fabrykami słodyczy: „Wedlem” i „Fuchsem”.

$\overline{50}$ Informacja ustna, w rozmowie $\mathrm{z}$ autorem niniejszej pracy, lipiec 2013. 
Według świadectwa „Robotnika” - głównego organu PPS - na przełomie lat 20. i 30. ubiegłego wieku strajki w branży cukierniczej były stosunkowo częste. Na przykład rok 1928 przyniósł strajk fabryk „Machlejda”, „Plutosa” i „Fuchsa”. „Wedla” dotknęły strajki w latach 1929 i 1930. „Robotnik” z 5 IV 1928 roku tak opisywał stosunki pracy: ,położenie tych pracowników, znaczną część których stanowią kobiety, jest nad wyraz ciężkie, dość powiedzieć, że płace dla dorosłej robotnicy zaczynają się od 9-ciu zł tygodniowo. Traktowanie robotników przez administracje fabryczną ma formy nigdzie niepraktykowane: tykanie jest zjawiskiem powszechnym" (cyt. za Kazimierskim i Kołodziejczykiem 1978: 275).

Jan Wedel przyjął wówczas politykę zapewnienia na terenie swojej fabryki warunków pracy, które zostały wywalczone przez strajkujących w innych zakładach. Zyskał tym przychylność pracowników. Chronologicznie pierwsze znaczące podwyżki dali strajkującym właściciele „Fuchsa”. Dopiero kierując się tym faktem, Wedel także podwyższył wynagrodzenie swoim zatrudnionym. Od lutego 1929 roku w poszczególnych fabrykach słodyczy obowiązywała umowa zbiorowa, regulująca minimalne zarobki dla robotnic ( 22 zł tygodniowo) i robotników (38 zł tygodniowo).

Kilka lat później w 1937 roku robotnicy „Fuchsa” znowu zastrajkowali. Właściciel długo zwlekał z przyjęciem żądań pracowniczych dotyczących podwyżek oraz poprawy warunków pracy. Strajk się przedłużał. Wedel, który już wtedy miał rozbudowany jeden z nowocześniejszych w Europie systemów opieki socjalnej nad robotnikami, wszedł w lukę rynkową zrobioną przez Fuchsa i tym samym skutecznie go pokonał w walce konkurencyjnej ${ }^{51}$.

Jako kolejny mały krok zmierzający ku odpowiedzi na pytanie o możliwości i ograniczenia realizacji kapitału kulturowego organizacji opartego na triadzie „podmiotowość - zaangażowanie - zakorzenienie” proponuję analizę przypadku pojedynczego przedsiębiorcy, który rozwijał swą działalność gospodarczą zaraz po II wojnie światowej i został boleśnie doświadczony przez kryzys lat stalinowskich. Historia Stanisława Jachniaka została mi wskazana przez Kordiana Tarasiewicza. Następny podrozdział poświęcony Jachniakowi, zamykający moją pracę, jest też zarazem relacją, oczywiście przyczynkarską z ostatniego etapu przyzwoitej przedsiębiorczości „burżua oświeconych”. Jak mam nadzieję, tradycji rekonstruowanej także dziś nie tylko przez „Biedroneczkę”. Planuję to sprawdzić w następnych badaniach.

51 Podany przykład powstał dzięki opracowaniu Juliana Walczaka i Jacka Porębskiego, uczestników mojego wykładu ogólnouniwersyteckiego na UW z dziejów polskiej przedsiębiorczości w roku akademickim 2012/2013. 


\subsection{Rekonstrukcja biografii Władysława Jachniaka (1915-1994) i jej znaczenie dla dyskusji o optymalnym modelu biznesowym w kontekście kryzysu}

\subsubsection{Mit biograficzny, doświadczenia wojenne i szczyt działalności przedsiębiorczej Władysława Jachniaka}

Władysław Jachniak - przedsiębiorca reprezentujący kolejne pokolenie „niepokornych"52 - nie doczekał się dotąd ani pełnej biografii, ani analizy swoich prac. Przedstawiony szkic stanowi przyczynek do syntezy dostępnych archiwaliów, wspomnień oraz publikacji zarówno podmiotowych, jak i przedmiotowych dotyczących jego osoby ${ }^{53}$. Niniejszy podrozdział jest więc kolejnym w prezentowanej książce zaproszeniem do krytycznej dyskusji nad zapomnianym życiem i zapomnianą działalnością, zasługującymi - zgodnie z moją nieśmiałą nadzieją - na przywrócenie pamięci przede wszystkim przedsiębiorców.

Władysław Józef Jan Jachniak urodził się 10 lutego 1915 roku w Starym Sączu. Dokładnie rzecz ujmując przyszedł na świat jako wcześniak podczas przymusowej podróży ewakuacyjnej związanej z I wojną światową.

Świadek pierwszych chwil życia Władysława Jachniaka, Daniel Kalasiński (nauczyciel lwowskiego gimnazjum), miał tę historię opatrzyć następującym komentarzem: „Toć ty urodzony przed czasem, w pociągu. Sądzono, że umrzesz, ale uchwyciłeś się życia pazurami i chyba go nie popuścisz" (Sobolewski 2011).

Powyższy cytat najwyraźniej stał się rodzajem biograficznego mitu bohatera niniejszego szkicu, mitu rozumianego za Michaelem de Certeau (2008) - co warto przypomnieć - jako zbiór fragmentarycznych narracji związanych

52 Odwołuję się tu do znanej metafory Bohdana Cywińskiego z jego książki Rodowody niepokornych (1971/2010). Warto zauważyć, iż tytułowa kategoria doczekała się ostatnio analizy w kontekście historii idei istotnych dla Polaków na przestrzeni ostatniego półwiecza (Gawin 2013). Mam nadzieję, że naszkicowane w tym podrozdziale życie Jachniaka nie wymaga żadnego dodatkowego komentarza, który musiałaby uzasadniać włączenie go do grona „niepokornych”.

53 W niniejszym szkicu biograficznym wykorzystałem następujące źródła:

a) moje rozmowy z Kordianem Tarasiewiczem (od 2010 r.) i prof. Janem Śliwą, WZ UW (lipiec 2010 r. i później uzupełnianie);

b) publikacje: Poksiński J. (1992); Tatar-Utnik-Nowicki TUN. Represje wobec oficerów Wojska Polskiego w latach 1949-1956, Warszawa; Poksiński J. (1996), 'My sędziowie, nie od Boga...' Z dziejów sądownictwa Wojskowego PRL 1944-1956. Materiaty i dokumenty, Warszawa; Jachniak W. (1987), Oskarżam, Kraków; Suchorowska D. (1990), Wielka edukacja, Warszawa.

c) materiały archiwalne z prywatnego archiwum Kordiana Tarasiewicza (teczka Wtadystaw Jachniak 1915-1994); IPN (IPN BU 00 945) oraz archiwum Wydziału Zarządzania UW (Wtadystaw Jachniak. Przewód doktorski 1969-1971. Materiał archiwalny WZ $531)$. 
z różnorodnymi praktykami danej jednostki, które wyrażają jej życie w sposób symboliczny ${ }^{54}$.

Mityczną funkcję dla przyszłego handlowca spełniała prawdopodobnie również postać wcześnie zmarłego ojca. Świadczy o tym relacja Jachniaka udzielona w reportażu Janusza L. Sobolewskiego (2011): „Co innego (w przeciwieństwie do ojczyma - uwaga T.O.) mój ojciec. Przystojny. Skończył gimnazjum, ładnie tańczył. Bardzo żywy, zaradny. Zaczął studiować chyba nawet psychologię. Pamiętam go, choć kiedy umarł, miałem trzy lata. Razem z Ircią stawiał mi bańki. Siostra płakała, a ja nie. Za odwagę dostałem karmelki. Ojciec imał się każdej roboty, za groszem poszedł do pracy na kolei. Został dyżurnym ruchu w Starym Sączu 5 . Czasy ciężkie, wojna światowa. Z wojskami maszerowała epidemia tyfusu plamistego. Ojciec zaraził się. W lazarecie nabawił się zapalenia płuc. Umarł w grudniu 1918 roku”.

Matka, Stanisława z Krzyżanowskich, miała niepełne średnie wykształcenie, była uczennicą w szkoły handlowej ${ }^{56}$.

W 1920 r. rodzina pięcioletniego chłopca przeniosła się do Krakowa. Jachniakowi przyszło tam spędzić następne ćwierćwiecze w dość trudnych warunkach materialnych. Przez okres dzieciństwa jego adresem był dom rodziców matki, gdzie zamieszkał z nią i ze starszą od siebie o dwa lata siostrą Ireną. Dziadek stał się dla Jachniaka osobą wyraźnie psychologicznie ważniejszą niż ojczym (matka wyszła powtórnie za mąż). $\mathrm{Z}$ dziadkiem i babcią wiąże się także dopełnienie biograficznego mitu Jachniaka. Dokładnie w dniu urodzin przyszłego przedsiębiorcy zginął na froncie najstarszy syn Krzyżanowskich, Władysław, absolwent gimna-

54 Perspektywa retoryczna pozwala zobaczyć mit biograficzny na dwóch zazębiających się płaszczyznach: jako dyskursu „wyjaśniającego” daną biografię poprzez rekonstrukcję jej wiodącego argumentu (bądź argumentów) możliwą do uchwycenia przez zewnętrznego interpretatora oraz jako świadomie przyjętej przez bohatera biografii życiowej „,idei wiodącej" (i prezentowanej przez niego jako takiej), zaczerpniętej z rodzinnych opowieści. W przypadku Władysława Jachniaka obydwie płaszczyzny wydają się być wyraźnie widoczne, co jak mam nadzieję, pokazuje również niniejszy szkic. Mit biograficzny staje się tu podobny do skryptu życiowego z koncepcji Erica Berne'a, a także do „mitów rodzinnych" znanych z terapii systemowej.

55 Władysław Jachniak na kartach wyboru swoich tekstów wydanych pod redakcją Danuty Suchorowskiej (1987) podaje, iż ojciec był kolejarzem. Z kolei według raportu funkcjonariusza Urzędu Bezpieczeństwa w związku z inwigilacją Jachniaka w latach czterdziestych i pięćdziesiątych ubiegłego stulecia ojciec tegoż pracował jako buchalter na kolei. Przytoczony dokument twierdzi, że po 1920 roku ojciec utrzymywał całą rodzinę, która przeniosła się do Krakowa (zob. Pismo Naczelnika Wydziału A. kpt. A. Górnika do Naczelnika Wydziału I (Gdańsk, dn. 07.04.1950). IPN BU 00945/840/I/MF- 4088/1). Według świadectwa Jachniaka, ojciec zmarł w 1918.

56 Jak zwróciła uwagę Barbara Czarniawska, powołując się na analizy Nocy $i$ dni Marii Dąbrowskiej, zawód sprzedawczyni był zwyczajowo uznawany jako odpowiedni dla kobiet przełomu XIX i XX w. na ziemiach polskich. Niewątpliwie jednak nietypową sytuację stanowiło wykształcenie matki Jachniaka, z czego syn był bardzo dumny (zob. Sobolewski 2011). 
zjum. Powołanie do austriackiego wojska przerwało mu studia politechniczne. Jego rodzice, a więc dziadkowie Jachniaka, wiązali ze swym najstarszym synem duże nadzieje: „Dostałem imię po wujku z zobowiązaniem, by dojść do czegoś w życiu", wspominał po latach bohater niniejszego szkicu (Sobolewski 2011).

Gdy Jachniak dorósł, początkowo kontynuował tradycje rodzinne pracy na kolei, równocześnie rozwijając własne zainteresowania działalnością handlową (dziś nie sposób jest ustalić, jaki wpływ miało na to wykształcenie matki), którym pozostał wierny praktycznie przez cale życie, pomimo różnorodnych, często skrajnie trudnych przeciwności.

Bohater niniejszego szkicu ukończył najpierw Seminarium Nauczycielskie (w 1935 roku), a dwa lata później został absolwentem Gimnazjum Matematyczno-Handlowego. Następnie wybrał jako miejsce zdobycia wyższego wykształcenia krakowskie Wyższe Studium Handlowe ${ }^{57}$. Uczęszczał tam od 1937 do 1939 roku. Od początku szkoły średniej, to jest od czternastego roku życia, zarabiał korepetycjami. Finansowo pomagał również młodszym barciom. Podczas studiów odbył praktykę referendarską w Wydziale Handlowo-Taryfowym krakowskiej Dyrekcji Polskich Kolei Państwowych ${ }^{58}$.

Lata 1935 i 1936 Jachniak spędził - powołany do wojska - jako żołnierz 82. oraz 83. Pułku Piechoty na terenie Brześcia nad Bugiem i Kobrynia. W pierwszym z wymienionych miejsc ukończył Dywizyjną Szkołę Podchorążych Rezerwy przy 82. Pułku Piechoty, specjalizując się w zakresie karabinów maszynowych i dział pancernych. Otrzymał wówczas stopień sierżanta. Ostatecznie przeszedł do rezerwy jako podporucznik.

Tuż przed wybuchem II wojny znowu został wezwany do służby wojskowej (najprawdopodobniej chodziło o powszechną mobilizację 193959). Podczas wrześniowych walk dowodził kompanią ciężkich karabinów maszynowych. Brał

57 Wyższe Studium Handlowe w Krakowie - poprzednik obecnego Uniwersytetu Ekonomicznego w Krakowie, powstało w 1925 roku, od 1937 roku do 1950 roku pod nazwą Akademia Handlowa, w 1945 roku uczelnia zyskała prawa nadawania tytułu zawodowego magistra, w 1959 roku stopnia doktora, w 1961 roku habilitacji. W latach 1950-1974 nosiła nazwę Wyższa Szkoła Ekonomiczna, w latach 1947-2007 Akademia Ekonomiczna, od 2007 Uniwersytet Ekonomiczny w Krakowie.

58 Dokumenty wyprodukowane przez funkcjonariuszy Urzędu Bezpieczeństwa w związku z inwigilacją Jachniaka w latach 40. i 50. ubiegłego stulecia dość niejasno sugerują, iż wspomnianą praktykę odbył on po ukończeniu seminarium nauczycielskiego, a później - po odbyciu służby wojskowej - pracował na kolei jako urzędnik. Jednak za bardziej wiarygodną uznaję wersję Jachniaka podaną przez niego w dokumentacji związanej z przewodem doktorskim (przełom lat sześćdziesiątych i siedemdziesiątych ubiegłego wieku), por. Pismo Naczelnika Wydziału A... 1950... dz. cyt. oraz Wtadystaw Jachniak. Przewód doktorski 1969-1971. Materiał archiwalny WZ-531. Archiwum Wydziału Zarządzania UW.

59 Wiadomość o powołaniu do wojska podaje dokument związany z późniejszą inwigilacją: Jachniak Pismo Naczelnika...(1950), o którego niejasnościach pisałem w poprzednim przypisie. 
udział w obronie Brześcia. Później dotarł z rozbitymi oddziałami do Tarnopola, gdzie pod dowództwem gen. Aleksandra Narbutta-Łuczyńskiego z Armii Kraków organizowana była pomoc dla Lwowa. Gdy Tarnopol zajęły wojska radzieckie, Jachniak przedostał się do Krakowa. Czekali tam na niego nieletni bracia oraz umierająca matka.

Przez dalszy okres wojny, aż do stycznia 1945, Władysław Jachniak pracował w Składnicy i Rozdzielni Żywnościowej dla ludności polskiej na prawym brzegu Wisły. Był tam prokurentem. Podobnie jako opisany wcześniej Stanisław Bukowski, także bohater niniejszego szkicu reprezentował tych praktyków zarządzania, którzy w ciężkich warunkach okupacyjnych wykorzystywali swe kompetencje biznesowe nie tylko do utrzymania rodziny, ale także do realizacji szerszej służby społeczeństwu.

„I choć nie tędy przebiegała linia frontu z Niemcami - pisał po latach - był to bez wątpienia równie ważny odcinek działalności konspiracyjnej - niedopuszczenie do biologicznego wyniszczenia narodu" (Jachniak 1987: 10).

W przytoczonym cytacie warto zwrócić uwagę na zwrot: „,równie ważny odcinek działalności konspiracyjnej...”. Bowiem dwudziestokilkuletni handlowiec tylko oficjalnie był pracownikiem składnicy. Równocześnie głęboko angażował się w działalność Polskiego Państwa Podziemnego. Już od listopada 1939 należał do Organizacji „Białego Orła” i Związku Walki Zbrojnej. Jak wspominał później, wymienione struktury powstawały na terenie Krakowa głównie w oparciu o znanych sportowców oraz studentów (Jachniak 1987). Później zgodnie z przekształceniami organizacyjnymi podziemia Jachniak przeszedł do AK.

Zarówno w tej organizacji, jak i wcześniej, jako członek ZWZ pełnił obowiązki kwatermistrza IV Odcinka (rejonu) prawobrzeżnej części Krakowa. Jego działalność aprowizacyjna obejmowała tereny krakowskiego Podgórza, Płaszowa i Borka Falęckiego, łącznie z gettem i obozem koncentracyjnym Kraków-Płaszów, a także służyła żołnierzom oddziałów partyzanckich z Beskidów i Podhala.

Ponadto „Ludwik” czy „kpt. Zięba” (takich pseudonimów używał Jachniak) prowadził akcję wywiadowczą na temat dyslokacji sił zbrojnych wroga. Rozpoznanie to opierało się między innymi na rzetelnej znajomości niemieckich planów i działań aprowizacyjnych.

Jesienią 1944 Jachniak rozszerzył swe obowiązki kwatermistrzowskie także na ludność cywilną Warszawy, ewakuowaną po Powstaniu Warszawskim do Inspektoratu Krakowskiego.

Dwa lata wcześniej Władysław Jachniak został porucznikiem, a w 1943 kapitanem. Dwukrotnie (1942 i 1943) Komenda Główna AK uhonorowała go - kolejno brązowym i srebrnym - Krzyżem Zasługi z Mieczami „za pracę na rzecz pomocy Żydom, więźniom obozów koncentracyjnych i nauczycielom konspiracyjnego szkolenia" (Jachniak 1987: 10). Rozkazem tejże samej Komen- 
dy z dnia 3 września 1944 roku Jachniak został odznaczony Orderem Virtuti Militari V klasy. Był to wyraz uznania dla osiągnięć niespełna trzydziestoletniego oficera w służbie wywiadowczej oraz w sabotażu żywnościowym i zbrojeniowym na obszarze Okręgu Krakowskiego AK.

Koszmar okupacji i konspiracyjne zaangażowanie nie przeszkodziły Jachniakowi w rozwoju życia osobistego. Ożenił się z warszawianką Haliną Płatek, która podczas wojny zamieszkała w Krakowie i pracowała jako buchalterka prywatnej firmy „Maria Krzyżanowska”. W lutym 1944 urodziła się im córka Danuta.

Po zakończeniu okupacji niemieckiej bohater niniejszego szkicu ujawnił się i poddał wersyfikacji przez Komisję Weryfikacyjną AK Okręgu Krakowskiego. Otrzymał wówczas stopień majora rezerwy (styczeń 1945).

Zaraz po wojnie Władysław Jachniak stał się aktywnym uczestnikiem dynamicznego rozwoju przedsiębiorczości w Gdańsku, a zwłaszcza handlu zagranicznego. Ten fenomen drugiej połowy lat 40. ubiegłego stulecia wielokierunkowej działalności gospodarczej na wydłużonym po II wojnie polskim wybrzeżu, ze szczególnym uwzględnieniem Trójmiasta, do dziś nie doczekał się naukowej analizy A były to działania pełne entuzjazmu, a jednocześnie racjonalnie zarządzane przez takich liderów jak Eugeniusz Kwiatkowski. Ze szczątkowych opracowań, a przede wszystkim ze wspomnień wyłania się obraz całej rzeszy przedsiębiorców, którzy wyruszyli w tamtym czasie „nad morze”, by formalnie wspierani przez władze Polski komunistycznej, zagospodarować mienie poniemieckie, odbudować zniszczenia, rozwinąć przemysł stoczniowy, a także handel wewnętrzny i zagraniczny. W większości były to rentowne inicjatywy oparte na zasadach wolnorynkowych. Powstawało mnóstwo, dziś już niestety zapomnianych, mniejszych czy większych przedsiębiorstw różnego typu. Niektóre $\mathrm{z}$ nich napotykały trudności ze strony biurokracji państwowej już od samego początku swego istnienia, większość stalinowski reżim agresywnie zniszczył w końcu lat czterdziestych ubiegłego stulecia. Podstawową bronią w tej walce były horrendalnie duże tzw. domiary oraz oskarżenia o rzekome nadużycia. Nierzadko „pomorski epizod” kończył się dla przedsiębiorcy czy menedżera ciężkim więzieniem (zob. np. Dąbrowski 2004 i Trawicki 2010).

Losy Jachniaka stanowią swoistą kwintesencję wspomnianych zjawisk.

Już w kwietniu 1945, po wygraniu konkursu na rozwiązanie aprowizacji Wybrzeża i uruchomieniu tam przemysłu spożywczego, bohater niniejszego szkicu wyjechał z rodziną nad Bałtyk. Wziął bardzo aktywnie udział w ożywieniu przedsiębiorczości na tych terenach, szczególnie jeśli chodzi o handel zagraniczny. Początkowo pełnił tylko funkcje administracyjne, by dość szybko skanalizować swoją energię w równolegle rozwijanej działalności sensu stricto gospodarczej, koncepcyjnej i doradczej.

Został członkiem Grupy Operacyjnej nad Morzem Komitetu Ekonomicznego, następnie kierownikiem Przemysłu Spożywczego w Zarządzie Miejskim 
w Gdańsku. Zamieszkał na terenie Wrzeszcza. Jeszcze w 1945 roku założył Spółdzielnię Pracowników Biura Odbudowy Portów „Dźwig” oraz objął funkcję kierownika Wydziału Handlowego gdańskiego Urzędu Miejskiego. Następnie uruchomił własną firmę: Biuro Handlowo-Przemysłowe „Comercia” w swoim domu we Wrzeszczu'60. Kierował nią do 1947 roku.

Przez cały okres pobytu na Wybrzeżu (w latach 1945-1950) przedsiębiorczej działalności Jachniaka, jak wynika z jego późniejszych wspomnień, towarzyszyła równie intensywna własna aktywność koncepcyjna. Był on między innymi:

- projektodawcą prac dotyczących aktywizacji importu i eksportu oraz prac negocjacyjnych związanych z przygotowaniem umów i traktatów handlowych, przepisów standaryzacyjnych dla importerów oraz stabilizacją finansową Polski,

- autorem projektu organizacji importu marynarskiego, importu (związanego $\mathrm{z}$ amnestią kapitałową, eksportu wewnętrznego oraz tak zwanego eksportu małego i pionierskiego (realizowanego przez drobną wytwórczość),

- autorem licznych materiałów dotyczących interesów morskich przygotowanych dla potrzeb prac sejmowych Eugeniusza Kwiatkowskiego.

Możliwość współpracy z Kwiatkowskim Jachniak bardzo sobie cenił. Byłego wicepremiera i twórcę Gdyni, który po wojnie odmówił katedry uniwersyteckiej w Szwajcarii, by mimo panowania ustroju komunistycznego wziąć po raz drugi odpowiedzialność za rozwój polskiego Wybrzeża, bohater niniejszego szkicu wyraźnie uważał za swego mentora. „Wykonując te wszystkie prace - wspominał po latach - z pasją młodego człowieka, jakim wówczas byłem - miałem szczęście spotkać wspaniałego człowieka o ogromnej wiedzy i poczuciu humanizmu i sprawiedliwości - m.in. inż. Eugeniusza Kwiatkowskiego (...)” (Jachniak 1987: 10).

Również po latach Jachniak (1988) opublikował na łamach czasopisma „Wektory” szkic prezentujący sylwetkę Kwiatkowskiego, opatrując ten tekst znamiennym podtytułem: polscy humaniści XX wieku ${ }^{61}$.

Zresztą, przy zachowaniu proporcji, uznanie było obopólne. Jako wyraz wysokiej oceny materiałów przygotowanych przez Jachniaka dla potrzeb prac sejmowych, Kwiatkowski zaproponował, by ich autor został delegatem Zrzesze-

60 Według dokumentu inwigilacyjnego Władysław Jachniak założył „Comercię” w 1946 roku po zwolnieniu się ze stanowiska kierowniczego w Urzędzie Wojewódzkim (Pismo Naczelnika Wydziału A... 1950... dz. cyt.). Inne doniesienie tego typu mówi, że później założył także firmę „Nautic” w Gdyni (Pismo szefa Woj. UBP w Gdańsku ptk. Jurkowskiego do Naczelnika Wydz. III Dep. I-go MBP [Gdańsk, dn. 11.05. 1949] IPN BU 00945/840/I/ MF- 4088/1). Nie znalazłem potwierdzenia tych informacji w bardziej wiarygodnych źródłach, niż przytoczone tutaj.

61 Jachniak użył sformułowania „humanista” jako oceny sposobu działań menedżerskskich Kwiatkowskiego, a oczywiście nie jako określenie rodzaju wykształcenia twórcy Gdyni, który specjalizował się w naukach ścisłych. 
nia Importerów i Eksporterów z Wybrzeża do Zarządu Głównego w Warszawie, co się urzeczywistniło. Już wcześniej bohater niniejszego szkicu pełnił funkcję sekretarza, a następnie wiceprezesa Zrzeszenia na całe Wybrzeże.

Jak oceniał sam Jachniak (1987: 10) dzięki jego pracom koncepcyjnym i związanym z nimi zabiegom „do kasy państwowej wpłynęły miliony dolarów i miliony złotych". Widział w tych działaniach, ale także w swojej aktywności jako prywatnego przedsiębiorcy realizację zapisów prawnych Ustawy o Ulgach Inwestycyjnych z czerwca 1947 roku, która przynajmniej literalnie nastawiona była na wprowadzenie „do gospodarki kraju jak najwięcej środków finansowych, celem zaspokojenia palących potrzeb społeczeństwa i jak najszybszego zlikwidowania zniszczeń wojennych" (cyt. za Jachniakiem 1987: 10). Trudno stwierdzić, na ile wspomniany wątek „propaństwowy”, który uwypuklam za wspomnieniami Jachniaka powstałymi w czasach PRL-u, stanowi element retoryki oddający „ducha czasu” spisania autobiografii, gdy prywatni przedsiębiorcy musieli „tłumaczyć się" ze swej aktywności, a na ile jest relacją faktów, które były ważne dla samego bohatera, stanowiąc tym samym świadectwo prospołecznych zaangażowań działacza gospodarczego, czy może - szerzej - działaczy gospodarczych $z$ kręgu idei symbolizowanych przez postacie takie jak Eugeniusz Kwiatkowski. Być może też łączenie aktywności na rzecz państwa oraz własnej działalności biznesowej było zjawiskiem typowym z przyczyn strategicznych lub/i ideowych dla polskich przedsiębiorców pierwszych lat powojennych. Konieczność, ale także entuzjazm odbudowy życia zarówno prywatnego jak i społecznego musiały się przecież zmieścić w coraz bardziej ciasnych ramach uwarunkowań nowego ustroju, stanowiącego pochodną braku suwerenności państwa.

Taka swoista „mieszanka kulturowa”, w znaczeniu szeroko rozumianej kultury organizacyjnej czasów bezpośrednio powojennych, szczególnie do lat 1948-1950, gdy nie wszystkie cechy „nowego porządku” były jeszcze oczywiste dla mieszkańców Polski, zasługuje na oddzielną analizę. Dotychczas zostaje ona pomijana nawet przez tak wnikliwych badaczy jak znawcę dziejów Pomorza po 1945 roku Piotra Perkowskiego (2013), który relację z aktywności prywatnych przedsiębiorców na terenie powojennego Gdańska ogranicza do opisu wąskiej, choć niewątpliwie istotnej, grupy właścicieli barów i restauracji.

Pozostaje świadectwo wspomnień. Janowi Łopuskiemu (2007), autorowi autobiograficznej pracy pod sugestywnym tytułem Pozostać soba w Polsce Ludowej. Życie w cieniu podejrzeń atmosfera polskiego Wybrzeża bezpośrednio po II wojnie przypominała tę z lat 1937-1939, gdy jako student odbywał wakacyjne praktyki $\mathrm{w}$ przedsiębiorstwie związanym $\mathrm{z}$ handlem morskim na terenie Gdyni. „Działały państwowe i prywatne, także przedwojenne firmy” - pisał o czasach oraz miejscach wspólnych jemu i Jachniakowi, którego najwyraźniej jednak nie spotkał - agencyjne, maklerskie, spedycyjne i składowe, wracała rozproszona po świecie flota handlowa (...). Czuło się powszechne zaangażo- 
wanie w odbudowę i rozbudowę polskiej gospodarki morskiej. Nie odczuwało się presji ideologicznej” (Łopuski 2007: 45-46). Autor cytowanego fragmentu wspomnień odnoszącego się do okresu 1947-1948 podkreśla również dość dużą wówczas swobodę w nawiązywaniu przez obywateli polskich kontaktów handlowych, a także osobistych z działającymi w Gdyni cudzoziemcami, zagranicznymi firmami i konsulatami.

Wracając - na tym tle - do doświadczeń Władysława Jachniaka, to wyraźnie jego największym sukcesem z „okresu pomorskiego” była firma Zjednoczenie Kupców dla Handlu Zagranicznego „Unia”62 w Gdyni, którą współorganizował w 1946 roku i z którą związał się zawodowo. Rok później został członkiem Zarządu tego przedsiębiorstwa, a od 1948 wiceprezesem Rady Nadzorczej. Co jednak najważniejsze, bohater niniejszego szkicu pracował w „Unii” jako dyrektor finansowy. Głównie dzięki niemu wspomniana inicjatywa biznesowa stała się jedną z dynamicznych firm importu i eksportu, szczególnie marynarskiego na polskim Wybrzeżu. Jachniak wprowadził na przykład krótkofalówki jako narzędzie pracy handlowej, dzięki czemu przedstawiciele „Unii” mogli szybciej niż konkurencja rozpoczynać negocjacje z marynarzami, których statki wpływały do portów Trójmiasta. Konieczne jest przy tym podkreślenie faktu, iż opisywana firma przez cały czas swego niezależnego istnienia, nawet podczas końcowej fazy, gdy była brutalnie niszczona przez stalinowski reżim, „nie straciła - co z dumą podkreślał dyrektor finansowy - ani jednego centa i ani jednego grosza" (Jachniak 1987: 13).

W archiwach IPN zachowały się niezwykłe wyrazy uznania dla tych i innych działań przedsiębiorczych bohatera niniejszego szkicu na Wybrzeżu. Zapewne nigdy się on o nich nie dowiedział. Chodzi o charakterystykę Jachniaka sporządzoną przez oficera MO w 1958 roku. „Z pełnym oddaniem rzucił się - raportował kapitan Turała o gdańskich i gdyńskich latach omawianego przedsiębiorcy - w wir odbudowy życia gospodarczego na Wybrzeżu. Szczególnie na odcinku importu-eksportu" 63 . Dalej funkcjonariusz podkreślał fakt pozytywnych opinii o pracy Jachniaka. Autor podobnego, wcześniejszego o rok raportu, towarzysz Curyło, pisał, że były dyrektor „Unii” opowiadał podczas przesłuchania w gmachu Komendy Głównej MO o swej pracy we wspomnianej firmie. Kontekst przytoczonej informacji pozwala przypuszczać, iż Jachniak właśnie tę pracę uważał za główne źródło swych doświadczeń zawodowych ${ }^{64}$.

62 Przypadkowa zbieżność nazwy z konspiracyjną organizacją zrzeszającą liderów Nowej Kultury Pracy (zob. rozdz. III, podrozdział 3.3. niniejszej książki).

63 Raport o zezwolenie na werbunek informatora... sporzadzony przez kpt. Z. Turate (Warszawa 08.05.1958), IPN BU 00945/840/I/MF-4088/1, s. 2.

64 Raport z przeprowadzonej rozmowy na kandydata do werbunku... protokotowat tow. Curyto (Warszawa 07.12.1957) IPN BU 00945/840/I/MF-4088/1. 
Wracając do „czasów pomorskich” prezentowanego przedsiębiorcy, trudno oprzeć się konkluzji, że „Unia” realizowała model prywatnego przedsiębiorstwa, który stanowił bolesny wyrzut dla państwowych podmiotów „planowej” gospodarki PRL-u. Na karty literatury pięknej ten spór „socjalistycznej teorii” z życiową praktyką przeniósł Leopold Tyrmand w książce Siedem dalekich rejsów (1972/2009: 123-124) posługując się przykładem organizacji zbliżonej charakterem działania do „Unii”:

„- Panie kapitanie - zdenerwował się Tołłoczko - ja jednak myślę, że jak prywatna firma weźmie się za robotę, to potrafi obskoczyć stateczek jak trzeba i wyekspediuje go w jeden dzień. Tak już jest, panie kapitanie. Co innego firma państwowa. U niej to trwa.

- Znakomicie, Tołłoczko - ucieszył się Stołyp - Jak na dziejowego materialistę i członka partii, przemawiacie olśniewająco.

- Nic na to nie poradzę - odparł Tołłoczko - ale tak już jest. Ja wcale nie mówię, że tak powinno być, ale tak jest”.

Wyrazem sprawności organizacyjnej dyrektora finansowego „Unii” niech będzie choćby fakt, przytaczany przez Jachniaka, zrealizowania przez opisywane przedsiębiorstwo 52 transakcji z 40 krajami w ciągu 60 dni. Co warto pokreślić, przy tak dużym przedsięwzięciu nikt spośród kadry zarządczej i personelu firmy ani razu nie wyjechał za granicę. Było to ewenementem wobec praktyki podobnych instytucji nie tylko w tamtych czasach. Inny wyjątek stanowił poziom zarobków dyrektora, tylko o $40 \%$ większy od przeciętnego wynagrodzenia pracownika „Unii”65.

Nie znaczy to jednak, że rodzina Jachniaka cierpiała biedę. Dotychczasowe osiagnięcia gospodarcze bohatera niniejszego szkicu, sprawne współkierowanie „Unią” i prawdopodobne udziały w niej, podobne związki z inną firmą handlu zagranicznego „Harpun”, funkcja radcy - korespondenta gdyńskiej Izby Przemysłowo-Handlowej w Gdyni oraz członka Komisji Morskiej66 sprawiły, iż dla Władysława Jachniaka lata 1945-1947 to niepowtórzony już nigdy później czas harmonii między zaangażowaniem w sprawy społeczeństwa a osobistym dobrobytem. Od 1947 lub 1948 roku Jachniakowie z małą córeczką mieszkali na terenie Gdyni. Żona nie podejmowała pracy zawodowej. W ich domu starczyło miejsca także dla jej matki i brata, dla jednego z przyrodnich braci Władysława, dla pomocy domowej oraz dla jednego z pracowników „Unii”67.

65 A był to już czas powolnego demoralizowania się w atmosferze PRL-u kadry zarządzającej firmami handlu zagranicznego, szczególnie państwowych, której „celem było napełnianie własnego portfela pod szyldem państwowym oraz stałe wyjazdy za granicę, podobno w celu 'pertraktacji' handlowych (Jachniak 1987: 13).

66 Trudno powstrzymać się od zwrócenia uwagi na niezwykle dynamiczną dekompresję ryzyka w działalności przedsiębiorczej Jachniaka.

67 Do 1948 roku, według cytowanego już wielokrotnie doniesienia agenturalnego, w domu Jachniaków mieszkała także Joanna Styczeń, inna pracownica „Unii” (Pismo Naczelnika Wydziatu A... 1950... dz. cyt.). 
Jeszcze kilka lat później funkcjonariusz gdańskiego Urzędu Bezpieczeństwa raportował swoim zwierzchnikom, wykorzystując dane z inwigilacji, że Jachniakowe „żyją na wysokim poziomie” i przypisywał im posiadanie pensjonatu w Zakopanem, połowy domu w Krakowie oraz taksówki w którymś z mniejszych miast Pomorza ${ }^{68}$. Znacznie wcześniej stalinowska biurokracja lokalna ukuła dla rzutkiego przedsiębiorcy przezwisko „Polski Ford”. Przydomek ten będzie elementem bezpardonowych prób zniszczenia Jachniaka.

\subsubsection{Represje i wysiłki zmierzające do odbudowy drogi zawodowej przedsiębiorcy}

Czas względnego tolerowania wolnej przedsiębiorczości na terenie Polski podległej ZSRR szybko się skończył. Rok 1948, uważany powszechnie przez historyków za początek apogeum stalinizacji, zapisał się tragicznie także dla tego sektora. Od połowy tego roku obowiązywała decyzja władz państwowych o szybkiej likwidacji firm prywatnych (Krajewski 2004). Radykalne zmiany nie ominęły również Wybrzeża.

Wojewoda gdański dał Eugeniuszowi Kwiatkowskiemu trzy dni na opuszczenie regionu, któremu twórca Gdyni poświęcił sporą część swego życia, kompetencji i energii. Były premier, pozbawiony pracy od 30 kwietnia 1948, przeniósł się z rodziną do Krakowa, by odtąd zajmować się już tylko działalnością naukową (zob. np. Drozdowski 1989, 2005, także Jachniak 1987). Zaś Jachniak (1978: 11) swoje doświadczenia z tamtego czasu, podobne do losu wielu innych przedsiębiorców nie tylko Trójmiasta, lapidarnie ujął w późniejszych wspomnieniach: „Ja zaś zostałem przez władze wykończony jako były Akowiec oraz jako zbyt niezależny organizator życia gospodarczego na Wybrzeżu".

Warto przypomnieć, że podstawową „broń” stalinowskich władz używaną przeciw „niepokornej przedsiębiorczości” stanowiły domiary i grzywny absurdalnie wysokie, wymierzane $\mathrm{z}$ absurdalnych powodów, a często zupełnie bez rzeczywistego powodu (zob. liczne przykłady w: Knyt i Gluza 2004, Jabłkowski 2005, Tarasiewicz $2010 \mathrm{i}$ in.). Tak też było w wypadku dyrektora „Unii”. Równocześnie jednak sprawa miała swoiste „drugie dno”, być może typowe dla patologii zarządzania wywoływanych przez otoczenie społeczne biznesu, które kreował stalinizm. Przeciwko Jachniakowi sprzęgła się represyjna polityka władz przygotowujących już „bitwę o handel” oraz reakcja konkurentów zaadaptowanych do lub/i wykorzystujących „nową kulturę organizacyjną” w skali państwowej. Ludzie ci kierowali się nieograniczoną maksymalizacją

68 Pismo Naczelnika Wydziatu A... 1950... dz. cyt. Brak potwierdzenia tych informacji w źródłach bardziej wiarygodnych niż cytowany dokument. Niezależnie od ich prawdziwości przytoczone informacje świadczą o przede wszystkim o tym, jak Jachniak był postrzegany przez tajne służby PRL. 
zysku własnego bądź firm, którymi zarządzali (najczęściej chodziło o jedno i o drugie), nie stroniąc nawet od zachowań pozaprawnych ${ }^{69}$. Takim działaniom dyrektor „Unii” aktywnie się przeciwstawiał. Stąd wspomniana reakcja osób mu nieprzychylnych. Istotną rolę odegrała też zwykła ludzka zazdrość i zawiść. Warto znowu wrócić do wspomnień Jachniaka (1987: 13): „Pracując całymi dniami i nocami, wykonując wszystkie arbitraże towarowe i finansowe, brałem za każdą decyzję osobistą odpowiedzialność. To moje sukcesy zawodowe oparte na »pracy do upadłego « i wiedzy teoretycznej, stały się »solą w oku « dyrektorów i kierowników innych firm handlu zagranicznego, których celem było napełnianie własnego portfela pod szyldem państwowym oraz stałe wyjazdy za granicę, podobno w celu »pertraktacji« handlowych (...). Nie mając się czym wykazać w pracy, zaczęli wykorzystywać wszelkie koneksje do stosowania wobec mnie rozmaitych szykan".

Wydarzeniem bezpośrednio prowokującym spiralę represji skierowanych przeciw dyrektorowi „Unii” był jego zdaniem fakt, iż przeciwstawił się oszukańczej transakcji z marynarzami głównych polskich statków pasażerskich tamtego czasu (MS „Batory”, MS „Sobieski” i MS „Puławski”), którą chciało zrealizować kierownictwo gdańskiej Izby Skarbowej. W wyniku pozaprawnych działań zapłata za legalnie przywieziony przez wymienione załogi towar miała trafić nie do nich, ale właśnie do Izby Skarbowej. Byłby to więc swoisty zabór mienia, niewykluczone, że posiadający tło polityczne. Stanowił bowiem typowy dla stalinowskiego reżimu przykład „zasilania” skarbu państwa (czy raczej kieszeni stojących za tym eufemizmem rzeczywistych beneficjantów) z wykorzystaniem lamania prawa (por. inne przypadki tego typu: Ochinowski 1997, Jabłkowski 2005 i in.). Jachniak (1987: 12) uważając, że nie jest „przecież egzekutorem, tylko przedstawicielem Handlu70" nie tylko nie zgodził się na współudział w tym de facto przestępczym procederze, ale także ujawnił całą sprawę Związkowi Zawodowemu Marynarzy, co w konsekwencji skutecznie zastopowało przedsięwzięcie.

Jednak dyrektor „Unii” sam stał się odtąd obiektem zmasowanych szykan. Niemal półroczne, nieustające kontrole różnorodnych władz w firmie przyniosły horrendalny domiar sześćdziesięciomilionowy, to jest równy wartości około 24 domów typu kamienica. Przy czym kara ta obciążała osobiście Jachniaka za jego „prowizje i inne operacje finansowe” pod pretekstem „niedokładności

69 Na kryminogenną funkcję systemu stalinowskiego w Polsce jako pierwszy zwrócił uwagę Czesław Czapów w niezrachowanych analizach dotyczących „małego” i „wielkiego” gangu (Krajewski 2004, zob. także Kaczyńska 2003). Interesujące, iż Jachniak (1987) w swoich wspomnieniach do radykalnych ocen osób patologizujących jego zdaniem życie gospodarcze lokalnej Polski lat stalinowskich też używa podobnej terminologii.

70 Warto zwrócić uwagę na dużą literę słowa „Handel” wybraną w tym kontekście przez Jachniaka. 
w książkach handlowych dotyczących transakcji zagranicznych"71. Skarb państwa przejął wszystkie udziały dyrektora w „Unii” oraz cały osobisty majątek, „nawet nocne pantofle żony zostały zajęte przez władze skarbowe” (Jachniak 1987: 12), co nie było niestety humorystyczną metaforą.

Mimo tak skrajnie trudnej sytuacji pomorski przedsiębiorca przygotował materiały odwoławcze, znosząc równocześnie ośmiomiesięcznie kontrole władz wszelkiego szczebla oraz biegłych sądowych, nie przerywając przy tym realizacji zagranicznych transakcji handlowych, a nawet - co musi brzmieć niewiarygodnie, ale według relacji Jachniaka było faktem - intensyfikując je w związku z trwającymi przez lata 1948 i 1949 fluktuacjami finansowymi na rynku międzynarodowym, które spowodowały duże straty u wielu polskich firm. „Unia”, nawet wobec opisanych szykan dotykających jej dyrektora, znowu okazała się jednym z wyjątków. W wyniku rządów Jachniaka osiągnęła ona znaczny dodatni bilans. To właśnie wtedy zintensyfikowała się opisana wcześniej „praca do upadłego" dyrektora firmy. Jachniak zakończył wszystkie transakcje i przygotował materiały odwoławcze do sądu.

Następnie „nie mogąc nigdzie znaleźć sprawiedliwości”, oddał przedsiębiorstwo w 1949 roku dyrektorowi gdańskiej Izby Skarbowej, którego obwiniał za „niszczenie gospodarki nad morzem” (Jachniak 1987: 13). Dalszy los „Unii” był krótki. Ten sam 1949 rok przyniósł decyzję władz stalinowskich o tak zwanej konsolidacji branży związanej z obługą importu i eksportu realizowanego drogą morską. Monopolistą branżowym zostało upaństwowione przedsiębiorstwo „Baltona Zaopatrzenie Statków” (PZH Baltona S.A. 2009), z którym wcześniej, jak się wydaje, „Unia” skutecznie konkurowała. Firmę, do niedawna efektywnie kierowaną przez Jachniaka, czekało już tylko rozwiązanie.

W międzyczasie jej dyrektora władze skarbowe przez półtora roku nakłaniały do wyjazdu za granicę. Jachniak (1987: 12), jak wspomniał później, bezceremonialnie odpowiadał na te sugestie: „(...) w Polsce wolę skonać, a za granicą nie będę prosił o pracę, ponieważ jestem Polakiem, mam zawód i tutaj praca powinna się dla mnie znaleźć 72 ".

71 Cyt. za: Pismem szefa Woj. UBP... 1949..., dz. cyt. Cytowany dokument mówi o znacznie mniejszej kwocie domiaru, choć też dużej, o 7 mln złotych. Być może wysokość rzeczywistego domiaru, który Jachniak (1987) podaje w swoich pamiętnikach był tak absurdalny, że nie pisali o nim nawet tajni informatorzy, bądź opracowujący ich zeznania funkcjonariusze UB.

72 Trudno nie wskazać tu na pewną analogię ze słynną odpowiedzią daną w zupełnie innych warunkach przez Stefana Banacha Johnowi von Neumanowi, który przedstawił propozycję, by polski matematyk przeniósł się do USA za praktycznie dowolną sumę pieniędzy. Banach miał odpowiedzieć, że to „o wiele za mało”, żeby wjechał z Polski (zob. np. Kozielecki 1999). Przy wszystkich różnicach wyłaniają się być może z tych wypowiedzi elementy tradycji nowoczesnego patriotyzmu polskiego osadzonego w myśleniu przedsiębiorczym. Na jej ciekawą kontynuację zwrócił niedawno uwagę Alojzy Z. Nowak, wówczas dziekan Wydziału Zarządzania UW, relacjonując spotkanie wybitnych młodych 
Zamiast emigracji gdyński przedsiębiorca uzyskał - mimo wspominanego wcześniej okresu apogeum stalinizmu i w znacznym stopniu instrumentalnego charakteru szykan - sądowe oczyszczenie z wszystkich zarzutów, najpierw wyrokiem gdyńskiego Sądu Rejonowego (lipiec 1949), a następnie, po kolejnych odwołaniach składanych przez Izbę Skarbową i związanych z tym kolejnych rozprawach przed sądami różnych instancji, na mocy ostatecznej decyzji Komisji Społecznej (7 maja 1950). Wspomniane rozwiązanie problemu było tym większym sukcesem Jachniaka, okupionych przez niego bardzo dużym wysiłkiem, że sprawy przed wymiarem sprawiedliwości były tak ustawione przez władze skarbowe, iż to oskarżony, wbrew wielowiekowej tradycji europejskiego prawa, musiał dowodzić swej niewinności.

Były dyrektor „Unii” przynajmniej jeszcze raz wrócił po latach do spraw swego głównego przedsiębiorstwa. Zimą 1958 roku wysłał protest do jednego z sądów powiatowych w sprawie podziału masy upadłościowej opisywanej firny. Nie udało mi się ustalić dalszych losów tej interwencji.

Tymczasem ani sam proces odwoływania się od domiaru ani jego pozytywne zakończenie nie przerwało szykan wobec bohatera niniejszego szkicu, a także wobec jego najbliższych. Najciężej przė̇ył on, jak sam po latach wspominał, fakt, że pięcioletnią córeczkę w ciągu jednego 1949 roku pięciokrotnie usuwano z przedszkola „pomimo, że cieszyła się opinią spokojnego i pilnego dziecka” (Jachniak 1987: 14).

Po odejściu z „Unii” Jachniak zgłosił się do pracy na nieporównanie niższym, niż dyrektorskie stanowisku w Państwowym Przedsiębiorstwie Kontroli Ladunków i Rzeczoznawców „Polargo”. Został delegatem tej firmy na Warszawę. Niedługo tam jednak pracował. Po trzech miesiącach, prawdopodobnie w styczniu 1950 bez podania mu przyczyny ${ }^{73}$ został pozbawiony pracy. Pozostał bez środków do życia z niepracującą żoną i małym dzieckiem. Pismo naczelnika Wydziału A gdańskiego Urzędu Bezpieczeństwa kapitana Górnika z kwietnia 1950, raportujące wyniki inwigilacji byłego dyrektora „Unii”, podawało, iż obserwowany wykładał wówczas trzy razy na tydzień w gdyńskim Gimnazjum Spółdzielczo-Handlowym. Z kolei od czwartku do niedzieli przebywał na terenie Warszawy, gdzie był słuchaczem kursów planowania i statystyki ${ }^{74}$. Chodziło o Kurs Planowania w Przemyśle organizowany przez Polskie Towarzystwo Eko-

informatyków w Polsce z Billem Gatesem. Na ofertę skierowaną do jednego z nich przez twórcę Microsoftu, zapewniającego, iż Dolina Krzemowa stoi przed nim otworem, polski student odpowiedział kontrpropozycją, iż on sam posiada duże możliwości umysłowe, zaś Gates pieniądze, zaprasza więc gościa, by na dłużej przyjechał do Polski i będą tutaj robić razem interesy (sytuacja przytoczona z pamięci przez autora niniejszej pracy).

73 Jeden $\mathrm{z}$ dokumentów inwigilacji Jachniaka podaje lakonicznie, iż został zwolniony z powodu niezatwierdzenia na zajmowane dotąd przez niego stanowisko (Pismo Naczelnika Wydziatu A... 1950... dz. cyt.).

74 Pismo Naczelnika Wydziału A... 1950... dz. cyt. 
nomiczne, na który Jachniak uczęszczał w latach 1949-1950. Wcześniej (w 1949 roku) ukończy1, także przy PTE, Kurs Gospodarki Dewizowej i Finansowej. Zdaniem „rozpracowujących” go funkcjonariuszy Urzędu Bezpieczeństwa, po skończeniu tego drugiego szkolenia praktycznie bezrobotny przedsiębiorca spodziewał się zdobyć pracę w Warszawie i planował tam zamieszkać. Rzeczywiście Jachniak przeprowadził się do stolicy. Został tam zatrudniony jako dyrektor organizacyjny Państwowego Przedsiębiorstwa Drobnej Wytwórczości na Eksport „Pantex”.

Dość często cytowałem dwa dokumenty wyprodukowane przez gdański Urząd Bezpieczeństwa, obecnie znajdujące się w IPN, które raportowały inwigilację Jachniaka z końcówki „okresu pomorskiego” (były one datowane na maj 1949 i kwiecień 1950 roku). Rysują one ponury obraz osaczanego człowieka, na którego „nasadza się” zgodnie ze stylistyką szefa wojewódzkiego UB pułkownika Jurkowskiego (autora pierwszego z przywołanych raportów) agenta „Macieja”, a pomoc domową werbują do współpracy stalinowskie służby (co nie było zresztą zbyt efektywne, bo w drugim piśmie, już o innej pomocy domowej kapitan Górnik pisał, że pracuje ona u Jachniaków od niedawna, a informatorzy nie zdołali jeszcze ustalić jej poglądów politycznych). Lokalny Urząd bezpieczeństwa kolekcjonuje i przesyła zwierzchnikom bez żadnego komentarza także nieprawdziwe informacje na temat Jachniaka, wyraźnie o charakterze oszczerstw.

Były dyrektor „Unii”, bardzo towarzyski, zwykle posiadający szeroką sieć znajomości, teraz te z marynarzami i przedstawicielami firm ograniczył do zera (informatorzy UB donosili, że tylko prowadził korespondencję). Jedyne osoby, z którymi kontakty Jachniaka były notowane w 1950 roku to Eugeniusz Matuszewski, dyrektor „Polargo”, Tadeusz Walczak, były oficer „Batorego” oraz Józef Kaźmierczak, profesor Politechniki Gdańskiej. Tę część raportu tajnych służb PRL-u traktuję jako swoiste świadectwo (oczywiście nie wolne od ryzyka przekłamań) najściślejszego kręgu towarzyskiego bohatera niniejszego szkicu, z którym nie zerwał relacji nawet w najgorszym czasie.

Ostatnie zdanie wymaga jednak natychmiastowej korekty. Najgorszy czas miał bowiem dopiero nadejść, i to bardzo szybko. 16 maja 1950 roku Władysław Jachniak został aresztowany w biurze „Pantexu” przez funkcjonariuszy Głównej Informacji Wojskowej pod zarzutem szpiegostwa ${ }^{75}$. Pretekstem aresztowania

75 J. Poksiński (1992 i 1996) opierając się na wojskowych dokumentach archiwalnych błędnie opublikował informację, iż Jachniak był aresztowany w 1952 r. Dokładnie rzecz biorąc, bohatera niniejszego szkicu odwiedziło 16 maja 1950 r. w biurze Pantexu dwóch mężczyzn (agentów UB), którzy zaprosili go na wręczenie rzekomej nagrody, którą miał otrzymać za zorganizowanie wystawy na Targach Poznańskich (w poprzednim miejscu pracy Jachniak taką wystawę rzeczywiście zorganizował). Zamiast po nagrodę został przewieziony do kazamatów Informacji Wojskowej. 
stało się wcześniejsze spotkanie energicznego przedsiębiorcy z generałem Stanisławem Tatarem. Było to spotkanie służbowe, istotne, ale jedno $\mathrm{z}$ wielu, jakie omawiany przedsiębiorca odbywał podczas pracy na stanowisku delegata Zrzeszenia Eksporterów. Jednak ten właśnie kontakt handlowy, wykorzystany przez stalinowski reżim, dramatycznie zaważył, jako pretekst wykorzystany przez stalinowskie władze, na dalszych losach Jachniaka. Walnie przyczynił się do zmiany trajektorii jego życia, by użyć znanej metafory Glasera i Strausa. Dlatego warto i przy tym epizodzie znowu sięgnąć do pamiętników bohatera niniejszego szkicu: „W trakcie wykonywania swoich obowiązków służbowych zetknąłem się ze sprawą gen. Tatara, który w latach 1947-1949 przesyłał dary do Polski drogą morską. Osobiście zaś spotkałem się z generałem w 1948 roku w Warszawie, w mieszkaniu płk. Pluty-Czachowskiego, w obecności dwóch przedstawicieli Min. Handlu Zagranicznego. Ustaliliśmy wtedy, że dary będą zatrzymywane w strefie wolnocłowej, a przedstawiciele obdarowanych instytucji sami je odbiorą na Wybrzeżu. Przypominam sobie, że gen. Tatar odniósł się do mnie serdecznie, jako do człowieka »konkretnej« roboty w tym gronie i że wkrótce potem przyjechało po niego auto z szoferem w stopniu majora z godłem państwowym. Nietrudno się domyśleć, że udał nim na rozmowy na najwyższym szczeblu" (Jachniak 1987: 11).

Teraz w 1950 roku dla Informacji Wojskowej wspomniany epizod stanowil podstawę do stworzenia „hipotezy śledczej” zakładającej, że kontakty te służyły przekazywaniu do „ośrodka w Londynie” materiałów wywiadowczych ${ }^{76}$. Sprawa, do której „podłączono” Jachniaka, najwyraźniej jednak - co warto raz jeszcze podkreślić - służyła tylko jako pretekst, a absurdalność oskarżenia o szpiegostwo niepokoiła nawet samych wykonawców represji ${ }^{77}$.

Już w czasie „odwilży'56” na naradzie aktywu partyjnego Najwyższego Sądu Wojskowego w dniach 20 i 21.07.1956 roku służącej wewnętrznemu rozliczeniu wojskowego sądownictwa $\mathrm{z}$ jego działań w okresie stalinowskim, płk Jan Mitek, zeznał co następuje: „W jednej ze spraw Talarowskich, a mianowicie w sprawie Jachniaka, w której było brak dowodów, chciano na gwałt przyczepić mu zarzut z art. 87 k.k. WP. Wniosek w tej sprawie opracowywał kpt. Stanisław Zalewski i gen. Zarakowski, który stał mocno na stanowisku, aby tak zrobić" (cyt. za Poksińskim 1996: 1947, to samo źródło podaje, że przytoczoną wersje potwierdził także wymieniony w cytacie kpt. Zalewski). Art. 87 k.k.

76 Wcześniej, gdy Jachniak powtórnie odwiedził mieszkanie Pluty-Czachowskiego został tam zatrzymany na dwa tygodnie w tak zwanym kotle.

77 Jak widać, ostatecznie na zmianę kwalifikacji „czynów” Jachniaka, pozwalającą oskarżyć go o zbrodnię stanu nie zdobył się nawet stalinowski „wymiar sprawiedliwości”. Podczas narady aktywu partyjnego „rozliczającej” sądownictwo wojskowe lat stalinowskich, płk Mitek sobie przypisywał zasługę oprotestowania wspomnianego pomysłu, co potwierdził również kpt. Zalewski (Poksiński 1996). Niezależnie od tego, czy były to deklaracje prawdziwe, warto pamiętać, iż przede wszystkim musiała tu mieć znaczenie nieugięta postawa Jachniaka. 
WP dotyczył zbrodni stanu (zazwyczaj karanej śmiercią) polegającej na podjęciu przygotowań do takich przestępstw jak usiłowanie pozbawienia Państwa Polskiego niepodległości lub oderwania jego części oraz usunięcia przemocą ustawowych władz Polski lub usiłowanie zmiany przemocą ustroju Państwa Polskiego (Ziemba 1997). Takie zarzuty rzeczywiście postawione zostały (obok wspomnianego szpiegostwa, a także faszyzacji kraju) Jachniakowi podczas długotrwałego i okrutnego śledztwa. Była to oczywiście wyłącznie śmiercionośna retoryka stalinowskiego „wymiaru sprawiedliwości”.

Wyraźnie bowiem główny powód aresztowania, nieludzkiego traktowania i dążenia do śmierci byłego dyrektora „Unii” stanowiły jego sukcesy jako niepokornego przedsiębiorcy. Oprawcy niemal przyznali się do tego. Na kartach cytowanych już wspomnień Jachaniak (1987: 14) przytoczył słowa, które usłyszał na początku swej więziennej epopei w Naczelnej Informacji Głównego Zarządu WP:

„Skarb państwa cię nie wykończył i nawet wygrałeś w sądzie, bo tam opinia społeczna ma dostęp, ale teraz jesteś w naszych rękach, a tu nie ma dojścia ani członek rządu, ani żadna inna władza i tu zostaniesz zgnojony i wykończony jak masa innych, bez podania powodu".

Władysław Jachniak przeszedł, jak już wspominałem, wyjątkowo brutalne śledztwo na terenie Głównego Zarządu Informacji WP. W sumie trwało ono cztery i pół miesiąca, często 16 do 24 godzin na dobę. Dawny dyrektor „Unii” był skrajnie głodzony i męczony między innymi za pomocą takich metod jak „konwejer”, „kostka lodu”, czy „stójka”. Podczas tortur w śledztwie doznał pęknięcia przepony. Funkcjonariusze informacji wojskowej stosowali wobec niego również wiele metod przemocy psychicznej: „reżyserowali” pozorowane sceny duszenia żony i dziecka w przeciwległym pokoju, lżyli jego i bliskich, pluli w twarz i temu podobne. Przynajmniej raz Jachniak nie wytrzymał zniewag. Rzucił się na oprawcę, co oczywiście przyniosło nowe szykany ${ }^{78}$. Jachniak szczególnie wiele wycierpiał od „tandemu”: pułkownik Kochański, kierownik wydziału śledczego oraz śledczy, kapitan Wiktor Popiołek. Jachniak był brutalnie zmuszany, aczkolwiek zupełnie bezskutecznie, do obciążania licznych osób, w tym znanych osobistości, z którymi mógł, choćby pośrednio, spotkać się dzięki swej pracy handlowca, a także naukowców, wśród których znaleźli się tacy luminarze polskiej myśli ekonomicznej jak Edward Taylor (1884-1964), Zygmunt Sarna (1890-1974) czy Albin Żabiński (1883-1959) oraz kilkudziesięciu innych, których więzień znał tylko z publikacji lub ze słyszenia ${ }^{79}$.

78 W swych wspomnieniach tak skomentował to wydarzenie: „Ale zareagowałem prawidłowo. Jak można było taką zniewagę puścić płazem” (Jachniak 1987: 22). Chodziło o splunięcie mu w twarz przez śledczego.

79 Jednym ze szczegółowych oskarżeń, które śledczy wysuwali wobec Jachniaka, było przypisanie mu organizowania spisku wśród naukowców. 
W marcu lub kwietniu 1951 roku Jachniak dowiedział się od śledczych, iż został skazany na czterokrotną karę śmierci, a wyrok może być wykonany każdego dnia. Około roku spędził w celi śmierci. Mimo wielokrotnych starań nie otrzymał ani aktu aresztowania, ani oskarżenia. Rzekome skazanie na śmierć później okazało się blefem, o czym więzień oczywiście nie wiedział podczas pobytu w celi śmierci. Nawet jednak to nie złamało bohatera niniejszego szkicu. Nie oskarżył nikogo, sam natomiast obciążany był, jak pisze na kartach swych wspomnień, przez innych aresztowanych.

Ostatecznie przypisano mu przestępstwo z art. 7 MKK, czyli szpiegostwo rozumiane jako gromadzenie lub przekazywanie wiadomości, dokumentów i innych przedmiotów stanowiących tajemnicę państwową lub wojskową. Za takie czyny stalinowskie ustawodawstwo przewidywało karę więzienia nie krótszą niż 5 lat, karę dożywocia lub karę śmierci (Ziemba 1997).

1 września 1952 roku podczas jednego z ostatnich, odpryskowych procesów związanych ze „sprawą Tatara”, bez świadków, bez obrony, a nawet bez dowodów winy, Władysław Jachniak został przy drzwiach zamkniętych skazany wyrokiem Naczelnego Sądu Wojskowego na 15 lat pozbawienia wolności. Spędził za kratami łącznie 6 i pół roku, do 25 kwietnia 1956. Tego dnia Naczelna Prokuratura Wojskowa umorzyła z braku dowodów winy postępowanie karne w sprawie „obywatela Jachniaka”, na podstawie artykułu 169 KWPK, co oznaczało całkowitą rehabilitację.

Pełny opis śledztwa i przeżyć więziennych byłego dyrektora „Unii” znacznie przekroczyłby zakres niniejszego szkicu. Jego bohater przedstawił między innymi także i te doświadczenia na kartach wspomnień, które wielokrotnie cytuję (zob. Jachniak 1987). Wcześniej zgodził się być rozmówcą Danuty Suchorowskiej (1990) dla potrzeb książki Wielka Edukacja (I wydanie 1983), stanowiącej pierwszą w Polsce publikację z zakresu historii mówionej więźniów politycznych okresu stalinowskiego.

Pobyt za kratami były dyrektor „Unii” przypłacił utratą zdrowia oraz rozpadem małżeństwa. Jeszcze podczas śledztwa schudł 54 kilo (przed aresztowaniem ważył $116 \mathrm{~kg}$ ). Tortury oraz inne przeżycia $\mathrm{z}$ ponad sześciu lat stalinowskich kazamatów okrutnie przyczyniły się do tego, że Jachniak, przed uwięzieniem wysportowany, o atletycznej budowie, bez żadnych kłopotów zdrowotnych, po latach stał się inwalidą I grupy.

Dziś trudno jest odtworzyć przyczyny rozpadu małżeństwa „więźnia Jachniaka”. Warto jednak mieć na uwadze fakt, iż sprzyjanie rozbijaniu rodzin więźniów było jeszcze jedną szykaną stosowaną w stalinowskim systemie represji. Na przykład można było uzyskać rozwód zaocznie bez powiadamiania o tym współmałżonka, który odbywał karę pozbawienia wolności. Więzień dowiadywał się o całej sprawie najczęściej podczas widzenia jako o fakcie dokonanym. Trudno powiedzieć, czy tak było w przypadku Jachniaka. Na pewno jednak 
jego rodzina, jak bliscy wszystkich „politycznych”, narażona była na różnorodne szykany i represje. Zaliczyć do nich trzeba także bardzo rzadkie możliwości „widzeń", zawsze skrajnie krótkich i odbywanych w obecności strażnika, a najczęściej także innych osadzonych, utrudnianie ich, a często uniemożliwianie oraz związane $\mathrm{z}$,widzeniami” upokarzające procedury wobec starających się o spotkanie (z reguły odbywane przez kraty). Podobnie rzecz się miała z cenzurowaną i bardzo limitowaną korespondencją.

Ale nawet stalinowski „system penitencjarny” nie zniszczył psychicznej kondycji Jachniaka. Był on między innymi aktywnym organizatorem „więziennych uniwersytetów" jak cytowana już Danuta Suchorowska (1990: 110) metaforycznie nazwała fenomen licznych wykładów i prelekcji inicjowanych w celach spontanicznie przez inteligencję - ofiary reżimu stalinowskiego, mimo grożących za to dodatkowych represji ze strony personelu zakładów karnych. „Już na początku pobytu w więzieniu zwróciłem uwagę - relacjonował Suchorowskiej po latach bohater niniejszego szkicu - że więźniowie za bardzo rozpamiętują swoje życie, bez końca snują opowiadania o rodzinach, o rodzicach i dziadkach. Pomyślałem sobie: nie dam się 'zadziadkować'. Zaproponowałem organizowanie wykładów. Było przecież kilka osób, które miały do tego kwalifikacje” (cyt. za Suchorowską 1990: 117). Na kartach cytowanej relacji z więziennych lat Jachniak opisuje jak za pomocą sugestii wyobrażenia o atrakcyjnej kobiecie „wyciągną”” ze stanu depresyjnego i skłonił do wykładania współwięźnia - lekarza. Innemu koledze z celi, tym razem spoza grupy inteligenckiej, pomógł uwierzyć we własne siły intelektualne. „Była jeszcze historia z mechanikiem ze stoczni gdańskiej. Słuchał on z ogromnym zainteresowaniem naszych wykładów. Zaproponowałem mu kiedyś, żeby się włączył. Roześmiał się i mówi, że on przecież nie ma o czym mówić, bo nie ma odpowiedniego wykształcenia. Udowodniłem mu, że jest w stanie również nas czegoś nauczyć. Zadawałem mu konkretne pytania, np.: - Widziałem kiedyś - mówiłem - na końcu skweru Kościuszki zatopiony niemiecki okręt i nurków tnących pod wodą stal pilnikami. Jak to jest możliwe, że ogień palił się w wodzie? Albo: w jaki sposób zgina się rury? - Chłopak zapalił się do tematu i zorganizował nam bardzo fachowy i interesujący wykład. A potem - bardzo zadowolony - oświadczył, że po wyjściu z więzienia musi zrobić maturę" (cyt. za Suchorowską 1990: 118). Trudno w tym miejscu nie zwrócić uwagi na fakt, iż wykształcenie pedagogiczne Jachniaka nie było przypadkiem, a działalność edukacyjna, do której bohater niniejszego szkicu zwracał się, gdy nie mógł rozwijać swych pasji przedsiębiorcy, miała solidne podstawy w jego kompetencjach. Dalsza część niniejszego rozdziału dostarcza szeregu przykładów dokumentujących tę sugestię.

Ale gdy tylko pojawiła się sposobność, również jeszcze na terenie zakładu karnego Jahchniak wrócił do swych głównych zawodowych pasji. W latach 1953-1955 jako pracownik specjalny - więzień był kierownikiem planowania 
oraz głównym księgowym Przedsiębiorstwa Obróbki Metalu przy zakładzie karnym we Wronkach, gdzie odbywał wyrok. Korzystając z tej funkcji oraz ze względnego rozluźnienia więziennego reżimu po śmierci Stalina, wzbogacał wiedzę z zakresu gospodarki i polityki przez lektury, które, w pewnym bardzo ograniczonym zakresie, stały się dostępne także dla „antypaństwowców”80.

Również na terenie wronkowskiego więzienia miało miejsce wydarzenie, które trudno nie nazwać krytycznym dla dalszego życia Jachniaka. Podczas spotkania zorganizowanego dzięki życzliwemu strażnikowi w więziennej ubikacji generał Tatar, który poczuł się fizycznie bardzo źle, powierzył byłemu dyrektorowi „Unii” tajemnicę złotego Funduszu Obrony Narodowej ${ }^{81}$, najprawdopodobniej rozgrabionego przez władze stalinowskiej Polski. Wyjaśnienie oraz pełne ujawnienie opinii publicznej wspomnianej sprawy stało się odtąd misją życiową Jachniaka, być może nawet graniczącą z rodzajem obsesji. Problematyka ta, aczkolwiek stanowiąca także ważne świadectwo zatroskania bohatera niniejszego szkicu finansami państwa, a więc istotna dla jego poglądów na temat zarządzania, wymaga oddzielnej analizy. Tu tylko wspomnę, iż wiele lat później, niemal natychmiast po powołaniu przez Sejm PRL Trybunału Konstytucyjnego i Trybunału Stanu (26.03.1982) Jachniak wysłał do Komisji Odpowiedzialności Konstytucyjnej oficjalne oskarżenie o kradzież złotego FON-u przeciwko reprezentantom peerelowskich władz i związanych z nimi członkom establishmentu. W cytowanym piśmie oskarżył wymienione osoby także o „ludobójstwo i mord dokonany na parudziesięciu tysiącach Akowców po okupacji niemieckiej” (cyt. za Jachniakiem 1987: 6) oraz byłego prezesa ZBOWiD-u o zawłaszczenie części odszkodowania rządu RFN dla ofiar hitlerowskich eksperymentów lekarskich. Warto zauważyć, iż pomimo praktycznego braku odzewu na wspomniane oskarżenia, Jachniak był najprawdopodobniej pierwszym obywatelem w historii polskiego Trybunału Konstytucyjnego, który odwoływał się w swych roszczeniach do faktu powołania tej instytucji82.

80 Zob. Raport kpt. R. Bryczyńskiego do Naczelnika Wydziatu V Oddziału IV K. G. MO o zezwolenie na werbunek informatora (Warszawa 8 maja 1958). IPN BU 00945/840/I/ MF-4088/1. Warto przypomnieć, że przez przeważającą część okresu stalinowskiego więźniowie polityczni byli pozbawieni dostępu do jakiejkolwiek literatury i prasy, nawet do czysto propagandowej.

81 Chodzi o złote zasoby zebrane przez Rząd II Rzeczpospolitej wśród mieszkańców Polski na potrzeby obrony kraju przez II wojną światową. Po $1945 \mathrm{r}$. gen. Tatar przywiózł ten skarb do PRl-u wbrew opinii większości liderów emigracji.

82 Pismo Jachniaka nosi datę 9 kwietnia 1982, a więc powstało dwadzieścia dni od sejmowej decyzji o powołaniu tej instytucji i kilka lat przed rozpoczęciem przez nią działania. Autor przygotował do niego dwa tysiące stron uzasadniającej dokumentacji. Na oskarżenia bohatera niniejszego szkicu odpowiedział autorowi oficjalnym listem z dnia 24.01.1983 Zdzisław Czeszejko-Sochacki, przewodniczący Komisji Odpowiedzialności Konstytucyjnej (personalnie do niego kierowana była omawiana skarga), powiadamiając, iż ze względu na kryminalny charakter zarzutów zwartych w piśmie Jachniaka oraz wspierającym je 
Warto raz jeszcze powtórzyć, że represje stalinowskie nie zniszczyły „niepokornego przedsiębiorcy”. Na długo jednak pozostawiły bolesne ślady w jego pamięci. Jak przekazali świadkowie życia bohatera niniejszego szkicu, jeszcze wiele lat po wyjściu $\mathrm{z}$ więzienia wspominał on przede wszystkim przeżycia $\mathrm{z}$ celi śmierci.

25 kwietnia 1956 roku Władysław Jachniak, zrehabilitowany na podstawie artykułu 169 KWPK z braku dowodów winy opuścił więzienie. Praktycznie natychmiast przystąpił do odbudowy swego życia osobistego i zawodowego. Zamieszkał w jednym domu $\mathrm{z}$ generałem Tatarem. Uczuciowo związał się z adwokat Leonią Kawczyńską (być może ta relacja miała swój początek jeszcze podczas uwięzienia). Wkrótce wzięli ślub. Gorzej przedstawiały się możliwości pracy zawodowej. Pomimo pełnej rehabilitacji i zmian politycznych po 1956 roku długo nie mógł znaleźć przyzwoitego zatrudnienia. Starał się o pracę w gospodarce uspołecznionej. Od licznych instytucji otrzymał wymijające odpowiedzi.

Niezrażony ani obecnymi trudnościami, ani wcześniejszymi represjami podjął kolejną próbę zaangażowania się w rozwój handlu zagranicznego. Znowu, jak przed aresztowaniem, Jachniak planował położyć punkt ciężkości na przedsiębiorczości prywatnej, przy pełnym respektowaniu obowiązującego prawa i rozpoznaniu polityki państwa. Wykorzystał do realizacji tego celu fakt poznania prezesa polsko-amerykańskiej firmy „Amerpol Enterprises Inc.” działającej w Detroit, Harry'ego Kutkowskiego. Zaproponował mu współpracę przy organizacji bazy surowcowej dla polskiego rzemiosła. Powołując się na tak zwaną amnestię kapitałową 83 były dyrektor „Unii” wysłał 28 listopada 1956 roku do Ministerstwa Przemysłu Lekkiego memoriał „dotyczący sprawy produkowania przez rzemiosło lub drobną wytwórczość z surowców importowanych towarów nieprodukowanych przez przemysł państwowy, a szczególnie poszukiwanych przez konsumenta" ${ }^{4}$. Bohater niniejszego szkicu proponował zaradzenie problemowi braku dewiz, który dotykał małe zakłady uzyskujące koncesję na wspomnianą produkcję i - argumentował Jacyniak - powodował zagrożenie wystąpienia praktyk spekulacyjnych. Rozwiązaniem miała być współpraca konkretnych firm polskich i polonijnych. W praktyce chodziło o to, że „Amerpol” określił zapotrzebowanie na produkty rzemieślnicze, atrakcyjne dla rynku

analogicznym dokumencie wysyłanym przez byłych więźniów obozów koncentracyjnych, korespondencja ta została przekazana Prokuratorowi Generalnemu PRL. Na tym sprawa się urwała. Dopiero po przełomie roku 1989 podjęte zostały prawne działania mające na celu wyjaśnienie problemu „złotego FON-u”; działania zresztą dość szybko umorzone z powodu braku dowodów (Jachniak 1987 i Noskowicz-Bieroniowa 1991).

83 Chodziło o wydane na fali „październikowych” zmian zarządzenie ministra finansów dopuszczające przeprowadzanie transakcji importowej przez każdą osobę, która posiada odpowiednią ilość obcej waluty.

84 Pismo Wtadystawa Jachniaka z 22.02. 1957 do Ministerstwa Przemystu Lekkiego na ręce Dyrektora Departamentu Prof. Kardaszewskiego. IPN BU 00945/840/I/MF-4088/1. 
zachodniego. Towary te miał produkować koncesjonowany warsztat z Polski. Aby rozwiązać problem surowców firma polonijna zadeklarowała przysyłanie dewiz dla rodzin w Kraju za pośrednictwem Banku PKO. Utworzone zostało konto przedstawiciela „Amerpolu”, to jest Jachniaka. Waluta obca miała być przeliczana na złotówki według oficjalnych operacji wspomnianego banku, który zamiast wypłaty gotówki sprzedawałby odpowiednią ilość surowca.

Ta skomplikowana procedura wymagająca ze strony współczesnego czytelnika, nawet znającego się na sprawach gospodarczych, sporo wysiłku by zrozumieć jej meandry, sama w sobie stanowi interesujące świadectwo warunków funkcjonowania prywatnej przedsiębiorczości czasów PRL-u także po ustaniu stalinowskiego terroru.

28 lutego 1957, a więc trzy miesiące po wysłaniu, wspomniany memoriał uzyskał pozytywne opinie z Ministerstwa Finansów, Ministerstwa Przemysłu Drobnego i Rzemiosła oraz ze Związku Izb Rzemieślniczych. Na podstawie tych ocen Ministerstwo Przemysłu Lekkiego skłonne było wydać koncesję współpracującemu z Jachniakiem włókienniczemu zakładowi drobnej wytwórczości, którego właściciele mieszkali w Pabianicach. Były dyrektor „Unii” zobowiązał się zorganizować dla nich bazę surowcową.

Praktycznie natychmiast przedstawiciele amerykańskiej Polonii przesłali do PKO dolary (w ilości 5500) jako pomoc dla rodzin w Polsce. Jachniaka obowiązywała wypłata udziału każdemu $\mathrm{z}$ obdarowanych zaraz po dostarczeniu surowca przez bank i zatwierdzeniu jego ceny. Wypłata miała być zrealizowana w złotówkach. Niestety, władze polskie i PKO bardzo przeciągały procedury.

Wspomniana wpłata była wręcz wyrazem zniecierpliwienia „Amerpolu” i nastąpiła bez żadnej inicjatywy ze strony Jachniaka. Bohater niniejszego szkicu znalazł się w dość kłopotliwej sytuacji. Przez wiele miesięcy nie miał decyzji PKO co do realizacji transakcji, na jego koncie znajdowała się spora suma dolarów, których nie był właścicielem, a zbliżały się Święta Wielkanocne. Jachniak wypłacił więc obradowanym część ich udziału, pożyczając złotówki od znajomych. Depozyt dewizowy został nienaruszony. Wreszcie po następnych miesiącach zwłoki, 13 kwietnia 1957 roku, Jachniak otrzymał pisemne zapewnienie ze strony Banku PKO, że instytucja ta sprzeda za dewizy 1000 kilogramów surowców, pobierając przy tym $50 \%$ prowizję (!) w dewizach. Były dyrektor „Unii” zinterpretował przytoczone pismo jako ostateczne potwierdzenie dla swoich działań. Tymczasem cztery dni później, 17 kwietnia telegram PKO zawiadomił go o anulowaniu wymienionej wcześniej decyzji sprzedaży. Równocześnie zamknięte zostało konto Jachniaka, o czym już nie został poinformowany. Według władz bankowych, powodem tych decyzji miało być dopatrzenie się w przedsięwzięciu elementów spekulacji. Nie pomogły próby wyjaśnienia sytuacji poprzez bezpośrednie rozmowy niepokornego przedsiębiorcy z kierownictwem PKO ani listy do instytucji na poziomie ministerialnym. 
Z opisanymi próbami kontynuowania przez Jachniaka działalności w zakresie prywatnego handlu zagranicznego także w warunkach PRL-u wiąże się sprawa firmy „Togo”. Wymaga ona dalszych badań85, także jeśli chodzi o jej ścisłe relacje do wspomnianych wcześniej wysiłków przedsiębiorczych, które władze państwowe ostatecznie zniszczyły. W każdym razie „Togo” stanowił formę gospodarczej współpracy z „Amerpolem”. Powstała na terenie Gdyni w lutym 1957 roku. Jej założycielami byli Tadeusz Ogorzały i Janusz Dunst, współpracownicy dawnego dyrektora z „Unii”. Według materiałów milicji, pod której nadzorem Jachniak pozostawał po wyjściu z więzienia (co było typowe dla sytuacji byłych więźniów politycznych omawianego okresu ${ }^{86}$ ), on sam oficjalnie nie reprezentował firmy. Przypisywano mu jednak rolę głównego inicjatora powstania „Togo"87. Po kilku miesiącach działania firmy, prawdopodobnie latem 1957 roku odbyła się w niej rewizja, podczas której zakwestionowano przesyłkę zagraniczną. Sprawa została skierowana do prokuratora, a Jachnika aresztowano. Po 10 dniach niepokorny przedsiębiorca opuścił areszt z powodu braku dowodów winy. Jeszcze bardziej utrudniło mu to jednak zdobycie pracy adekwatnej do jego kwalifikacji. Pod koniec 1957 roku przesłuchujący go w gmachu Komendy Głównej Milicji Obywatelskiej tow. Curyło raportował, iż Jachniak pracuje dorywczo „w różnych kontrolach finansowych raczej dla umiłowania zawodu" 88 . Cytowany raport sugerowat, że bohater niniejszego szkicu pozostawał wówczas na utrzymaniu żony.

Władze PRL zlikwidowały przedsiębiorstwo „Togo”. Tylko przez około 4 miesiące (w 1957 roku) mógł Jachniak pracować jako koordynator spraw importowo-eksportowych „Amerpolu” i wycieczek Polonii amerykańskiej do kraju, które firma ta organizowała. Były dyrektor „Unii” nigdy już później nie podejmował prywatnej działalności gospodarczej.

By w końcu zdobyć jakiekolwiek stałe zatrudnienie Jachniak ukrył swe prawdziwe kwalifikacje i jako osoba z wykształceniem podstawowym przez kilka miesięcy pracował na stanowisku zastępcy magazyniera warszawskiej hurtowni Wojewódzkiego Zrzeszenia Spółdzielczości Pracy. Tam spotkał go przypadkowo ówczesny wiceprezes Centralnego Zarządu Spółdzielczości Pracy, o nazwisku Rominger ${ }^{89}$, wcześniej związany zawodowo z gdyńską „Polcargo”.

85 Na razie jedynymi źródłami na temat firmy „Togo”, do których dotarłem, są raporty milicyjne z rozmów z Jachniakiem, na które był wzywany w latach 1957-1958. Nawet nazwa firmy nie pewna jest.

86 W tak zwanej ewidencji ogólno-informacyjnej służ specjalnych PRL-u Jachniak został wpisany jeszcze podczas odbywania kary („Raport o zarejestrowaniu...” z dn. 30.08.1955. IPN BU 00945/840/I/MF-4088/1.

87 Zob. „Notatka służbowa” z 24 IX 1957 (ppor. H. Cuyrło) IPN BU 00945/840/I/MF-4088/1.

88 Raport z przeprowadzonej rozmowy na kandydata do werbunku... protokótowat tow. Curyto (Warszawa 07.12.1957) IPN BU 00945/840/I/MF-4088/1, s. 3.

89 Podczas pracy nad niniejszym szkicem nie udało mi się ustalić imienia tej osoby. 
Znał on Jachniaka jako organizatora handlu zagranicznego na Wybrzeżu i bliskiego współpracownika Eugeniusza Kwiatkowskiego. Teraz, dzięki interwencji Romingera bohater niniejszego szkicu dostał stanowiska inspektora hurtowni, w której pracował, oraz analityka Spółdzielni Wyrobów Mięsnych w Karczowie ${ }^{90}$. „Pracowałem dziennie po 18 godzin, zarabiając łącznie ok. 3 tys. złotych miesięcznie" - wspomniał później ten czas (Jachniak 1987: 33).

Przed lub podczas działalności zawodowej we wspomnianej spółdzielni Jachniak, niezmiennie zatroskany nieprawidłowościami życia ekonomicznego czasów PRL-u, zgodził się na współpracę z milicją w zakresie zwalczania przestępstw gospodarczych. Współpraca ta trwała przez 5 miesięcy, od maja do października 1958 roku. Zdaniem jednego z „prowadzących” (by użyć języka tamtej epoki) Jachniaka funkcojnariuszy, były dyrektor „Unii” przyczynił się do wykrycia wielomilionowych nadużyć w karczowskiej (lub karczewskiej) Spółdzielni Wyrobów Mięsnych. Aresztowano wówczas 14 osób ${ }^{91}$. Milicja zawiesiła współpracę z Jachniakiem, gdy otrzymał on odmowę na prośbę o zatrudnienie w Instytucie Organizacji Pracy Ministerstwa Handlu Zagranicznego, gdzie chciał prowadzić działalność naukową. Powodem odmowy była wciąż niezakończona sprawa zlikwidowanej firmy „Togo”. Po wielu latach od opisywanych wydarzeń bohater niniejszego szkicu został uznany przez służbę bezpieczeństwa PRL-u za jej Tajnego Współpracownika. Trzeba raz jeszcze podkreślić, iż teczka dotycząca tej „roli” przypisywanej Jachniakowi, nosząca datę 8 maja 1975 roku $^{92}$ powstała wyłącznie na podstawie pięciomiesięcznego współdziałania byłego dyrektora „Unii” z milicją w zakresie zwalczania przestępstw kryminalnych w 1958 roku. Wyraźnie też niepokorny przedsiębiorca wykorzystywał spotkania na terenie milicyjnych komend przede wszystkim do przekazywania władzom swoich krytycznych opinii dotyczących funkcjonowania handlu zagranicznego czasów PRL-u oraz konkretnych propozycji jego usprawniania. Materiały te, które przygotowywał sam Jachniak, lub spisywali je milicjanci, były rejestrowane jako „doniesienia agenturalne”.

Jachniak stopniowo budował swą drogę zawodową w nowej rzeczywistości. W latach 1957-1959 pracowal jak radca i analityk ekonomiczny dla Wojewódzkiego Związku Spółdzielczości Pracy oraz Społecznej Organizacji Gospodarczej przy ZBOWiD. Raczej jednak nie była to posada stała, choć dziś trudno to dokładnie określić. Praca w spółdzielni mięsnej, wspomniana wcześniej, to być może rok 1958. Około roku 1960 były dyrektor „Unii” został głównym

90 Być może chodzi o Karczew.

91 Raport o zawieszeniu tączności z informatorem pseudonim 'Zakrzewski' (10 X 1958); zob. także „Raport o zezwolenie na werbunek informatora... (8 V 1958) IPN BU 00945/840/I/ MF-4088/1.

92 Ankieta Personalna. Tajny wspótpracownik 4878/I. Pseudonim Zakrzewski' (teczkę utworzył P. Ficko, 8.04.1975). IPN BU 00945/840/I/MF-4088/1. 
ekonomistą - analitykiem Głównego Komitetu Kultury Fizycznej i Turystyki. Mniej więcej w tym samym czasie (może nieco wcześniej) prowadził prace analityczne na potrzeby przemysłu (tzw. Przemysłu Kluczowego) w ramach Zakładu Doradztwa Organizacyjnego Towarzystwa Naukowego Organizacji i Kierownictwa. Wreszcie - co uznać należy za szczególne osiągnięcie Jachniaka, biorąc pod uwagę jego „więzienną przeszłość” - uzyskał etat analityka w Najwyższej Izbie Kontroli. Przepracował tam 3 lub 4 lata (1962-1965 lub 1966) by następnie objąć stanowisko wicedyrektora Departamentu Planowania i Analiz Gospodarczych w Komitecie Drobnej Wytwórczości w Warszawie. Po zamianie na stanowisku ministerialnym, został w 1971 roku przez nowego ministra zwolniony ze wspomnianej pracy. Tak Jachniak na kartach swoich wspomnień opisywał główny powód zwolnienia: „Zapoznałem go (nowego ministra - uwaga T.O.) z moimi metodami przygotowania analiz i usłyszałem w odpowiedzi, że on nie będzie słuchał żadnych analityków i dyrektorów, tylko będzie robił tak, jak sam uważa (...). Powiedziałem, że jestem fachowcem, który zobowiązany jest ukazywać prawdę obiektywną, służącą poprawie gospodarki i że nie będę robił analiz dla mojego przełożonego według jego życzeń, tylko w oparciu o stan faktyczny. Minister (...) jeszcze raz z naciskiem twierdził, że będę musiał robić tak, jak on zechce, w przeciwnym razie wyciagnie wobec mnie jako buntownika jak najdalej idące konsekwencje" (Jachniak 1987: 37). Po nie więcej niż roku od przytoczonej rozmowy i po następnych trudnościach niepokorny dyrektor o duszy przedsiębiorcy nie tylko dostał wymówienie, ale również znowu dotknęły go trudności ze zdobyciem godziwego zatrudnienia: „Zacząłem szukać innej pracy. Ale 'długa ręka' nie pozwoliła mi zająć odpowiedniego stanowiska nawet w takich instytucjach, które wcześniej pertraktowały ze mną i prosiły o przejście do nich, czy takich, dla których robiłem analizy w ramach pracy zleconej (Instytut Badań Atomowych, Górniczy itp.). Zająłem więc najniższe stanowisko w Instytucie Drobnej Wytwórczości, który mi wcześniej podlegał, pomimo, że prawnie przysługiwało mi przez rok wynagrodzenie z ostatniego zajmowanego przeze mnie stanowiska dyrektorskiego. Odebrano mi także natychmiast opiekę lekarką w lecznicy państwowej" (Jachniak 1987: 38).

Następnie były dyrektor „Unii” pracował na stanowisku głównego specjalisty ds. postępu ekonomicznego w Zjednoczeniu „ZREMB” oraz w Instytucie Mechanizacji Budownictwa w Warszawie (lata 1972-1975). Później taką samą pozycję zawodową uzyskał w Instytucie Ekonomiki Przemysłu Chemicznego w Warszawie (od 1976 roku). Pracował również jako wykładowca Ośrodka Szkolenia Kadr Kierowniczych Przemysłu Chemicznego. Otrzymał złoty medal Komisji Edukacji Narodowej oraz złotą odznakę Polskiego Towarzystwa Ekonomicznego i Towarzystwa Naukowej Organizacji i Kierowania.

W 1978 roku został zmuszony, jak sam twierdzil, do przejścia na wcześniejszą emeryturę. Miał wówczas 63 lata. 
Nie zaprzestał jednak działalności wykładowej i szkoleniowej, a prawdopodobnie jeszcze je zintensyfikował. $Z$ dużym powodzeniem wśród słuchaczy prowadził tę działalność co najmniej od początku lat 60. ubiegłego stulecia jako wykładowca analizy ekonomicznej, ekonomiki przedsiębiorstwa, arytmetyki gospodarczej i księgowości oraz rachunku ekonomicznego. Prowadził kursy w Polskim Towarzystwie Ekonomicznym, Towarzystwie Naukowej Organizacji i Kierownictwa oraz we wspomnianym ośrodku szkolenia kadr dla przemysłu chemicznego. Był także nauczycielem w liceum ekonomicznym, prawdopodobnie w Radomiu. Mówiąc szczegółowo, Jachniak rozpoczął działalność wykładową jeszcze w więzieniu. Już tam przygotował jedną z pomocy dydaktycznych, planszę -,klasyfikator pomocy modułów informacyjnych (...). Zamieściłem w niej w skondensowanej formie to na co inni zużywają masy papieru. Jest to aktualne do dziś" (Jachniak 1987: 38).

Były dyrektor „Unii” intensywnie dbał też o własny rozwój intelektualny. Między 1956 a 1960 rokiem odbył kolejnych 5 kursów specjalistycznych organizowanych przez Polskie Towarzystwo Ekonomiczne. W latach 1958-1961 uzupełnił studia w krakowskiej Wyższej Szkole Handlowej ${ }^{93} .28$ września 1961 roku został magistrem ekonomii ze specjalizacją obrotu towarowego. Miał wówczas 46 lat. W 1969 roku Rada Wydziału Nauk Społecznych Uniwersytetu Warszawskiego otworzyła przewód doktorski Władysława Jachniaka. Praca pod tytułem Zarządzanie $w$ drobnej wytwórczości - optymalne rozwiazania, miała powstać w Instytucie Ekonomii UW pod kierunkiem Jerzego Więckowskiego (1921-1988), jednego z późniejszych twórców Wydziału Zarządzania UW, prawdopodobnie pierwszej uniwersyteckiej szkoły biznesu po 1945 roku w Europie Środkowej. Doktorant przedstawił konspekt pracy. Obrona była planowana nieco ponad rok później. Rzeczywistość jednak, której również w tym aspekcie musiał stawić czoła Jachniak, okazała się znowu znacznie bardziej skomplikowana, niż można było by to przewidzieć. Pod koniec 1975 roku temat pracy uległ zmianie na Produkcja dodana jako instrument zarzadzania jednostkami gospodarczymi. Rozprawa miała być teraz realizowana w powstałym 3 lata wcześniej Instytucie i Organizacji i Kierowania UW i PAN, który dał początek Wydziałowi Zarządzania UW. Kilka miesięcy później zmienił się promotor pracy Jachniaka. Został nim Jan Śliwa, wówczas docent, później wieloletni profesor Wydziału Zarządzania UW, gdzie wykłada do dziś (2013 rok). Ostatecznie 9 marca 1978 roku sześćdziesięciotrzyletni Władysław Jachniak uzyskał tytuł doktora. Jak wspomniał po latach Kordian Tarasiewicz, obrona doktorska

93 Nazwę uczelni podaję za dokumentacją przewodu doktorskiego Władysława Jachniaka. Być może jednak chodzi o uczelnię, która wówczas nosiła nazwę Wyższa Szkoła Ekonomiczna. Była ona następczynią Wyższego Studium Handlowego w Krakowie, które przed II wojną światową ukończył Jachniak i poprzedniczką obecnego Uniwersytetu Ekonomicznego w Krakowie. 
byłego dyrektora „Unii”, mająca miejsce na Wydziale Zarządzania UW była ważnym wydarzeniem także dla środowisk przedsiębiorców, ze względu na wiek oraz doświadczenia życiowe nowego doktora nauk organizacji i zarządzania.

Po przejściu na emeryturę Jachniak oprócz szkoleń dla PTE i TNOiK oraz Ośrodka Doskonalenia Kadr Kierowniczych i Szkolenia Zawodowego Ministerstwa Przemysłu Chemicznego prowadził także wykłady w Szkole Głównej Planowania i Statystki (obecnie Szkoła Główna Handlowa). Po koniec lat 80. XX w. bez nadmiernej skromności, tak podsumował swoje doświadczenia edukacyjne i aplikacyjne, które wtedy jeszcze kontynuował: „Przeszkoliłem ponad 30 tys. analityków i prognostyków ekonomiczno-organizacyjnych, wykonałem setki analiz mikro i makro w siedmiu dziedzinach gospodarki, opracowałem ponad 100 artykułów, ponad 40 skryptów i ponad 250 plansz i wykresów z dziedziny analiz ekonomicznych i rachunku gospodarczego w celu przyczynienia się do integracji teorii z praktyką, do rozwoju i postępu" (Jachniak 1987: 38). Bohater niniejszego szkicu jest również autorem około 7 pozycji książkowych. Poświęcone są one przede wszystkim problematyce finansowania przedsiębiorstw i usług oraz spółdzielczości pracy, którą wyraźnie były dyrektor „Unii” traktował jako szansę rozwijania przynajmniej elementów prawdziwej przedsiębiorczości w warunkach gospodarki planowej, przedsiębiorczości, która zgodnie z przekonaniami Jachniaka, nastawiona powinna być na długofalowy zysk, ale także służyć społeczeństwu ${ }^{94}$ (Jachniak 1973, 1981, 1983, 1984). Zasygnalizowanej tu ideologii działań przedsiębiorczych i szerzej życia publicznego bohater niniejszego szkicu pozostawał wierny na różnych polach swej aktywności. Szczególnie domagał się respektowania zasad prawdy i sprawiedliwości.

Podczas „Odwilży 1956” wziął, jako świadek, udział w procesie swoich stalinowskich oprawców. Później, w związku z jedną z „afer gospodarczych” PRL-u przyjął rolę eksperta, by bronić jednego z niesłusznie oskarżonych o nadużycia w handlu zagranicznym. Sąd postawił warunek, aby wspomniany ekspert miał tytuł naukowy i był członkiem Polskiego Towarzystwa Naukowego. Jachniak spełniał te wymagania. Błyskotliwie wykazał absurdalność zarzutów.

Od chwili wyjścia z więzienia aż do śmierci niemal obsesyjnie, ale niestety bezskutecznie, zabiegał o wyjaśnienie sprawy Złotego FON-u i sprawiedliwe ukaranie winnych także różnych innych przestępstw państwowych okresu stalinowskiego.

94 Wstępnej analizy publikacji Jachniaka dokonała Aleksandra Kabała, wówczas studentka Międzykierunkowych Studiów Ekonomiczno-Menedżerskich UW w napisanej pod moim kierunkiem pracy licencjackiej Modus bycia vs modus posiadania czyli skuteczność motywatorów finansowych i pozafinansowych $w$ oparciu o prace dr Wtadystawa Jachniaka (Warszawa 2011, UW).

Na przytoczone w niniejszym szkicu charakterystyki ideologii przedsiębiorczej, której hołdował Jachniak zwrócił mi uwagę Piotr Gołaszewski, przedsiębiorca - praktyk, obecnie także rzecznik prasowy spółki „Szpital Mazowiecki”. 
Gdy tylko miał możliwość, angażował się w dyskusje na tematy gospodarcze. W latach Pierwszej „Solidarności” (1980-1981) mógł to robić intensywnie także za pośrednictwem mediów, z czego skwapliwie korzystał. Nigdy nie pogodził się z działaniami ekonomicznymi urągającymi logice. „Wszystkie te kłopoty (chodzi o trudności Jachnika z pracą zawodową w czasach PRL-u - uwaga T.O.) - w sposób typowy dla swego radykalizmu były dyrektor „Unii” pisał pod koniec lat 80. ubiegłego wieku - „były jednak niczym w porównaniu z tym, co przechodziłem, stykając się wszędzie tam, gdzie pracowałem, z absurdami i nonsensem gospodarki, którą zarządzali dyletanci i kombinatorzy. Aż się dziwię czasem sam sobie, jak to się stało, że nie zwariowałem" (Jachniak 1987: 38).

Pod koniec życia nprzedsiębiorca podjął tematykę - jak to nazwał - „ekonomicznej" wartości cierpienia. Refleksje te pozostały w maszynopisach. W niedalekiej przyszłości planuję podjąć się ich analizy.

Władysław Jachniak nie osiągnął stabilności małżeńskiej. Rozstał się także z drugą żoną. Jak sam mówił, głównym źródłem jego szczęścia osobistego była przede wszystkim wnuczka.

Ostatni okres życia założyciel „Unii” spędził u swojej siostry w Krakowie. Zmarł tam w 1994 roku. Został pochowany na Cmentarzu Rakowickim.

\subsubsection{Biografia zawodowa Władysława Jachniaka jako argument w dyskusji nad kierunkiem zmian modelu biznesowych działań w kontekście kryzysu}

Warto doświadczenie Jachnika umieścić także w kontekście zmagań ludzi biznesu z różnymi rodzajami kryzysów, wyznaczającym ramy treściowe mojej pracy. Powstaje więc pytanie, jaki kapitał kulturowy niesie szkicowo tu przedstawiona droga zawodowa twórcy firmy „Unia”, który nie przestał być przedsiębiorcą ani w stalinowskim więzieniu, ani gdy przez wiele lat pracował w dużych instytucjach państwowych okresu gospodarki planowej.

Przy czym przykład Jachniaka wydaje się przekraczać zjawisko przedsiębiorczości korporacyjnej, które polskiemu czytelnikowi przybliża na kartach swych opracowań podręcznikowych Beata Glinka (Glinka i Gudkova 2011, Glinka 2013). W przedsiębiorczości korporacyjnej chodzi o zdolność do innowacyjnego ryzyka podejmowanego przez jednostkę na rzecz organizacji stworzonej przez kogoś innego. Potrzebna jest więc wola ze strony pracowników, by działać przedsiębiorczo i klimat organizacyjny sprzyjający twórczemu podejściu do pracy. Przedsiębiorczość korporacyjna nastawiona jest na szanse (ich identyfikację i urzeczywistnianiem) oraz zmiany, których wprowadzaniu ma służyć.

Dla Jachniaka przedsiębiorczość wydawała się być czymś znacznie bardziej fundamentalnym. W najlepszym okresie swej działalności bezkonfliktowo łączył przecież pracę $\mathrm{w}$ strukturach administracyjnych, przygotowanie analiz obejmu- 
jących problematyką całego regionu czy nawet kraju i prowadzenie kilku firm prywatnych. Przedsiębiorczość stanowiła więc dla Jachniaka żywiol, naturalny sposób funkcjonowania. I zupełnie naturalnie służyła także celom społecznym. Innowacyjność zarówno dla firmy jak i różnych kręgów jej otoczenia była po prostu treścią codziennych działań omawianego przedsiębiorcy. Rodzaje organizacji (na przykład prywatne czy administracyjne) stawały się sprawą drugorzędną, a najlepszym rozwiązaniem okazywała się ich harmonijna różnorodność Do tego dochodziło jeszcze respektowanie podstawowych wartości ogólnoludzkich, traktowanych jako naturalne ramy przedsięwzięć.

Sięgając do rodzajów przedsiębiorczości wyróżnianych przez Glinkę (2013 i in.), można wskazać w działalności Jachniaka duży „ładunek” przedsiębiorczości społecznej „nasycony” przedsiębiorczością pasjonata i „obudowany” respektowaniem zasad wynikających z wartości ogólnoludzkich.

Przy czym przedsiębiorczość społeczną ${ }^{95}$ proponuję ujmować szeroko za Jakubem Wygnańskim (2008). Jest to sposób działania gospodarczego, polegający na:

a) urynkowieniu problemów społecznych, to znaczy interpretowaniu ich w kategoriach szans na prowadzenie biznesu (jak zdaje się sugerować Glinka 2013), a także polegający na

b) uspołecznieniu rynku, czyli uznaniu kwestii społecznych za istotny regulator działań biznesowych (por. Borchard 2009).

Słabością, niezawinioną przez twórcę „Unii”, był fakt, iż ze względów systemowych od pewnego czasu został on osamotniony w realizacji naszkicowanego tu modelu, modelu nie tylko przedsiębiorczości, ale i zarządzania.

Bo wyraźnie biografia zawodowa Jachniaka stanowi przykład zniesienia tradycyjnej (z perspektywy nauk o organizacji i często praktyki organizacyjnej) dychotomii między przedsiębiorczością a zarządzaniem, o które to zniesienie apelują na przykład Kostera i Śliwa (2013) analizując najnowsze trendy myśli i praktyki menedżerskiej.

Permanentny kryzys, za jaki można uważać metaforycznie ujmowaną kulturę organizacyjną państwa takiego, jakim był PRL, przynosił nie tylko liczne, często ekstremalnie duże przeszkody dla działalności przedsiębiorczej, ale także skutkował wspomnianym wcześniej osamotnieniem niepokornego przedsiębiorcy. Naturalna wierność zasadom przyzwoitości biznesowej powodowała, że w świecie ich permanentnego łamania, a także postępowania wbrew logice dobrej organizacji, bezkompromisowość Jachniaka stawała się konfliktowością, za którą płacił dużą cenę zarówno w sferze zawodowej, jak i prawdopodobnie także prywatnej, a na pewno zdrowotnej. Nie znaczy to jednak, że inne stra-

95 Kategoria „przedsiębiorczość pasjonata” nie wymaga wyjaśnienia. Glinka (2013) opisuje ją zgodnie z potocznym znaczeniem terminu ,pasjonat”. 
tegie mogłyby przynieść twórcy „Unii” większe korzyści, niż te, które osiągnął w życiu. I nie znaczy, że jego model działań biznesowych nie jest wart uwagi. Interesujące, iż postulaty bardzo podobne do tego, co ilustruje życie Jachniaka, sformułowal - jako remedium na ostatni kryzys - James Hoopes (2001) patrzący na teraźniejszość zarządzania w kontekście jej przeszłości. Niedawno zasugerował on zmiany modelu działalności biznesowej, wprawdzie adresowane tylko dla amerykańskich korporacji, ale z uwzględnieniem głębokiej perspektywy historycznej od Wielkiego Kryzysu lat 30. ubiegłego stulecia do ostatnich turbulencji skumulowanych w roku 2007.

Jego zdaniem, wątłość ruchów antykorporacyjnych każą rokować, iż przyszłość głównego nurtu działalności gospodarczej, przynajmniej na terenie USA, nadal należy do organizacji typu korporacyjnego. Jednak powinny one zmodyfikować swój model działania poprzez rzeczywiste realizowanie ideologii społecznej odpowiedzialności biznesu. Za drogę prowadzącą do tego celu Hoopes (2011) proponuje podjęcie także przez wielki biznes zadań z zakresu ekonomii społecznej. Uzasadniając przydatność, a nawet konieczność włączenia ideologii społecznej odpowiedzialności biznesu do praktyk menedżerskich współczesnych korporacji cytowany historyk przywołuje ustalenia Michaela Portera jako nestora zarządzania strategicznego. Tuż przed kumulacją zjawisk kryzysowych 2007 Porter wraz ze swym współpracownikiem Markiem Kramerem zaproponowali uwzględnienie w strategii firm kategorii „zdrowe społeczeństwo". Właśnie zdrowego społeczeństwa, w szerokim, potocznym znaczeniu tego terminu, potrzebują korporacje, a z kolei zdrowe społeczeństwo potrzebuje przedsiębiorstw, które odnoszą sukcesy. Ideologia społecznej odpowiedzialności biznesu i wypracowane przez nią praktyki włączone do strategii firm umożliwiają zharmonizowanie celów społeczeństwa i celów organizacji biznesowych. „Świetnie rozwijający się biznes (...) może mieć większy wpływ na dobro społeczne, niż jakakolwiek inna instytucja lub filantropijna organizacja (Porter i Kramer 2006: 7, 13, cyt. za Hoopesem 2011: 20496). Hoopes przypomina przy tym słynną tezę Miltona Friedmana przeciwko idei społecznej odpowiedzialności przedsiębiorstw, głoszącą, iż korporacje najlepiej służą społeczeństwu poprzez skupienie się na osiagganiu zysków (zob. Friedman 1999, oryginalny tekst Friedmana pochodzi z 1970 roku). Nie są przecież organizacjami charytatywnymi, jak podkreślają współcześni następcy Friedmana. Hoopes opatruje tę opinię polemicznym komentarzem. „Dokładnie dlatego, że firmy nie są organizacjami charytatywnymi konieczny jest zewnętrzny nacisk (wobec nich - uwaga T.O.) na rzecz społecznej odpowiedzialności biznesu" (Hoopes 2011: 205). Amerykański historyk kończy cytowaną tu książkę następującą konkluzją: „W demokratycz-

96 Hoopes powołuje się na: Porter M.E. i Kramer M.R. (2006), Strategy and Society: The Link between Competitive Advantage and Corporate Social Responsibility, „Harvard Business Rview", 84, 7 (13). 
nym społeczeństwie, społeczna odpowiedzialność przedsiębiorstw jest sprawą każdego"97 (Hoopes 2011: 207).

Kierunki zmian rzeczywistości zarządzania sugerowanej przez Hoopesa wyraźnie korespondują ze scharakteryzowaną wcześniej triadą „podmiotowość - zaangażowanie - zakorzenienie”. Być może są one opisem „warunków brzegowych" realizacji tej triady w danym przedsiębiorstwie.

I choć postulaty Hoopesa (2011) adresowane są do wielkiego biznesu, to przecież opierają się na doświadczeniach sektora MŚP, w którym znacznie łatwiej niż na poziomie korporacji o rzeczywistą odpowiedzialność społeczną firmy, powiązaną licznymi więzami ze swym otoczeniem i stosunkowo łatwo rozpoznającą jego potrzeby. Jak dotąd także efektywna przedsiębiorczości społecznej to w skali światowej praktyka przede wszystkim małych i średnich przedsiębiorstw.

Uwagi te nie mają charakteru polemiki z główną tezą Hoopesa o dominującej pozycji korporacji na rynku amerykańskim. Są tylko sugestią, w myśl głównych założeń historii organizacyjnej, by nie marginalizować także kapitału doświadczeń zgromadzonego przez MŚP. Tym bardziej, że „na prowincjach” globalizacji, takich jak Polska, małe i średnie firmy nadal są głównym „kołem zamachowym" gospodarki.

Być może także w amerykańskim „centrum” nastąpią procesy przewidywane przez zmarłego przed kilku laty nestora historyków biznesu Alfreda Chandlera jr, iż korporacje będą rezygnować $\mathrm{z}$ centralizacji zarządzania i nastąpi ich „poszatkowanie” - takie, że nawet może zaniknąć klasa menedżerów (poglądy Chandlera podaję za Karlgaardem 2006 por. Koźmiński 2008).

Do wielu punktów widzenia obecnych na kartach dość obfitej już literatury przedmiotu (również w języku polskim), poświęconej zarówno przedsiębiorczości społecznej, jak i społecznej odpowiedzialności biznesu warto - skromnym zdaniem autora niniejszej pracy - dodać także perspektywę wyznaczaną przez nurt retoryczny w naukach społecznych. Pozwala ona zobaczyć obydwa fenomeny (przedsiębiorczość społeczną i społeczną odpowiedzialność biznesu) jako element ideologii dyskutowanej otwarcie lub implicite w grupach bezpośrednio zainteresowanych problematyką biznesową lub - znacznie rzadziej - przywoływanej przez przedstawicieli szerszych kręgów ${ }^{98}$.

97 Generalnie głównym wątkiem zainteresowań badawczych Hoopesa są relacje między biznesem a demokracją (zob. np. Hoopes 2004 i 2011).

98 W niniejszym rozdziale wykorzystuję oczywiście tylko jeden, szczegółowy aspekt spojrzenia na przedsiębiorczość społeczną i społeczną odpowiedzialność biznesu z perspektywy retorycznej. Chodzi o występowanie (wprost lub implicite) zagadnień związanych z obydwoma kwestiami jako argumentów w dyskusjach społecznych/biznesowych lub jako przedmiotów tych dyskusji. Pozostając w ramach perspektywy retorycznej (Billig 1996, 2006 i in.) uznaję treści zbiorowych dyskursów dotyczące przedsiębiorczości społecznej i CSR za elementy lub wskaźniki różnych ideologii. Pomijam natomiast, skądinąd nie- 
I tak na przykład, odnośnie do przedsiębiorczości społecznej, Carl Anderson (2009) proponuje włączyć działania przedsiębiorców społecznych do międzynarodowego dyskursu na temat ostatniego kryzysu ekonomicznego, przedstawiając ich aktywność jako remedium na „kryzysorodne” tendencje współczesnego biznesu. Jeszcze dalej idzie David Bernstein (2009) - na którego książce opiera się cytowany w poprzednim zdaniu autor - opisując przedsiębiorców społecznych za pomocą metafory „wizjonerzy naszych czasów”. Rafael Chaves i Jose Luis Monzono (2012) widzą w ekonomii społecznej (którą można traktować jako kontekst teoretyczny przedsiębiorczości społecznej) fundament nowego modelu zrównoważonego rozwoju gospodarczego, który był w stanie sprostać wyzwaniom kryzysu (por. Hoopes 2011). Ryszard Praszkier i Andrzej Nowak (2012) zwracają uwagę na fakt, iż przedsiębiorcy społeczni reprezentują nowy styl przywództwa, „przywództwo umacniające”. Jego istotą jest „proces wyzwalania potencjałów, grup lub społeczności oraz stwarzania im możliwości utożsamiania się z ideą, brania za nią odpowiedzialności i dążenia do jej realizacji poprzez (...) uruchomienie trwałego procesu zmian zorientowanego na zaspokojenie potrzeb społecznych" (Praszkier i Nowak 2012: 182). Marie J. Bouchard (2012) generalnie proponuje spojrzeć na ekonomię społeczną jako na laboratorium innowacyjności społecznej, umożliwiające krytykę stanu obecnego oraz nowe zdefiniowane relacji między rynkiem, państwem i społeczeństwem. Najbardziej spektakularne „zagoszczenie” omawianej problematyki w przestrzeni globalnych ideologii spowodowała oczywiście działalność i publikacje Mohammada Yunusa (np. 2010), szczególnie od czasu, gdy dostał pokojową Nagrodę Nobla (2006). Rola Yunusa w promowaniu zagadnień przedsiębiorczości społecznej jest niekwestionowana, niezależnie od dotykających go ostatnio krytyk (zob. np. Banerjee i Duflo 2012).

Z kolei na lokalnym, polskim „rynku wymiany myśli”, warto wskazać środowisku periodyk „Nowy Obywatel”, wyraźnie traktujące działalność przedsiębiorców społecznych także jako argument ideologiczny w dyskusji nad optymalnym kształtem państwa i społeczeństwa.

Nawiasem mówiąc, już powyższe, wybiórczo zaprezentowane przykłady pokazują, że przedsiębiorczość społeczna, nie tracąc nic ze swojej praktyczności, okazuje się być istotną kandydatką do kategorii idei, które „mają konsekwencje" (przynajmniej potencjalnie) zgodnie z klasycznym określeniem Richarda M. Weavera (1948/1996).

Jednakże ideologiczne funkcjonowanie problematyki przedsiębiorczości społecznej ma także „drugą stronę medalu”. Chodzi o bariery rozwoju tego typu

zwykle ważny, problem ideologicznych podstaw i korzeni obydwu zjawisk, takich jak idee niesione przez adekwatne do tej tematyki dokumenty Unii Europejskiej oraz przez tradycje biznesowe, spółdzielcze, religijne i związane ze światem polityki jak na przykład ruchy socjal- czy chrześcijańsko-demokratyczne. 
działań gospodarczych tkwiące w mentalności zbiorowej. Zgodnie z retoryczno-dyskursywnym nurtem nauk społecznych (Billig1996, $2006 \mathrm{i}$ in.), bariery te przybierają przede wszystkim postać stereotypów wyrażających różnorodne przekazy ideologiczne.

Realizacja jakościowego programu badań „Przedsiębiorstwo społeczne z sukcesem. Promocja dobrych praktyk" (projekt prowadzony przez Fundację „Nadzieja” ze wsparciem finansowym EFS, 2010-2011, zob. Ochinowski 2010)99 pozwoliła (oczywiście między innymi wynikami) zidentyfikować dwa stereotypy wspomnianego typu.

Pierwszy z nich to pojawiające się czasami oczekiwanie, iż osoby ze środowisk defaworyzowanych powinny same sobie radzić przy prowadzeniu przedsiębiorstw społecznych. W tym kontekście można przywołać słynny obraz Pietera Breughla „Ślepcy”. Tymczasem wyraźnie źródłem dobrych praktyk przedsiębiorczości społecznej wydają się te jej podmioty, które mają profesjonalne wsparcie menedżerskie (zob. np. Ochinowski 2010).

Przekonaniu temu towarzyszy inny stereotyp, traktujący funkcjonowanie przedsiębiorczości społecznej jako „przedsiębiorczości niepełnosprawnej”. W skrajnych wydaniach tego poglądu pojawia się więc oskarżenie o „psucie rynku” przez działania przedsiębiorców społecznych jako subwencjonowaną i na różne inne sposoby sztucznie podtrzymywaną aktywność gospodarczą. Takiemu ujęciu przeciwstawia się z kolei przeświadczenie, iż przedsiębiorczość społeczna, służąc osobom/obszarom marginalizowanym, stanowi również interesującą propozycję dla „twardego” biznesu jako sposób zagospodarowania również takiego rynku (ludzi biednych), co wyraźnie koresponduje z tezami Hoopesa (2011).

Dyskusje, także ideologiczne, wokół społecznej odpowiedzialności biznesu mają już długą tradycję i obszerny zapis na kartach literatury przedmiotu, którego choćby pobieżna relacja znacznie przekroczyłaby zakres niniejszej pracy (zob. np. Żemigała 2007, 2013, Bernatt, Bogdanienko i Skoczny 2011, Klincewicz 2013). Zwrócę więc uwagę jedynie na jeden aspekt tej problematyki ściśle wiążący się z sugestiami Hoopesa (2011).

Obecnie coraz częściej niektóre postulaty związane ze społeczną odpowiedzialnością biznesu rozwijane są w ramach problematyki zrównoważonego rozwoju gospodarczego (Zasady... 2011 i Żemigała 2011). Warto przypomnieć, iż teoretyczne podstawy dla tej perspektywy działań biznesowych sformułował

99 Badania zostały przeprowadzone w czerwcu i lipcu 2010 przez zespół reprezentujący różne nauki społeczne w składzie: Ewa Krakowińska (Wydział Zarządzania UW), Ryszard Skrzypiec (PWSZ w Cieszynie), Mateusz Przywara (niezależny badacz ekonomii społecznej związany z organizacjami pozarządowymi), Jan Urmański (badacz i praktyk przedsiębiorczości społecznej, PTS), Tomasz Ochinowski (Wydział Zarządzania UW) oraz Piotr Gołaszewski (refleksyjny przedsiębiorca związany z Uczelnią Łazarskiego w Warszawie). 
w 1971 roku rumuński ekonomista Nicolas Georgescu-Roegen, (wówczas główny ekonomista departamentu ochrony Banku Światowego) na kartach swej publikacji Prawo entropii i proces ekonomiczny. Zaproponował on trzy główne zasady definiujące tak zwaną termodynamikę funkcjonowania zrównoważonego rozwoju i ekologii:

1. zasoby odnawialne (jak np. ryby, ziemia i wody gruntowe) nie powinny być eksploatowane w tempie szybszym niż tempo ich regeneracji;

2. zasoby nieodnawialne (jak np. złoża mineralne czy kopalne paliwa) nie powinny być eksploatowane na poziomie przewyższającym eksploatację zasobów odnawialnych, którymi można je zastąpić;

3. zanieczyszczenia i odpady powinny być eliminowane w takim tempie, które umożliwi ich wchłonięcie lub rozkład przez biosferę.

Ogół działań gospodarczych, które prowadzą do wdrożenia założeń zrównoważonego rozwoju w praktyce biznesowej, tak by zmniejszać przepaść między gospodarką i środowiskiem określa się dziś terminem „zielona gospodarka”. Jednym ze sposobów włączenia się biznesmenów do wspomnianego procesu jest na przykład realizacja - jako element społecznej odpowiedzialności przedsiębiorstwa - zasady „trzech U” przy codziennym zarządzaniu odpadami. Chodzi o „unikanie” (ograniczanie produkcji odpadów na przykład poprzez używanie opakowań i generalnie produktów wielokrotnego użytku), „użycie powtórne” (naprawianie zepsutych urządzeń i przedmiotów oraz, podobnie jak już było powiedziane wcześniej, używanie trwałych narzędzi i produktów) oraz „utylizacja” (wielokrotne przetwarzanie odpadów, co oprócz oszczędności materiałów stwarza też szanse na ekologiczną edukację pracowników oraz klientów, poprzez wyrabianie u nich nawyków ekologicznych). W wersji angielskiej chodzi o zasadę trzech „r”: reduce, reuse, recycle.

Od kilkunastu lat idea zrównoważonego rozwoju zyskuje coraz bardziej klarowny aspekt humanistyczny w dyskusjach dotyczących biznesu i - szerzej - społecznych. Chodzi nie tylko o zasoby przyrodnicze, a także o najgę̨biej rozumiane, wbrew tradycyjnemu znaczeniu tego słowa w biznesie, zasoby ludzkie. Zresztą harmonia między tymi dwoma rodzajami zasobów to także cecha sygnalizowanego tu, względnie nowego spojrzenia na kwestię zrównoważonego rozwoju. Wspomniana tendencja wyraźnie prowadzi, poprzez manifesty i publikacje naukowe, do sprecyzowania humanistycznego nurtu zarządzania jako przeciwwagi dla wyłącznie instrumentalnego ujęcia społecznej odpowiedzialności biznesu, według którego jest ona przede wszystkim narzędziem przewagi konkurencyjnej (Kostera 2005, 2012 i 2013, Batko 2013, Kostera i Śliwa 2012).

W tym nurcie umieścić można na przykład europejską wersję koncepcji „Good Business”. Zaproponowana została przez Steve'a Hiltona i Gliesa Gibbonsa (2003) po skandalu „Enronu”. Ma ona taką samą nazwę co podobny ideologicznie, nieco wcześniejszy projekt amerykański, choć powstała niezależnie 
od niego (por. Csíkszentmihályi 2003, zob. także Kostera i Śliwa 2013, projekt ten omawiam w podrozdziale 3.3. niniejszej pracy). Główne założenia „Good Business" Hiltona i Gibbonsa mają swe korzenie w (szczególnie widocznym na terenie Europy) powszechnym kryzysie zaufania do polityków, połączonym ze wzrastającą siłą korporacji. Autorzy sygnalizowanej idei uważają, że społeczna odpowiedzialność biznesu już w tej sytuacji nie wystarczy. Obecnie potrzeba „społecznego przywództwa” organizacji, czyli wykorzystania firm do realizacji celów społecznych i edukacji społeczeństw w tym zakresie. Równocześnie takie podejście jest drogą do podnoszenia efektywności samych organizacji.

Trudno nie oprzeć się wrażeniu, że ludzie typu Jachniaka działali tak już przed laty, realizują wzorce biznesowe aktualne także dziś. Projekt „Good Business" może więc czerpać kapitał kulturowy także z tradycji i to również prowincjonalnej. Nie wydaje się bowiem, by przykład polskich przedsiębiorców pierwszych lat powojennych był odosobniony, co oczywiście trzeba sprawdzić poprzez analizy historyczne.

Doświadczenie Jachniaka każe na nowo przemyśleć znaczenie otoczenia społecznego dla możliwości uprawiania przyzwoitego biznesu. Jachniak dzięki swemu kapitałowi psychofizycznemu przetrwał najgorsze nawet warunki. Musiał jednak porzucić zawodową pasję swojego życia, to jest działalność prywatnego przedsiębiorcy. Najwyraźniej niezmiennie aktualna pozostaje teza Alasdaira MacIntyre'a sprzed lat o konieczności tworzenia społeczności lokalnych, bo inaczej moralność oraz poszanowanie człowieka nie przetrwa kolejnych nawrotów barbarzyństwa. Przy czym działania skierowane na budowę otoczenia sprzyjającego uprawianiu przyzwoitego biznesu, czyli działalności gospodarczej opartej na triadzie „podmiotowość - zaangażowanie - zakorzenienie”, nie powinny ograniczać się tylko do obszaru lokalnej „małej ojczyzny”.

Prezentowane w niniejszej pracy studia historycznych przypadków ukazały przedsiębiorców biorących odpowiedzialność praktycznie za całość życia społecznego. Nietrudno zauważyć, iż ta cecha stanowiła wyraźne wyprzedzenie, antecedencję europejskiej wersji programu „Good Business” (powstałego przecież dopiero po aferze „Enronu”), a także postulatów Hoopesa wobec korporacji (sformułowanych dopiero po pierwszej fali ostatniego kryzysu).

Niedawno Jerzy Kociatkiewicz i Monika Kostera (2012) podjęli problem „przywództwa zrównoważonego moralnie”. Wykorzystując perspektywę badania archetypów w organizacjach, poddali analizie kategorię „dobrego menedżera”. Poprzez interpretację wywołanych do celów badawczych opowieści o dobrym menedżerze (czyli wykorzystanie metodologii collage'u narracyjnego, zob. Kostera 2006) pokazali, iż dobroć jest kluczową metaforą menedżerskich opowieści. Jawi się ona jako coś realnego, ale zarazem ukrytego, coś, co każe bohaterom historii stawać twarzą w twarz wobec budzących grozę pytań o sprawy ostateczne, zrywać maski, ujawniając ukryty pod nimi fałsz i budzi niedookreśloną 
nadzieję na zmianę. „Tak widziana dobroć jest ‘Świętym Graalem' zarządzania” (Kociatkiewicz i Kostera 2012: 875).

Co istotne dla problematyki niniejszej pracy, takie kluczowe metafory są poprzez treść historii, w których występują, osadzane w kulturowym kontekście zarządzania (Kociatkiewicz i Kostera 2012).

Z takiej perspektywy doświadczenie Władysława Jachniaka już nie tylko zwiera kapitał kulturowy organizacji, ale także samo w sobie staje się tym kapitałem. Pomaga zarządzać sensem nie tylko działań przedsiębiorczych, ale także bycia przedsiębiorcą $\mathrm{w}$ trudnych czasach. 


\section{Zakończenie}

Głównym zagadnieniem historii organizacyjnej jest wykorzystanie doświadczeń historycznych do optymalizowania działań współczesnych organizacji. Dotąd problem ten nie doczekał się wielu opracowań. Zarówno na wydziałach historii, jak i zarządzania traktowany jest jako ciekawy, ale rzadko podejmowany w badaniach. Natomiast systemy punktacji prac naukowych obowiązujące środowiska akademickie większości krajów raczej nie nagradzają przedsięwzięć interdyscyplinarnych. Na Zachodzie działają jednak, wprawdzie poza głównymi nurtami nauk o zarządzania czy historiografii, środowiska systematycznie podejmujące kwestie relacji organizacyjnej przeszłości do organizacyjnej teraźniejszości i przyszłości. Dwa różne ujęcia tej problematyki starają się na przykład rozwijać redakcje periodyków „Business History” i omawianego przeze mnie „Management and Organizational History”. Niektóre uczelnie amerykańskie, poza historią biznesu ${ }^{1}$, którą jeszcze od lat 40 . ubiegłego stulecia promuje Harvard Business School, oferują również dziedzinę badań i dydaktyki, o trudnej do przetłumaczenia na język polski (bez narażenia się na złośliwe komentarze) nazwie „Public History” 2 . Rozwijają ją zazwyczaj wspólnie pracownicy wydziałów historycznych oraz szkół biznesu.

W Polsce badacz zainteresowany praktykami zarządzana z przeszłości w kontekście ich znaczenia dla dnia dzisiejszego i przyszłości organizacji zwykle działa w pojedynkę, często zajmując się równocześnie innymi zagadnieniami, zaliczanymi do „głównego nurtu” problematyki menedżerskiej. Dlatego też publikacje dotyczące historii organizacyjnej mają u nas charakter przede wszystkim sprawozdań z danego etapu refleksji historiograficznej i pojedynczych badań. Taka jest również niniejsza monografia. Stanowi ona propozycję wykorzystania tradycji przedsiębiorczości w Polsce jako źródła wartości i pomysłów dotyczących dobrych praktyk dla organizacji zmagających się ze współczesnymi wyzwaniami.

1 Warto przypomnieć, iż tradycyjna historia biznesu zajmuje się rekonstrukcją przeszłości, natomiast podejście propagowane $\mathrm{w}$ ramach historii organizacyjnej (i podjęte także przez niektórych historyków biznesu) relacjami przeszłości i teraźniejszości oraz przyszłości.

2 Chodzi o analizę funkcjonowania historii w przestrzeni publicznej, włączając w to świat biznesu. Na fakt, iż „Management and Organizational History” powstał, w zamierzeniu Rowlinsona, jako forum alternatywnego wobec większości prac publikowanych na łamach „Business History” sposobu uprawiania historii organizacyjnej, zwróciła mi uwagę Martyna Śliwa z Uniwersytetu w Essex (korespondencja e-mailowa, sierpień 2013). 
Wspomniane wartości oraz pomysły dotyczące rozwiązań praktycznych tworzą kapitał kulturowy organizacji. W niniejszej pracy za główny kontekst współczesnych wyzwań wobec zarządzania został uznany kryzys światowy, którego kumulację przyniósł rok 2007. Analiza dyskusji okołokryzysowych pozwoliła określić wyłaniający się z nich kapitał kulturowy organizacji. Stanowi on zestaw oczekiwań wobec współczesnej praktyki menedżerskiej, formułowanych przede wszystkim przez analityków obecnej sytuacji ekonomicznej świata (chodzi o rok 2013). Tak rozumiany kapitał kulturowy organizacji opiera się na triadzie wartości: podmiotowość - relacyjność - zakorzenienie.

Oprócz określenia kapitału kulturowego współczesnej organizacji istotną sprawą jest poszukiwanie efektywnych sposobów jego budowania i wykorzystania w praktyce. Do dyskusji dotyczącej tych wyzwań, dodaję perspektywę wybranych, historycznych doświadczeń przedsiębiorczości na ziemiach polskich. Zostały one:

a) wyselekcjonowane pod kątem ich związków ze wspomnianym kapitałem kulturowym,

b) zrekonstruowane tak, na ile pozwala obecny stan źródeł oraz

c) skonfrontowane ze współczesną myślą menedżerską.

Praca koncertuje się na pięciu przejawach wspomnianej tradycji.

(1) Jako źródło inspiracji dla współczesnej edukacji menedżerskiej został zaprezentowany jeden z mitów proprzedsiębiorczych, rozwiniętych na ziemiach polskich przełomu XIX i XX wieku. Chodzi o mit związany przede wszystkim z metaforą „lodzermenscha”. Jest on do dziś popularyzowany przez literaturę piękną, bardziej niż jakikolwiek inny mit bądź wzorzec kulturowy dotyczący działalności gospodarczej w Polsce. Spośród różnych mitów proprzedsiębiorczych, związanych na przykład z osiągnięciami gospodarczymi Polaków w zaborze pruskim (szczególnie w Wielkopolsce), w Galicji (szczególnie w okolicach Lwowa i Borysławia) i późniejszymi - z okresu międzywojennego, takimi jak Gdynia czy Centralny Okręg Przemysłowy - mit nawiązujący do metafory „lodzremenscha” najbardziej wydaje się nawiązywać treściowo do „Amerykańskigo snu".

Mit związany z metaforą „lodzermenscha” stanowi wyrosłą na polskich ziemiach (zaboru rosyjskiego) opowieść o życiu i przedsięwzięciach biznesmena, mniej lub bardziej świadomego napięcia między „czynnikiem ludzkim” a walką o zysk, a zarazem gotowego sprostać wyzwaniom globalizacji. Omawiany mit zawiera takie elementy treściowe, jak: wrażliwość na puls gospodarczej koniunktury, świadomość ryzyka i tajemniczość finansów, zmniejszanie niebezpieczeństwa niepowodzenia finansowego poprzez angażowanie się w różnorodne przedsięwzięcia biznesowe oraz zmaganie się z problematyką „praca-życie”, ze szczególnym uwzględnieniem napięcia między efektywnym przystosowaniem 
się do reguł rynkowych a wiernością tradycji kulturowej. Przypomniany tu mit zawiera wizję spełnienia w postaci dużego sukcesu finansowego, a równocześnie nasycony jest sporą dozą realizmu, aż do oswajania odbiorcy z możliwością zupełnej klęski. Wyraźnie jest więc lokalną, a zarazem urealistycznioną wersją ideologii Amercian dream.

(2) Niektóre elementy projektu „Nowej Kultury Pracy”, zainicjowanego przez niszową grupę polskich publicystów i przedsiębiorców w drugiej połowie lat. 40. ubiegłego stulecia okazały się dobrym tworzywem do konstruowania tzw. filozofii biznesu współczesnego przedsiębiorstwa z sektora MŚP.

Współwłaściciel działającej dziś firmy, należącej do branży edukacyjnej (sieć przedszkoli), wykorzystuje zmodyfikowane idee, postulowane przez wspomniany projekt, takie jak: personalistyczne ujęcie pracy jako aktu twórczego; zastąpienie maksymalizacji zysku, jego optymalizacją; płaca rodzinna, współdziałanie przedsiębiorców i pracowników z ludźmi kultury; wspomaganie instytucji rodziny; racjonalne zarządzanie zasobami środowiska lokalnego; traktowanie własności prywatnej jako osiągnięcia, a zarazem zobowiązania społecznego; preferencja dla drobnej przedsiębiorczości i spółdzielczości oraz dowartościowanie życia codziennego jako ważnej sfery edukacji i przedsiębiorczości.

Aplikacja przytoczonych elementów ideologii „Nowej Kultury Pracy” (szczegółowo je omówiłem w tej monografii) we współczesnej firmie okazała się szczególnie użyteczna podczas kryzysu, choć równocześnie warunki okołokryzysowe utrudniły realizację przynajmniej niektórych z tych elementów.

Już po zakończeniu moich badań współwłaściciel wspomnianej sieci przedszkoli wprowadził jeszcze jedno rozwiązanie „z ducha” omawianego projektu, inicjując powstanie lokalnego stowarzyszenia branżowego.

„Nowa Kultura Pracy” okazuje się ponadto ideową poprzedniczką współczesnych rozwiązań w obszarze etyki biznesu, co pokazała jej analiza porównawcza z realizowanym aktualnie na Zachodzie programem "Good Work”. Wspomniana polska koncepcja sprzed lat zawiera też idee, które wyraźnie nadają się do wykorzystania podczas dzisiejszych dyskusji o tak zróżnicowanej tematyce jak problemy dochodu narodowego, edukacja proprzedsiębiorcza czy procesy integracji europejskiej.

(3) Historiograficzna analiza badań realizowanych metodą historii mówionej przez Jana Górskiego w latach 60. i 70. ubiegłego stulecia - z udziałem przedstawicieli kierownictwa odbudowy Warszawy po II wojnie światowej uwypukliła rolę konfliktu wśród kadry kierowniczej jako istotnego elementu twórczej działalności menedżerskiej. Przemilczanie konfliktowości procesów organizowania grozi ideologizacją obrazu organizacji oraz pamięci organizacyjnej. Ważną rolę demistyfikacyjną może w tym kontekście spełnić historia mówiona. Rozwijając doświadczenie cytowanego badacza najnowszych dziejów Warszawy warto stosować historię mówioną nie tylko jako narzędzia badania 
przeszłości, ale także diagnozy aktualnej sytuacji danej firmy czy różnych kręgów jej otoczenia społecznego.

Nietrudno zauważyć, iż działania i sugestie Górskiego były wyraźną antycypacją koncepcji „dobrej rozmowy”, którą Theodore Zeldin, od kilkunastu lat propaguje wśród środowisk światowego biznesu. Propozycjom Zeldina dotyczącym generalnie historii organizacyjnej, poświęciłem oddzielny podrozdział niniejszej monografii.

Prace Górskiego zawierają ponadto (godny uwagi również specjalistów zajmujących się zarządzaniem) zarys koncepcji wyjaśniającej fakt, iż konflikty są nieodłącznie, lub niemal nieodłączne od procesów organizowania. Podobnie jak stała jest groźba ideologizacji tych procesów w dyskursie menedżerskim. Badacz proponował rozwijać „historię ludzką”, to jest taką perspektywę poznawczą, która będzie ujmować zasadniczą sprzeczność między dążeniem pojedynczych osób oraz szerszych zbiorowości do takich celów, jak: polityczna aktywność, rozwój demokracji itp., a rozczarowaniem, które dotyka człowieka w zetknięciu z bezduszną rzeczywistością różnorodnych struktur czy procesów przywołujących myśl o determinizmie. Zdaniem tego historyka i socjologa sprzeczność ta stanowi charakterystyczną cechę współczesności. Przywołane tu refleksje Górskiego pochodzą z lat 60 . ubiegłego stulecia. Warto je podjąć w kontekście obecnego czasu okołokryzysowego.

(4) Doświadczenia branży kawowo-herbacianej na ziemiach polskich (od ok. XIX do połowy XX wieku) dostarczają danych umożliwiających skonstruowanie „mapy” dobrych praktyk środowiska biznesowego o następujących cechach:

- dominacja małych i średnich przedsiębiorstw,

- zasięg krajowy,

- mit założycielski przypisujący istotne znaczenie polskim doświadczeniom branżowym jako prekursorskim w skali europejskiej,

- międzykulturowy charakter środowiska branżowego oraz zarządzanie różnorodnością w niektórych firmach,

- ekspansja na rynek krajowy zagranicznych potentatów posiadających znaczące przewagi konkurencyjne,

- duża zależność powodzenia przedsięwzięć handlowych od sytuacji międzynarodowej,

- próby wprowadzenia monopolu ze strony państwa i podmiotów zagranicznych,

- wynikająca ze specyfiki produktu i klientów antycypacja pewnych elementów współczesnego zarządzania na rynku doznań.

Palarnia Kawy „Pluton” Tarasiewiczów (1882-1950) stanowi przykład doświadczeń wspomnianej branży. W niniejszej monografii skupiam się więc na przypadku pojedynczej firmy. Jednakże relacje Kordiana Tarasiewicza, ostatniego dyrektora Plutona i najprawdopodobniej najstarszego żyjącego polskiego przedsiębiorcy, a zarazem historyka przedsiębiorczości, pozwalają na uchwyce- 
nie także niektórych rysów całego środowiska branży kawowo-herbacianej na ziemiach polskich od połowy XIX do połowy XX wieku. Ponadto firma Pluton stanowi dość dobrze udokumentowany przykład przedsiębiorstwa zarządzanego w taki sposób, który pozwala przypuszczać, iż główne idee wspomnianej wcześniej „Nowej Kultury Pracy” znała nie tylko mała grupa publicystów z lat 40. ubiegłego stulecia. „Nową Kulturę Pracy” można raczej uznać za zradykalizowane i nieco zideologizowane podsumowanie standardów zarządzania, obecnych także w polskiej tradycji przedsiębiorczości już wcześniej. Standardy te realizowało na przykład niszowe, ale zauważalne przez historyków środowisko, któremu Ireneusz Ihnatowicz (1971) nadał nazwę „burżua oświeceni”. „Pluton” Tarasiewiczów był przykładem działań wspomnianego środowiska złożonego głównie z małych i średnich przedsiębiorców rozwijających swoje przedsięwzięcia od połowy XIX do połowy XX wieku.

Firma Tarasiewiczów jest ponadto szczególnie predystynowana do roli „historycznego przewodnika” po zarządzaniu kryzysowym. Jej dzieje zaczęły się bowiem od najostrzejszej formy kryzysu organizacji, to jest bankructwa pierwszej inicjatywy biznesowej późniejszego założyciela rodzinnego przedsiębiorstwa Tadeusza Tarasiewicza. Na przestrzeni swej niemal 80-letniej historii Palarnia „Pluton” musiała stawiać czoła wewnętrznym i zewnętrznym kryzysom. Kolejni właściciele, a także dyrektorzy przedsiębiorstwa rozwiązywali sytuacje kryzysowe poprzez budowanie więzi środowiskowych i wykorzystywanie już istniejących (przede wszystkim towarzyskich) oraz łączenie innowacyjności z racjonalnym dbaniem o pracowników.

Jeśli chodzi o pierwszy z wymienionych aspektów - budowanie sieci powiązań, to do dziś w Polsce w żadnej branży nie został powtórzony sukces zainicjowanego przez „Plutona” Zrzeszenia Importerów Kawy i Herbaty R.P. (1931-1932 i 1936-1939), do którego dobrowolnie należało ok. 90\% handlowców zajmujących się sprzedażą wymienionych produktów na terenie kraju. Organizacja ta zbudowała i monitorowała stan efektywnej równowagi między wewnętrzną konkurencją a dbaniem o wspólne interesy w całym segmencie przedsiębiorców herbaciano-kawowych.

W zakresie relacji między innowacyjnością a dbaniem o pracowników filozofia biznesowa „Plutona” najwyraźniej ujmowała te dwa elementy jako jedną całość. Właściciele Palarni byli pierwszymi przedsiębiorcami na ziemiach polskich, którzy rozdali część akcji swej firmy pracownikom, co wówczas (1914 rok) było nadal nowością także na poziomie międzynarodowym. W okresie międzywojennym ówczesny dyrektor „Plutona” i syn właściciela Kordian Tarasiewicz zgodził się na warunki innowacyjnego przedstawiciela handlowego firmy, by ten mógł tak działać, że zarabiał więcej od wspomnianego dyrektora. Podczas II wojny światowej dla pracowników przedsiębiorstwa powstała spółdzielnia, gwarantująca im bezpłatne świadczenia medyczne (łącznie z bezpłatnymi lekami) 
oraz tanią żywność, a najmłodsi z zatrudnionych zostali objęci kursami szkoleniowymi, które prowadzili wybitni znawcy problematyki branżowej, zarówno naukowcy, jak i praktycy. Te innowacyjne rozwiązania były zresztą rozwinięciem analogicznych inicjatyw kierownictwa Palarni realizowanych przed i podczas I wojny światowej. Wracając do okresu międzywojnia, warto podkreślić, iż tradycje dbania o pracowników „Plutona” sprawiły, że Kordian Tarasiewicz zyskał na początku sprawowania swej funkcji dyrektorskiej duży kredyt zaufania ze strony zatrudnionych, co znacznie ułatwiało mu wyprowadzanie firmy z ostrego kryzysu w latach 30. ubiegłego wieku. Zażegnał wspomniany kryzys poprzez radykalne działania, takie jak obniżenie pensji oraz wprowadzenie procedur dyscyplinujących, a następnie stosunkowo szybkie zastosowanie innowacji technicznych i organizacyjnych. Uzyskał od większości pracowników społeczne przyzwolenie na te działania. Nawet obniżenie pensji nie spowodowało obniżenia morale personelu.

Warto podjąć dalsze badania by sprawdzić, na ile traktowanie łącznie innowacyjności w wąskim znaczeniu tego słowa i troski o pracowników, bez popadania w idealizm, dotyczyło także innych (i jakich) grup przedsiębiorców na terenie Polski. O tym, że środowisko reprezentowane przez „Plutona” nie było w tym kontekście jedyne, sugeruje choćby uwaga Jana Zieleniewskiego (1981), autora pierwszego po II wojnie polskiego podręcznika zarządzania, który pisząc na temat spontanicznej innowacyjności menedżerów początku XX wieku, nie znających zasad tayloryzmu, jako przykład właśnie tej innowacyjności podaje propracownicze działania właścicieli dużego przedsiębiorstwa należącego niegdyś do jego rodziny ${ }^{3}$. Na szczegółową analizę z tej perspektywy czekają także dzieje takich firm, jak: fabryka Wedla, Dom Towarowy Braci Jabłkowskich, sklepy braci Pakulskich, „Gazolina”, by wymienić tylko takie przypadki przedsiębiorstw, co do których posiadam wstępne rozpoznanie badawcze wykonane głównie na prowadzonych przeze mnie seminariach magisterskich.

Obecnie, w czasie okołokryzysowym kwestia rozumienia działań propracowniczych jako elementu innowacyjności firmy stała się problemem zarządzania przenikającym nawet do publicystyki. Na przykład „Magazyn Świąteczny Gazety Wyborczej” opublikował niedawno następującą refleksję Krzysztofa Mądela, zajmującego się etyką rynku: „wiele firm marnuje zasoby ludzkie, lekceważąc jakość relacji międzyosobowych albo podporządkowując je prostym kryteriom wydajności. Tymczasem na dłużą metę relacje decydują o wszystkim, bo to od nich zależy, czy firma w ogóle jest firmą, czyli zespołem osób zdolnych do współpracy i reorganizacji”"4.

3 Chodzi o fabrykę maszyn Zieleniewskiego w Krakowie, która pod różnymi nazwami działa nieprzerwanie od 1804 roku. Dziś są to Zakłady Budowy Maszyn i Aparatury im. Ludwika Zieleniewskiego, mieszczące się w Niepołomicach.

4 K. Mądel, A. Klich, (2013). Kto boi się Franciszka? „Magazyn Świąteczny Gazety Wyborczej”, 03-04.08.2013, s. 19. 
(5) Biografia zawodowa Władysława Jachniaka (1915-1994) pokazuje za pomocą jednego przypadku możliwość realizacji „niepokornej” przedsiębiorczości, która jest nie tyle „sposobem na życie”, ile „sposobem życia” względnie niezależnym nawet od możliwości (bądź zupełnego braku tej możliwości) prowadzenia prywatnej działalności gospodarczej. Jachniak nie przestał być przedsiębiorcą ani w stalinowskim więzieniu, ani gdy przez wiele lat pracował w dużych instytucjach państwowych okresu gospodarki planowej. Przedsiębiorczość okazuje się, z perspektywy takiego doświadczenia, naturalnym sposobem funkcjonowania człowieka. Równocześnie zupełnie naturalnie służy również celom społecznym. Jachniak za tak samo ważne jak rozwój swoich przedsięwzięć uważał współpracę z Eugeniuszem Kwiatkowskim przy odbudowie wybrzeża oraz projektowanie rozwiązań w zakresie rozwoju handlu zagranicznego Polski po II wojnie światowej. Innowacyjność zarówno dla firmy, jak i różnych kręgów jej otoczenia staje się po prostu treścią codziennych działań przedsiębiorcy. Rodzaje organizacji (na przykład prywatne czy administracyjne), w których działa człowiek o wspomnianym nastawieniu do biznesu, stają się sprawą drugorzędną, a najlepszym rozwiązaniem dla niego wydaje się być harmonijna różnorodność podmiotów z którymi zarządza, lub z którymi współpracuje. Ważnym element przedsiębiorczości omawianego typu stanowi respektowanie podstawowych wartości ogólnoludzkich, traktowanych także jako naturalne ramy przedsięwzięć biznesowych bądź administracyjnych.

Reprezentowany przez Jachniaka sposób funkcjonowania w rzeczywistości gospodarczej Polski powojennej wyraźnie antycypował europejską wersję projektu z dziedziny etyki biznesu „Good Business” Hiltona i Gibbonsa (2001), sformułowaną dopiero po aferze Enronu. Projekt Hilotna i Gibbonsa postuluje konieczność podjęcia przez firmy społecznie odpowiedzialnego przywództwa w zakresie realizacji celów społecznych i edukacji społeczeństw.

Doświadczenie Jachniaka dotyka również współczesnego nam zagadnienia przywództwa biznesowego „zrównoważonego moralnie”, by odwołać się do terminu, który zaproponowali Kociatkiewicz i Kostera (2012b). Pokazuje, iż w pewnych odmianach tradycji działań gospodarczych także w Polsce nie istniały różnice między przedsiębiorczością (rozumianą jako kreatywność) a zarządzaniem (rozumianym jako porządkowanie rzeczywistości), ani między przedsiębiorczością społeczną i innymi jej rodzajami. Przedsiębiorcy tacy jak Jachniak brali odpowiedzialność praktycznie za całość życia społecznego. Postulaty niwelowania wspomnianych różnic pojawiają się dziś w centrum dyskusji dotyczących optymalizacji bądź zmian modeli biznesowych wobec wymagań sytuacji okołokryzysowej (Kostera i Śliwa 2012; Hoopes 2011).

Nie wydaje się, by przykład Jachniaka był odosobniony w tradycji polskiej przedsiębiorczości. Dalsze analizy historyczne powinny wykazać, czy należał do typowych czy raczej niszowych jej przejawów. Jednak już teraz widać, iż Jachniak 
kontynuował rodzaj przedsiębiorczości, a zrazem zarządzania (przynajmniej jeśli chodzi o najważniejsze cechy), realizowany przez „burżua oświeconych”, postulowany w programie „Nowej Kultury Pracy” i pojawiający się także w wysitkach budowniczych Warszawy po 1945 roku. Równocześnie jednak biografia tego przedsiębiorcy ukazuje dramatyczne przerwanie tej tradycji. Odporność psychofizyczna pozwoliła mu godnie przetrwać skrajnie trudne warunki jakiś doświadczał, choć już nie udało mu się ocalić życia rodzinnego (po dwóch rozwodach ostatecznie pozostał osobą samotną). Nie mógł też kontynuować swej życiowej pasji, to jest działalności prywatnego przedsiębiorcy. Istniejące fragmentaryczne opracowania dziejów przedsiębiorczości w Polsce po II wojnie światowej oraz dostępne wspomnienia (jedne i drugie przywoływałem w niniejszej monografii) pozwalają mówić o wielu takich dramatach na terenie naszego kraju - i szerzej - naszej części Europy.

Permanentny kryzys, jak można metaforycznie określić czasy gospodarki planowej w Polsce (od 1947 do 1989 roku), a szczególnie ich pierwszą fazę (lata 1947-1956) warto zobaczyć także jako krańcową zmianę kapitału kulturowego organizacji, przeprowadzoną przez radyklany przymus administracyjny. Oczekiwania ówczesnego otoczenia (przede wszystkim politycznego) polskiej przedsiębiorczości - wyrażane wprost za pomocą propagandy lub w sposób ukryty przez działania administracji - wobec podmiotów działalności gospodarczej miały po 1947 roku charakter przede wszystkim promowania, a de facto także realizowania przez władze państwowe nieuczciwej konkurencji. Skutkiem takiej wieloletniej sytuacji było nie tylko powstawanie i utrwalanie się nowych ról „komunistycznych menedżerów” (Kostera i Wicha 1994; Kostera 2003) czy zachowań przystosowawczych w organizacji (Kostera 2002, podaję za Kosterą i Śliwą 2012), ale także zmiany mentalności zbiorowej. Zmiany te polegały między innymi na destrukcji tego sposobu myślenia o przedsiębiorczości, który reprezentowały przykłady poddane analizie w mojej pracy. Niektóre ze skutków wspomnianego procesu przemian mentalności zbiorowej Polaków trwają do dziś.

Roman Głowacki (Głowacki i Karasiewicz 2007, 2009) analizując bariery rozwoju marketingu w naszym kraju po 1989 roku wskazuje na dwa rodzaje tych barier: ekonomiczne i mentalne. Obydwie stanowią brzemię przeszłości z czasów gospodarki planowej. Bariery ekonomiczne, już nieistniejące, tłumaczą opóźnienie wejście Polski do grona krajów rozwijających działania gospodarcze typu marketingowego ${ }^{5}$. Należały do tych barier takie cechy gospodarki planowej jak: centralizacja, monopole administracyjne oraz wysoki stopień koncentracji

5 W USA początek szerokiego wykorzystania marketingu przypada na lata 60 . ubiegłego stulecia. W Europie Zachodniej nieco później (Hoopes 2011). Warto przypomnieć, iż cytowany Głowacki już w latach 60. ubiegłego wieku, wykorzystując swoją wiedzę sukcesywnie zdobywaną na uniwersytetach amerykańskich, pisał w polskiej literaturze naukowej o marketingu. Jednak jeszcze w 1978 roku podręcznik do marketingu jego 
w sferze produkcji i handlu. Towarzyszyły im, a także były ich długofalowym skutkiem, bariery mentalne:

- niska produktywność (w mentalności zbiorowej wyrażana powiedzeniem „czy się stoi, czy się leży... [wynagrodzenie - T.O.] się należy”),

- brak poszanowania własności prywatnej (własność państwowa i spółdzielcza postrzegana była jako niczyja, dlatego też rzeczą zwykłą stały się kradzieże w miejscu pracy, często za przyzwoleniem społeczny). „Niektóre z tych zachowań, mimo przekształceń własnościowych nie straciły na aktualności” (Głowacki i Karasiewicz 2007: 82).

Warto w tym kontekście przypomnieć, iż gdy Leopold Tyrmand w połowie ubiegłego wieku przedstawiał na kartach powieści Zly literacką pochwałę polskiej przedsiębiorczości, to musiał posłużyć się kostiumem ze świata przestępczego ${ }^{6}$.

Natomiast wydany przed kilku laty pod redakcją Małgorzaty Szpakowskiej wnikliwy zbiór opracowań Obyczaje polskie. Wiek XX w krótkich hastach (2008) o działalności przedsiębiorczej, wspomina niemal wyłącznie w związku z „kombinowaniem” czasów gospodarki planowej, ówczesnym losem „prywaciarzy” oraz odradzaniem się spontanicznej działalności gospodarczej pod koniec lat 80 . ubiegłego stulecia. Starsze tradycje przedsiębiorczości wydają się być - na poziomie obyczajów Polaków - niezauważalne nawet dla badaczy.

Być może więc należy przeanalizować okres gospodarki planowej w Polsce, jako brzemię historii stanowiące „cień” zarządzania w naszym kraju, zgodnie z jungowskim znaczeniem tego terminu, które do problematyki menedżerskiej przeniosła Kostera (2012). Jest to jednak tylko sugestia do dalszych badań. Nie posiadając odpowiednich kompetencji warsztatowych jedynie wyrażam intuicję, iż tradycje przedsiębiorczości w Polsce zawierają w sobie materiał interesujący dla antropologów organizacji, szczególnie tych zorientowanych na analizę archetypów (Kostera 2003, 2012).

pióra musiał być, ze względów cenzuralnych, wydany pod tytułem Przedsiębiorstwo na rynku (Głowacki 1978, Głowacki i Karasiewicz 2007, 2009, Karasiewicz 2010).

6 Moim zdaniem warto czytać Tyrmanda jako zapalonego piewcę polskiej przedsiębiorczości. Taką jej pochwałą, dla zmylenia cenzury lat stalinowskich, ubraną w kostium działań przestępczych, jest również Zly (książka napisana w 1954 roku). Spółdzielnia „Woreczek” w przywołanej powieści literalnie stanowi strukturę kryminalną. Jeśli jednak pominąć ten literacki sztafaż, to reprezentuje ona efektywne, dobrze zarządzane, duże prywatne przedsiębiorstwo. Na przykład słynna powieściowa scena, w której jeden z pracowników „spółdzielni” nakłania przypadkowego przechodnia do zakupu cegły, stanowi precyzyjny, choć literacki opis kultury organizacyjnej jako ważnego organizacyjnie fenomenu, który ma duży wpływ na firmę, poszczególne grupy w jej obrębie oraz na indywidualne zachowania. Jest czymś, co podzielają członkowie danej organizacji. Istnieje na wielu poziomach (grupowym, organizacyjnym, narodowym i tak dalej). Składa się ze wspólnych wartości, przekonań czy założeń. Wpływa nie tylko na zachowania, ale także na postawy członków danej organizacji. 
Niniejsza monografia zatrzymuje się na progu antropologii. Pozostaje wyłącznie w obszarze historiografii. $Z$ tej perspektywy sytuacja przywołana przez prace pod redakcją Szpakowskiej Obyczaje w Polsce. Wiek XX w krótkich hastach uwypukla istotną cechę kapitału kulturowego organizacji, który proponują tradycje analizowane w tej monografii. Mimo różnic między poszczególnymi przypadkami i oczywiście wybiórczego charakteru tych przypadków, wszystkie dotyczą działalności przedsiębiorczej jako rodzaju obyczajowości, równocześnie przez dobre obyczaje - mniej lub bardziej skutecznie - regulowanej. Taka perspektywa ułatwiała rozwiązywanie przynajmniej niektórych problemów menedżerskich, które dziś są dyskutowane jako wyzwania czasów okołokryzysowych. Obyczaje stawały się nieraz źródłem rozwiązań proceduralnych.

Świadomość napięcia między życiem osobistym, ze szczególnym uwzględnieniem rodzinnego, a wymaganiami rynku prowadziła na przykład do „złotej reguły” „Plutona”, by precyzyjnie rozgraniczać finanse firmy i rodziny. Najwyraźniej troska o to rozgraniczenie nie stanowiła jedynie wyrazu respektowania prawa, ale była elementem rodzinnego, a zarazem firmowego obyczaju. Jednocześnie istotny element pamięci organizacyjnej przedsiębiorstw omawianego rodzaju stanowiło doświadczenie kryzysów przywództwa powodowane dylematami przedstawicieli kolejnych pokoleń, czasami zmuszonych do wyboru między podjęciem odpowiedzialności za rodzinne przedsięwzięcie a innymi pasjami życiowymi. Warto przypomnieć, iż przedsiębiorczość, aby angażowała osobę ją prowadząca, musi być istotna dla jej życia, stwarzać możliwości zmian na lepsze (por. (Banerjee i Duflo 2012)). Warunek ten bez obawy o nadmierną ekstrapolację można rozumieć w kontekście zarówno wysokości dochodów, jak i czynników pozafinansowych oraz objąć nim nie tylko osoby kierujące firmą, ale także pracowników.

Jednak rekonstruowana przeze mnie tradycja wskazuje na jeszcze jeden aspekt sygnalizowanego tu zagadnienia relacji „praca-życie”. Przedsiębiorstwa związane $\mathrm{z}$ omawianą tradycją działały $\mathrm{w}$ otoczce rozbudowanych sieci kontaktów interpersonalnych. Przy czym znaczące źródło wspomnianych sieci stanowiły więzi rodzinne, sąsiedzkie i towarzyskie. Uławiało to zatrudnianie znanych, a zarazem kompetentnych osób na różnych, szczególnie kluczowych stanowiskach, dostarczało pomysłów do naśladowania i innowacyjnego rozwijania, dawało możliwość wielorakiego wsparcia podczas kryzysów oraz wyznaczało wzory obyczajowe zachowań wobec konkurencji czy pracowników. Charakterystyczne, że w pewien sposób otoczka ta, wypośrodkowując jednak między paternalizmem a „zrównaniem” kadry kierowniczej i personelu obejmowała także zatrudnionych. Otrzymywali oni różnorodną pomoc od swoich firm w sytuacjach kryzysowych, w czasach stabilnych pozostawiani byli własnej samodzielności, a praktycznie zawsze mogli korzystać z takich inicjatyw kierownictwa, jak: regularne zajęcia sportowe, wydarzenia kulturalne, świętowanie 
jubileuszy itp., które stwarzały okazję do integracji na różnych poziomach. Przy czym inicjatywy te nie miały charakteru doraźnie organizowanych eventów, ale były naturalnie wpisane w obyczajowość przedsiębiorstw. Wspomniana otoczka była tak ważna dla kierownictwa firm, takich jak „Pluton”, iż zdarzało się, że respektowali on wynikłe z niej zobowiązania nawet jeśli tymczasowo utrudniało to realizację niektórych zamierzeń biznesowych.

I tak na przykład Kordian Tarasiewicz, gdy jako jeden z najmłodszych wówczas w Polsce dyrektorów obejmował zarządzanie „Plutonem” (miał 24 lata, chodzi o rok 1934), zastał jako personel firmowych sklepów zatrudnione „panie z towarzystwa", które nie nadążały już za wymaganiami rynku sprzedażowego. Tarasiewicz utrzymał ich zatrudnienie, ale objął obniżką pensje, przede wszystkim zaś skupił się na rozwoju pozasklepowych form sprzedaży (rozbudował system przedstawicieli handlowych) i otwieraniu następnych sklepów - już $\mathrm{z}$ personelem o nowych standardach.

Jednocześnie warto podkreślić, iż tenże dyrektor Palarni, dzięki omawianej tu otoczce kontaktów interpersonalnych, zyskał na przykład już na początku swej działalności bliskiego, długoletniego współpracownika, dzięki któremu mógł elastycznie przeprowadzić różne przedsiębiorcze inicjatywy. Był to Antoni Kamiński, starszy kolega Kordiana Tarasiewicza ze studenckiej korporacji „Jagiellonia”, zaprzyjaźniony z nim. Razem zwiedzili centralę głównego konkurenta polskich przedsiębiorstw kawowych firmy J. Mainl w Wiedniu. Wyjazd ten stanowił jedno z pierwszych przedsięwzięć młodego dyrektora „Plutona” (1934). Dwa lata później po ukończonych studiach handlowych i praktyce zagranicznej Kamiński został zatrudniony w firmie Tarasiewiczów jako „wskazujący dużo nerwu organizacyjnego i pomysłowości w dziedzinie reklamy" (Tarasiewicz 1971: 119). Należał do grupy młodych kierowników (w wieku 30-34 lat), stopniowo obejmujących najważniejsze działy „Plutona”. Był odpowiedzialny za zespół przedstawicieli handlowych (dział sprzedaży) oraz za działy reklamy i opakowań, czyli te obszary przedsiębiorstwa, które zdaniem Kordiana Tarasiewicza wymagały znaczących udoskonaleń. Utrzymywał również ścisłe kontakty towarzyskie z Tarasiewiczami i ze środowiskiem przedsiębiorców, a także grafików i architektów, co znacznie ułatwiło zmiany elementów plastycznych wspomagających działalnie firmy (przede wszystkim wprowadzenie nowego logo, nowych opakowań i materiałów reklamowych). Podczas II wojny światowej Kamiński po czynnym udziale w walkach 1939 roku, dzięki staraniom kierownictwa „Plutona” uniknął obozu jenieckiego. Gdy hitlerowcy uniemożliwili polskim firmom legalne działania na rynku kawowym, znacząco przyczynił się do rozwinięcia przez Palarnię Tarasiewiczów innych obszarów funkcjonowania. W 1940 roku przeszedł do Towarzystwa Przemysłowego „Lawina” jako jeden ze współwłaścicieli, aby umożliwić „Plutonowi” sprzedaż cukierków. Został dyrektorem tej firmy. W pierwszych latach okupacji hitlerowskiej sprzedaż 
cukierków z „Lawiny” stanowiła znaczącą część obrotów „Plutona”, do czasu gdy okupant zabronił i tej działalności (1942 rok). W grudniu 1944 roku wraz z Kordianem Tarasiewiczem oraz innym przedstawicielem kierownictwa Palarni - Stanisławem Pągowskim, Kamiński pracował przy uruchomieniu produkcji marmolady w Radoniach dla potrzeb handlowych „Plutona”. Wcześniej był uczestnikiem i gospodarzem towarzyskich spotkań warszawskich przedsiębiorców, stanowiących ważny element konsolidacji środowiska w warunkach okupacji hitlerowskiej. Po powojennym przekształceniu „Pultona” (w 1948 roku) ze spółki akcyjnej w spółkę z o.o. Kamiński wszedł do jej Rady Nadzorczej (Tarasiewicz 1971, 2010 oraz moje rozmowy z Kordianem Tarasiewiczem 2013).

Podobne do przytoczonych tu przejawów funkcjonowania sieci powiązań interpersonalnych, związanych z Palarnią Tarasiewiczów, zawierają także inne przykłady ideologii biznesowych oraz podmiotów działań gospodarczych analizowane w niniejszej monografii. Tworzona przez wspomniane sieci otoczka między innymi pomagała zdobywać poczucie bezpieczeństwa zarówno właścicielom firm, kadrze menedżerskiej, jak i pracownikom wobec wielorakich zmian otoczenia organizacji. Dziś poczucie bezpieczeństwa zawodowego staje się coraz ważniejszym problemem zarządzania. Ostatnio Krzysztof Cybulski (2013) badając polskich menedżerów sprzedaży, zidentyfikował fakt, iż ta grupa zawodowa, zaliczana przecież do najbardziej elastycznych na rynku pracy, ceni w swoich firmach przede wszystkim rozwiązania prawne i organizacyjne dające wspomniane poczucie bezpieczeństwa. Nie wydaje się, żeby była to tylko polska specyfika i tylko stanowiąca skutek kryzysu. Taką tezę potwierdza m.in. szeroko zakrojony sondaż, który dotyczył organizacji biznesowych, zrealizowany przez University Fellows International Research Consortium, obejmujący 14 krajów świata z różnych kontynentów. Sondaż ten obejmował między innymi kulturę organizacyjną firm charakteryzowaną przez właścicieli lub osoby odpowiedzialne za zarządzanie zasobami ludzkimi. Podstawę teoretyczną omawianej części badań stanowiła koncepcja kultury organizacyjnej zawarta w modelu wartości konkurujących Camerona i Quinna. Wyniki próby z badanych krajów, tak zróżnicowanych kulturowo jak: Polska, Czechy, Dania, Niemcy, Włochy, Holandia, Portugalia, Szwajcaria, Turcja, Australia, Kanada, Kolumbia, Hongkong i Tajwan pokazały, iż we wszystkich z nich popularna jest kultura klanu, a więc taka, która daje poczucie bezpieczeństwa uczestnikom organizacji wynikające ze stosunków interpersonalnych typu rodzinnego. Wspomniany pojedynczy sondaż, w dodatku oparty na ankietach, które nie miały adaptacji kulturowej (były tylko tłumaczone), wypełnianych drogą korespondencyjną przez przedstawicieli kierownictwa firm, oczywiście nieunieważnia innych, cytowanych w licznych podręcznikach psychologii kulturowej i zarządzania badań, pokazujących, iż kultura klanu nie jest bynajmniej na świecie powszechna. Jest typowa dla kultur Dalekiego Wschodu, zwłaszcza Chin kontynentalnych i chińskich enklaw oraz krajów, 
w których Chiny miały swoje historyczne wpływy (Japonia, Korea, i in.). Ale dla USA, Wielkiej Brytanii, Kanady, Australii, i wielu innych powszechność kultury klanu jest wątpliwa. Dane z przytoczonego sondażu mówiące o międzykulturowej popularności kultury klanu proponuję traktować wyłącznie jako swoiste działania Public Relations badanych firm. Pytania o kulturę organizacyjną przedsiębiorstwa są przecież mocno obciążone zmienną aprobaty społecznej. W kontekście mojej monografii wspomniane wyniki proponuję interpretować jako rozpoznanie przez globalny świat biznesu rodzaju kapitału kulturowego, jakiego oczekują od przedsiębiorstw szeroko rozumiani interesariusze. Były to oczekiwania zarejestrowane tuż przed kumulacją kryzysu ekonomicznego w 2007 roku (wspomniane wyniki uzyskano rok wcześniej) ${ }^{7}$.

Kapitał kulturowy zawarty w tradycji przedsiębiorczości na ziemiach polskich wyraźnie wychodzi naprzeciw tym oczekiwaniom. Uwagi tej nie podważa oczywisty fakt, iż analizowane tu historyczne przykłady dotyczyły czasów i uwarunkowań, w których pracownicy wiązali się z firmami długookresowo, nieraz na całe życie. Jednak dziś, gdy tymczasowość zatrudnienia staje się codziennością, budowa międzyosobowych więzi w samych przedsiębiorstwach, oraz wokół nich, może być przydatna zarówno kadrze zarządzającej jak i pracownikom bardziej niż kiedykolwiek wcześniej. „W epoce postindustrialnej coraz częściej będziemy zmieniać miejsce i charakter pracy, coraz więcej będzie więc zależeć od umiejętności nawiązywania kontaktu $z$ innymi. Minęły czasy wielkich samotnych karier, dziś liczy się kooperacja, także ta na poziomie nieformalnym, czyli związki koleżeńskie łączące ludzi różnych zawodów, bo często tylko dzięki nim można zmienić profil firmy"8.

Konkretne wykorzystanie kapitału kulturowego organizacji zawartego w tradycjach polskiej przedsiębiorczości zależy od potrzeb poszczególnego menedże-

7 Był to część projektu „Globalny sondaż na temat organizacji biznesowych i ich otoczenia" (ang. Survey of Businesses and Their Public). Projekt koordynowała Carolyn Egri (Uniwersytet Simona Frasera, Kanada). Badanie było wykonane w 2007 roku, drogą korespondencyjną. Podwykonawcy krajowi wysyłali kwestionariusze do wybranych firm na podstawie przystosowanej do rzeczywistych warunków próby, której pierwotną wersję, dobraną losowo przygotował zespół prowadzący całość projektu. Ostatecznie badanie objęło 14 państw. Następujące państwa (w nawiasach podaję liczebność firm, od których otrzymano odpowiedzi w danym kraju): Polska $(n=107)$, Czechy $(n=173)$, Dania $(\mathrm{n}=201)$, Niemcy $(\mathrm{n}=138)$, Włochy $(\mathrm{n}=77)$, Holandia $(\mathrm{n}=115)$, Portugalia $(\mathrm{n}=197)$, Szwajcaria $(\mathrm{n}=224)$, Turcja $(\mathrm{n}=113)$, Australia $(\mathrm{n}=193)$, Kanada $(\mathrm{n}=465)$, Kolumbia (nie posiadam danych o liczebności próby), Hongkong $(\mathrm{n}=202)$ i Tajwan $(\mathrm{n}=174)$. Kierowałem zespołem podwykonawców w Polsce złożonym ze studentów Wydziału Zarządzania UW. Wyniki dotyczące kultury organizacyjnej nie zostały opublikowane. Piszę o nich za zgodą Carolyn Egri. W sprawie szczegółowych danych dotyczących wspomnianych badań proszę o kontakt pod adresem: ochinto@wz.uw.edu.pl

8 K. Mądel, A. Klich, (2013), Kto boi się Franciszka?, „Magazyn Świąteczny Gazety Wyborczej”, 03-04.08.2013, s. 19. 
ra, jego otwarcia na doświadczenie historyczne bez popadania w prezentyzm ${ }^{9}$, a także od „ducha czasu”, czyli aktualnych wyzwań zarządzania, które kształtują wspomniane potrzeby (oprócz przypadków podanych w prezentowanej monografii; zob. np. Jabłkowski 2013). Niniejsza praca stanowi przykład uogólniającej10 interpretacji wybranych elementów tej tradycji wykonanej z perspektywy współczesności.

Ograniczenia prezentowanej monografii wynikają oczywiście z faktu, iż opiera się ona na badaniach pojedynczego autora (choć odnoszę się w niej do poglądów i wyników prac wielu inny osób), z konieczności więc ma charakter selektywny. Wobec braku kompleksowych badań dziejów przedsiębiorczości11 w Polsce zainteresowałem się pierwszym okresem intensywnego jej rozwoju, to jest stuleciem od połowy XIX do połowy XX wieku. Wybrałem z tego okresu mało znane przypadki ideologii i praktyk przedsiębiorczych, które zawierały kapitał kulturowy interesujący dla menedżerów współczesnych nam organizacji.

Dalsze badania powinny poddać wspomniane stulecie (od połowy XIX do połowy XX wieku) systematycznej analizie, uwzględniając doświadczenie przedsiębiorców działających na terenie wszystkich zaborów i tych, którzy wybrali emigrację, a także analizując kapitał kulturowy dużych przedsięwzięć Polski międzywojennej realizowanych dzięki takim postaciom jak Eugeniusz Kwiatkowski. Na pilne poznanie zasługuje też kapitał kulturowy zawarty w odradzającej się dynamicznie polskiej przedsiębiorczości lat 90 . XX wieku.

Zgodnie z logiką podejścia jakościowego, a także - czy raczej szczególnie z założeniami historii organizacyjnej, respektującej podstawowe reguły historiografii, opublikowanie w prezentowanej monografii wyników badań i propozycji interpretacyjnych to jedynie zaproszenie do dyskusji, początek a nie koniec procesu interpretacji i weryfikacji przedstawionych tez.

Zarówno wspomnianą dyskusję, jak i ogólnie percepcję tradycji przedsiębiorczości, może znacznie utrudnić ahistoryczny charakter współczesnych nauk o zarządzaniu i organizacji „głównego nurtu” oraz podobna atmosfera dydaktyki w szkołach biznesu, szczególnie na terenie naszego kraju.

Znany amerykański kosmolog Roger Penrose swoją popularnonaukową książkę Nowe szaty króla opatrzył uwagą, iż zamieszcza w niej wzory matematyczne, choć jest świadom tego, że każdy z tych wzorów zmniejsza liczbę potencjalnych czytelników o połowę. $\mathrm{Z}$ zachowaniem wszelkich proporcji, bardzo podobny los, jak się wydaje, czeka większość prób mówienia o historii na

9 O prezentyzmie w teorii organizacji dość obszernie piszę w rozdziale III. Tu ograniczam się do wąskiego rozumienia terminu „prezentyzm” w znaczeniu mechanicznego używania doświadczeń z przeszłości jako „wzorów” tłumaczący zjawiska współczesne i odwrotnie.

10 W historiograficznym znaczeniu terminu „uogólniający”, które wyjaśniam we „Wstępie” do niniejszej monografii.

11 W znaczeniu terminu „przedsiębiorczość” związanym z gospodarką kapitalistyczną. 
wydziałach zarządzania, chyba że byłaby to wąsko rozumiana historia gospodarcza lub historia zarządzania jako dyscypliny naukowej. Przynajmniej w naszej części Europy przedstawiciele nauk o zarządzaniu wyraźnie podobni są do tych psychologów, o których przed laty Michaell Billig (1999: 31) pisał z przekąsem: „(...) are supposed to be modern”. Billig stwierdził również, że postawa taka skutkuje zapominaniem ważnych ustaleń z przeszłości lub/i odkrywaniem na nowo dawno już poznanych „Ameryk”.

Zdarzają się też badacze zarządzania przekonani o braku jakiejkolwiek historii godnej uwagi teoretyka, a tym bardziej praktyka przedsiębiorczości działającego na terenie Polski: „,...) trudno mówić o tradycji polskiego biznesu, bo co to za tradycja, która nie ma nawet dwudziestu lat”, by zilustrować wspomnianą tendencję cytatem z wykładu na Wydziale Zarządzania UW12. Wreszcie - last but not least - oddziaływać mogą w tym kontekście jeszcze dwa czynniki, opisane jak dotychczas tylko przez publicystykę naukową i literaturę piękną. O pierwszym z nich, dotyczącym skali globalnej, tak pisał przed wielu laty brytyjski popularyzator dziejów nauki James Burke (2010: 10; oryginał cytowanej publikacji pochodzi z 1999 roku):

„Korporacje są zdolne przeżyć w zmieniającym się świecie, wyłącznie skłaniając zatrudnionych specjalistów do wprowadzania zmian, zanim ktoś ich uprzedzi. Zwycięstwo na rynku osiąga się przez zaskakiwanie konkurentów. Nie da się ukryć, że cały ten proces zaskakuje również konsumentów, szczególnie w dzisiejszym świecie elektroniki, gdzie zanim użytkownik zabierze się do przeczytania instrukcji, opisywany w niej gadżet zazwyczaj jest już przestarzały".

Wrażenie, iż większość adeptów i wykładowców zarządzania pomija refleksję historyczną opieram wyłącznie na mojej wybiórczej znajomości sytuacji w Polsce. Nie jestem jednak pewien, czy nie obejmuje ona jednak szerszej tendencji13. Oczywiście na Zachodzie istnieją odrębne jednostki akademickie oraz wyłącznie badawcze podejmujące problematykę dziejów myśli menedżerskiej. Podręczniki i monografie z tej dziedziny mają już swoich klasyków, by wymienić choćby Daniela A. Wrena (1972). Również w Polsce szereg wykładowców wplata wątki historyczne do swoich zajęć lub proponuje wykłady monograficzne poświęcone wspomnianej problematyce. Jednak jest u nas rodzaj ,intelektualnego przemytu”, a na Zachodzie, jak się wydaje, nadal akademicki margines.

Drugi z zasygnalizowanych wcześniej czynników, dodatkowo utrudniających sięganie do przeszłości dla potrzeb współczesnego zarządzania, ma z kolei charakter lokalny, związany ze specyfiką dziejów najnowszych naszej części Europy. Dotąd znalazł on swój wyraz niemal wyłącznie na kartach literatury pięknej, choć nawiązuje do „cienia” czasów gospodarki planowej. Chodzi o pro-

12 Informacja ustna otrzymana od Piotra Gołaszewskiego w grudniu 2009 roku dotyczy lat wcześniejszych, gdy cytowany informator był studentem WZ UW.

$13 \mathrm{~W}$ przyszłości planuję wrażenie to weryfikować empirycznie. 
blem poruszany na przykład przez Marka Nowakowskiego (2010) w opowiadaniu Zaduma. Jako narrator tego utworu występuje były działacz podziemnej „Solidarności”, represjonowany przez władze PRL-u, obecnie prowadzący wraz z synem małą firmę hydrauliczną. Spotyka on przypadkowo dawnego funkcjonariusza SB, który szczególnie brutalnie go szykanował przed 1989 rokiem. Były pracownik aparatu represji okazuje się teraz bogatym biznesmenem. „Szybko ruszył do wyjścia (dawny funkcjonariusz SB - uwaga T.O.), głowę spuścił i prawie biegiem z lokalu wypadł" (Nowakowski 2010: 13).

Zarysowanej tu sytuacji ahistoryczności głównych nurtów zarządzania, także w Polsce, zaradzić może jedynie kompleksowa oferta badawcza i dydaktyczna ukazująca znaczenie refleksji historycznej dla pomnażania wiedzy o organizacjach oraz optymalizacji praktyki menedżerskiej.

Mayo i Nohria (2007) wskazują, iż zainteresowanie przeszłością jest niezbędne do rozwoju tak zwanej inteligencji kontekstualnej biznesmena. „Bez uwrażliwienia na kontekst długoterminowy sukces (w działalności gospodarczej - T.O.) jest mało prawdopodobny, a osoba dążąca do sukcesu ryzykuje tym, iż zostanie pokonana przez konkurencję bądź padnie ofiarą własnej pychy. Firmy nie odnoszą sukcesów ani porażek w próżni. Ważnym jest, by zrozumieć ramy kontekstualne, w których ma miejsce sukces bądź porażka" (Mayo i Nohria 2007: 487) ${ }^{14}$. Zdaniem cytowanych autorów, decydujące dla rozwoju myślenia kontekstualnego ma właśnie zainteresowanie historią i jej zrozumienie.

Umiejętność spoglądania na przeszłość przedsiębiorczości z perspektywy kapitału kulturowego organizacji, a więc z punktu widzenia potencjałów jakie współczesny człowiek biznesu może zyskać dzięki tej przeszłości, przywodzi na myśl zespół kompetencji społecznych, które określa się mianem wyobraźni organizacyjnej (Morgan 2002; Kostera 2012; Kociatkiewicz i Kostera 2012a) ${ }^{15}$ Kociatkiewicz i Kostera określają wyobraźnię jako „zdolność do czynienia niezwyczajnych związków między ludźmi, rzeczami, perspektywami i doświadczeniami (...), która rozkwita poprzez otwarcie się na poczucie zdziwienia oraz poprzez bycie w kontakcie z tym, co inspiruje" (Kociatkiewicz i Kostera 2012a: 165). W tym kontekście cytowani badacze przypominają tezę Josepha Litterera z 1970 roku, że dla przyszłości zarządzania konieczna jest zmiana edukacji menedżerskiej tak, by dawała więcej niż dotąd wiedzy ogólnej zarówno z zakresu nauk ścisłych jak i humanistycznych (Kociatkiewicz i Kostera 2012a). Perspektywa historyczna, będąca głównym motywem niniejszej monografii, upoważnia do wskazania, że taki typ kształcenia menedżerów znany jest tradycji edukacyjnej, także polskiej.

14 Tłum. Jacek Mikołajczyk i Anna Żak.

15 Aktualnie (chodzi o sierpień 2013 roku) w druku jest publikacja Moniki Kostery Organizować z polotem: Wyobraźnia organizacyjna $w$ praktyce, którą przygotowuje warszawskie wydawnictwo Sedno. 
Na przykład cytowany już wcześniej Roman Głowacki, obecnie emerytowany profesor Wydziału Zarządzania UW, zrelacjonował Grzegorzowi Karasiewiczwi (2009) własne doświadczenia edukacji akademickiej z lat 40. i 50. ubiegłego wieku. Przypomniał postać Zygmunta Sarny, profesora i rektora Akademii Handlowej (obecnie Uniwersytet Ekonomiczny w Krakowie), „a przede wszystkim wspaniałego wykładowcy, który chcąc zapalić słuchaczy zapalał się najpierw sam". Jednocześnie zaś zdanie egzaminu u wspomnianego naukowca było poważnym wyzwaniem intelektualnym. „Uważał on bowiem (profesor Sarna - uwaga T.O.), iż skoro tyle daje od siebie, tym samym musi wymagać od innych" (Karasiewicz 2009: 52).

Głowacki scharakteryzował także ogólnie atmosferę intelektualną Krakowa pierwszych lat powojennych, gdzie studenci kierunków ekonomicznych spontanicznie uczęszczali na wykłady z fenomelogi Romana Ingardena i filozofi przyrody ks. Kazimierza Kłósaka, czy z historii literatury prowadzone przez Kazimierza Wykę, Juliusza Kleinera i Stanisława Pigonia.

Spośród innych doświadczeń Głowackiego warto przytoczyć w kontekście poszukiwania modelu edukacji menedżerskiej, rozwijającej wyobraźnię, inicjatywę dydaktyczną Kazimierza Romaniuka, rektora SGPiS-u na początku lat 50., który włączył swoich magistrantów do seminarium doktorskiego (Karasiewicz 2009).

Synteza wspomnianych tradycji edukacyjnych, które nadal okazują się innowacyjne oraz nowoczesności treści i metod nauczania stanowi założone przez Romana Głowackiego w 1990 roku i kierowane przez niego do dziś Centrum Kształcenia Menedżerów (CMT), działające w strukturach Uniwersytetu Warszawskiego (Głowacki 1999 i nast., Karasiewicz 2009).

Tego typu wzory ośmielają do podjęcia próby wprowadzenia w obszar nauk o zarządzaniu i dydaktyki menedżerskiej historii organizacyjnej także w Polsce. Historia organizacyjna, jak każdy dział dziejopisarstwa, musi mieć swój lokalny charakter. Nie może być uprawiana w danym kraju tylko jako kopia zagadnień rozwijanych przez silne zagraniczne ośrodki. „Wszyscy jesteśmy historykami lokalnymi” - uświadomił mi tę prawdę dotyczącą badania przeszłości Jan Art16, profesor Uniwersytetu w Gandawie, lider europejskiego środowiska poszukującego sposobów współpracy historii i nauk społecznych.

Konieczne jest więc podjęcie systematycznych poszukiwań zarówno w zakresie metodologii jak i zasobów źródłowych dla historii organizacyjnej, uwzględniających tradycję przedsiębiorczości w Polsce. Jako niewielkie kroki w tych kierunkach planuję podjąć w roku akademickim 2013/2014, kontynuując problematykę niniejszej monografii, dwa projekty badawcze:

16 Cytat z pamięci mający swe źródło w mojej rozmowie z Janem Artem sprzed kilku lat w Gandawie. 
- analizę porównawczą polskiej szkoły historii gospodarczej (zainicjowanej przez Franciszka Bujaka na początku XX wieku i kontynuowanej praktycznie do dziś) oraz współczesnej historii biznesu i historii organizacyjnej uprawianych przez środowiska czasopism „Business History” i „Management and Organizational History" na Zachodzie. Badanie to będzie miało na celu wypracowanie rozwiązań metodologicznych, najbardziej adekwatnych do rekonstrukcji tradycji przedsiębiorczości w Polsce z perspektywy kapitału kulturowego zawartego $\mathrm{w}$ tej tradycji oraz skorzystanie $\mathrm{z}$ doświadczeń historycznych organizowania środowiska naukowego, które zechciałoby zająć się problematyką nową na naszym terenie, choć już rozwiniętą w ośrodkach zagranicznych,

- redakcję naukową materiałów archiwalnych dotyczących historii kilkudziesięciu prywatnych firm warszawskich. Materiały te powstały pół wieku temu z inicjatywy Kordiana Tarasiewicza i zostały przygotowane przez żyjących jeszcze wówczas, właścicieli przedsiębiorstw okresu międzywojennego lub ich współpracowników. W tym projekcie zgodził się ze mną współpracować Tadeusz Władysław Świątek.

Franciszek Bujak rozpoczynając w 1905 roku pierwsze na ziemiach polskich wykłady z historii gospodarczej, wtedy bardzo młodej dziedziny badań, mówił co następuje: „Powinien u nas powstać cały kierunek ekonomiczno-historyczny na wzór narodów zachodnich, nie dla ślepego ich naśladownictwa, ale z istotnej potrzeby (...). Uwzględnienie strony gospodarczej naszej przeszłości wpłynie z pewnością bardzo silnie i korzystnie nie tylko na pełność jej obrazu, lecz także na główne tego obrazu linie" (Bujak 1905/1976: 448, zob. także Grabski 2000).

Mam nadzieję, że zamiana „kierunku ekonomiczno-historycznego” na „kierunek organizacyjno-historyczny” „strony gospodarczej” na „stronę organizacyjną”, a „obrazu przeszłości” na „obraz przeszłości i teraźniejszości” sprawi, iż nie będzie uzurpacją odniesienie cytowanych słów do aktualnej sytuacji problematyki historii organizacyjnej w naszym kraju.

Natomiast prace takich badaczy, jak: Kordian Tarasiewicz (1974 i in.) Zbigniew Martyniak (np. 1983, 1989, 2000a), Alojzy Czech (np. 1983, 1984, 1999, 2005, 2009 i 2012), Piotr Górski (2005, 2007, 2008) czy Martyna Śliwa (2013) - jedyna badaczka z Polski działająca w głównym nurcie historycznego zwrotu w zarządzaniu na Zachodzie, gdzie promuje polską problematykę - sprawiają, że nieaktualne byłoby odniesienie do naszej sytuacji w zakresie historii organizacyjnej następnego cytatu z wykładu Bujaka: „Wprawdzie nie brak nam pięknych początków, ale są to tylko początki, wszystko jest jeszcze niemal do zrobienia" (Bujak 1905/1976: 448). 


\title{
BIBLIOGRAFIA
}

\author{
Materiały archiwalne
}

\section{Instytut Pamięci Narodowej}

Akta Władysława Jachniaka. IPN BU 00 945. 4878/I.

Akta Stanisława Wiktora Bukowskiego. IPN 660/99.

Akta Jerzego Brauna. IPN. ZHP J-4/10/I/1.

\section{Archiwum Miasta Stołecznego Warszawy}

Dokumenty firmy „Pluton”. Firma „Pluton” w Warszawie, zespół 62/I.

Archiwum Wydziału Zarządzania UW

Dokumenty rozprawy doktorskiej W. Jachniaka. Władysław Jachniak. Przewód doktorski 1969-1971. Materiał Archiwalny WZ-531.

Archiwum Domowe Kordiana Tarasiewicza

Dokumenty dotyczące firmy „Pluton”.

Dokumenty dotyczące Władysława Jachniaka.

Dokumenty dotyczące branży kawowo-herbacianej.

Sprawozdanie Zrzeszenia Importerów Kawy i Herbaty za 1947 rok. (1938). Warszawa (druk).

Pluton (1911). Lwów [okolicznościowa broszura wydana na 30-lecie firmy].

Opracowania (I semestr roku akad. 2001/2013) dotyczące firm omawianych w podrozdziale 6.2, rozdziału VI (oparte na wstępnej kwerendzie w Bibliotece M. St. Warszawy, Żydowskim Instytucie Historycznym, w źródłach internetowych i zdigitalizowanych archiwaliach dotyczących poszczególnych przedsiębiorstw). Autorzy: Joanna Kowalczyk, Michał Śliwiński, Małgorzata Kasińska, Mateusz Michalski, Wiktor Jasinowski, Jakub Kopczyński, Paweł Murtynowski, Aleksander Awdziejczyk, Michał Pluta, Marta Czapnik, Krzysztof Mańkowski i Wojciech Różycki (koordynacja: T. Ochinowski).

\section{Prace magisterskie i licencjackie związane z problematyką niniejszej monografii}

1. Cieplak, J. (2005). Zaburzenie równowagi między życiem osobistym a praca zawodowa, niepublikowana praca magisterska, maszynopis w bibliotece WZ UW. Warszawa.

2. Czerniak, D. (2010). Bracia Pakulscy. Zarys historii organizacyjnej firmy, niepublikowana praca magisterska. Wydział Zarządzania UW. Warszawa.

3. Dąbrowska, M. (2005). Zjawisko kultu korporacyjnego - II etap badań porównawczych $w$ firmach na terenie Polski, niepublikowana praca magisterska. UKSW. Warszawa.

4. Gochna, D. (2009). Występowanie elementów »dobrej rozmowy« wedtug koncepcji Theodore'a Zeldina w organizacji biznesowej na przyktadzie firmy telekomunikacyjnej, niepublikowana praca magisterska. Wydział Zarządzania UW. Warszawa. 
5. Gołaszewski, P. (2010). »Nowa kultura pracy«. Rekonstrukcja koncepcji i analiza jej aktualności, niepublikowana praca magisterska, Wydziału Zarządzania UW. Warszawa.

6. Kabała, A. (2011). Modus bycia vs modus posiadania czyli skuteczność motywatorów finansowych i pozafinansowych $w$ oparciu o prace dr. Wtadystawa Jachniaka, niepublikowana praca licencjacka. Wydział Zarządzania UW. Warszawa.

7. Komorowska-Wachulec, K. (2011). Zjawisko oraz poziom kultowości w organizacjach $w$ Polsce $w$ warunkach kryzysu ekonomicznego, niepublikowana praca magisterska. Wydział Zarządzania UW. Warszawa.

8. Mitrofaniuk, M. (2011). Kult korporacyjny w warunkach kryzysu ekonomicznego, niepublikowana praca licencjacka. Wydział Zarządzania UW. Warszawa.

9. Pachowska, P. (2013). Możliwości funkcjonowania standardów »Good Business« $w$ branży budowlanej na przyktadzie firmy KiP sp. $z$ o.o., niepublikowana praca licencjacka. Wydział Zarządzania UW. Warszawa.

10. Papiz, E. (2003). Zjawisko kultu korporacyjnego $w$ firmach działajacych na terenie Polski. Analiza wyników badań porównawczych, niepublikowana praca magisterska. Wydział Zarządzania UW. Warszawa.

11. Wójcik, M. (2009). Polacy w Wielkiej Brytanii - codzienność emigracyjna jako determinanta procesu autoidentyfikacji, niepublikowana praca magisterska. Wydział Zarządzania UW. Warszawa.

12. Zdanowska, J. (2011). Zarys dziejów palarni kawy»Pluton« na tle przemian gospodarczych XIX i XX wieku. Studium z zakresu historii organizacyjnej, niepublikowana praca magisterska. Wydział Zarządzania UW. Warszawa.

\section{Literatura}

1. Adamczyk-Grabowska, M. (1998). Dwie opowieści o jednym mieście. Tygiel kultury, nr 4-5, s. 89.

2. Ahlstrom, D., Lamond, D. \& Ding, Z. (2009). Reexamining some management lessons from military history. Asia Pacific Journal of Management, 26, pp. 617-642.

3. Alejchem, S. (1989). Z jarmarku. Wrocław: Wyd. Dolnośląskie.

4. Allen, G. (1998). Supervision. Management Modern. Pozyskano z: http://telecollege. dcccd.edu/mgmt1374/book_contents/1overview/business_environment/bus_envior. htm [pobrano: 30.09.2007].

5. Alveson, M. (2002). Understanding Organizational Culture. London: Sage.

6. Amatori, F. i Colli, A. (2011). Business History. Complexities and comparisons. London and New York: Routledge.

7. Andersen, N. ̊. (2011). Conceptual history and the diagnostics of the present. Management \& Organizational History, 6(3), pp. 248-267.

8. Anderson, C. (2009). Cywilizacja miłości. Co każdy katolik może zrobić, by zmienić świat. Kraków: Wyd. Stanisława BM.

9. Aniszewska, G. (red.). (2007). Kultura organizacyjna w zarzadzaniu. Warszawa: Polskie Wydawnictwo Ekonomiczne.

10. Antonovsky, A. (2005). Rozwiktanie tajemnicy zdrowia - jak radzić sobie ze stresem $i$ nie zachorować. Warszawa: Instytut Psychiatrii i Neurologii.

11. Ariely, D. i Zetter, K. (2009). TED: Dan Ariely on Why We Cheat. Pozyskano z: http://www.wired.com/epicenter/2009/02/ted-1/ [pobrano: 31.12.2010]. 
12. Arnott, D. (2000). Corporate cults. The Insidious Lure of the All-Consuming Organization. New York: AMACCOM.

13. Assorodobraj-Kula, N. (1946). Poczatki klasy robotniczej: problem rąk roboczych w przemyśle polskim epoki stanistawowskiej. Warszawa: Czytelnik.

14. Assorodobraj-Kula, N. (1995). Świadomość historyczna. W: Szacki, J. (red.). Sto lat socjologii polskiej (s. 856-869). Warszawa: PWN.

15. Artemenko, E. (2013). Czynniki społeczno-psychologicznego bezpieczeństwa gospodarczego Ukrainy. Niepublikowana praca przygotowana pod kierunkiem T. Ochinowskiego w ramach Programu Stypendialnego Rządu RP dla Młodych Naukowców. Warszawa: WZ UW.

16. Bainbridge, W. S. (2003). After the New Age: Parareligion and Pseudoscience. Referat zgłoszony na doroczne spotkanie Stowarzyszenia Badań Religioznawczych (SSSR), Norfolk (USA), październik/listopad 2003. Preliminary Program. Pozyskano z: http:// las.alfred.edu/ soc/SSSR/Preliminary\%20program\%201\%20web.htm [pobrano: 03.07.2004].

17. Baker, K. A. (2004). Organizational Culture. In: Taher, N. (Ed.). Organizational Culture: An Introduction (pp. 1-13). ICFAI University Press, India.

18. Baldoni, J. (2003). Great Communication Secrets of Great Leaders. New York: Mc Grew - Hill.

19. Balicki, W. (2009). Egoista, najlepszy altruista. W drodze, 4, s. 14-18.

20. Bandsuch, M., Thies, Pate, L. i Thiel, A. (2008). Rebuilding Stakeholder Trust in Business: An Examination of Principle-Centered Leadership and Organizational Transparency in Corporate Governance. Business and Society Review, 1, p. 99.

21. Banerjlee, A. V. i Duflo, E. (2011). Poor Economics. New York: BBS Public Affairs.

22. Barański, M. K. (2012). Historia Polski średniowiecznej. Poznań: Wyd. Zysk i S-ka.

23. Barley, S. i Kunda, G. (1992). Design and devotion: Surges of rational and normative ideologies of control in managerial discourse. Administrative Science Quarterly, 3, pp. 363-400.

24. Barnes, P. (2011). Minsky's financial instability hypothesis, accounting information and the 2007-2009 financial crisis in the UK and US. Accounting History, 16, pp. 423-437.

25. Bartkiewicz, K. (red.). (1998). Polska - Saksonia w czasch Unii (1697-1763). Próba nowego spojrzenia. Zielona Góra.

26. Batko, R. (2013). Czym jest dla mnie humanistyczne zarządzanie? W: Monika Kostera homepage. Pozyskano z: http://www.kostera.pl/spis.htm [28.08.2013].

27. Bauman, Z. (2007). Plynne życie. Kraków: Wyd. Literackie.

28. Belis-Legis, S. (1989). Wstęp. W: Alejchem, S. Z jarmarku (s. 15-16). Wrocław: Wyd. Dolnośląskie.

29. Bella, E. \& Taylor, S. (2013). Writing history into management research. Management \& Organizational History, 8(2), pp. 127-136.

30. Bernatt, M., Bogdanienko, J. i Skoczny, T. (red.). (2011). Spoteczna odpowiedzialność biznesu. Krytyczna analiza. Warszawa: Wyd. Naukowe WZ UW.

31. Bernstein, D. (2009). Jak zmieniać świat. Przedsiębiorcy społeczni - wizjonerzy naszych czasów. Gdańsk: Wyd. AnWero.

32. Bertram, Ł. I. i Kowalczyk, M. (2010). Przedsiębiorczość po polsku. Warszawa: PARP i Ośrodek Karta.

33. Biełaszko, M. (2007). „Tygodnik Warszawski” i jego środowisko (1945-1948). Biuletyn IPN, 4, s. 77-83. 
34. Billig, M. (1996). Arguing and thinking. A rhetorical approach to social psychology. Cambridge: Cambridge University Press. New edition.

35. Billig, M. (2008a). Banalny nacjonalizm. Kraków: Znak.

36. Billig, M. (2008b). The Hidden Roots of Critical Psychology: Understanding the Impact of Locke, Shaftesbury and Reid. London: Sage.

37. Biskupski, M. B. B. (2011). Nieznana wojna Hollywood przeciwko Polsce 1939-1945. Warszawa.

38. Błachowska, K. (2012). Feliks Koneczny a problemy badawcze historii organizacyjnej. Tekst niepublikowany, zaprezentowany podczas wykładu ogólnouniwersyteckiego „Historyczny sukces”, IH UW, semestr zimowy 2012/2103.

39. Boje, D. M. (1995). Stories of the story telling organization: A postmodern analysis of Disney as 'Tamara-land'. Academy of Management Journal, 38, pp. 997-1035.

40. Bolecki, W. (2007). Ptasznik z Wilna. O Józefie Mackiewiczu (Zarys monograficzny). Kraków: Arcana.

41. Bolesta-Kukułka, K. (2003). Socjologia ogólna. Warszawa: Wyd. Naukowe WZ UW.

42. Bombała, B. (2006). Karola Adamieckiego harmonia duchowa jako podstawa etycznej kultury organizacji. Annales. Etyka w życiu gospodarczym, t. 9, 1, s. 125-132.

43. Boorstin, D. J. (1973/1995). Amerykanie. Fenomen demokracji. Warszawa: Wydawnictwo Bellona i Wydawnictwa Artystyczne i Filmowe.

44. Booth, Ch. i Rowlinson, M. (2006). Management and Organizational History: Prospects. Management and Organizational History, 1, pp. 5-30.

45. Borchard, M. (2009). The social market economy as a bridge in times of crisis. European View, 8, pp. 13-20.

46. Bourdieu, P. (2003/2006). Medytacje pascaliańskie. Warszawa: Oficyna Naukowa.

47. Bourdieu, P. (1994/2009). Rozum praktyczny. O teorii działania. Kraków 2009: Wyd. UJ.

48. Bouchard, M. J. (2012). Social innovation, an analytical grid for understanding the social economy: the example of the Que'bec housing sector. Serv Bus, 6. pp. 6: 47-59.

49. Bratkowski, A. (1989). Jak robić interesy razem. Warszawa: Iskry.

50. Braun, J. (b. d. w.) Marksizm, kapitalizm a gospodarka dynamiczna. Studium o nowej polityce socjalnej. Warszawa: Unia.

51. Braun, J. (1947a). Dynamiczna rozbudowa miast polskich. Tygodnik Warszawski, nr 23, s. 4-5.

52. Braun, J. (1947b). Kontrola zysku a prawo własności. Tygodnik Warszawski, nr 9, s. 2-3.

53. Braun, J. (1947c). Marksizm a społeczeństwo przyszłości. Tygodnik Warszawski, nr 19, s. 7.

54. Braun, J. (1947d). Problem wychowania. Tygodnik Warszawski, nr 24, s. 1-2.

55. Braun, J. (1981). Jan Hope - polityk w służbie idei. W: Braun, J., Popiel, K. i Sieniewicz, K. Człowiek ze spiżu (s. 117-223). Londyn: Odnowa.

56. Braun, J. (1999). Unionizm. Warszawa: Wyd. Ogólnopolski Klub Miłośników Litwy.

57. Braun, J. (2003). Nowy świat kultury. Warszawa: Biblioteka Frondy.

58. Braun, J. (2006). Zarys filozofii Hoene Wrońskiego. Warszawa: Wyd. Ogólnopolski Klub Miłośników Litwy.

59. Braun, J. (1985). Zarys historii i doktryny „Unii” 1940-1945. Chrześcijanin w świecie, nr 139. 
60. Brzeziński, J. (1985). Zasady statystycznego opracowania danych w psychologii klinicznej. W: Waligóra, B. (red.). Elementy psychologii klinicznej (s. 107-160). Poznań: Wyd. Nauk. UAM.

61. Budrewicz, O. (1990). Sagi warszawskie, t. I/III. Warszawa: Czytelnik.

62. Bugaj, R., Dembiński, P. i Jankowiak, J. (2001). Kto zyskuje, a kto traci? - dyskusja. Więź, 10, s. 30-47.

63. Bujak, A. (2007). Światowe dziedzictwo. Polska na liście UNESCO. Kraków: Biały Kruk.

64. Bujak, F. (1976). Wybór pism. Warszawa: PWN.

65. Bujak, W. (1988). Historia Stronnictwa Pracy 1937. 1946. 1950. Warszawa: ODiSS.

66. Bułgakow, S. (1990). Filosofia chozjajstwa. Brak miejsca wydania i wydawnictwa.

67. Bułgakow, S. (1992). Prawostawie zarys nauki kościoła prawostawnego. Białystok: Orthdruk.

68. Burger, J. M. (2009). Replicating Milgram. Would People Still Obey Today? American Psychological Association, 1, pp. 1-11.

69. Burke, J. (2010). Pajęczyna wiedzy. Do Stonehenge $i$ z powrotem oraz inne wyprawy w krainę nauki. Warszawa: Prószyński i S-ka.

70. Burleigh, M. (2011). Święta racja. Warszawa: Świat Książki.

71. Cameron, K. S. i Quinn, R. E. (1998/2003). Kultura organizacyjna - diagnoza i zmiana. Model wartości konkurujacych. Kraków: Oficyna Ekonomiczna.

72. Carroll, C. E. (2000). New ListServ on Strategic Use(s) of Organizational. Pozyskano z: https://www.jiscmail.ac.uk/cgi-bin/webadmin?A2=management-history;855e2547.0004 [pobrano: 17.08.2011].

73. Carroll, C. E. (2002). The strategic use of the past and future in organizational change. Journal of Organizational Change Management, 15(6), pp. 556-562.

74. Chapman, M. D. i Zeldin, Th. (2004). Annual CMI Lecture - The spirit of work: an exploration of ethical leadership. RSA Lectures, 22nd April 2004, pp. 1-20.

75. Chan, A. (2001). Toward a Genealogy of Organizational Culture. The perspectives of Foucault. Philadelphia: John Benjamins Publishing Company.

76. Chancellor, E. (2001). Historia spekulacji finansowych. Warszawa: Muza.

77. Chaves, R. i Monzon, J. L. (2012). Beyond the crisis: the social economy, prop of a new model of sustainable economic development. Serv Bus, 6, pp. 5-26.

78. Chrzanowski, W., Mierecki, P. i Kiernicki, B. (1997). Pót wieku polityki czyli rzecz o obronie czynnej. Warszawa: Ad Astra.

79. Chrzanowski, W. (2005). Za nami, przed nami. Polityczny wybór pism. Warszawa: Rosner i Wspólnicy.

80. Cihodariu, M. (2012). Narratives as instrumental research and as attempts of fixing meaning. The uses and misuses of the concept of „narratives”. Journal of Comparative Research in Anthropology and Sociology, 2, pp. 27-43.

81. Corbett, J. M. (2008). Towards neuroscientific management? Geometric chronophotography and the thin-slicing of the labouring body. Management \& Organizational History, 3, pp. 107-125.

82. Costea, B., Crump, N. i Holm, J. (2006). Conceptual history and the interpretation of managerial ideologies. Management \& organizational history, 1, pp. 159-175.

83. Csíkszentmihályi, I. (1998). Flow in a historical context: the case of the Jesuits, pp. 232-248. In: Csíkszentmihályi, M. and Csíkszentmihályi, I. S. Optimal experience. Psychological studies of the flow in consciousness. Cambridge: Cambridge University Press. 
84. Csíkszentmihályi, M. (1998). Urok codzienności. Warszawa: Cis i WAB.

85. Csíkszentmihályi, M. (2003). Good business: Leadership, flow and the making of meaning. New York: Viking.

86. Csíkszentmihályi, M. (2005). Przeptyw. Taszów: Biblioteka Moderatora.

87. Csíkszentmihályi, M. (2011). Popłyń pozytywnie. Charaktery, 9.

88. Chwiszczuk, R. (2006). Warszawa mało znana. Warszawa: Wyd. Veda.

89. Cywiński, B. (1971/2010). Rodowody niepokornych. Warszawa: Literatura Faktu PWN.

90. Czapiński, J. (2009). Referat [bez tytułu] wygłoszony na konferencji „Psychologiczne aspekty kryzysu", 27.05.2009. WZ UW. Warszawa.

91. Czarniawska, B. (2010a). Jak sztuka imituje życie a życie sztukę. Wykład Inauguracyjny, 04.10.2010. WZ UW. Warszawa.

92. Czarniawska, B. (2010b). Trochę inna teoria organizacji. Warszawa: Poltext.

93. Czarniawska, B. (2010c), Zarządzanie, Zbrodnia w bibliotece. Pozyskano z: http:// zbrodniawbibliotece.pl/analizy/1402,zarzadzanienapisalaczarniawskacz1/ [pobrano: 31.09.2013].

94. Czarniawska, B. (2011). Book reviews. Scandinavian Journal of Management, 27, pp. 341-346.

95. Czech, A. (1984). Aleksander Rothert: prekursor i kontynuator nauki organizacji. Katowice: Towarzystwo Naukowe Organizacji i Kierownictwa w Katowicach.

96. Czech, A. (1997). Józef Lizak $i$ Wyższe Studium Nauk Spoteczno-Gospodarczych w Katowicach. Katowice: Wyd. AE im. K. Adamieckiego w Katowicach.

97. Czech, A. (1999). Józefa Lisaka »Ekonomia jednostkowa«. Katowice: Wyd. AE im. K. Adamieckiego w Katowicach.

98. Czech, A. (2005). Adamiecki, Hauswald, Rothert: at the Centenary of scientific organization and management in Poland. Katowice: The Publishing House of the Karol Adamiecki University of Economics.

99. Czech, A. (red.). (2008). Stowarzyszenia i towarzystwa a społeczeństwo obywatelskie, zycie gospodarcze $i$ przestrzeń spoteczna: praca zbiorowa wydana z okazji 60-lecia Oddziału Polskiego Towarzystwa Ekonomicznego w Katowicach 1948-2008. Katowice: PTE. Oddział Katowice.

100. Czech, A. (2009). Karol Adamiecki - polski wspóttwórca nauki organizacji i zarzadzania. Katowice: Wyd. AE im. K. Adamieckiego w Katowicach.

101. Czech, A. (red.). (2012). Nauki o zarządzaniu - u początków i wspótcześnie. Katowice: Wyd. UE w Katowicach.

102. Czech, A. i Suwara, K. (1983). Piotr Drzewiecki - mecenas naukowej organizacji. Katowice: Towarzystwo Naukowe Organizacji i Kierownictwa w Katowicach.

103. Damon, W. (2004). The Moral Advantage. How to Succeed in Business by Doing the Right Thing. San Fracisco: BK.

104. Davis, N. (1998). Europa. Kraków: Znak.

105. de Cereteau, M. (1990/2008). Wynaleźć codzienność. Sztuki dziatania (s. 135). Kraków: UJ.

106. de Hueck, D. C. (2012). Jurodliwi. Święci głupcy. Kraków: Wyd. Karmelitów Bosych.

107. de Neeve, E. (2009). Lonergan's Economic Ideas Today. In: Lawrence, F. (Ed.). Lonergan Workshop, 21, pp. 65-84.

108. de Neeve, E. (b. d. w.). The Economic Crisis: Ideas from Bernard Lonergan. Pozyskano z: http://www.eileendeneeve.com/The\%20Economic $\% 20$ Crisis $\% 20$ Complete.pdf [pobrano: 31.09.2013]. 
109. Deal, T. E., Kennedy, A. A. (1982). Corporate Cultures: The Rites and Rituals of Corporate Life. Reading. MA: Addison - Wesley.

110. Dedecius, K. (2008). Europejczyk z Łodzi. Wspomnienia. Kraków: Wydawnictwo Literackie.

111. Decker, S. (2013). The silence of the archives: business history, post-colonialism and archival ethnography. Management \& Organizational History, 8(2), pp. 155-173.

112. Dembiński, P. H. (2003). Nowa gospodarka globalna. Formy współ(zależności), Znak, 4, s. 49-71.

113. Dembiński, P. H. (2009). Manifest Observatoire de la Finance. Observatoire de la Finance. Polski. Geneve: Observatoire de la Finance.

114. Dembiński, P. H. (2011). Finanse po zawale. Warszawa: Studio EMKA.

115. Dembiński, P. H. (2012). Humanizm gospodarczy. Społeczna gospodarka rynkowa w czasach kryzysu. Więź, s. 5-18.

116. Dembiński, P. H. (2013). Financjalizacja - co nam kryzys pokazat, czego nas nauczyt, co dalej? Wykład wygłoszony na 45 ,Seminarium Interdyscyplinarnym u Koźmińskiego". Warszawa: Akademia Koźmińskiego.

117. Derbyshire, S. (2009). Behavioral psychology can't avert economic crisis. The First Post. Pozyskano z: http://www.thefirstpost.co.uk/47624,news-comment,newspolitics,behavioural-psychology-cant-avert-economic-crisis [pobrano: 31.12.2010].

118. Diatłowicka, M. (2010). Mozaika rodzinna. Warszawa: Wyd. Nowy Świat.

119. Dobrzyński, M. (2012). Prekariat jako produkt niepewnej pracy. W: Klincewicz, K. i Grzywacz, W. (red.). Rozwój potencjatu spotecznego organizacji w XXI wieku (s. 19-39). Warszawa: Wyd. Naukowe WZ UW.

120. Dobrzyński, M. (2012). Doktryna szoku jako inspiracja współczesnego zarządzania W: Klincewicz, K. i Grzywacz, W. (red.). Rozwój potencjału spotecznego organizacji w XXI wieku (s. 269-293). Warszawa: Wyd. Naukowe WZ UW.

121. Dobrzyński, M. i Klincewicz, K. (2005). (R)ewolucja w zarządzaniu i co z niej wynika (s. 11-25). W: Dobrzyński, M. i Grzywacz, W. (red.). R-ewolucja zarzadzania i co z niej wynika... Warszawa: Wyd. Naukowe WZ UW.

122. Doktór, K. (2011). Transgraniczna elita menedżerów. W: Michalak, A., Sakson, A. i Stasieniuk, Ż. (red.). Polskie ziemie zachodnie. Studia socjologiczne (s. 159-173). Poznań: Instytut Zachodni.

123. Dołęgowski, T, Czerniak, A. i Siewierski, J. (2012). Rozwój gospodarczy a wartości wspólnotowe. Warszawa: SGH.

124. Domańska, E. (2008). Obrazy PRL w perspektywie postkolonialnej. Studium przypadku (s. 167-180). W: Brzechczyna, K. (red.). Obrazy PRL. Konceptualizacja realnego socjalizmu $w$ Polsce. Poznań: IPN.

125. Domańska, E. (2013). Wiedza o przesztości w kontekście posthumanistyki. Referat wygłoszony w IH PAN (07.12.2013). Warszawa.

126. Drozdowski, M. M. (1976). Warszawa w XX wieku. Warszawa: Wyd. MON.

127. Drozdowski, M. M. (1989). Eugeniusz Kwiatkowski: człowiek i dzieło. Kraków: Wydawnictwo Literackie.

128. Drozdowski, M. M. (2005). Eugeniusz Kwiatkowski. Warszawa: WSiZ.

129. Drozdowski, M. M. i Tarasiewicz, K. (1964). Rozwój przemysłu Warszawy w latach 1918-1939. Rocznik Warszawski, V, s. 136-186.

130. Drucker, P. (2001). Lider XXI wieku w społeczeństwie wiedzy. Wykład video prezentowany w Polsce w 2001 roku. 
131. Drucker, P. (2009). Zarzadzanie w XXI wieku. Warszawa: MT Biznes.

132. Eliach, Y. i Gurewitsch, B. (1996). Holocaust Oral History Manual. New York: International Universities Press.

133. Fentress, J. i Wickham, Ch. (1992). Social Memory. Oxford: Blackwell.

134. Finke, R. i Wittberg, P. (2000). Organizational Revival From Within: Explaining Revivalism and Reform in the Roman Catholic Church. Journal for the Scientific Study of Religion, 2, s. 154-170.

135. Fischman, W. i Barendsen, L. (2010). Good Work. Toolkit. Cambridge: The Presidents and Fellows of Harvard College on behalf of Project Zero.

136. Fischman, W., Solomon, B., Greenspan, D. i Gardner, H. (2004). Making good. How Young People Cope with Moral Dilemmas at Work. Cambridge and London: Harvard University Press.

137. Fox, C. R. \& Poldrack, R. A. (2008). Prospect theory on the brain: Studies on the neuroeconomics of decision under risk (pp. 145-173). In: Glimcher, P., Camerer, C., Fehr, E. \& Poldrack, R. (Eds.). Handbook of Neuroeconomics. New York: Elsevier.

138. Franciszek, P. (2000). Słowo wstępne (s. 7-12). W: Franciszek, P. (red.). (2000). Celem nauki jest człowiek. Kraków: Wyd. UJ.

139. Franciszek, P. (red.). (2000). Celem nauki jest cztowiek. Kraków: Wyd. UJ.

140. Frączek, M., Husner, J. i Mazur, S. (red.). (2012). Wokót ekonomii spotecznej. Kraków: Uniwersytet Ekonomiczny w Krakowie MSAP.

141. Gardner, H. (Ed.). (2007). Responsibility at work. How leading professionals act (or don't act) responsibly. San Fracisco: Jossey - Bass.

142. Gardner, H. (2007). Zmiana pogladów. Sztuka kształtowania wtasnych i cudzych przekonań. Kraków: Wyd. UJ.

143. Gardner, H. (Ed.). (2010). Good Work: Theory and Practice. The GoodWork Project. Pozyskano z: from http://www.goodworkproject.org/ [pobrano: 03.01.2011].

144. Gardner, H., Csikszentmihalyi, M. \& Damon, W. (2001). Good Work. When Excellence and Ethics Meet. New York: Basic Books.

145. Gärling, T., Kirchler, E., Lewis, A. \& van Raaij, F. (2009). Psychology, Financial Decision Making, and Financial Crises. Psychological Science in the Public Interest, 10, pp. 1-47.

146. Gasparski, W. (2000). Tadeusz Kotarbiński. Edukacja Filozoficzna, 29, s. 155-185.

147. Gasparski, W. i Pszczołowski, T. (Ed.). (1983). Praxiological studies: Polish contributions to the science of efficient action. Warszawa, Dordrecht: PWN, D. Reidel Publishing Company.

148. Geerardyn, P. (2000). Conclusions: Applied Psychoanalysis and Psychological History (pp. 333-335). W: Art., J. i Geerardyn, F. (Eds.). The Sublime Object of Religion. Procedeengs of the Second I nternational Conference on Psychological History. Ghent. Nov. 23-24. 2000. Gent: Universiteit Gent.

149. Gębarski, K. (1960). Elementarne metody grupowania zmiennych. W: Biuletyn Psychometryczny, t. II (Warszawa).

150. Glaser, B. G. i Strauss, A. L. (2009). Odkrywanie teorii ugruntowanej. Kraków: ZW Nomos.

151. Glinka, B. (2008). Kulturowe uwarunkowania przedsiębiorczości w Polsce. Warszawa: PWE. 
152. Glinka, B. (2011). Wielokulturowość w organizacji: źródła, przejawy, wpływ na zarządzanie (s. 55-71). W: Glinka, B. i Jelonek, A. (red.). Zarządzanie międzykulturowe. Kraków: Wyd. UJ.

153. Glinka, B. (2013). Przedsiębiorczość (s. 59-75). W: Bogdanienko, J. i Piotrowski, W. (red.), Zarzadzanie. Tradycja i nowoczesność. Warszawa: PWE.

154. Glinka, B. i Gudkova, S. (2011). Przedsiębiorczość. Warszawa: Wolters Kluwer busisness.

155. Gluza, Z. (2004). Inicjatywa zwana prywatną (s. 5). W: Knyt, A. i Wincerz-Gluza, A. (red.), Prywaciarze 1945 - 89. Warszawa: Ośrodek Karta.

156. Głowacki, R. (1968). Zarządzanie przedsiębiorstwem handlowym (próba zarysowania kierunków usprawnień). Roczniki $I H W$, s. 4-24.

157. Głowacki, R. (1978). Przedsiębiorstwo na rynku. Warszawa: PWE.

158. Głowacki, R. (1999 i nast.). International Business Programme. Warszawa: CMT.

159. Głowacki, R. i Karasiewicz, G. (2007). Transformacja systemowa jako stymulator dynamicznego rozwoju marketingu w Polsce (s. 79-94). W: Zarzadzanie i rozwój. Warszawa: Wydawnictwo Naukowe Wydziału Zarządzania Uniwersytetu Warszawskiego.

160. Głowacki, R. i Karasiewicz, G. (2009). Marketing Evolution in Transition Economics. In: Kirpalani, V. H. M., Garbarski, L. \& Kaynak, E. (Ed.). Successfully Doing Business/Marketing in Eastern Europe. New York: Routledge.

161. Goody, J. (2006). Kapitalizm i nowoczesność - Islam, Chiny, Indie a narodziny Zachodu. Warszawa: Wydawnictwo Akademickie Dialog.

162. Goody, J. (2009). Kradzież historii. Warszawa: Wyd. Naukowe PWN.

163. Górski, J. (1964). Historia powszechna i osobista. Kraków: Wyd. Literackie.

164. Górski, J. (oprac.). (1972a). Pamięć warszawskiej odbudowy. Antologia. Warszawa: PIW.

165. Górski, J. (red.). (1972b). Warszawa stolica Polski Ludowej, z. 2. Studia Warszawskie, t. XV.

166. Górski, J. (1972c). Warszawa współczesna w świadomości społecznej (s. 189-210). Warszawa w oczach Śląska i Zagłębia (s. 172-185). W: Nowakowski, S., Drozdowski, M. M., Górski, J. i Tewiaszew, A. (1972). Jaka jesteś Warszawo? Warszawa: PIW.

167. [Górski, J.]. (1973a). O zniszczeniach, odbudowie i przyszłości Warszawy. W: Górski, J. (red.). Warszawa stolica Polski Ludowej, z. 3. „Studia Warszawskie”, t. XV, s. 268-300.

168. Górski, J. (1973b). Zblizenia do wspótczesności. Warszawa: PWN.

169. Górski, J. (1981). Warszawa prawie wspótczesna. Warszawa.

170. Górski, J. (1990). Warszawa w latach 1944-1949. Odbudowa. W: Kieniewicz, S. (red.). Dzieje Warszawy, t. VI. Warszawa: PWN.

171. Górski, P. (2005). Między inteligencka tradycja a menedżeryzmem. Kraków: Wyd. UJ.

172. Górski, P. (2007). Management and Organizational History. Nowe czasopismo z dziedziny organizacji i zarządzania. Organizacja i Kierowanie, nr 2 (128), s. 141.

173. Górski, P. (2008). Profesjonalizacja administracji państwowej w Polsce 1918-1939. Kraków: Wyd. UJ.

174. Grabiński, A. Dekret Bieruta i jego realizacja. W: Ochinowski T. (red.). (2008). Przemoc i zarzadzanie. Warszawa (w druku). Pozyskano z: www.dekretowiec.pl [pobrano: 19.06.2008]. 
175. Grabski, A. F. (1990). Problemy syntezy w historii historiografii. Historyka, XX, s. 3-9.

176. Grabski, A. F. (2000). Zarys historii historiografii polskiej. Poznań: Wyd. Poznańskie.

177. Grabski, A. F. (2003). Dzieje Historiografii. Poznań: Wyd. Poznańskie.

178. Greenspan, S. (2008). Annals of Gullibility: Why We Get Duped and How to Avoid It. Westport: Praeger.

179. Grohman, J. (1998). [Głos w dyskusji]: Lodzermensch - historia i mit. Tygiel kultury, nr $4-5$, s. 38 .

180. Grzegorek, A. (2008). Dobrzy ludzie i zło, Tygodnik Powszechny, 43. Dodatek Książki w Tygodniku. Pozyskano z: http://tygodnik.onet.pl/15,172,nr_43_3094_26_pazdziernika_2008,temat.html [03.12.2009].

181. Grzywacz, W., Ochinowski, T. i Nawrocki, M. (2001). Tradycja i rozwój. Wybrane koncepcje kultury organizacyjnej jako inspiracja badań w nowych obszarach psychologii organizacji. Zarzadzanie i Edukacja, 1, s. 145-172.

182. Grzywacz, W. i Ochinowski, T. (2003). „Badanie zaangażowane” jako metoda szkolenia z zakresu etyki zawodowej dla pracowników administracji publicznej (s. 233-246). W: Gospodarka i przedsiębiorstwo. Nowe tendencje w zarzadzaniu. Ksiega jubileuszowa XXX-lecia Wydziału Zarzadzania Uniwersytetu Warszawskiego. Warszawa: Wyd. Naukowe WZ UW.

183. Guranowski, J. (red.). (1951). Sojusznicy Gestapo. Proces Kwasiborskiego i innych. Warszawa: Książka i Wiedza.

184. Haidt, J. (2007). Szczęście. Od mądrości starożytnych uczonych po koncepcje wspótczesne. Gdańsk: GWP.

185. Haigh, G. (2005). Fat Cats: The Strange Cult of the CEO. New York: Basic Books.

186. Halbwasch, M. (1925/1969). Spoteczne ramy pamięci. Warszawa: PWN.

187. Handy, Ch. (1995). Gods of Management. Oxford: Oxford University Press.

188. Hansen, P. H. (2012). Making sense of financial crisis and scandal: a Danish Bank failure in the first era of finance capitalism. Enterprise \& Society: the International Journal of Business History, 3, pp. 672-706.

189. Harrison, L. i Huntington, S. P. (2000/2003). Kultura ma znaczenie. Poznań: Zysk i S-ka.

190. Hartnell, Ch. A., Ou, A. Yi i Kinicki, A. (2011). Organizational culture and organizational effectiveness: A meta-analytic investigation of the competing values framework's theoretical suppositions. Journal of Applied Psychology, 4, pp. 677-694.

191. Haumann, H. (1993). Rola przedsiębiorców w procesie uprzemysłowienia Rosji i Niemiec. Z problematyki związków między pochodzeniem a orientacją polityczną (s. 27-37). W: Kołodziejczyk, R. (red.). Image przedsiębiorcy gospodarczego w Polsce w XIX i XX wieku. Warszawa: IH. PAN.

192. Hay, J. D. (2006). Jakość życia/jakość zarządzania: znaczenie świadomości relacyjnej. Problemy Zarzadzania [numer monograficzny, Jakościowe badania organizacji, Glinka, B., Konecki, K. T. i Ochinowski, T., red.], 1, s. 122-135.

193. Hay, D. (2007). Why Spirituality Is Difficult for Westerners? Exter: Imprint Academic.

194. Hay, D. i Nye, R. (1998). The Spirit of the Child. London: HarperCollins.

195. Hein, S. (2008). From Art of War to Attila the Hun: A Critical Survey of Recent Works on Philosophy/Spirituality and Business Leadership. Philosophy East \& West, 1, pp. 126-143.

196. Heller, M. (2006). Podróże z filozofia w tle. Kraków: Znak. 
197. Hens, Th. i Bachmann, K. (2010). Psychologia rynku dla doradców finansowych. Warszawa: Cedetu.pl.

198. Herbaczyński, W. (2005). W dawnych cukierniach i kawiarniach warszawskich. Warszawa: Wyd. Veda.

199. Hilton, S. i Gibbons, G. (2003). Good Business. NewYork: Texere LLC.

200. Historia firm konsultingowych. (2010). Pozyskano z: http://www.cognitis.pl/pl/konsulting/historia-firm-konsultingowych [pobrano: 03.01.2011].

201. Hochschild, R. A. (2003). The Commercialization of Intimate Life: Notes from Home and Work. Berkely CA: University of California Press.

202. Hofstede, G. (2000). Kultury i organizacje. Warszawa: PWE.

203. Hofstede, G. i Hofstede, G. J. (2005/2007). Kultury i organizacje. Zaprogramowanie umystu. Warszawa: Polskie Wydawnictwo Ekonomiczne.

204. Hoopes, J. (2003). False prophets: the gurus who created modern management and why their ideas are bad for business today. Cambridge, MA [Oxford]: Perseus.

205. Hoopes, J. (2004). The Dehumanized Employee. Pozyskano z: http://www.cio.com. au/index.php/id;451554300;fp;512;fpid;1002206570 [pobrano: 17.01.2005].

206. Hoopes, J. (2011). Corporate Dreams. New Brunswick: Rutgers University Press.

207. Hoppe, J. (1972). Wspomnienia, przyczynki, refleksje. Londyn: Wydawnictwo Odnowa.

208. Huntington, S. P. (1996/2004). Zderzenie cywilizacji i nowy ksztatt tadu światowego. Warszawa: Muza.

209. Hutton, P. H. (1993). History as an Art of Memory. Hanover: University Press of New England.

210. Ihnatowicz, I. (1971). Obyczaj wielkiej burżuazji warszawskiej w XIX wieku. Warszawa: PIW.

211. Inglot, K. (2013). Zmiany miejsca pracy - nieuniknione. Work Service dla biznesu. 13.08.2013. Pozyskano z: http://www.workservice.pl/Dla-pracodawcow/Ekspert-HRkomentuje/Zmiany-miejsca-pracy-nieuniknione [pobrano: 31.08.2013].

212. Izquierdo, R. J. S. i Vicedo, J. C. (2011). Corporate social responsibility of financial organizations in the social economy: a case study on savings banks. Serv Bus Journal, 6, s. 99-115.

213. Jabłkowski, F. (2005). Dom Towarowy Bracia Jabłkowscy. Romans Ekonomiczny. Warszawa: Iskry.

214. Jabłkowski, J. (2013). Historia (naprawdę) żywa. Czy praktyki menedżerskie Domu Towarowego Bracia Jabtkowscy pomagaja w zarzadzaniu innowacyjnym instytutem badawczym? Wykład wygłoszony na WZ UW (26.04.2013). Warszawa.

215. Jachniak, W. (1987). Oskarżam...! Wrocław: Agencja Wydawnicza Solidarności Walczącej.

216. Jacques, E. (1951). The Changing Culture of a Factory. London: Tavistock Publications.

217. Jacques, R. S. (1996). Manufacturing the Employee. London: Sage.

218. Jacques, R. S. (2006). History, historiography and organization studies: The challenge and the potential. Management \& Organizational History, 1, pp. 31-49.

219. Jaques, R. S. \& Hopson, M. (2009). The Sergeant Major Syndrome. Pozyskano z: http://www.managementdevelopment.biz/thebook/chapter_one.php [pobrano: 23.08.2011].

220. Jakubik, A. (1997). Zaburzenia osobowości. Warszawa: PZWL.

221. Jezernik, B. (2011). Kawa. Wołowiec: Wyd. Czarne. 
222. Jasiecki, K. (2000). Elita biznesu w Polsce. Drugie narodziny kapitalizmu. Warszawa: IFiS PAN.

223. Jesionowski, A. (1936). Tajemnice twórczości. Tadeusz Kudliński. Prosto z Mostu, 51, s. 5.

224. Jones, G., van Leeuwen, M. H. D. \& Stephen Broadberry, S. (2012). The future of economic, business, and social history. Scandinavian Economic History Review, 3, pp. 225-253.

225. Jones, P. (1965). The Consumer Society. A History of American Capitalism. Harmondsworth: Penguin Books.

226. Juchnowicz, M. (red.). (2009). Postawy Polaków wobec pracy w zarzadzaniu kapitatem ludzkim. Kraków: Oficyna a Wolters Kluwer business.

227. Judt, T. (2007). Wywiad pt. „Polacy zaskoczyli Europe””. Dziennik. Pozyskano z: http://wiadomosci.dziennik.pl/wydarzenia/artykuly/63842,polacy-zaskoczyli-europe. html [pobrano: 21.02.2013].

228. Judt, T. (2008). Powojnie. Kraków: Znak.

229. Judt, T. (2011). Źle ma się kraj. Sękowa Polska: Wyd. Czarne.

230. J. Z. [Zieliński, J.]. (2008). Warszawa - z ruin do życia. Stolica, nr 5, s. 54.

231. Kaczkowski, J. (1918). Zasady prawa akcyjnego. Warszawa: Gebethner \& Wolff.

232. Kaczyńska, W. (red.). (2003). Czesław Czapów 1925-1980. Świadectwa trzech pokoleń. Warszawa: IPSiR UW.

233. Kaczyński, A. (2004). Czesław Czapów, niepokorny uczony w PRL. Między małym a wielkim gangiem. Rzeczpospolita, 27.03.2004. Archiwum Internetowe Rzeczpospolitej.

234. Kaelble, H. (2010). Społeczna historia Europy. Od 1945 do wspótczesności. Warszawa: Wyd. Naukowe PWN.

235. Kahneman, D. (2012). Putapki myślenia. Poznań: Media Rodzina.

236. Karasiewicz, G. (2009). Osiemdziesięciolecie nestora marketingu w Polsce - profesora Romana Głowackiego (s. 47-62). W: Karasiewicz, G. (red.). Ekonomia. Etyka. Organizacja. Warszawa: Wyd. Naukowe WZ UW.

237. Karlgaard, R. (2006). The End of Managerial Capitalism? Forbes, 25.10.2006. Pozyskano z: http://www.forbes.com/sites/digitalrules/2006/10/25/the-end-of-managerial-capitalism/ [pobrano: 09.09.2013].

238. Kasprzycki, J. (2000). Korzenie miasta. Tom I. Śródmieście potudniowe. Warszawa: Wyd. Veda.

239. Kasprzycki, J. i Majewski, J. (2004). Korzenie miasta. Tom VI. Niedaleko od Warszawy. Warszawa: Wyd. Veda.

240. Kasprzycki, J. i Stępień, M. (1971). Pożegnania Warszawskie. Warszawa: Arkady.

241. Kazimierski, J. i Kołodziejczyk, R. (red.). (1978). Wielkie zaktady przemystowe Warszawy. Warszawa: PWN.

242. Keen, S. (2010). Bernanke winien kryzysu. Obserwator Finansowy. pl, 04.03.2010. Pozyskano z: http://www.obserwatorfinansowy.pl/forma/debata/bernanke-winienkryzysu/ [pobrano: 31.08.2013].

243. Keulen, S. i Kroeze, R. (2012). Back to Business: A Next Step in the Field of Oral History - The Usefulness of Oral History for Leadership and Organizational Research. The Oral History Review, 1, pp. 15-36.

244. Kielak, D. (2013). Żywiot kultur w prozie Reymonta. Pozyskano z: http://tygielkultury.eu/1_3_2003/aktual/18ram.htm [pobrano: 07.04.2013]. 
245. Kiełbicka, A. (2003). Izba przemystowo-handlowa w Krakowie 1850-1950. Kraków: TMHiZK.

246. Kirschner, J. (1994). Manipulować - ale jak? Warszawa: Sokrates.

247. Kisielnicki, J. (2003). Wirtualizacja jako strategia rozwoju przedsiębiorczości. W: Przedsiębiorczość Innowacyjność - Foresight, t. I (s. 88-100). Rzeszów: Politechnika Rzeszowska.

248. Kisielnicki, J. (2013). Zarządzanie. Jak zarzadzać i być zarządzanym. Warszawa: PWE.

249. Kisielnicki, J. i Ochinowski, T. (2005). Etyka w organizacji wirtualnej: Stan obecny i prognozy (s. 307-324). W: Studziński, J. i in. (red.). Zastosowania informatyki $w$ nauce, technice $i$ zarzadzaniu. Warszawa: PAN IBS.

250. Kisielnicki, J. i Ochinowski, T. (2008). Perception of VO reliability (pp. 1192-1195). In: Putnik, G. D. \& Cunha, M. (Ed.). Encyclopedia of Networked and Virtual Organizations. Hershey, PA Idea Group Reference.

251. Kisielnicki, J., Ochinowski, T. i Yu, H. F. (2010). Rhetoric of private health offers presented to SMEs over the Internet (pp. 546-578). In: M. Cunha, A. Tavares \& R. Simoes (Ed.). Handbook of Research on Development in e-Helath and Telemedicine: Technological and Social Perspectives. Hershey, PA: Information Science Reference.

252. Klimowicz, M. (2009). Psychologia i kryzys gospodarczy. Supermózg. Internetowa Gazeta Festiwalu Nauki. Pozyskano z: http://supermozg.gazeta.pl/supermozg/1,91626,6252233,Psychologia_i_kryzys_gospodarczy.html [pobrano: 31.12.2010].

253. Klincewicz, K. (2004). Zarządzanie wiedzą jako przykład mody w zarządzaniu. Organizacja i Kierowanie, 1, s. 15-32.

254. Klincewicz, K. (red.). (2013). Pracownicy o pracodawcach. Spoteczna odpowiedzialność biznesu w świetle badań jakościowych. Warszawa: Wyd. Naukowe WZ UW.

255. Knyt, A. i Wincerz-Gluza, A. (red.). (2004). Prywaciarze 1945 - 89. Warszawa: Ośrodek Karta.

256. Koch, R. (1997). Stownik zarządzania i finansów. Narzędzia, terminy, techniki od $A$ do $Z$. Kraków: Profesjonalnej Szkoły Biznesu.

257. Kochanowicz, J. (2010). Duch kapitalizmu na polskiej peryferii: perspektywa historyczna (s. 21-51). W: Kochanowicz, J. i Marody, M. (red.). Kultura i gospodarka. Warszawa: Schola.

258. Kochanowicz, J. i Marody, M. (red.). Kultura i gospodarka. Warszawa.

259. Kochanowski, J. (red.). (2006). W połowie drogi. Warszawa między Paryżem a Kijowem. Warszawa: Trio.

260. Kochanowski, J., Majewski, P., Rokicki, K. i Markiewicz, T. (2003). Zbudować Warszawe pięknq..., Warszawa: Trio.

261. Kociatkiewicz, J. i Kostera, M. (2012a). Sherlock Holmes and the adventure of the rational manager: Organizational reason and its discontents. Scandinavian Journal of Management, 28, pp. 162-172.

262. Kociatkiewicz, J. i Kostera, M. (2012b). The Good Manager: An Archetypical Quest for Morally Sustainable Leadership. Organization Studies, 7, pp. 861-878.

263. Kokka, G. i Jönsson, S. (2013). Visual research methods and the importance of analytical spaces. Management \& Organizational History, (8) 2, pp. 174-184.

264. Kołodziejczyk, R. (1962). Bohaterowie nieromantyczni. O pionierach kapitalizmu w Królestwie Polskim. Warszawa: WP. 
265. Kołodziejczyk, R. (1968). Portret warszawskiego milionera. Warszawa: KiW.

266. Kołodziejczyk, R. (red.). (1993). Image przedsiębiorcy gospodarczego w Polsce w XIX i XX wieku. Warszawa: IH. PAN.

267. Kołodziejczyk, R. Image przedsiębiorcy gospodarczego w Polsce. Próba nakreślenia problematyki badawczej oraz miejsce tematu w naszej historiografii (1-7). W: Kołodziejczyk, R. (red.). (1993). Image przedsiębiorcy gospodarczego w Polsce w XIX i XX wieku. Warszawa: IH. PAN.

268. Koneczny, F. (1921). Polskie Logos a Ethos. Poznań: Księgarnia św. Wojciecha.

269. Koneczny, F. (1935/1997). O wielości cywilizacyj. Kraków: WAM.

270. Koneczny, F. (1946-1949/2006). O sprawach ekonomicznych. Komorów: Wyd. Antyk.

271. Korolko, M. (1998). Sztuka retoryki. Przewodnik encyklopedyczny. Warszawa: WP.

272. Korolko, M. (2001). Retoryka i erystyka dla prawników. Warszawa: Wyd. Prawnicze PWN.

273. Kostera, M. (1995). Postmodernizm w zarzadzaniu. Warszawa: Wyd. Naukowe PWN.

274. Kostera, M. (2002). Space and silence. In: Heather Höpfl, H. and Kostera, M. (Eds.). Interpreting the maternal organization (pp. 224-234). London-New York: Routledge.

275. Kostera, M. (2003). Od aktywisty do bossa: Historia polskiego kierownika 1950-2000 (s. 69-92). W: Sulima, R. (red.). Życie codzienne Polaków na przełomie XX i XXI wieku. Łomża: Stopka.

276. Kostera, M. (2005). Antropologia organizacji. Metodologia badań terenowych. Warszawa: WN PWN.

277. Kostera, M. (2006). The narrative collage as research method. Storytelling, Self, Society 2/2, pp. 5-27. Pozyskano z: http://www.kostera.pl/pubmk.htm [pobrano: 01.09.2013].

278. Kostera, M. (2007). Kultura organizacyjna jako przedmiot badań jakościowych (s. 165-182). W: Księga Jubileuszowa. Zarzadzanie i rozwój. Warszawa: Wyd. Naukowe WZ UW.

279. Kostera, M. (2012). Organizations and archetypes. Cheltenham: Edward Elgar.

280. Kostera, M. (2013). Wyobraźnia organizacyjna. Pozyskano z: http://www.kostera.pl/ documents/11_Wyobraźnia.pdf [pobrano: 01.09.2013].

281. Kostera, M., Hatch, M. J. i Kozminski, A. (2006). The three faces of leadership: Manager, artist, priest. Organizational Dynamics, 35(1), pp. 49-68.

282. Kostera, M., Kownacki, S. i Szumski, A. (2002). Zachowania organizacyjne: motywacja, przywództwo, kultura organizacyjna (s. 311-395). W: Koźmiński, A. K. i Piotrowski, W. W. (red.). Zarzadzanie. Teoria i praktyka. Warszawa: Wydawnictwo Naukowe PWN.

283. Kostera, M. i Śliwa, M. (2011). Nowe tendencje w badaniach kulturowych i badaniach kultury (s. 269-290). W: Glinka, B. i Jelonek, A. (red.). Zarządzanie międzykulturowe. Kraków: Wyd. UJ.

284. Kostera, M. i Śliwa, M. (2012). Zarzadzanie w XXI wieku. Jakość, twórczość, kultura. Warszawa: Oficyna a Wolters Kluwer business.

285. Kostera, M. \& Wicha, M. (1994). Symbolism of communist manager roles: A study of scenarios. Scandinavian Journal of Management, 11(2), pp. 139-158.

286. Kozacki, P. (2009). Drodzy Czytelnicy. $W$ drodze, 4, s. 1.

287. Kozaczyńska, B. (2011). Ocalone z transportów Dzieci Zamojszczyzny. Siedlce: Stowarzyszenie tutaj teraz. 
288. Kozielecki, J. (1999). Banach. Geniusz ze Lwowa. Warszawa: Wyd. Akademickie Żak. 289. Koźmiński, A. K. (2008). Koniec świata menedżerów. Warszawa: WAP.

290. Krajewska, J. (2013). Projekt wydawniczy, maszynopis.

291. Krajewski, A. (2004). Postowie (s. 149-152). W: Knyt, A. i Wincerz-Gluza, A. (red.). Prywaciarze 1945-89. Warszawa: Ośrodek Karta.

292. Krakowski, A. (2011). Pollywood. Jak stworzyliśmy Hollywood. Warszawa: PWN.

293. Kriegseisen, W. (1998). »Warszawa dysydencka« (s. 75-88). W: Drozdowski, M. M. (red.). Warszawa $w$ dziejach Polski. Warszawa: IH PAN.

294. Król, M. (2006). Kościół wobec wyzwań XIX i XX wieku. Res Publica Nowa, nr 1, s. $64-76$.

295. Król, Z. (1980). Stanisław Bukowski - wspomnienia i refleksje (s. 464-467). W: Bejze, B. (red.). Chrześcijanie. Tom V. Warszawa: ATK.

296. Krueger, J., Lucifer's last laugh: The devil is in the details. Review of 'The Lucifer effect: Understanding how good people turn evil' by Philip G. Zimbardo. American Journal of Psychology, 121, pp. 337-343.

297. Kubiak, Z. (2003). Dzieje Greków i Rzymian. Warszawa: Świat Książki.

298. Kudliński, T. (1932). Wygnańcy Ewy. Kraków: Biblioteka Gazety Literackiej.

299. Kudliński, T. (1984). Młodości mej stolica. Kraków: Wyd. Literackie.

300. Kudliński, T. (1992). Starość nie radość. Kraków: Wydawnictwo Literackie.

301. Kula, W. (1955). Ksztattowanie się kapitalizmu w Polsce. Warszawa: PIW.

302. Kultura i praca, założenia. (1947). Tygodnik Warszawski, 23, s. 6.

303. Kunda, G. (1992). Engineering Culture. Control and Commitment in a High-Tech Corporation. Philadelphia: Temple Univeristy Press.

304. Küng, H. (2002). Tracing the Way. Spiritual Dimensions of the World Religions. London and New York: Continuum.

305. Küng, H. (2005). Spowiedź heretyka (rozmawiają B. Mauerberg i K. Sperber). Frankfurter Rundschau. Forum, 4, s. 32-35.

306. Kurtz, H. (2001). The Fortune Tellers. Inside Wall Street's game of Money, media and manipulation. New York: A Touchstone Book.

307. Kwiatkowski, J. (1990). Literatura Dwudziestolecia. Warszawa: PWN.

308. Kwiatkowski, M. (2007). Warszawa $-z$ ruin do życia. Warszawa: NeoMedia.

309. Lafuente, E., Vaillant Y. i Rialp, J. (2006). Regional Differences in the Influence of Role Models: Comparing the Entrepreneurial Process of Rural Catalonia. Regional Studies, 41(6), pp. 779-795.

310. Lam, D. and Clark, C. (1994). Beyond the Developmental State: The Cultural Roots of „Guerilla Capitalism” in Taiwan. Governace, 4, pp. 412-430.

311. Lamont, M. (1992). Money, Morals and Manners: The Culture of the French and the American Upper-Middle Class.

312. Landes, D. S., Mokyr, J. I. i Baumol, W. J. (2010). The Invention of Enterprise. Princeton: Princeton University Press. Chicago: The University of Chicago Press.

313. Laskowska-Otwinowska, J. (2010). Podróże do pracy jako element nowego stylu życia. Postulaty ruchu społecznego Slow Dow. Kultura i Społeczeństwo, 1, s. 141-160.

314. Leblebici, H. \& Shah, N. (2004). The Birth, Transformation, and Regeneration of Business Incubators as New Organisational Forms: The Interplay between Organisational History and Organisational Theory. Business History, 46, pp. 353-380.

315. Leski, K. (2009). Życie niewtaściwie urozmaicone. Tom I. Gdańsk: Oficyna Wyd. FINNA. 
316. Lewicka, M. (2013). Gtos $w$ dyskusji panelowej: Historia rodziny - historia $w$ rodzinie. IV Konferencja z cyklu Historia rodziny - historia w rodzinie, Uniwersytet Warszawski, Wydział „Artes Liberales”, luty 2013.

317. Lifton, R. J. (1985). Home from the war: Vietnam veterans - nieither victims nor executioners. New York: Basic Books.

318. Lifton, R. J. (1986). The Nazi doctors: medial killing and the psychology of genocide. New York: Basic Books.

319. Lifton, R. J. (1987). The Future of Immortality and Other Essays for a Nuclear Age. New York: Basic Books.

320. Lifton, R. J. (1993). The Protean Self: Human Resilience in an Age of Fragmentation. New York: Basic Books.

321. Lifton, R. J. (1999). Destroying the World to Save it. New York: Metropolitan Books.

322. Lipartito, K. J. Culture and the Practice of Business History. Business and Economic History, vol. 24, no. 2, 1995.

323. Lipiński, E. Wstęp (s. 7-8). W: Nowoczesne zasady organizacji przedsiębiorstwa. Poznań: PTE Oddział w Poznaniu.

324. Lisak, J. (1939). Ekonomia jednostkowa. Nauka o przedsiębiorstwie. Katowice: Nakładem Wyższego Studium nauk społeczno-gospodarczych w Katowicach. Skład Główny Gebethner i Wolff - Warszawa.

325. Lockhart, H. W. (2002). Reconstructing the Protestant Work Ethics: an element of faith-based and secular poverty-to-work programs. Paper presented at SSSR annual meetings in Salt Lake City, UT, USA.

326. Lockhart, H. W. (2005). Building Bridges and Bonds: Generating Social Capital in Secular and Faith-Based Poverty-to-Work Programs. Sociology of Religion, 66, pp. $45-60$.

327. Lowney, Ch. (2011). Heroiczne przywództwo. Kraków: WAM.

328. Lüchinger, R. (2007). 12 ikon ekonomii. Warszawa: Wyd. Studio EMKA.

329. Lazarewicz, C. (2013). Sześć pięter luksusu. Przerwana historia Domu Braci Jabtkowskich. Kraków: Znak.

330. Łętocha, R. (2006). »Oportet vos nasci denuo«. Myśl spoteczno-polityczna Jerzego Brauna. Kraków: Zakład Wydawniczy „NOMOS”.

331. Łoza, St. (red.). (1938). Czy wiesz kto to jest? Warszawa: Główna Księgarnia Wojskowa.

332. Machlejd, K. (2006). Saga urlichowsko-machlejdowska (Wiśniewska, J. i in. [red.]). Warszawa: Muzeum Historyczne m. st. Warszawy.

333. Mackiewicz, J. (2002). Okna zatkane szmatami. London: Kontra.

334. Made in Warszawa. (2008). Strona programu badawczo-edukacyjnego. Pozyskano z: http://www.madein.waw.pl/ [pobrano: 05.09.2013].

335. Madurowicz-Urbańska, H. (1976). Franciszek Bujak - o nowy kształt historii (s. 1-167). W: Bujak, F. Wybór pism. Warszawa: PWN.

336. Mahadevan, J. (2009). Redefining Organizational Cultures: An Interpretative Anthropological Approach to Corporate Narratives. Forum: Qualitative Social Research, 1. Pobrano z: FQS http://www.qualitative-research.net/ [pobrano: 31.09.2013].

337. Magala, S. (2002). Cold wars and hot issues: management of responsibilities. HRDI, 5(4), pp. 493-505. 
338. Magala, S. (2006). Kompetencje, tożsamość, czy przekład: metafory w życiu badań międzykulturowych. Problemy zarzadzania, 1, s. 63-77.

339. Magala, S. (2011). Kompetencje międzykulturowe. Warszawa: Oficyna a Wolters Kluwer business.

340. Maielli, G. (2007). Counterfactuals, superfactuals and the problematic relationship between business management and the past. Management \& Organizational History, 2(4), pp. 275-294.

341. Majewski, J. S. i Markiewicz, T. (1998). Warszawie nie odbudowana. Warszawa. Wyd. DIG.

342. Majewski, J. S. i Markiewicz, T. (2012). Budujemy nowy dom. Warszawa: Dom spotkań z historią.

343. Makin, P., Cooper, C., i Cox, Ch. (2000). Organizacje a kontrakt psychologiczny. Warszawa: Wyd. Naukowe PWN.

344. Makomaska, E. (1968). Michat Tarasiewicz. Warszawa: PIW.

345. Maliszewski, K. (2010). Z dziejów staropolskiej kultury i cywilizacji. Lublin: Fundacja IED.

346. Management \& Organizational History (2011). Pozyskano z: http://moh.sagepub. com/ [pobrano: 17.08.2011].

347. Marcinkowski, A. (2000). O diagnozowaniu kultury organizacyjnej. W: Borkowski, T., Marcinkowski, A i Oherow-Urbaniec, A. (red.). (2000). W kręgu zarzadzania: spojrzenie multidyscyplinarne. Kraków: Księgarnia Akademicka.

348. Marens, R. (2005). Timing is Everything: Historical Contingency as a Factor in the Impact of Catholic Social Teaching Upon Managerial Practices. Journal of Business Ethics, 57, pp. 285-301.

349. Markiewicz, T., Świątek T. W. i Wittels K. (2012). Polacy z wyboru. Warszawa: Dom Spotkań z Historią.

350. Marsh, K. \& Musson, G. (2008). Men at Work and at Home: Managing Emotion in Telework. Gender, Work and Organization, 1, pp. 31-48.

351. Martyniak, Z. (1983). Stanistaw Bieńkowski - krzewiciel naukowej organizacji i kierownictwa: (w 100-lecie urodzin). Wyd. AE w Krakowie.

352. Martyniak, Z. (1989). Prekursorzy nauki organizacji i zarzadzania. Warszawa: PWE.

353. Martyniak, Z. (2002a). Historia myśli organizatorskiej Wybitni autorzy z zakresu organizacji i zarządzania w pierwszej połowie XX wieku. Kraków: Wyd. AE w Krakowie.

354. Martyniak, Z. (2002b). Nowe metody i koncepcje zarządzania. Wyd. AE w Krakowie.

355. Mayo, J. i Nohira, N. (2007). Czas rekinów. Gliwice: Onepress.

356. Metler, M. (2009). Myśliwi z czerwonymi gwiazdami nad polami Żabieńca, Kresowe Stanice, 1, Pozyskane z: http://www.osadnicy.org/spis_tresci44.htm [pobrano: 05.09.2013].

357. McCloskey, D. (2000). How to Be Human, Though an Economist. Ann Arbor: University of Michigan Press.

358. McCloskey, D. (2001). Measurement and Meaning in Economics. The Essential Deirdre McCloskey. Northampton: Edward Elgar.

359. McGoldrick, P. (2012). New perspectives on Pius XII and Vatican financial transactions during the Second World War. The Historical Journal, 55, Issue 04, pp. 1029-1048. 
360. McKinlay, A. (2006). Managing Foucault: Genealogies of Management. Management \& Organizational History, 1(1), pp. 87-100.

361. Micklethwait, J., Wooldridge, A. (2000). Szamani zarzązania. Poznań: Zysk i S-ka.

362. Mikołejko, Z. (2013). Brzuch wielkiego miasta, [Tygodnik Powszechny] Tygodnik onet.pl. 23.03. 2013. Pozyskano z: https://www.facebook.com/TygodnikPowszechny/ posts/507630129300617 [pobrano: 07.09.2013].

363. Milewski, St. (2010). Codzienność niegdysiejszej Warszawy. Warszawa: Iskry.

364. Milkovich, G. T. \& Boudreau. (1988). Personnel Management. Plano: Business Pub. Inc.

365. Mills, C. W. (1964). Białe kotnierzyki. Amerykańskie klasy średnie. Warszawa: Wyd. Książka i Wiedza.

366. Mincer, L. Q. (2009). Literatura jidysz i żydowsko-polska [Yiddish and PolishJewish literature]. W: Marinlelli, L. (red.). Historia literatury polskiej [History of Polish Literature] (s. 433-461). Wrocław: Zakład Narodowy im. Ossolińskich.

367. Minitz, A. (2008). Understanding Evil and Educating Heroes. Journal of Philosophy of Education, 42, p.185.

368. Morgan, G. (2002). Obrazy organizacji. Warszawa: PWN.

369. Morton, W. S. i Lewis Ch. M. (2007). Chiny. Historia i kultura, Kraków: UJ.

370. Motyka, M. i Pawlak, J. (red.). (2012). Podmiotowość człowieka w organizacji. Kraków: Wyd. Uniwersytetu Ekonomicznego w Krakowie.

371. Musacchio Adorisioa, A. L. i Mutchb, A. (2013). In search of historical methods. Management \& Organizational History, 8(2), pp. 105-110.

372. Newton, T., Handy, J. \& Fineman, S. (1996). »Managing« Stress. Emotion and power of work. London: Sage.

373. Nofsinger, J. R. (2010). Psychologia inwestowania. Wyd. IV. Gliwice: Onepress.

374. Nowak, K. (1990). Metody taksonomiczne w klasyfikacji obiektów społeczno-gospodarczych. Warszawa: PWE.

375. Nowakowski, M. (2010). Moja Warszawa. Powidoki drugie. Warszawa: Iskry.

376. Nowakowski, S., Drozdowski, M. M., Górski, J. i Tewiaszew, A. (1972). Jaka jesteś Warszawo? Warszawa: PIW.

377. Nowicka, M. (2007). Rzeczpospolita postkolonialna, Wiedza i Życie, 9. Pozyskano z: http://wyborcza.pl/1,76506,4431065.html [pobrano: 03.09.2013].

378. Ochinowski, T. (1998). „Odwilz” w Polsce jako zjawisko społeczne i kulturowe. Analizy. Oceny. Przewidywania (s. 77-82). W: Drozdowski, M. M. (red.). Ochinowski, T. i Żaryn, J. (wybór i oprac.), 1956. Polska emigracja a Kraj. Wybór dokumentów. Warszawa: TMH i Typografika.

379. Ochinowski, T. (2002). Nie tylko psychoanaliza. Wybrane programy współpracy badawczej historii i psychologii. Historyka, 32, s. 62-88.

380. Ochinowski, T. (2004). Kult korporacyjny - nieoczekiwany aspekt globalizacji (s. 399-409). W: Wyzwania globalizacji. Odpowiedzi przedsiębiorstw. Warszawa: Wyd. Naukowe WZ UW i Wyd. Naukowe WSPiZ im. Leona Koźmińskiego.

381. Ochinowski, T. (2006). Kultowość korporacyjna - patologia, czy zapomniany potencjał motywacyjny firmy? (s. 72-81). W: Dobrzyński M. i Grzywacz W. (red.). R-ewolucja zarzadzania i co z niej wynika... Warszawa: Wyd. Naukowe WZ UW.

382. Ochinowski, T. (2009a). Coaching biznesowy a psychologia pozytywna (s. 170-188). W: Sidor-Rządkowska, M. (red.). Coaching. Teoria, praktyka, studia przypadków. Warszawa: Wolters Kluwer Polska. 
383. Ochinowski, T. (2009b). Verba movent. Przyczynek do obecności historii oralnej w historiografii polskiej po 1945 roku (s. 119-136). W: Wierzbicki, A. (red.). Klio Polska. Studia i materiały $z$ dziejów historiografii polskiej XIX i XX wieku, t. 4. Warszawa: Wydawnictwo Neriton i IH PAN.

384. Ochinowski, T. (red.). (2010). Przedsiębiorstwa ekonomii spotecznej - czynniki sukcesu. Warszawa: Fundacja Archidiecezji Warszawskiej Pomocy Bezrobotnym i Biednym NADZIEJA.

385. Ochinowski, T. (2011). Magistra Vitae? Zachowania organizacyjne (ze szczególnym uwzględnieniem relacji przedsiębiorca-pracownik) w świetle wyzwań obecnego kryzysu (s. 136-154). W: Bernatt, M., Bogdanienko, J. i Skoczny, T. (red.). Społeczna odpowiedzialność biznesu. Krytyczna analiza. Warszawa: Wyd. Naukowe WZ UW.

386. Ochinowski, T. (2012a). Czy mit literacki może być argumentem dla historyków gospodarki? „Lodzermensch” jako przyczynek do dyskusji dotyczącej kulturowych korzeni kapitalizmu na ziemiach polskich (s. 219-240). W: Wierzbicki, A. (red.). Klio Polska. Studia i materiaty $z$ dziejów historiografii polskiej XIX $-X X$ wieku. t. 6. Warszawa: Wyd. Neriton i IH PAN.

387. Ochniowski, T. (2012b). Historia i psychologia. Krótki raport o niespełnionym projekcie. Annales Univeristats Paedagogice Cracoviensis. Studia Historica. XII, s. 227-244.

388. Ochinowski, T. (2012c). Non-American »American dream«. »Lodzermensch « myth as a vehicle of work ethics, referat prezentowany na Światowym Kongresie Etyki Biznesu, ISBEE, Akademia im. L. Koźmińskiego, lipiec 2012, Warszawa.

389. Ochinowski, T. (2012d). Proteusz na rynku pracy tymczasowej, czyli trening kondycji psychicznej i motywacji konsultanta (s. 116-128). W: Bogdanienko, J. (red.). Profesjonalna rekrutacja i selekcja na potrzeby wspótczesnej organizacji. Warszawa: Wyd. Naukowe WZ UW.

390. Ochinowski, T. (2013). Wstęp. Przyzwoita przedsiębiorczość warszawskich mieszczan (s. 9-15). Posłowie. Kordian Tarasiewicz jako nauczyciel przedsiębiorczości (s. 198-205). W: Tarasiewicz, K. Zapach świeżej kawy (Ochinowski, T. [red.]). Warszawa: PWN.

391. Ochinowski, T. i Gołaszewski, P. (2011). Development of Social Entrepreneurship in Masovia. In: Nowak, A. Z. and Szałański, M. (Ed.). 7 years of Poland's presence in the European Union (s. 114-130). Warszawa: Wyd. Naukowe WZ UW.

392. Ochinowski, T. i Gołaszewski, P. (2012). Gospodarka narodowa - indywidualna przedsiębiorczość - rodzina. Zaskakująco nowoczesne pomysły z dawnych lat (s. 5-24). W: Wareccy, M. i M., Jabłoński, P., Ochinowski, T., Gołaszewski, P. i Dajczak, T. Rodzina receptą na kryzys. Warszawa: Narodowy Dzień Życia. Fundacja.

393. Ochinowski, T. i Grzywacz, W. (2003a). Gdy się zaciera granica między pracą zawodową a życiem prywatnym (s. 73-92). W: Borkowska S. (red.). Programy praca - życie a efektywność firm. Warszawa: IPiSS.

394. Ochinowski, T. i Grzywacz, W. (2003b). Kult korporacyjny jako specyficzny sposób funkcjonowania organizacji w warunkach turbulentnych (s. 193-201). W: Lisiecki M. (red.). Zmiana jako czynnik rozwoju organizacji. Lublin: Wyd. KUL.

395. Ochinowski, T. i Grzywacz, W. (2004). Organizacje „,inteligentne inaczej”. Zjawisko kultu korporacyjnego w firmach działających na terenie Polski (s. 139-152). W: Grudzewski, W. i Merski, J. (red.). Zarzadzanie wiedza istota wspótczesnych organizacji inteligentnych. Warszawa: WSE w Warszawie i Centrum Promocji Karier. 
396. Ochinowski, T. i Jagodziński J. (2007). »Oh Poles, you romantic souls«! The case of Poland in EU (pp. 1-10). In: Conference on 50 years of the Treaty of Rome and the EU Current Development. Taipei: Tamkang Univeristy and NaHua University.

397. Ochinowski, T., Kisielnicki J., Kodwani, A. D., Tsai, H. \& Strocka, M. (2013). Hospital's Websites and Virtual Health Support Community - A cross-cultural Contribution to the Issue. Procedia Technology (przyjęte do druku).

398. Ochinowski, T. i Kseba, A. (2013). Podmiotowość - relacyjność - zakorzenienie. Społeczna historia biznesu jako źródło dobrych praktyk dla MŚP w warunkach kryzysu (s. 263-292). W: Nowak, A. Z. i Szałański, M. (red.). Mikrofirmy sita napędowa gospodarki Mazowsza. Warszawa: Wyd. Naukowe WZ UW.

399. Ochinowski, T. i Pawelec, T. (2010). Historia psychologiczna a problematyka źródeł (s. 39-78). W: Kolbuszewska, J. i Stobiecki, R. (red.). Historyk wobec źródet. Historiografia klasyczna i nowe propozycje metodologiczne. Łódź.

400. Od redakcji (1945). Tygodnik Warszawski, 1, s. 1.

401. O nową kulturę pracy - założenia myślowe. Tygodnik Warszawski, dodatek Kultura i Praca (1947), nr 19, s. 6.

402. Ooi, C.-S. (2002). Persuasive Histories: Decentering, Recentering and the Emotional Crafting of the Past. Journal of Organizational Change Management, 15(6), pp. 606-621.

403. Osica, J., Sowa, A. i Wieczorkiewicz, P. (2009). 1939. Ostatni rok pokoju, pierwszy rok wojny. Poznań: Zysk i S-ka.

404. Otwinowska, B. (1980). Humanistyczna koncepcja „otium” w Polsce na tle tradycji europejskiej. W: Michałowska, T. i Ślaski J. (red.). Studia porównawcze o literaturze staropolskiej (s. 169-186). Wrocław: Ossolineum.

405. Otwinowska, B. (1997). Więzień Jerzy Braun. Niepodlegtość i Pamięć, 1, s. 287-306.

406. Ouchi, W. G. (1981). Theory Z: How American Business Can Meet the Japanese Challenge. Massachusetts: Addison-Wesley Publishing Company.

407. Ozcobanlar, M. (2013). Anatolian Tigers. Referat niepublikowany przygotowany w ramach seminarium doktorskiego, Warszawa: WZ UW.

408. Paczkowski, A. (1991). Aresztowanie ks. Zygmunta Kaczyńskiego. Więź, 4, s. $109-114$.

409. Pakulski, J. (2011). Polskość jagiellońska w Australii. Więź, 4, 46-54.

410. Paprocki, H. (2011). Prawostawie wobec zagrożeń ekonomicznych. Pozyskano z: http://www.liturgia.cerkiew.pl/texty.php?id_n=133\&id=113 [pobrano: 04.09.2013].

411. Pascale, R. T. i Athos, A. G. (1982). The Art of Japanese Management: Applications for American Executives. London, UK: Penguin Books Ltd.

412. Penrose, R. (1995). Nowy umyst cesarza: o komputerach, umyśle i prawach fizyki. Warszawa: Wyd. Naukowe PWN.

413. Perkitny, T. (2009). Okrą̇amy świat raz jeszcze. Poznań: Zysk i S-ka.

414. Peters, T. i Waterman, R. H. Jr (1982/2000). Poszukiwanie doskonatości w biznesie. Warszawa: Wydawnictwo Medium.

415. Peterson, Ch. i Seligman M. E. P. (2004). Character Strenghts and Virtues: A Handbook and Classification. Oxford: Oxford University Press.

416. Pettigrew, A. (1979). On Studying Organizational Cultures. Administrative Science Quarterly, 4, pp. 570-581. 
417. Pietraszek, E. (1981). Etos robotniczy na przełomie epoki (1890-1918). Pozyskano z: http://strebski.dyktatura.info/wp-content/texts/sociology/Edward_Pietraszek.pdf [21.02.2013].

418. Poksiński, J. (1992). „TUN”. Tatar-Utnik-Nowicki. Represje wobec oficerów Wojska Polskiego w latach 1949-1956. Warszawa: Wyd. Bellona.

419. Poksiński, J. (1996). »My, sędziowie, nie od Boga..."Z dziejów Sądownictwa Wojskowego PRL 1944-1956. Materiaty i dokumenty. Warszawa: Oficyna Wyd. Gryf.

420. Pomorski, J. Metodologiczne problemy historii najnowszej (s. 20-35). W: Maternicki, J. (red.). (1990). Historia najnowsza jako przedmiot badań i nauczania. Warszawa.

421. Poole, R. (2008). Memory, history and the claims of the past. Memory Studies, 1, s. 149-166.

422. Popper, K. (1993). Spoteczeństwo otwarte i jego wrogowie. Warszawa: Wyd. Naukowe PWN.

423. Portelli, A. (1991). The Death of Luigi Transtulli and Other Stories: Form and Meaninig in Oral History. Albany: State University of New York Press.

424. Possati, L. M. (2013). Dolary Papieża przeciwko Hitlerowi. L'Osservatore Romano, 3-4, s. 56-57.

425. Pospiszyl, K. (1985). Psychopatia. Warszawa: PWN.

426. Poynting, S. \& Mason, V. (2008) “"Tolerance, Freedom, Justice and Peace”?: Britain, Australia and Anti-Muslim Racism since September 11th 2001?' (pp. 128-157). In: B. Spalek, B. (Ed.). Ethnicity and Crime: A Reader. Maidenhead: Open University Press.

427. Poznańska, B. (1993). Obraz warszawskiego bourgeois w okresie międzywojennym (s. 217-224). W: Kołodziejczyk, R. (red.). Image przedsiębiorcy gospodarczego w Polsce $w$ XIX $i$ XX wieku. Warszawa: IH. PAN.

428. Praszkier, R., Nowak, A. (2012). Przedsiębiorczość społeczna. Teoria i praktyka. Warszawa: Wolters Kluwer.

429. Programy Ośrodka Karta. Pozyskano z: http://www.karta.org.pl/ [pobrano: 11.03.2008].

430. Prokop-Janiec, E. (1998). Wstęp. W: Singer, I. J. Bracia Aszkenazy. Wrocław: Wyd. Dolnośląskie.

431. Przeciszewski, P. (2011). Warszawa. Prawostawie i rosyjskie dziedzictwo. Warszawa: Wyd. Egros.

432. Przewodnik po Gdańsku. Reprint z 1939 r. (1997). Łódź: Piątek Trzynastego Wydawnictwo.

433. Pytlas, S. (1994). Łódzka burżuazja przemystowa w latach 1864-1914. Łódź: Wyd. UŁ.

434. Pytlas, S. (1994). Wizerunek wielkiej burżuazji przemysłowej Łodzi w okresie zaborów (s. 49-59). W: Kołodziejczyk, R. (red.). Image przedsiębiorcy gospodarczego $w$ Polsce $w$ XIX i XX wieku. Warszawa: IH. PAN.

435. Rahmati, V., Darouian, S. \& Ahmadinia, H. (2012). A Review on Effect of Culture, Structure, Technology and Behavior on Organizations. Australian Journal of Basic and Applied Sciences, 3, pp. 128-135.

436. Ramo, H. (2004). Moments of trust: temporal and spatial factors of trust in organizations. 1. Journal of Managerial Psychology, 9, pp. 760-775.

437. Reimer, S. (2003). Sect Appeal: Rethinking the class-sect link, szkic referatu wygłoszonego na Dorocznym Spotkaniu Society for the Scientific Study of Religion. Norfolk, USA, październik 2003, materiał powielany.

438. Reymont, Wł. (1990). Ziemia Obiecana. Warszawa: Wyd. Muza. 
439. Rhead, J. C. (2009). What Might Psychotherapy Have to Do With Peace? Explore: The Journal of Science and Healing, 5, pp. 186-193.

440. Robin, R. (1980). Badanie pól semantycznych: doświadczenie Ośrodka Leksykologii Politycznej w Saint-Cloud (s. 252-281). W: Głowiński, M. (red.) Język i społeczeństwo. Warszawa: Czytelnik.

441. Robbins, S. P. (2001). Zasady zachowania w organizacji. Poznań: Zysk i S-ka.

442. Romek, Z. (2010). Cenzura a nauka historyczna w Polsce 1944-1970. Warszawa: NERITON.

443. Roth, J. (2002). Hotel Savoy. Łódź: Cyklop.

444. Rowlinson, M., Booth, Ch., Clark, P., Delahaye, \& Procter, S. (2010). Social Remembering and Organizational Memory. Organization Studies, 31, pp. 69-87.

445. Rowlinson M. i Hassard V. (2013). Historical neo-institutionalism or neo-institutionalist history? Historical research in management and organization studies. Management \& Organizational History, 8(2), pp. 111-126.

446. Rowlinson, M., Jaques, R. S. \& Booth, C. (2009). Critical Management and Organizational History. In: Alvesson, M., Willmott, H., Bridgman, T. (Eds.). Handbook of Critical Management Studies. Oxford: Oxford University Press.

447. Runyan, W. Mc. (1992). Historie życia a psychobiografia. Warszawa: PWN.

448. Salamucha, A. (rec.). (2009). The Lucifer Effect. Understanding How Good People Turn Evil/Efekt Lucyfera. Dlaczego dobrzy ludzie czynią zło? Forum Philosophicum: International Journal for Philosophy, 14, pp. 166-168.

449. Salmi, H. (2010). Europa XIX wieku. Historia kulturowa. Kraków: Wyd. UJ.

450. Sanderson, K., Parsons, D. B., Mills J. H. \& Mills A. J. (2010). Riding the Second Wave: Organizing Feminism and Organizational Discourse - Stewardesses For Women's Rights, Management \& Organizational History, 5(3-4), pp. 360-377.

451. Schein, E. H. (1993). The Academic as Artist: Personal and Professional Roots. In: Bedean, A. G. (Ed.). Management Laureates, 3. Greenwich, CT: JAI Press.

452. Schein, E. H. (1999). The Corporate Culture Survival Guide. Sens and Nonsense About Culture Change. San Francisco: Jossey - Bass Inc. Publishers.

453. Schein, E. H. (2004). Organizational Culture and Leadership. San Francisco: Jossey - Bass Inc. Publishers.

454. Shepard, J. (2012). Bizancjum, ok. 500-1024. Warszawa: Dialog.

455. Sedláček, T. (2012). Ekonomia dobra i zła. W poszukiwaniu istoty ekonomii od Gilgamesza do Wall Street. Warszawa: Wyd. Studio Emka.

456. Sedláček, T., Orrel, D. i Chlupatý, R. (2012). Zmierzch Homo Economicus. Warszawa: Wyd. Studio Emka.

457. Seligman, M. E. P. (1993). Optymizmu można się nauczyć, Poznań: Media Rodzina of Poznań.

458. Seligman, M. E. P. (2005). Prawdziwe szczęście. Psychologia pozytywna a urzeczywistnienie naszych możliwości trwatego spetnienia. Poznań: Media Rodzina.

459. Seligman, M. E. P. (2011). Flourish. A Visionary New Understanding of Happiness and Well - being. Free Press: New Yor; polski przekład: Petnia życia. Nowe spojrzenie na kwestię szczęścia i dobrego życia. Poznań: Media Rodzina.

460. Sennett, R. (2006). Korozja charakteru. Warszawa: Muza.

461. Sennett, R. (2008). Kapitalizmu życie po życiu. Europa, dodatek do Nesweeka Pozyskano z: http://www.newsweek.pl/artykuly/sekcje/Europa/kapitalizmu-zycie-pozyciu,43884,1 [pobrano: 30.12.2010]. 
462. Sennett, R. (2010). Kultura Nowego Kapitalizmu. Warszawa: Muza.

463. Sennett, R. (2012). Szacunek w świecie nierówności. Warszawa: Muza.

464. Shermer, M. (2009). Sztuka kantowania. Świat Nauki, 4, s. 24.

465. Siewierski, J. (2010). Idea wielokulturowości. Tradycje Rzeczypospolitej i doświadczenia obecne. Warszawa: SGH.

466. Sikorski, T. i Kulesza, M. (2013). Nieztomni w epoce fatszywych proroków. Warszawa: Wyd. von Borowiecky.

467. Sikorski, Cz. (1999). Zachowania ludzi w organizacji. Warszawa: PWN.

468. Singer, I. B. (1992). Szumowiny. Gdańsk: Phantom Press International.

469. Singer, I. B. (1998). Bracia Aszkenazy. Wrocław: Wyd. Dolnośląskie.

470. Skibińska, W. i Bukowska, H. (1980). Szkic wprowadzający (s. 462-464). W: Bejze, B. (red.). Chrześcijanie, t. V. Warszawa: ATK.

471. Skoczyński, J. (1997). Koneczny dzisiaj. W: Koneczny F. (1935/1997). O wielości cywilizacyj. Kraków: WAM.

472. Skoczyński, J. (2003). Koneczny. Teoria cywilizacji. Warszawa: Wyd. IFiS PAN.

473. Skoczyński, J. (2010). Od końca XVII do połowy XVIII wieku. W: Woleński, J. (2010). Historia filozofii polskiej (s. 149-191). Kraków: Wyd. WAM.

474. Skowroński, A. (1928). Władystaw Ochenkowski jako ekonomista. Poznań: Skł. Gł. Gebethner i Wolff.

475. Skowroński, A. (1949). Istota i przedmiot nauki o przedsiębiorstwie. Poznań: Księgarnia Wł. Wiłak w Poznaniu.

476. Skowroński, A. (1965). Nowoczesne zasady organizacji przedsiębiorstwa. Poznań: PTE Oddział w Poznaniu.

477. Skrzypek, M. (red.). (2000). Filozofia i myśl spoteczna w latach 1700-1830. T. 1: Okres saski 1700-1763. Warszawa: Wydaw. IFiS PAN.

478. Snowman, D. (1999). „Theodore Zeldin” [interview]. History Today, 49, p. 27.

479. Sobolewski, J. L. (2011). Władystaw Jachniak. Nie jedno mam życie. Pozyskano z: http://report.republika.pl/strona14.html [pobrano: 07.09.2013].

480. Sorkin, A. R. i Woś, R. (2013). Wiara. Nadzieja. Pieniądze. Dziennik Gazeta Prawna.15-17.02.2013, s. A8-A9.

481. Sorman, G. (2009). Ekonomia nie ktamie. Warszawa: Prószyński i S-ka.

482. Spodenkiewicz, P. (2006). Piasek z Atlantydy. Rozmowy z Jerzym Grohmanem [A sand from Atlantis. Interview with Jerzy Grohman]. Lodzt: HOBO.

483. Spychalski, M. (1965). Marszatek M. Spychalski w TMH (s. 757). Streszczenie wystąpienia opublikowane na łamach „Kwartalnika Historycznego”, tekst niepodpisany.

484. Spychalski, M. (1966). Problemy wyzwolenia i odbudowy Warszawy (s. 55-68). Spotkanie z marszałkiem Marianem Spychalskim opublikowane na łamach „Kwartalnika Historycznego”.

485. Stańczyk, S. (2008). Nurt kulturowy w zarzadzaniu. Wrocław: Wyd. UE we Wrocławiu. 486. Staszewski, J. (2010). August III Sas. Wrocław: Ossolineum.

487. Steinborn, A. (1979). „Krajowa Hurtowania Herbaty, dawniej Towarzystwo M. Szumilin” podczas wojny. Rocznik Warszawski, 15, s. 369-382.

488. Stiglitz, J. E. (2010). Freefall. Free Markets and the Sinking of the Global Economy. London: Penguing Books.

489. Stix, G. (2009). Psychologia bańki spekulacyjnej. Świat Nauki, 8, s. 74-81.

490. Stix, G. (2011). Neurobiologia odporności psychicznej. Świat Nauki, 4, s. 27-31. 
491. Stobiecki, R. (2003). Wprowadzenie (s. V-XX). W: Grabski, A. F. (2003). Dzieje Historiografii. Poznań: Wyd. Poznańskie.

492. Stopa, M. (2010). Słodka Warszawa. Warszawa: Stopa studio.

493. Stopa, M. i Brykczyński, J. (2007). Rzemieślnicy Warszawy. The Craftsmen of Warsaw. Warszawa: Stowarzyszenie Vox Humana.

494. Stopa, M. i Caponi, F. (2012). Chleb po warszawsku. Warszawa: Wyd. Veda.

495. Strack, F. (2009). The Crisis in Economics, a Challenge for Psychology. Psychological Science in the Public Interest, 10.

496. Strocka, M. (2012). Model etycznej przedsiębiorczości ukryty w zapominanej warszawskiej tradycji jako źródto dobrych praktyk dla wspótczesnego sektora MSP, materiał niepublikowany.

497. Strocka, M., Gołaszewski, P. i Dreilich, L. (2012) Provincial antecedents of the $»$ Good Work « Project and the good practices for contemporary business resulting from these antecedents. Referat prezentowany na V Światowym Kongresie Etyki Biznesu, Akademia Leona Koźmińskiego, Warszawa.

498. Strozier, Ch. B. \& Flynn, M. (1992). Lifton's Method, Psychohistory Review, Vol. 20 (2), pp. 131-141.

499. Strzałecki, A. (red.). (2011). Innowacyjna przedsiębiorczość. Warszawa: Academica.

500. Strzeżek, A. (2012). Od konsumpcji do konspiracji czyli warszawskie lokale gastronomiczne 1939-1944. Warszawa: Wyd. Trio.

501. Suchorowska, D. (1990). Wielka edukacja. Warszawa: Agencja Omnipress.

502. Sułkowski, Ł. (2012). Kulturowe procesy zarzadzania. Warszawa: Difin.

503. Sutowski, M. (2013). Omówienie wyktadu prof. Jana Kregla »Alternative theories of money«. Pozyskano z: http://www.krytykapolityczna.pl/instytut/omowienie-wykladuprof-jana-kregla-alternative-theories-money [pobrano: 30.06.2013].

504. Symchowicz, S. (2005). Pasierb nad Wista. Warszawa: Wyd. Więź.

505. Szarota, T. (1995). Życie codzienne w stolicach okupowanej Europy. Warszawa: PIW.

506. Szarota, T. (2010). Okupowanej Warszawy dzień powszedni. Warszawa: Czytelnik.

507. Szklarski, A. (2007). Tajemnicza wyprawa Tomka. Warszawa: Muza.

508. Szpakowska, M. (red.). (2008). Obyczaje polskie. Wiek XX w krótkich hastach. Warszawa: W.A.B.

509. Szpringer, W. (2009). Społeczna odpowiedzialność banków. Warszawa: Oficyna a Wolters Kluwer business.

510. Sztumski, J. (red.). (1995). Elity w procesie transformacji spoteczno-gospodarczej i politycznej Polski. Katowice: Wyd. UŚ.

511. Szwankowska, H. (2002). Wspomnienie o Janie Górskim (s. 107-111). W: Drozdowski, M. M. (red.). Od Edwarda Abramowskiego do Jana Józefa Lipskiego. Warszawa: Typografika.

512. Szymański, R. (2013). Ograniczenia w handlu zewnętrznym kawa lub herbata oraz projekt utworzenia monopolu państwowego na import kawy w Polsce międzywojennej. Regulacje prawne. Referat przygotowany na potrzeby wykładu ogólnouniweryteckiego „Biznes jak wino”. Wykorzystanie historii organizacyjnej do optymalizacji współczesnej działalności gospodarczej, semestr letni 2012/2013, WZ UW. Warszawa.

513. Szymik, J., Nęcek, R. i Białek, M. (2009). Rozmowy (nie) roztropne. Kraków: Dom Wydawniczy Rafael. 
514. Śliwa, M. \& Taylor, B. (2011). 'Everything comes down to money'?: Migration and working life trajectories in a (post-)socialist context. Management \& Organizational History, 6(4), pp. 347-366.

515. Śliwa, M., (2013). Learning to listen: an organizational researcher's reflections on 'doing oral history'. Management \& Organizational History, 8(2), pp. 185-196.

516. Św. Serafin z Sarowa. (2008). Ogień Ducha Świętego. Kraków: Wyd. Espirit.

517. Świątek, T. W. (2006). Mokotów przez wieki. Pruszków: Wyd. M.M.

518. Świątek, T. W. (2010). Rody warszawskie. Warszawa: Veda.

519. Świątek, T. W. (2012). Konstancin i jego pasjonaci. Biuro Usług Turystycznych Mokotów.

520. Świątek, T. W. i Chwiszczuk, R. (2012). Królowa Wista. Warszawa: Fundacja Cultus.

521. Taleb, N. N. (2006). Ślepy traf. Rola przypadku w sukcesie finansowym. Gdańsk: GWP.

522. Tarasiewicz, K. (1971). Kawa po warszawsku. Dzieje firmy »Pluton«. Warszawa: Gospodarczy Instytut Wydawniczy.

523. Tarasiewicz, K. (2001). Przygoda z kawa i herbata. Warszawa: Wyd. Veda.

524. Tarasiewicz, K. (2009). Kawa i herbata na ziemiach polskich. Handel, konsumpcja, obyczaje. Warszawa: SGH.

525. Tarasiewicz, K. (2010). Caty wiek $w$ Warszawie. Warszawa: Wyd. Veda.

526. Tarasiewicz, K. (2013a). Dzieje domu przy ulicy Grzybowskiej 37 w Warszawie. Warszawa: Wyd. Veda.

527. Tarasiewicz, K. (2013b). Zapach świeżej kawy (Ochinowski, T. red.). Warszawa: PWN.

528. Tatakis, B. (2012). Filozofia bizantyjska. Kraków: WAM.

529. Taylor, S., Bell, E. \& Cooke, B. (2009). Business history and the historiographical operation. Management \& Organizational History, 4(2), pp. 151-166.

530. Tazbir, J. (2010). Opus vitae Stanisława Wasylewskiego (s. 5-13). W: Wasylewski, S. Życie polskie w XIX wieku. Warszawa: Iskry.

531. Thompson, E. (2000). Trubadurzy Imperium. Kraków: Universitas.

532. Thompson, E. i Memhes, F. (2007). Polski nacjonalizm jest niezwykle łagodny. Magazyn Europa. Dodatek do „Dziennika”, 156, s. 11.

533. Thompson, P. R. (1990). The Voice of the Past. Oxford. Oxford University Press.

534. Thorsby, D. (2010). Ekonomia i kultura. Warszawa: Narodowe Centrum Kultury.

535. Topolski, J. (1984). Metodologia historii. Warszawa: PWN.

536. Topolski, J. (1996). Jak się pisze i rozumie historię. Tajemnice narracji historycznej. Warszawa: Oficyna Wydawnicza RYTM.

537. Topolski, J. (1996). Mity a problem prawdy historycznej (s. 15-27). W: BarszczewskaKrupa, A. (red.). Historia, mity, interpretacje. Łódź: Wydawnictwo Uniwersytetu Łódzkiego.

538. Tosh, J. (1991). The Pursuit of History Aims, Methods and New Directions in the Study of Modern History. Essex: Longman House.

539. Touraine, A. (2013). Po kryzysie. Warszawa: Oficyna Naukowa.

540. Touraine, A. i in. (2010). Solidarność. Analiza ruchu spotecznego 1980-1981. Gdańsk: Europejskie Centrum Solidarności.

541. Trojnar, E. (2011). Kręgi kulturowe a kultury organizacyjne. Wpływ kultury narodowej na procesy zarządzania (s. 33-54). W: Glinka, B. i Jelonek, A. (red.). Zarządzanie międzykulturowe. Kraków: Wyd. UJ. 
542. Trzebińska, E. (2008). Psychologia pozytywna. Warszawa: Wydawnictwa Akademickie i Pro-fesjonalne.

543. Turowski, K. (1989). Historia ruchu chrześcijańsko-demokratycznego w Polsce. Warszawa: ODISS.

544. Turowski, K. (1991). Bukowski Stanisław Wiktor (1896-1976) (s. 66-67). W: Bender, R. i in. (red.). Stownik biograficzny katolicyzmu spotecznego w Polsce. T. I, A-J. Warszawa: ODISS.

545. Twórcy teorii ekonomicznych (2007). Warszawa: PWN (Biblioteka Gazety Wyborczej).

546. Tygiel Kultur (1998). Lodzermnensch - historia i mit, nr 4-5.

547. Tyrmand, L (2009). Zly. Warszawa: Prószyński i S-ka.

548. Tyrmand, L. (1972/2009). Siedem dalekich rejsów. Warszawa: MG.

549. Tyszka, T. (2009). Wypowiedź na konferencji Psychologiczne aspekty kryzysu. 27.05.2009. Wydział Zarządzania UW. Warszawa.

550. Tyszka, T. (2010). Decyzje. Podejście psychologiczne i ekonomiczne. Warszawa: Scholar.

551. Vaillant, Y i. Lafuente, E. (2007). Do different institutional frameworks condition the influence of local fear of failure and entrepreneurial examples over entrepreneurial activity? Entrepreneurship \& Regional Development, 19, pp. 313-337.

552. Vanderbroeck, P. (2012). Crises: Ancient and Modern Understanding ancient Roman crisis can help us move beyond our own. Management \& Organizational History, 7(2), pp. 113-131.

553. Veblen, Th. (2008). Teoria klasy próżniaczej. Warszawa: Wyd. Muza S.A.

554. Wagner, B. i Wiślicz, T. (red.). (2008). Obserwacja uczestnicząca w badaniach historycznych. Zabrze: Inforteditions.

555. Wandycz, P. S. (1992/1995). Cena wolności. Historia Europy Środkowo-Wschodniej od średniowiecza do wspótczesności. Kraków: Znak.

556. Ware, K. (2003). Królestwo wnętrza. Tom I Dzieł Zebranych. Lublin: Prawosławna Diecezja Lubelsko-Chełmska.

557. Waschko, St. (1963). Handel Zagraniczny Polski. Sopot: WSE w Sopocie.

558. Wasylewski, St. (1962/2010). Życie Polskie w XIX wieku. Warszawa: Iskry.

559. Weaver, R. M. (1996). Idee maja konsekwencje. Kraków: WPSB.

560. When Good People Behave Badly. What Will You Do? (2004). Boston: Harvard Business School Press.

561. White, H. (2010). Poetyka pisarstwa historycznego (Domańska, E. i Wilczyński, M. [red.]). Kraków: Univeristas. (I wyd. 2000).

562. Whybrow, P. C. (2005/2008). American mania. Ciagle więcej ale nigdy dość. Poznań: Termedia.

563. Whybrow, P. C. i Król, A. (2009). Przerwany amerykański sen. Charaktery, 5, s. $88-89$.

564. Wieczorkowska-Wierzbińska, G. (2009). Wypowiedź na konferencji Psychologiczne aspekty kryzysu. 27.05.2009. Wydział Zarządzania UW. Warszawa.

565. Wieczorkowska-Wierzbińska, G. (2011). Psychologiczne ograniczenia. Warszawa: Wyd. Naukowe WZ UW.

566. Wieleżyński, L. (1985). Wspólna praca. Wspólny plon: życie i dzieto mądrego człowieka. Londyn: Verotas.

567. Wielicki, K. (2012). Kryzys i socjologia. Warszawa: Wyd. UW.

568. Wierzbicki, A. (1999). Historiografia polska doby romantyzmu. Wrocław: FNP. 
569. Wierzbicki, A. (2001). Groźni $i$ Wielcy. Polska myśl historyczna XIX i XX wieku wobec rosyjskiej despotii. Warszawa: Wyd. Sic.

570. Wierzbicki, A. (2006). Od historiografii do mitografii? „Mit” w historiografii polskiej ostatniego półwiecza (t. II, s. 179-196). W: Wierzbicki, A. (red.). Polska Klio. Warszawa: Wyd. Neriton IH PAN.

571. Wierzbicki, A. (2009). Europa w polskiej myśli historycznej i politycznej XIX i XX wieku. Warszawa: Centrum Europejskie Natolin i Wyd. Trio.

572. Wierzbicki, A. (2010). Spory o polska duszę. Wyd. II. zmienione. Warszawa: Collegium Civitas, Muzeum Historii Polski i Wyd. Trio.

573. Wierzbicki, A. (2001). Żywy Lewiatan. Wspomnienia. Warszawa: KAW.

574. Wilk, R. R. i Cliggett, L. (2011). Ekonomie i kultury: podstawy antropologii ekonomicznej. Kraków: UJ.

575. Wilkin, J. (2008). Dlaczego warto wspierać gospodarkę społecznie zakorzenioną? (s. 17-21). W: Rymsza, A. (red.). Gospodarka spoteczna w Polsce. Możliwości, wybrane inicjatywy oraz szanse dalszego rozwoju. Warszawa: Fundacja Archidiecezji Warszawskiej Pomocy Bezrobotnym i Biednym Nadzieja.

576. Wiszniewski, J. (1998). Tygodnik Warszawski 1945-1948. Z historii prasy katolickiej w Polsce. Kraków: PiT.

577. Wiśniewska-Rutkowska, L. (2004). Mesjanizm Jerzego Brauna. Myślenie w perspektywie Józefa Marii Hoene-Wrońskiego. Kielce: Wyd. Akademii Świętokrzyskiej.

578. Wittlin, J. (1949/1991). Pisma pośmiertne i inne esje. Warszawa: Więź.

579. Włodarek J. i Ziółkowski M. (red.). (1990). Metoda biograficzna w socjologii, Poznań-Warszawa: PWN.

580. Wong, J. T. Y., Hui, E. C. M. (2006). Research notes - power of expectations. Property Management, Vol. 24, Iss: 5, pp. 496-506.

581. Woś, R. (2013). Polak Polakowi liberałem. Wiara w nieomylność wolnego rynku zamienia nas w socjopatycznych egoistów. Dziennik Gazeta Prawna Weekend, 22-24.02.2013, s. A8-A9.

582. Woźniak, K. (1998). Głos w dyskusji: Lodzermensch - historia i mit. Tygiel kultury, nr 4-5, s. 32.

583. Woźniak, M. (2010). Kiedy pamięć staje się źródłem historycznym. Historycy wobec tradycji ustnej (s. 79-89). W: Kolbuszewska, J. i Stobiecki, R. (red.). Historyk wobec źródet. Historiografia klasyczna i nowe propozycje metodologiczne. Łódź: Ibidem.

584. Wóycicki, A. (1922). Rozwój warstwy robotniczej pod wpływem rozwoju produkcji. (s. 109-159) W: Kepner, St. A. (red.). Dzieje gospodarcze Polski, t. II. Warszawa: Druk K. Kowalewskiego.

585. Wóycicki, A. (1929). Dzieje robotników przemystowych w Polsce. Warszawa: Skład Główny w Księgarni F. Hoesika. Wydawnictwo Polskiego Towarzystwa Polityki Społecznej.

586. Wren, D. A. (1972). The Evolution of Management Thought. New York: The Ronald Press Company.

587. Wróbel, J. (2005). Kościół w łódzkiem w Październiku' 56 (s. 90-106). W: Wróbel, J. i Próchnik, L. (red.). Wtadze komunistyczne wobec Kościoła Katolickiego $w$ tódzkiem 1945 - 67. Warszawa: IPN.

588. Wrzosek, W. (1995). Historia - kultura - metafora. Wrocław: Leopoldinum.

589. Wrzosek, W. (red.). (2011). Oblicza przeszłości. Bydgoszcz: Oficyna Wydawnicza Epigram. 
590. Wspólnota kultury i pracy (1947). Tygodnik Warszawski, 29, s. 21.

591. Wu, J. C. H. (1994). Ponad Wschodem i Zachodem. Autobiografia chińskiego konwertyty. Warszawa: Verbinum.

592. Wu, J. C. H. (1975). The Interior Carmel: The Threefold Way of Love. Taipei: Hwakang Bookstore.

593. Wong, J. T. Y. \& Hui, E. C. M. (2006). Research notes - power of expectations. Property Management, Vol. 24, 5, pp. 496-506.

594. Wygnański, J. (2008). Ekonomia społeczna - sprzeczność czy konieczność? Więź, $4-5$, s. $15-25$.

595. Yunus, M. (2010). Building Social Business: The New Kind of Capitalism that Serves Humanity's Most Pressing Needs. New York: BBS Public Affairs.

596. Young, J. E. (1993). The Texture of Memory. Holocaust Memorials and Meaning. New Haven.

597. Yousaf, N. (2011). Types of Organizational Culture and Behavior. Pozyskano z: http://management.corporatemanagementsolution.com/main/articles/types-of-organizational-culture-and-behavior/ [19.04.2012.].

598. Zasady zrównoważonej gospodarki. Nauka Ekstra. Tom. 18. (2011). Warszawa: Biblioteka GW.

599. Zeldin, Th. (2001). Jak rozmowa zmienia twoje życie. Warszawa: W.A.B.

600. Zeldin, Th. (1994/1998). Intymna historia ludzkości. Warszawa: W.A.B.

601. Zeldin, Th. (1995). An Intimate History of Humanity. London: Vintage.

602. Zeldin, Th. (1999). How work can be made less frustrating and conversation less boring (Education and Debate). British Medical Journal, 319, p. 1633.

603. Zeldin, Th. \& Wylie, I. (2000). Talk Is Cheap. Let's Have a Conversation By Ian Wylie. Fast Company.

604. Zespół red. „Karty” oraz Jeżowska, E i Kudosz, E. (red.). (2013). Ziemia zwana obiecaną. Karta, 75, s. 2-31.

605. Zhu, Y. \& Hildebrandt, H. (2002). Greek and Chinese Classical Rhetoric: The Root of Cultural Differences in Business and Marketing Communication. Asia Pacific Journal of Marketing and Logistics, Vol. 14, 4, pp. 89-114.

606. Zieleniewski, J. (1981). Organizacja i zarzadzanie. Warszawa: PWN.

607. Zieliński, J. G. (1962). Big Business. Z problematyki nowych technik zarzadzania. Warszawa: Książka i Wiedza.

608. Zieliński, J. i in. (2012). Korzenie miasta. Tom 7. Warszawa 1945-1978. Warszawa: Wyd. Veda.

609. Ziemba, Z. A. (1997). Prawo przeciwko społeczeństwu. Polskie prawo karne w latach 1944-1956. Warszawa: Katedra Socjologii Moralności i Aksjologii Ogólnej ISNS UW.

610. Zimbardo, P. G. \& Hartley, C. F. (1985). Cults go to High Schools: A Theoretical and Empirical analysis of the Initial Stage in the Recruitment Process. Cultist Studies Journal, 2, pp. 91-147.

611. Zimbardo, P. (2008). Efekt Lucyfera. Warszawa: PWN.

612. Zimbardo, P. (2009). The Lucifer Effect. Pozyskano z: http://www.lucifereffect.com/ [pobrano: 03.12.2009].

613. Zrebst, R. (1992/2010). Gaudi. Wszystkie budowle. Köln: Taschen. 
614. Zweig, J. (2008). Twój mózg, twoje pieniądze. Zarabiaj, wykluczając błędy percepcji. Najnowsze odkrycia neuroekonomii i psychologii finansowej. Warszawa: Wyd. Laurum.

615. Żemigała, M. (2007). Spoteczna odpowiedzialność przedsiębiorstwa. Kraków: Wolters Kluwer business.

616. Żemigała, M. (2011). Ekologiczny kontekst działalności przedsiębiorstwa (s. 182-192). W: Bernatt, M., Bogdanienko, J. i Skoczny, T. (red.). Spoteczna odpowiedzialność biznesu. Krytyczna analiza. Warszawa: Wyd. Naukowe WZ UW.

617. Żemigała, M. (2013). Spoteczna odpowiedzialność biznesu $w$ świetle analiz bibliometrycznych $i$ opinii pracowników na temat równowagi między życiem zawodowym a prywatnym. Warszawa: Wyd. Naukowe WZ UW.

618. Żyto, K. i Pieńkowski, M. (2011). Billy Wilder. Mistrz kina z Suchej Beskidzkiej. Warszawa: Wyd. Trio. 


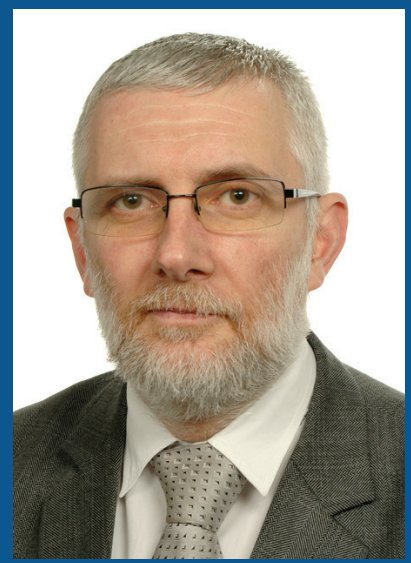

Tomasz Ochinowski - dr psychologii, pracuje w Katedrze Psychologii i Socjologii Zarządzania Wydziału Zarządzania Uniwersytetu Warszawskiego. Prowadzi także zajęcia w ramach International Business Program oraz na studiach podyplomowych. Członek zespołu wykładowców Centrum Kształcenia Menadżerów przy WZ UW (MBA). Odbył gościnne prezentacje na uniwersytetach w USA, Belgii i na Tajwanie. Aktualnie współpracuje z Sam Houston State University, w Teksasie. Był ekspertem Unii Europejskiej w zakresie rozwoju lokalnego. Członek zespołu recenzentów pisma ICT - Information and Communication Technologies for the Advanced Enterprise.

Od wielu lat prowadzi badania nad kompetencjami społecznymi i kondycją psychiczną menedżerów oraz pracowników różnego typu firm i instytucji, przedsiębiorczością społeczną, kulturą organizacyjną i międzykulturowymi problemami zarządzania oraz coachingiem i mentoringiem w kontekście tradycji różnych kultur.

Jego ostatnie zaangażowania naukowe związane są z projektem mentoringu w Służbie Więziennej oraz programem optymalizacji zarządzania w Policji, finansowanym przez Narodowe Centrum Badań i Rozwoju.

Pasją poznawczą dr. Ochinowskiego jest rozwój i promowanie perspektywy historycznej w zarządzaniu, w szczególności odtwarzanie zapomnianych tradycji biznesowych (przede wszystkim polskich) jako źródła inspiracji dla obecnych, innowacyjnych działań podmiotów i instytucji gospodarczych.

Dr Tomasz Ochinowski od 2001 roku współpracuje z warszawskim środowiskiem historiografów, skupionym wokół Prof. Andrzeja Wierzbickiego (IH PAN). Jest członkiem Towarzystwa Historiograficznego. Przez klika lat współpracował z Uniwersytetem w Gandawie w zakresie łączenia perspektyw badawczych psychologii $\mathrm{i}$ historii. Za prace $\mathrm{z}$ tej problematyki otrzymał nagrodę im. Jana Górskiego oraz II nagrodę Programu Wspierania Badań Naukowych Uniwersytetu Środowo-Europejskiego w Budapeszcie (CEU), którego był stypendystą. 